\begin{abstract}
MORAN, AMY CHRISTINE. A North Carolina Field Study to Evaluate Greenroof Runoff Quantity, Runoff Quality, and Plant Growth. (Under the direction of Gregory D. Jennings and William F. Hunt)
\end{abstract}

Two greenroofs were constructed for research and demonstration purposes in North Carolina; the first was constructed at the Neuseway Nature Center in Kinston in April 2002 and the second greenroof was constructed at Wayne Community College (WCC) in Goldsboro in May 2002. The $27 \mathrm{~m}^{2}$ Nature Center Greenroof, with a 3\% pitch, was constructed with $102 \mathrm{~mm}$ deep media. The relatively flat, $70 \mathrm{~m}^{2}$ WCC Greenroof was constructed with two different media depths of $102 \mathrm{~mm}$ and $51 \mathrm{~mm}$ to research the effect of media depth on plant growth. Each greenroof was compared to a reference roof, or a control roof, on site.

Data was gathered at the WCC Greenroof for a consecutive nine month period from April 2003 to December 2003 and at the Nature Center Greenroof during a portion of July 2003, August 2003, November 2003, and December 2003. The two greenroofs were not directly compared because they are located approximately $48 \mathrm{~km}$ apart; therefore, each greenroof was analyzed separately. Over the entire monitoring period, the WCC Greenroof retained $62 \%$ of the total $901 \mathrm{~mm}$ of precipitation recorded at the site. The Nature Center Greenroof retained $63 \%$ of the $262 \mathrm{~mm}$ of precipitation measured. Variability of percent precipitation retained within each month of data was dependent upon the rainfall pattern and the seasonal effects on evapotranspiration rates.

Percent flow reduction of the greenroof was determined by comparing the greenroof runoff peak flow and the peak rainfall rate. The Nature Center Greenroof observed an 
average $87 \%$ reduction in peak flow from the greenroof during the monitoring period. The WCC Greenroof observed an average peak flow reduction of $78 \%$ during the monitoring period. Average Rational runoff coefficients were developed from the runoff flows observed at the WCC Greenroof. The average greenroof Rational coefficients ranged from 0.25 for storms between $25 \mathrm{~mm}$ and $39 \mathrm{~mm}$ to 0.55 for rain events greater than $39 \mathrm{~mm}$; typical rooftop Rational coefficients range between 0.75 and 0.95 .

Water quality samples were taken of the greenroof runoff, the rainfall, and the control roof runoff at each site for select rain events. While no statistical trends were observed, higher concentrations and higher mass loadings of nitrogen were generally observed in the greenroof runoff. The concentration and mass loading of phosphorus were statistically higher in the greenroof runoff than in the rainfall and the control roof runoff. This was an indication that the media was serving as an additional source of nitrogen and phosphorus from the greenroof runoff. If a media had been used which did not have high nitrogen and phosphorus loadings in the initial composition, fewer nutrients would have leached from the media into the greenroof runoff.

A brief laboratory study was performed to determine the leaching effects of nitrogen and phosphorus from various greenroof soil media with varying percentages of compost in the media mix. This laboratory study provided vital information for greenroof media composition: less nitrogen and phosphorus will be present in the greenroof runoff when less compost is included in the mix. Results also indicated that concentrations of nitrogen leaching from the soil media will decrease to a minimum over time.

Plant growth in $102 \mathrm{~mm}$ deep soil media was determined to be significantly higher than plant growth in $51 \mathrm{~mm}$ deep soil media. Extensive greenroof plant species 
recommended for growth in North Carolina are Delosperma nubigenum, Sedum album, Sedum album murale, Sedum floriferum, Sedum reflexum, Sedum sexangulare, and Sedum spurium fuldaglut. 


\section{A NORTH CAROLINA FIELD STUDY TO EVALUATE GREENROOF RUNOFF QUANTITY, RUNOFF QUALITY, AND PLANT GROWTH}

by

\section{AMY CHRISTINE MORAN}

A thesis submitted to the Graduate Faculty of

North Carolina State University

In partial fulfillment of the

Requirements for the Degree of

Master of Science

\section{BIOLOGICAL AND AGRICULTURAL ENGINEERING}

Raleigh, North Carolina

2004

\section{APPROVED BY:}

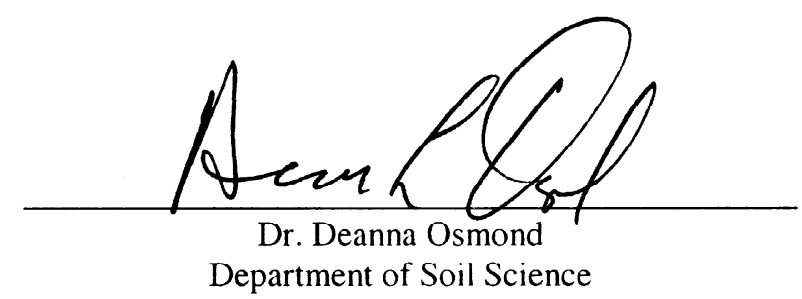

Department of Soil Science

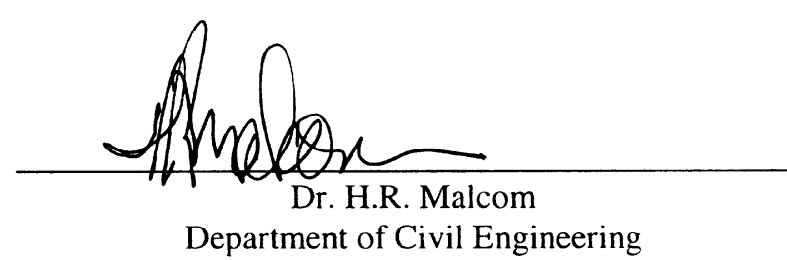

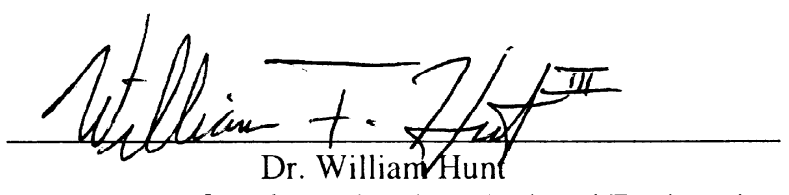

Department of Biological and Agricultural Engineering Co-chair of Advisory Committee

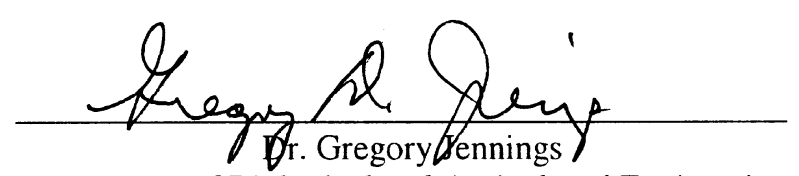

Department of Biological and Agricultural Engineering Co-chair of Advisory Committee 
For my love, who is always by my side supporting me

For my friend, who always helps me keep my mind on the important things in life, such as playing with his toy mice

For Mike, who will always be in our hearts

And most of all, for my Savior

I can do everything through Him who gives me strength.

Philippians 4:13 (NIV) 


\section{BIOGRAPHY}

Amy Christine Moran was born to Susie and Joe Moran in Mississippi in October 1980. As her father was a Lieutenant Colonel in the U.S. Army, Amy's family called many different places "home" as she was growing up. However, after moving to Atlanta, Georgia in 1989, her father retired from the U.S. Army in 1993 and Atlanta, Georgia became their permanent home. After spending the majority of her adolescent years in Atlanta, Amy now refers to Atlanta as her homeland.

To satisfy the desire to spread her wings, Amy decided to attend college at North Carolina State University. Amy matriculated into the Environmental Engineering program within the Civil Engineering Department in her sophomore year at the university. It was through this program Amy was able to channel her interests into the stormwater engineering field. After interning with the City of Raleigh's Storm Water Engineering Department, Amy received further confirmation that this was the path she should take in her career.

Amy graduated from the Civil Engineering Department with her Bachelor of Science in Environmental Engineering in May 2002, under the guidance of Dr. H.R. Malcom. She then immediately began her studies with the Biological and Agricultural Engineering Department during the summer of 2002. Amy's keen interest in improving water quality was directed into the field of stormwater best management practices (BMPs) when she began her

studies of greenroof runoff. Amy received her Master of Science in Biological Engineering in the summer of 2004.

Both of Amy's parents and her sister, Sasha, still reside in Atlanta, GA. Her brother, Joe, lives in Durham, NC. Amy has been living in Raleigh, NC for six years and now considers it her home. 


\section{ACKNOWLEDGEMENTS}

The author would like to acknowledge many of the people who contributed to the success of this research project. The author would like to thank her co-advisors, Dr. Bill Hunt and Dr. Greg Jennings, for without their guidance, this research project would not have become a reality. Many thanks for their constant encouragement and ingenuity whenever a complication arose with the research. The author would like to thank Dr. Deanna Osmond for all her guidance in the laboratory study and her direction through the soil science aspect of the research. Thanks also to Dr. H.R. Malcom for his guidance in the water quantity aspects of the research.

The author would also like to especially thank all those who worked directly on the field research sites. Special thanks to Mr. Mike Regans, who was the Cooperative Extension Agent for both greenroof sites. Mike identified each retrofit location and was able to smooth the way for equipment installation. Mike also secured the majority of the funding for this research. Much to our heartache, Mike was unable to see the research to its completion; he passed away in March 2004. His charismatic attitude and jovial spirit made it a pleasure to do research. This research would have been impossible without the help of Mr. Jonathan Smith and Mr. Dave Bidelspach. Special thanks for their aid in installing the sampling equipment at each site. Successful monitoring of the research sites was strictly a result of their expertise with the monitoring equipment. Many thanks also to the graduate students of the Biological and Agricultural Engineering Department who volunteered their time to help with the field research including Mr. Jon Hathaway, Mr. Mike Shaffer, Mr. Lucas Sharkey, 
Miss Heather Schaetzle, Mr. Eban Bean, Mr. Derrick Williams, and Mr. Mageswaran Prasath.

The author would also like to thank those who helped with the laboratory research. Research laboratory space would not have been available within the Soil Science Department without Dr. Deanna Osmond and Mr. Barrett Richards. Special thanks to Mr. Barrett Richards for all his guidance in the soil texture analysis aspect of the laboratory research. Thanks also to Ms. Rachel Huie for her guidance through the weekly composition of the synthetic rainwater. The author would like to extend special thanks to fellow graduate students Mr. Jon Hathaway, Mr. Eban Bean, and Mr. Lucas Sharkey who worked as hard as the author to spray the soil columns with synthetic rainwater each week. The author would also like to thank Mr. Guillermo Ramirez for finding the time to analyze all the water quality samples from the laboratory study.

The author would like to especially thank Dr. Jason Osborne for all this guidance through the statistical analysis of this research. His extensive knowledge of statistics provided much needed relief during the final weeks of producing the thesis.

Special thanks again to Dr. Bill Hunt for providing the research and serving not only as the co-advisor of the author, but also as a mentor and a friend.

The author sends many thanks to all her friends and family for always offering support through the many months of research and the final months of preparing the thesis. Most of all, the author thanks her Savior, Jesus Christ, for giving her the knowledge, the desire, and the strength to see this project through to its completion, for we can do all things in Him. 


\section{TABLE OF CONTENTS}

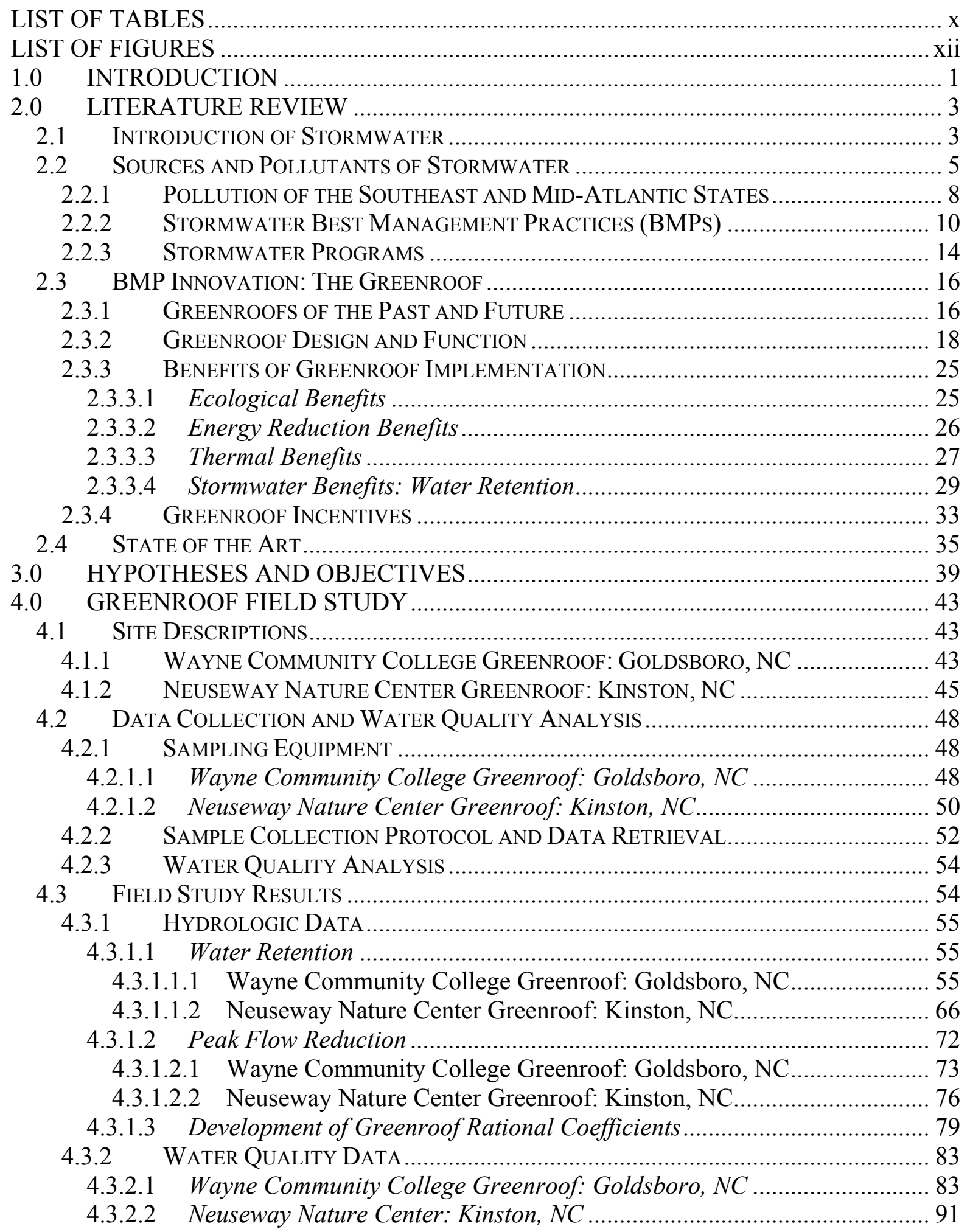


TABLE OF CONTENTS Nii vii vis

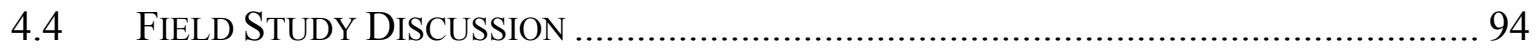

5.0 GREENROOF SOIL MEDIA LABORATORY STUDY ….................................. 99

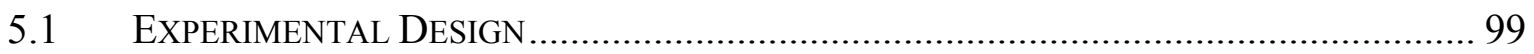

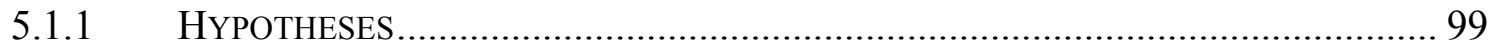

5.1.2 SOIL MEDIA VARIATIONS ........................................................................... 100

5.1.2.1 Carolina Stalite Perma Till Light Weight Roof Garden Soil Mix.............. 100

5.1.2.2 ERTH HydRocks Soil Mix .................................................................... 101

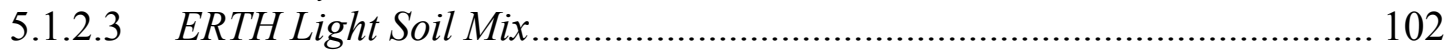

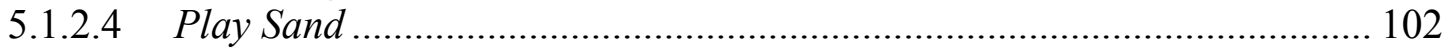

5.1.3 NCDA SOIL TEST REPORT .................................................................. 103

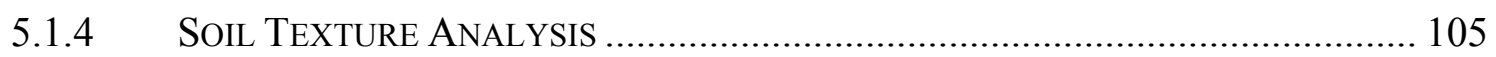

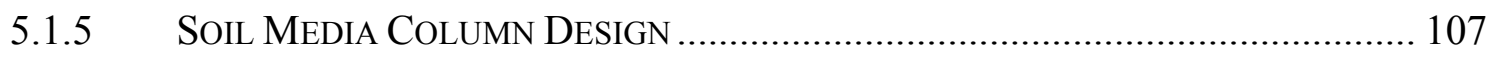

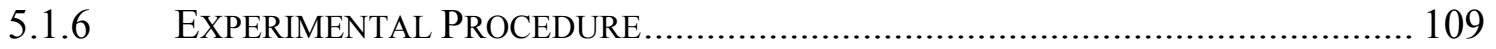

5.1.7 SYNTHETIC RAINWATER COMPOSITION ....................................................... 113

5.1.7.1 Synthetic Rainwater Laboratory Procedure ......................................... 115

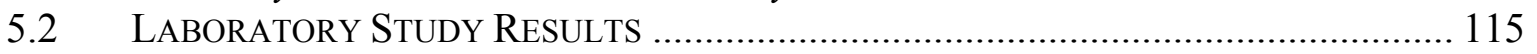

5.2.1 ERTH HYDROCKS SOIL MIX............................................................... 116

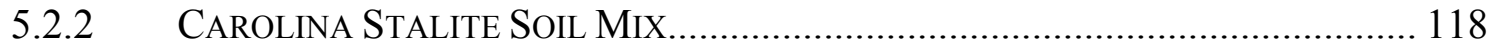

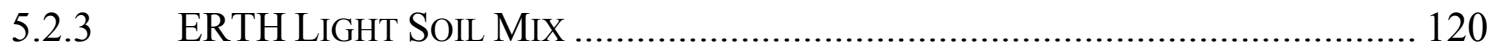

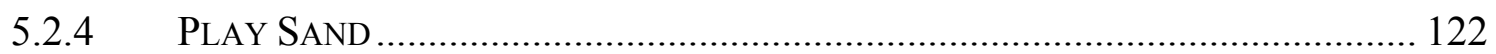

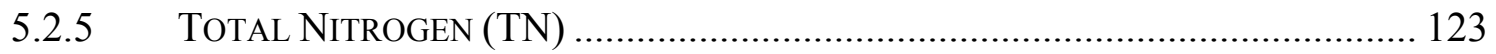

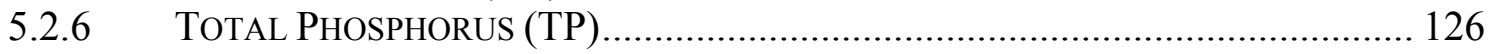

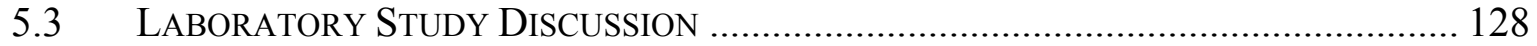

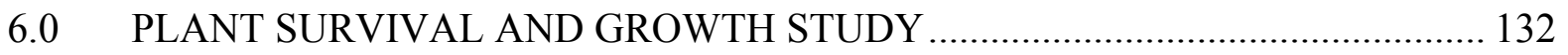

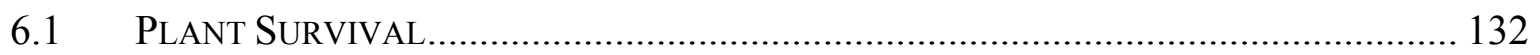

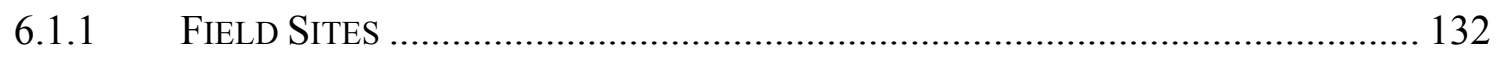

6.1.2 PLANT SPECIES .............................................................................. 133

6.1.3 Plant Species SuRVival and Plant SElection ReCOMMENDATIONS ...... 135

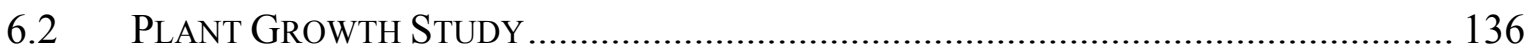

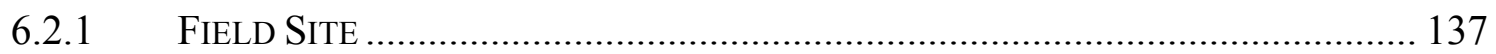

6.2.1.1 Soil Depth Variation and Plant Species................................................. 137

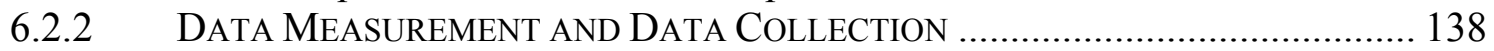

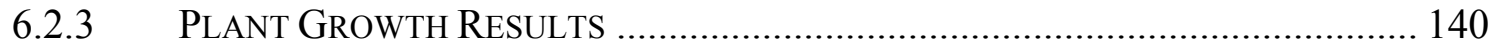

6.3 Plant SURVIVAL AND GROWTH STUDY DiSCUSSION ....................................... 141

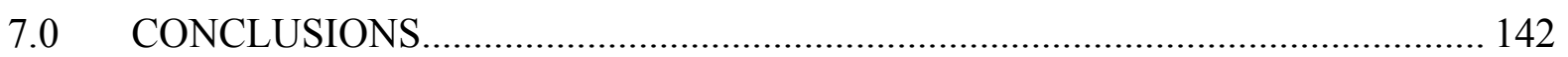

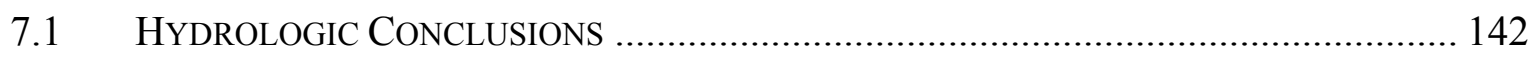

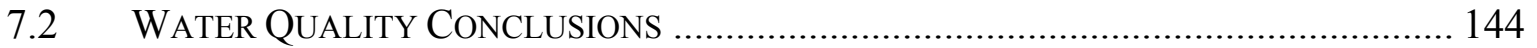

7.3 PlaNT SURVIVAL AND PLANT GROWTH CONCLUSIONS ........................................ 148

8.0 RECOMMENDATIONS FOR FURTHER RESEARCH .................................. 151

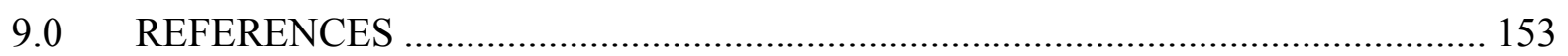

A.0 APPENDIX A — GOLDSBORO HYDROLOGIC DATA ................................. 159

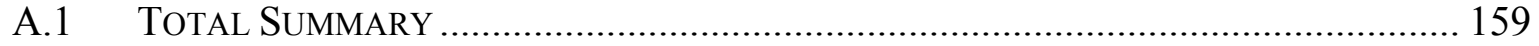

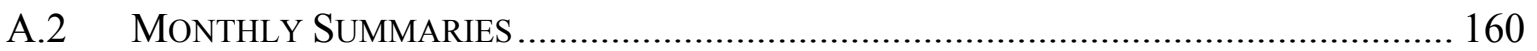

B.0 APPENDIX B — GOLDSBORO HYDROLOGIC DATA: STATISTICAL

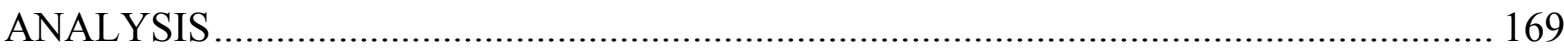


TABLE OF CONTENTS viii

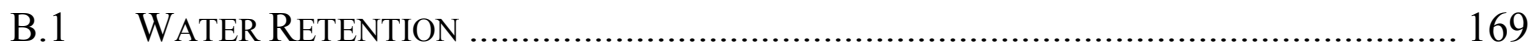

B.2 PEAK FLOW REDUCTION ...................................................................................... 170

C.0 APPENDIX C — KINSTON HYDROLOGIC DATA ………….......................... 171

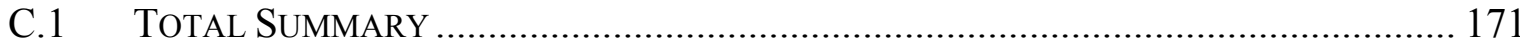

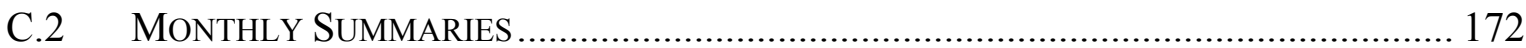

D.0 APPENDIX D - KINSTON HYDROLOGIC DATA: STATISTICAL ANALYSIS..

A

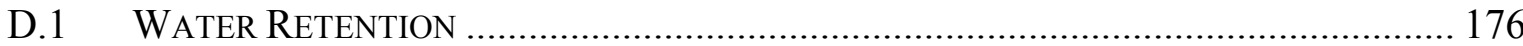

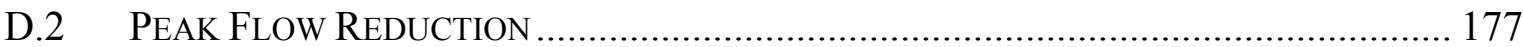

E.0 APPENDIX E — GOLDSBORO WATER QUALITY DATA ............................. 178

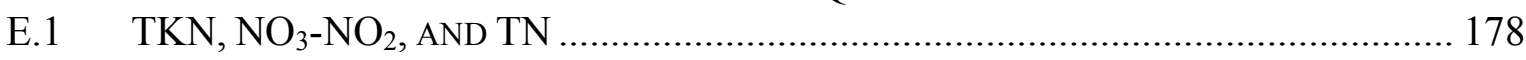

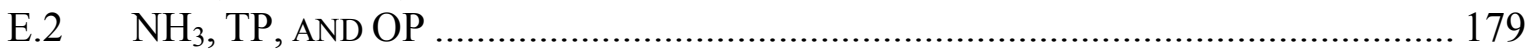

E.3 GRAPHS OF CONCENTRATIONS AND MASS LOADINGS FOR EACH NUTRIENT .......... 180

F.0 APPENDIX F — GOLDSBORO WATER QUALITY DATA: STATISTICAL

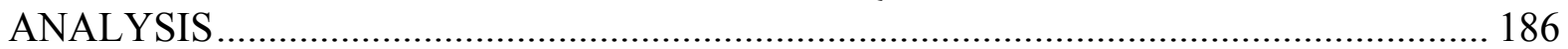

F.1 CONCENTRATION OF TOTAL KJELDAHL NitROGEN (TKN AS N) ............................ 186

F.2 MASS LoAdING OF TOTAL KJELDAHL NitRogen (TKN AS N).............................. 189

F.3 CONCENTRATION OF NitRATE-NITRITE $\left(\mathrm{NO}_{3}-\mathrm{NO}_{2} \mathrm{AS} \mathrm{N}\right)$................................... 192

F.4 MASS LOADING OF NitRATE-NITRITE $\left(\mathrm{NO}_{3}-\mathrm{NO}_{2}\right.$ AS N) ................................... 195

F.5 CONCENTRATION OF TOTAL NITROGEN (TN) ……….................................... 198

F.6 MASS LOADING OF TOTAL NITROGEN (TN) ........................................................ 201

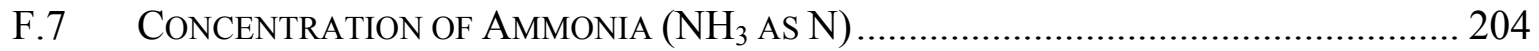

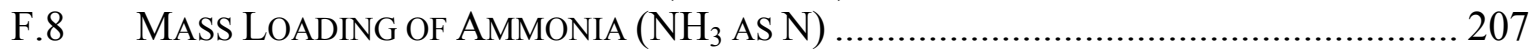

F.9 CONCENTRATION OF TOTAL PHOSPHORUS (TP) .............................................. 210

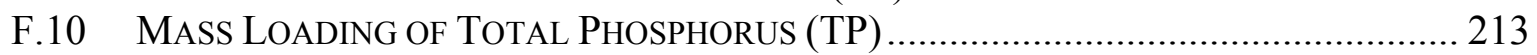

F.11 CONCENTRATION OF ORTHO-PHOSPHORUS (OP) …………………………..... 216

F.12 MASS LOADING OF ORTHO-PHOSPHORUS (OP) ……....................................... 219

G.0 APPENDIX G - KINSTON WATER QUALITY DATA …………………........ 222

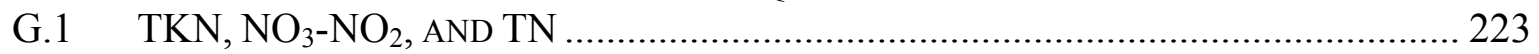

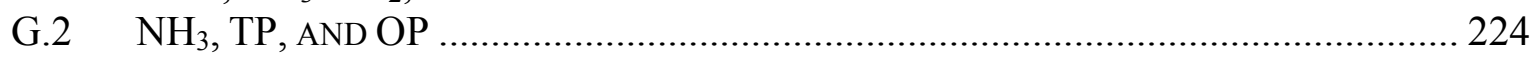

G.3 GRAPHS OF CONCENTRATIONS FoR EACH NUTRIENT ………………………..... 225

H.0 APPENDIX H - KINSTON WATER QUALITY DATA: STATISTICAL

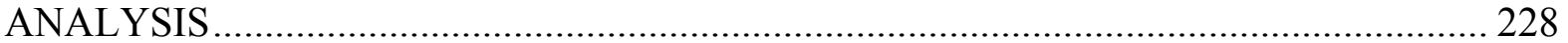

H.1 CONCENTRATION OF TOTAL KJELDAHL NITROGEN (TKN AS N) ........................... 228

H.2 CONCENTRATION OF NitRATE-NitRite $\left(\mathrm{NO}_{3}-\mathrm{NO}_{2} \mathrm{AS} \mathrm{N}\right)$.................................. 231

H.3 CONCENTRATION OF TOTAL NITROGEN (TN) …………................................ 234

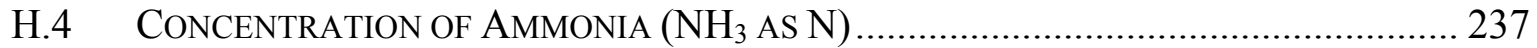

H.5 CONCENTRATION OF TOTAL PHOSPHORUS........................................................ 240

H.6 CONCENTRATION OF ORTHO-PHOSPHORUS......................................................... 243

I.0 APPENDIX I — SYNTHETIC RAINFALL CALCULATIONS .............................. 246

J.0 APPENDIX J_SOIL MEDIA STUDY DATA .................................................. 248

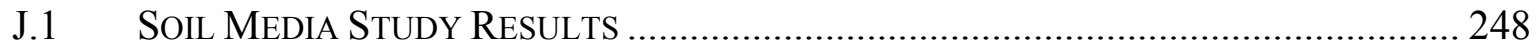

J.2 GRAPHICS OF AVERAGE CONCENTRATIONS FOR EACH SOIL NUTRIENT ................. 255

J.3 GRAPHICS OF AVERAGE CONCENTRATIONS FOR EACH SOIL MEDIA ........................ 258

K.0 APPENDIX K - SOIL MEDIA STUDY DATA: STATISTICAL ANALYSIS ... 262 
TABLE OF CONTENTS

K.1 CONCENTRATiOnS OF TOTAL KJELDAhL Nitrogen (TKN AS N) ....................... 262

K.2 CONCENTRATIONS OF NitRATE-Nitrite $\left(\mathrm{NO}_{3}-\mathrm{NO}_{2} \mathrm{AS} \mathrm{N}\right)$............................... 264

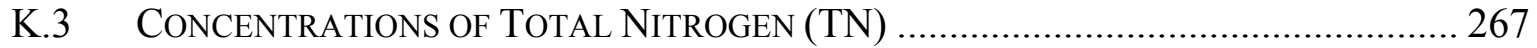

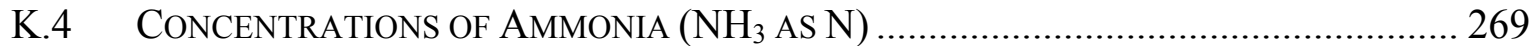

K.5 CONCENTRATIONS OF TOTAL PhOSPHORUS (TP) ............................................. 272

K.6 CONCENTRATIONS OF ORTHO-PHOSPHORUS (OP) ......................................... 274

L.0 APPENDIX L — PLANT GROWTH DATA .................................................... 278

M.0 APPENDIX M - PLANT GROWTH DATA: STATISTICAL ANALYSIS ........ 280 


\section{LIST OF TABLES}

Table 4-1. Analyses Performed on Each Runoff and Rainfall Sample............................... 54

Table 4-2. Summary Table of Water Retention at WCC Greenroof in Goldsboro, NC....... 57

Table 4-3. Approximate PET rates for Goldsboro and Kinston, NC.................................. 60

Table 4-4. Summary Table of Water Retention Data at Neuseway Nature Center Greenroof

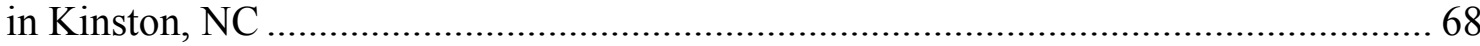

Table 4-5. Summary Table of Peak Flow Reduction at WCC Greenroof in Goldsboro, NC.73

Table 4-6. Summary Table of Peak Flow Reduction at Neuseway Nature Center Greenroof

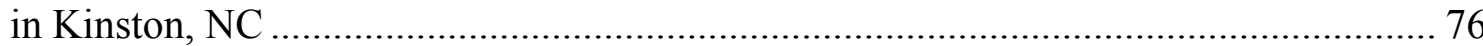

Table 4-7. Typical Rational Coefficients for Several Different Land Use Types $\dagger$.............. 80

Table 4-8. Greenroof Rational Coefficients for Select Storm Sizes .................................. 82

Table 4-9. Summary Table of Statistical Significance for Nutrient Concentrations at WCC

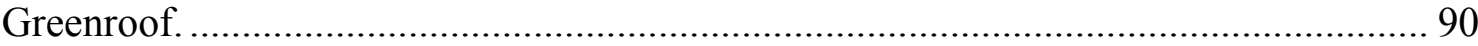

Table 4-10. Summary Table of Statistical Significance for Nutrient Mass Loadings at WCC

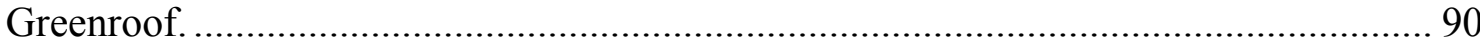

Table 4-11. Summary Table of Statistical Significance for Nutrient Concentrations at Nature

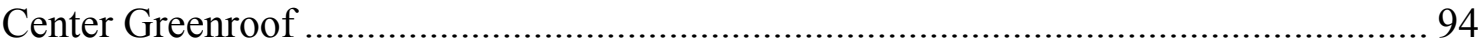

Table 5-1. Summary of NCDA Soil Test Report........................................................... 100

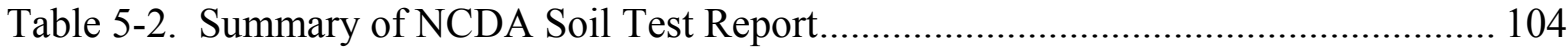

Table 5-3. Explanation of NCDA Abbreviations $\dagger$............................................................. 104

Table 5-4. Summary Table of Soil Texture Analysis Results ........................................ 106

Table 5-5. Corresponding Soil Media Depths and Mass for Each Media Type................. 110

Table 5-6. Chemical Composition of Synthetic Rainwater ............................................. 113

Table 5-7. Chemical Supply for Synthetic Rainfall .......................................................... 114

Table A-1. Summary Table of all Rainfall Events Recorded at WCC Greenroof in

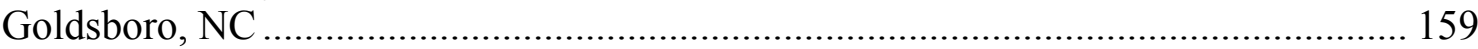

Table A-2. Summary Table of Rainfall Events in April 2003 at WCC Greenroof in Goldsboro, NC

Table A-3. Summary Table of Rainfall Events in May 2003 at WCC Greenroof in Goldsboro, NC

Table A-4. Summary Table of Rainfall Data for June 2003 at WCC Greenroof in Goldsboro, $\mathrm{NC}$

Table A-5. Summary Table of Rainfall Data in July 2003 at WCC Greenroof in Goldsboro, $\mathrm{NC}$

Table A-6. Summary Table of Rainfall Data in August 2003 at WCC Greenroof in Goldsboro, NC

Table A-7. Summary Table of Rainfall Data in September 2003 at WCC Greenroof in Goldsboro, NC

Table A-8. Summary Table of Rainfall Data in October 2003 at WCC Greenroof in Goldsboro, NC

Table A-9. Summary Table of Rainfall Data in November 2003 at WCC Greenroof in Goldsboro, NC

Table A-10. Summary Table of Rainfall Data in December 2003 at WCC Greenroof in Goldsboro, NC 
Table C-1. Summary Table of Rainfall Events Recorded at Neuseway Nature Center Greenroof in Kinston, NC....

Table C-2. Summary Table of Rainfall Events in July 2003 at Nature Center Greenroof in Kinston, NC

Table C-3. Summary Table of Rainfall Events in August 2003 at Nature Center Greenroof in Kinston, NC 173

Table C-4. Summary Table of Rainfall Events in November 2003 at Nature Center Greenroof in Kinston, NC.

Table C-5. Summary Table of Rainfall Events at Nature Center Greenroof in December 2003

Table E-1. Summary Table of TKN as $\mathrm{N}, \mathrm{NO}_{3}-\mathrm{NO}_{2}$ as $\mathrm{N}$, and TN Concentration and Mass Loading at WCC Greenroof in Goldsboro, NC

Table E-2. Summary Table of $\mathrm{NH}_{3}$, TP, and OP Concentration and Mass Loading at WCC Greenroof in Goldsboro, NC. 179

Table G-1. Summary Table of $\mathrm{TKN}, \mathrm{NO}_{3}-\mathrm{NO}_{2}$, and $\mathrm{TN}$ Concentrations and Mass Loadings at Nature Center Greenroof in Kinston, $\mathrm{NC}$

Table G-2. Summary Table of $\mathrm{NH}_{3}$, TP, and OP Concentrations and Mass Loadings at Nature Center Greenroof in Kinston, NC 224

Table J-1. Table of Results from Soil Media Column Study..... 248

Table L-1. Summary Table of Plant Growth Data after 1 Year of Growth 278 


\section{LIST OF FIGURES}

Figure 2-1. Ancient Greenroof in Ireland.

Figure 2-2. (a) Extensive Greenroof near Chemnitz, Germany (Courtesy of ZinCo GmbH).

(b) Intensive Greenroof near Berlin, Germany (Courtesy of ZinCo GmbH).

Figure 2-3. (a) Typical Extensive Greenroof Profile. (b) Close-up View of Drainage Layer with Water Storage.

Figure 2-4. (a) Two volunteers cutting protection layers for placement atop the roof during greenroof installation in Raleigh, NC in 2003. (b) View of protection layers covering rooftop before soil media is spread during greenroof installation in Raleigh, NC in 2003

Figure 2-5. (a) View of pumping truck used to transport soil media to roof surface in Germany. (b) View of pumping hose used to transport soil media to roof surface and workers spreading the soil media with rakes in Germany. (c) A shingle lift was used to transport 6 to 7 buckets of soil lat a time to the roof surface in Raleigh, NC in 2003. (d) View of volunteers spreading soil atop the drainage layers during greenroof construction in Raleigh, NC in 2003.

Figure 4-1. Map of North Carolina illustrating locations of research sites. ....................... 43 Figure 4-2. (a) Sketch of WCC Greenroof. Note: This drawing is not to scale. (b) View of storage building at WCC in Goldsboro (June 2002). (c) Overview of greenroof atop storage building at WCC, nearly 1 year old (April 2003).

Figure 4-3. (a) Sketch of Neuseway Nature Center. Note: This drawing is not to scale. (b) Neuseway Nature Center (May 2002). (c) Overview of Neuseway Nature Center Greenroof, 1 year after installation (May 2003).....

Figure 4-4. (a) Monitoring equipment for WCC control roof. Weir box is on left side; green sampler storage box in on right side (September 2002). (b) View inside weir box with baffle, level sensor, and weir plate.

Figure 4-5. (a) Monitoring equipment for Nature Center Greenroof (February 2004). (b) Monitoring equipment for Nature Center Control Roof (February 2004)...

Figure 4-6. Display of Monthly Precipitation Retention at WCC Greenroof in Goldsboro, NC.

Figure 4-7. Display of Variances of Percent Retention for Three Consecutive Rain Events in April 2003. 61

Figure 4-8. Display of Variability of Percent Retained in May 2003................................. 62

Figure 4-9. Display of Variatiability in Percent Retained in July 2003 .............................. 63

Figure 4-10. Display of Variability of Percent Retained in October 2003 ......................... 65

Figure 4-11. Display of Monthly Percent Retention at Nature Center Greenroof in Kinston, NC.

Figure 4-12. Display of Variation in Water Retention during August 2003. ...................... 69

Figure 4-13. Display of Variation in Water Retention during December 2003................... 71

Figure 4-14. Display of Peak flow Reduction for Three Consecutive Rain Events in April

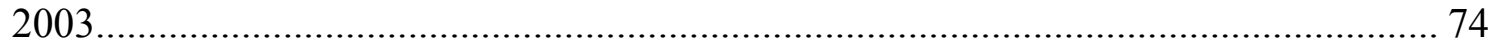

Figure 4-15. Display of Peak Flow Reduction of Rain Event on 7 April 2003.................. 75

Figure 4-16. Display of Peak Flow Reduction for two Rainfall Events in August 2003. .... 77 
Figure 4-17. Display of Peak Flow Reduction of Rain Event Beginning on 17 August 2003.

Figure 4-18. Display of Total Nitrogen Concentrations for Select Rain Events from April to

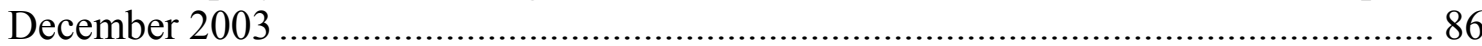

Figure 4-19. Display of Total Nitrogen Mass Loadings for Select Rain Events from April to

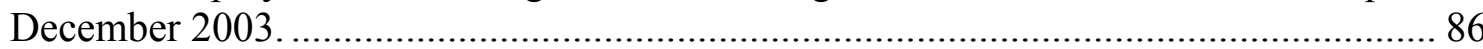

Figure 4-20. Display of Total Phosphorus Concentrations for Select Rain Events from April

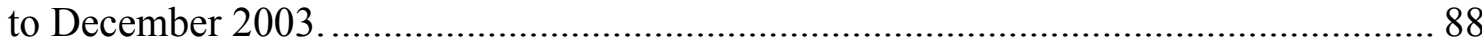

Figure 4-21. Display of Total Phosphorus Mass Loadings for Select Rain Events from April

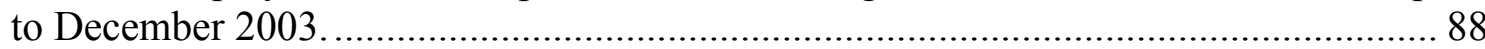

Figure 4-22. Display of Total Nitrogen Concentrations for Select Rainfall Events from May

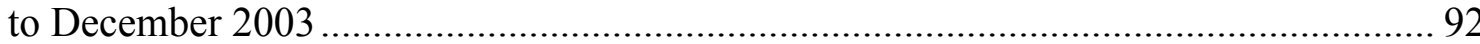

Figure 4-23. Display of Total Phosphorus Concentrations for Select Rainfall Events from

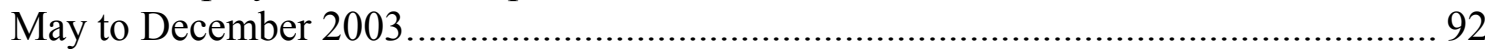

Figure 5-1. Column Design Schematic....................................................................... 108

Figure 5-2. Column and Rack Combination................................................................. 108

Figure 5-3. (a) View of Media Column Empty. (b) View of Media Column with Drainage

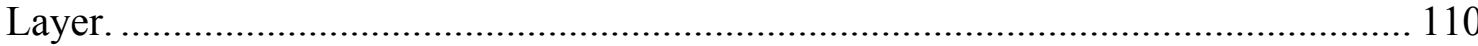

Figure 5-4. (a) View of Two Soil Media Columns. (b) View of One Column Filled with Soil Media.

Figure 5-5. (a) View of 8 Media Columns Covered with Saran ${ }^{\mathrm{TM}}$ Quick Covers $^{\mathrm{TM}}$ in Lab Space. (b) Two Graduate Students, Eban Bean and Lucas Sharkey, Volunteer Time to Apply Synthetic Rainwater to Media Columns. ..................................................... 111

Figure 5-6. Display of Nitrogen Concentrations in ERTH HydRocks Soil Mix (5\%

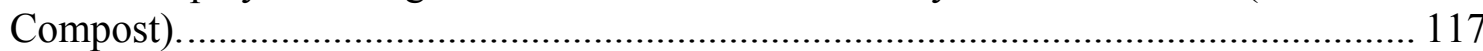

Figure 5-7. Display of Phosphorus Concentrations in ERTH HydRocks Soil Mix (5\% Compost).

Figure 5-8. Display of Nitrogen Concentrations in Carolina Stalite Soil Mix (15\% Compost).

Figure 5-9. Display of Phosphorus Concentrations in Carolina Stalite Soil Mix (15\% Compost).

Figure 5-10. Display of Nitrogen Concentrations in ERTH Light Soil Mix (33\% Compost).

Figure 5-11. Display of Phosphorus Concentrations in ERTH Light Soil Mix (33\%

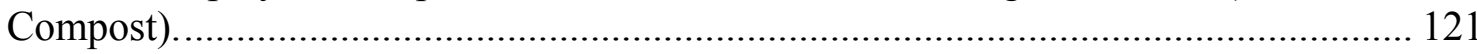

Figure 5-12. Display of Nitrogen Concentrations in Play Sand. .................................... 122

Figure 5-13. Display of Phosphorus Concentrations in Play Sand.................................. 123

Figure 5-14. Average Concentration of TN for Each Soil Media..................................... 124

Figure 5-15. Smaller Scale Display of Average TN Concentrations in Each Soil Media... 125

Figure 5-16. Average Concentrations of TP for Each Soil Media................................... 127

Figure 6-1. Delosperma cooperi in bloom (left) and Delosperma nubigenum in bloom

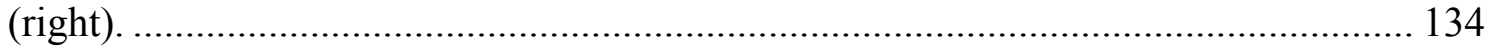

Figure 6-2. Sedum album in bloom (left) and Sedum album chloroticum (right)............... 134

Figure 6-3. Sedum album murale (left) and Sedum floriferum (right)............................... 134

Figure 6-4. Sedum grisebachii (left) and Sedum reflexum (right) ................................... 135 
Figure 6-5. Sedum sexangulare (left) and Sedum spurium fuldaglut (right). .................... 135

Figure 6-6. Display of $50 \mathrm{~mm}$ (2 in.) Soil Media Depth Block Section............................. 138

Figure 6-7. Display of 100 mm (4 in.) Soil Media Depth Block Section......................... 139

Figure 6-8. Display of Average Percent Coverage for Each Plant Species in Each Soil Media Depth

Figure A-1. Display of Percent Retention in April 2003 at WCC Greenroof in Goldsboro, $\mathrm{NC}$

Figure A-2. Display of Percent Retention in May 2003 at WCC Greenroof in Goldsboro, $\mathrm{NC}$.

Figure A-3. Display of Percent Retention for June 2003 at WCC Greenroof in Goldsboro, $\mathrm{NC}$.

Figure A-4. Display of Percent Retention in July 2003 at WCC Greenroof in Goldsboro, $\mathrm{NC}$

Figure A-5. Display of Percent Retention in August 2003 at WCC Greenroof in Goldsboro, $\mathrm{NC}$.

Figure A-6. Display of Percent Retention in September 2003 at WCC Greenroof in Goldsboro, NC

Figure A-7. Display of Percent Retention in October 2003 at WCC Greenroof in Goldsboro, NC. 166

Figure A-8. Display of Percent Retention in November 2003 at WCC Greenroof in Goldsboro, NC.

Figure A-9. Display of Percent Retention in December 2003 at WCC Greenroof in Goldsboro, NC. 168

Figure C-1. Display of Percent Retention in July 2003 at Nature Center Greenroof in Kinston, NC

Figure C-2. Display of Percent Retention in August 2003 at Nature Center Greenroof in Kinston, NC

Figure C-3. Display of Percent Retention in November 2003 at Nature Center Greenroof in Kinston, NC

Figure C-4. Display of Percent Retention in December 2003 at Nature Center Greenroof in Kinston, NC

Figure E-1. Display of TKN Concentrations at WCC Greenroof in Goldsboro, NC. ........ 180

Figure E-2. Display of TKN Mass Loadings at WCC Greenroof in Goldsboro, NC......... 180 Figure E-3. Display of $\mathrm{NO}_{3}-\mathrm{NO}_{2}$ Concentrations at WCC Greenroof in Goldsboro, NC... 181 Figure E-4. Display of $\mathrm{NO}_{3}-\mathrm{NO}_{2}$ Mass Loadings at WCC Greenroof in Goldsboro, $\mathrm{NC} \ldots 181$ Figure E-5. Display of TN Concentrations at WCC Greenroof in Goldsboro, NC ............ 182 Figure E-6. Display of TN Mass Loadings at WCC Greenroof in Goldsboro, NC............ 182 Figure E-7. Display of $\mathrm{NH}_{3}$ Concentrations at WCC Greenroof in Goldsboro, NC.......... 183 Figure E-8. Display of $\mathrm{NH}_{3}$ Mass Loadings at WCC Greenroof in Goldsboro, NC.......... 183 Figure E-9. Display of TP Concentrations at WCC Greenroof in Goldsboro, NC............. 184 Figure E-10. Display of TP Mass Loadings at WCC Greenroof in Goldsboro, NC............ 184 Figure E-11. Display of OP Concentrations at WCC Greenroof in Goldsboro, NC.......... 185 Figure E-12. Display of OP Mass Loadings at WCC Greenroof in Goldsboro, NC. .......... 185 Figure G-1. Display of TKN Concentrations at Nature Center Greenroof in Kinston, NC. 225 
Figure G-2. Display of $\mathrm{NO}_{3}-\mathrm{NO}_{2}$ Concentrations at Nature Center Greenroof in Kinston,

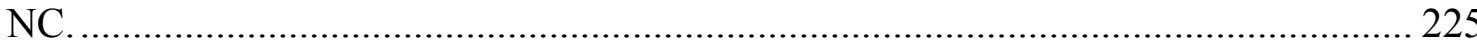

Figure G-3. Display of TN Concentrations at Nature Center Greenroof in Kinston, NC. .. 226

Figure G-4. Display of $\mathrm{NH}_{3}$ Concentrations at Nature Center Greenroof in Kinston, NC.. 226

Figure G-5. Display of TP Concentrations at Nature Center Greenroof in Kinston, NC... 227

Figure G-6. Display of OP Concentrations at Nature Center Greenroof in Kinston, NC.... 227

Figure J-1. Display of Average TKN Concentrations in All Four Soil Media................... 255

Figure J-2. Display of Average $\mathrm{NO}_{3}-\mathrm{NO}_{2}$ Concentrations in All Four Soil Media............. 255

Figure J-3. Display of Average TN Concentrations in All Four Soil Media..................... 256

Figure J-4. Display of Average $\mathrm{NH}_{3}$ Concentrations in All Four Soil Media.................... 256

Figure J-5. Display of Average TP Concentrations in All Four Soil Media...................... 257

Figure J-6. Display of Average OP Concentrations in All Four Soil Media...................... 257

Figure J-7. Display of Nitrogen Concentrations in ERTH HydRocks Soil Mix (5\%

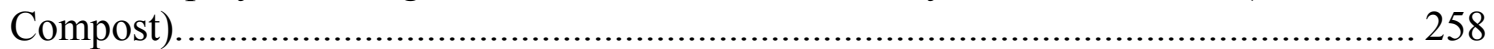

Figure J-8. Display of Phosphorus Concentrations in ERTH HydRocks Soil Mix (5\%

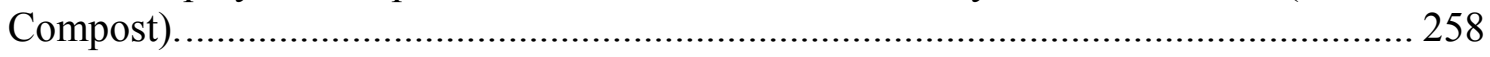

Figure J-9. Display of Nitrogen Concentrations in Carolina Stalite Soil Mix (15\% Compost).

Figure J-10. Display of Phosphorus Concentrations in Carolina Stalite Soil Mix (15\%

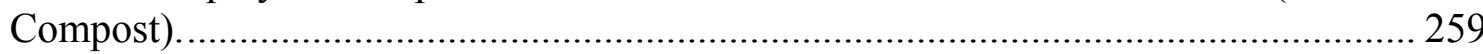

Figure J-11. Display of Nitrogen Concentrations in ERTH Light Soil Mix (33\% Compost).

Figure J-12. Display of Phosphorus Concentrations in ERTH Light Soil Mix $(33 \%$

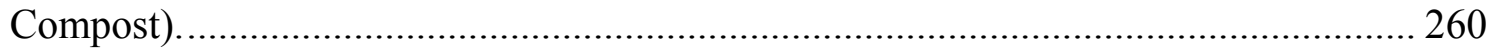

Figure J-13. Display of Nitrogen Concentrations in Play Sand....................................... 261

Figure J-14. Display of Phosphorus Concentrations in Play Sand. .................................. 261

Figure L-1. Display of Average Plant Growth Data for each Plant Species in $50 \mathrm{~mm}$ (2 in.) and $100 \mathrm{~mm}$ (4 in.) Soil Media Depths.................................................................... 279 


\subsection{INTRODUCTION}

Recent reports by the United States Environmental Protection Agency (EPA) indicate that stormwater runoff is one of the major sources of water quality impairment in water bodies across the United States (U.S. EPA, 1994; U.S. EPA, 2002a). The EPA classifies stormwater runoff as runoff from impervious surfaces including streets, buildings, lawns, and other paved areas that enter a sewer, pipe, or ditch before discharging into surface waters (U.S. EPA, 1994). Pollutants found in stormwater runoff range from oils and greases to nutrients and sediments.

In urban environments, because less pervious land space is available to allow precipitation to infiltrate into the ground, the volume of runoff and the velocity of runoff are also causes for concern. The volume of runoff creates flash floods during intense rainfall events, quite common during the summer months in North Carolina. When this large volume of water channels through the network of storm sewer pipes, it can cause stream bank erosion when the runoff is directed to nearby streams and rivers. The peak flows of the stormwater runoff can also scour stream beds and cause further degradation of urban water bodies.

Many stormwater best management practices (BMPs), such as wet ponds, constructed wetlands, and bio-retention areas, are currently in practice throughout North Carolina and the United States to retain and detain stormwater runoff and improve the water quality of stormwater runoff. Many of these BMPs require a large amount of surface area, such as wet ponds and wetlands, and in congested, urban environments with high land costs, large amounts of surface area are often times unavailable for BMP construction. 
Recently, smaller scaled BMPs, such as the bio-retention area and the sand filter, have been used in these environments because of the small surface area requirement and high pollutant reduction rates. Pervious pavement has also become more prominent because, unlike impervious pavement, the precipitation and stormwater runoff that enters the area of the pervious pavement infiltrates into the ground instead of creating more runoff.

A new BMP innovation is the greenroof. A greenroof is a layer of drainage material and soil media placed upon a rooftop and planted with vegetation. The greenroof behaves much like a sponge; precipitation falls upon the roof and the soil media absorbs the precipitation until it cannot hold any more water, precipitation then drains from the greenroof. Precipitation that is retained by the greenroof is temporarily stored within the soil media and is then either taken up by the vegetation through transpiration or it is released into the atmosphere through evaporation.

Greenroofs have the potential to significantly reduce the volume of runoff from a rooftop and significantly reduce the peak flow of runoff from a rooftop. In addition to these stormwater benefits, greenroofs offer a number of other benefits including reduction of the urban heat island effect, providing an additional layer of insulation and thereby reducing building heating and cooling costs, restoration of lost habitat, and extending roof life. However, while an abundance of research has been performed in Europe, little data is available in the United States to demonstrate the many benefits of greenroof implementation. Therefore, this research intends to provide information focusing on the implementation of greenroofs as a stormwater BMP. 


\subsection{LITERATURE REVIEW}

The first section of this chapter provides background information pertaining to stormwater regulations and stormwater pollution and an introduction to stormwater best management practices (BMPs). The next segment of this chapter is devoted to greenroof history, design and function, and benefits of their implementation. The final section introduces the focus of this research and its necessity to the greenroof industry of North America.

\subsection{INTRODUCTION OF STORMWATER}

Water quality across the globe has decreased sharply ever since the Industrial Age. As more factories were constructed, water bodies were filled with more pollution. The phrase "the solution to pollution is dilution" was coined and the popular thought was that if you release pollutants into larger bodies of water, then the effects of pollution would not be felt. The disastrous effects of practices similar to this can be seen in the water bodies across the world today. In the mid to late twentieth century, the United States Environmental Protection Agency (EPA) began to take action to improve the water quality in the United States. Early regulations primarily focused on point source pollutants, or pollutants from a known source such as a factory. The 1972 Clean Water Act (CWA) concentrated on point source pollutants, prohibiting the discharge of polluted waters unless the discharge was authorized by a National Pollutant Discharge Elimination System (NPDES) permit (U.S. EPA, 1996). However, in the second half of the twentieth century, data illustrated that point source discharges were not the only pollutant source degrading our nation's waters. In the late 1980s, stormwater discharges were recognized as an important pollutant source. In 1987, 
congress amended the CWA to also require NPDES permits for stormwater discharges. Based on 1992 reports from the EPA, urban runoff was the second leading source of water quality impairment in lakes and estuaries and urban runoff was the third largest source of water quality impairment in streams and rivers (U.S. EPA, 1994). The EPA's 2000 National Water Quality Inventory reported that the primary sources of pollution affecting the United States shoreline included urban runoff, storm sewers, and non-point source runoff. Nonpoint pollutant sources include atmospheric deposition, contaminated sediments, and land use activities that generate polluted runoff, such as construction and agriculture (U.S. EPA, 1994).

The NPDES Storm Water Program was developed by the EPA to improve the quality of stormwater runoff; this program would be implemented across the United States in two separate phases. Phase I of the NPDES Storm Water Program was developed in 1990 and established the initial permit applications for stormwater discharges within industrial activity, construction activity disturbing more than 5 acres, and municipal separate storm sewer systems (MS4s) serving areas with populations greater than 100,000 (U.S. EPA, 1996). While the initiation of the Phase I Storm Water Program has improved the quality of many of our country's waters, water pollution still remains a significant issue. In 1996, the National Water Quality Inventory determined that approximately $40 \%$ of the surveyed U.S. waters were still impaired by pollution, not satisfying current water quality standards (U.S. EPA, 2000). While the first phase of the NPDES Storm Water Program focused on larger municipalities and larger construction activities, the second phase produced more unyielding standards and focused on smaller municipalities and construction locations. The Phase II Final Rule of the NPDES Storm Water Program required NPDES permits for small 
construction sites disturbing areas between 1 and 5 acres and MS4s serving populations of less than 100,000 (U.S. EPA, 2000). As a result of these regulations, all storm sewer systems in all municipalities are required to obtain NPDES permits.

In 2000, thirteen years after the initial stormwater regulations were in effect, states, tribes, territories, and interstate commissions reported that approximately $40 \%$ of streams, $45 \%$ of lakes, and $50 \%$ of estuaries that were assessed in the United States were not clean enough to support such uses as fishing and swimming (U.S. EPA, 2002a). This is clear evidence that while the United States has taken many important steps to improve the water quality of the country's waters, there is still much work to be done.

\subsection{Sources ANd Pollutants of Stormwater}

The 1992 Report to Congress characterizes stormwater runoff as runoff from impervious surfaces that enter a sewer or ditch before discharging into surface waters (U.S. EPA, 1994). In the 2000 National Water Quality Inventory, the EPA reported that runoff from agricultural lands, municipal point sources, and hydrologic modifications were the primary sources of water quality impairment (U.S. EPA, 2002a). Other sources of non-point source pollution are atmospheric deposition, in-place contaminants, and natural sources (U.S. EPA, 1994). The pollutants found in stormwater runoff range from pesticides and fertilizers to oils and petroleum products to construction chemicals, salt, and sediment.

Two pollutant areas of concern are the high nutrient loadings and high peak flows associated with rainfall events. Excess nutrient loads in surface waters are associated with algae blooms and fish kills along the eastern seaboard of the United States, especially in the 
mid-Atlantic and southeastern states. High nutrient loads are primarily due to urban runoff and agricultural use. One study, investigating nutrient loads from various land uses in a multiuse urban watershed within the Upper Neuse River Basin of North Carolina, revealed the impact of development on nutrient pollution in stormwater runoff. The average total nitrogen, phosphorus, and sediment of four different urban land uses was, respectively, $269 \%, 302 \%$, and $256 \%$ greater than the exports from a wooded site representing predevelopment conditions (Line et al., 2002).

The increase of impervious area due to urbanization also increases the volume and rate of urban stormwater runoff. High peak flows from intense rainfall events result in increased stream flow velocities, which can scour stream beds and increase stream bank erosion. Another concern is illicit discharges from sanitary sewer lines, thus increasing fecal coliform levels and creating a public health issue. The result of these pollutants impacting water bodies can be seen in fish kills, contamination of drinking supplies, and the destruction of wildlife habitats.

One of the pollutant sources associated with heavy rainfall events is combined sewer overflows (CSOs). Slone and Evans (2003) define a combined sewer system as a municipal wastewater collection system that conveys both sanitary wastewater and stormwater through the same pipe system to a municipal wastewater treatment plant. Many newly developed cities have separate sanitary sewers and storm sewer lines; however, older cities, such as New York City, still contain areas that are served by a combined sewer system (Osmundson, 1999). Combined sewer systems typically do not cause environmental problems for nearby waterways, but during intense rainfall events water flow in CSOs may exceed the wastewater 
plant's capacity (Slone and Evans, 2003; Bas and Baskaran, 2003). As a result of the CSO, raw, untreated human waste is emptied into nearby waterways.

Another stormwater pollutant source associated with rainfall events is the actual rainfall. Studies have revealed that a considerable portion of nitrogen found in stormwater runoff is from atmospheric deposition of nitrogen in rainfall (Line et al., 2002; Wu et al., 1998). Research investigating nutrient loads determined that in several different land uses, the rainfall contained significant concentrations of nitrogen loadings. For example, nutrient loads from residential land use indicated that atmospheric deposition contributed $91 \%$ of the nitrate loads and $38 \%$ of the total nitrogen loading found in stormwater runoff; nutrient loads from wooded land use indicated that $98 \%$ of the total nitrogen found in the runoff resulted from atmospheric deposition (Line et al., 2002). Studies in Charlotte, North Carolina found that atmospheric deposition accounted for $10-30 \%$ of runoff pollutant loadings for phosphorus and total suspended solids, $30-50 \%$ of runoff pollutant loadings for copper and lead, and 70-90\% of runoff pollutant loadings for nitrogen (Wu et al., 1998). Studies in Monroe County, New York have also demonstrated the amount of nutrients found in atmospheric deposition. An estimated $65 \%$ of the total phosphorus and nearly $100 \%$ of the total Kjeldahl nitrogen entering Irondequoit Creek basin was due to atmospheric deposition (Johnston and Sherwood, 1996). Large scale animal production is also a contributing factor to atmospheric deposition. The high concentration of animal production in eastern North Carolina has contributed to higher concentrations of total nitrogen in rainfall at locations within $3 \mathrm{~km}$ (1.9 mi) of animal production systems (Robarge and Cure, 1999). 


\subsubsection{Pollution of the Southeast and Mid-Atlantic States}

The EPA has reported that the second leading source of estuary impairment in the MidAtlantic region is stormwater runoff (U.S. EPA, 2002a). Excess nutrients found in urban runoff have been identified as a key factor in the decline of the Chesapeake Bay (MDE, 2000). Within the past ten years, fish kills have become a significant problem affecting fin fish and shellfish along the eastern seaboard. Toxic Pfiesteria dinoflagellates have been implicated as causative agents in many major fish kills affecting thousands of fish in the midAtlantic and southeastern states (Burkholder and Glasgow, 1997). These Pfiesteria outbreaks have not only had an effect on aquatic life; the Pfiesteria species also have had a harmful effect on humans. Several Laboratory workers handling Pfiesteria piscicida cultures experienced effects including eye irritation, respiratory distress, stomach cramping, vomiting, and short-term memory loss (Burkholder and Glasgow, 1997). Public health also became an issue during these fish kills as members of the public began to experience effects similar to those experienced by the lab workers (Burkholder, 1998).

The coast of North Carolina is protected from the Atlantic Ocean by a series of barrier islands known as the Outer Banks which enclose the Albemarle-Pamlico Estuarine System. As a result, several North Carolina estuaries remain poorly flushed and are eutotrophic due to nutrient inputs. These nutrient rich waters provide an environment where toxic dinoflagellates can reach high densities (Mallin et al., 2000). Lab studies to investigate the behavior of these Pfiesteria species have shown that high concentrations of nutrients can also result in higher densities of Pfiesteria piscicida zoospores (Burkholder and Glasgow, 1997). Burkholder (1998) also notes that recently discovered toxic or harmful taxa have been correlated with cultural eutrophication in poorly flushed estuaries and coastal waters. 
As a result of the intensity of the fish kills and their correlation to high nutrient loads in estuarine waters, the State of Maryland has aspirations of reducing the amount of nutrients found in stormwater runoff. Maryland is now committed to reducing the tributary nutrient loadings by $40 \%$ as part of the Chesapeake Bay restoration effort (MDE, 2000). Urbanization and large scale animal production are major sources of non-point source pollution in coastal waters (Mallin et al., 2000). Rapid urbanization of coastal areas has also led to the closing of shellfish beds in North Carolina, because in many locations, stormwater runoff is channeled directly into shellfish beds without any pretreatment (Mallin et al., 2000). In an effort to reduce the amount of nutrients entering estuarine waters, the North Carolina Environmental Management Commission set a goal of reducing the nitrogen load into the Neuse River Estuary by 30\% (NCDENR, 1998).

In 1997, the North Carolina Environmental Management Commission developed the Neuse River Nutrient Sensitive Waters Management Strategy, commonly known as the Neuse Rules. The main objective of these rules was to reduce nitrogen runoff from stormwater runoff in urban areas. Similar rules have been applied to the Tar-Pamlico River Basin, both the Neuse River and the Tar-Pamlico River flow into the Pamlico Sound. The Tar-Pamlico Rules established nutrient reduction goals of 30\% in nitrogen loadings from 1991 levels and holding phosphorus loading to 1991 levels in non-point source runoff (NCDENR, 2001). As more local governments are required to improve stormwater quality through reducing nutrient loads reaching river basins in North Carolina, the installation of stormwater best management practices (BMPs) will be a more common occurrence across the state. Stormwater BMPs are used to attenuate stormwater runoff and reduce the 
concentration and loading of many pollutants found in stormwater runoff including, total suspended solids, nitrogen, phosphorus, and heavy metals.

\subsubsection{Stormwater Best Management Practices (BMPs)}

Within the past decade, stormwater BMPs have been developed to aid in the improvement of water quality in stormwater runoff. Stormwater BMPs include a variety of practices, such as wet and dry detention ponds, sand filters, bio-retention areas, and constructed wetlands. Research has been conducted throughout the United States and developed world to evaluate and determine the water quality benefits of BMPs.

Wet ponds function by detaining stormwater runoff for a short period of time, before the runoff is allowed to flow out of the pond. While stormwater is temporarily detained in the wet pond, the wet pond acts as a large sedimentation basin and allows sedimentation to occur; thus, fewer pollutants are present in the pond's effluent. A study of annual removal rates in two wet ponds in North Carolina has shown total suspended solids (TSS) removals up to $56 \%$, total phosphorus (TP) removals up to $41 \%$, and total nitrogen (TN) removals up to $36 \%$ (Borden et al., 1998). One of the ponds studied also demonstrated higher reduction rates in the summer months. When three urban wet detention ponds were researched in the North Carolina piedmont, one pond demonstrated average pollutant removal efficiencies of $62 \%$ for TSS, $21 \%$ for total Kjeldahl nitrogen (TKN), 36\% for TP, and $52 \%$ for iron (Wu et al., 1996).

Constructed stormwater wetlands perform much like a wet pond. The wetland typically has several inches of ponded water, instead of several feet of ponded water in the wet pond, and as the runoff is temporarily detained in the wetland, pollutants settle out of the 
stormwater runoff. Wetlands often have a forebay, which allows much of the TSS to settle before reaching the areas of the wetland where the majority of the vegetation is located. In a summary of BMPs used in North Carolina, Hunt (1999) reported higher pollutant removal rates in constructed stormwater wetlands than in wet ponds. Wet ponds typically have TSS removal rates of $70 \%$ and nitrate as nitrogen removal rates of $20 \%$; constructed wetlands typically have TSS removal rates of $80 \%$ and nitrate as nitrogen removal rates of 40 to $45 \%$ (Hunt, 1999). Research of an in-stream constructed wetland in Edenton, North Carolina revealed pollutant concentration removal rates of $60 \%$ for nitrate as nitrogen, $20 \%$ for total nitrogen, 30\% for ammonia as nitrogen (Bass, 2000). This in-stream constructed wetland received runoff from several land uses, including agricultural, intense commercial development, and urban sources.

The function of a bio-retention area is similar to the wetland. While the bio-retention area usually has no ponded water present, it does allow shallow ponding during rain events. Water is ponded on the surface for only a short period of time before it infiltrates into the soil. Bio-retention lab experiments in Maryland have shown high reductions of copper, lead, and zinc concentrations $(>92 \%)$, and moderate reduction of phosphorus $(\sim 80 \%)$, TKN (65 to 75\%), and ammonium (60 to 80\%) (Davis et al., 2001). Davis et al. (2001) also noted that higher phosphorus and TKN removal is possible with greater soil depths in bio-retention areas. Research has also been performed focusing on engineered bio-retention areas designed specifically for higher denitrification rates. In this study, Kim et al. (2003) reports nitrate nitrite removal rates of up to $80 \%$. The removal rates of metal and nutrient pollution in stormwater runoff show bio-retention to be an excellent BMP. In a North Carolina field study of bio-retention areas, Hunt (2003) observed 40\% reductions in mass loadings of TN 
from two conventionally drained bio-retention areas. Results from this research study of multiple field sites also determined the importance of media selection for bio-retention areas. Analysis of the bio-retention outflow from the bio-retention areas indicated that soil media with higher soil test phosphorus (STP) levels would have higher phosphorus loadings in the outflow; in some cases, it was observed that the bio-retention area had more phosphorus present in the outflow than in the inflow to the BMP (Hunt, 2003).

Analysis of the design of wet ponds, constructed stormwater treatment wetlands, and bio-retention areas illustrates the evolution of the BMP. Wet ponds have the ability to serve larger watersheds and allow significant reduction of sediment pollution through sedimentation processes. Wet ponds also serve as detention basins by capturing stormwater runoff and, therefore, reducing the peak flow to streams during rain events. Constructed stormwater treatment wetlands offer greater nutrient reduction than wet ponds and typically serve smaller watersheds. Runoff peak flows are also reduced as runoff is stored in wetlands for a short period of time before outflow occurs. Bio-retention areas on average serve smaller watersheds than wetlands and also offer increased nutrient and metal reduction from stormwater runoff. By allowing water to pond for approximately 48 hours before draining into the soil, bio-retention areas also provide some moderate peak flow reduction (Hunt and White, 2001). As the wet pond evolved into the wetland, the depth of water decreased and the amount of vegetation increased in the BMP. The wetland then evolved further into the bio-retention area, allowing for short-term, shallow ponding and the bio-retention area is able to support vegetation that lives in drier conditions.

While a major focus of the performance of the typical BMP is pollutant reduction, another significant attribute is peak flow reduction. Because the wet pond, wetland, and bio- 
retention area all store runoff for a period of time before outflow from the BMP occurs, all these BMPs offer some benefit of peak flow reduction. It has been documented in Washington and California that increased sediment loads within watersheds can be directly linked to increased discharge rates into streams causing stream bank erosion (Nelson and Booth, 2002; Trimble, 1997). The increased peak discharge rates are a result of the increase of runoff due to urbanization. Sedimentation loads and peak flows decrease with the implementation of these BMPs, resulting in lower sediment loads in surface waters.

Bio-retention areas and permeable pavement are two BMPs that are very applicable in high land-cost sites because of the small surface area of the bio-retention areas and the practical use of the surface area of permeable pavements. Permeable pavement is a relatively new BMP; this BMP has the ability to significantly reduce runoff peak flows as the stormwater runoff seeps into the voids of the permeable layer. A wide variety of permeable pavement designs are currently available ranging from grass pavers to permeable concrete. Each design has the same fundamental objective: to provide a permeable layer that is strong enough to endure vehicle traffic. Research conducted in Washington revealed that virtually all the rainfall measured during several months in 2001 and 2002 infiltrated through the permeable pavement (Brattebo and Booth, 2003). Brattebo and Booth (2003) also reported a delay of approximately 1 hour for the runoff peak flow. Research also shows significantly lower levels of copper, zinc, and motor oil present in runoff infiltrated through permeable pavement when compared to asphalt runoff (Brattebo and Booth, 2003). Another study evaluating four different permeable pavements showed no significant difference between the pavements and, again, showed virtually no runoff from the permeable pavements (Booth and Leavitt, 1999). This BMP is highly applicable in high land-cost areas because it can replace 
the imperviousness of an asphalt parking lot with a pervious parking lot. No additional surface area would be needed for stormwater management controls.

Pervious pavements lead the way towards greenroof implementation. While pervious pavements can transform a previously impervious area into a pervious area on the ground, greenroofs can also, in effect, do the same for a rooftop. Through shallow soil media depths, typically less than $152 \mathrm{~mm}$ (6 in.), extensive greenroofs have the capacity to retain significant portions of rainfall events, thus, reducing the volume of stormwater runoff from a previously impervious rooftop area. The greenroof is also the result of pervious pavement and bioretention evolution. As the bio-retention BMP evolved to support vegetation in drier conditions than the wetland and the wet pond and shallow ponding was incorporated into bioretention design; the greenroof design supports vegetation in conditions drier than the bioretention area and does not allow for ponding of water. Extensive greenroofs also act similar to a pervious pavement area in that the soil media is very porous and, after the media is saturated with rainfall, water flows through the media and is considered to be runoff from the rooftop. Greenroofs can almost be envisioned as a layer of permeable pavement atop a roof which supports vegetation.

\subsubsection{StormWATER Programs}

Many states and city municipalities have initiated their own stormwater programs to focus on specific areas that require extra attention. Maryland is one of the leading states in developing stormwater programs statewide. Maryland provides a user friendly manual to help developers select appropriate BMPs for their development site and provides guidance on factors to consider when deciding where to locate the BMPs (MDE, 2000). A significant 
portion of the Maryland stormwater manual is devoted to design guidelines and design examples for a variety of BMPs.

The State of Maryland has also developed a program with stormwater incentives. A series of six stormwater credits are provided for designers who use the following site planning techniques: natural area conservation, disconnection of rooftop runoff, disconnection of non-rooftop runoff, sheet flow to buffers, open channel use, and environmentally sensitive development (MDE, 2000). The credit serves to reduce the area of imperviousness a site will contribute to runoff volume. For example, if rooftop runoff is successfully disconnected and directed to a pervious area, then the rooftop area can be deducted from the amount of impervious area of the development site, resulting in less runoff volume to account for from the development site. The City of Portland has a similar stormwater program that offers benefits for reducing the amount of impervious areas on new or redeveloped sites. An example of two mechanisms used to reduce the amount of impervious area is the use of contained planter boxes or pervious pavement systems (Environmental Services et al., 2002).

In North Carolina, regulations are being established to encourage further treatment of stormwater runoff. As a result of the Phase II Final Rule of the NPDES Stormwater Program, 123 municipalities within North Carolina must develop a stormwater program. For example, the North Carolina Environmental Management Commission developed the Neuse River Nutrient Sensitive Waters Management Strategy which applied to the ten largest cities and five most populous counties in the Neuse River Basin (NCDENR, 1998). Each affected government must implement a local stormwater plan to include the following: (1) Reviewing and approving stormwater management plans for new development, (2) Educating the public, 
(3) Identifying and removing illegal discharges, and (4) Identifying sites where water quality management projects can be inserted into existing development (NCDENR, 1998). These rules reflect the goal of reducing the amount of nitrogen reaching the Neuse River in runoff (NCDENR, 1998). As a result of the Tar-Pamlico Rules, six municipalities and five counties in the Tar-Pamlico River Basin are required to develop and implement stormwater programs (NCDENR, 2001). Both the Neuse Rules and the Tar-Pamlico Rules require the affected governments to reduce the nitrogen loadings found in stormwater runoff by $30 \%$; the TarPamlico Rules also require affected governments to reduce phosphorus loadings to 1991 levels (NCDENR, 1998; NCDENR, 2001).

Recent publications have also presented decision makers with general economic information to help guide developers in their decision of which BMP is best for their watershed size, land use, and pollutant type (Wossink and Hunt, 2003). Wossink and Hunt (2003) present pollutant removal benefits and an economic comparison of wet ponds, wetlands, sand filters, and bio-retention areas in their report. The study showed that as land values increased, the more likely expensive BMPs, such as sand filters and bio-retention areas, were to be installed.

\subsection{BMP INNOVATION: THE GREENROOF}

\subsubsection{GREENROOFs OF THE PASt AND FUture}

Evidence of the presence of greenroofs, or roof gardens, has been found almost since the beginning of architecture, from the ziggurats of ancient Mesopotamia to the gardens of the 
Mont-Saint-Michel Monastery in France (Osmundson, 1999). Figure 2-1 illustrates an ancient burial tomb in Ireland that is covered by a greenroof.

Sod roofs were constructed for the more practical purpose of insulation in Scandinavia centuries ago. A roof would be covered with soil and planted with grasses

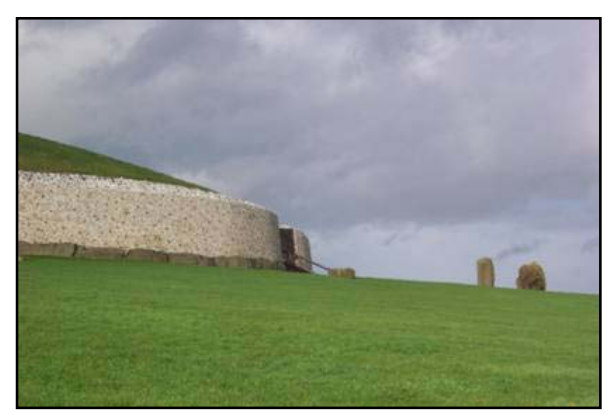

Figure 2-1. Ancient Greenroof in Ireland. and other plants to stabilize the soil; this provided homes with an extra layer of insulation on the rooftop (Osmundson, 1999; Lindhqvist, 2003; Emilsson, 2003). Grant et al. (2003) notes that the settlers of the American mid-west constructed houses completely made of turf. Roof gardens became fashionable and elegant in the castles and manor houses of Germany at the turn of the $18^{\text {th }}$ century (Herman, 2003). From there, the popularity of roof gardens grew throughout Europe. Drawings and plans of the Moscow Kremlin in Russia during the $19^{\text {th }}$ century illustrate the fortress adorned with expansive roof gardens (Osmundson, 1999; Grant et al., 2003). Osmundson (1999) also notes that roof gardens atop hotels were seen around the turn of the $20^{\text {th }}$ century in New York City. The evolution of the greenroof led to the design of the first combination plaza/subterranean garage in the United States: Union Square in San Francisco, California in the early 1940s (Osmundson, 1999).

The greenroof had evolved from the practical application of insulation to a sign of elegance in castles and hotels. Now, greenroofs would again be utilized for their practical benefits. In the 1950 s and 1960 s, studies in Germany investigated vegetation found growing on standard, gravel roofs and this led to experiments that proved low-growing Sedum plants could establish themselves on shallow, gravel-covered rooftops (Herman, 2003). From there, 
research on the practical benefits of extensive greenroof installation began. Herman (2003) reported that in the last 25 years, the presence of greenroofs in Germany has increased due to the benefits of greenroof installation. This increase in greenroof installation may be due to strict policy enforcement of "greening" new developments and financial incentives for greenroof construction (Grant et al., 2003). For example, the City of Esslingen, Germany will pay $50 \%$ of the cost of greenroof installation and $17 \%$ of German cities offer reduced sewage disposal chargers for developments with greenroofs (Herman, 2003; Grant et al., 2003). In addition, laws in Switzerland require $25 \%$ of all new commercial developments to be "greened" in an attempt to maintain microclimates (Grant et al., 2003).

As cities continue to grow across the world, greenroofs may begin to play a more important role. In the past, roof gardens were a symbol of elegance and wealth, built to serve as a place of refuge, high above city streets below. Now, greenroofs are being built to replace some of the green space taken away by development in ultra-urban areas. Greenroofs of today can serve as an environmental refuge for people, producing new habitat for plants, birds, and insect species. With a greater environmental concern for our cities, greenroofs of tomorrow may provide greater benefits to the environment, such as reducing stormwater runoff and reducing the urban heat island effect.

\subsubsection{GREENROOF DESIGN AND FUNCTION}

There are two distinct types of greenroofs: intensive and extensive greenroofs. Extensive greenroofs support low-growing succulents, such as Sedums and mosses, and have soil media depths ranging from less than $25 \mathrm{~mm}$ (1 in.) to $150 \mathrm{~mm}$ (6 in.); Figure 2-2a is an example of an extensive greenroof. Little maintenance is necessary for extensive greenroofs. Plant 
selection during the design process of the greenroof should ensure that plant survival will be possible with rainfall as the sole source of irrigation; however, some developers do irrigate the greenroof initially to help establish the vegetation. Irrigation is usually not necessary. Exceptions typically arise during a drought or when the greenroof vegetation is in its initial growth stages. Typical maintenance includes weeding in the spring and summer months, and clearing the drains of any obstructions, such as leaf litter and plant roots.

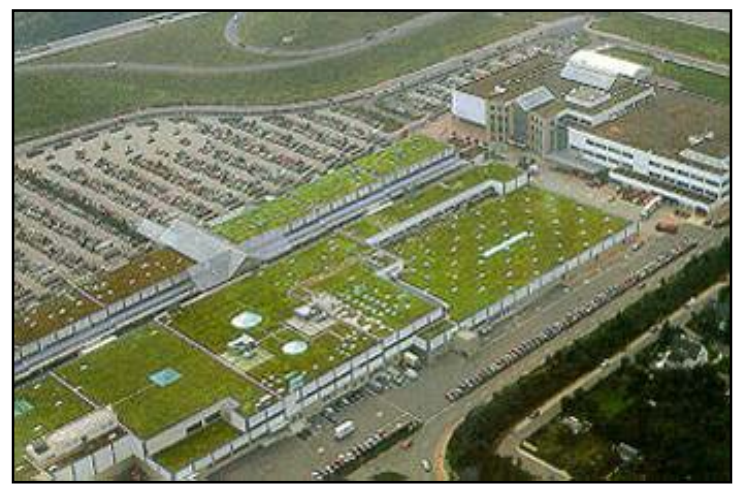

(a)

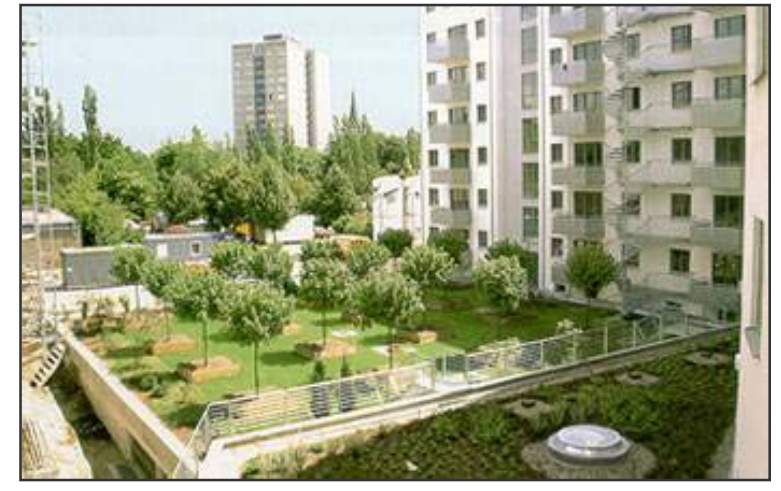

(b)

Figure 2-2. (a) Extensive Greenroof near Chemnitz, Germany (Courtesy of ZinCo GmbH). (b) Intensive Greenroof near Berlin, Germany (Courtesy of ZinCo $\mathrm{GmbH}$ ).

Intensive greenroofs can support much more elaborate vegetation, such as trees and shrubs; Figure $2-2 b$ is an example of an intensive greenroof. However, due to the more intense vegetation, deeper media depths are required; intensive greenroof soil media depths can range from $150 \mathrm{~mm}(6 \mathrm{in}$.$) to 1 \mathrm{~m}(3 \mathrm{ft})$. Intensive greenroofs are almost always more expensive than extensive greenroofs, due to the increased structural reinforcement that is required for the additional weight, additional soil media, and increased maintenance. Unlike the extensive greenroofs, regular irrigation is usually required for the intensive greenroofs; additional fertilization' may also be required to ensure plant survival in the rooftop 
environment. Because a more diverse population of vegetation is possible in intensive greenroofs, these greenroofs may be more capable of re-creating natural habitat.

The profile of a typical greenroof is somewhat complex, containing many different layers. Please refer to Figure 2-3. The bottom layer of the greenroof is the roof construction. The roof construction must have a waterproofing layer so no water can penetrate through the roofing material. Above the waterproofing layer lies a moisture retention protection mat (referred to in Figure 2-3a as the "Protection Layers"). The moisture retention protection mat serves as a root barrier and it also retains a portion of the rainwater for later uptake by the vegetation. Root barriers often contain copper sulfate to retard plant growth, thus preventing roots from penetrating the water proofing membrane. Above the protection layer is the drainage layer. A wide variety of drainage layers are available from various green roofing companies. Some drainage layers simply provide drainage canals for the rainwater; however, others are equipped with miniature cups for water storage (as depicted in Figure 2-3b). Water is stored within the drainage layer for a period of time before it is absorbed into the media layer to be taken up by the plant roots. Above the drainage layer, a filter fabric mat is placed to prevent small particles from entering the drainage layer and possibly obstructing the drainage layer. The media layer consists of a lightweight greenroof soil media, typically less than $25 \mathrm{~mm}$ ( 1 in.) to $150 \mathrm{~mm}$ (6 in.) for an extensive greenroof. The vegetation layer consists of drought-resistant plants that can survive in the rooftop environment. The profile of an intensive greenroof would be very similar to that of the extensive greenroof, but would have deeper soil media, larger species of vegetation, and possibly more extensive protection layers. 


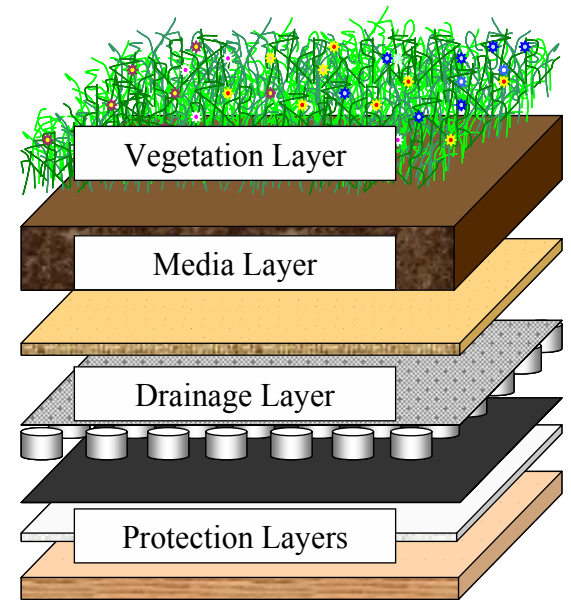

(a)

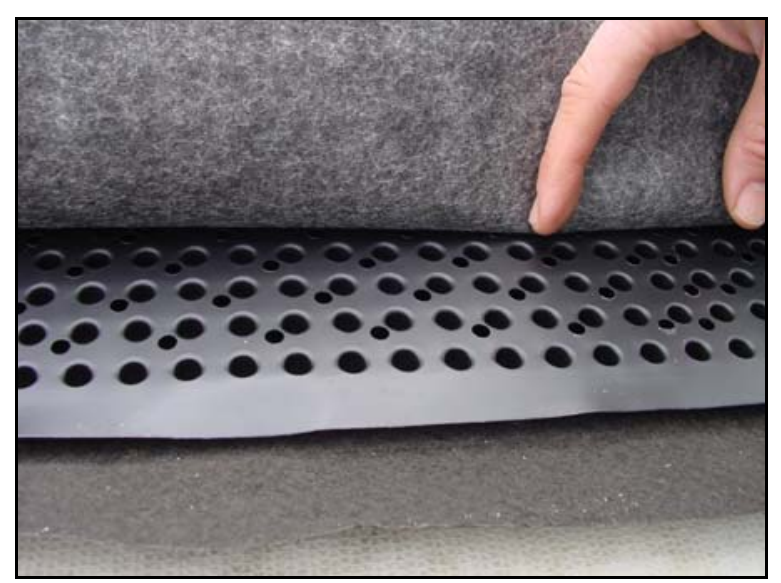

(b)

Figure 2-3. (a) Typical Extensive Greenroof Profile. (b) Close-up View of Drainage Layer with Water Storage.

The construction procedure for extensive greenroofs and intensive greenroofs are relatively the same; however, there may be small variations. First, the roof of the building should be fully constructed with enough load bearing structures to support the additional weight of the drainage layers, soil media, and vegetation. For example, depending on the type of drainage layer and soil media selected, the installation of an extensive greenroof could add $1436 \mathrm{~N} / \mathrm{m}^{2}\left(30 \mathrm{lbs} / \mathrm{ft}^{2}\right)$ of additional weight on the roof. Due to the additional weight of the greenroof, load bearing structures for the building may need to be modified. For instance, on an outdoor shelter consisting of a $42 \mathrm{~m}^{2}\left(450 \mathrm{ft}^{2}\right)$ roof supported by columns with no walls, the initial weight of the roof, without the greenroof, could be supported by seven $100 \mathrm{~mm}$ by $100 \mathrm{~mm}$ (4 in. by 4 in.) columns. With the added weight of the greenroof materials installed, the greenroof could be sufficiently supported by seven $152 \mathrm{~mm}$ by 152 mm (6 in. by 6 in.) columns instead of the previous sized columns. 
After the roof is constructed, the water proofing layer is placed and then sealed. It is essential to first test the waterproofing layer to make certain the roof will not leak. In many retrofit locations, the waterproofing layer will already be in place. With the roof fully constructed and the water proofing layer sealed, construction of the actual greenroof begins. Above the water proofing membrane lie the protection and drainage layers of the greenroof. The protection and drainage layers include the moisture retention mat, root barrier, filter fabric, and drainage medium. Various designs have been produced for these layers; some companies offer one product with the root barrier, filter fabric, and drainage medium combined, while others provide each layer separately. Whether these different systems are combined into one product or several, each layer is spread across the surface of the roof. Typically, the moisture retention mat is laid first, followed by the root barrier and the drainage medium. After all the protection and drainage layers have been installed, the soil media can be spread atop the roof. Figure 2-4 illustrates how the drainage layers are laid across the rooftop during the greenroof construction process.

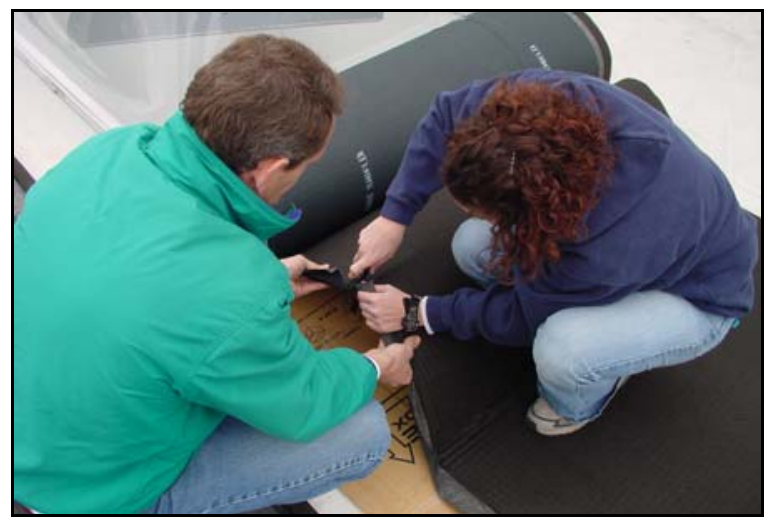

(a)

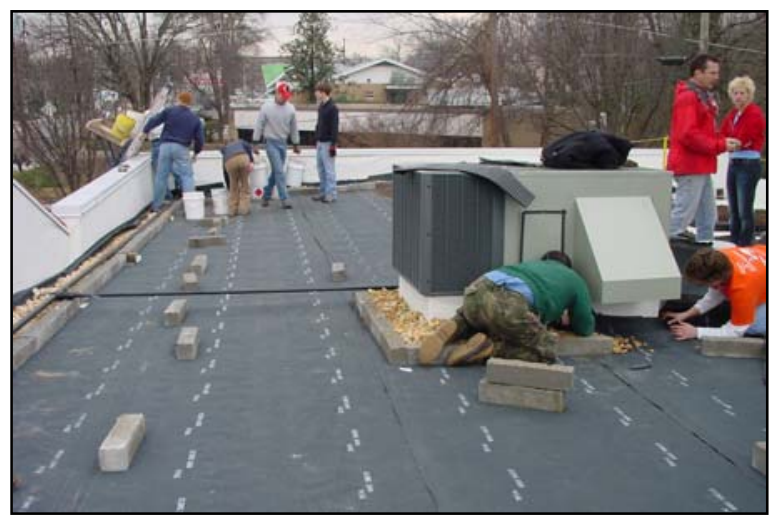

(b)

Figure 2-4. (a) Two volunteers cutting protection layers for placement atop the roof during greenroof installation in Raleigh, $\mathrm{NC}$ in 2003. (b) View of protection layers covering rooftop before soil media is spread during greenroof installation in Raleigh, NC in 2003. 
German greenroof construction companies have developed pumping mechanisms for transporting the soil media to the rooftops. This is a much more advanced method than what is available in most areas of the United States. In North Carolina, more primitive methods were used to transport the soil media to the roof surface. On the first greenroof research site constructed by North Carolina State University (NCSU) in 2002, a series of buckets and pulleys were used to hand-lift the soil media to the rooftop. However, in 2003 a mechanical roof shingle lift was used to lift seven to eight buckets at a time to the roof surface at the third greenroof constructed for NCSU research. While lifting the soil media in buckets to the rooftop by a shingle lift may be more time-consuming than having the media pumped to the rooftop, this may be more cost-effective for smaller scaled greenroofs. Figure 2-5 illustrates the different methods used to transport the soil media to the rooftop. After the soil media layer is in place, the vegetation can be planted. Vegetation can be planted in various forms such as seeds, roots, plugs, or vegetation mats. As more greenroofs are constructed in the United States, more efficient methods for transporting the soil media may be developed.

The successful design of a greenroof is dependent upon the collaboration of the drainage layer, soil media, and vegetation. The vegetation present on the greenroof survives through the intense heat of the rooftop environment because rainwater is stored within the soil media and drainage layer for a period of time. During a rain event, precipitation falls onto the greenroof and is absorbed into the soil media where the highly absorbent media stores water for a period of time. Light weight soil media is recommended for extensive greenroofs to minimize the need for extra structural support (DeNardo et al., 2003). 


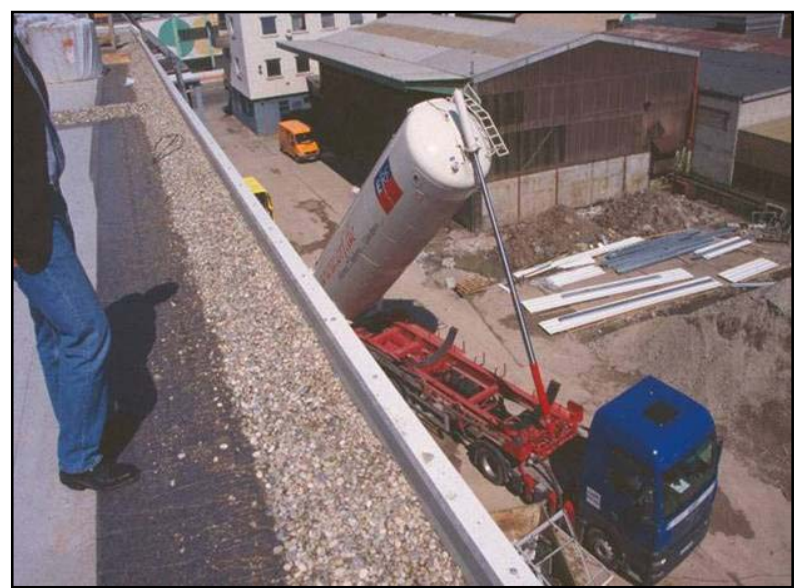

(a)

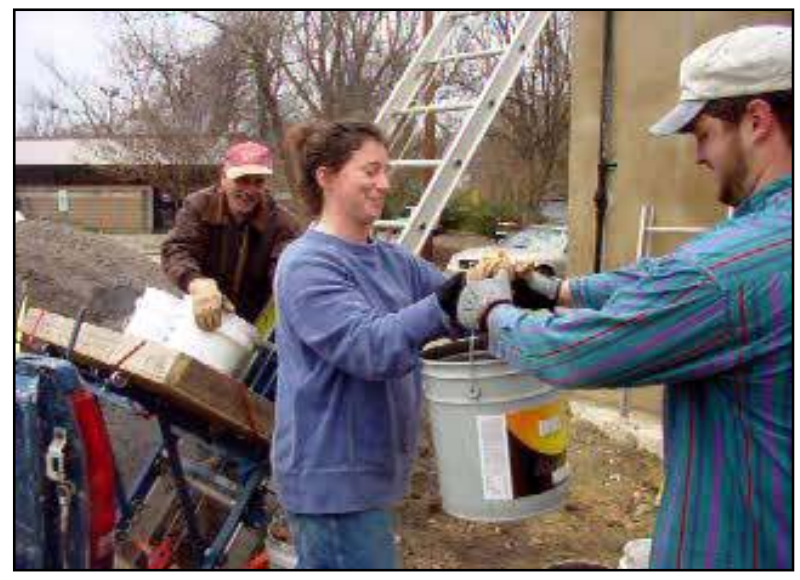

(c)

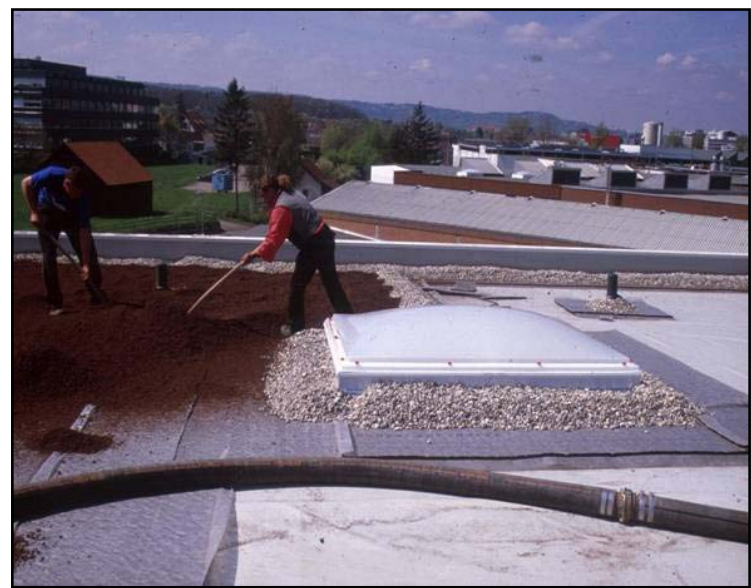

(b)

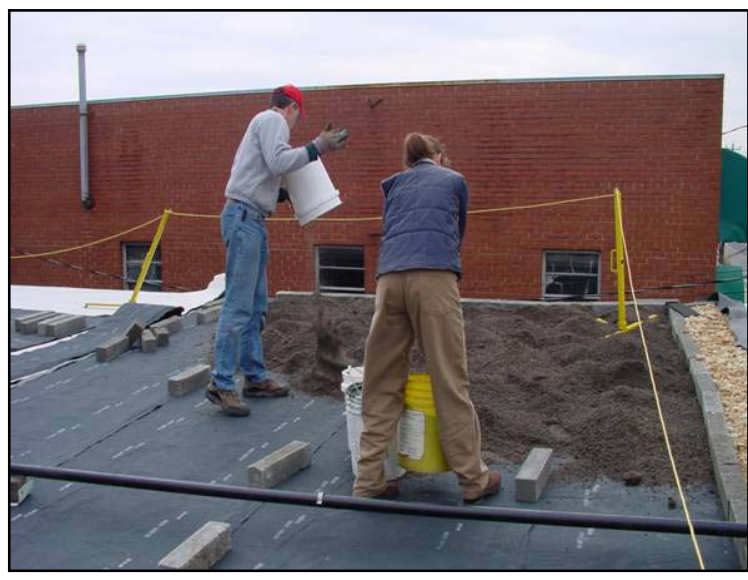

(d)

Figure 2-5. (a) View of pumping truck used to transport soil media to roof surface in Germany. (b) View of pumping hose used to transport soil media to roof surface and workers spreading the soil media with rakes in Germany. (c) A shingle lift was used to transport 6 to 7 buckets of soil lat a time to the roof surface in Raleigh, $\mathrm{NC}$ in 2003. (d) View of volunteers spreading soil atop the drainage layers during greenroof construction in Raleigh, NC in 2003.

Runoff occurs from the greenroof when both the water content of the soil media has reached a maximum and it can not absorb any more water, and when the drainage material has also reached its full capacity and can not store any more precipitation. This usually occurs during a long duration or high intensity rain event (Liesecke, 1998). As a result, runoff from the greenroof may not be observed until hours after a rainfall event has 
begun. After runoff from the greenroof ceases, water is stored within the pores of the soil media and drainage layer for uptake by the plant media. Precipitation is absorbed by the soil media and temporarily stored within the drainage media; it then returns to the natural water cycle through transpiration of the plants and evaporation from the soil media layer (Liesecke, 1998).

\subsubsection{BENEFITS OF GREENROOF IMPLEMENTATION}

There are numerous benefits attributed with greenroofs including the following; each benefit will be discussed in more detail throughout the rest of this section (Grant et al., 2003; ZinCo $\mathrm{GmbH}, 2000)$ :

- Attenuation of stormwater runoff;

- Adsorption of air pollutants and dust;

- Reduction of the urban heat island effect;

- Provision of wildlife habitat;

- Protection of building fabric from sunlight and temperature fluctuations, therefore extending roof life;

- Provision of additional thermal insulation and therefore reducing heating and cooling costs of the building; and

- Creation of additional living space in congested urban areas.

\subsubsection{Ecological Benefits}

Many proponents of greenroof usage view the greenroof as a way of giving back to nature. When a building is constructed, the natural space of earth it lies upon becomes impervious 
and the natural vegetation and wildlife that may have been present beforehand are eliminated. Greenroof supporters view them as natural oases in the middle of an urbanized sea. The space atop a roof can be planted with vegetation ranging from low-lying plants to trees. While not all habitats can be re-created on a rooftop, certain types of habitat such as grassland and moss mats can be re-created on greenroofs (Grant et al., 2003). Grant et al. (2003) describe different ways of re-creating natural habitat atop a roof including natural colonization, turf, and sedum mats. This re-created natural habitat can be home to many species of beetles, insects, and birds (Brenneisen, 2003; Grant et al., 2003).

Research in Switzerland has focused on quantifying the number of spider and beetle fauna on greenroofs. These studies have shown that greenroofs with a variety of plant species and plant density contain a wide variety of spider, beetle fauna, and bird species. In his studies, Brenneisen (2003) compared the greenroof habitat to comparable natural habitats found at ground level containing similar vegetation as the greenroof; he determined that the spider species present at each habitat were not notably different. This shows that greenroofs can adequately re-create natural habitat. Studies in Switzerland have also observed many different species of birds present on greenroofs looking for food and breeding (Brenneisen, 2003).

\subsubsection{Energy Reduction Benefits}

Layers of soil media and plants on a rooftop provide an additional layer of insulation to the already present insulation in the roof construction. This additional layer of insulation aids in lowering heating and cooling requirements and therefore results in energy savings for the building (Osmundson, 1999; Grant et al., 2003). Researchers hope to provide evidence that 
will demonstrate this benefit of greenroofs: the reduction of energy usage that can result from the added insulation provided by the greenroof.

Liu and Baskaran (2003) report that field research in Ottawa, Canada has revealed that the energy required for space conditioning due to the heat flow through the greenroof was reduced by more than $75 \%$. The study compared an extensive greenroof to a reference roof and showed an energy reduction from 6.0-7.5 $\mathrm{kWh} /$ day $(20,500-25,600 \mathrm{BTU} / \mathrm{day})$ for the reference roof to less than $1.5 \mathrm{kWh} /$ day $(5,100 \mathrm{BTU} /$ day) for the greenroof (Liu and Baskaran, 2003; Bass and Baskaran, 2003). The reference roof and the greenroof were of equal dimensions; the experimental roof surface area was $72 \mathrm{~m}^{2}\left(800 \mathrm{ft}^{2}\right)$ with the greenroof on one half and the reference roof on the other half (Liu and Baskaran, 2003).

\subsubsection{Thermal Benefits}

Across the world, cities continue to expand and the urban heat island effect has a more significant effect on the lives of the city population. The urban heat island effect is a phenomenon where ambient temperatures within city areas are warmer than ambient temperatures in the city's outlying areas. This phenomenon has been studied; cities have been measured to be as much as $7^{\circ} \mathrm{C}\left(12^{\circ} \mathrm{F}\right)$ warmer at night and $3^{\circ} \mathrm{C}\left(5^{\circ} \mathrm{F}\right)$ warmer during the day than their outlying areas (Osmundson, 1999). For example, NASA thermal infrared photography has shown that temperatures in downtown Atlanta, Georgia, are often $6^{\circ} \mathrm{C}$ $\left(10^{\circ} \mathrm{F}\right)$ warmer than its surrounding areas (Taube, 2003). The urban heat island effect is caused by the presence of a larger amount of heat absorbing materials, such as asphalt, covering the ground throughout urban areas. These materials absorb the heat instead of reflecting it as plant cover does. As a result, urban areas retain warmth longer and ambient 
temperatures remain warmer than in rural areas (Osmundson, 1999). Other impacts of the urban heat island effect include increased energy demand as a result of the higher temperatures, smog production, higher ozone production, heat stress related illness, and the emission of carbon dioxide and other pollutants due to higher energy demand (Cheney and Rosenzweig, 2003; Taube, 2003).

Greenroof proponents hope that greenroofs may be able to reduce the urban heat island effect if implemented on a large scale throughout the city. A field research site in Ottawa, Canada has shown that while temperatures on a conventional rooftop reached higher than $55^{\circ} \mathrm{C}\left(131^{\circ} \mathrm{F}\right)$; the typical extensive greenroof maintained temperatures near $21^{\circ} \mathrm{C}\left(70^{\circ} \mathrm{F}\right)$ (Liu and Baskaran, 2003; Bass and Baskaran, 2003). On another hot day when ambient temperatures reached $35^{\circ} \mathrm{C}\left(95^{\circ} \mathrm{F}\right)$, the reference roof surface temperature reached $70^{\circ} \mathrm{C}$ $\left(158^{\circ} \mathrm{F}\right)$ and the greenroof temperature remained around $25^{\circ} \mathrm{C}\left(77^{\circ} \mathrm{F}\right)$ (Bass and Baskaran, 2003). Liu and Baskaran (2003) also reported that the greenroof reduced temperature fluctuations on the roof throughout the day. In this Canadian field study, the temperature of the reference rooftop in the spring and summer months had a median daily fluctuation of $45^{\circ} \mathrm{C}\left(81^{\circ} \mathrm{F}\right)$ and the greenroof had a fluctuation of $6^{\circ} \mathrm{C}\left(11^{\circ} \mathrm{F}\right)$ (Liu and Baskaran, 2003). The reference rooftop was equivalent to a typical, ungreened rooftop.

The 2,044 $\mathrm{m}^{2}\left(22,000 \mathrm{ft}^{2}\right)$ greenroof atop the Chicago City Hall has been used to compare the rooftop temperatures of the paved surfaces of the City Hall roof, the planted areas of the City Hall roof, and the asphalt of the adjacent Cook County Building. Rooftop temperatures taken on August 9, 2001 by an infrared thermometer indicated the following temperatures: $52-54^{\circ} \mathrm{C}\left(126-130^{\circ} \mathrm{F}\right), 33-48^{\circ} \mathrm{C}\left(91-119^{\circ} \mathrm{F}\right)$, and $76^{\circ} \mathrm{C}\left(169^{\circ} \mathrm{F}\right)$ for the paved surface, planted area, and black asphalt surface, respectively (Laberge, 2003). During the 
same month, the ambient air temperature above the City Hall greenroof was approximately $42^{\circ} \mathrm{C}\left(107^{\circ} \mathrm{F}\right)$ and air temperatures above the County Building were $46^{\circ} \mathrm{C}\left(114^{\circ} \mathrm{F}\right)$ (Laberge, 2003). A more dramatic temperature difference was not observed between the ambient temperatures above each roof because the entire greenroof area is not covered with vegetation. This intensive greenroof is adorned by two small trees and many small walkways through plant beds; also, vegetation does not cover $100 \%$ of the roof surface area. Higher temperature reductions may be observed when vegetation growth is denser. This demonstrates the reduction of roof surface temperature and ambient temperature that can occur as a result of greenroof implementation.

A pilot-scale research study at Pennsylvania State University (PSU) compared temperatures of three $4.5 \mathrm{~m}^{2}\left(48 \mathrm{ft}^{2}\right)$ typical extensive greenroofs and three $4.5 \mathrm{~m}^{2}\left(48 \mathrm{ft}^{2}\right)$ regular rooftops. DeNardo et al. (2003) reports that the maximum temperatures of the greenroofs were significantly lower than the maximum temperatures of the conventional rooftops for all months observed; differences between the two roof types of $31^{\circ} \mathrm{C}\left(88^{\circ} \mathrm{F}\right)$ were seen in June and $4^{\circ} \mathrm{C}\left(39^{\circ} \mathrm{F}\right)$ were seen in December. Reduction of temperatures in the Pennsylvania climate was greater in the summer months than in the winter. Similar to the Canadian study by Liu and Baskaran (2003), researchers at PSU observed that daily temperature fluctuations were $41^{\circ} \mathrm{C}\left(106^{\circ} \mathrm{F}\right)$ cooler on the greenroofs than the conventional rooftops in June (DeNardo et al., 2003).

\subsubsection{Stormwater Benefits: Water Retention}

One of the most notable benefits of greenroof implementation is the retention of rainwater that occurs in the soil media and vegetation of the greenroof; this is the most researched 
potential greenroof benefit to date. A typical roof retains little to no rainwater, however flat roofs can retain approximately $5 \mathrm{~mm}(0.2 \mathrm{in}$.) in rooftop depressional storage. Precipitation almost immediately runs off the rooftop, enters the storm sewer system, and the runoff is routed to the nearest body of water. This fast moving runoff from rooftops in urban areas increases the chances of flash flooding during intense rainfall events. In older cities, where combined sewer systems are in place, flash flooding may result in combined sewer overflows (CSOs), sending untreated human sewage to nearby waterway systems. As a result of this problem, existing and emerging stormwater programs call for a reduction in the volume and intensity of stormwater entering the municipal sewer system (Slone and Evans, 2003). Greenroofs are a potential solution.

While greenroof research has been ongoing in Germany since 1975 and over 950 reports on extensive greenroof research have been published, few papers have been translated into English (Herman, 2003). One of the prominent leaders of German greenroof research is Dr. Hans-Joachim Liesecke. In Das Retentionsvermögen von Dachbegrünungen (In English: "The Retention of Greenroofs"), Liesecke discusses the potential greenroofs have for water retention. Evapotranspiration plays the most significant role in the water retention capability of the greenroof; water retention during summer months is much higher than in winter months because evapotranspiration rates are much higher in the summer season (Liesecke, 1998; Liesecke 1999). Therefore, in climates where the majority of the precipitation occurs in the winter months, greenroofs may not be as effective because less water retention occurs in the winter. Evapotranspiration rates in Germany are approximately $64 \mathrm{~mm} / \mathrm{year}(25$ in./year) with lower evapotranspiration in January of $0.3 \mathrm{~mm} / \mathrm{month}(0.1 \mathrm{in} . / \mathrm{month})$ and 
much higher evapotranspiration rates in July of $12 \mathrm{~mm} /$ month (5 in./month). Germany receives approximately $580 \mathrm{~mm}$ (23 in.) of rainfall annually.

In another study, Liesecke tested a variety of extensive greenroof soil media depths ranging from $80 \mathrm{~mm}$ (3 in.) to $120 \mathrm{~mm}$ (5 in.). The study included greenroofs with heavy soil media, light soil media, some with drainage layers, some without drainage layers, and each greenroof had a $5^{\circ}$ pitch, with the exception of one with a $0^{\circ}$ pitch. Data from 1995 to 1997 shows that the precipitation was $918 \mathrm{~mm}$ (36 in.), $712 \mathrm{~mm}(28 \mathrm{in}$.$) , and 827 \mathrm{~mm}$ (33 in.) for 1995, 1996, and 1997 respectively (Liesecke, 1999). For all three years, annual water retention in the conventional roof top ranged from $10 \%$ to $20 \%$, while annual water retention in the greenroofs ranged from $50 \%$ to $65 \%$ with two exceptions; in 1995 the thinnest extensive greenroof only retained $47 \%$ and in 1996 , the thickest greenroof with a slope of $0^{\circ}$ retained 74\% (Liesecke, 1999). General rainfall intensities for these study years were not reported and more runoff may be present in climates with higher rainfall intensities.

German research has provided German companies with general industry standards for greenroof annual water retention. For example, annual water retention for greenroofs with a $2 \%$ slope and a $20-40 \mathrm{~mm}(0.8-1.6$ in.) media depth is $40-45 \%$, a $60-80 \mathrm{~mm}(2.4-3 \mathrm{in}$.$) media$ depth is $50-55 \%$, and a $100-120 \mathrm{~mm}$ (4-5 in.) media depth is $55-60 \%$ (Liesecke, 1998). Liesecke has also reported results that demonstrate the greenroof's ability to mitigate the peak flow of rooftop runoff. Another study conducted in Germany compared runoff from a conventional rooftop covered with gravel to runoff from an extensive greenroof $40 \mathrm{~mm}(1.6$ in.) thick; 15 minutes after precipitation began, $20 \mathrm{~mm}(0.79 \mathrm{in}$.) of the total $27 \mathrm{~mm}(1.1 \mathrm{in}$.) precipitation had runoff from the conventional roof and only $0.043 \mathrm{~mm}(0.17 \mathrm{in}$.) of the total precipitation had drained from the greenroof (Liesecke, 1998). While the conventional roof 
had already drained $74 \%$ of the total precipitation from the rainfall event, the greenroof had drained only $16 \%$ of the total $27 \mathrm{~mm}(1.1 \mathrm{in}$.) at the same point in time; the rest of the flow from the greenroof would either be retained for vegetation uptake or slowly drained from the soil media. This demonstrates the reduction in peak flow possible with the installation of a greenroof.

Limited research on water retention in greenroofs has been conducted in the United States; however, officials with the City of Portland, Oregon, are leading research in this area. The water retention capability of a greenroof depends on a variety of factors, such as rainfall intensity, seasonal variation, evapotranspiration rates, and the soil moisture content of the roof media. During a 15-month monitoring period in 2002 and 2003, the water retention of an extensive greenroof with a $100-120 \mathrm{~mm}$ (4-5 in.) soil media depth was $69 \%$ of the total rainfall (Hutchinson et al., 2003). During the months from May 2002 to October 2002, upwards of $90 \%$ retention of monthly precipitation was measured at the greenroof, however these are the dry months of the year with less than $50 \mathrm{~mm}$ (2 in.) of rainfall occurring each month (Hutchinson et al., 2003). High rainfall retention has also been seen during the wet winter months in Portland. Hutchinson et al. (2003) reports approximately 30\% retention during January 2002, 50\% retention in December 2002, and 60\% retention in March 2003 with monthly precipitation totals of approximately $160 \mathrm{~mm}$ (6.3 in.), $108 \mathrm{~mm}$ (4.25 in.), and $127 \mathrm{~mm}$ (5 in.) for each month, respectively. The results of this study reflect how more precipitation may result in less retention and higher evapotranspiration rates in the spring may result in higher retention rates. This greenroof study has also demonstrated an $80 \%$ reduction of peak flows from the greenroof. Peak rainfall flows for a selection of storms in 2002 and 2003 ranged from $1.2 \mathrm{E}-3$ to $5.5 \mathrm{E}-3 \mathrm{~m}^{3} / \mathrm{s}$ (18.4 to $\left.86.6 \mathrm{gpm}\right)$ and the corresponding 
runoff peak flows ranged from 2.3E-4 to $3.4 \mathrm{E}-4 \mathrm{~m}^{3} / \mathrm{s}$ (3.59 to $5.39 \mathrm{gpm}$ ) (Hutchinson et al., 2003).

Research conducted at Michigan State University has shown that $66 \%$ of the precipitation was retained by a $127 \mathrm{~mm}$ ( 5 in.) deep extensive greenroof that was studied for 24 rainfall events (Rowe et al., 2003). Rowe et al. (2003) also noted that the greenroof reduced the peak runoff rate and delayed total runoff from the rooftop. Studies at Michigan State University included greenroof platforms constructed at 2\% and 6.5\% slopes; each slope had platforms with $25 \mathrm{~mm}$ (1 in.), $40 \mathrm{~mm}$ (1.5 in.) and $60 \mathrm{~mm}$ (2.5 in.) soil media depths. This study demonstrated that, as suspected, shallower substrate depths and steeper roof slopes resulted in greater runoff from the greenroof (Rowe et al., 2003). For instance, platforms at $6.5 \%$ slope resulted in $72 \%$ and $69 \%$ retention at media depths of $60 \mathrm{~mm}(2.4$ in.) and $40 \mathrm{~mm}$ (1.6 in.), respectively (Rowe et al., 2003). In addition, at a constant depth of $40 \mathrm{~mm}$ (1.6 in.), 69\% retention was observed from the platforms with a slope of $6.5 \%$ and $74 \%$ retention was observed from the $2 \%$ sloped platforms (Rowe et al., 2003). Schade (2000) also reported runoff results for thin-layered extensive greenroofs in Germany with varying slopes up to $30^{\circ}$; again, increased rooftop slopes produced increased amounts of runoff in less time than flatter greenroofs.

\subsubsection{GREENROOF INCENTIVES}

Theodore Osmundson has done extensive research on greenroofs throughout North America, Europe, and Asia. Osmundson's research revealed that the dramatic increase of greenroof implementation throughout Germany within the past several years can be attributed to the financial incentives offered by many cities in the country. Forty-three percent of German 
cities offer financial incentives for roof greening; cities such as Berlin, Karlsruhe, Böblingen, and Stuttgart give financial support to roof garden implementation ranging from 25 to $100 \%$ of the installation cost (Osmundson, 1999).

Following Germany's lead, several cities in the United States have begun to offer incentives for greenroof implementation. In Portland, Oregon, a zoning bonus is offered for greenroofs. In the 1970 s, the City of Portland established a charge for stormwater drainage that was directly related to the amount of impervious surfaces. As a result of a greenroof's retention capability, reduced stormwater drainage fees are available for buildings with greenroofs (Liptan, 2003; Environmental Services et al., 2002). In addition to reduced stormwater fees, the City offers a zoning bonus for greenroofs. Currently, buildings in Portland are zoned with a maximum height to floor area ratio; buildings proposed with greenroofs that cover up to $30 \%$ of the rooftop surface area can add $0.09 \mathrm{~m}^{2}\left(1 \mathrm{ft}^{2}\right)$ of bonus floor area for each square-foot of greenroof coverage and greenroofs that cover up to $60 \%$ of the roof area are eligible for $0.18 \mathrm{~m}^{2}\left(2 \mathrm{ft}^{2}\right)$ of bonus floor area for each square-foot of greenroof area (Liptan, 2003). This bonus allows buildings with planned greenroofs to have larger floor areas than buildings without greenroofs.

In 2003, Mayor Franklin of the City of Atlanta announced the Clean Water Atlanta program which would include a stormwater management utility within the City (Taube, 2003). Similar to the City of Portland, the City of Atlanta will offer reduced stormwater fees to commercial, residential, municipal, and industrial developers who offer the detention/retention of stormwater; it is proposed that the credit system be operational by mid2004 (Taube, 2003). This credit process will be applicable to greenroofs and other innovative BMPs throughout the City. 


\subsection{StATE OF THE ART}

Recent regulations require more local governments to develop and implement stormwater plans in an effort to improve the water quality of river basins in North Carolina. As a result of regulations, such as Phase I and Phase II of the NPDES Stormwater Program developed by the EPA, city and county governments are relying more heavily on the implementation of BMPs to improve the stormwater quality of urban and agricultural runoff. The BMP has evolved from wet ponds to wetlands to bio-retention areas to pervious pavement, and into the greenroof. In ultra-urban areas and areas of high land cost, there is little surface area available at ground level to install such BMPs as wet ponds and wetlands that require large amounts of surface area. A new option for BMP construction is the greenroof, which can utilize the thousands of square meters (square feet) available on rooftops in city environments. Numerous benefits are associated with greenroof implementation, including re-creating wildlife habitat, creating more living space in congested urban areas, reduction of the urban heat island effect, energy savings, and attenuation of stormwater runoff. Three benefits which have been supported by multiple research studies are thermal benefits, energy benefits, and water retention benefits.

Through reduction of ambient temperatures above greenroofs, the effect of the urban heat island can be reduced. Research in Ottawa, Canada demonstrated reductions in rooftop temperatures; when ambient temperatures reached $35^{\circ} \mathrm{C}\left(95^{\circ} \mathrm{F}\right)$ one day, the reference roof temperature reached $70^{\circ} \mathrm{C}\left(158^{\circ} \mathrm{F}\right)$ and the greenroof temperature remained near $25^{\circ} \mathrm{C}\left(77^{\circ} \mathrm{F}\right)$ (Bass and Baskaran, 2003). Reduced temperature fluctuations were also observed at this research site (Liu and Baskaran, 2003). This demonstrates how greenroofs may improve the 
lifetime of conventional rooftops because there is not as great a temperature fluctuation on the roofing membrane.

In addition to the thermal research conducted in Canada, energy reductions were also observed at the same research site. An energy reduction from $6.0-7.5 \mathrm{kWh} /$ day $(20,500-$ $25,600 \mathrm{BTU} /$ day) for the reference roof to less than $1.5 \mathrm{kWh} /$ day $(5,100 \mathrm{BTU} /$ day $)$ for the greenroof was observed (Liu and Baskaran, 2003; Bass and Baskaran, 2003). This research revealed more than $75 \%$ reduction energy for space conditioning as a result of greenroof implementation (Liu and Baskaran, 2003).

Some greenroof proponents regard water retention as the most important benefit to greenroof implementation. Officials with the City of Portland have conducted research on the water retention and peak flow reduction capabilities of greenroofs in Portland, Oregon. During a 15-month monitoring period of an extensive greenroof with a 102-127 mm (4-5 in.) media depth, the observed retention was $69 \%$ of the total precipitation (Hutchinson et al., 2003). Results from this study also demonstrated that higher amounts of precipitation may result in less retention and higher evapotranspiration rates in the spring may result in more retention than during the winter. Liesecke $(1998,1999)$ also notes that evapotranspiration plays the most significant role in the water retention capability of the greenroof; water retention during summer months is much higher than in winter months because evapotranspiration rates are much higher in the summer season

Research conducted at Michigan State University (MSU) has shown that $66 \%$ of the precipitation was retained by a $127 \mathrm{~mm}$ ( 5 in.) deep extensive greenroof that was studied for 24 rainfall events (Rowe et al., 2003). Similar to the Portland and MSU studies, Liesecke 
(1999) has also reported retention rates of $80 \mathrm{~mm}$ (3 in.) and $120 \mathrm{~mm}$ (5 in.) deep greenroofs in Germany ranging from 50 to 65\% over a three year period from 1995 to 1997.

The greenroof study in Portland also demonstrated an $80 \%$ reduction of peak flows from the greenroof (Hutchinson et al., 2003). Research conducted at Michigan State University also observed reduced peak flows from the greenroof and delayed total runoff from the greenroof (Rowe et al., 2003). In addition, German research has shown reductions in peak flow from greenroofs when compared to conventional rooftops (Liesecke, 1998).

Within the past decade, greenroof construction has increased greatly throughout Germany; this may be a reflection of recent financial incentives and the need for regulatory compliance. In the United States, many questions surround greenroofs and remain unanswered thereby delaying wide spread greenroof implementation. The general public does not understand the function of a greenroof, nor the many benefits associated with greenroof implementation. Contractors are unfamiliar with how to properly install greenroofs and are inefficient with greenroof construction processes. In Germany, the most appreciated benefit of greenroof implementation is water retention. While many studies in Germany have determined the approximate water retention capability of different greenroof media depths and standards of water retention have been published, this data cannot be directly applied to areas in the United States because of the differences in climate between the two countries. Several studies have been performed in the United States, but these have occurred sparingly across the nation, in Pennsylvania, Michigan, and Oregon.

No greenroof research has been performed in the southeastern United States. Currently, there are no design guidelines for greenroof construction in North Carolina. Therefore, if a developer wanted to construct a greenroof, several design parameters would 
be unknown. For example, plant selection is an important factor in greenroof design, and currently there are no design standards indicating which greenroof plant species thrive in the North Carolina climate.

Additionally, many stormwater BMPs offer peak flow attenuation and water quality benefits. While the water retention capability of greenroofs has been shown, possible water quality benefits of greenroofs are unknown at this time. In areas of North Carolina affected by the Neuse River Rules and the Tar-Pamlico Rules, where reductions in nitrogen and phosphorus are required in stormwater runoff, the possible water quality benefits of greenroof implementation are especially of interest. The effect of greenroofs on stormwater quality must be researched. The average water retention of greenroofs in the North Carolina climate is also unknown. For example, data gathered from Portland, Oregon cannot be directly applied to greenroofs in North Carolina because the climate and rainfall pattern contrast between the two locations.

The focus of this research is to provide design guidelines for developers in the greenroof industry in North Carolina and elsewhere in the southeastern United States. This research will add several pieces of knowledge to the North American greenroof industry, described in Chapter 3. 


\subsection{HYPOTHESES AND OBJECTIVES}

The literature review demonstrated how little data is available on greenroof runoff mitigation and nutrient removal from the runoff. A limited number of greenroof research sites are located across the United States and no research has been done in North Carolina, or the Southeastern United States. Due to the lack of research and data available, there are no design guidelines available for developers to use for the installation of a greenroof in North Carolina. It is not known how much rainfall greenroofs will retain in North Carolina, possible water quality benefits are unknown, and appropriate greenroof plant species for the North Carolina climate are also unknown. The quantity of nutrients present in stormwater runoff is important in eastern and central North Carolina due to recent regulations aimed at reducing the amount of nitrogen and phosphorus entering the eastern North Carolina river basins. The overall goals of the field research were as follows:

1. Estimating the percent precipitation retained by the greenroof and, therefore, flood peak mitigation;

2. Discovering whether greenroofs can be used at nutrient reduction BMPs and if so, what removal efficiency should be assigned to greenroofs;

3. Identifying vegetation types that thrive in central and eastern North Carolina rooftop environments; and

4. Determining an optimal depth of soil for desirable plant growth within the first year of establishment in North Carolina. 
In addition to the field research, a laboratory study was conducted to determine if varying amounts of compost present in greenroof soil media affect the resulting nutrients present in greenroof runoff.

A significance level of $\alpha<0.05$ was selected to ensure that the probability of incorrectly concluding in favor of the research hypothesis was kept small. For example, if the research hypothesis is determined to be true, there is a $5 \%$ chance the hypothesis is wrong. This Type I error is controlled to ensure that each research hypothesis is proved beyond a reasonable doubt (Rao, 1998).

The goals of the field research were tested by the following hypotheses:

First Hypothesis: The amount of precipitation retained by the greenroof is significantly less than the amount of precipitation $(\alpha<0.05)$.

Second Hypothesis: The peak flow of the greenroof is significantly less than the peak rainfall rate $(\alpha<0.05)$.

Third Hypothesis: The nutrient concentrations of total nitrogen (TN), nitrate-nitrite as nitrogen $\left(\mathrm{NO}_{3}-\mathrm{NO}_{2}\right.$ as $\left.\mathrm{N}\right)$, total Kjeldahl nitrogen $(\mathrm{TKN})$, ammonia as nitrogen $\left(\mathrm{NH}_{3}\right.$ as $\mathrm{N}$ ), total phosphorus (TP) and orthophosphorus (OP) are significantly less in the greenroof runoff than in the rainfall $(\alpha<0.05)$.

Fourth Hypothesis: The nutrient mass loadings of $\mathrm{TN}, \mathrm{NO}_{3}-\mathrm{NO}_{2}$ as $\mathrm{N}, \mathrm{TKN}, \mathrm{NH}_{3}$ as $\mathrm{N}, \mathrm{TP}$, and OP are significantly less in the greenroof runoff than in the rainfall $(\alpha<$ $0.05)$. 
Fifth Hypothesis: The nutrient concentrations of $\mathrm{TN}, \mathrm{NO}_{3}-\mathrm{NO}_{2}$ as $\mathrm{N}, \mathrm{TKN}, \mathrm{NH}_{3}$ as $\mathrm{N}, \mathrm{TP}$, and OP are significantly less in the greenroof runoff than in the control roof runoff $(\alpha<0.05)$

Sixth Hypothesis: The nutrient mass loadings of $\mathrm{TN}, \mathrm{NO}_{3}-\mathrm{NO}_{2}$ as $\mathrm{N}, \mathrm{TKN}, \mathrm{NH}_{3}$ as $\mathrm{N}, \mathrm{TP}$, and OP are significantly less in the greenroof runoff than in the control roof $\operatorname{runoff}(\alpha<0.05)$.

Seventh Hypothesis: Vegetation growth is significantly higher in $102 \mathrm{~mm}$ (4 in.) deep soil media than $51 \mathrm{~mm}$ (2 in.) deep soil media at the end of the first year of growth $(\alpha$ $<0.05)$.

The goal of the laboratory research was tested by the following hypotheses:

First Hypothesis: The nutrient concentrations of $\mathrm{TN}, \mathrm{NO}_{3}-\mathrm{NO}_{2}$ as $\mathrm{N}, \mathrm{TKN}, \mathrm{NH}_{3}$ as $\mathrm{N}$, TP, and OP are significantly less in drainage from soil media with $5 \%$ organic matter content than soil media with $15 \%$ or $30 \%$ organic matter content $(\alpha<0.05)$. Second Hypothesis: The nutrient concentrations of $\mathrm{TN}, \mathrm{NO}_{3}-\mathrm{NO}_{2}$ as $\mathrm{N}, \mathrm{TKN}, \mathrm{NH}_{3}$ as N, TP, and OP present in drainage from greenroof soil media are significantly less after a period of 10 weeks of laboratory testing $(\alpha<0.05)$.

The following objectives were used to test the seven field study hypotheses:

1. Determine the amount of precipitation retained on the greenroof for rainfall events and estimate the percent precipitation for the rain events to serve the first hypothesis; 
2. Determine the peak flow of greenroof runoff and the rainfall rate for each possible rain event observed and estimate the peak flow reduction for each event to satisfy the second hypothesis;

3. Determine the concentration of $\mathrm{TN}, \mathrm{NO}_{3}-\mathrm{NO}_{2}$ as $\mathrm{N}, \mathrm{TKN}, \mathrm{NH}_{3}$ as $\mathrm{N}, \mathrm{TP}$, and $\mathrm{OP}$ in the greenroof runoff, control roof runoff, and the rainfall for each sampled rain event to serve the third and fifth hypotheses;

4. Transform the nutrient concentration data into nutrient mass loadings present in the greenroof runoff, control roof runoff, and the rainfall to serve the fourth and sixth hypotheses; and

5. Measure the percent coverage of select vegetation in $51 \mathrm{~mm}$ (2 in.) deep soil media and in $102 \mathrm{~mm}$ (4 in.) deep soil media on a greenroof after the first year of growth to serve the seventh hypothesis.

The following objectives were used to test the two laboratory study hypotheses:

1. Determine the concentration of $\mathrm{TN}, \mathrm{NO}_{3}-\mathrm{NO}_{2}$ as $\mathrm{N}, \mathrm{TKN}, \mathrm{NH}_{3}$ as $\mathrm{N}, \mathrm{TP}$, and $\mathrm{OP}$ present in the drainage water from columns containing varying greenroof soil mix compositions to serve the first hypothesis; and

2. Determine any visible or statistical trends in the concentrations of nutrients in the leaching analysis over a period of 10 weeks to serve the second hypothesis. 


\subsection{GREENROOF FIELD STUDY}

\subsection{Site DESCRIPTIONS}

This research project tested two extensive greenroofs in eastern North Carolina (NC); both locations are shown in Figure 4-1. Highlighted in red (dark grey) is the City of Raleigh, in Wake County. Highlighted in blue (light grey) are the City of Goldsboro,

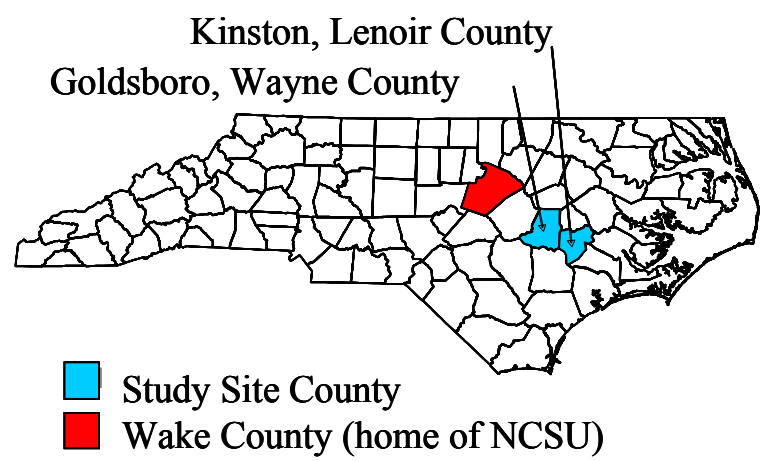
in Wayne County, and the City of Kinston, in Lenoir County. Both research sites fall within the Neuse River Basin.

\subsubsection{Wayne Community College Greenroof: Goldsboro, NC}

The greenroof at Wayne Community College (WCC) in Goldsboro, NC, was constructed in May 2002 and was approximately $70 \mathrm{~m}^{2}\left(750 \mathrm{ft}^{2}\right)$. This essentially flat greenroof (see Figure 4-2) took approximately 50 person-hours to construct. The original rooftop of this storage building was divided into two equal $70 \mathrm{~m}^{2}\left(750 \mathrm{ft}^{2}\right)$ halves for research purposes; one half remained unchanged and became the control for the experiment and the other half was transformed into the WCC Greenroof. The greenroof was separated from the control roof by a series of wooden dividers and concrete blocks; a layer of plastic was also secured to the dividers to prevent water on the control roof from draining to the greenroof side. Each roof had one drain in the center of the roof; all flow exited from the roof through these two center 


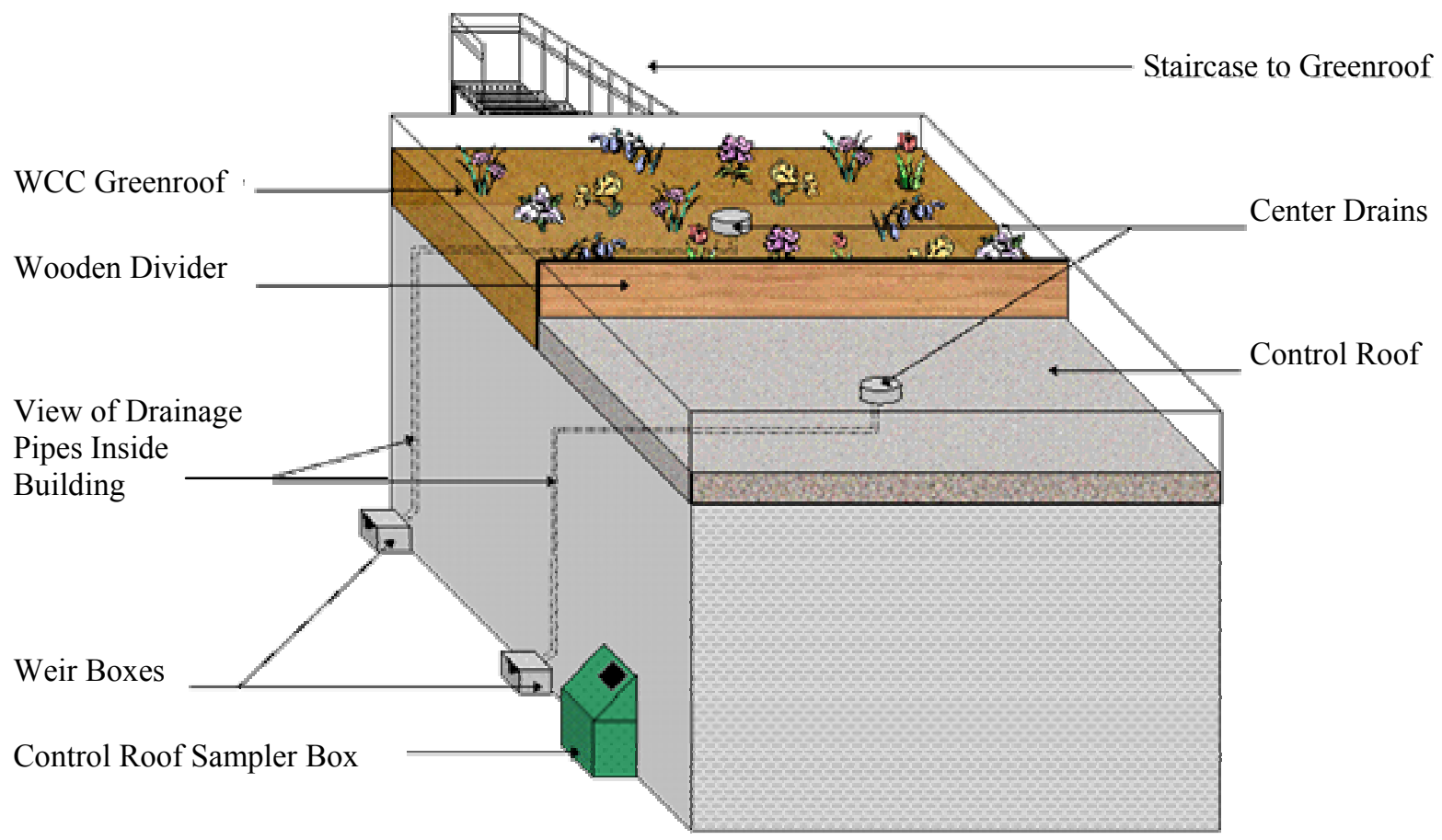

(a)

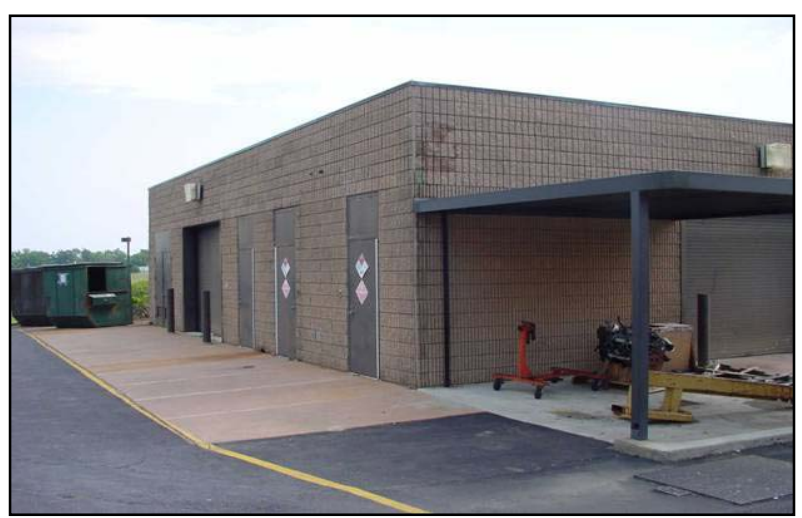

(b)

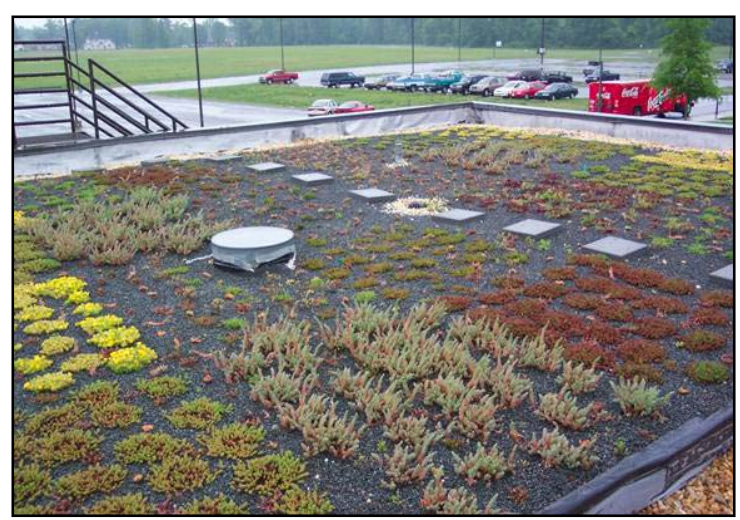

(c)

Figure 4-2. (a) Sketch of WCC Greenroof. Note: This drawing is not to scale. (b) View of storage building at WCC in Goldsboro (June 2002). (c) Overview of greenroof atop storage building at WCC, nearly 1 year old (April 2003).

drains. Two soil media depths were studied at this site: half the greenroof had a media depth of $51 \mathrm{~mm}(2 \mathrm{in.})$ and the other half of the greenroof had a soil media depth of $102 \mathrm{~mm}$ (4 in.). The media depths were arranged to resemble a checkerboard pattern with each matching soil 
substrate depth diagonally across from the other. The plant species researched at this site included Delosperma nubigenum, Sedum reflexum, Sedum sexangulare, Sedum album, Sedum acre, Sedum album chloroticum, Sedum album murale, Sedum spurium fuldaglut, Sedum grisebachii, and Delosperma cooperi. The variety of plant species was purchased from Emory Knoll Farms, located in Street, Maryland, based on the recommendations by Mr. Ed Snodgrass, President of Emory Knoll Farms, that the majority of the selected plant species would survive the NC climate.

The drainage layer used at the WCC Greenroof was Hydrodrain $300^{\mathrm{TM}}$; this drainage material had negligible storage. Hydrodrain $300^{\mathrm{TM}}$ had a filter fabric system already incorporated into the design, so an additional layer of geotextile fabric was unnecessary. The Moisture Retention Mat, Root Barrier, and the Hydrodrain $300^{\mathrm{TM}}$ were purchased from American Hydrotech, Inc.

Carolina Stalite's Perma Till Lightweight Roof Garden Soil Mix was donated for use as the soil media at the WCC Greenroof. This soil media was composed of 55\% Perma Till (Stalite 3/8" expanded slate), 30\% Rootzone Sand, and 15\% approved compost. This lightweight soil media had a dry bulk density of $993 \mathrm{~kg} / \mathrm{m}^{3}\left(62 \mathrm{lbs} / \mathrm{ft}^{3}\right)$ and a saturated drained bulk density of $1250 \mathrm{~kg} / \mathrm{m}^{3}\left(78 \mathrm{lbs} / \mathrm{ft}^{3}\right)$.

\subsubsection{Neuseway Nature Center Greenroof: Kinston, NC}

The approximately $27 \mathrm{~m}^{2}\left(290 \mathrm{ft}^{2}\right)$ greenroof at the Neuseway Nature Center in Kinston, NC, was constructed in April 2002 (see Figure 4-3). The greenroof was constructed atop an additional room that was built onto the rear of the Nature Center during its renovation and 
construction phase. This greenroof took approximately 40 person-hours to construct. The Neuseway Nature Center Greenroof had a 3\% pitch greenroof and consisted of $102 \mathrm{~mm}$ (4 in.) deep soil media. This greenroof was also compared with the remaining unchanged 180 $\mathrm{m}^{2}\left(1820 \mathrm{ft}^{2}\right)$ of the rooftop of the Nature Center. The $180 \mathrm{~m}^{2}\left(1820 \mathrm{ft}^{2}\right)$ area of the control roof was the two uppermost roof levels of the conventional roof of the building (see Figure 43a). The lowest level of the conventional roof area was not considered part of the defined control roof; this is where the monitoring equipment was located (see Figure 4-3a). For each roof, typical roofing gutters were installed and runoff exited each roof through a single drain.

The same variety of plant species used at the WCC Greenroof was planted at this site and was also purchased from Emory Knoll Farms. However, only four of the ten plant species were used simply because the surface area of the Nature Center Greenroof was smaller than the surface area of the WCC Greenroof. The drainage layer used at the Neuseway Nature Center Greenroof was Floradrain FD40 ${ }^{\mathrm{TM}}$ with a System Filter SFTM layer. Unlike the drainage system used at the WCC Greenroof, the Floradrain FD40 ${ }^{\mathrm{TM}}$ did not have a filter fabric system incorporated into the design; therefore, a separate filter fabric layer was required. Also unlike the system used at the WCC Greenroof, the Floradrain FD40 ${ }^{\mathrm{TM}}$ did have storage capabilities. This drainage system had storage pockets $40 \mathrm{~mm}(1.6$ in.) deep, resulting in a storage capacity of $4 \mathrm{~L} / \mathrm{m}^{2}\left(0.1\right.$ gal $\left./ \mathrm{ft}^{2}\right)$ (American Hydrotech, Inc., 1997). The Moisture Retention Mat, Root Barrier, and Floradrain FD40 ${ }^{\mathrm{TM}}$ were donated by American Hydrotech, Inc. The same Carolina Stalite Perma Till Lightweight Roof Garden Soil Mix used at the WCC Greenroof was donated for use as the soil media at the Neuseway Nature Center Greenroof in Kinston, NC. 


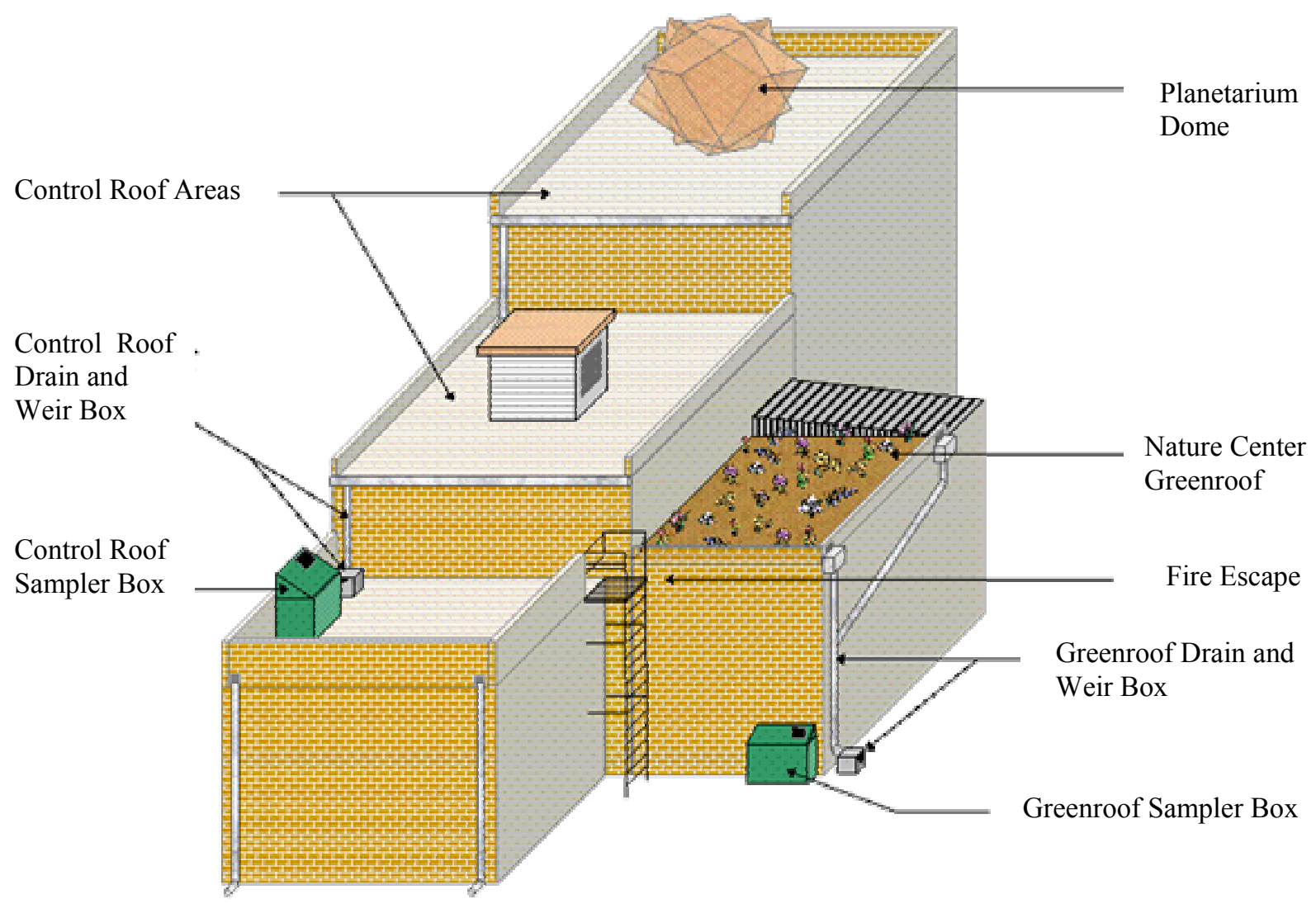

(a)

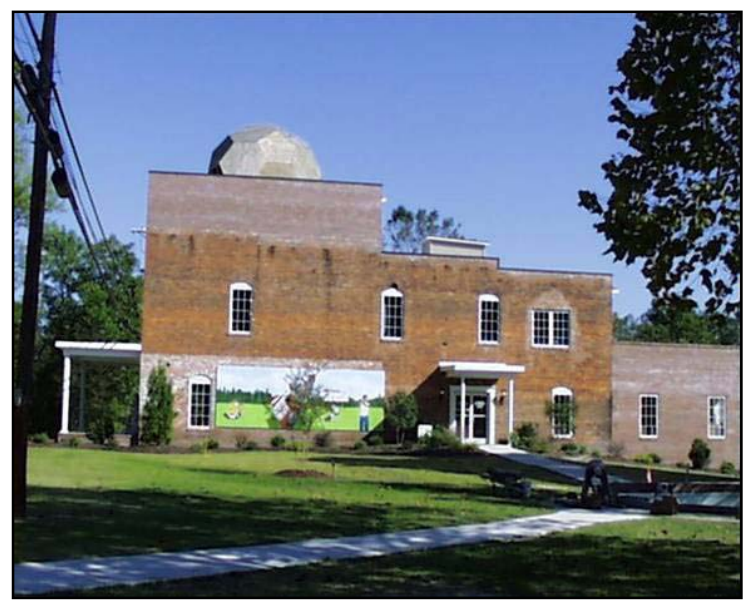

(b)

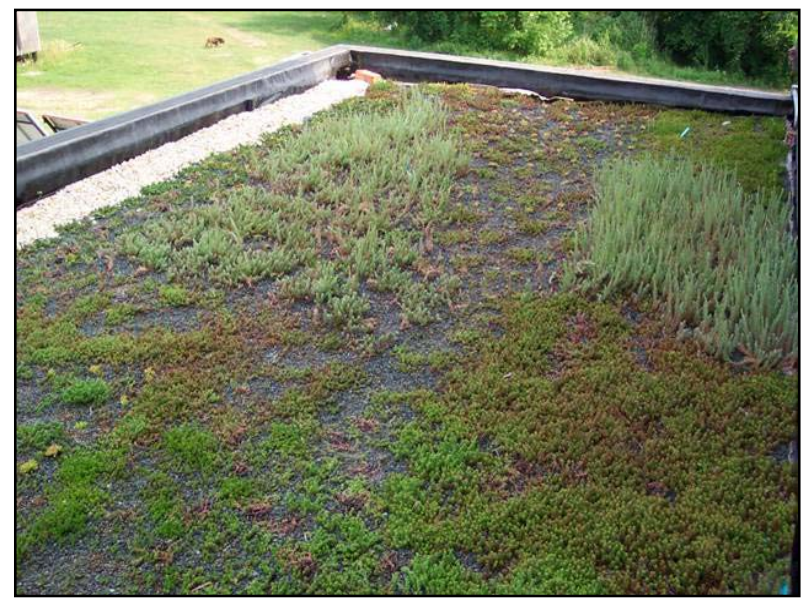

(c)

Figure 4-3. (a) Sketch of Neuseway Nature Center. Note: This drawing is not to scale. (b) Neuseway Nature Center (May 2002). (c) Overview of Neuseway Nature Center Greenroof, 1 year after installation (May 2003). 


\subsection{Data Collection And Water Quality Analysis}

\subsubsection{SAMPLING EQUIPMENT}

Both greenroof research sites were installed with the same basic equipment: two Sigma 900 $\mathrm{Max}^{\mathrm{TM}}$ automatic samplers, two weir boxes, and a rain gauge. All additional equipment at each site was essentially the same; however, placement and site details were different at each site. Equipment installation at the WCC Greenroof was completed in September 2002 and installation at the Neuseway Nature Center greenroof was completed in May 2003.

\subsubsection{Wayne Community College Greenroof: Goldsboro, NC}

Two Sigma 900 $\mathrm{Max}^{\mathrm{TM}}$ automatic portable samplers were located at the WCC Greenroof site. One sampler was connected to the greenroof drain and the other sampler was connected to the control roof drain. The power source for the automatic samplers was a 12-volt battery and a Solarex Solar Panel was wired to the battery to maintain its full charge. Both Sigma 900 $\mathrm{Max}^{\mathrm{TM}}$ samplers were stored in separate large, secured green storage boxes. Figure 4-4a is a photograph illustrating the control roof sampling equipment at the WCC Greenroof.

Runoff was measured from each separate drain pipe by a weir in a galvanized steel box, termed a weir box. Each weir box stored approximately $0.05 \mathrm{~m}^{3}\left(0.5 \mathrm{ft}^{3}\right)$ of water before runoff began to flow over the $30^{\circ}$ v-notch, sharp crested weir. An integral submerged depth level sensor rested on the bottom of each weir box; the level sensor measured the height of the water above the weir notch. The maximum range for the $\mathrm{P} / \mathrm{N} 2963,2.5$ psi depth level sensor was 0.1 to $1.75 \mathrm{~m}$ (0.4 to $5.75 \mathrm{ft}$ ) (American Sigma, 2004). The depth level sensor 
was also accurate within $\pm 1 \%$ of the full scale and operational between $0^{\circ} \mathrm{C}$ and $71{ }^{\circ} \mathrm{C}\left(32^{\circ} \mathrm{F}\right.$ to $160^{\circ} \mathrm{F}$ ) (American Sigma, 2004). The weir boxes were designed to have permanent water storage to ascertain that runoff from each storm event would freely fall over the weir with no delay during a rain event. The permanent water storage ensured no delay of sample retrieval would occur because runoff would flow over the weir as soon as runoff drained from the rooftop, otherwise, flow would not be observed until the weir box had filled up to the water level of the weir crest. Each weir box was equipped with one baffle at the center point to essentially still the runoff flow over the weir. Stormwater flowed over the weir plate as it drained from the steel box and exited the site. Figure $4-4 b$ displays a view of the inside of the weir box. The water level was then equated into a flow measurement by the Sigma 900 $\mathrm{Max}^{\mathrm{TM}}$ through Equation 4-1.

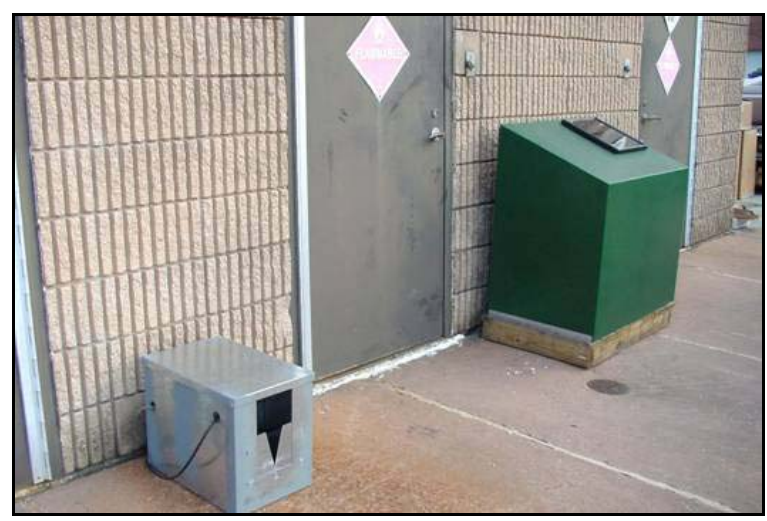

(a)

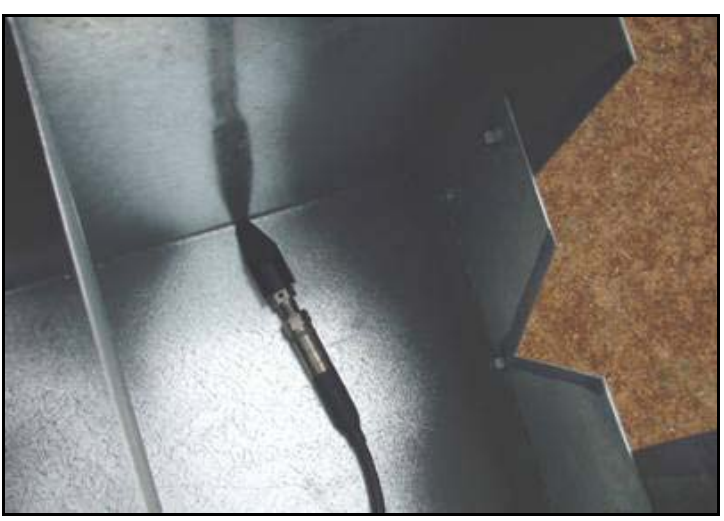

(b)

Figure 4-4. (a) Monitoring equipment for WCC control roof. Weir box is on left side; green sampler storage box in on right side (September 2002). (b) View inside weir box with baffle, level sensor, and weir plate. 
Equation 4-1.

$$
\begin{aligned}
& Q=C_{w t}\left(\frac{8}{15}\right)\left[\tan \left(\frac{\theta}{2}\right)\right] \sqrt{\left(2 G H^{5 / 2}\right)} \\
& \text { Where: } \mathrm{Q}=\text { Flow over weir (cfs) } \\
& \qquad \mathrm{C}_{\mathrm{wt}}=\text { Triangle weir coefficient (unitless) } \\
& \mathrm{G}=\text { Gravity (ft/s) } \\
& \mathrm{H}=\text { Height of water above weir (ft) } \\
& \theta=\text { Full angle of weir (rad). }
\end{aligned}
$$

The automatic samplers were programmed to retrieve a $50 \mathrm{~mL}$ sample in intervals of 23 L (5 gallons) of flow over the weir. This interval ensured that a composite sample representative of the entire storm event, including the rising limb, peak, and falling limb of the hydrograph, was taken without overfilling the sample bottle. The flow weighted samples were retrieved through a suction tube that rested at the bottom of the weir box, just below the drainage pipe connection into the weir box. An $11 \mathrm{~L}$ ( 3 gal) glass jar inside the automatic sampler stored the samples until the composite runoff sample was collected after the rain event ceased. A Global Water Instruments, Inc. tipping bucket rain gauge was also installed on site and recorded data in 5-minute intervals though the greenroof's Sigma $900 \mathrm{Max}^{\mathrm{TM}}$ sampler. The rain gauge had a resolution of $0.25 \mathrm{~mm}(0.01 \mathrm{in}$.) and an accuracy of $3 \%$ up to $102 \mathrm{~mm} / \mathrm{hr}(4 \mathrm{in} . / \mathrm{hr})$ and an accuracy of $8 \%$ up to $152 \mathrm{~mm} / \mathrm{hr}(6 \mathrm{in} . / \mathrm{hr})$ (Global Water Instrumentation, Inc., 2004).

\subsubsection{Neuseway Nature Center Greenroof: Kinston, NC}

Two Sigma 900 $\mathrm{Max}^{\mathrm{TM}}$ Automatic Samplers were installed at the Neuseway Nature Center Greenroof site; one sampler was installed to record runoff from the greenroof and one 
sampler was installed to measure runoff from the control roof. The power source of each sampler was a 12-volt battery wired to a Solarex Solar Panel to recharge the battery. Each sampler was stored in a separate, secured, green storage box (as shown in Figure 4-5).

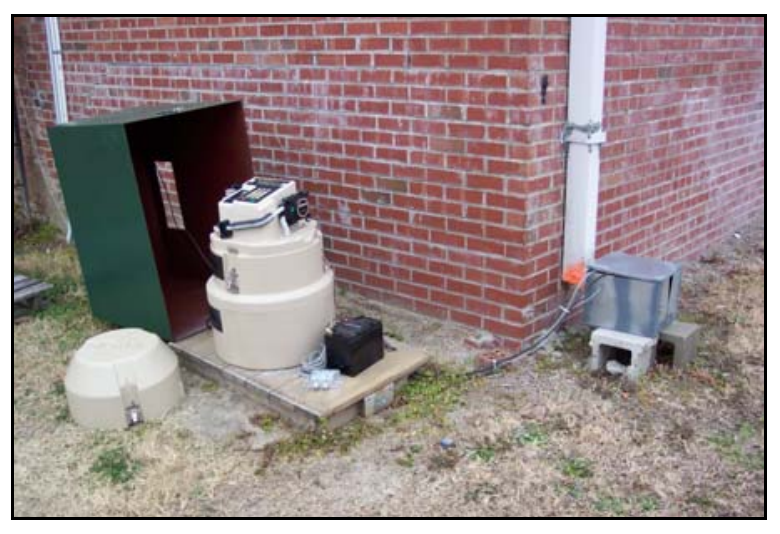

(a)

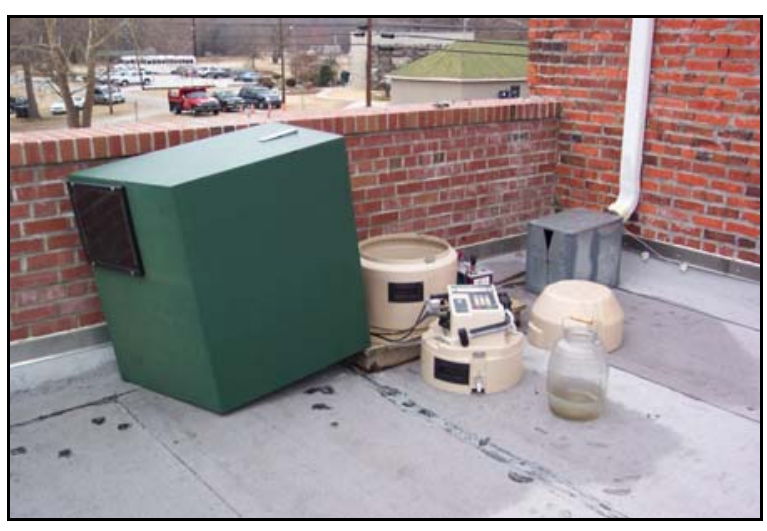

(b)

Figure 4-5. (a) Monitoring equipment for Nature Center Greenroof (February 2004). (b) Monitoring equipment for Nature Center Control Roof (February 2004).

The final drains for the control roof and the greenroof were each attached to a weir box constructed of galvanized steel. For the greenroof, runoff flowed over a $23^{\circ}$ v-notch, sharp crested weir plate before it exited the site. Runoff from the control roof flowed over the $30^{\circ}$ sharp crested, v-notch weir plate before leaving the site. The smaller angle of $23^{\circ}$ was selected for the greenroof weir plate because of the very low flows expected from the small roof dimensions; the surface area of the greenroof was only $27 \mathrm{~m}^{2}\left(290 \mathrm{ft}^{2}\right)$. As at the WCC Greenroof in Goldsboro, each weir box was equipped with a weir plate, a level sensor to measure water level, a baffle to still the flow of runoff over the weir, and a sampler hose to retrieve samples. The Sigma $900 \mathrm{Max}^{\mathrm{TM}}$ automatic samplers equated the water level data measured by the level sensor into flow data through Equation 4-1. The maximum range for the P/N 2963, 2.5 psi depth level sensor was 0.1 to $1.75 \mathrm{~m}(0.4$ to $5.75 \mathrm{ft})$ (American Sigma, 
2004). The depth level sensor was also accurate within $\pm 1 \%$ of the full scale and operational between $0^{\circ}$ and $71^{\circ} \mathrm{C}\left(32 \mathrm{o}\right.$ to $160^{\circ} \mathrm{F}$ ) (American Sigma, 2004). The greenroof Sigma $900 \mathrm{Max}^{\mathrm{TM}}$ was programmed to retrieve a sample every $23 \mathrm{~L}$ (5 gal); this ensured that flow weighted samples would be retrieved throughout the duration of the entire storm event, instead of all at once. Due to the much larger surface area of the control roof, $180 \mathrm{~m}^{2}$ (1820 $\mathrm{ft}^{2}$ ), samples were retrieved by the Sigma $900 \mathrm{Max}^{\mathrm{TM}}$ after every $76 \mathrm{~L}$ (20 gal) of runoff flowed over the weir. The flow weighted samples ensured that composite samples, representative of the entire storm event, were taken; the select intervals were chosen to assure that the composite sample was collected without overflowing the sample bottle. Samples were stored within the sampler unit in an $11 \mathrm{~L}$ (3 gal) glass jar until the samples were collected after the rain event ceased. Rain data was recorded in 5-minute intervals with a Global Water Instruments, Inc. tipping bucket rain gauge installed on site and programmed into the control roof's Sigma $900 \mathrm{Max}^{\mathrm{TM}}$ sampler unit. The rain gauge had a resolution of $0.25 \mathrm{~mm}(0.01 \mathrm{in}$.) and an accuracy of $3 \%$ up to $102 \mathrm{~mm} / \mathrm{hr}(4 \mathrm{in} . / \mathrm{hr})$ and an accuracy of $8 \%$ up to $152 \mathrm{~mm} / \mathrm{hr}$ (6 in./hr) (Global Water Instrumentation, Inc., 2004).

\subsubsection{Sample Collection Protocol and Data Retrieval}

The composite runoff sample was stored within an $11 \mathrm{~L}$ (3 gal) glass bottle inside the sampler unit for approximately 24 hours after the rainfall had ceased. When the samples were collected from each sampler, the runoff was poured into individual sample bottles provided by Tritest, Inc.; the samples were then transported to Tritest, Inc. in Raleigh, NC for water quality analysis. After the composite runoff sample was transferred into Tritest, Inc. 
sample bottles, the $11 \mathrm{~L}$ ( 3 gal) glass bottle was emptied and then replaced to its original position inside the sampler unit.

At each site, a container was used to capture rainfall. At the WCC Greenroof in Goldsboro, a rectangular Rubbermaid ${ }^{\circledR}$ container, with approximate dimensions of $0.46 \mathrm{~m}$ by $0.61 \mathrm{~m}$ by $0.15 \mathrm{~m}$ (18 in. by $24 \mathrm{in.}$ by 6 in.) was used to collect rainwater. In Kinston, a plastic, circular oil collection pan, approximately $0.46 \mathrm{~m}$ (18 in.) in diameter, was used at the Neuseway Nature Center Greenroof to collect rainwater. After the rain event had ceased, samples of the rainwater were also taken to the Tritest, Inc. laboratory for analysis; this rainwater was analyzed and regarded as the input for each greenroof system. As with the 11 L (3 gal) bottle inside the sampler unit that collected runoff, the rainwater collection container was emptied after samples were taken and then replaced to its original position.

Samples were retrieved from only select rainfall events at the research sites. Some rainfall events did not produce enough sample volume for the required analyses and other circumstances prevented sampling of some storm events. For example, samples from weekend rainfall events could not be collected because the laboratory was not open to analyze the samples. The same was true for holidays and if no one was available to drive to the sites to retrieve the samples within the 24-hour holding period. Goldsboro is approximately $80 \mathrm{~km}$ (50 miles) from Raleigh and Kinston is approximately $130 \mathrm{~km}(80$ miles) from Raleigh.

Rainfall, water level, and flow data were measured and recorded by each Sigma 900 $\mathrm{Max}^{\mathrm{TM}}$ automatic sampler unit. All data was recorded in 5 minute increments. The data 
was downloaded every three or four weeks and then was transferred into a Microsoft ${ }^{\circledR}$ Excel spreadsheet for analysis.

\subsubsection{WATER QUALITY ANALYSIS}

Water quality samples were taken from each research site to Tritest, Inc. in Raleigh, NC for analysis. Table 4-1 displays the analyses run on each runoff and rainfall sample retrieved from each greenroof research site.

Table 4-1. Analyses Performed on Each Runoff and Rainfall Sample.

\begin{tabular}{|c|c|c||}
\hline Test Performed & Abbreviation & $\begin{array}{c}\text { Test Method } \\
\text { (U.S. EPA, 1983; U.S. EPA, 1993) }\end{array}$ \\
\hline \hline Total Kjeldahl Nitrogen in Water & $\mathrm{TKN}$ as N & EPA Method 351.2 \\
\hline Nitrate-Nitrite in Water & $\mathrm{NO}_{3}$ as $\mathrm{N}-\mathrm{NO}_{2}$ as $\mathrm{N}$ & EPA Method 353.2 \\
\hline Total Nitrogen Calculation & $\mathrm{TN}$ & $\mathrm{TN}=\mathrm{TKN}+\left(\mathrm{NO}_{3}\right.$ as $\mathrm{N}-\mathrm{NO}_{2}$ as $\left.\mathrm{N}\right)$ \\
\hline Ammonia in Water & $\mathrm{NH}_{3}$ as $\mathrm{N}$ & EPA Method 350.1 \\
\hline Total Phosphorus & $\mathrm{TP}$ & EPA Method 365.4 \\
\hline Orthophosphate & $\mathrm{OP}$ & EPA Method 365.2 \\
\hline
\end{tabular}

\subsection{Field Study Results}

The hydrologic data and water quality data are presented separately for each greenroof site. The two sites in Goldsboro and Kinston could not be directly compared because of fundamental differences in their design, such as different surface areas, different drainage mediums, different roof pitch, and different average soil media depths. In addition, the two 
greenroof sites are approximately $48 \mathrm{~km}$ (30 miles) apart, and therefore, subject to different climate effects.

\subsubsection{HYdRologic Data}

\subsubsection{Water Retention}

Precipitation retained within the greenroof was defined as the difference between the depth of rainfall and the depth of runoff for each individual rain event. The amount of precipitation retained was temporarily stored within the soil media and the drainage layers; the precipitation retained was eventually lost from the system due to evapotranspiration.

\subsection{Wayne Community College Greenroof: Goldsboro, NC}

Water retention data for the Wayne Community College greenroof is presented in Appendix A; data was collected for the consecutive nine-month period from April 2003 to December 2003. A total of 39 measurable storm events were recorded and included in the analysis. Many smaller storms, such as less than $5 \mathrm{~mm}(0.2$ in.), were not included because no measurable runoff occurred from the greenroof. Statistical analysis of the water retention data is exhibited in Appendix B.

Of the measurable rainfall events at the WCC Greenroof in Goldsboro, a total 901 $\mathrm{mm}$ (35 in.) of rainfall fell on the greenroof and $345 \mathrm{~mm}$ (14 in.) drained from the greenroof, resulting in a retention of $556 \mathrm{~mm}$ (21 in.). Because the distribution of the mean differences between the amount of precipitation and the amount of runoff for each rain event were not normally distributed, a statistical t-test analysis was invalid; therefore, a Sign test was 
performed to analyze the significance of the amount retained. The amount of precipitation retained by the greenroof was significantly greater than the amount of runoff from the greenroof $(\alpha<0.05)$. The greenroof retained $62 \%$ of the total precipitation in the nine-month period from April 2003 to December 2003. Figure 4-6 displays the precipitation patterns observed in each month during the monitoring period. Table 4-2 also displays the information displayed in Figure 4-6. A rainfall event was defined by two rainfalls having an inter-event dry period of 6 hours or more (U.S. EPA, 2002b). It was seen that the drier months later in the year had higher retention rates. This indicated that during dry months the soil media does not remain as saturated as it does during wet months and the media can therefore retain more rainfall.

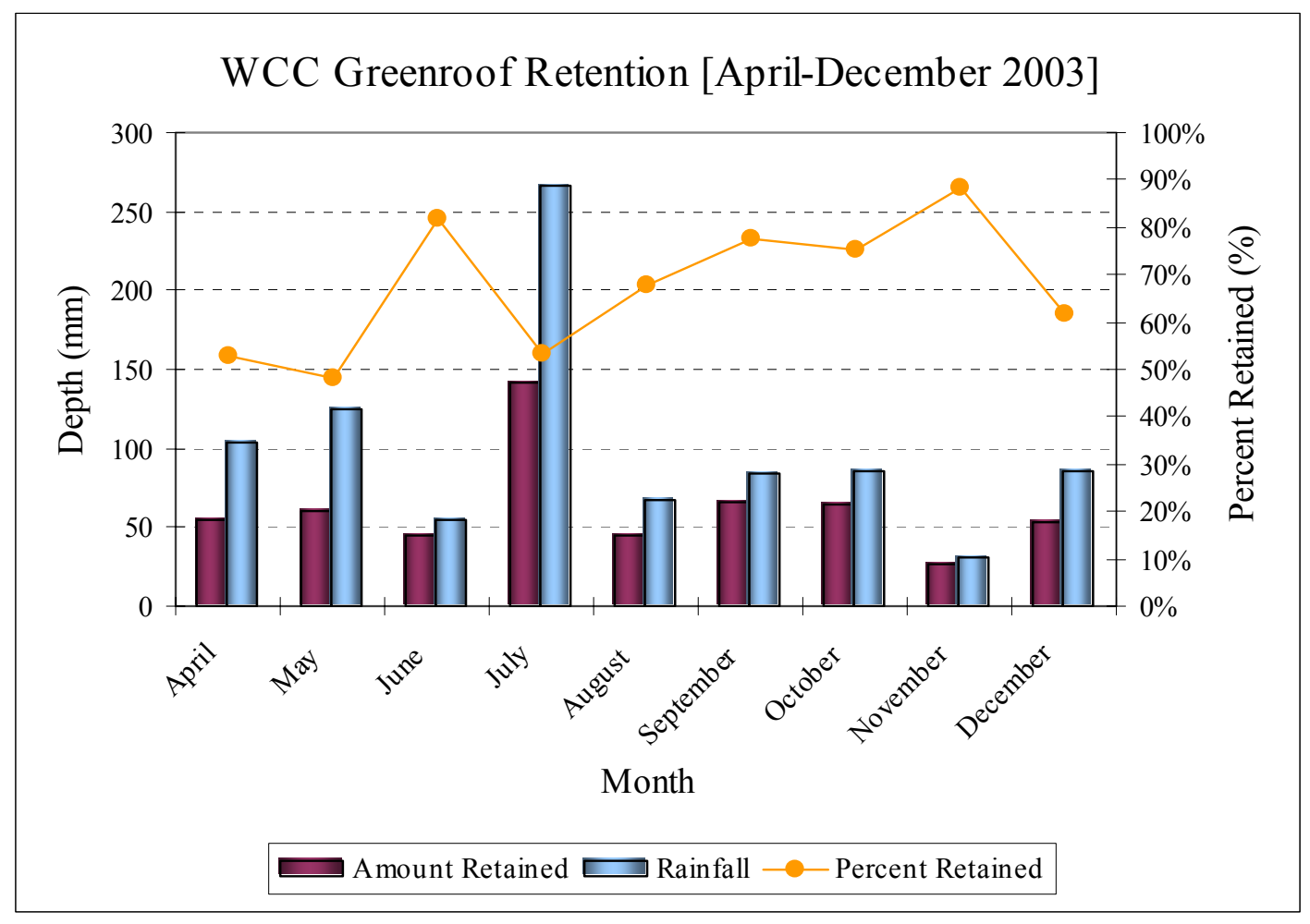

Figure 4-6. Display of Monthly Precipitation Retention at WCC Greenroof in Goldsboro, NC. 
Table 4-2. Summary Table of Water Retention at WCC Greenroof in Goldsboro, NC

\begin{tabular}{|c|c|c|c|c|}
\hline Period & Rainfall & Runoff & $\begin{array}{l}\text { Amount } \\
\text { Retained }\end{array}$ & $\begin{array}{l}\text { Percent } \\
\text { Retained }\end{array}$ \\
\hline April 2003 & $104 \mathrm{~mm}$ (4.1 in.) & $49 \mathrm{~mm}$ (1.9 in.) & $55 \mathrm{~mm}$ (2.2 in.) & $53 \%$ \\
\hline May 2003 & $124 \mathrm{~mm}$ (4.9 in.) & $64 \mathrm{~mm}$ (2.5 in.) & $60 \mathrm{~mm}(2.4$ in. $)$ & $48 \%$ \\
\hline June 2003 & $55 \mathrm{~mm}$ (2.2 in.) & $10 \mathrm{~mm}(0.4$ in. $)$ & $45 \mathrm{~mm}$ (1.8 in.) & $82 \%$ \\
\hline July 2003 & $266 \mathrm{~mm}$ (10.5 in.) & 124 mm (4.9 in.) & $142 \mathrm{~mm}$ (5.6 in.) & $53 \%$ \\
\hline August 2003 & $67 \mathrm{~mm}$ (2.6 in.) & $22 \mathrm{~mm}(0.8$ in. $)$ & $45 \mathrm{~mm}$ (1.8 in.) & $68 \%$ \\
\hline September 2003 & $84 \mathrm{~mm}$ (3.3 in.) & $19 \mathrm{~mm}(0.7$ in. $)$ & $65 \mathrm{~mm}$ (2.6 in.) & $78 \%$ \\
\hline October 2003 & $86 \mathrm{~mm}$ (3.4 in.) & $21 \mathrm{~mm}(0.8$ in. $)$ & $65 \mathrm{~mm}(2.6$ in.) & $75 \%$ \\
\hline November 2003 & $31 \mathrm{~mm}$ (1.2 in.) & $4 \mathrm{~mm}$ (0.1 in.) & $27 \mathrm{~mm}$ (1.1 in.) & $88 \%$ \\
\hline December 2003 & $85 \mathrm{~mm}$ (3.4 in.) & $32 \mathrm{~mm}$ (1.3 in.) & $53 \mathrm{~mm}$ (2.1 in.) & $62 \%$ \\
\hline TOTAL & $901 \mathrm{~mm}(35.5 \mathrm{in})$. & $345 \mathrm{~mm}$ (13.6 in.) & $556 \mathrm{~mm}$ (21.9 in.) & $62 \%$ \\
\hline
\end{tabular}

The total percent retention of this nine-month period reflected studies in Germany that showed annual retention of 50 to $65 \%$ for a 76 to $102 \mathrm{~mm}$ (3 to 4 in.) deep extensive greenroof (Liesecke, 1999; Liesecke, 1998). The total percent retention seen at the WCC Greenroof was also comparable to the $69 \%$ precipitation retention observed from a 102 to $127 \mathrm{~mm}$ (4 to $5 \mathrm{in}$.) deep extensive greenroof during a 15-month period during 2002 and 2003 in Portland, Oregon, which received approximately $1115 \mathrm{~mm}$ (44 in.) of rainfall (Hutchinson et al., 2003). Similarly, a study at Michigan State University reported 66\% precipitation retention by a greenroof studied over 24 rainfall events (Rowe et al., 2003).

The total percent precipitation retained was $62 \%$; however, when the monthly data was reviewed, the percent of precipitation varied between $48 \%$ and $88 \%$. Numerous factors affected how much rainfall was absorbed into the greenroof. Rainfall was measured on site and eliminated any possible location errors. For example, summer scattered showers in eastern North Carolina can be intense storms, but can also rain in one location and not rain in an area only $3 \mathrm{~km}$ ( 2 miles) away. The location of the rain gauge would play an important 
role in this type of summer storm. No known drainage leaks were found in the greenroof; therefore, the system was secure. In other words, the rainfall that was measured on location and fell on the roof either drained out of the system or was lost through evapotranspiration.

Other factors that affected the absorption capacity of the greenroof were climatological. The greenroof was not able to retain as much water during a month with excessive rainfall amounts than during a month when only small amounts of rain fell. If the soil media was already wet, it would not be able to retain much additional water before runoff would be observed from the greenroof. Evapotranspiration played a significant role in this process. Water temporarily stored within the soil media and drainage layer was either taken up by the vegetation through transpiration or it evaporated from the soil media. With summer ambient temperatures above $32^{\circ} \mathrm{C}\left(90^{\circ} \mathrm{F}\right)$ a large portion of the time, the soil media temperatures were also approximately, or above, $32^{\circ} \mathrm{C}\left(90^{\circ} \mathrm{F}\right)$. Water was easily able to evaporate from the soil media at such high temperatures.

Potential evapotranspiration (PET) rates were calculated using Thornthwaite's method (Skaggs, 2003), shown in Equation 4-2.

\section{Equation 4-2.}

$$
P E T=1.6 L_{d}(10 T / I)^{a}
$$

Where: $\mathrm{PET}=$ Potential evapotranspiration $(\mathrm{cm} /$ month $)$

$$
\begin{aligned}
& \mathrm{L}_{\mathrm{d}}=\text { Length of day coefficient }=(\text { daylight hours }) / 12 \quad \text { (unitless) } \\
& \mathrm{T}=\text { Average monthly temperature }\left({ }^{\circ} \mathrm{C}\right) \\
& \mathrm{I}=\text { Annual heat index defined by Equation } 4-3 \\
& \mathrm{a}=0.016 I+0.5
\end{aligned}
$$




\section{Equation 4-3.}

$I=\sum_{j} i_{j}$

Where: $i_{j}=$ Monthly heat index for month $j$, defined by Equation $4-4$

$\mathrm{j}=1,2,3 \ldots 12$

\section{Equation 4-4.}

$$
i_{j}=\left(\frac{T}{5}\right)^{1.514}
$$

$$
\begin{aligned}
& \text { Where: } i_{j}=\text { Monthly heat index for month } j \\
& \mathrm{~T}=\text { Average temperature for month } \mathrm{j} \\
& \mathrm{j}=1,2,3 \ldots 12 \text {. }
\end{aligned}
$$

Table 4-3 displays the average monthly temperature and the monthly PET rates in Goldsboro, NC. Approximate evapotranspiration rates were determined using the average daily temperature and the hours of daylight in Goldsboro, NC. Average daily temperatures were gathered from the Center for Environmental Farming Systems (CEFS) in Goldsboro and the hours of daylight were referenced from the Astronomical Applications Department of the U.S. Naval Observatory. The PET rates were assumed to be the same for Kinston, NC because while the rainfall patterns may be different between the two sites, the temperature and hours of daylight were assumed not to be significantly different $48 \mathrm{~km}$ (30 miles) apart. As evident from Table 4-3, summer PET rates are much higher than those in the winter. PET rates in July and August are more than 20 times larger than PET rates in December. Seasonal evapotranspiration rates will have a large effect on the amount of water retained on the greenroof because the retained water is lost from the system through evapotranspiration. 
Table 4-3. Approximate PET rates for Goldsboro and Kinston, NC.

\begin{tabular}{|l|c|c|c|}
\hline Month & Average Temperature & PET (mm/month) & PET (in./month) \\
\hline \hline January & $6.3^{\circ} \mathrm{C}\left(43^{\circ} \mathrm{F}\right)$ & 10 & 0.4 \\
\hline February & $8.1^{\circ} \mathrm{C}\left(47^{\circ} \mathrm{F}\right)$ & 16 & 0.6 \\
\hline March & $12^{\circ} \mathrm{C}\left(54^{\circ} \mathrm{F}\right)$ & 35 & 2.4 \\
\hline April & $17^{\circ} \mathrm{C}\left(63^{\circ} \mathrm{F}\right)$ & 69 & 3.8 \\
\hline May & $20^{\circ} \mathrm{C}\left(68^{\circ} \mathrm{F}\right)$ & 96 & 5.5 \\
\hline June & $24^{\circ} \mathrm{C}\left(75^{\circ} \mathrm{C}\right.$ & 139 & 5.9 \\
\hline July & $25^{\circ} \mathrm{C}\left(77^{\circ} \mathrm{F}\right)$ & 151 & 5.7 \\
\hline August & $26^{\circ} \mathrm{C}\left(79^{\circ} \mathrm{F}\right)$ & 144 & 3.8 \\
\hline September & $22^{\circ} \mathrm{C}\left(72^{\circ} \mathrm{F}\right)$ & 96 & 2.0 \\
\hline October & $15^{\circ} \mathrm{C}\left(59^{\circ} \mathrm{F}\right)$ & 51 & 1.5 \\
\hline November & $14^{\circ} \mathrm{C}\left(57^{\circ} \mathrm{F}\right)$ & 38 & 0.3 \\
\hline December & $5^{\circ} \mathrm{C}\left(41^{\circ} \mathrm{F}\right)$ & 7 & \\
\hline
\end{tabular}

In April 2003, three consecutive rain events occurred on April 7, April 8, and April 9, each with respective precipitation totals of $23 \mathrm{~mm}(0.89$ in.), $26 \mathrm{~mm}$ (1.02 in.), and $41 \mathrm{~mm}$ (1.63 in.). As shown in Figure 4-7, the amount of precipitation retained declines slightly after the first rain event. This shows that with three consecutive rain events, the two later storms were not able to retain the same amount of water as the first storm. Figure 4-7 also illustrates how the percent precipitation retained can steadily decrease as the precipitation increases. By the end of the third rain event, approximately $90 \mathrm{~mm}$ (3.5 in.) of precipitation fell on the greenroof. It is evident that during each rain event, the soil media did become fairly saturated; otherwise there would not have been runoff from the greenroof. However, even after the third rain event, the greenroof was able to retain a portion of the rainfall because the approximate evapotranspiration rates were approximately $69 \mathrm{~mm} / \mathrm{month}(2.7$ in./month). 


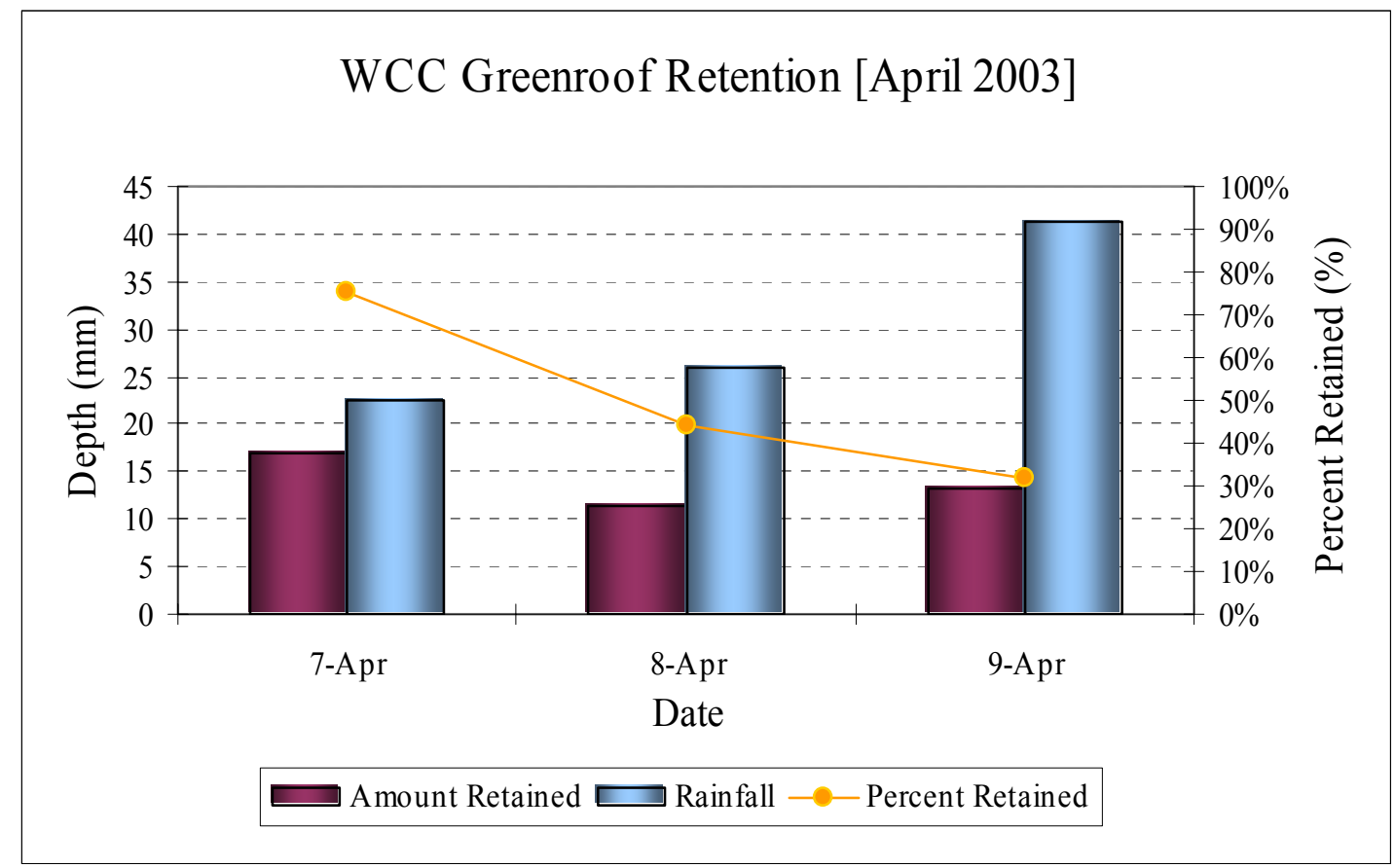

Figure 4-7. Display of Variances of Percent Retention for Three Consecutive Rain Events in April 2003.

Variability of percent retained can also be seen within each month. For example, Figure 4-8 displays each of the 6 rainfall events which occurred during May 2003. The first three rain events each retained more than $80 \%$ of the rainfall and the latter three storms all retained less than $40 \%$ of the precipitation from each rain event. This is a large difference of percent retained. However, after reviewing the data, one can understand why such a reduction in the percent precipitation retained was observed. The first rain event on May 6 had a precipitation depth of $20 \mathrm{~mm}(0.77$ in.) and $16 \mathrm{~mm}(0.64 \mathrm{in}$.$) was retained. The second$ rain event on May 15, only $8 \mathrm{~mm}$ (0.31 in.) of rainfall occurred and all was retained within the greenroof. This rain event was nine days after the first rain event, which provided ample time for moisture within the soil media to evapotranspirate out of the system. Average daily temperatures during this period were near $24^{\circ} \mathrm{C}\left(76^{\circ} \mathrm{F}\right)$, allowing for high evapotranspiration 
rates. The third rain event was only three days after the second, but the amount retained was still high because the rainfall on May 15 was not large.

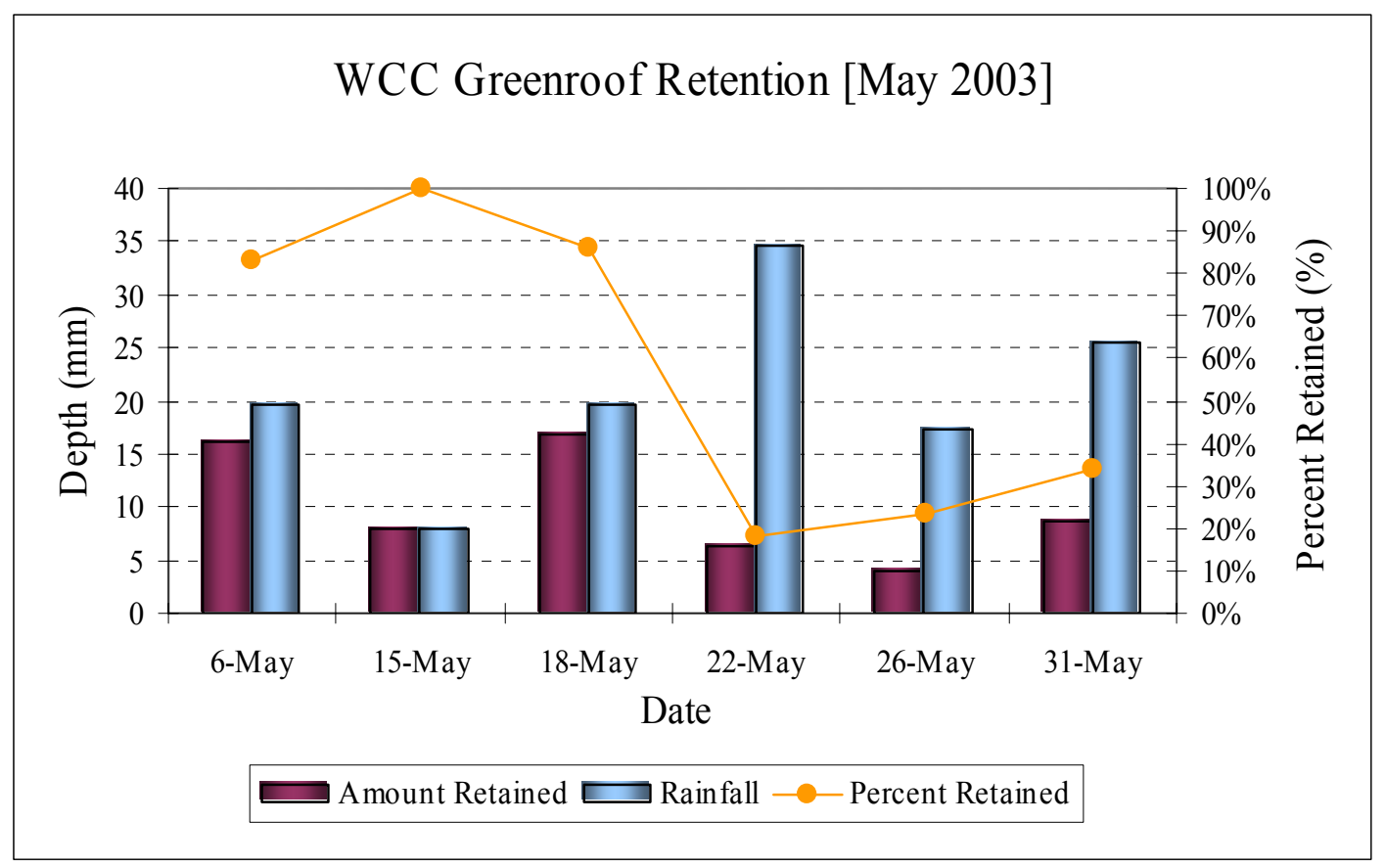

Figure 4-8. Display of Variability of Percent Retained in May 2003.

However, the fourth rainfall event was only 4 days after the third, and was a considerable rain event of $35 \mathrm{~mm}$ (1.36 in.). The moisture content of the soil media may still have been high from the previous rain event, thus resulting in a low amount of precipitation retained. Again, the fifth rain event was only four days after the fourth and was approximately $17 \mathrm{~mm}(0.70 \mathrm{in}$.$) ; the sixth rain event was five days after the fifth and was$ also a considerable storm of $25 \mathrm{~mm}$ (1.0 in.). The drop in the amount of precipitation retained in the latter half of the month is a result of the moisture content of the soil media remaining high due to the frequent occurrence of rain events throughout the month. Average ambient temperatures during the last three rain events were also lower than in the first 
portion of May, temperatures averaged near $18^{\circ} \mathrm{C}\left(65^{\circ} \mathrm{F}\right)$. This drop in temperature from the first portion of May indicates that the PET rate would have also dropped and less rainfall could have been lost to the atmosphere.

Figure 4-9 displays the variability in the percent precipitation retained during July 2003. Over $254 \mathrm{~mm}$ (10 in.) of precipitation fell during July 2003; the largest interval between rain events was eight days and the smallest was less than 24 hours. A notable drop in the amount of precipitation retained is seen in the July 14 rain event of $8 \mathrm{~mm}(0.31 \mathrm{in}$.), which immediately followed a $43 \mathrm{~mm}$ (1.7 in.) rainfall the prior day. The percent retention on 18 July is also low for the $31 \mathrm{~mm}$ (1.2 in.) sized rain event. This may be a result of a measurement error by the rain gauge because the majority of this rainfall occurred in a 50 minute period; the rain gauge can become inaccurate at such high rainfall intensities.

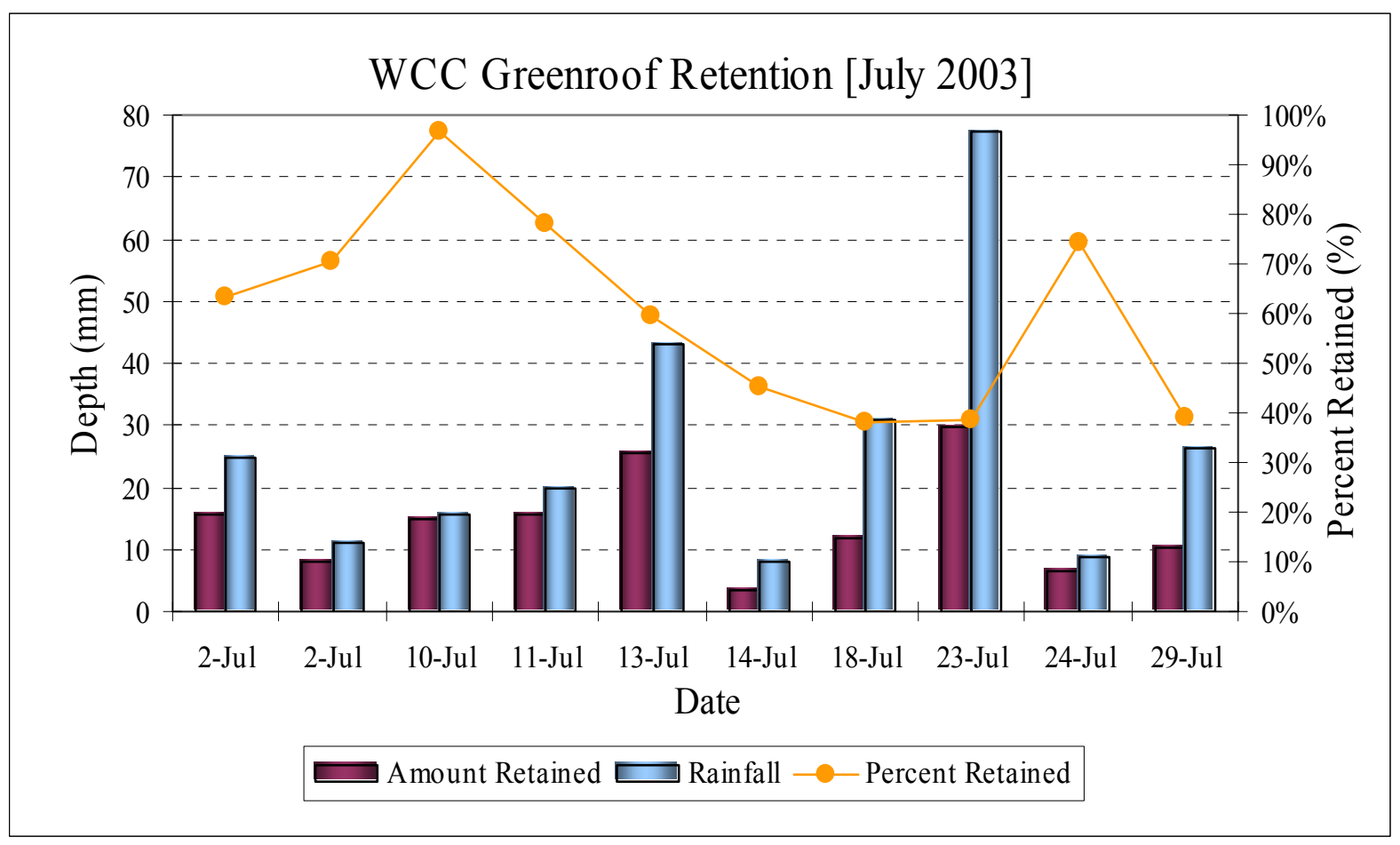

Figure 4-9. Display of Variability in Percent Retained in July 2003. 
Additionally, there was almost no delay in runoff from the greenroof after rainfall began, this may be a result of sheet flow to the drain under such intense rainfall conditions. The amount of precipitation retained on July 23 was similar to the amount of precipitation retained on July 13, indicating that the moisture content of the soil media had had sufficient time to dry before the rain event on 23 July. The rain event on 23 July was the largest recorded rainfall event during the 9-month monitoring period; $78 \mathrm{~mm}$ (3.1 in.) of precipitation fell onto the roof and $48 \mathrm{~mm}(1.2 \mathrm{in}$.) was retained by the greenroof. This rainfall was almost the size of a 2-year, 24-hour rain event; a 2-year, 24-hour rain event for the Raleigh-Durham area of North Carolina is $91 \mathrm{~mm}$ (3.60 in.) (Malcom, 2003).

Little variability in the amount of precipitation retained was seen in months with numerous days between each rainfall. For example, in October 2003, only three rain events were observed; Figure 4-10 displays the retention data for October 2003. The first rain events were separated by six days and recorded the same amount of rainfall, $14 \mathrm{~mm}(0.54 \mathrm{in}$.). The first and second rain event each retained $12.4 \mathrm{~mm}(0.49 \mathrm{in}$.) and $11.9 \mathrm{~mm}(0.47 \mathrm{in}$.$) of the 14$ $\mathrm{mm}(0.54$ in.) rainfall, respectively. The third rain event was separated from the second by 14 days, thus providing ample time for the moisture content within the soil media to be at a minimum for the October 28 storm; the average PET for October is $51 \mathrm{~mm} / \mathrm{month}(2$ in./month). The October 28 rain event produced $58 \mathrm{~mm}$ (2.3 in.) of precipitation and $40 \mathrm{~mm}$ (1.6 in.) of precipitation was retained by the greenroof. However, while the percent of precipitation retained decreased from the previous two rain events, a higher amount of precipitation was retained. This illustrates how the amount of precipitation plays an imperative role on the percent precipitation retained. 


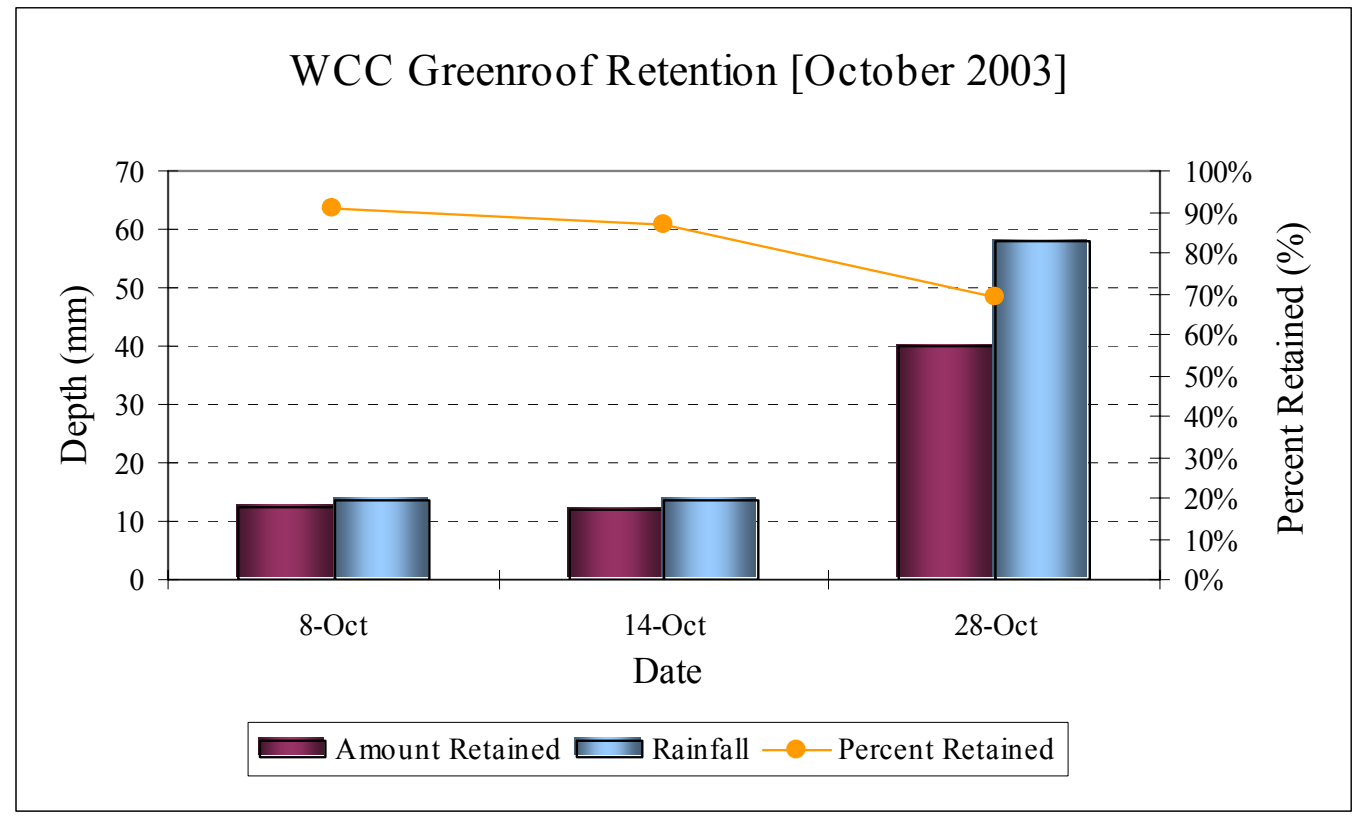

Figure 4-10. Display of Variability of Percent Retained in October 2003.

Figure 4-9 and Figure 4-10 both display the percent retention for relatively large storms. While the 28 October rain event is approximately $18 \mathrm{~mm}(0.75 \mathrm{in}$.$) less than the 23$ July rain event, the greenroof retained approximately $10 \mathrm{~mm}(0.25 \mathrm{in}$.) more during the 28 October event than the 23 July rain event. It is important to review the rainfall patterns for these two events. The July rain event was typical of a summer thunderstorm; this storm event was very intense and runoff was observed from the greenroof 25 minutes after rainfall began; the total duration of the rain event was approximately 4 hours. The October rain event had a much longer duration than the July event; the total approximate duration of the October storm event was 17 hours. On 28 October, runoff was not observed from the greenroof until approximately 6.5 hours after rainfall began. The nature of these two storms indicates that the retention of the greenroof will vary, depending on the duration and intensity of the rainfall event. More retention may be observed during rainfalls of lesser intensities 
and longer durations. The 23 July rain event was the largest amount of precipitation retained for any individual event observed at the WCC Greenroof

\subsection{Neuseway Nature Center Greenroof: Kinston, NC}

The water retention data of the Neuseway Nature Center greenroof is presented in Appendix C; statistical analysis of the data is presented in Appendix D. Data was collected for a total of four months including July 2003, August 2003, November 2003, and December 2003. A total of 11 measurable storm events were recorded and included in the analysis. Many smaller storms, such a less than $5 \mathrm{~mm}(0.2$ in. $)$, were not included because no measurable runoff occurred from the greenroof. Relative to the WCC greenroof, much less data is available. This is due to leaks in the gutter drainage system on the exterior of the Nature Center Greenroof during the spring and early summer months of 2003; these leaks were fixed in early July 2003, therefore, only a portion of July 2003 is available. Data is also unavailable in the fall of 2003 due to equipment malfunction; data is unavailable for October 2003 because the sampling equipment was temporarily removed due to the threat of flooding from an approaching hurricane.

While there is limited data available on the water retention performance of the Nature Center Greenroof in Kinston, the total retention data is similar to the retention data of the WCC Greenroof in Goldsboro. A total of $262 \mathrm{~mm}$ (10.3 in.) of rainfall was recorded in Kinston during the four month period of July, August, November and December 2003. Of the $262 \mathrm{~mm}$ (10.3 in.) of rainfall, $166 \mathrm{~mm}$ (6.5 in.) was retained within the greenroof, resulting in a total retention of $63 \%$. This total retention of the recorded rainfall events 
strongly correlates with the water retention data of the WCC Greenroof in Goldsboro, which had a total retention of $62 \%$. It is clear that the greenroof retained a significant portion of the rainfall $(\alpha<0.05)$. As with the WCC Greenroof retention data, the mean differences between the precipitation and the depth of runoff were not normally distributed, therefore, a statistical t-test was invalid. A Sign test was performed to analyze the significance of the precipitation retention of the greenroof.

Figure 4-11 displays the retention data for the Neuseway Nature Center Greenroof in Kinston, NC. Table 4-4 summarizes the results presented in Figure 4-11. The amount of rainfall recorded in July 2003 at the Nature Center Greenroof is much less than the $266 \mathrm{~mm}$ (10.5 in.) recorded at the WCC Greenroof during the same month. This is because only the $18 \mathrm{~mm}(0.71$ in.) rainfall on 11 July was recorded at the Nature Center. All other storms in July 2003 at the Nature Center were lost either due to leaks in the greenroof drainage system or due to equipment malfunctions.

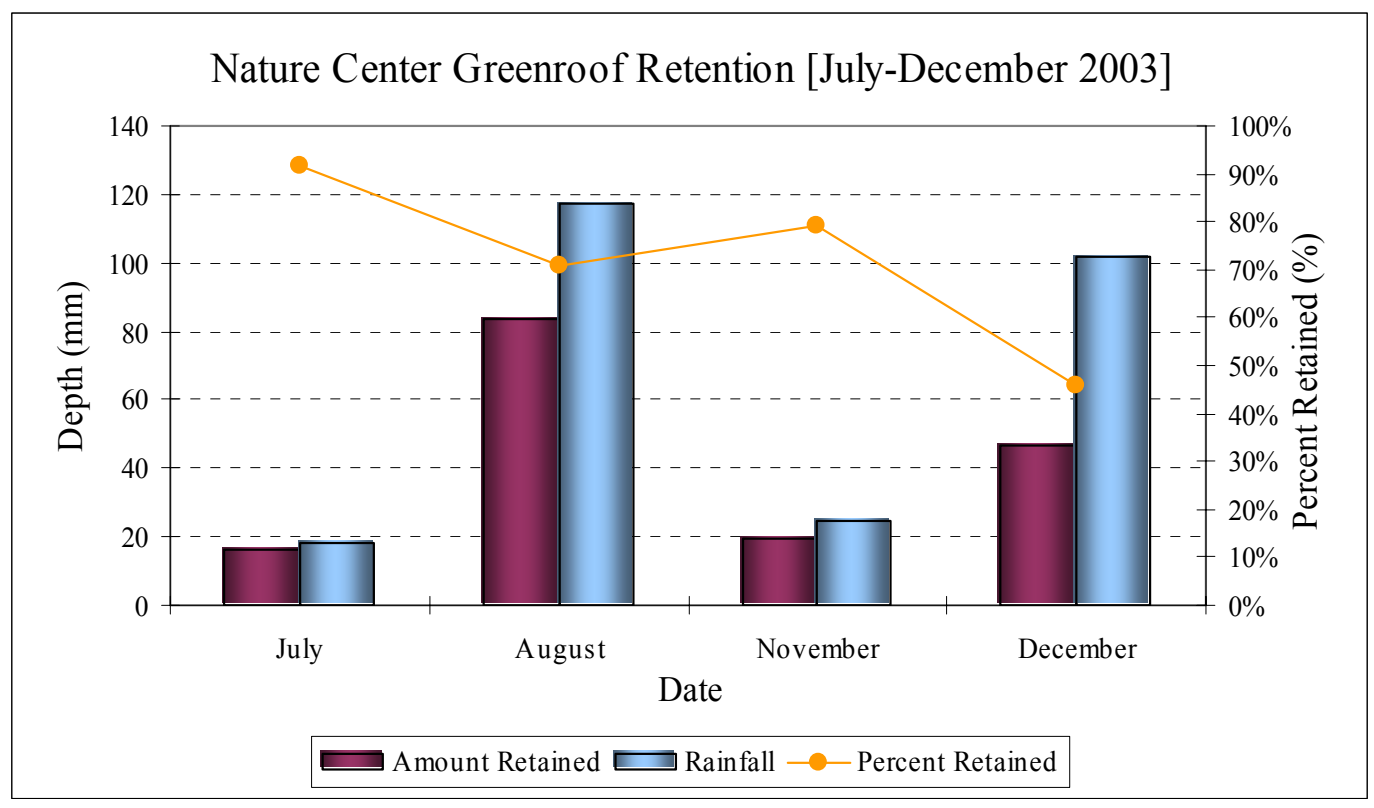

Figure 4-11. Display of Monthly Percent Retention at Nature Center Greenroof in Kinston, NC. 
Table 4-4. Summary Table of Water Retention Data at Neuseway Nature Center Greenroof in Kinston, NC

\begin{tabular}{|l|c|c|c|c||}
\hline Period & Rainfall & Runoff & $\begin{array}{c}\text { Amount } \\
\text { Retained }\end{array}$ & $\begin{array}{c}\text { Percent } \\
\text { Retained }\end{array}$ \\
\hline \hline July 2003 & $18 \mathrm{~mm}(0.71 \mathrm{in})$. & $1.5 \mathrm{~mm}(0.06$ in. $)$ & $16.5 \mathrm{~mm}(0.65$ in. $)$ & $92 \%$ \\
\hline August 2003 & $118 \mathrm{~mm}(4.6$ in. $)$ & $34 \mathrm{~mm}(1.3 \mathrm{in})$. & $84 \mathrm{~mm}(3.3 \mathrm{in})$. & $71 \%$ \\
\hline November 2003 & $25 \mathrm{~mm}(0.97$ in. $)$ & $5.1 \mathrm{~mm}(0.20$ in. $)$ & $20 \mathrm{~mm}(0.77$ in. $)$ & $79 \%$ \\
\hline December 2003 & $102 \mathrm{~mm}(4 \mathrm{in})$. & $55 \mathrm{~mm}(2.2 \mathrm{in})$. & $47 \mathrm{~mm}(1.8 \mathrm{in})$. & $45 \%$ \\
\hline TOTAL & $262 \mathrm{~mm}(10.3 \mathrm{in})$. & $96 \mathrm{~mm}(3.8 \mathrm{in})$. & $166 \mathrm{~mm}(6.5 \mathrm{in})$. & $63 \%$ \\
\hline
\end{tabular}

The percent retention of this $102 \mathrm{~mm}$ (4 in.) deep extensive greenroof also correlates to the data Dr. Liesecke has presented showing annual retention of 50 to $65 \%$ for 76 to 102 mm (3 to 4 in.) deep extensive greenroofs in Germany (Liesecke, 1999; Liesecke, 1998). The $63 \%$ retention of the Neuseway Nature Center Greenroof in Kinston is similar to the $69 \%$ retention observed during a 15-month period in Portland, Oregon, and the $66 \%$ precipitation retention observed over an average of 24 rainfall events at Michigan State University (Hutchinson et al., 2003; Rowe et al., 2003).

The total precipitation retention was $63 \%$; however, the monthly retention ranged from $45 \%$ to $92 \%$. The monthly precipitation retention was dependent upon the PET rates (displayed in Table 4-3), the seasonal rainfall patterns, the individual rainfall intensities and durations of each storm event, and the moisture content of the soil media at the time of the rain event. Because Kinston is only $48 \mathrm{~km}$ (30 miles) east of Goldsboro, NC, the PET rates calculated with Goldsboro temperature data were assumed to be the same PET rates for the Nature Center Greenroof in Kinston.

As with the WCC Greenroof in Goldsboro, variation of percent retention is also examined within each month. Figure 4-12 displays the precipitation retention data for 
August 2003. The total precipitation was $118 \mathrm{~mm}$ (4.6 in.) and the retention did not reach below $60 \%$. The average PET rates in August are the second highest rates during the year; high PET rates contributed to the high precipitation rates for the month of August. Rainfall events with less than $10 \mathrm{~mm}(0.40 \mathrm{in}$.) typically had higher percent retention rates due to the small amount of precipitation, while higher rainfall events typically had smaller retention rates due to the larger amount of precipitation. This is demonstrated in Figure 4-12 because three of the six rainfall events were less than $8 \mathrm{~mm}$ ( $0.31 \mathrm{in}$.) and each had a percent retention of $86 \%$ or higher.

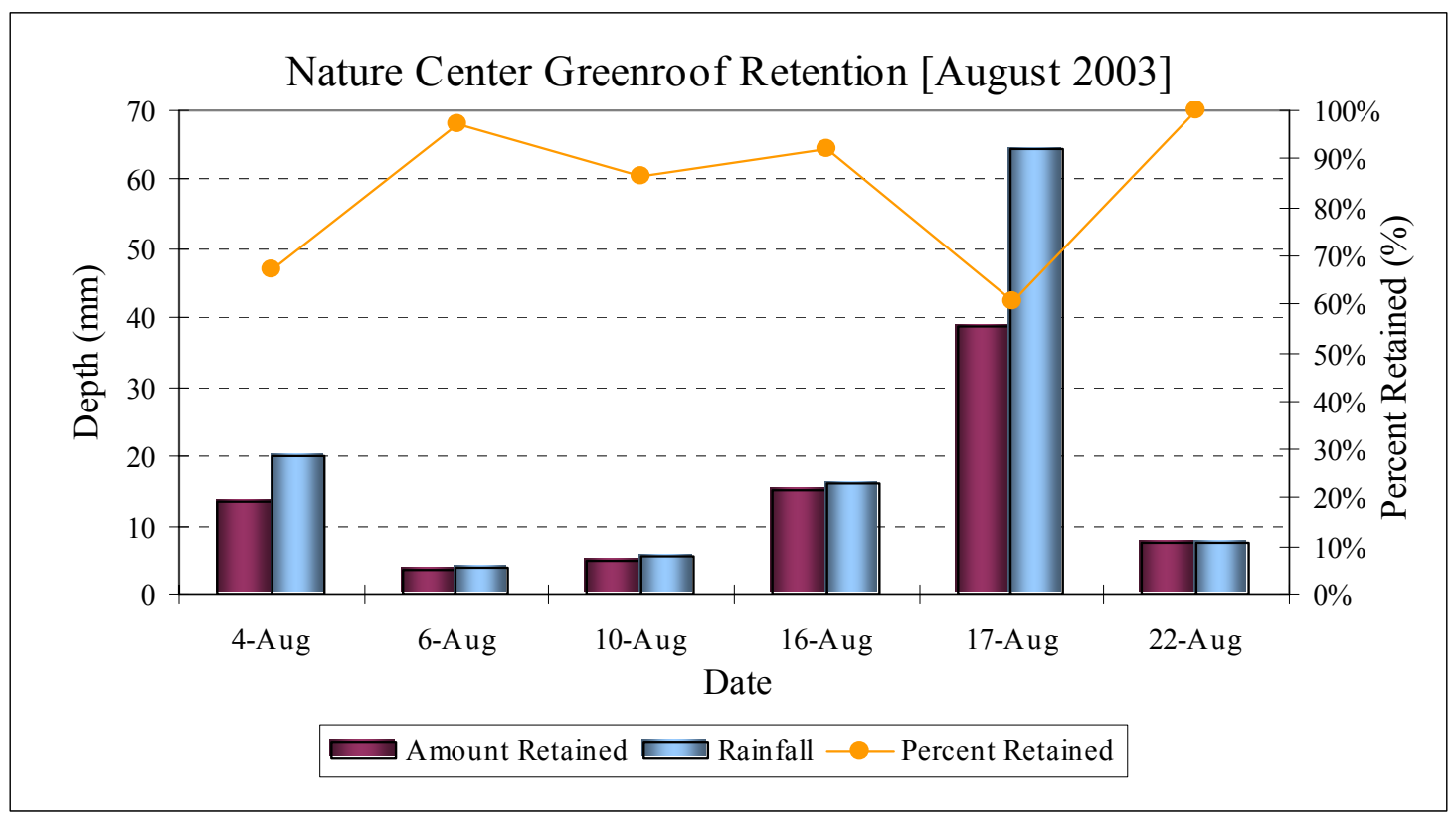

Figure 4-12. Display of Variation in Water Retention during August 2003.

The $64 \mathrm{~mm}$ (2.5 in.) rain event on 17 August had a high percent retention of $60 \%$ even though the greenroof received a $16 \mathrm{~mm}(0.64 \mathrm{in}$.) rainfall the prior day. While the rain event on 16 August was somewhat intense, the rainfall lasted approximately 2.5 hours. The rain event on 17 August had a much lower intensity and a longer duration than the 16 August 
event; the duration of the 17 August event was approximately 6 hours. The 17 August event observed at the Nature Center Greenroof and the 28 October event observed at the WCC Greenroof both demonstrate that the maximum amount of precipitation can be retained during rainfalls of low intensity and long duration. The 28 October storm at the WCC Greenroof and the 17 August storm at the Nature Center Greenroof both represented the maximum amount of rainfall retained, approximately $40 \mathrm{~mm}$ (1.6 in.).

The rain event on 17 August was the largest recorded rainfall event during the 4month monitoring period; $64 \mathrm{~mm}$ (2.5 in.) of precipitation fell onto the roof and $25 \mathrm{~mm}(1.0$ in.) was retained by the greenroof. This rainfall was less than the size of a 2-year, 24-hour rain event; a 2-year, 24-hour rain event for the Raleigh-Durham area of North Carolina is 91 mm (3.60 in.) (Malcom, 2003).

Figure 4-13 displays the precipitation retention data for December 2003. The total precipitation for the month was $102 \mathrm{~mm}$ (4 in.); unlike in August 2003, the percent retention drops below $60 \%$ for two of the three rainfall events. The decrease in the percent retention is a result of the decreased evapotranspiration rates and the larger storms present in December. Potential evapotranspiration rates during the month of December are the lowest of the year (See Table 4-3). While two of the rain events were of near $40 \mathrm{~mm}$ (1.6 in.), there were still several days between each rain event. For example, on December 10 , only $23 \%$ of the rainfall was retained and the previous rain event was 6 days before. In August 2003, a 64 $\mathrm{mm}$ (2.5 in.) rain event occurred on August 17 with $60 \%$ of the precipitation retained, even with a $16 \mathrm{~mm}(0.64 \mathrm{in}$.) rain event the previous day that retained 92\%. In comparison, the 39 
$\mathrm{mm}$ (1.5 in.) rain event on December 10 only retained $23 \%$. This illustrates the difference in percent retention as a result of decreased evapotranspiration rates in the winter months.

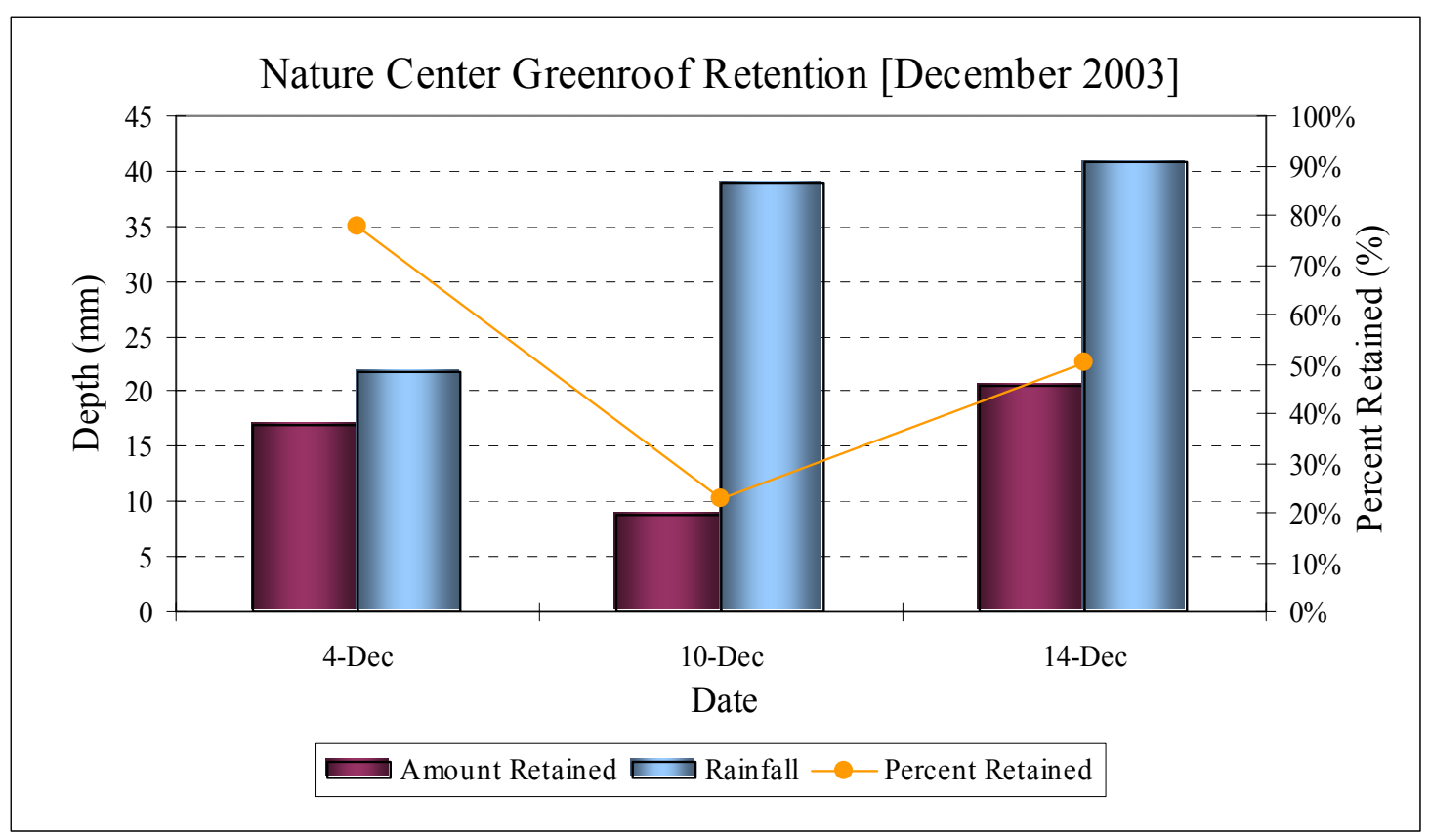

Figure 4-13. Display of Variation in Water Retention during December 2003.

The two rain events on 10 December and 14 December had approximately the same amount of precipitation but the amount retained on 10 December was less than half the amount retained on 14 December. This was mainly an effect of evapotranspiration. While $17 \mathrm{~mm}(0.7$ in.) was retained on 4 December, the temperature range of the 6 days between the two events was between 0.6 and $4.4^{\circ} \mathrm{C}\left(33\right.$ and $\left.40^{\circ} \mathrm{F}\right)$, allowing for low PET rates. Some of the retained precipitation from the 4 December event may have still been saturated within the soil media, resulting in the lower amount of precipitation retained on 10 December. The ambient temperature range between 10 December and 14 December was 2.8 to $12^{\circ} \mathrm{C}$ (37 to 
$50^{\circ} \mathrm{F}$ ), as the PET rates were higher during this period, more moisture was lost from the soil media, allowing for more retention to be possible for the rain event on 14 December.

\subsubsection{Peak Flow Reduction}

Little information is documented on the peak flow reduction benefits of a greenroof. One of the primary functions of a greenroof is to retain rain water through absorption of the precipitation into the soil media and drainage layers (Liesecke, 1998). Runoff typically does not occur from the greenroof until the soil is fully saturated. As a result, there is a delay between the time when precipitation begins and the time when runoff is observed from the greenroof; this delay can sometimes be several hours, depending upon the intensity and duration of the rain event. A delay is also caused by the amount of time it takes for the water to laterally move through the drainage medium. Runoff from a sloped, hard-surfaced conventional rooftop would occur almost immediately after rainfall began because the initial interception of the roof would be negligible. In a design manual published by the U.S. Department of Transportation, typical interception depths are recorded as $0.51 \mathrm{~mm}(0.02 \mathrm{in}$.) (Masch et al., 1984). Runoff from this type of a conventional rooftop would also very nearly follow the same intensity patterns as the rainfall. However, on a flat, hard-surfaced roof, precipitation would pond on the roof surface for a period of time before runoff would begin; typically, flat, hard-surfaced roofs may retain 5 to $6 \mathrm{~mm}(0.2$ to $0.25 \mathrm{in}$.) of rainfall before runoff is observed. 


\subsection{Wayne Community College Greenroof: Goldsboro, NC}

The peak flow reduction data for individual rain events at the WCC Greenroof is presented in Appendix A; statistical analysis of the peak flow reduction is presented in Appendix B. The peak flow of runoff from the WCC Greenroof in Goldsboro, NC, was compared against the peak rate of precipitation onto the greenroof. Runoff flow rates from the control roof at Goldsboro were not measured due to reported leaks in the drainage system. The difference between the peak rainfall rate and the peak runoff flow rate from the greenroof was determined to be not normally distributed; therefore, a statistical t-test was invalid. A Sign test was performed to analyze the statistical significance of the reduction of peak flow by the greenroof. The peak flow of the runoff from the greenroof was significantly less than the peak rainfall rate onto the greenroof $(\alpha<0.05)$. The average peak rainfall rate of the ninemonth period was $38 \mathrm{~mm} / \mathrm{hr}(1.5 \mathrm{in.} / \mathrm{hr})$ and the average greenroof runoff peak of the ninemonth period was $8.3 \mathrm{~mm} / \mathrm{hr}(0.3 \mathrm{in} . / \mathrm{hr})$, resulting in an average percent reduction of $78 \%$. Table 4-5 displays the average monthly reductions of peak flow from the greenroof.

Table 4-5. Summary Table of Peak Flow Reduction at WCC Greenroof in Goldsboro, NC

\begin{tabular}{|l|c|c|c|}
\hline Period & Average Rainfall Peak & Average Runoff Peak & Percent Reduction \\
\hline \hline April 2003 & $37 \mathrm{~mm} / \mathrm{hr}(1.5 \mathrm{in} . / \mathrm{hr})$ & $10 \mathrm{~mm} / \mathrm{hr}(0.4 \mathrm{in} . / \mathrm{hr})$ & $73 \%$ \\
\hline May 2003 & $23 \mathrm{~mm} / \mathrm{hr}(0.9 \mathrm{in} . / \mathrm{hr})$ & $3.6 \mathrm{~mm} / \mathrm{hr}(0.1 \mathrm{in} . / \mathrm{hr})$ & $78 \%$ \\
\hline June 2003 & $49 \mathrm{~mm} / \mathrm{hr}(1.9 \mathrm{in} . / \mathrm{hr})$ & $3.5 \mathrm{~mm} / \mathrm{hr}(0.1 \mathrm{in} . / \mathrm{hr})$ & $95 \%$ \\
\hline July 2003 & $55 \mathrm{~mm} / \mathrm{hr}(2.2 \mathrm{in} . / \mathrm{hr})$ & $21 \mathrm{~mm} / \mathrm{hr}(0.8 \mathrm{in} . / \mathrm{hr})$ & $72 \%$ \\
\hline August 2003 & $48 \mathrm{~mm} / \mathrm{hr}(1.9 \mathrm{in} . / \mathrm{hr})$ & $6.6 \mathrm{~mm} / \mathrm{hr}(0.3 \mathrm{in} . / \mathrm{hr})$ & $86 \%$ \\
\hline September 2003 & $49 \mathrm{~mm} / \mathrm{hr}(1.9 \mathrm{in} . / \mathrm{hr})$ & $5.2 \mathrm{~mm} / \mathrm{hr}(0.2 \mathrm{in} . / \mathrm{hr})$ & $91 \%$ \\
\hline October 2003 & $12 \mathrm{~mm} / \mathrm{hr}(0.5 \mathrm{in} . / \mathrm{hr})$ & $2.1 \mathrm{~mm} / \mathrm{hr}(0.1 \mathrm{in} . / \mathrm{hr})$ & $86 \%$ \\
\hline November 2003 & $27 \mathrm{~mm} / \mathrm{hr}(1.1 \mathrm{in} . / \mathrm{hr})$ & $1.2 \mathrm{~mm} / \mathrm{hr}(0.05 \mathrm{in} . / \mathrm{hr})$ & $95 \%$ \\
\hline December 2003 & $13 \mathrm{~mm} / \mathrm{hr}(0.5 \mathrm{in} . / \mathrm{hr})$ & $5.2 \mathrm{~mm} / \mathrm{hr}(0.2 \mathrm{in} . / \mathrm{hr})$ & $69 \%$ \\
\hline $\begin{array}{l}\text { MONITORING } \\
\text { PERIOD AVERAGE }\end{array}$ & $38 \mathrm{~mm} / \mathrm{hr}(1.5 \mathrm{in} . / \mathrm{hr})$ & $8.3 \mathrm{~mm} / \mathrm{hr}(0.3 \mathrm{in} . / \mathrm{hr})$ & $78 \%$ \\
\hline
\end{tabular}


The reduction in peak flow can best be characterized by a hydrograph. Figure 4-14 displays the rainfall rate $(\mathrm{mm} / \mathrm{hr})$ and the runoff flow $(\mathrm{mm} / \mathrm{hr})$ of three consecutive rain events in April 2003. A clear reduction of peak flow is evident between the rainfall rate and the flow of runoff from the greenroof.

The three rain events displayed in Figure 4-14 display how the peak flow reduction can decrease after consecutive rainfall events. The first rain event on 7 April had the longest delay before runoff was observed; the delays on the latter two storms were not as pronounced. While the first two rain events on 7 April and 8 April both had high reductions in peak flow, the peak runoff during the third storm event on 9 April was much higher. This was a result of the soil remaining saturated from the previous two rain events and the high intensity of the rainfall. It is possible that sheet flow may have briefly occurred on the surface of the greenroof, due to the high rainfall intensity, thus increasing the peak flow rate of the greenroof runoff.

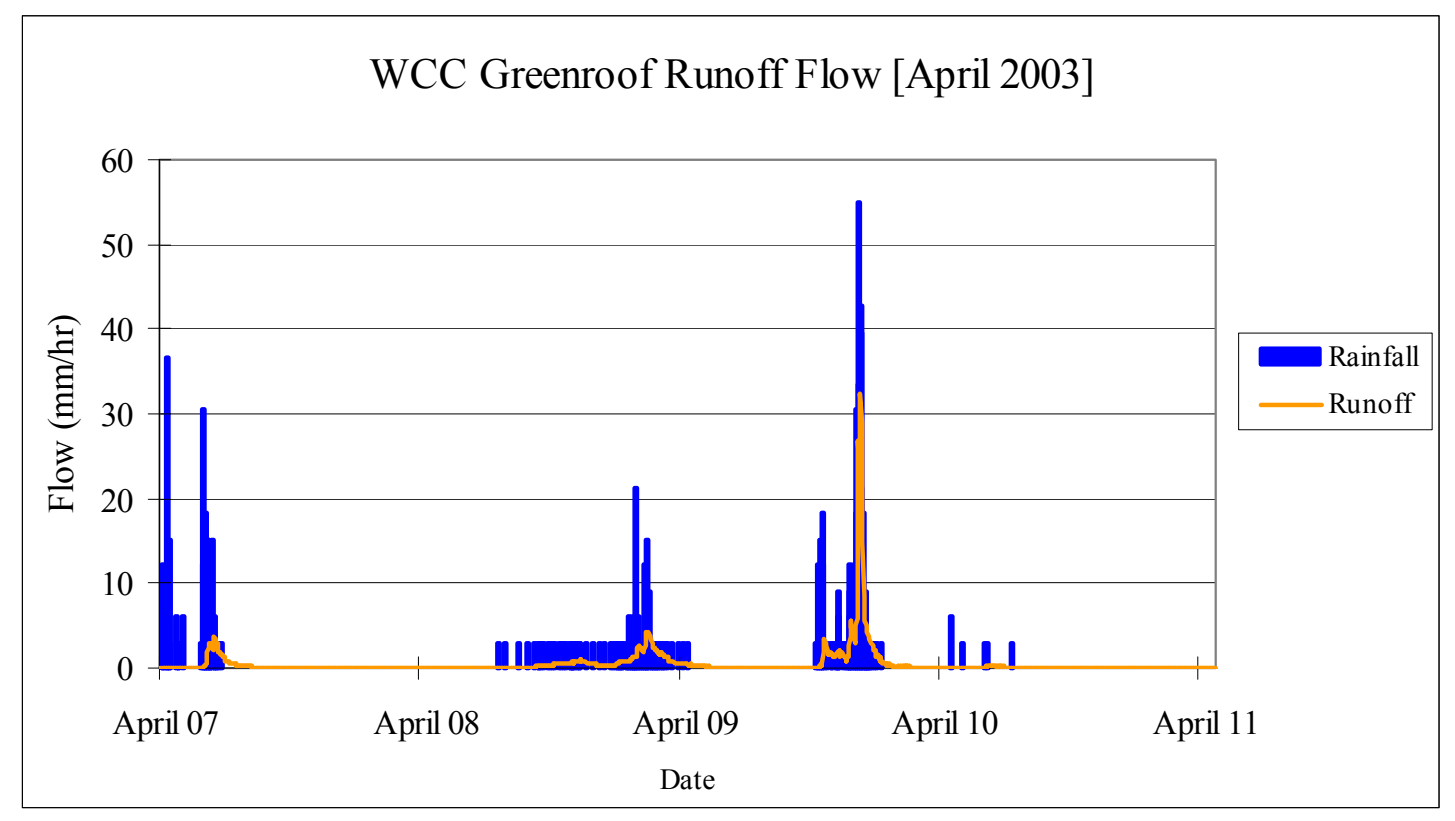

Figure 4-14. Display of Peak flow Reduction for Three Consecutive Rain Events in April 2003. 
Figure 4-15 displays a close-up hydrograph of the rain event on April 7. This rain event had a total precipitation of $23 \mathrm{~mm}(0.89 \mathrm{in}$.$) and the greenroof retained a total of 17$ $\mathrm{mm}(0.67$ in.). It is clear in Figure 4-15 that there was a delay of more than 3 hours after precipitation began before runoff was observed from the greenroof. In the first portion of the rain event, no runoff was observed from the greenroof. During this time frame, the precipitation was being absorbed by the soil media; runoff was not observed until approximately 3.5 hours after precipitation began. It was during this period that the soil media was becoming saturated with the precipitation and the moisture within the media was traveling laterally through the soil media to the center drain of the roof. Runoff was observed from the greenroof for approximately 16 hours after the precipitation ended.

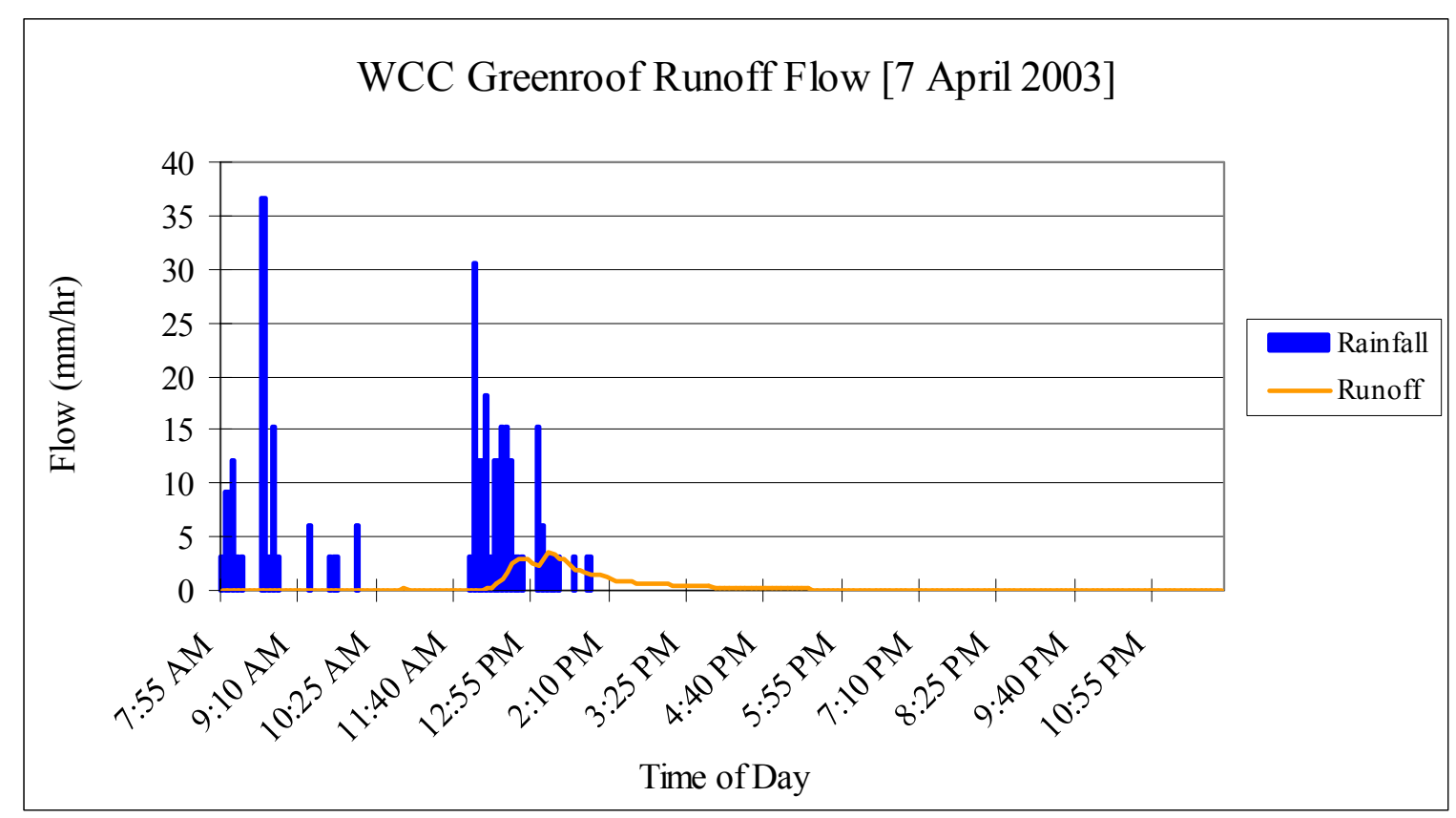

Figure 4-15. Display of Peak Flow Reduction of Rain Event on 7 April 2003. 


\subsection{Neuseway Nature Center Greenroof: Kinston, NC}

Peak flow reduction data for individual rain events at the Nature Center Greenroof is presented in Appendix C; statistical analysis of the peak flow reduction data can be reviewed in Appendix D. As with the WCC Greenroof in Goldsboro, the runoff peak flow from the greenroof was compared to the peak rainfall rate. Compared to the greenroof in Goldsboro, more limited data is available for the Kinston Greenroof; data is only available for a fraction of July 2003, August 2003, November 2003, and December 2003. The average peak flow of rainfall in this four month period was $42 \mathrm{~mm} / \mathrm{hr}(1.7 \mathrm{in} . / \mathrm{hr})$ and the average peak flow of runoff from the greenroof was $5.6 \mathrm{~mm} / \mathrm{hr}(0.2 \mathrm{in} . / \mathrm{hr})$, resulting in an $87 \%$ reduction in peak flow during the monitoring period. As with the WCC Greenroof data, the mean differences between the peak rainfall rate and the runoff peak flows from the greenroof were determined to not be normally distributed. Therefore, a statistical t-test was invalid; a Sign test was performed on the data to analyze the statistical significance of the reductions of peak flow by the greenroof. The peak flow of the runoff from the greenroof was significantly less than the peak rainfall rate $(\alpha<0.05)$. Table 4-6 displays a summary of the peak flow rates and the percent reduction of the Neuseway Nature Center Greenroof in Kinston, NC.

Table 4-6. Summary Table of Peak Flow Reduction at Neuseway Nature Center Greenroof in Kinston, NC

\begin{tabular}{|l|c|c|c|}
\hline Period & Average Rainfall Peak & Average Runoff Peak & Percent Reduction \\
\hline \hline July 2003 & $83 \mathrm{~mm} / \mathrm{hr}(3.2 \mathrm{in} . / \mathrm{hr})$ & $1.8 \mathrm{~mm} / \mathrm{hr}(0.1 \mathrm{in} . / \mathrm{hr})$ & $98 \%$ \\
\hline August 2003 & $46 \mathrm{~mm} / \mathrm{hr}(1.8 \mathrm{in} . / \mathrm{hr})$ & $4.4 \mathrm{~mm} / \mathrm{hr}(0.2 \mathrm{in} . / \mathrm{hr})$ & $93 \%$ \\
\hline November 2003 & $21 \mathrm{~mm} / \mathrm{hr}(0.8 \mathrm{in} . / \mathrm{hr})$ & $2.0 \mathrm{~mm} / \mathrm{hr}(0.1 \mathrm{in} . / \mathrm{hr})$ & $90 \%$ \\
\hline December 2003 & $27 \mathrm{~mm} / \mathrm{hr}(1.1 \mathrm{in} . / \mathrm{hr})$ & $10 \mathrm{~mm} / \mathrm{hr}(0.4 \mathrm{in} . / \mathrm{hr})$ & $67 \%$ \\
\hline $\begin{array}{l}\text { MONITORING } \\
\text { PERIOD AVERAGE }\end{array}$ & $42 \mathrm{~mm} / \mathrm{hr}(1.7 \mathrm{in} . / \mathrm{hr})$ & $5.6 \mathrm{~mm} / \mathrm{hr}(0.2 \mathrm{in} . / \mathrm{hr})$ & $87 \%$ \\
\hline
\end{tabular}


The clearest display of the peak flow reduction is seen in the hydrograph. Figure 416 displays the runoff hydrograph of the greenroof for two consecutive rainfall events in August 2003 at the Neuseway Nature Center in Kinston, NC. The rain event on August 16 had a total precipitation of $16 \mathrm{~mm}(0.64 \mathrm{in}$.) and $92 \%$ of the rainfall was retained. The second rain event shown in Figure 4-16 began in the evening on August 17 and ended early in the morning on August 18; the total rainfall was $64 \mathrm{~mm}$ (2.5 in.) and $60 \%$ was retained by the greenroof. The reduction of peak flow is depicted in Figure 4-16 for the two rain events. The flow from the first rain event on August 16 is barely visible, and there is an obvious reduction of peak flow for the second rain event on 17 August.

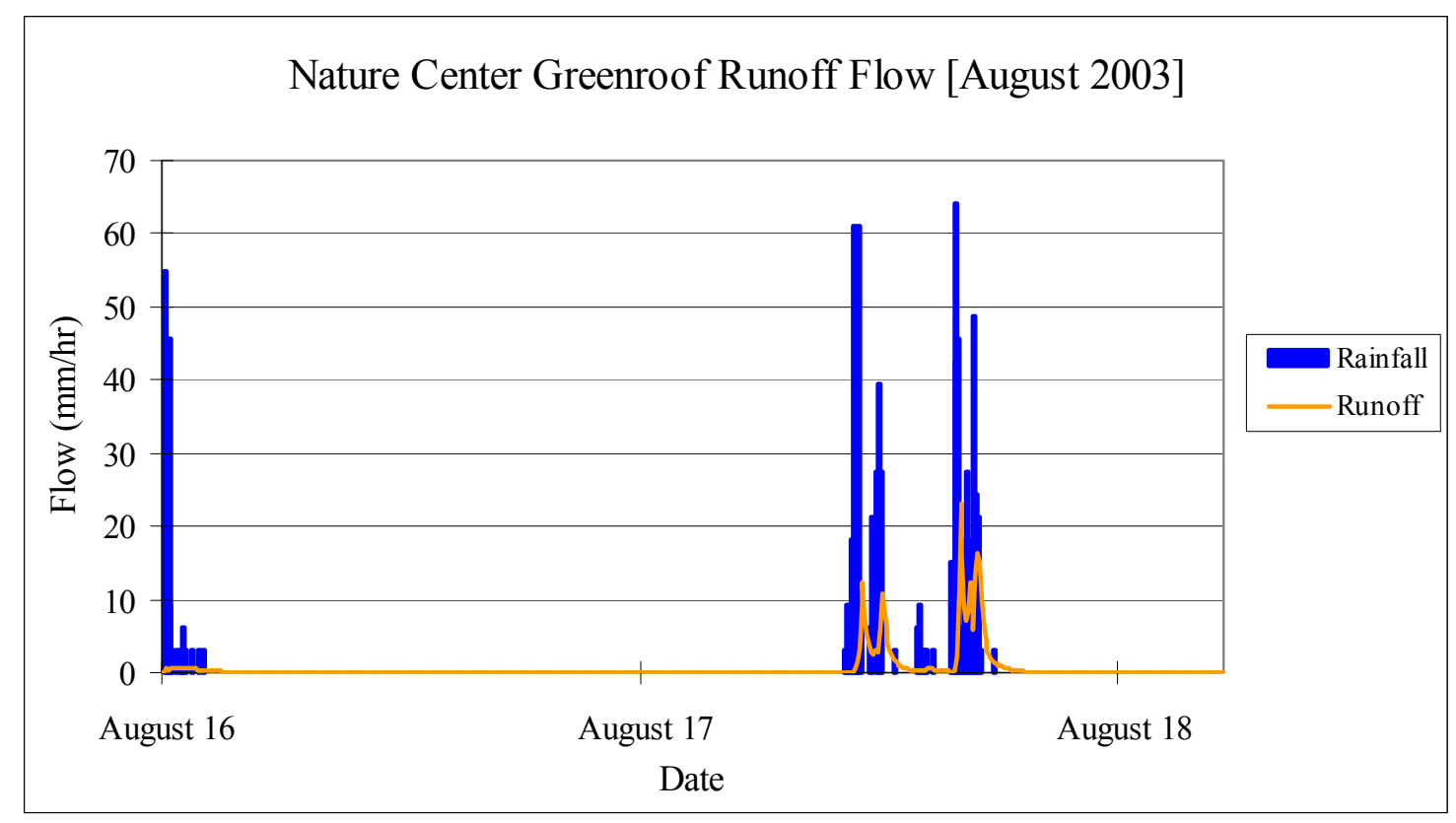

Figure 4-16. Display of Peak Flow Reduction for two Rainfall Events in August 2003.

Figure 4-17, displays a close-up view of the second rain event. The rain event on 17 August was a relatively large storm, but the reduction of peak flow is unmistakable. A delay of approximately 20 minutes was observed between the initial runoff from the greenroof and 
the initial precipitation. A smaller delay was observed here, when compared to the 7 April rain event observed at the WCC Greenroof, discussed earlier. The 7 April rain event at the WCC Greenroof was the first of three consecutive rainfall events. The peak rainfall rates during the 7 April event were also much less intense than the two rain events displayed in Figure 4-16. The latter two storm events in April observed at the WCC Greenroof each had smaller runoff delays, especially the more intense rain event observed on 9 April which had a delay of only approximately 20 minutes between when precipitation began and runoff was observed. The short delay observed on 17 August at the Nature Center Greenroof is a result of the soil remaining fairly saturated from the $16 \mathrm{~mm}(0.64 \mathrm{in}$.) rain event the prior day.

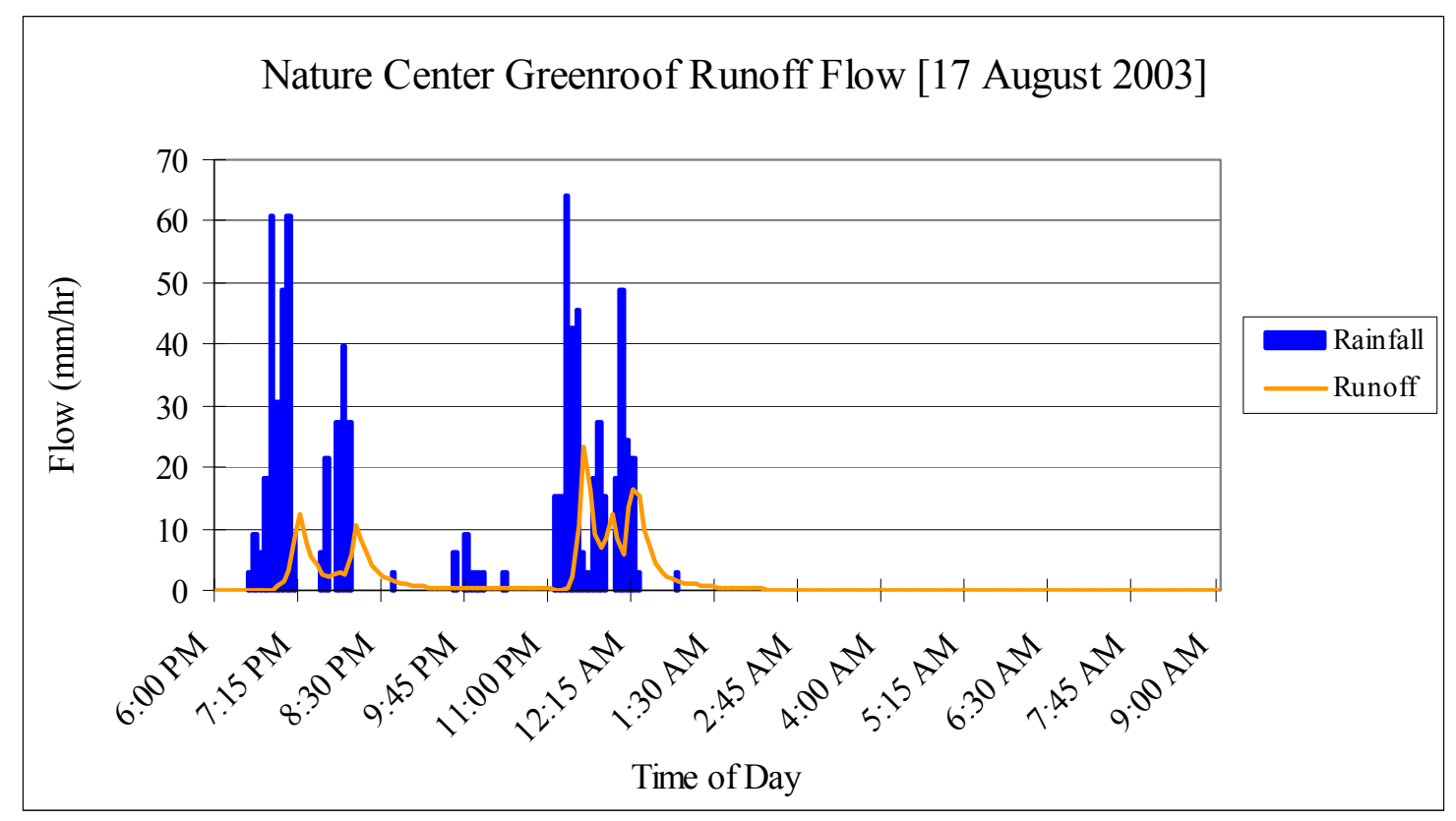

Figure 4-17. Display of Peak Flow Reduction of Rain Event Beginning on 17 August 2003.

During the 17 August rain event shown in Figure 4-17, runoff was not observed from the greenroof until the soil media and drainage layer appeared to be fully saturated, approximately 20 minutes after rainfall began. After the point of initial runoff, the runoff 
patterns from the greenroof follow the same rainfall patterns. The flow rate of runoff increased after the intensity of the rainfall rate increased and the runoff flow rate decreased as the intensity decreased throughout the remainder of the storm. While peak reductions can be observed in Figure 4-17, delays in peak flow can also be observed because the peak flow of runoff lags behind the peak rainfall intensity.

\subsubsection{Development of Greenroof Rational Coefficients}

Several parameters are utilized in urban hydrologic analysis, including the curve number (CN) and the Rational coefficient of a watershed. The CN and Rational coefficient of a watershed are dimensionless numbers that represent the amount of impervious area in a watershed. The $\mathrm{CN}$ is used to predict the depth of runoff that will be observed from a given amount of precipitation in a watershed through the SCS Curve Number Method. In the Rational Method, the Rational coefficient is used to predict the peak flow of runoff in a small watershed with a given rainfall intensity. The Rational Method has become the most widely used method for designing drainage facilities for small urban and rural watersheds (Viessman

et al., 1989). The Rational Method equation is shown below in Equation 4-5 (Viessman et al., 1989).

\section{Equation 4-5.}

$$
Q_{p}=C I A
$$

$$
\begin{aligned}
& \text { Where: } Q_{p}=\text { Peak discharge rate }(\mathrm{cfs}) \\
& \mathrm{C}=\text { Rational runoff coefficient (dimensionless) } \\
& \mathrm{I}=\text { Rainfall intensity }(\mathrm{in} / \mathrm{hr}) \\
& \mathrm{A}=\text { Watershed area }(\mathrm{ac})
\end{aligned}
$$


The Rational coefficient is a dimensionless decimal ranging from 0 to 1 . As the coefficient approaches 1 , the more impervious the watershed is, resulting in higher runoff intensities; likewise, as the coefficient approaches 0 , the less impervious the watershed is. Table 4-7 presents a selection of typical runoff coefficients and illustrates how the coefficient increases in highly impervious urbanized areas. Among the highest Rational coefficients are highly impervious areas, including downtown business areas, asphalt streets, concrete streets, and rooftops.

Table 4-7. Typical Rational Coefficients for Several Different Land Use Types $\dagger$

\begin{tabular}{|l|l|}
\hline Land Use Description & Rational Coefficients \\
\hline \hline Business: Downtown areas & $0.70-0.95$ \\
\hline Business: Neighborhood areas & $0.50-0.70$ \\
\hline Residential: Single-family areas & $0.30-0.50$ \\
\hline Residential: Multiunits, attached & $0.60-0.75$ \\
\hline Residential: Suburban & $0.25-0.40$ \\
\hline Industrial: Heavy areas & $0.60-0.90$ \\
\hline Parks, cemeteries & $0.10-0.25$ \\
\hline Playgrounds & $0.20-0.35$ \\
\hline Streets: Asphalt & $0.70-0.95$ \\
\hline Streets: Concrete & $0.80-0.95$ \\
\hline Drives and walks & $0.75-0.85$ \\
\hline Roofs & $0.75-0.95$ \\
\hline Lawns; sandy soil: Flat, 2\% & $0.05-0.10$ \\
\hline Lawns; heavy soil: Average, 2-7\% & $0.18-0.22$ \\
\hline
\end{tabular}

†Viessman et al., 1989

Rational coefficients were developed for the rainfall events observed at the WCC Greenroof in Goldsboro, NC. This site was selected because it had substantially more recorded rain events than the Nature Center Greenroof in Kinston, NC. During each rainfall event, the peak rainfall intensity $(\mathrm{mm} / \mathrm{hr})$ and peak runoff rate $(\mathrm{mm} / \mathrm{hr})$ were recorded; these 
data are presented in Appendix A. To determine the Rational coefficient, Equation 4-5 was manipulated to determine the Rational coefficient with the other known parameters and transformed into Equation 4-6, which is shown below. The peak rainfall rate $(\mathrm{mm} / \mathrm{hr})$ and the peak flow of runoff $(\mathrm{mm} / \mathrm{hr})$ were converted into inches per hour and cubic feet per second, respectively (Rational Method Unit). The watershed size was the surface area of the greenroof, $750 \mathrm{ft}^{2}$ and converted to acres (Rational Method Unit).

\section{Equation 4-6.}

$$
C=\frac{Q_{p}}{I A}
$$

$$
\begin{aligned}
& \text { Where: } \mathrm{C}=\text { Rational } \mathrm{C} \text { coefficient }(\text { dimensionless }) \\
& \mathrm{Q}_{\mathrm{p}}=\text { Peak flow of runoff from the greenroof }(\mathrm{cfs}) \\
& \mathrm{I}=\text { Peak rainfall rate }(\mathrm{in} / \mathrm{hr}) \\
& \mathrm{A}=\text { Watershed size }(\mathrm{ac}) .
\end{aligned}
$$

The 39 rain events observed at the WCC Greenroof between April and December 2003 were divided into four different categories depending on the size of the rain event. Small rain events were less than $13 \mathrm{~mm}(0.5 \mathrm{in}$.); medium rain events were greater than or equal to $13 \mathrm{~mm}(0.5 \mathrm{in}$.) and less than $25 \mathrm{~mm}(1 \mathrm{in}$.); large rain events were greater than or equal to $25 \mathrm{~mm}$ ( $1 \mathrm{in}$.) and less than $38 \mathrm{~mm}$ (1.5 in.); extra large rain events were greater than $38 \mathrm{~mm}$ (1.5 in.). In the Raleigh-Durham area, medium events typically occur 2.5 times a month, large events occur once a month, and extra large events once every three months (Hunt, 1999). The rain events were divided into size categories because larger storm events typically have higher rainfall intensities which would result in higher peak runoff rates, which would affect the runoff coefficient. Therefore, a Rational coefficient was calculated for each individual rain event in each size category, then an average Rational coefficient was 
determined for each size category based on the number of observations in each category; this was not a weighted average. The results are shown in Table 4-8. As suspected, the larger rainfall events with typically higher rainfall and runoff intensities had higher runoff coefficients.

Table 4-8. Greenroof Rational Coefficients for Select Storm Sizes

\begin{tabular}{||l|c|c|c|}
\hline Size Category & Storm Size & $\begin{array}{c}\text { Number of } \\
\text { Observations }\end{array}$ & $\begin{array}{c}\text { Average Rational } \\
\text { Coefficient }\end{array}$ \\
\hline \hline Small & $<13 \mathrm{~mm}(0.5 \mathrm{in})$. & 10 & 0.07 \\
\hline Medium & $13 \mathrm{~mm}(0.5 \mathrm{in}.) \leq \mathrm{x}<25 \mathrm{~mm}(1.0 \mathrm{in})$. & 14 & 0.13 \\
\hline Large & $25 \mathrm{~mm}(1.0 \mathrm{in}.) \leq \mathrm{x}<39 \mathrm{~mm}(1.5 \mathrm{in})$. & 10 & 0.25 \\
\hline Extra Large & $\geq 39 \mathrm{~mm}(1.5 \mathrm{in})$. & 5 & 0.55 \\
\hline
\end{tabular}

The small, medium, and large rain event Rational coefficients are simply presented for informational purposes. Rational coefficients are used to predict flooding and therefore pertain to storms that typically produce flooding, which would not be the small, medium, or large rain events. Therefore, the category of particular interest is the extra large sized rain events; of the 39 recorded rain events, five fell within the extra large category. The depths of the five extra large rain events were $41 \mathrm{~mm}$ (1.6 in.), $43 \mathrm{~mm}$ (1.7 in.), $78 \mathrm{~mm}(3.1 \mathrm{in}),$. $\mathrm{mm}$ (2.3 in.), and $39 \mathrm{~mm}$ (1.5). Of these five rain events, the single rain event would was most applicable for the Rational coefficient application was the $78 \mathrm{~mm}$ (3.1 in.) rain event, which had a Rational coefficient of 0.87 . This coefficient was high due to extremely high rainfall intensity observed during this event.

While Table 4-8 illustrates the increasing trend in Rational coefficient values with increasing storm sizes, all observed runoff coefficients are dramatically less than the typical runoff coefficient of a rooftop, as shown in Table 4-7. An average Rational coefficient of 
0.25 was observed for the large events, indicating that the greenroof was behaving like a park or a playground (See Table 4-7). During the extra large rain events, the average Rational coefficient of 0.55 illustrates that the greenroof was behaving as a moderately impervious area such as a residential district, rather than an impervious rooftop (See Table 4-7). These observed Rational coefficients will provide aid in designing and modeling greenroofs in urban stormwater analysis.

\subsubsection{WATER Quality DATA}

\subsubsection{Wayne Community College Greenroof: Goldsboro, NC}

The water quality data for the WCC Greenroof is presented in Appendix E; statistical analysis of the data is displayed in Appendix F. Data is available for a total of nine rain events from April 2003 to December 2003. Results were initially reported in concentrations $(\mathrm{mg} / \mathrm{L})$; data was then transformed into mass loadings $(\mathrm{g})$ present in the rainfall, in the runoff from the greenroof, and in the runoff from the control roof. Due to reported leaks in the drainage system of the WCC Control Roof, the flow rates recorded by the Sigma $900 \mathrm{Max}^{\mathrm{TM}}$ automatic sampler were deemed unreliable and were not used; the discussion in the next paragraphs explain how the mass loadings for the control roof were derived. The nutrients included in the analysis were total Kjeldahl nitrogen as nitrogen (TKN as N), nitrate-nitrite as nitrogen $\left(\mathrm{NO}_{3}-\mathrm{NO}_{2}\right.$ as $\left.\mathrm{N}\right)$, total nitrogen $(\mathrm{TN})$, ammonia as nitrogen $\left(\mathrm{NH}_{3}\right.$ as $\left.\mathrm{N}\right)$, total phosphorus (TP), and orthophosphorus (OP).

Few conclusions can be made from the concentration data alone because different volumes of runoff drained from each roof. For example, if the concentration of $\mathrm{TN}$ in the 
greenroof runoff was $2 \mathrm{mg} / \mathrm{L}$ and the volume of runoff was $50 \mathrm{~L}$, then the mass loading of $\mathrm{TN}$ from the greenroof would be $100 \mathrm{mg}$; if the concentration of $\mathrm{TN}$ in the control roof was 1 $\mathrm{mg} / \mathrm{L}$ and the volume of runoff was $150 \mathrm{~L}$, then the mass loading of TN from the control roof would be $150 \mathrm{mg}$. While the concentration of $\mathrm{TN}$ may have been lower in the control roof runoff, more mass of $\mathrm{TN}$ would have been present in the runoff from the control roof.

Therefore, the volume of runoff was necessary to determine the mass loadings. The flow rate of the greenroof runoff was measured by the Sigma $900 \mathrm{Max}^{\mathrm{TM}}$ automatic sampler in 5-minute intervals. This incremental flow data was then used to calculate a total volume of runoff from the greenroof in liters by multiplying the runoff depth (in.) by the surface area of the greenroof $\left(750 \mathrm{ft}^{2}\right)$ with an international system of units (SI) conversion factor. The volume of rainfall was calculated simply by multiplying the depth of rainfall (in.) by the surface area of the greenroof $\left(750 \mathrm{ft}^{2}\right)$. Using a SI conversion factor, total rainfall was converted to liters.

Flow rates from the control roof were not used because of internal leaks in the drainage system from the roof; therefore, the volume of runoff from the control roof was derived separately. A depressional storage equivalent to $6 \mathrm{~mm}(0.25$ in. $)$ of rainfall was measured atop the control roof by conducting a survey of the rooftop. Therefore, the depth of runoff from the control roof was estimated to be the initial abstraction of $6 \mathrm{~mm}(0.25 \mathrm{in}$. subtracted from the total rainfall of that rainfall event; the volume of runoff (L) was calculated by multiplying the depth of runoff (in.) by the surface area of the control roof (750 $\mathrm{ft}^{2}$ ) with a SI conversion factor. 
Figure 4-18 and Figure 4-19 demonstrate the total nitrogen concentration and mass loadings from each of the nine rain events. Figure 4-18 illustrates that while four rain events have data unavailable from the control roof; the concentration of $\mathrm{TN}$ was higher in the greenroof runoff than the concentration of $\mathrm{TN}$ present in the rainfall in each rain event. Because the concentration data was normally distributed, a standard t-test was performed on the data; the concentration of $\mathrm{TN}$ is significantly higher in the greenroof runoff than in the rainfall $(\alpha<0.05)$. There were also two instances when the concentration of TN in the control roof runoff was higher than that of the greenroof runoff; however, a standard t-test was performed on the data and there was no statistically significant difference between the concentration of $\mathrm{TN}$ in the greenroof runoff and the control roof runoff.

Figure 4-19 highlights that, again four data points are not available for the control roof runoff; however, there is more variability in the mass loadings than the concentrations. For example, on May 6, July 23 and December 10, the control roof mass loading of TN was higher than the greenroof and the rainfall; on July 23, September 18 , and October 8 , the rainfall mass loading of TN was higher than that of TN in the greenroof runoff; on May 22, July 2, and September 4, the greenroof mass loading of TN was higher than the rainfall. As a result of this variability, there was no statistically significant difference between the mass loading of $\mathrm{TN}$ in the greenroof runoff and the rainfall or the greenroof runoff and the control roof runoff, using the standard t-test for statistical analysis. This is an example demonstrating that while the concentrations of $\mathrm{TN}$ in the greenroof were typically higher than the concentrations of $\mathrm{TN}$ in the rainfall and the control roof runoff, the mass loadings did not necessarily follow the same pattern due to the different volumes for each source. 


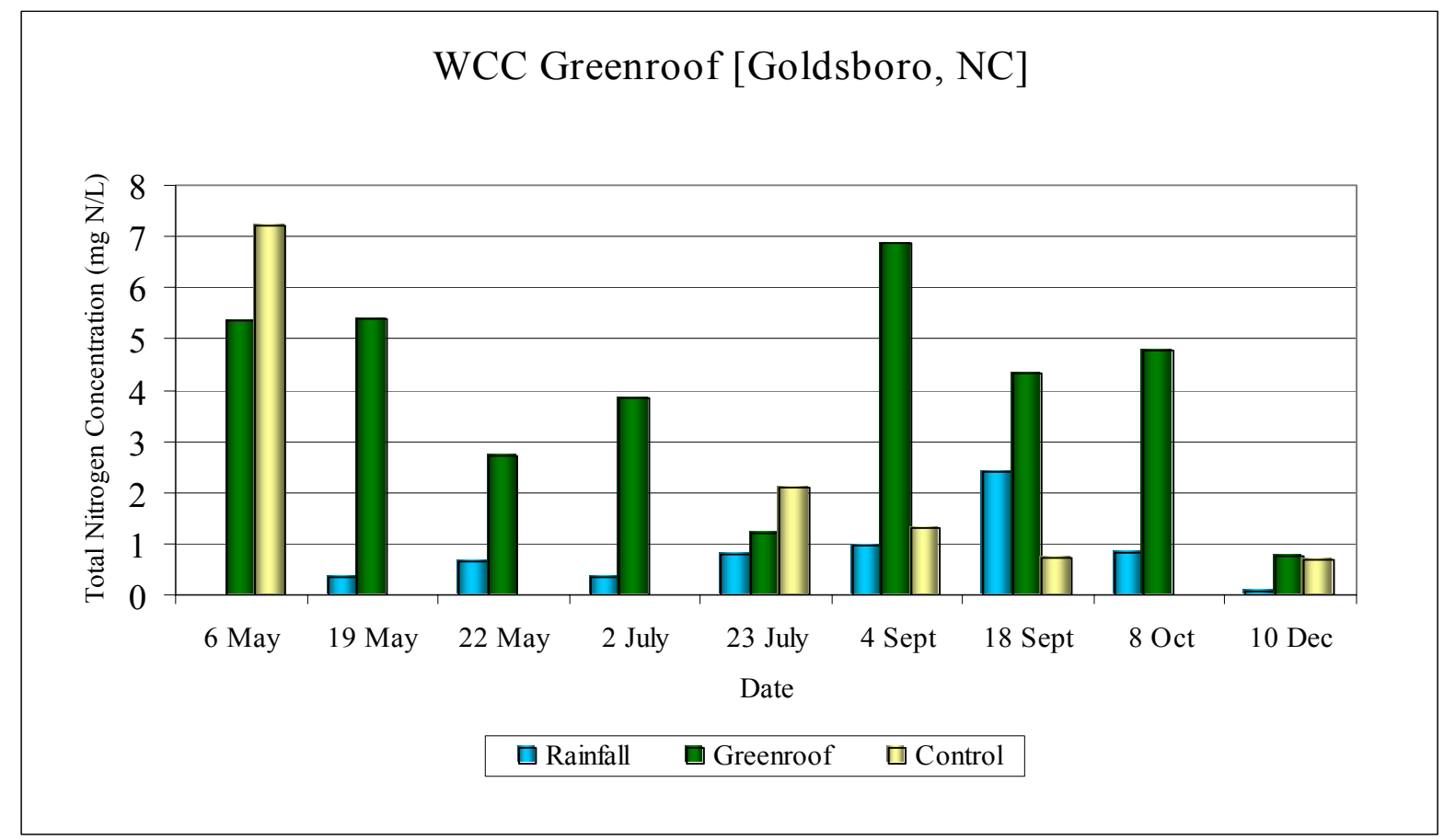

Figure 4-18. Display of Total Nitrogen Concentrations for Select Rain Events from April to December 2003. (Note: Rainfall data is not available for 6 May; Control data is not available for 19 May, 22 May, 2 July, and 8 October)

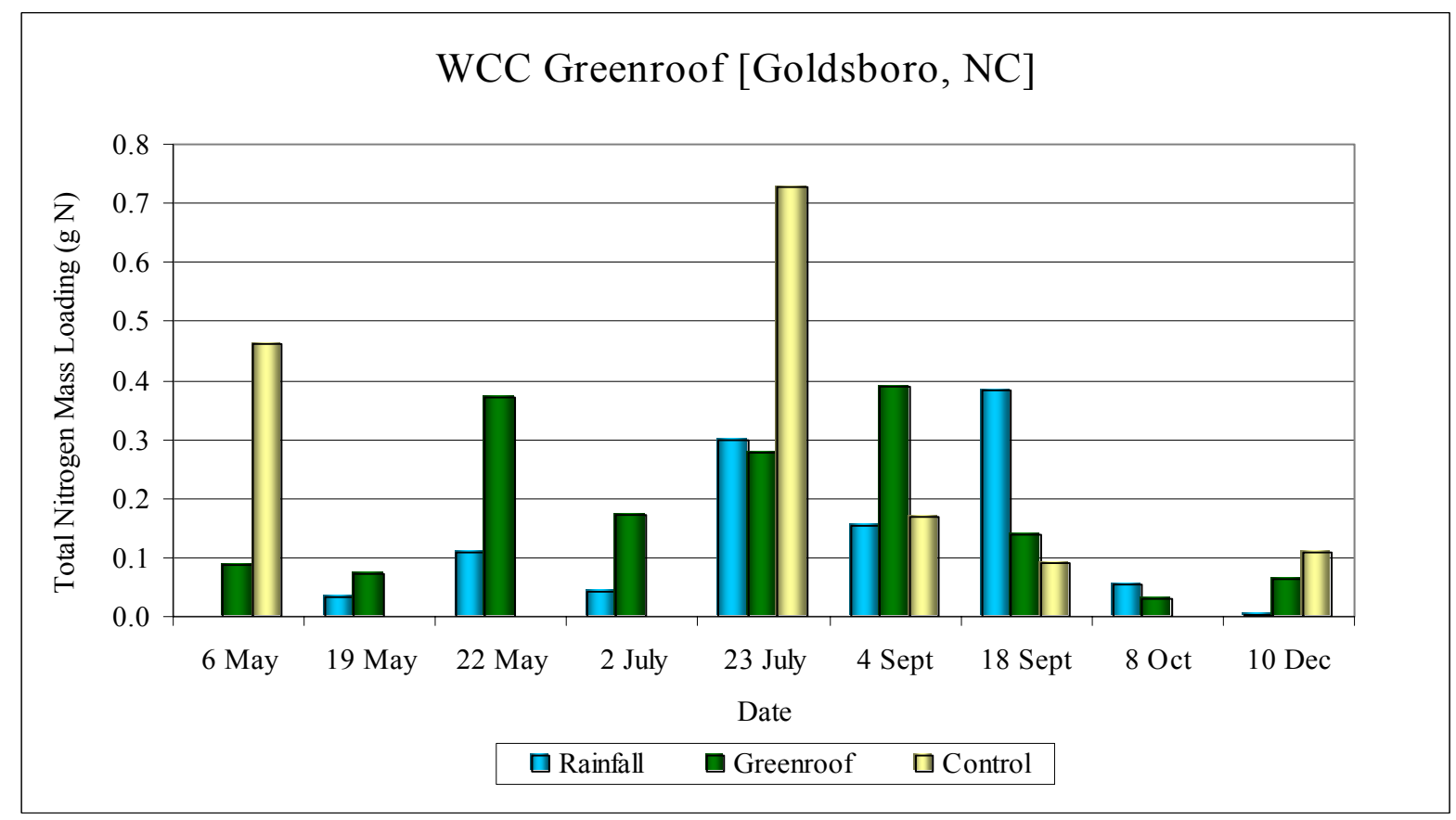

Figure 4-19. Display of Total Nitrogen Mass Loadings for Select Rain Events from April to December 2003. (Note: Rainfall data is not available for 6 May; Control data is not available for 19 May, 22 May, 2 July, and 8 October) 
The variability of mass loading of TN between the rainfall, the greenroof, and the control roof is dependent upon the rainfall concentration of $\mathrm{TN}$ and the volume of runoff from the greenroof. The variation of $\mathrm{TN}$ mass loading among the rainfall, the control roof, and the greenroof can be explained by examining each rain event. For example, the mass loading of TN from the control roof was higher than that of the greenroof on May 6 because the concentration of $\mathrm{TN}$ and the volume of outflow from the control roof were higher than that of the greenroof. On May 19, the mass loading of TN was higher in the greenroof runoff than the rainfall because while the volume of runoff from the greenroof was $85 \%$ less than the rainfall, the concentration of $\mathrm{TN}$ in the greenroof runoff was 15 times higher than the rainfall. Again, on July 2, the greenroof mass loading of TN was higher than the rainfall because the concentration of $\mathrm{TN}$ in the greenroof was 11 times higher than the rainfall. However, on July 23, the volume of runoff from the greenroof was $40 \%$ less than the rainfall and the concentration of TN in the greenroof was only $34 \%$ higher than the rainfall, but due to the large amount of rainfall $(77.5 \mathrm{~mm})$, the mass loading of $\mathrm{TN}$ was higher in the rainfall than the greenroof. For this same rain event on July 23, the control roof had the highest mass loading because it had more runoff than the greenroof and it also had a TN concentration twice as high as the greenroof and more than two and half times as high as the rainfall.

Figure 4-20 and Figure 4-21 illustrate the total phosphorus concentration and mass loading from each of the nine rain events. Figure 4-20 displays results similar to Figure 418; the greenroof's concentration of TP was significantly higher than the concentration of TP in the rainfall and the control roof $(\alpha<0.05)$; a standard t-test was performed on the data to 


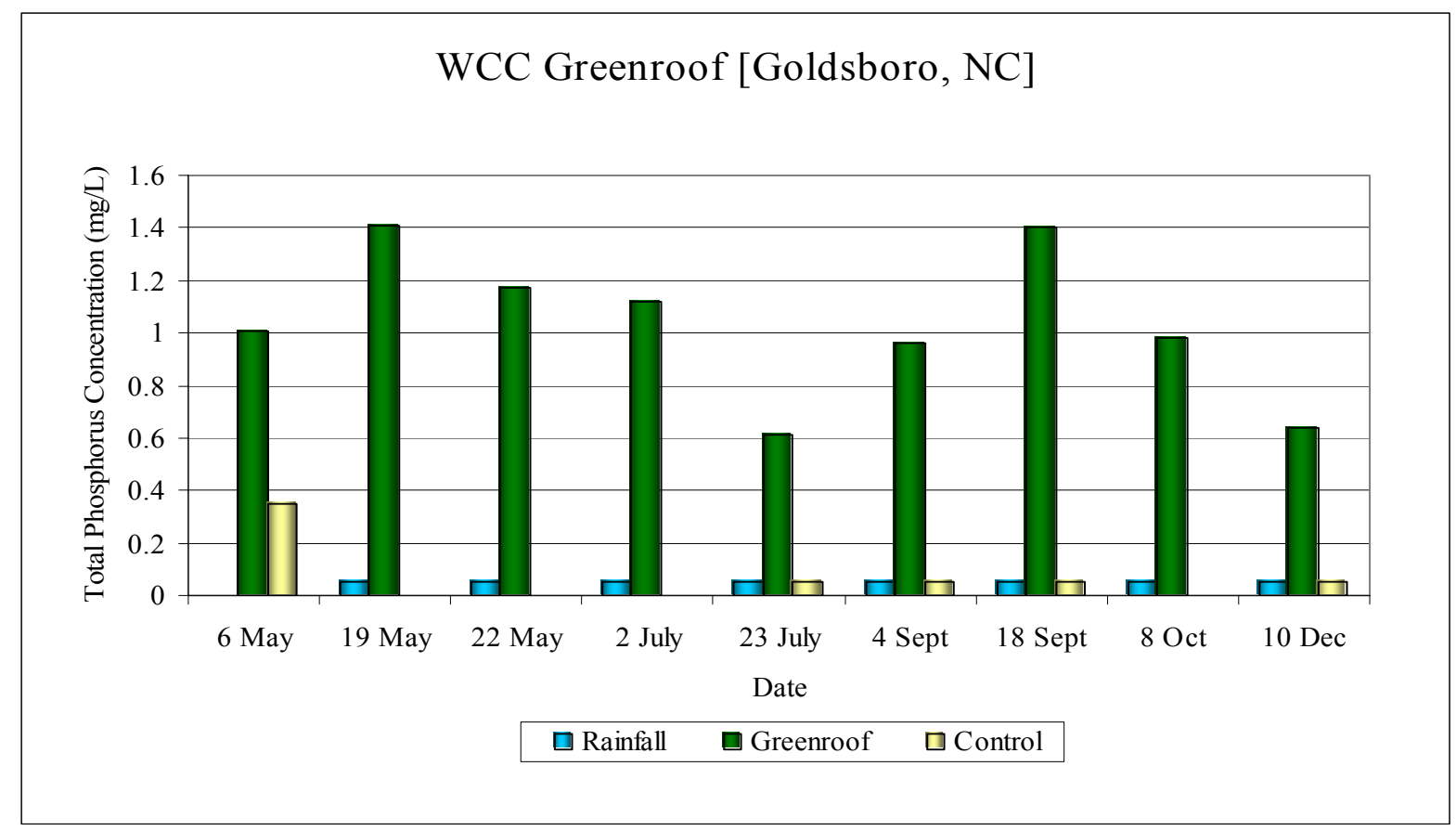

Figure 4-20. Display of Total Phosphorus Concentrations for Select Rain Events from April to December 2003. (Note: Rainfall data is not available for 6 May; Control data is not available for 19 May, 22 May, 2 July, and 8 October)

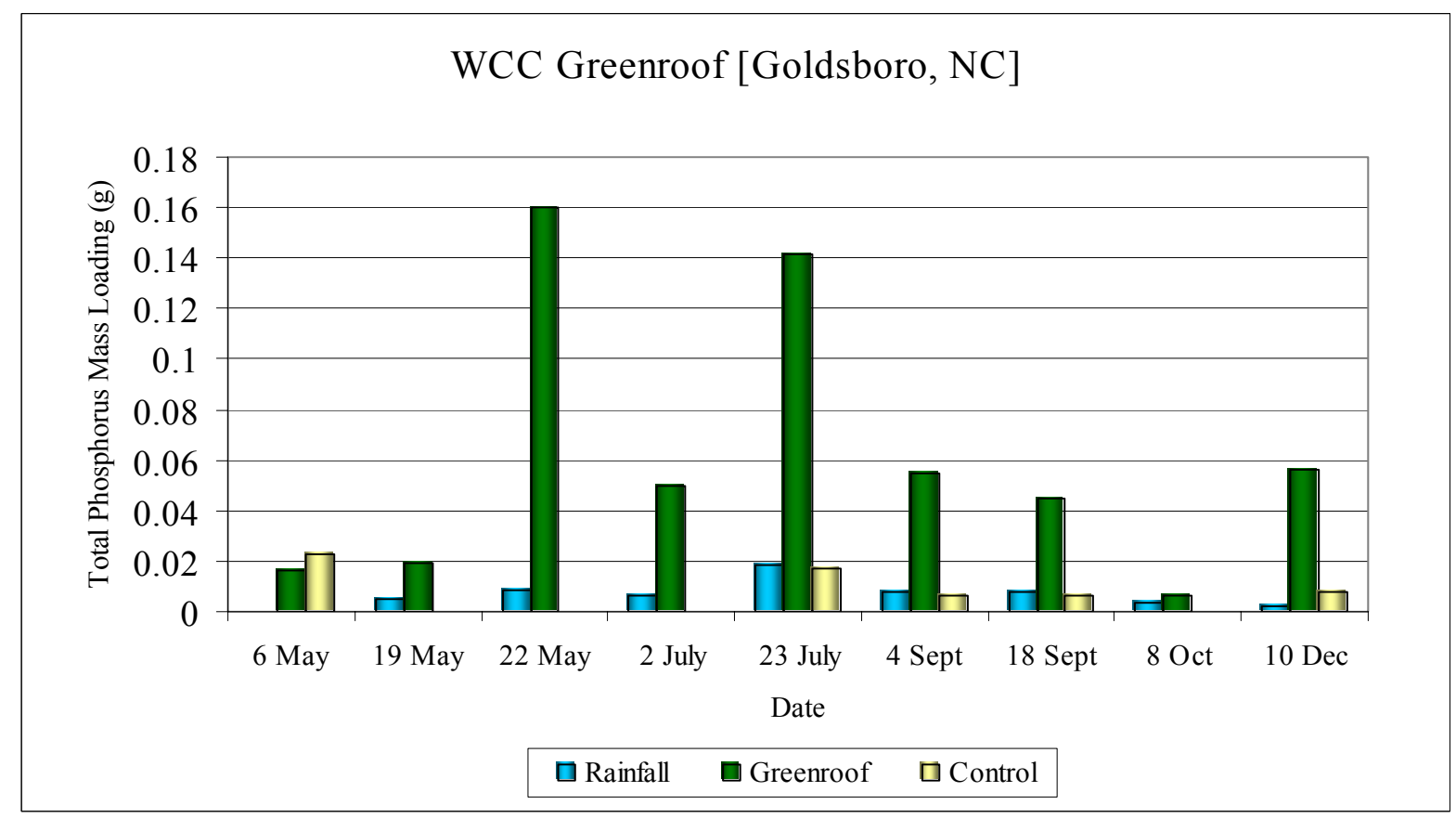

Figure 4-21. Display of Total Phosphorus Mass Loadings for Select Rain Events from April to December 2003. (Note: Rainfall data is not available for 6 May; Control data is not available for 19 May, 22 May, 2 July, and 8 October) 
determine statistical significance. Figure 4-21 displays the mass loading of TP from the rainfall, the greenroof runoff, and the control roof runoff for each rainfall event. The mass loading of TP was significantly higher in the greenroof runoff than in the rainfall $(\alpha<0.05)$. Because the mean differences between the greenroof and rainfall mass loadings were not normally distributed, a Sign test was performed to analyze for statistical significance. There was no statistically significant difference between the greenroof and the control roof mass loadings of TP, found through a standard t-test for statistical analysis. The mass loading of TP in the greenroof runoff was not statistically greater than the mass loading of TP in the control roof runoff because only five rain events could be included in the statistical analysis and one of the five rain events had a TP mass loading in the control roof higher than the mass loading of TP in the greenroof runoff; therefore, there was no statistically significant difference. Because the TP concentrations and TP mass loadings were typically higher in the greenroof runoff than in the rainfall or the control roof runoff, this indicated that there was an additional source of phosphorus in the greenroof runoff. The additional source of TP may be the organic matter in the soil media; the soil media is comprised of $15 \%$ compost.

In addition to the $\mathrm{TN}$ and $\mathrm{TP}$ statistical analysis, $\mathrm{TKN}$ as $\mathrm{N}, \mathrm{NO}_{3}-\mathrm{NO}_{2}$ as $\mathrm{N}, \mathrm{NH}_{3}$ as $\mathrm{N}$, and OP were analyzed for statistical differences between the rainfall, the greenroof runoff, and the control roof runoff. Table 4-9 summarizes the statistical data for the concentrations of each nutrient species. A summary of the statistical data for the mass loadings of each nutrient species is displayed in Table 4-10. A statistically significant difference was observed between each source when the p-value was less than $0.05(\alpha<$ 0.05). The shaded cells indicate where a statistical difference was observed. 
Table 4-9. Summary Table of Statistical Significance for Nutrient Concentrations at WCC Greenroof.

\begin{tabular}{|l|c|c|c|c|c|}
\hline \multirow{2}{*}{$\begin{array}{l}\text { Nutrient } \\
\text { Species }\end{array}$} & \multicolumn{3}{|c|}{ Number of Observations $(n)$} & \multicolumn{2}{c|}{ Statistical Significance (p-value) } \\
\cline { 2 - 6 } & Greenroof & Rainfall & Control Roof & $\begin{array}{c}\text { Greenroof vs. } \\
\text { Rainfall }\end{array}$ & $\begin{array}{c}\text { Greenroof vs. } \\
\text { Control Roof }\end{array}$ \\
\hline \hline $\mathrm{TN}$ & 8 & 8 & 5 & $\mathbf{0 . 0 0 4 2}$ (t-test) $[\mathrm{G}]$ & 0.4089 (t-test) \\
\hline $\mathrm{TKN}$ as N & 8 & 8 & 5 & $\mathbf{0 . 0 0 3 7}$ (t-test) $[\mathrm{G}]$ & 0.9022 (t-test) \\
\hline $\mathrm{NO}_{3}-\mathrm{NO}_{2}$ as N & 8 & 8 & 5 & $\mathbf{0 . 0 0 7 8}$ (Sign test) $[\mathrm{G}]$ & 0.2460 (t-test) \\
\hline $\mathrm{NH}_{3}$ as N & 7 & 7 & 4 & 0.4799 (t-test) & 0.1250 (Sign test) \\
\hline $\mathrm{TP}$ & 8 & 8 & 5 & $<\mathbf{0 . 0 0 0 1}$ (t-test) $[\mathrm{G}]$ & $\mathbf{0 . 0 0 5 3}$ (t-test) [G] \\
\hline $\mathrm{OP}$ & 7 & 7 & 4 & $\mathbf{0 . 0 0 0 5}$ (t-test) $[\mathrm{G}]$ & $\mathbf{0 . 0 0 5 6}$ (t-test) [G] \\
\hline
\end{tabular}

Note: $[\mathrm{G}]$, $[\mathrm{R}]$, or $[\mathrm{C}]$ denotes which source had higher concentrations, when a statistical difference was observed. The statistical test performed is in parentheses. Sign tests were performed when the data was not normally distributed.

Table 4-10. Summary Table of Statistical Significance for Nutrient Mass Loadings at WCC Greenroof.

\begin{tabular}{|l|c|c|c|c|c|}
\hline \multirow{2}{*}{$\begin{array}{l}\text { Nutrient } \\
\text { Species }\end{array}$} & \multicolumn{3}{|c|}{ Number of Observations $(n)$} & \multicolumn{2}{c|}{ Statistical Significance (p-value) } \\
\cline { 2 - 6 } & Greenroof & Rainfall & Control Roof & $\begin{array}{c}\text { Greenroof vs. } \\
\text { Rainfall }\end{array}$ & $\begin{array}{c}\text { Greenroof vs. } \\
\text { Control Roof }\end{array}$ \\
\hline \hline $\mathrm{TN}$ & 8 & 8 & 5 & 0.3687 (t-test) & 0.3699 (t-test) \\
\hline $\mathrm{TKN}$ as N & 8 & 8 & 5 & 0.6970 (t-test) & 0.2382 (t-test) \\
\hline $\mathrm{NO}_{3}-\mathrm{NO}_{2}$ as N & 8 & 8 & 5 & 0.2891 (Sign test) & 0.9086 (t-test) \\
\hline $\mathrm{NH}_{3}$ as N & 7 & 7 & 4 & $\mathbf{0 . 0 1 5 6}$ (Sign test) [R] & 0.1937 (t-test) \\
\hline $\mathrm{TP}$ & 8 & 8 & 5 & $\mathbf{0 . 0 0 7 8}$ (Sign test) [G] & 0.0736 (t-test) \\
\hline $\mathrm{OP}$ & 7 & 7 & 4 & $\mathbf{0 . 0 0 4 6}$ (t-test) [G] & 0.0589 (t-test) \\
\hline
\end{tabular}

Note: $[\mathrm{G}],[\mathrm{R}]$, or $[\mathrm{C}]$ denotes which source had higher concentrations, when a statistical difference was observed. The statistical test performed is in parentheses. Sign tests were performed when the data was not normally distributed

Concentrations of each phosphorus species were higher in the greenroof runoff than both the rainfall and the control roof runoff; mass loadings of each phosphorus species were also higher in the greenroof than in the rainfall. These statistical results support the hypothesis that there was an additional input of phosphorus in the greenroof runoff from the soil media. There is no statistical difference between concentrations of any of the nitrogen species in the greenroof runoff and the control roof runoff. This indicates that the organic 
matter within the soil media of the greenroof did not have a significant effect on the nitrogen. The concentrations and mass loadings of nitrogen are a result of variability of nitrogen concentrations in each source and the volume of roof runoff or rainfall.

Appendix E contains figures similar to Figure 4-20 and Figure 4-21, displaying the concentrations and total mass loadings of TKN as $\mathrm{N}, \mathrm{NO}_{3}-\mathrm{NO}_{2}$ as $\mathrm{N}, \mathrm{NH}_{3}$ as $\mathrm{N}$, and $\mathrm{OP}$ in addition to TN and TP. Appendix F displays all the statistical analysis for each nutrient concentration and mass loading.

\subsubsection{Neuseway Nature Center: Kinston, $N C$}

The water quality data for the Neuseway Nature Center in Kinston, NC is presented in Appendix G and the statistical analysis of the water quality data is exhibited in Appendix $\mathrm{H}$. Data was collected for six rain events. Data was initially reported in concentration form and then converted into mass loadings when flow data was available. Due to numerous technical problems with the site and sampling equipment, greenroof runoff data was unattainable for

four of the six rain events, rainfall data was not collected for two of the rain events, and control roof runoff data was unavailable for two of the rain events. Therefore, statistical analysis was not performed on the mass loadings data due to the lack of adequate data to compare the greenroof mass loadings, rainfall mass loadings, and control roof mass loadings of nutrients. However, the mass loadings data is presented in Appendix G with the concentrations of each nutrient.

Figure 4-22 and Figure 4-23 exhibit the concentrations of TN and TP for each rainfall event sampled at the Nature Center Greenroof in Kinston, NC. As evident from Figure 4-22, 


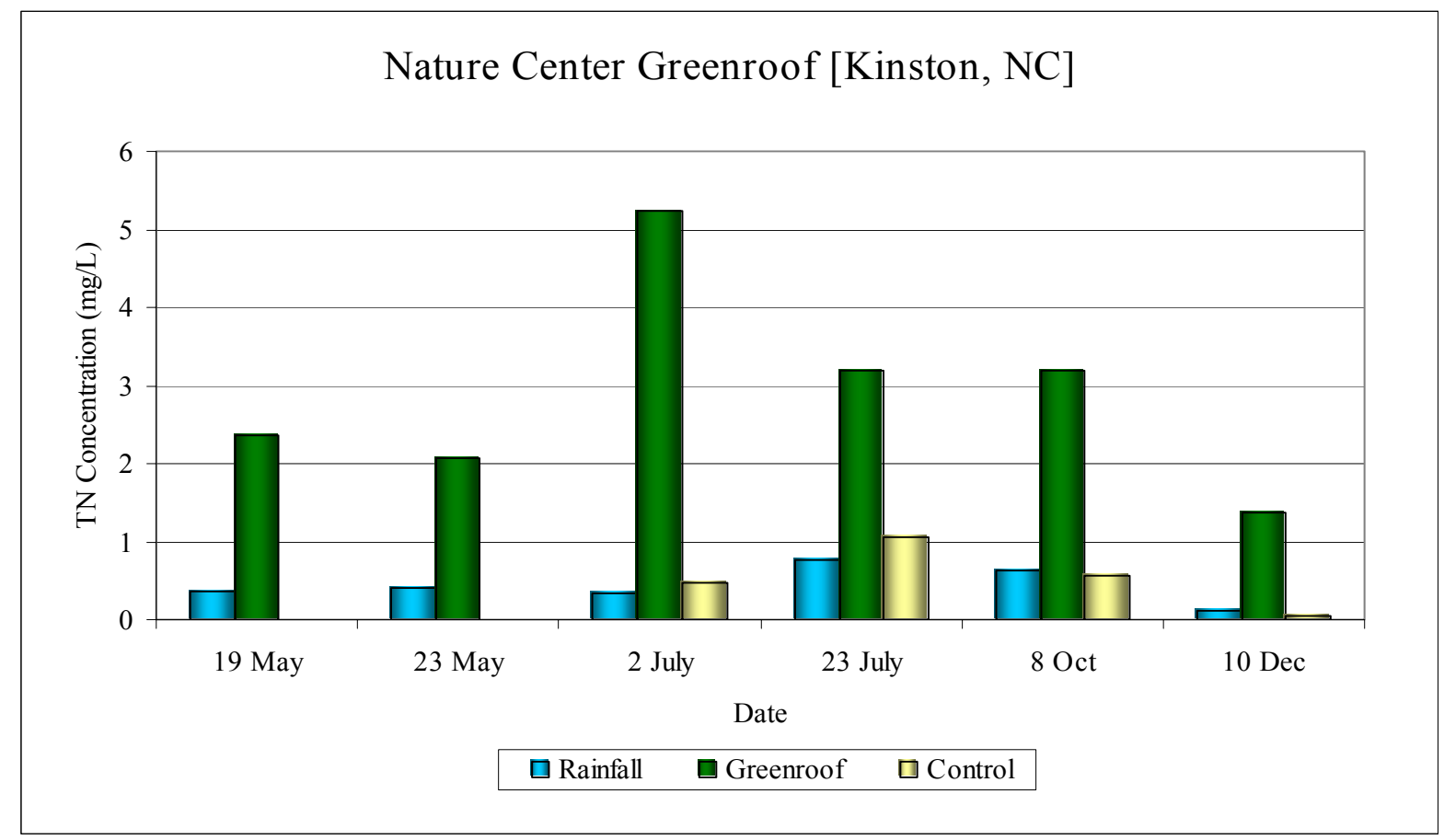

Figure 4-22. Display of Total Nitrogen Concentrations for Select Rainfall Events from May to December 2003. (Note: Control data is unavailable for 19 May and 23 May)

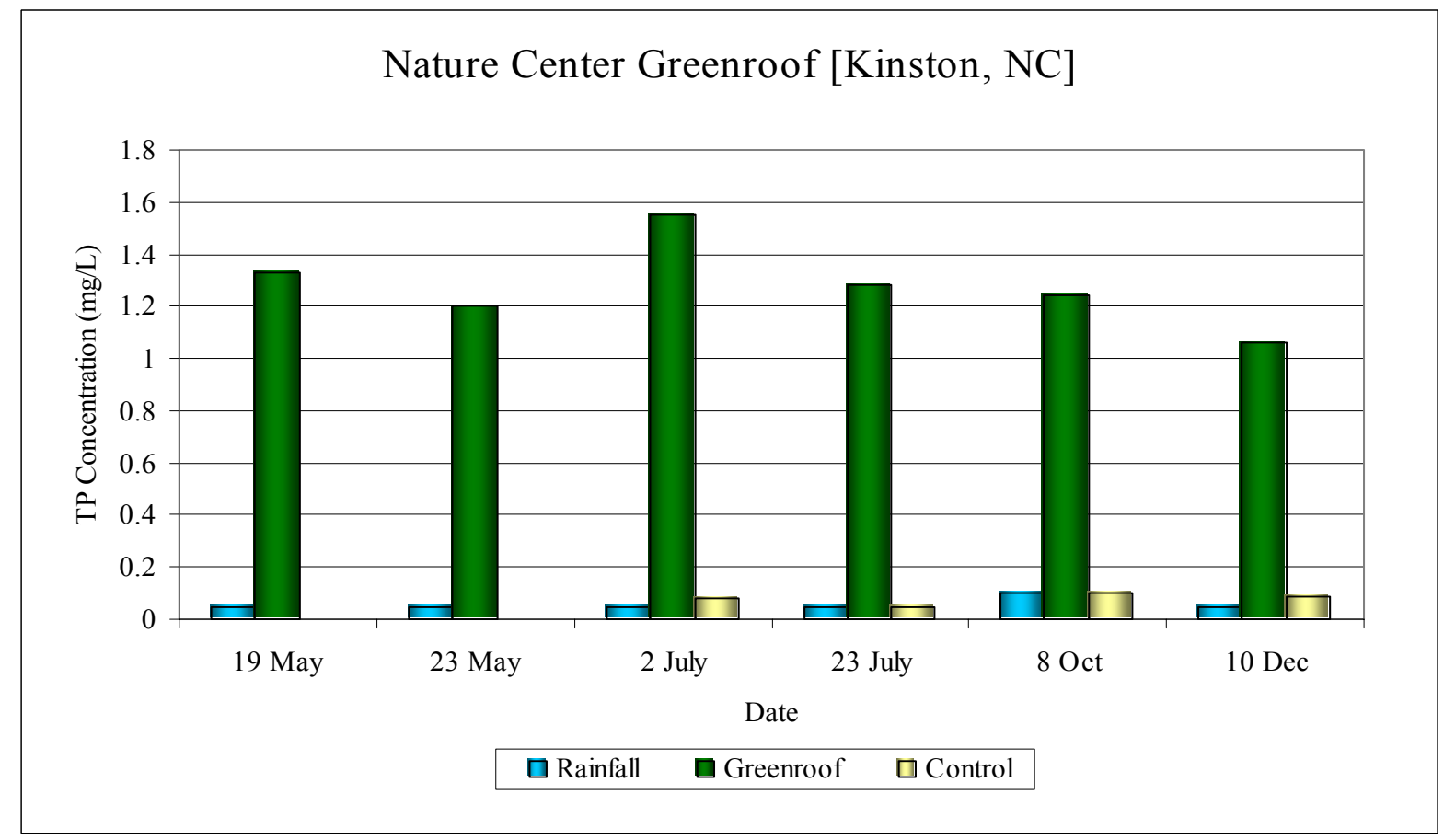

Figure 4-23. Display of Total Phosphorus Concentrations for Select Rainfall Events from May to December 2003. (Note: Control data is unavailable for 19 May and 23 May) 
the concentration of TN was significantly higher in the greenroof runoff than in the rainfall and the control roof runoff $(\alpha<0.05)$. This supports the results of TN concentrations observed at the WCC Greenroof in Goldsboro. Figure 4-23 displays the total phosphorus (TP) concentrations for the available rain events. As with the TN concentrations, Figure 4-23 illustrates that the concentrations of TP in the greenroof runoff are significantly higher than the concentration of TP in the rainfall and the concentration of TP in the control roof runoff $(\alpha<0.05)$. The same media used at the WCC Greenroof site was used at the Nature Center Greenroof.

Additional figures displaying the concentrations of TKN as $\mathrm{N}, \mathrm{NO}_{3}-\mathrm{NO}_{2}$ as $\mathrm{N}, \mathrm{NH}_{3}$ as N, and OP are presented in Appendix G. Statistical analysis was also performed on each of these nutrients and is presented in Appendix H. All phosphorus species and nitrogen species, except for $\mathrm{NO}_{3}-\mathrm{NO}_{2}$ as $\mathrm{N}$ and $\mathrm{NH}_{3}$ as $\mathrm{N}$, were statistically higher in the greenroof runoff than in the control roof runoff and the rainfall. This is different from the other research site results; there were no statistical differences between the nitrogen species in the greenroof runoff and the control roof runoff at the WCC Greenroof site. However, firm conclusions cannot be made from the results presented in Table 4-7 because of the low number of observations. Because there is no significant difference between the concentration of $\mathrm{NO}_{3}-\mathrm{NO}_{2}$ as $\mathrm{N}$ in the greenroof runoff and the rainfall, nor between the greenroof runoff and the control roof runoff, this is an indication that the majority of the nitrogen present in the samples was organic nitrogen. Moreover, the concentration of $\mathrm{NH}_{3}$ as $\mathrm{N}$ is significantly higher in both the rainfall and the control roof runoff when compared to the greenroof runoff. This indicates that the $\mathrm{NH}_{3}$ was mineralizing within the soil media into 
other forms of nitrogen; this process was not happening in the rainfall or on the control roof. This is also supported by data from the WCC Greenroof; the mass loading of $\mathrm{NH}_{3}$ as $\mathrm{N}$ was significantly higher in the rainfall than in the greenroof runoff at the WCC Greenroof.

Table 4-11. Summary Table of Statistical Significance for Nutrient Concentrations at Nature Center Greenroof

\begin{tabular}{|c|c|c|c|c|c|}
\hline \multirow{2}{*}{$\begin{array}{l}\text { Nutrient } \\
\text { Species }\end{array}$} & \multicolumn{3}{|c|}{ Number of Observations (n) } & \multicolumn{2}{|c|}{ Statistical Significance ( $p$-value) } \\
\hline & Greenroof & Rainfall & Control Roof & $\begin{array}{c}\text { Greenroof vs. } \\
\text { Rainfall } \\
\end{array}$ & $\begin{array}{l}\text { Greenroof vs. } \\
\text { Control Roof }\end{array}$ \\
\hline $\mathrm{TN}$ & 6 & 6 & 4 & $\mathbf{0 . 0 0 5 2}$ (t-test) $[\mathrm{G}]$ & $\mathbf{0 . 0 3 4 4}$ (t-test) $[\mathrm{G}]$ \\
\hline TKN as $\mathrm{N}$ & 6 & 6 & 4 & 0.0004 (t-test) $[\mathrm{G}]$ & $\mathbf{0 . 0 1 0 6}(\mathrm{t}$-test) $[\mathrm{G}]$ \\
\hline $\mathrm{NO}_{3}-\mathrm{NO}_{2}$ as $\mathrm{N}$ & 6 & 6 & 4 & 0.2188 (Sign) & 0.2188 (t-test) \\
\hline $\mathrm{NH}_{3}$ as $\mathrm{N}$ & 5 & 5 & 3 & $\mathbf{0 . 0 2 0 4}$ (t-test) [R] & $\mathbf{0 . 0 3 4 6}$ (t-test) [C] \\
\hline $\mathrm{TP}$ & 6 & 6 & 4 & $<0.0001$ (t-test) $[\mathrm{G}]$ & $\mathbf{0 . 0 0 1 4}$ (t-test) $[\mathrm{G}]$ \\
\hline OP & 5 & 5 & 3 & 0.0091 (t-test) $[\mathrm{G}]$ & $\mathbf{0 . 0 1 5 3}$ (t-test) $[\mathrm{G}]$ \\
\hline
\end{tabular}

Note: $[\mathrm{G}]$, $[\mathrm{R}]$, or $[\mathrm{C}]$ denotes which source had higher concentrations, when a statistical difference was observed. The statistical test performed is in parentheses. Sign tests were performed when the data was not normally distributed

\subsection{Field Study Discussion}

The hydrologic performance of the WCC Greenroof in Goldsboro and the Neuseway Nature Center Greenroof in Kinston was well-defined. The average precipitation retention for each greenroof was approximately $63 \%$, which correlates strongly with data published in different regions of the United States and Germany (Hutchinson et al., 2003; Rowe et al., 2003; Liesecke, 1999; Liesecke, 1998). Monthly retention rates vary and are largely dependent upon the seasonal evapotranspiration rates and the rainfall pattern of each individual month.

Figure 4-9 and Figure 4-10 display the precipitation retention pattern in July 2003 and October 2003 at the WCC Greenroof in Goldsboro, NC; these figures illustrate the seasonal 
effect of rainfall patterns on the retention capacity of the greenroof. In July 2003, the percent retention steadily decreased due to the frequent occurrence of rain events typical in the summer seasons of the North Carolina climate. The percent retention, however, was more constant in Figure 4-10 because only three rain events occurred in October 2003 and all were evenly spaced apart to allow for sufficient time, at least six days, for the moisture content of the soil media to decrease to a minimum through evapotranspiration.

Figure 4-12 and Figure 4-13 display the precipitation retention pattern in August 2003 and December 2003 at the Neuseway Nature Center Greenroof in Kinston, NC. These figures illustrate how higher evapotranspiration rates can affect the amount of precipitation retained for a rain event. For example, the greenroof retained $60 \%$ of the precipitation from a $64 \mathrm{~mm}(2.5$ in.) rain event on August 17 with a $16 \mathrm{~mm}(0.64$ in.) rain event the prior day where the greenroof retained $92 \%$ of the precipitation. On December 10, a $39 \mathrm{~mm}(1.5 \mathrm{in}$.) rain event occurred that the greenroof retained only $23 \%$ of the rainfall; the previous rain event was six days before. The rain event in August was able to retain a larger percentage of the precipitation because higher evapotranspiration rates in the summer months allowed for the water temporarily stored within the soil media to be removed more rapidly than during winter months when evapotranspiration rates were lower. Average PET rates for July are approximately $151 \mathrm{~mm} /$ month $(5.9 \mathrm{in} . /$ month$)$ and average PET rates for October are approximately $51 \mathrm{~mm} / \mathrm{month}$ (2.0 in./month) in Goldsboro and Kinston, NC.

The North Carolina climate typically has brief, intense thunderstorms in the afternoons throughout the summer and storms of longer durations in the winter season. This research has shown that the precipitation retention of the greenroof is dependent upon the 
moisture content of the soil media at the time of the rain event. The soil moisture content and water storage capacity are a function of how rapidly precipitation is removed from temporary storage within the soil media, which is dependent upon the evapotranspiration rates. It is expected that precipitation retention will be higher in summer months because evapotranspiration rates are higher and will allow sufficient time for the moisture content of the soil media to be reduced before the next rain event. On average, the greenroof soil media requires four to five days to remove the precipitation temporarily stored within the media through evapotranspiration. However, this is difficult to quantify seasonally because rain events are more frequent during the summer months, often reoccurring in less than four to five days. Data provided in this chapter also illustrated the benefit of peak flow reduction offered by the greenroofs. The significant peak flow reduction of runoff by greenroof could reduce flash flooding in urban areas and would, therefore, aid in reducing stream bank erosion due to reduced flow velocities of runoff from the greenroof.

The observed Rational coefficients will also provide aid in greenroof design in the Southeastern United States. For storms between $25 \mathrm{~mm}$ (1 in.) and $39 \mathrm{~mm}$ (1.5 in.), an average Rational coefficient of 0.25 was observed. This is the same coefficient of areas with minimal impervious area such as a park or a playground, indicating that the greenroof was behaving as a park instead of an impervious rooftop. An average Rational coefficient of 0.55 was observed for storms greater than $39 \mathrm{~mm}$ (1.5 in.). This runoff coefficient is equivalent to areas of moderate imperviousness, such as residential and neighborhood business areas. This is a clear reduction from the typical Rational coefficient of 0.75 to 0.95 for rooftops. The Rational coefficient is an important element in flood analysis and these greenroof Rational 
coefficient values serve as a starting point for future greenroof hydrologic design in urban watersheds.

It was initially hypothesized that the greenroof would function as a nutrient reduction BMP. However, evidence showed that the greenroofs significantly increased the concentration of nitrogen and phosphorus in the runoff, when compared to the rainfall inflow and the conventional rooftop runoff. In the majority of the cases, the mass loading of TN and TP was higher in the greenroof runoff due to exceedingly high concentrations. This data exemplified that the outflow of nitrogen and phosphorus was higher than the inflow, indicating the greenroof was acting as a source of nitrogen and phosphorus instead of a sink.

It was originally hypothesized that the greenroof would act as a sink, accumulating nitrogen and phosphorus deposited from atmospheric deposition. Because the concentrations of nitrogen and phosphorus were so much higher in the greenroof runoff than the rainfall and the control roof runoff, the reduction in volume of runoff by the greenroof did not play a significant role in the mass loading calculation of nitrogen and phosphorus.

Since the greenroof was a source of nitrogen and phosphorus, then the nutrient source was the soil media. It was then hypothesized that the source of nitrogen and phosphorus present in the soil media was a result of the soil media composition. Fifteen percent of the soil media composition was composted cow manure, a clear source of nutrients. It appeared that the nutrients were leaching from the soil media. It was also hypothesized that the amount of nitrogen leaching from the soil would decrease over time because nitrogen does not bind to soil particles, therefore, more nitrogen would be flushed from the system during the first several rain events and then less nitrogen will be present runoff from the greenroof. 
However, no trends of increasing or decreasing concentrations of nutrients were observed in the collected field data.

A laboratory study was performed to determine the extent of nutrient leaching in greenroof soil media. The experimental design and results of the laboratory study are presented in Chapter 5. 


\subsection{GREENROOF SOIL MEDIA LABORATORY STUDY}

The results presented in Chapter 4 revealed higher levels of nitrogen and phosphorus present in the greenroof runoff than in the rainfall or the control roof runoff. It was suspected this may be a result of the soil media composition; the Carolina Stalite Light Weight Roof Garden Soil Mix contained 15\% composted cow manure (Friedrich, 2003). The purpose of this laboratory study was to determine the extent of nitrogen and phosphorus leaching from greenroof soil media during simulated rainfall events; three different greenroof soil media of varying composition were tested.

Soil media columns were constructed and filled with three different types of greenroof soil media; sand was used as a control for the experiment. Each week, for a consecutive ten week period, synthetic rainwater was sprayed onto each soil column to simulate rainfall in the field. Samples of drained water, termed outflow, from each soil column were analyzed for nitrogen and phosphorus concentrations each week. The experimental design, soil specifications, and results are included within this chapter.

\subsection{EXPERIMENTAL DESIGN}

\subsubsection{HYPOTHESES}

The goal of this experiment was to determine the extent of nitrogen and phosphorus leaching of three different greenroof soil media. This was done by testing the following hypotheses: (1) the nutrient concentrations of nitrogen and phosphorus species are significantly less in drainage from sand and soil media with $5 \%$ compost than soil media with $15 \%$ or $30 \%$ 
compost, and (2) the nutrient concentrations of nitrogen and phosphorus species present in drainage from greenroof soil media are significantly less after a period of 10 weeks of laboratory testing.

\subsubsection{SOIL MEDIA VARIATIONS}

Three different greenroof soil media compositions were studied in this experiment to investigate the relationship between organic matter and nutrient leaching. Table 5-1 summarizes the manufacturers' descriptions of each different soil media.

Table 5-1. Summary of NCDA Soil Test Report

\begin{tabular}{|c|c|c|}
\hline Soil Media & $\begin{array}{c}\% \text { Compost by } \\
\text { Volume }\end{array}$ & Composition \\
\hline $\begin{array}{l}\text { Carolina Stalite } \\
\text { Soil Mix }\end{array}$ & $15 \%$ & $\begin{array}{c}55 \% \text { Expanded Slate } \\
30 \% \text { Rootzone Sand } \\
15 \% \text { Compost }\end{array}$ \\
\hline $\begin{array}{l}\text { ERTH HydRocks } \\
\text { Soil Mix }\end{array}$ & $5 \%$ & $\begin{array}{c}75 \% \text { HydRocks Expanded Clay } \\
10 \% \text { River Sand } \\
10 \% \text { Sandy Loam } \\
5 \% \text { ERTH Food Compost }\end{array}$ \\
\hline $\begin{array}{l}\text { ERTH Light Soil } \\
\text { Mix }\end{array}$ & $33 \%$ & $\begin{array}{c}\text { 33\% HydRocks Expanded Clay } \\
\text { 33\% Blackened Top Soil } \\
33 \% \text { ERTH Food Compost }\end{array}$ \\
\hline Play Sand & $0 \%$ & $100 \%$ Sand \\
\hline
\end{tabular}

\subsubsection{Carolina Stalite Perma Till Light Weight Roof Garden Soil Mix}

This media was used at the two NCSU greenroof research sites in Goldsboro and Kinston, North Carolina. The Perma Till Lightweight Roof Garden Soil Mix was manufactured by Carolina Stalite Company and was composed of 55\% Perma Till (Stalite 3/8" expanded 
slate), 30\% USGA Rootzone Sand, and 15\% approved compost (Friedrich, 2003). The approved compost was comprised of composted cow manure. Media samples were donated by Carolina Stalite for this study. A sample of the Carolina Stalite Perma Till Soil Mix was analyzed by Gold Hill Research Laboratory in Gold Hill, North Carolina, in April 2001 to determine the damp and saturated bulk density. The damp bulk density of the soil was 1097 $\mathrm{kg} / \mathrm{m}^{3}\left(68.5 \mathrm{lbs} / \mathrm{ft}^{3}\right)$; the saturated bulk density was $1461 \mathrm{~kg} / \mathrm{m}^{3}\left(91.2 \mathrm{lbs} / \mathrm{ft}^{3}\right)$. This resulted in a damp specific gravity of 1.1 and a saturated, drained specific gravity of 1.46.

\subsubsection{ERTH HydRocks Soil Mix}

The ERTH HydRocks Soil Mix was manufactured by ERTH Products, LLC in Peachtree City, Georgia, and consisted of $75 \%$ HydRocks expanded clay, $10 \%$ river sand, $10 \%$ sandy loam, and 5\% ERTH Food Compost (King, 2003). Media samples were donated by ERTH Products, LLC for this study. The HydRocks expanded clay was a lightweight aggregate produced by processing through a rotary kiln (King, 2003). The ERTH Food Compost consisted of peanut hulls and Class A Biosolids that underwent treatment to the point where the concentration of pathogens was reduced to levels low enough that no additional restrictions or special handling precautions are required by Federal regulations (King, 2004). A soil sample was analyzed by A \& L Southern Agricultural Laboratories, Inc. in Pompano Beach, Florida, in December 2003 to determine the dry and saturated bulk density of the ERTH HydRocks Soil Mix. The dry bulk density was measured as $917 \mathrm{~kg} / \mathrm{m}^{3}\left(57.23 \mathrm{lbs} / \mathrm{ft}^{3}\right)$ and the saturated bulk density was measured as $1317 \mathrm{~kg} / \mathrm{m}^{3}\left(82.22 \mathrm{lbs} / \mathrm{ft}^{3}\right)$. The resulting dry specific gravity was 0.92 and the saturated specific gravity was 1.32 . 


\subsubsection{ERTH Light Soil Mix}

The ERTH Light Soil Mix was manufactured by ERTH Products, LLC in Peachtree City, Georgia, and is composed of 33\% HydRocks expanded clay, 33\% blackened top soil, and 33\% ERTH Food Compost (King, 2003). Media samples were donated by ERTH Products, LLC for this study. The HydRocks expanded clay was a lightweight aggregate produced by processing through a rotary kiln; the blackened top soil was derived from aged yard and leaf waste that was blended with ash and screened (King, 2003). As with the ERTH HydRocks Soil Mix, the ERTH Food Compost contained peanut hulls and Class A Biosolids (King, 2004). A soil sample was analyzed by A \& L Southern Agricultural Laboratories, Inc. in Pompano Beach, Florida in December 2003 to determine the dry and saturated bulk density of the ERTH Light Soil Mix. The dry bulk density was measured as $618 \mathrm{~kg} / \mathrm{m}^{3}(38.55$ $\left.\mathrm{lbs} / \mathrm{ft}^{3}\right)$ and the saturated bulk density was measured as $1191 \mathrm{~kg} / \mathrm{m}^{3}\left(74.37 \mathrm{lbs} / \mathrm{ft}^{3}\right)$. This results in a dry specific gravity of 0.62 and a saturated specific gravity of 1.19 .

\subsubsection{Play Sand}

Quikrete ${ }^{\circledR}$ Play Sand ${ }^{\circledR}$ No. 1113 was purchased at Lowe's ${ }^{\circledR}$ and used as the control for the experiment. This sand was screened, washed, and dried by the manufacturer. Sand was used simply as a control for this experiment; sand would not normally be applied as a greenroof soil media. Sand is not as porous as the other three media and as a result, retains more water when compared to the other three media. Retaining more water is not only a structural burden, due to the added weight of the water, but it is also an ecological problem because if 
the soil media remain too moist, the media conditions are unfavorable for certain plant species' survival.

\subsubsection{NCDA SOIL TEST REPORT}

A sample of each soil media was taken to the North Carolina Department of Agriculture (NCDA) Agronomic Division in Raleigh, NC for a soil test. The purpose of the soil test is to chemically extract elements essential to plant nutrition (Hardy et al., 2003b). Table 5-2 is a summary of the NCDA Soil Test Report; Table 5-3 serves as an explanation of the abbreviations used in Table 5-2.

Each different soil media was determined by the NCDA to be a mineral type soil, based upon the percent humic matter (HM\%) present in the media; humic matter is a type of organic matter. The weight to volume ratio $(\mathrm{W} / \mathrm{V})$ describes how porous the media is; a higher $\mathrm{W} / \mathrm{V}$ denotes that the media has a larger proportion of fine particles present, indicating the media can compact and become denser and less porous. The $\mathrm{W} / \mathrm{V}$ also serves as an indicator for which media will retain more water. The more porous a soil is, or the smaller the $\mathrm{W} / \mathrm{V}$, the more water will drain through the soil. Therefore, because sand had the highest $\mathrm{W} / \mathrm{V}$, it was expected to retain the most water in the study. Similarly, Carolina Statlite would retain the most water of the three greenroof soil media.

The cation exchange capacity (CEC) is roughly a measure of the available locations for cation exchange within the soil. The percentage of CEC occupied by calcium and magnesium $(\mathrm{Ca} \%)$ and $(\mathrm{Mg} \%)$ is important because for each greenroof soil media, nearly $100 \%$ of the CEC is occupied by these base cations. Phosphate anions (ortho-phosphate) 
bind to iron (Fe) and aluminum (Al) oxides, thus providing a mechanism to retain phosphorus within the soil media.

Table 5-2. Summary of NCDA Soil Test Report

\begin{tabular}{|l|c|c|c|c|c|c|c|c|c|c||}
\hline $\begin{array}{l}\text { Sample } \\
I D\end{array}$ & $H M \%$ & $W / V$ & $C E C$ & $B S \%$ & $A c$ & $p H$ & $P-I$ & $K-I$ & $C a \%$ & $M g \%$ \\
\hline \hline Stalite & 0.56 & 1.37 & 9.9 & 100.0 & 0.0 & 7.4 & 87 & 148 & 77.0 & 16.0 \\
\hline Clay & 0.13 & 1.23 & 8.0 & 100.0 & 0.0 & 7.4 & 225 & 66 & 82.0 & 15.0 \\
\hline Light & 0.46 & 0.80 & 13.0 & 93.0 & 0.9 & 6.4 & 496 & 311 & 62.0 & 19.0 \\
\hline Sand & 0.04 & 1.53 & 0.3 & 33.0 & 0.2 & 4.7 & 0 & 1 & 35.0 & 9.0 \\
\hline
\end{tabular}

Table 5-3. Explanation of NCDA Abbreviations $\dagger$

\begin{tabular}{|c|c|}
\hline Abbreviation & Explanation \\
\hline Stalite & Carolina Stalite Perma Till Light Weight Roof Garden Soil Mix \\
\hline Clay & ERTH HydRocks Soil Mix \\
\hline Light & ERTH Light Soil Mix \\
\hline Sand & Play Sand \\
\hline $\mathrm{HM} \%$ & Percent humic matter \\
\hline $\mathrm{W} / \mathrm{V}$ & Weight to volume ratio expressed in $\mathrm{g} / \mathrm{cm}^{3}$ \\
\hline CEC & Cation exchange capacity expressed in meq $/ 100 \mathrm{~cm}^{3}$ \\
\hline $\mathrm{BS} \%$ & $\begin{array}{l}\text { Percentage of CEC occupied by the basic cations } \\
\text { calcium }(\mathrm{Ca}) \text {, magnesium }(\mathrm{Mg}) \text {, and potassium }(\mathrm{K})\end{array}$ \\
\hline Ac & Exchangeable acidity expressed in meq/100 $\mathrm{cm}^{3}$ \\
\hline $\mathrm{pH}$ & Soil $\mathrm{pH}$ : measure of the active acidity $(\mathrm{H}+)$ in the soil solution \\
\hline P-I & Phosphorus $(\mathrm{P})$ index \\
\hline K-I & Potassium $(\mathrm{K})$ index \\
\hline $\mathrm{Ca} \%$ & Percentage of CEC occupied by calcium \\
\hline $\mathrm{Mg} \%$ & Percentage of CEC occupied by magnesium \\
\hline
\end{tabular}

†Hardy et al., 2003b

Soil test phosphorus (STP), as measured by the phosphorus index (P-I), is a very important factor for each of these soil media. The STP serves as an indicator for the amount 
of phosphorus currently present within the soil media. One of the concerns for each of these greenroof soil media is leaching of phosphorus. The STP for Carolina Stalite Soil Mix, ERTH Light Soil Mix, and ERTH HydRocks Soil Mix is 87, 496, and 225, respectively. The minimum STP required for crop nutrition reported by the NCDA is 50 (Hardy et al., 2003a). While the STP of the Carolina Stalite Soil Mix is high, it is still acceptable. The STP of the ERTH Light Soil Mix and the ERTH HydRocks Soil Mix is far beyond the minimum STP level needed for plant nutrition. Therefore, any phosphorus leaching observed in each of these greenroof soil media could be reduced if the STP was lowered during the manufacturing process of the greenroof media.

\subsubsection{Soll TeXture ANALysis}

A soil texture analysis was performed within the Department of Soil Science at NCSU on each of the different soil media and the control. Each media sample was initially sifted through a $2 \mathrm{~mm}(0.078 \mathrm{in}$.) sieve. The portion of the sample which passed through the sieve was used as the soil media sample for the hydrometer test. The sample was mixed into a solution with $200 \mathrm{~mL}$ of distilled (DI) water and then placed in a $1 \mathrm{~L}$ beaker. Organic matter was burned from the sample through the addition of hydrogen peroxide $\left(\mathrm{H}_{2} \mathrm{O}_{2}\right)$ to the soil solution in a hot water bath over a period of 24 to 72 hours.

After the organic matter was burned from the soil solution, the sample was transferred into a $1 \mathrm{~L}$ graduated cylinder for the hydrometer test. Before the soil solution was transferred into the graduate cylinder, $50 \mathrm{~mL}$ of $10 \%$ Hexametaphosphate was added to the solution to act as a dispersing agent. If the sample did not fill the graduated cylinder to the $1 \mathrm{~L}$ mark, 
then DI water was added to the cylinder to produce a $1 \mathrm{~L}$ soil solution. In total, four hydrometer measurements were taken: (1) 0.5 minutes after mixing the solution with a brass plunger for 30 seconds, (2) 1.5 minutes after mixing the solution with a brass plunger for 30 seconds, (3) 6 hours after mixing the solution with a brass plunger for 30 seconds, and (4) 16 hours after mixing the solution with a brass plunger for 30 seconds. At each of these measurement times, measurements were recorded for each soil solution and for a reference blank solution. Table 5-4 displays the results of the soil texture analysis.

Table 5-4. Summary Table of Soil Texture Analysis Results

\begin{tabular}{|l|c|c|c|c|c|}
\hline Soil Media & $\%$ Sand & $\%$ Silt & $\%$ Clay & $\%$ Organic Matter & Textural Class \\
\hline Carolina Stalite Soil Mix & 95.8 & 1.1 & 3.1 & 3.3 & Sand \\
\hline ERTH HydRocks Soil Mix & 84.1 & 10.3 & 5.6 & 1.8 & Loamy Sand \\
\hline ERTH Light Soil Mix & 52.5 & 24.4 & 23.1 & 15.1 & Sandy Clay Loam \\
\hline Play Sand & 99.0 & 0.3 & 1.7 & 0 & Sand \\
\hline
\end{tabular}

After the hydrometer readings were made, it became obvious that the Play Sand was not reacting as it should. The hydrometer readings were increasing over time; hydrometer readings should always decrease over time. Small bubbles were also observed inside the graduated cylinder which would cause the hydrometer readings to be inaccurate. A second sample of Play Sand was mixed directly into solution with the $10 \%$ Hexametaphosphate dispersing agent, the small amount of organic matter present in the sample was not burned off by the addition of $\mathrm{H}_{2} \mathrm{O}_{2}$ to the soil solution. The soil solution without the $\mathrm{H}_{2} \mathrm{O}_{2}$ added had appropriate hydrometer readings for sandy soils. It was therefore concluded that the Play Sand had other chemicals added to it during the manufacturing process which were interacting with the $\mathrm{H}_{2} \mathrm{O}_{2}$ and creating inaccurate readings for the hydrometer. The first 
sample with the $\mathrm{H}_{2} \mathrm{O}_{2}$ added was disregarded and the Play Sand solution without the $\mathrm{H}_{2} \mathrm{O}_{2}$ was used in the final results.

The results indicated that the Carolina Stalite Soil Mix had the highest percentage of sand for the three greenroof soil media, followed closely by the ERTH HydRocks Soil Mix. The ERTH Light Soil Mix had the highest percentages of silt and clay present in the composition. The results of the soil texture analysis also indicated that the percentage of organic matter present in each soil media was different from what the manufacturers reported. ERTH Light Soil Mix was reported by the manufacturers to be composed of 33\% compost, ERTH HydRocks consisted of 5\% compost, and Carolina Stalite Soil Mix was composed of $15 \%$ compost. The compositions reported by the manufacturers are all on a volume basis and the percent organic matter measured in the soil texture analysis was reported on a weight basis.

\subsubsection{Soil Media Column Design}

A total of 16 soil media columns were constructed to allow four replications of each different media. All 16 soil columns were housed in the Tropical Soil Science Laboratory in the Department of Soil Science at NCSU. Each soil column consisted of a $152 \mathrm{~mm}$ (6 in.) diameter PVC pipe, which was cut into a $229 \mathrm{~mm}$ (9 in.) high column. The individual columns were fixed to $229 \mathrm{~mm}$ (9 in.) by $229 \mathrm{~mm}$ ( 9 in.) square PVC plates, $6.35 \mathrm{~mm}(0.25$ in.) thick, by a PVC air welder. In the center of each plate, a hole was drilled with an approximate $6.4 \mathrm{~mm}$ (0.25 in.) diameter drip nozzle screwed into the PVC plate to provide a path for the draining water. Figure 5-1 and Figure 5-2 illustrate the design schematics of the 
individual media columns and the rack on which the columns rested. A $600 \mathrm{~mL}$ Nalgene ${ }^{\circledR}$ plastic beaker was placed below each soil media column to collect outflow draining from the columns.

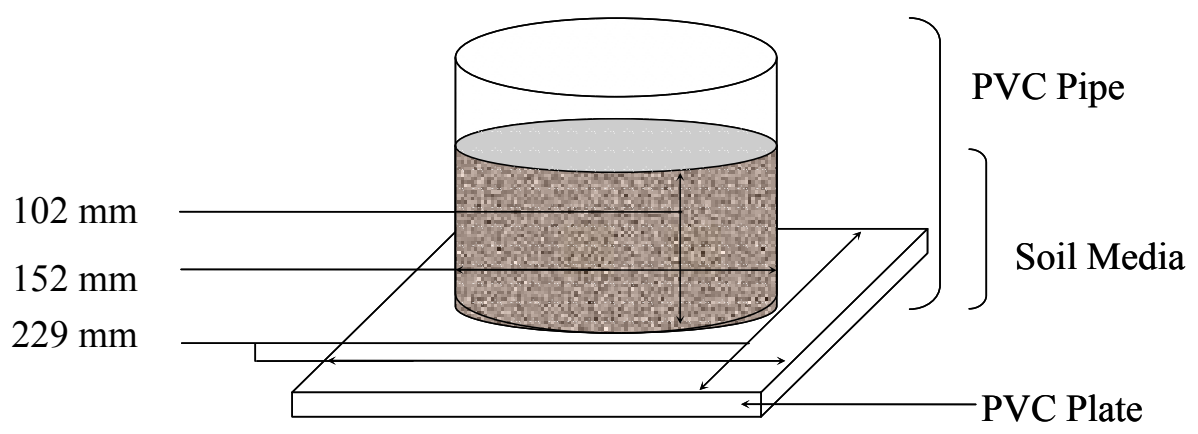

Figure 5-1. Column Design Schematic.

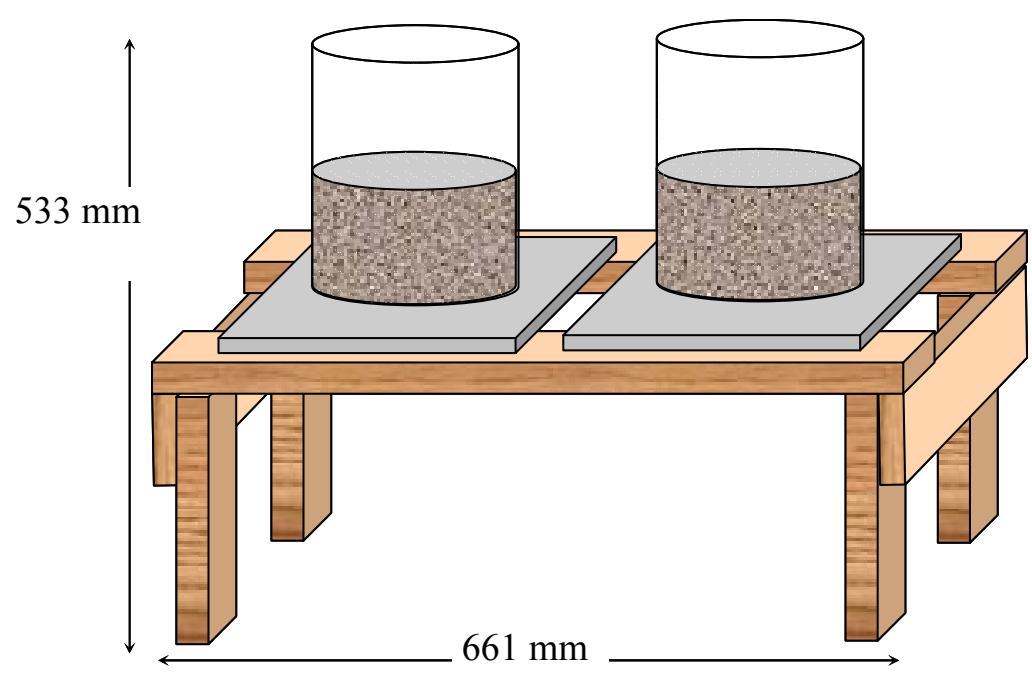

Figure 5-2. Column and Rack Combination.

Racks were constructed with $51 \mathrm{~mm}(2$ in.) by $102 \mathrm{~mm}$ (4 in.) wood materials; each rack supported two media columns (See Figure 5-2). The racks raised the soil media columns $254 \mathrm{~mm}(10 \mathrm{in}$.) above the surface of the laboratory counter to provide adequate 
clearance for beakers to sit below the soil columns. Lengths of Watts ${ }^{\circledR} 13 \mathrm{~mm}(0.5 \mathrm{in}$.) outside diameter, $9.5 \mathrm{~mm}$ (0.375 in.) inside diameter clear vinyl tubing were used to channel the draining water from the media column into the beaker resting below the column. One end of the tubing was connected to the drip nozzle and the other end was placed inside the 600 $\mathrm{mL}$ beaker; therefore, the outflow flowed directly from soil column into the beaker. The beakers were provided by NCSU's Soil Science Department.

\subsubsection{EXPERIMENTAL PROCEDURE}

With the columns constructed, the bottom of each soil column was initially covered with a layer of geotextile fabric followed by a layer of washed gravel with another layer of geotextile fabric above the washed gravel (See Figure 5-3). No. 5 Washed River Rock was used as the washed gravel and was purchased from R.L. Bradsher Contracting, Inc. in Raleigh, North Carolina and was approximately 12.7 to $25.4 \mathrm{~mm}(0.5$ in. to 1 in.) in diameter. The washed gravel was rinsed with DI water and served as a drainage layer for the water as it flowed through the column. Then, each column was filled with soil media up to a $102 \mathrm{~mm}$ (4 in.) depth above the drainage layer (See Figure 5-4). This is the typical depth of extensive greenroofs; this was also the approximate depth used at the NCSU greenroof research sites. As each column was packed with soil media, the total mass corresponding to the $102 \mathrm{~mm}$ (4 in.) depth of soil media was recorded. After the soil mass of the first column was measured, each of the other three columns for each respective soil mix was filled with the same mass of soil media. This eliminated any discrepancies that could arise if one column was packed denser than another and ensured that each column was packed with the 
same total mass of soil media. Table 5-5 exhibits the average gravel depth, media depth, and mass for each soil media type; the average gravel depth and average media depth is the average of the four columns for that respective media type.

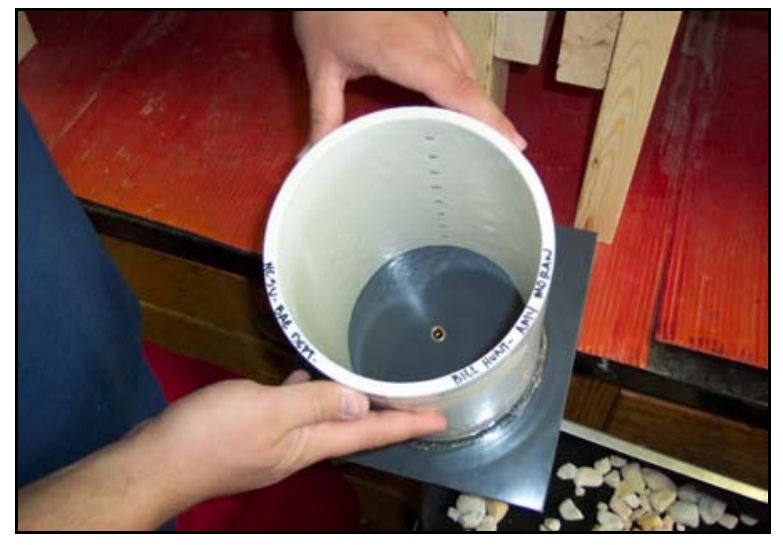

(a)

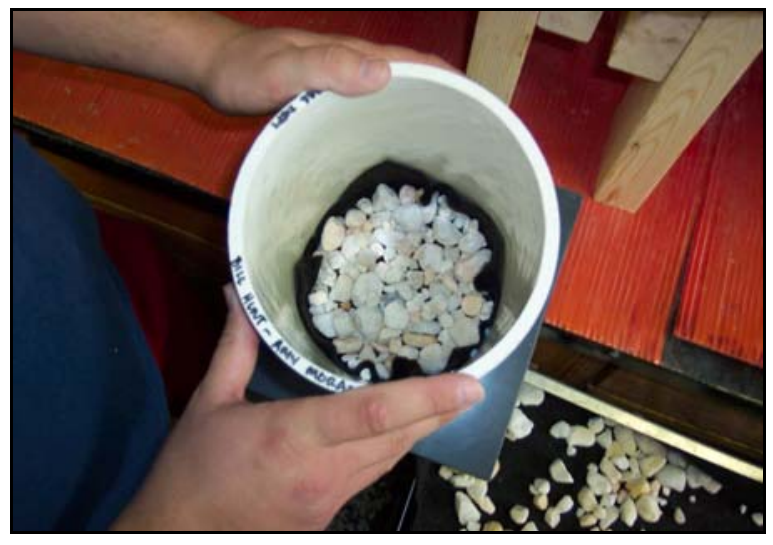

(b)

Figure 5-3. (a) View of Media Column Empty. (b) View of Media Column with Drainage Layer.

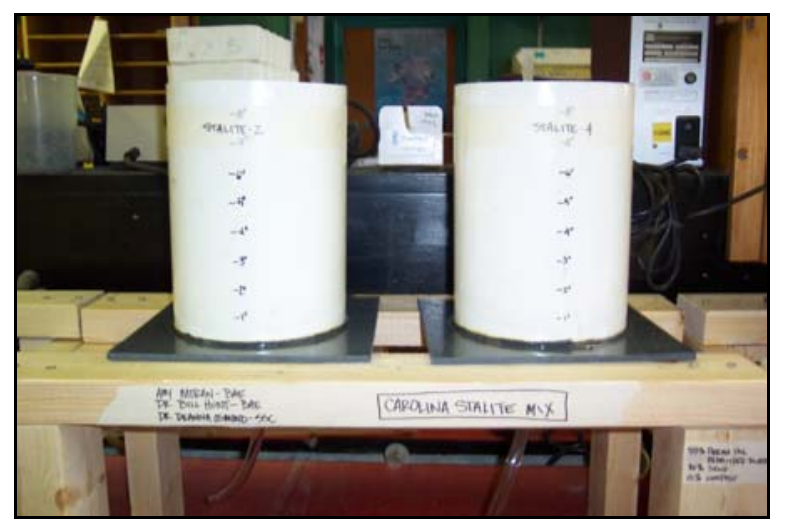

(a)

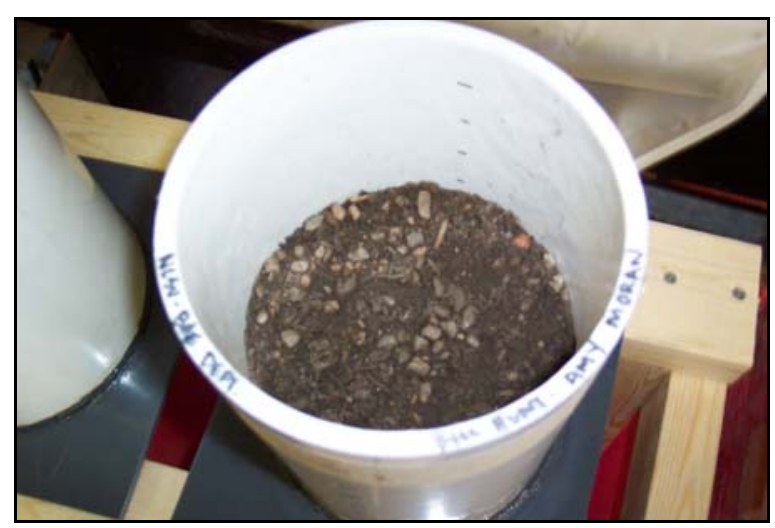

(b)

Figure 5-4. (a) View of Two Soil Media Columns. (b) View of One Column Filled with Soil Media.

Table 5-5. Corresponding Soil Media Depths and Mass for Each Media Type

\begin{tabular}{|c|c|c|c|}
\hline Soil Media Description & Average Gravel Depth & Average Media Depth & Media Mass \\
\hline \hline Play Sand & $19 \mathrm{~mm}(0.75 \mathrm{in.})$ & $102 \mathrm{~mm}(4 \mathrm{in})$. & $2866 \mathrm{~g}$ \\
\hline Carolina Stalite & $20 \mathrm{~mm}(0.80$ in. $)$ & $102 \mathrm{~mm}(4 \mathrm{in})$. & $2492 \mathrm{~g}$ \\
\hline ERTH Light Soil Mix & $19 \mathrm{~mm}(0.75$ in. $)$ & $102 \mathrm{~mm}(4 \mathrm{in})$. & $1518 \mathrm{~g}$ \\
\hline ERTH HydRocks Soil Mix & $22 \mathrm{~mm}(0.85$ in.) & $102 \mathrm{~mm}(4$ in. $)$ & $1778 \mathrm{~g}$ \\
\hline
\end{tabular}


The columns were fully constructed in December 2003; testing began in January 2004. For each weekly testing period, synthetic rainwater was sprayed into each soil column with a Johnson Wax Professional (C) Professional Grade 32 fl. oz. Spray Bottle (See Figure 55) and allowed to drain through the column; the outflow was then collected in the $600 \mathrm{~mL}$ Nalgene ${ }^{\circledR}$ plastic beaker below each column. For ten consecutive weeks, synthetic rainwater was applied to the columns each Monday, drained water samples were taken to the water quality lab for analysis each Tuesday, the final measurement of total drained water was recorded each Friday and all bottles and instruments were cleaned and reset for the next week's experiment each Friday.

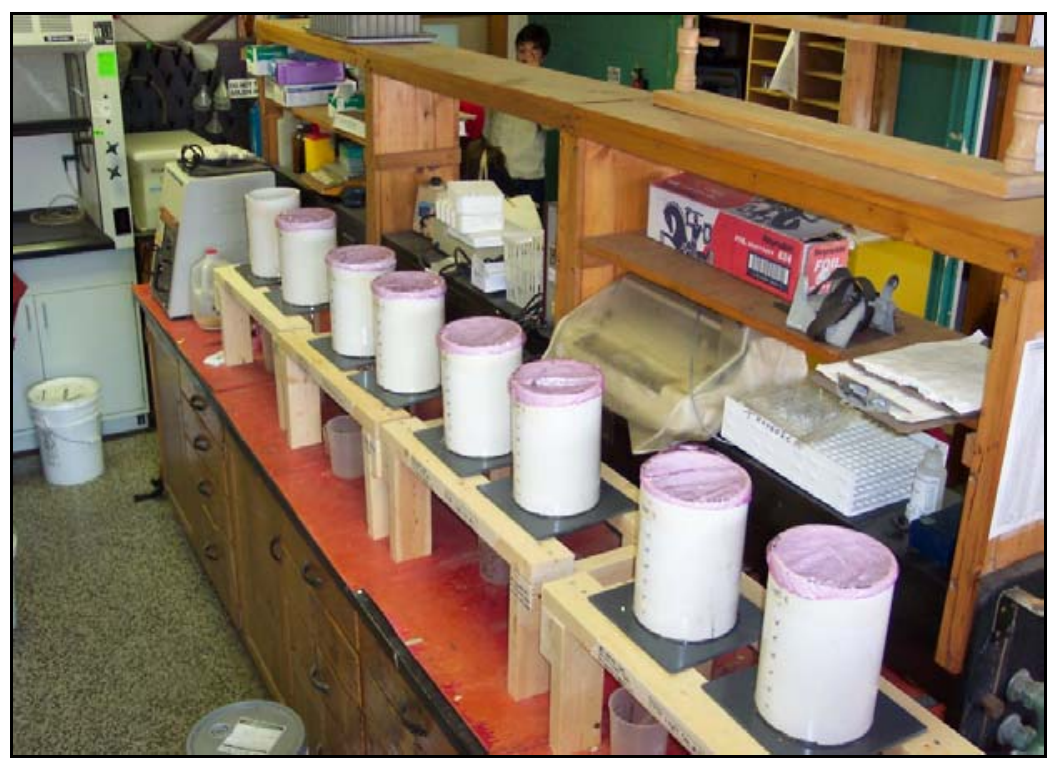

(a)

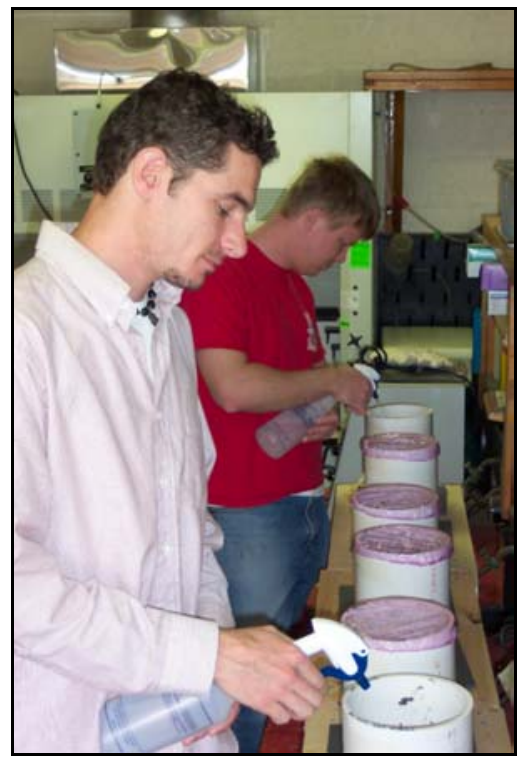

(b)

Figure 5-5. (a) View of 8 Media Columns Covered with Saran ${ }^{\mathrm{TM}}$ Quick Covers ${ }^{\mathrm{TM}}$ in Lab Space. (b) Two Graduate Students, Eban Bean and Lucas Sharkey, Volunteer Time to Apply Synthetic Rainwater to Media Columns.

Throughout the week, all water drained from the soil column was measured and recorded. The synthetic rainwater was DI water modified to have the same chemical 
composition for nitrogen and phosphorus as measured in rainfall at the greenroof field sites in eastern North Carolina. The amount of water sprayed onto each soil column corresponded to a $38 \mathrm{~mm}$ (1.5 in.) storm event and was equivalent to $700 \mathrm{~mL}$. The $38 \mathrm{~mm}$ (1.5 in.) storm event was selected to ensure appropriate saturation of the soil media and to ensure that the minimum volume of water required for the water quality analyses would drain from each soil column.

The experiment began Monday, January 12, 2004; the specified volume of artificial rainwater was sprayed on the column once a week for 10 consecutive weeks. The soil columns were kept in the Department of Soil Science's Tropical Soil Science Lab. This controlled environment, served as an alternative to keeping the soil columns outside; here, all weather variables constant throughout the duration of the experiment. The temperature in the laboratory remained at room temperature, $25^{\circ} \mathrm{C}\left(78^{\circ} \mathrm{F}\right)$.

To aid in simplifying the water balance for each soil column, each column was covered with Saran $^{\mathrm{TM}}$ Quick Covers ${ }^{\mathrm{TM}}$ (See Figure 5-5) to minimize any evaporation from occurring. As a result, the water balance for each column is shown in Equation 5-1.

\section{Equation 5-1.}

$$
\text { Water }_{\text {in }}=\text { Water }_{\text {out }}+\text { Water }_{\text {stored }}
$$

The outflow was analyzed for total phosphorous (TP), orthophosphorus (OP), ammonia $\left(\mathrm{NH}_{3}\right.$ as $\mathrm{N}$ ), nitrate-nitrite $\left(\mathrm{NO}_{3}-\mathrm{NO}_{2}\right.$ as $\left.\mathrm{N}\right)$, total Kjeldahl nitrogen ( $\mathrm{TKN}$ as $\left.\mathrm{N}\right)$, and total nitrogen (TN). Samples were analyzed at the Soil Science Laboratory in Williams Hall. 


\subsubsection{SYNTHETIC RAINWATER COMPOSITION}

Composition of the synthetic rainwater was determined through rainwater samples collected from the field study during the spring and summer months of 2003 in Kinston and Goldsboro, NC. Chemical analysis on the rainwater samples was performed at Tri-Test, Inc. and the average of 4 samples from Kinston and 4 samples from Goldsboro was used as the specified rainwater composition, displayed in Table 5-6. The $\mathrm{pH}$ was not regularly tested in all water quality samples from the field study; therefore, it was determined from three different rain samples (2 from Goldsboro and 1 from Kinston) in late 2003.

Table 5-6. Chemical Composition of Synthetic Rainwater

\begin{tabular}{|l|c|c|}
\hline \hline Constituent & Average Concentration in the Field & Desired Laboratory Concentration \\
\hline \hline TKN as N & $0.38 \mathrm{mg} / \mathrm{L}$ & $\mathrm{n} / \mathrm{a}$ \\
\hline $\mathrm{NO}_{3}$ as $\mathrm{N}-\mathrm{NO}_{2}$ as $\mathrm{N}$ & $0.12 \mathrm{mg} / \mathrm{L}$ & $0.12 \mathrm{mg} / \mathrm{L}$ \\
\hline $\mathrm{TN}$ & $0.50 \mathrm{mg} / \mathrm{L}$ & $0.50 \mathrm{mg} / \mathrm{L}$ \\
\hline $\mathrm{NH}_{3}$ as $\mathrm{N}$ & $0.16 \mathrm{mg} / \mathrm{L}$ & $0.38 \mathrm{mg} / \mathrm{L}$ \\
\hline $\mathrm{TP}$ & $0.05 \mathrm{mg} / \mathrm{L}$ & $0.04 \mathrm{mg} / \mathrm{L}$ \\
\hline $\mathrm{OP}$ & $0.04 \mathrm{mg} / \mathrm{L}$ & 4.5 \\
\hline \hline $\mathrm{pH}$ & 4.36 & \\
\hline
\end{tabular}

Due to the organic content that is measured in the analysis of TKN and TP, the concentrations of these constituents could not be re-created in the laboratory setting. Therefore, the only chemicals that were created in the synthetic rainwater composition were $\mathrm{NH}_{3}, \mathrm{NO}_{3}-\mathrm{NO}_{2}$, and OP. Table 5-7 displays the chemicals that were necessary to produce the desired concentrations in Table 5-6 for all the artificial rainwater samples of the entire experiment ( 1 sample per 16 columns for a total of 10 weeks). All chemicals displayed in Table 5-7 were supplied by NCSU's Biological and Agricultural Engineering Environmental 
Analysis Laboratory. A total of $12 \mathrm{~L}$ (3.2 gal) of synthetic rainwater was composed in solution each week; the solution was prepared in four separate $3.8 \mathrm{~L}$ ( 1 gal) jugs. For ease of preparing the synthetic rainwater, a solution volume of $3 \mathrm{~L}(0.79$ gal $)$ was prepared in a $5 \mathrm{~L}$ (1.32 gal) volumetric flask and then transferred to the $3.8 \mathrm{~L}$ (1 gal) jug; this process was repeated for each of the four jugs. Appendix I displays the calculations used to determine the amount of chemical required for the synthetic rainfall.

Table 5-7. Chemical Supply for Synthetic Rainfall

\begin{tabular}{|c|c|c|c|}
\hline Chemical & Constituent & Weekly Amount Required & Total Amount Required \\
\hline $\mathrm{KNO}_{3}$ & $\mathrm{NO}_{3}$ as $\mathrm{N}-\mathrm{NO}_{2}$ as $\mathrm{N}$ & $0.003 \pm 0.0005 \mathrm{~g} \mathrm{KNO}_{3}$ & $0.04 \mathrm{~g} \mathrm{KNO}_{3}$ \\
\hline $\mathrm{NH}_{3} \mathrm{Cl}$ & $\mathrm{NH}_{3}$ as $\mathrm{N}$ & $0.004 \pm 0.0005 \mathrm{~g} \mathrm{NH}_{3} \mathrm{Cl}$ & $0.05 \mathrm{~g} \mathrm{NH}_{3} \mathrm{Cl}$ \\
\hline $\mathrm{KH}_{2} \mathrm{PO}_{4}$ & OP & $0.0005 \pm 0.0003 \mathrm{~g} \mathrm{KH}_{2} \mathrm{PO}_{4}$ & $0.006 \mathrm{~g} \mathrm{KH}_{2} \mathrm{PO}_{4}$ \\
\hline $\mathrm{NaOH}$ & $\mathrm{pH}$ & $<5 \mathrm{~mL}$ & $<50 \mathrm{~mL}$ \\
\hline $\mathrm{H}_{2} \mathrm{SO}_{4}$ & $\mathrm{pH}$ & $<5 \mathrm{~mL}$ & $<50 \mathrm{~mL}$ \\
\hline
\end{tabular}

The TN calculation was modified slightly because the organic nitrogen concentration could not be replicated in the laboratory setting. Ordinarily, the TN calculation would be as displayed in Equation 5-2. However, Equation 5-2 was simplified to Equation 5-3 because the organic matter content could not be simulated in the laboratory. It should be noted that the $\mathrm{NH}_{3}$ concentration in the field was $0.16 \mathrm{mg} / \mathrm{L}$ and the $\mathrm{NH}_{3}$ concentration in the laboratory experiment was increased to $0.38 \mathrm{mg} / \mathrm{L}$. This concentration was modified to achieve the total nitrogen concentration of $0.50 \mathrm{mg} / \mathrm{L}$ because this was the nutrient of most concern. If the $\mathrm{NH}_{3}$ concentration had remained at $0.16 \mathrm{mg} / \mathrm{L}$, then the total nitrogen concentration would only be $0.28 \mathrm{mg} / \mathrm{L}$ instead of $0.50 \mathrm{mg} / \mathrm{L}$. Therefore, the concentration of $\mathrm{NO}_{3}-\mathrm{NO}_{2}$ or $\mathrm{NH}_{3}$ needed to be increased. 
Equation 5-2.

$$
\mathrm{TN}=\mathrm{NO}_{3}-\mathrm{NO}_{2}+\left(\mathrm{NH}_{3}+\text { Organic } \mathrm{N}\right)=\mathrm{NO}_{3}-\mathrm{NO}_{2}+(\mathrm{TKN})
$$

Equation 5-3.

$$
\mathrm{TN}=\mathrm{NO}_{3}-\mathrm{NO}_{2}+\mathrm{NH}_{3}
$$

\subsubsection{Synthetic Rainwater Laboratory Procedure}

In the NCSU Biological and Agricultural Engineering Environmental Analysis Laboratory, the appropriate amounts of each chemical were measured, using the Wettler ${ }^{\circledR}$ AE 200 Scale $(0.0001 \mathrm{~g})$ for each $3 \mathrm{~L}(0.79 \mathrm{gal})$ solution and then mixed into a $3 \mathrm{~L}(0.79 \mathrm{gal})$ solution of distilled water. After the solution was stirred, the $\mathrm{pH}$ was measured and adjusted with either $\mathrm{NaOH}$ to raise the $\mathrm{pH}$ or adjusted with $\mathrm{H}_{2} \mathrm{SO}_{4}$ to lower the $\mathrm{pH}$ to the appropriate value. After the $\mathrm{pH}$ was adjusted to the desired value, the $3 \mathrm{~L}(0.79$ gal $)$ solution of synthetic rainwater was funneled into a clean, empty $3.8 \mathrm{~L}(1 \mathrm{gal})$ jug. This process was repeated three times; the end result was $12 \mathrm{~L}$ ( 3.2 gal) of synthetic rainwater. The synthetic rainwater solution was prepared every Friday afternoon and then refrigerated until it was applied to the soil columns every Monday morning. The synthetic rainwater solution was refrigerated to minimize the potential for volatilization or biodegradation between when the solution was created in the laboratory and when it was applied to the soil media columns (Clesceri, et al., 1998).

\subsection{LABORATORY STUDY RESULTS}

All water quality results from the laboratory study are presented in Appendix $\mathrm{J}$ and the statistical analysis for the laboratory study water quality results are displayed in Appendix K. 


\subsubsection{ERTH HYDROCKS SOIL MIX}

Figure 5-6 and Figure 5-7 display the concentrations of nitrogen species and phosphorus species over the 10-week period of the leaching experiment for the ERTH HydRocks Soil Mix. A general decreasing trend was observed for $\mathrm{NO}_{3}-\mathrm{NO}_{2}$ as $\mathrm{N}, \mathrm{TKN}$ as $\mathrm{N}$, and $\mathrm{TN}$; the concentration of $\mathrm{NH}_{3}$ as $\mathrm{N}$ remained relatively constant throughout the duration of the experiment. The concentration of TKN as $\mathrm{N}$ was composed of organic $\mathrm{N}$ and $\mathrm{NH}_{3}$ as $\mathrm{N}$. Because the $\mathrm{NH}_{3}$ as $\mathrm{N}$ concentration remained relatively low throughout the experiment, and the TKN as $\mathrm{N}$ concentration distinctly remained above the concentration of $\mathrm{NH}_{3}$ as $\mathrm{N}$, it can be concluded a large proportion of organic $\mathrm{N}$ comprised the TKN observed in the outflow. TKN was not added to the media column through the synthetic rainwater; the source of TKN was solely from the media. It was also seen that the concentration of $\mathrm{NH}_{3}$ as $\mathrm{N}$ decreased during Week 2 and the concentration of $\mathrm{NO}_{3}-\mathrm{NO}_{2}$ as $\mathrm{N}$ increased in Week 2, indicating that the $\mathrm{NH}_{3}$ mineralized into $\mathrm{NO}_{3}-\mathrm{NO}_{2}$. The low levels of organic $\mathrm{N}$ in the latter 5 weeks of the study indicated that not all of the organic $\mathrm{N}$ leached from the soil, concentrations of $\mathrm{N}$ remained in the soil media at the conclusion of the study.

The TP and OP concentrations displayed in Figure 5-7 indicated that the phosphorus was becoming reduced under saturated conditions within areas of the media because the concentrations of OP were increasing during Week 2 through Week 4 and again from Week 5 to Week 7. This was also apparent because the majority of the TP was composed of OP, which indicated that the media had saturated zones and large concentrations of OP anions were released into the solution. The zones of saturation were a result of laboratory 
conditions and minimized evapotranspiration; these circumstances are not likely to occur in field conditions.

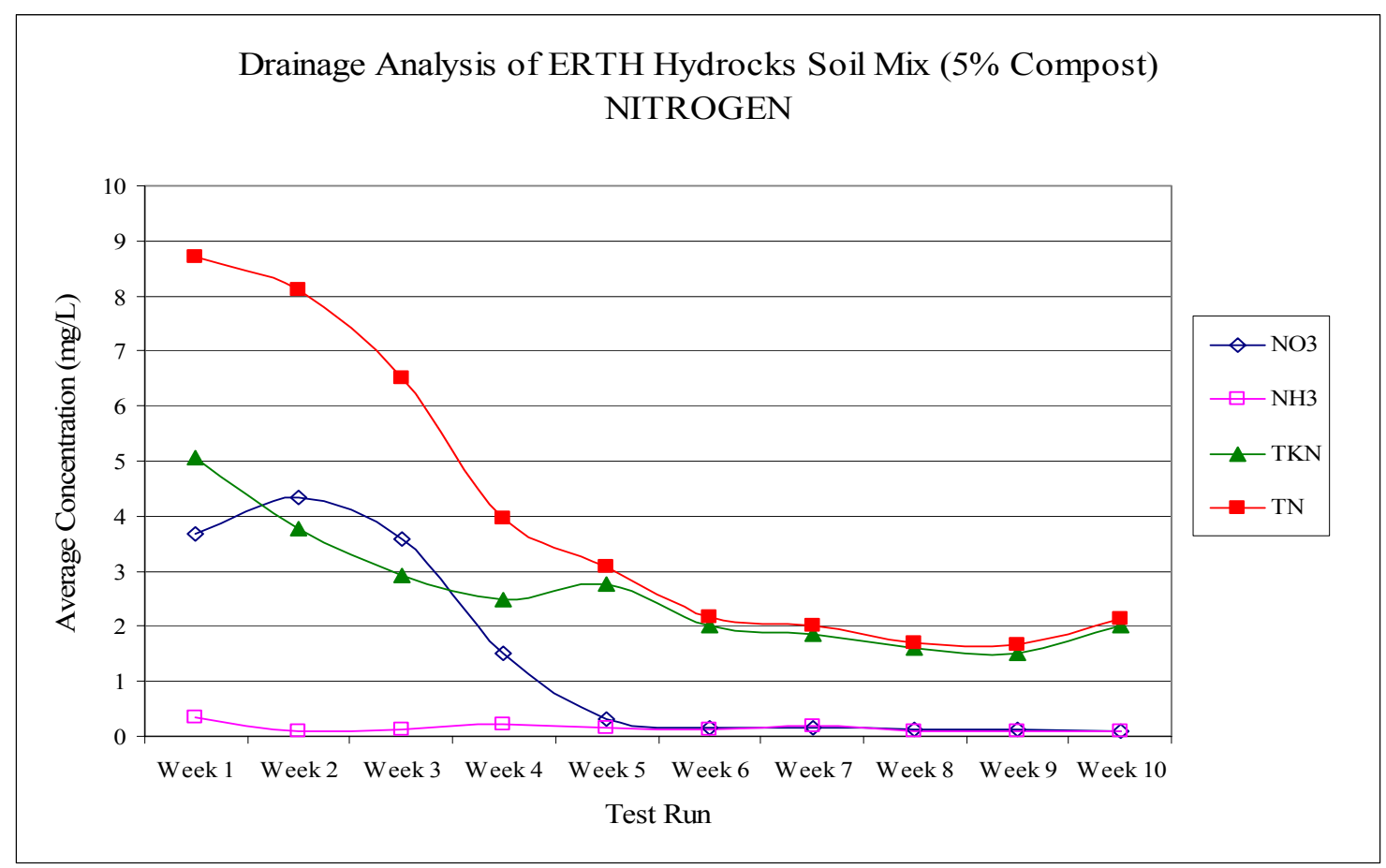

Figure 5-6. Display of Nitrogen Concentrations in ERTH HydRocks Soil Mix (5\% Compost).

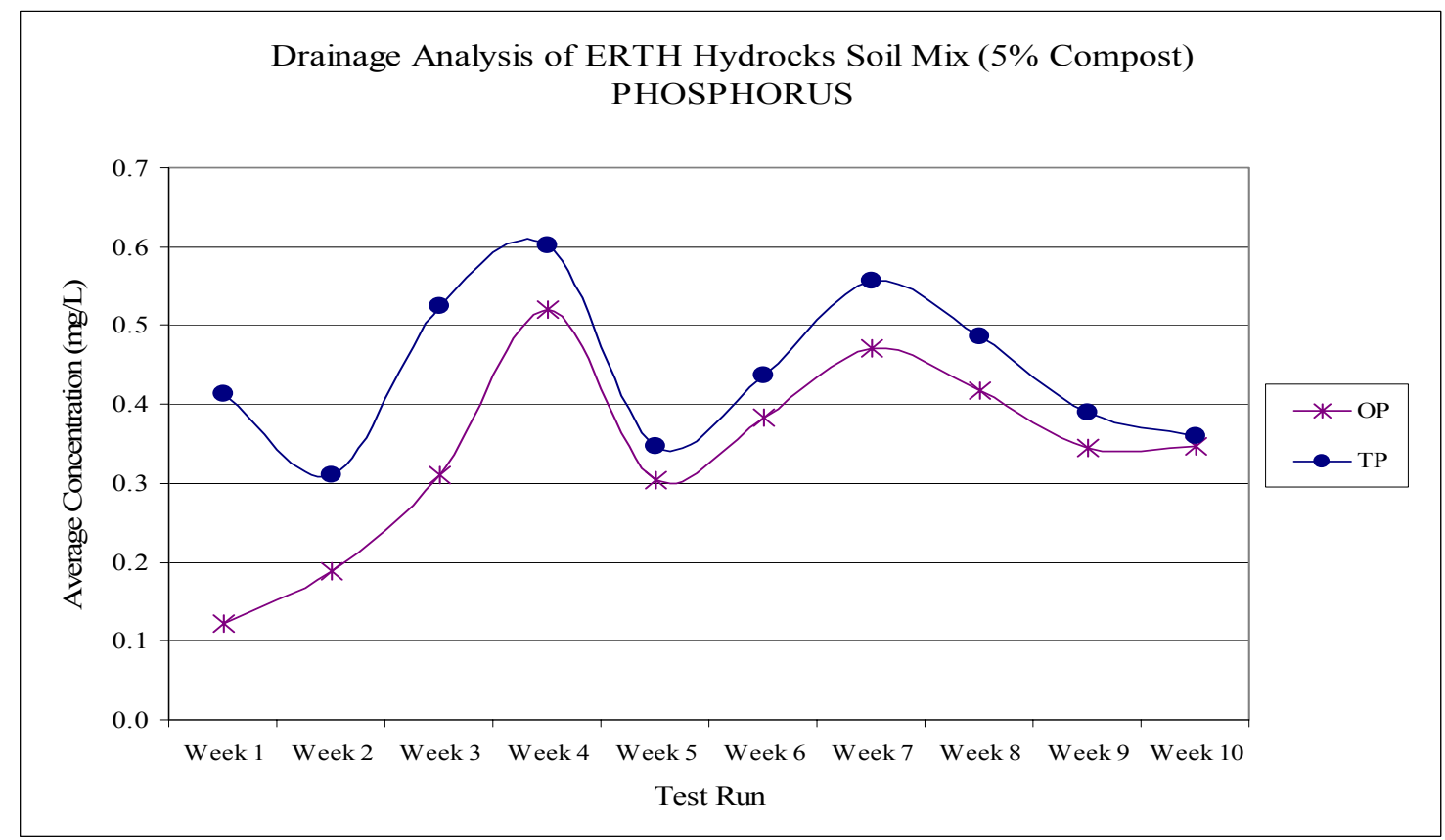

Figure 5-7. Display of Phosphorus Concentrations in ERTH HydRocks Soil Mix (5\% Compost). 


\subsubsection{CARolina Stalite SoIl Mix}

The concentrations of the nitrogen species observed in the outflow from the Carolina Stalite Soil Mix are shown in Figure 5-8; the concentrations of the phosphorus species observed in the outflow are presented in Figure 5-9. The nitrogen curves in Figure 5-8 demonstrate that, as with the ERTH HydRocks Soil Mix, the concentrations of $\mathrm{NO}_{3}-\mathrm{NO}_{2}$ as $\mathrm{N}$ decreased to a minimum during the first half of the study; the concentrations of $\mathrm{NH}_{3}$ as $\mathrm{N}$ also decreased to a minimum after Week 2. Similar to the ERTH HydRocks Soil Mix, the concentration of $\mathrm{NH}_{3}$ decreased at Week 2 and the concentration of $\mathrm{NO}_{3}-\mathrm{NO}_{2}$ increased at Week 2, indicating that the $\mathrm{NH}_{3}$ was mineralizing into $\mathrm{NO}_{3}-\mathrm{NO}_{2}$ through the nitrification process. These results also demonstrate how inorganic $\mathrm{N}$ leaches from the soil media before organic $\mathrm{N}$. TKN measures the concentration of organic $\mathrm{N}$ in the soil media and after Week 5; the TN concentration was solely composed of organic $\mathrm{N}$ because the inorganic forms had leached from the media.

A gradual increase of TP was observed from Week 3 to Week 6, as shown in Figure 5-9. Similar to the phosphorus data for the ERTH HydRocks Soil Mix, the TP was comprised mostly of OP through the majority of the weeks of the study. This, again, demonstrated that portions of the soil media remained saturated for a period of time, thereby releasing the OP anions from their binding sites to the soil media and releasing the OP into solution, thus increasing the concentration of OP in the outflow. Zones of saturation within the media became possible because the media received substantial amounts of synthetic rainwater each week and the columns were covered to reduce evaporation of the moisture 
from the soil media. Total $\mathrm{P}$ is a measure of organic $\mathrm{P}$ and $\mathrm{OP}$; OP represents the inorganic P. These results indicated that the main source of TP was not organic P.

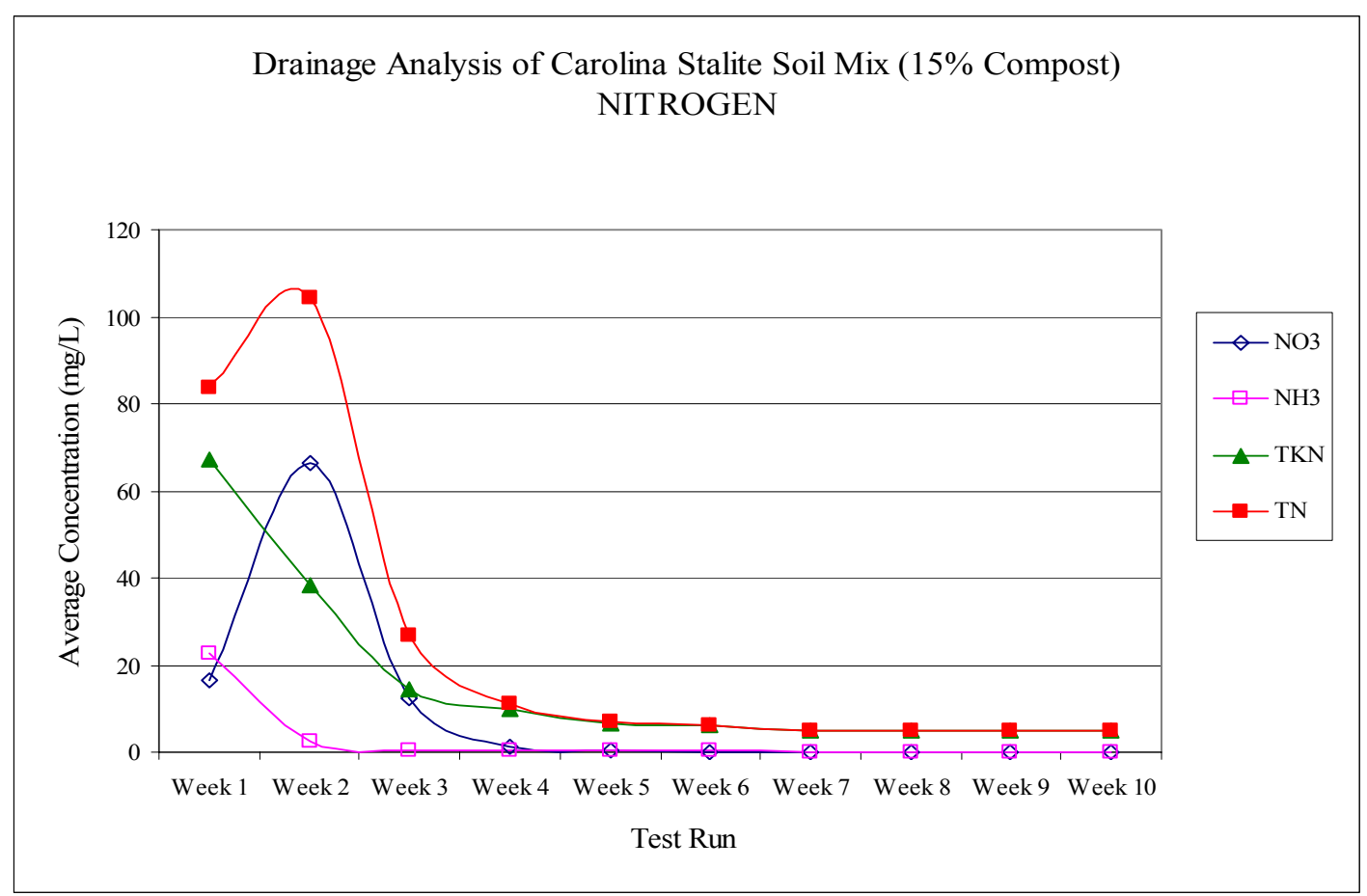

Figure 5-8. Display of Nitrogen Concentrations in Carolina Stalite Soil Mix (15\% Compost).

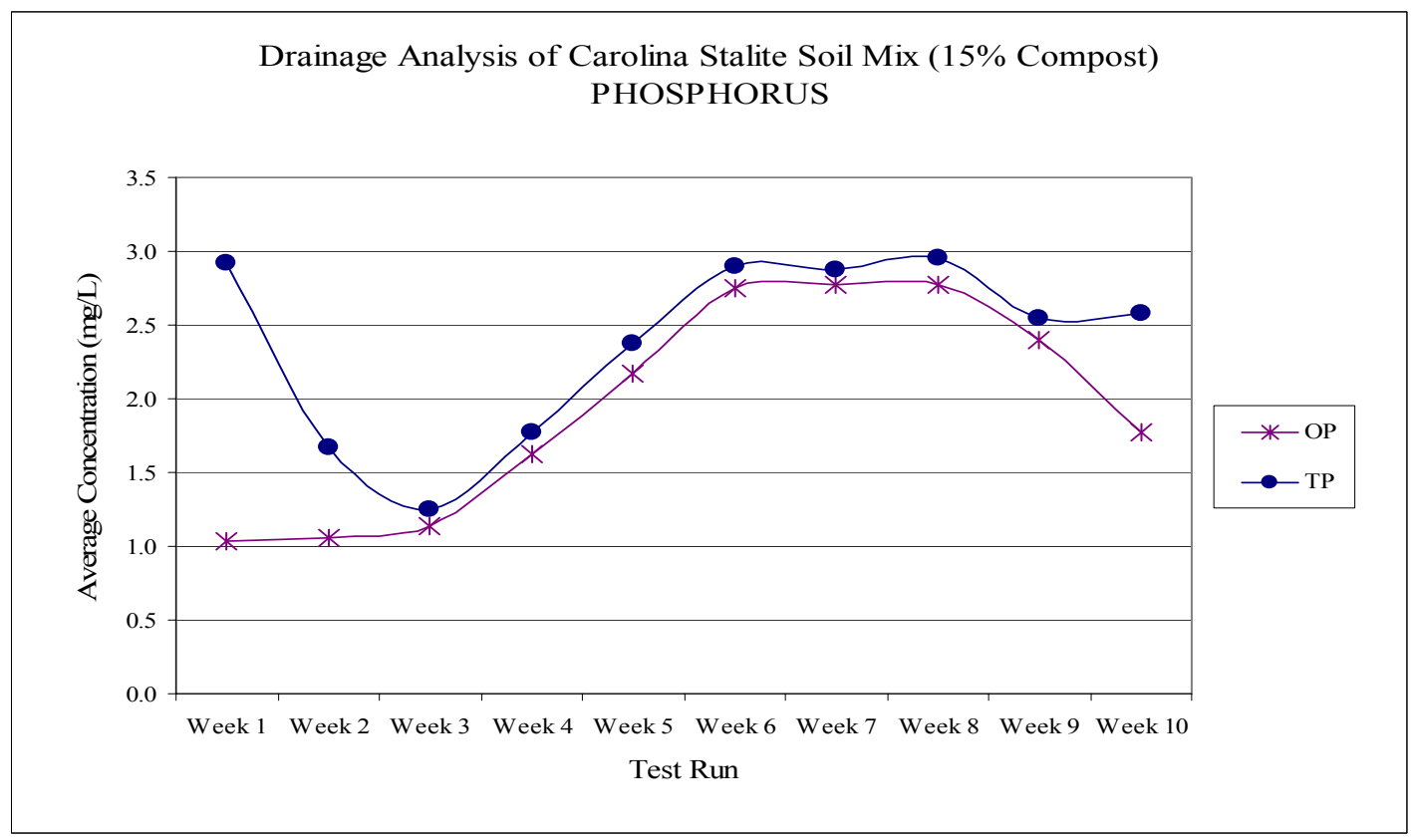

Figure 5-9. Display of Phosphorus Concentrations in Carolina Stalite Soil Mix (15\% Compost). 


\subsubsection{ERTH LIGHT SOIL Mix}

The nitrogen and phosphorus concentrations present in the outflow from the ERTH Light Soil Mix columns are shown in Figure 5-10 and Figure 5-11. The extreme increase in TN concentration in the first two weeks of the study was a result of high concentrations of $\mathrm{NO}_{3}-\mathrm{NO}_{2}$ as $\mathrm{N}$, indicating that the main source was inorganic $\mathrm{N}$. As with the two previous soil media, the concentration of $\mathrm{NH}_{3}$ as $\mathrm{N}$ decreased at Week 2 and then remained negligible throughout the majority of the study; the concentration of $\mathrm{NO}_{3}-\mathrm{NO}_{2}$ increased at Week 2 indicating that $\mathrm{NH}_{3}$ mineralized into $\mathrm{NO}_{3}-\mathrm{NO}_{2}$ through the nitrification process. After Week 5, the concentration of $\mathrm{NO}_{3}-\mathrm{NO}_{2}$ as $\mathrm{N}$ tapered off to a minimum of less than $0.2 \mathrm{mg} / \mathrm{L}$ and the remainder of the $\mathrm{TN}$ concentration was a result of the organic $\mathrm{N}$ present in the media. This same trend was observed in the ERTH HydRocks Soil Mix and the Carolina Stalite Soil Mix. The increasing and then decreasing trend of $\mathrm{NO}_{3}-\mathrm{NO}_{2}$ as $\mathrm{N}$ demonstrates that leaching of inorganic $\mathrm{N}$ had a high effect on the outflow during the first half of the study, but organic $\mathrm{N}$ dominated the TN concentration in the latter half of the study.

The phosphorus concentrations presented in 5-11 also demonstrate that, as with the other two greenroof soil media, the concentrations of TP and OP both generally increased over several weeks during the study. This was because the soil media had microsites that remained saturated for a period of time, thereby, releasing the OP anions from their binding sites to the soil media and into the soil solution. Throughout the majority of the study, inorganic P comprised the majority of the TP concentration. 


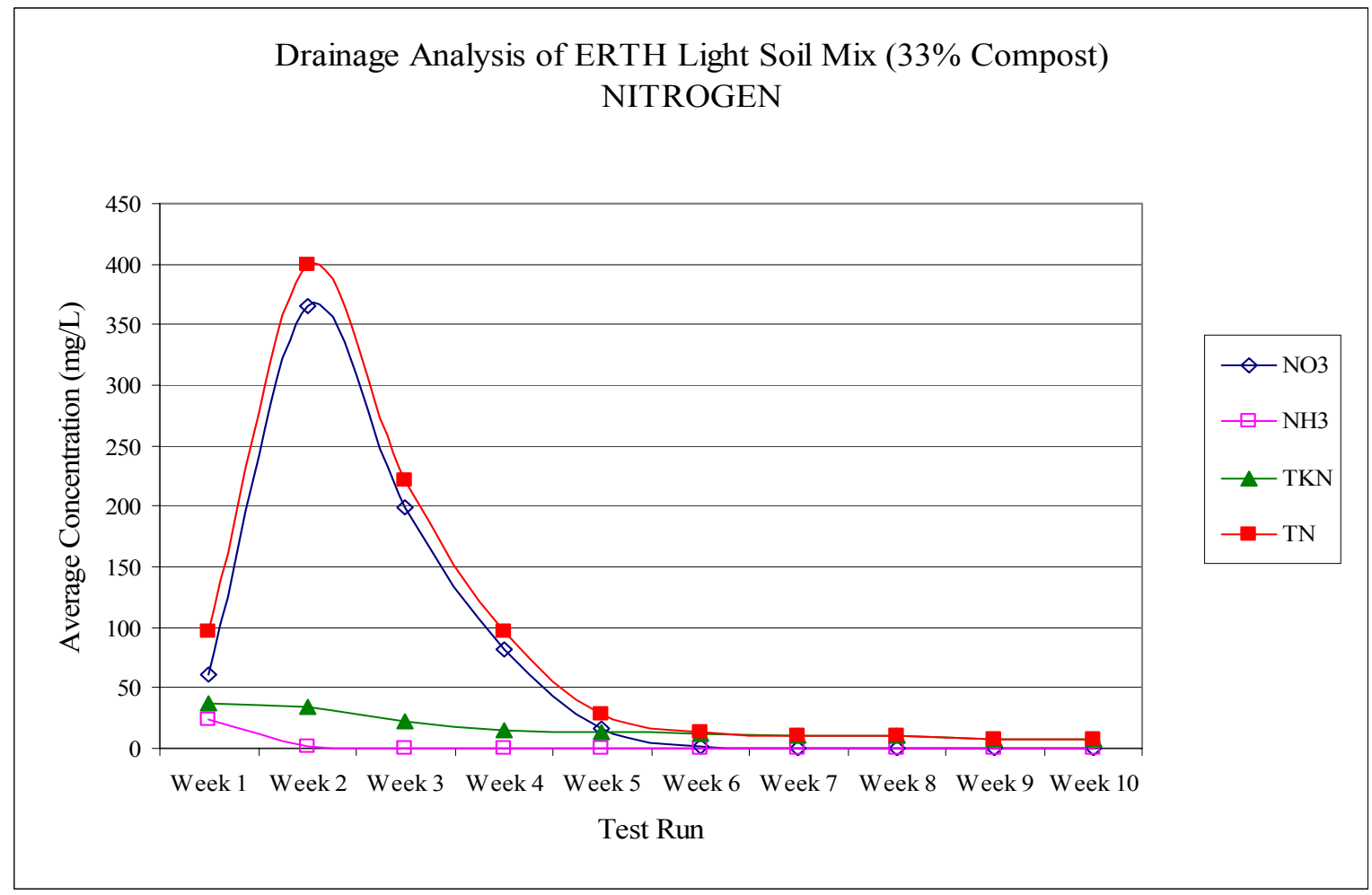

Figure 5-10. Display of Nitrogen Concentrations in ERTH Light Soil Mix (33\% Compost).

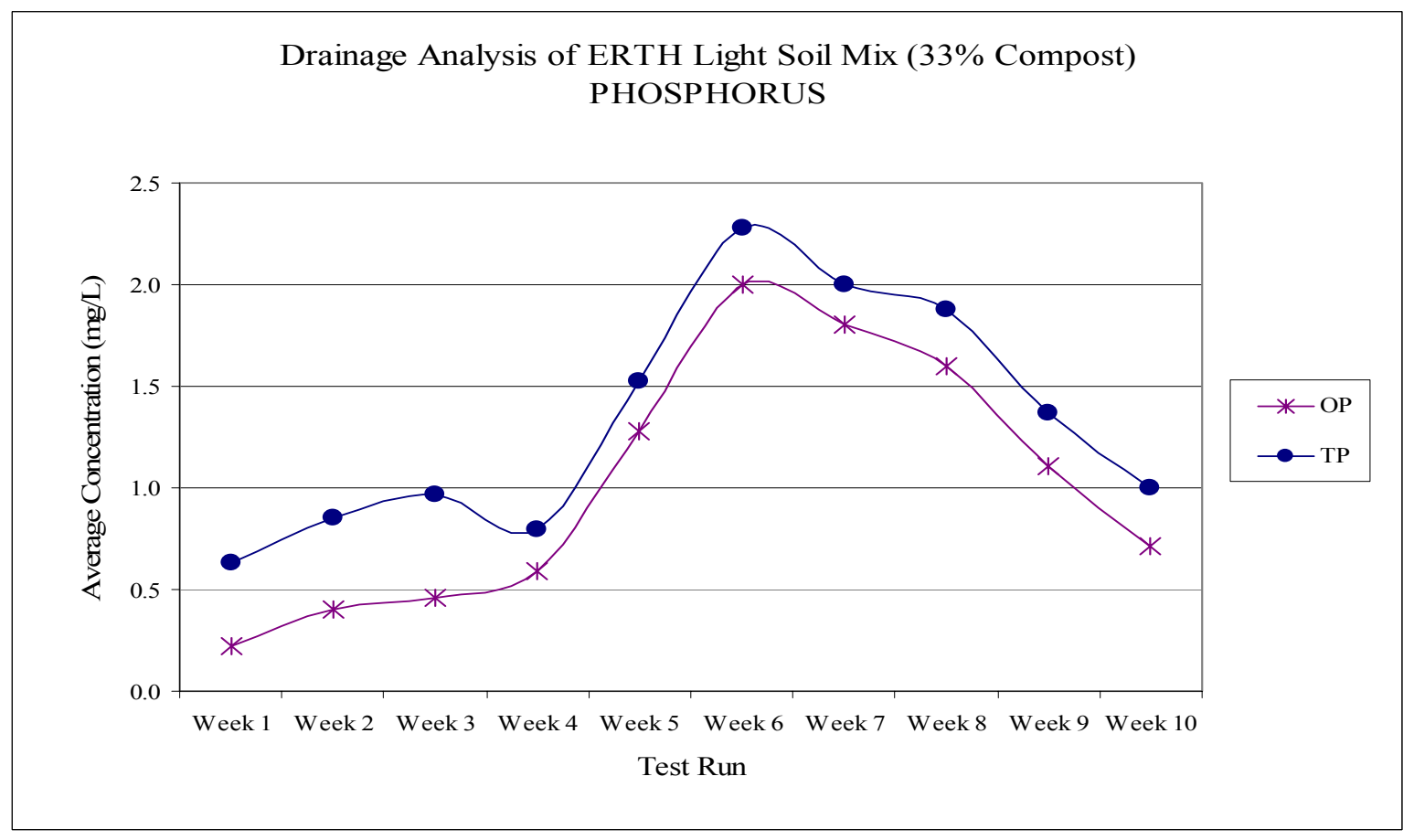

Figure 5-11. Display of Phosphorus Concentrations in ERTH Light Soil Mix (33\% Compost). 


\subsubsection{Play SAND}

The concentrations for the nitrogen species and phosphorus species in the outflow from the Play Sand columns are displayed in Figure 5-12 and Figure 5-13. Small concentrations of $\mathrm{NO}_{3}-\mathrm{NO}_{2}$ as $\mathrm{N}$ and $\mathrm{NH}_{3}$ as $\mathrm{N}$ are present in the outflow from the Play Sand. These small concentrations are almost approximate to the inflow concentrations, thus illustrating that the Play Sand did not have high concentrations of $\mathrm{NO}_{3}-\mathrm{NO}_{2}$ as $\mathrm{N}$ or $\mathrm{NH}_{3}$ as $\mathrm{N}$ present in the media. However, the TKN as $\mathrm{N}$ concentrations were higher than the $\mathrm{NO}_{3}-\mathrm{NO}_{2}$ as $\mathrm{N}$ and the $\mathrm{NH}_{3}$ as $\mathrm{N}$ concentrations; TKN was not an input to the system. This presence of organic matter in the play sand is due to small organic particles present in the media; the Play Sand was not $100 \%$ pure sand. Concentrations of TP and OP were both very low and indicate that negligible amounts of phosphorus were present in the Play Sand; weekly variability was a result of variations of the inflow concentration of OP.

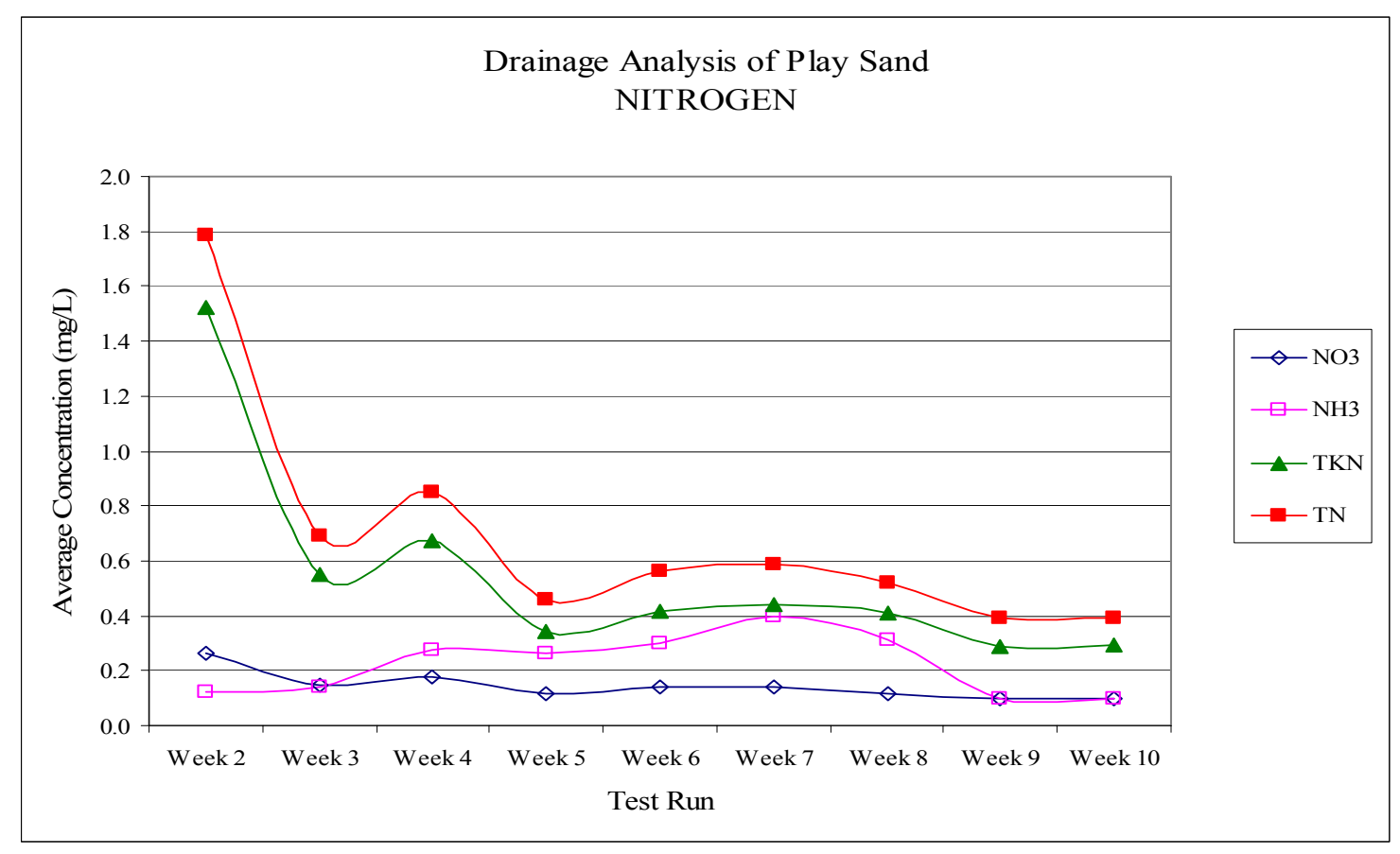

Figure 5-12. Display of Nitrogen Concentrations in Play Sand. 


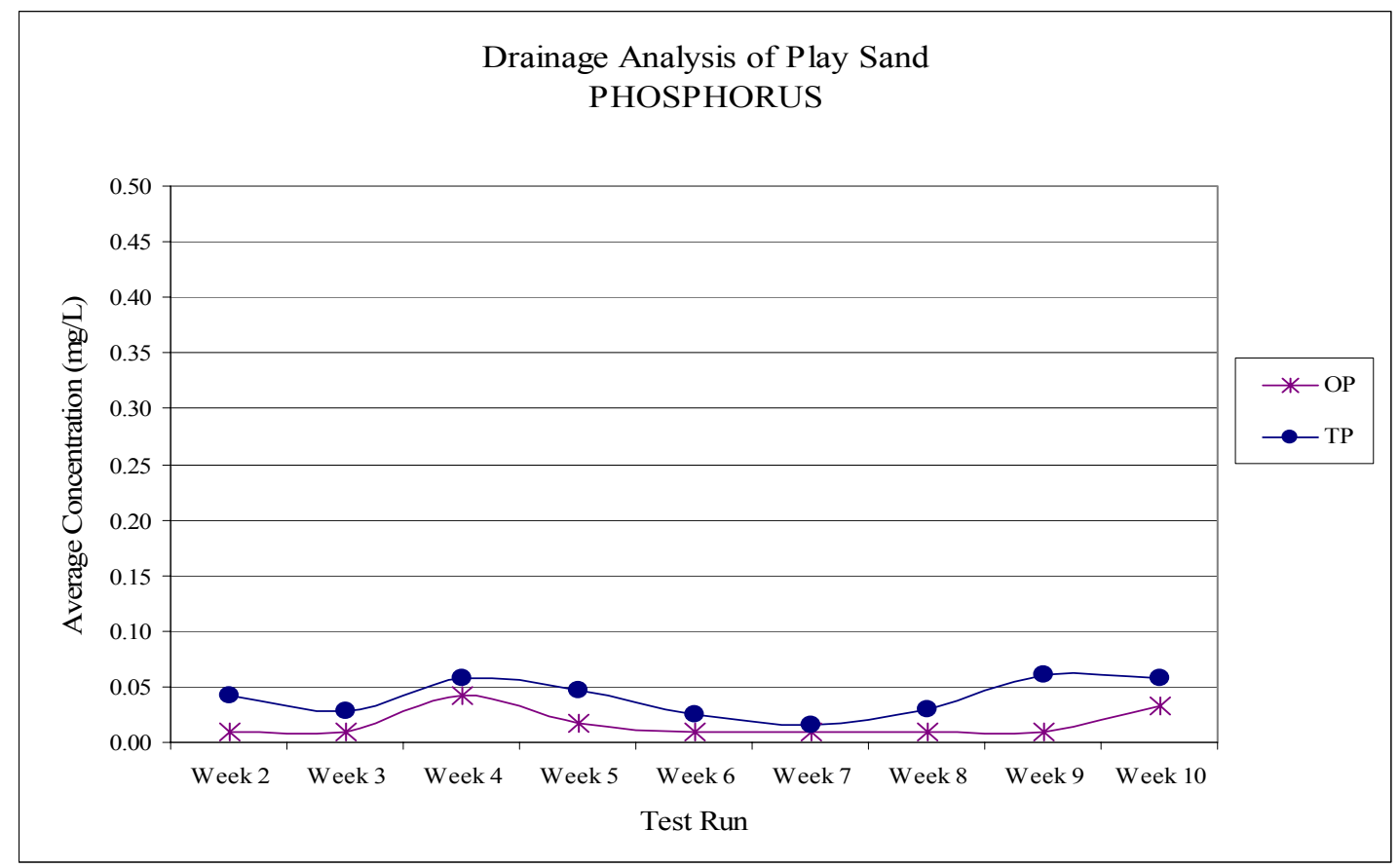

Figure 5-13. Display of Phosphorus Concentrations in Play Sand.

\subsubsection{Total Nitrogen (TN)}

In general, it was observed that, while forms of $\mathrm{N}$ had high concentrations during the first several simulated rainfall events, the $\mathrm{N}$ concentrations of each soil decreased to a constant minimum by the end of the study. Such is seen with the TN concentrations shown in Figure 5-14. Figure 5-15 illustrates the same curves visualized in Figure 5-14 on a smaller scale.

Figure 5-14 and Figure 5-15 demonstrate how outflow concentration of the ERTH HydRocks Soil Mix was very similar to the Play Sand throughout the entire experiment; the ERTH HydRocks Soil Mix had the least amount of organic matter present in the soil media: $5 \%$ compost. Much higher concentrations of TN were present in the outflow of the Carolina 
Stalite Soil Mix than in the HydRocks Soil Mix and the Play Sand. However, while much higher concentrations of TN were observed in the first three weeks, the TN concentrations had reduced to near the same levels as the HydRocks Soil Mix and the Sand in the final four weeks of the study. The Carolina Stalite Soil Mix was composed of 15\% compost. The soil media containing the highest percentage of compost, ERTH Light Soil Mix, clearly had the highest concentrations of TN throughout the 10 week study. Similar to the Carolina Stalite Soil Mix, the ERTH Light Soil Mix had very high concentrations of TN present in the outflow in the first half of the study and the concentrations of TN decreased to a minimum by the conclusion of the study.

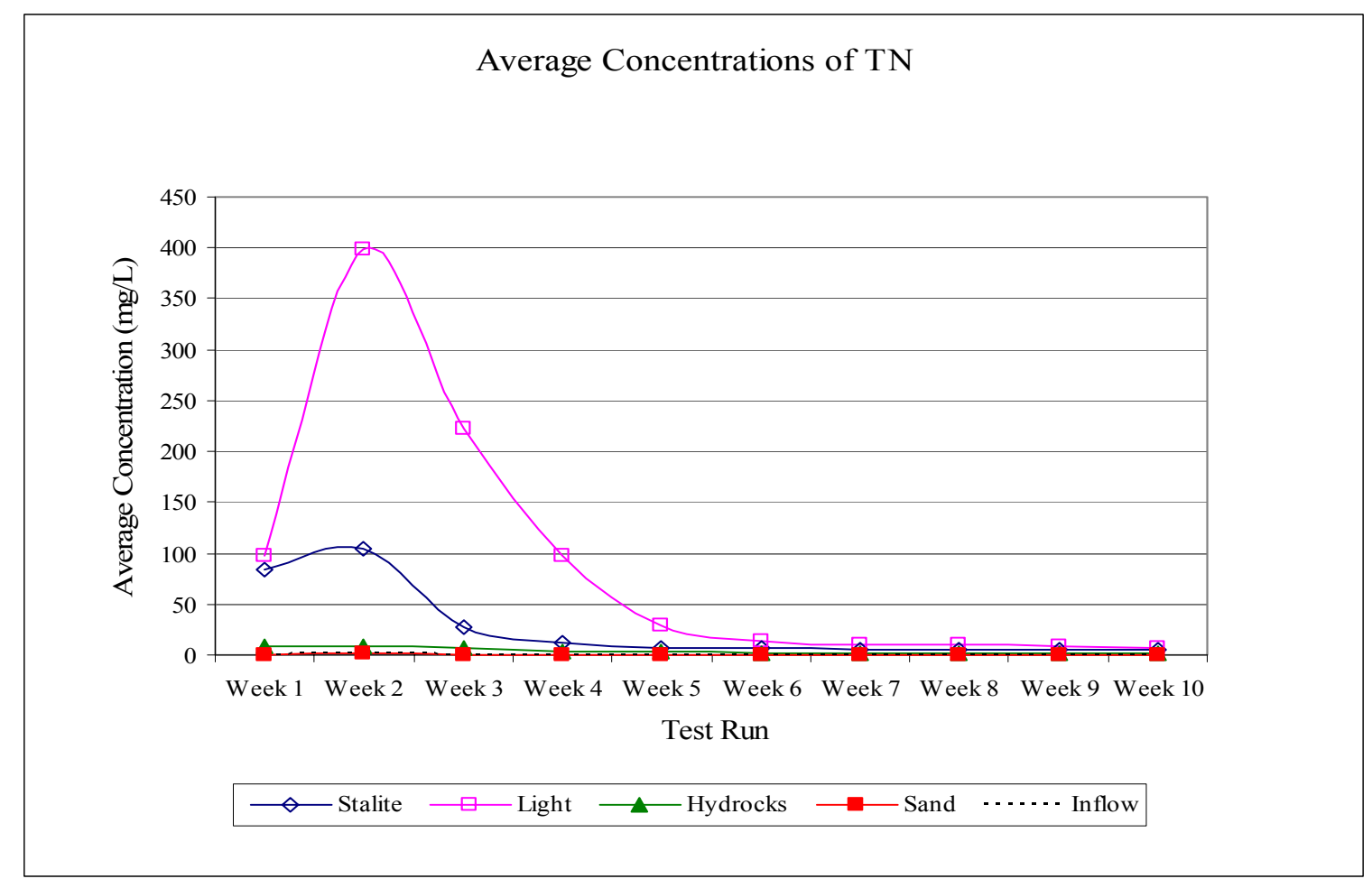

Figure 5-14. Average Concentration of TN for Each Soil Media. 


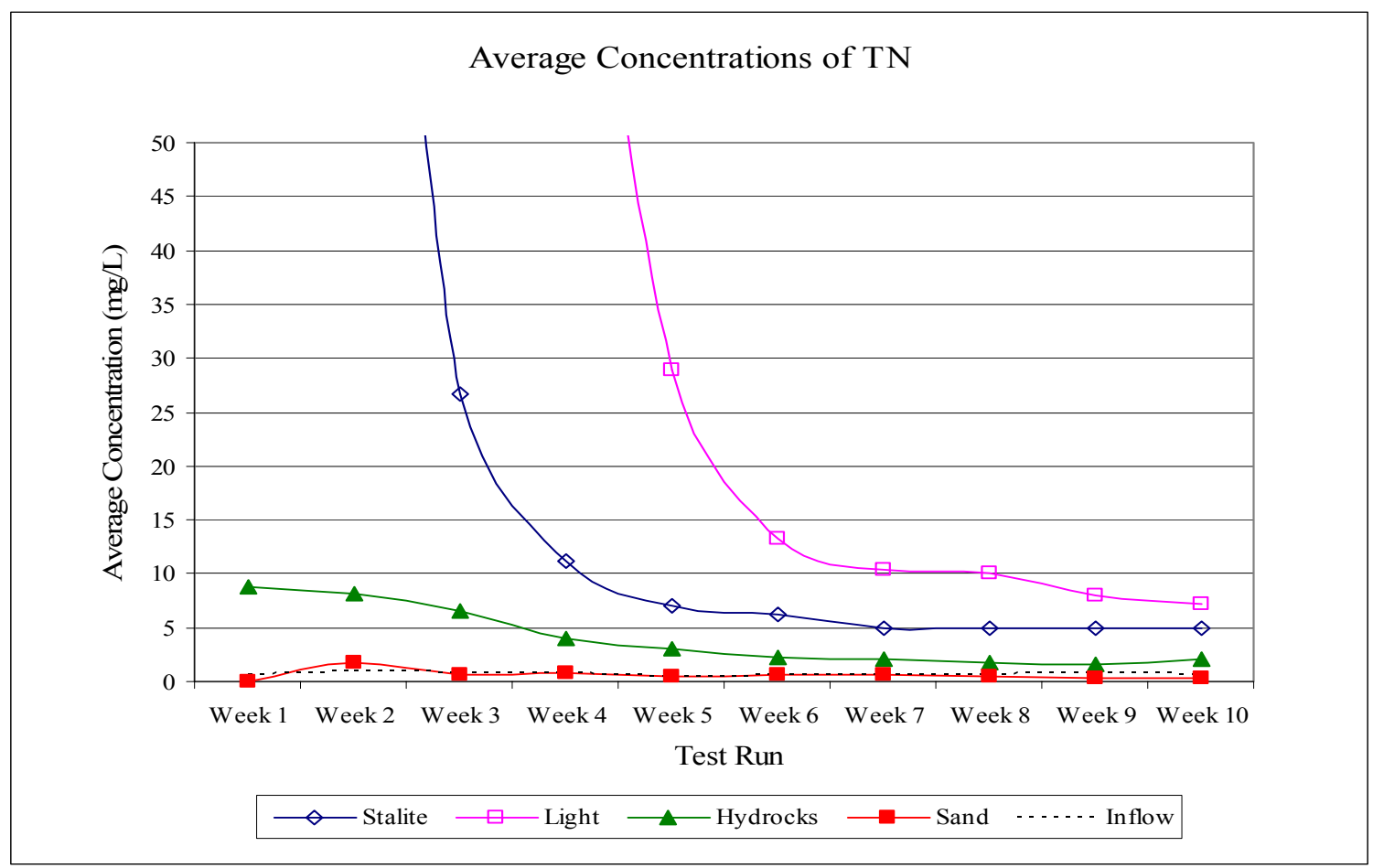

Figure 5-15. Smaller Scale Display of Average TN Concentrations in Each Soil Media.

While the ERTH HydRocks had the least leaching of TN when compared to the other two greenroof soil media, it still had average outflow concentrations of $\mathrm{TN}$ nine to twelve times higher than the inflow concentration of TN, as shown in Figure 5-15. This illustrated that while the ERTH HydRocks may have leached less TN than the other greenroof soil media, it did leach nutrients from within the media.

Analysis of the statistical data of the TN concentrations present in the outflow reveals that on average, over the ten week period, there was no statistically significant difference between any of the four media. When analyzing the four media averaged together, the concentrations of TN present in the outflow were all significantly higher in the first four weeks than the concentration of TN present in the final week of the study $(\alpha<0.05)$. There 
was no significant difference between the outflow of the last six weeks and the final week of the study. This is a clear demonstration of the leaching effect of TN. Higher concentrations of TN present in the outflow during the first several simulated rainfall events decreased to a minimum by the end of the study. The same trend was observed in all four media; the ERTH HydRocks Soil Mix and the Play Sand more closely followed the same trend than any other media combination.

An obvious trend is also visible in Figure 5-14; higher concentrations of TN are present in soil media with more compost in the soil composition. Concentrations of TN in the outflow of the ERTH Light Soil Mix with 33\% compost in the composition has the highest concentrations of TN present, followed by Carolina Statlite Soil Mix composed of 15\% compost and ERTH HydRocks Soil Mix composed of 5\% compost. The average minimum of the ERTH HydRocks Soil Mix, ERTH Light Soil Mix, Carolina Stalite Soil Mix, and the Play Sand was $2 \mathrm{mg} / \mathrm{L}, 7 \mathrm{mg} / \mathrm{L}, 5 \mathrm{mg} / \mathrm{L}$, and $0.5 \mathrm{mg} / \mathrm{L}$, respectively.

\subsubsection{TOTAL Phosphorus (TP)}

The decreasing trends observed in the $\mathrm{TN}$ concentrations were not observed in the phosphorus data, chiefly because phosphorus and nitrogen behave differently in soils. Figure 5-16 displays the average concentrations of TP present in the outflow of each soil media.

Figure 5-16 shows that, in general, Carolina Stalite Soil Mix had the highest concentrations of TP in the outflow, followed by ERTH Light Soil Mix and ERTH HydRocks Soil Mix. While the Carolina Stalite Soil Mix had the smallest phosphorus index (P-I) of the three greenroof media (See Table 5-2), it also had the greatest percentage of sand 
and smallest percentage of fine soil in the composition (See Table 5-4). Because this soil media had the least amount of clay and silt in the media composition, there were fewer binding sites for the $\mathrm{P}$, therefore, the $\mathrm{P}$ could easily leach into the soil solution and drain from the column. However, because the P-I of the ERTH Light Soil Mix was more than twice as high as the P-I for the ERTH HydRocks Soil Mix (See Table 5-2), the ERTH Light Soil Mix leached more P than the ERTH HydRocks Soil Mix, even though the ERTH Light Soil Mix had a greater percentage of fine soils in the composition (See Table 5-4). The only trend visible is that the soil media with the smallest proportion of compost in the soil mix has the lowest average concentrations of TP present in the outflow.

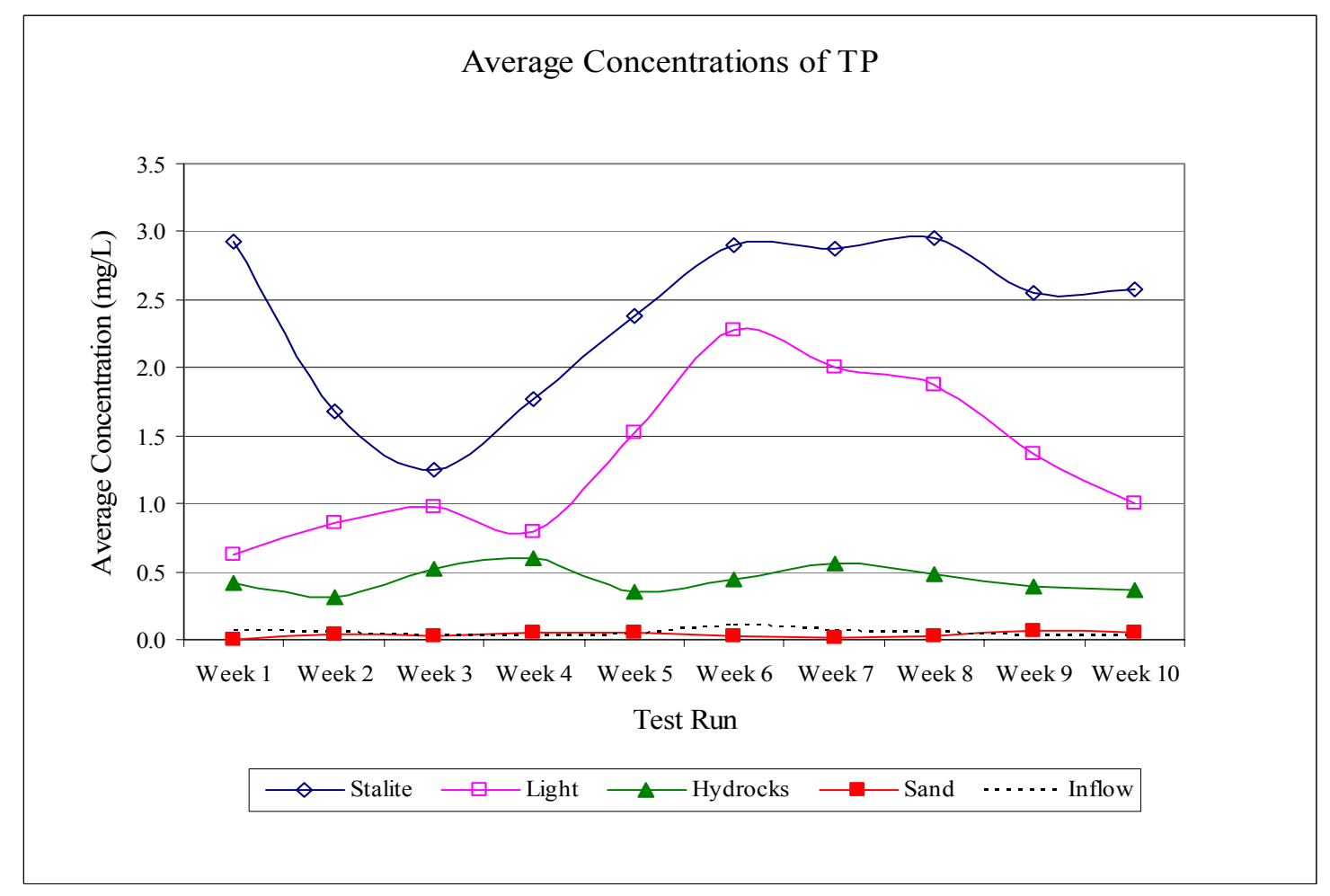

Figure 5-16. Average Concentrations of TP for Each Soil Media.

There is, however, a general increasing trend during Week 3 through Week 6 of TP present in the outflow of the Carolina Stalite Soil Mix and in the ERTH Light Soil Mix. This 
was a result of the phosphorus becoming reduced through partial saturation of the media and OP being released into the soil solution.

\subsection{LABORATORY STUDY DISCUSSION}

The results of this soil media laboratory study indicate that concentrations of TN were significantly higher in the first simulated rainfall events than in the final simulated rainfall events of the study $(\alpha<0.05)$; one $38 \mathrm{~mm}(1.5 \mathrm{in}$.) rain event was simulated each week for 10 consecutive weeks. It was evident that the concentrations of TN were decreasing with time for each soil media. Decreasing trends of TKN as $\mathrm{N}$ concentrations were also observed for each greenroof soil media. Because TKN as $\mathrm{N}$ is the sum of the $\mathrm{NH}_{3}$ as $\mathrm{N}$ concentration and the organic $\mathrm{N}$ concentration in the outflow, the decreasing trend of TKN as $\mathrm{N}$ indicates that organic $\mathrm{N}$ does leach from the soil over time. However, the most significant contributor to the $\mathrm{TN}$ concentrations was the concentrations of $\mathrm{NO}_{3}-\mathrm{NO}_{2}$ as $\mathrm{N}$ in the outflow; these curves most closely resembled the TN curves. This trend showed that inorganic $\mathrm{N}$ already present in the soil mixture made a larger contribution to the TN outflow than organic $\mathrm{N}$ present in the soil mix.

While the concentration of $\mathrm{NO}_{3}-\mathrm{NO}_{2}$ as $\mathrm{N}$ did decrease to a constant minimum by the conclusion of the study, concentrations of $\mathrm{NO}_{3}-\mathrm{NO}_{2}$ as $\mathrm{N}$ in the Carolina Stalite Soil Mix outflow and the ERTH Light Soil Mix were many times higher than the inflow concentration in the first several weeks of the study. This indicates that leaching of $\mathrm{NO}_{3}-\mathrm{NO}_{2}$ as $\mathrm{N}$ could be reduced if the amounts of $\mathrm{NO}_{3}-\mathrm{NO}_{2}$ as $\mathrm{N}$ originally present in the soil media were reduced. Decreases in $\mathrm{NH}_{3}$ as $\mathrm{N}$ concentrations and increases in $\mathrm{NO}_{3}-\mathrm{NO}_{2}$ as $\mathrm{N}$ 
concentrations in Week 2 also indicated that the $\mathrm{NH}_{3}$ as $\mathrm{N}$ was mineralizing into $\mathrm{NO}_{3}-\mathrm{NO}_{2}$ as $\mathrm{N}$ through the nitrification process. However, due to the rapid decrease in $\mathrm{NO}_{3}-\mathrm{NO}_{2}$ as $\mathrm{N}$ concentrations over the first several weeks of the study, this may indicate that $\mathrm{NO}_{3}-\mathrm{NO}_{2}$ as $\mathrm{N}$ concentrations may not be a point of concern after the greenroof is established.

A distinctive trend was visible in each of the three greenroof soil media: an increase of OP and TP was observed during at least three consecutive weeks during the study. In most cases, the OP concentration comprised the majority of the TP concentrations, indicating that the organic P present did not have a noteworthy effect on the concentration of TP present in the outflow. This may be a result of reduction of phosphorus occurring due to saturated soil microsites between each application of synthetic rainwater. Throughout the study, it was observed that the soil media remained fairly moist throughout each week, indicating that not all of the applied synthetic rainwater was draining from the media columns; this also suggested that saturated zones within the media may have occurred.

To provide a brief background on the behavior of $\mathrm{P}$ in soils, soil $\mathrm{P}$ exists in three major forms: organic P, fixed mineral P, and orthophosphate (OP) (Vepraskas and Faulkner, 2001). TP is the sum of all forms of $P$ in the solution. Ortho $P$ exists as an anion in the form of $\mathrm{H}_{2} \mathrm{PO}_{4}{ }^{2-}, \mathrm{HPO}_{4}{ }^{1-}$, and $\mathrm{PO}_{4}{ }^{3-}$, depending on the $\mathrm{pH}$. Fixed mineral $\mathrm{P}$ is $\mathrm{OP}$ bound to an oxide or hydroxide containing Aluminum (Al) or Iron $\left(\mathrm{Fe}^{3+}\right)$, or bound to cations, Calcium (Ca) or Magnesium (Mg) (Vepraskas and Faulkner, 2001). Organic P includes organic forms of $\mathrm{P}$ found in plants as well as partially decomposed plant tissue within the soil; organic P can also include OP anions that are bound to organic compounds (Vepraskas and 
Faulkner, 2001). OP binds to organic compounds by cation bridging, the OP binds to a cation and the cation binds to the organic compounds, similar to fixed mineral P.

Many forms of $\mathrm{P}$, such as fixed mineral $\mathrm{P}$ and $\mathrm{P}$ bound to organic compounds through cation bridging, are soluble at certain $\mathrm{pHs}$. These forms of $\mathrm{P}$ can also become soluble if the soil is saturated. With saturated soil, the bound P becomes soluble and then OP anions are released into the soil solution. This is what may have happened to the greenroof soil media in the columns. With the soils remaining partially saturated between synthetic rainwater applications, the OP within the soil media would become released into the soil solution and then drain out from the soil media column. This is evident because the OP concentrations are so close to the TP concentrations, the major form of TP is the OP.

While it is apparent that the three different greenroof soil media had saturated microsites during this column study, this would not typically occur in the field. Evapotranspiration was minimized for this experiment; this is not an appropriate assumption to make for field work. In the field, evapotranspiration would be constantly working to release moisture in the soil media to the atmosphere. The soil media columns had the potential to remain partially saturated for a full week; these conditions are unlikely in the field, except for possible locations that would have enough precipitation to saturate the soil with negligible evapotranspiration rates. In addition, the media in the laboratory study was constricted in a column; soil media in the field atop a greenroof would drain easier through vertical and lateral drainage. Therefore, the phosphorus trends observed in this study are not likely to be seen in the field. 
Of the three different greenroof soil media, the Carolina Stalite Soil Mix had the closest OP and TP relationship. The Carolina Stalite Soil Mix also retained the largest percentage of water when compared to the ERTH HydRocks Soil Mix and the ERTH Light Soil Mix; this probably illustrates the effect of soil saturation on P solubility. The Carolina Stalite Soil Mix retained approximately $27 \%$ of the total amount of synthetic rainwater applied; the ERTH HydRocks Soil Mix retained approximately $17 \%$ of the total amount of synthetic rainwater applied; and the ERTH Light Soil Mix retained approximately $25 \%$ of the synthetic rainwater applied. This was the total percentage of synthetic rainwater retained within the soil media at the culmination of the laboratory study.

The leaching effects of TP could also considerably be reduced if the soil test phosphorus (STP) of the greenroof media was reduced. Currently, the STP of the Carolina Stalite Soil Mix, the ERTH Light Soil Mix, and the ERTH HydRocks Soil Mix is 87, 496, and 255. The minimum STP required by the NCDA for plant nutrition is 50 (Hardy et al., 2003a). This is a clear indication that, especially in the ERTH Light Soil Mix and the ERTH HydRocks Soil Mix, that there is much more $\mathrm{P}$ initially present in the soil media than what is required to sustain plant growth. 


\subsection{PLANT SURVIVAL AND GROWTH STUDY}

\subsection{Plant Survival}

The purpose of this study was to determine what extensive greenroof vegetation survives in the eastern North Carolina climate region. The results of this study were also important to specify which plant species were not optimal for extensive greenroof construction in eastern North Carolina. Currently, with no greenroof design standards in North Carolina, developers do not know what vegetation to select for greenroof construction. Extensive greenroof plants must have the following characteristics: shallow root systems, resistance to direct radiation, drought resistance, frost resistance, wind resistance, and they should be regenerative (American Hydrotech, Inc., 1997). The results of this study will provide a list of plant species ideal for extensive greenroof construction in central and eastern North Carolina.

\subsubsection{FIELD SITES}

Both greenroof research sites were used in determining the plant species survival rate. During construction of the WCC Greenroof in Goldsboro, NC, each vegetation species was planted in different square plots across the entire surface area of the greenroof. This planting design aided in determining the survival rates because each plant species could be easily distinguishable. Vegetation planted at the Neuseway Nature Center Greenroof in Kinston, NC was not planted in different sections for each species, therefore, plant survival of

different species was slightly more difficult to determine because all plant species were mixed together during planting. 


\subsubsection{Plant Species}

A total of eleven different plant species were planted at the WCC Greenroof in Goldsboro, NC. As the surface area of the Neuseway Nature Center Greenroof is approximately $60 \%$ smaller than the WCC Greenroof, only five different plant species were planted at the Nature Center Greenroof.

Below is the list of plant species planted at the WCC Greenroof:

- Delosperma cooperi

- Delosperma nubigenum

- Sedum acre

- Sedum album

- Sedum album murale
- Sedum album chloroticum

- Sedum grisebachii

- Sedum reflexum

- Sedum sexangulare

- Sedum spurium fuldaglut

Below is the list of plant species planted at the Neuseway Nature Center Greenroof:

- Sedum album

- Sedum album murale

- Sedum floriferum
- Sedum reflexum

- Sedum sexangulare

The survival rate of eleven different species was evaluated. All the vegetation species planted at the Neuseway Nature Center Greenroof were the same as planted at the WCC Greenroof except for one species, Sedum floriferum. Therefore, four different plant species were evaluated at both greenroof sites; six plant species were evaluated specifically at the WCC Greenroof; one plant species was evaluated only at the Neuseway Nature Center Greenroof. Figure 6-1 through Figure 6-5 present photographs of ten of the eleven different plant species. 

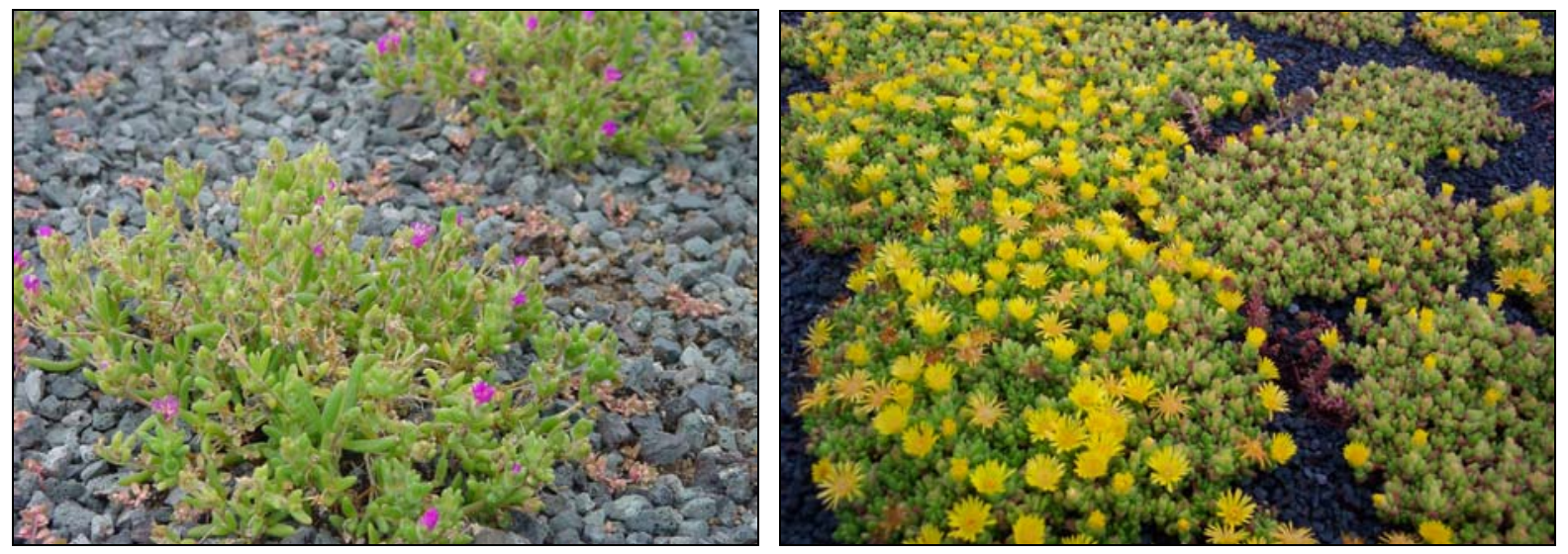

Figure 6-1. Delosperma cooperi in bloom (left) and Delosperma nubigenum in bloom (right).
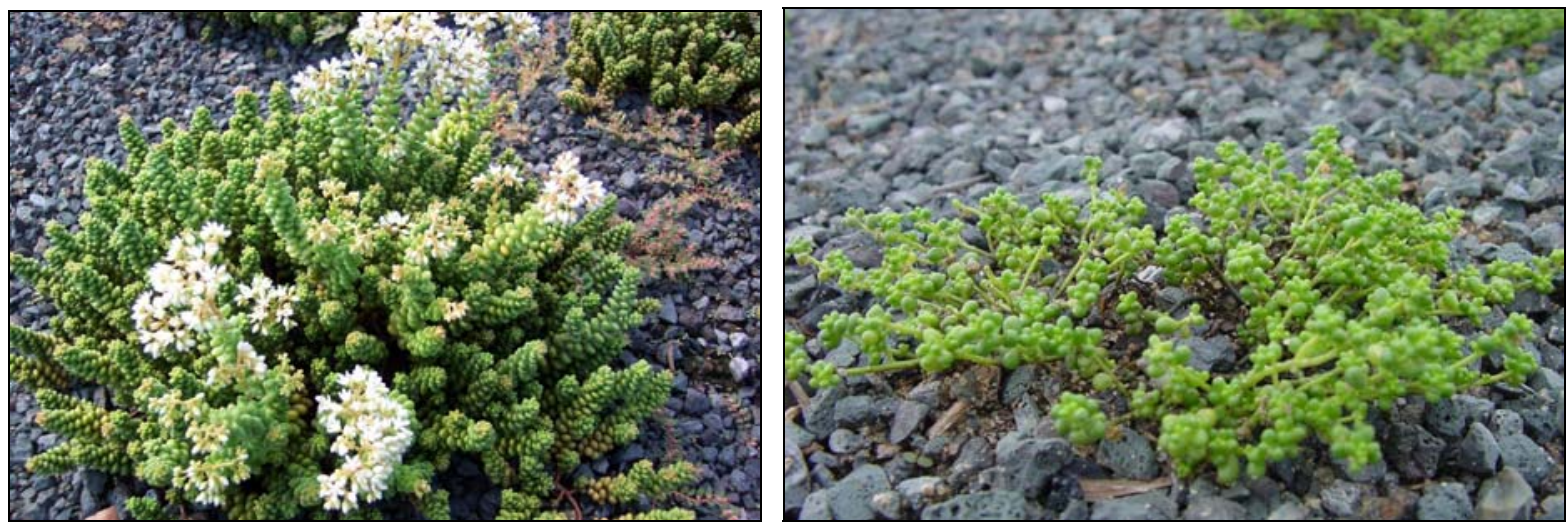

Figure 6-2. Sedum album in bloom (left) and Sedum album chloroticum (right).
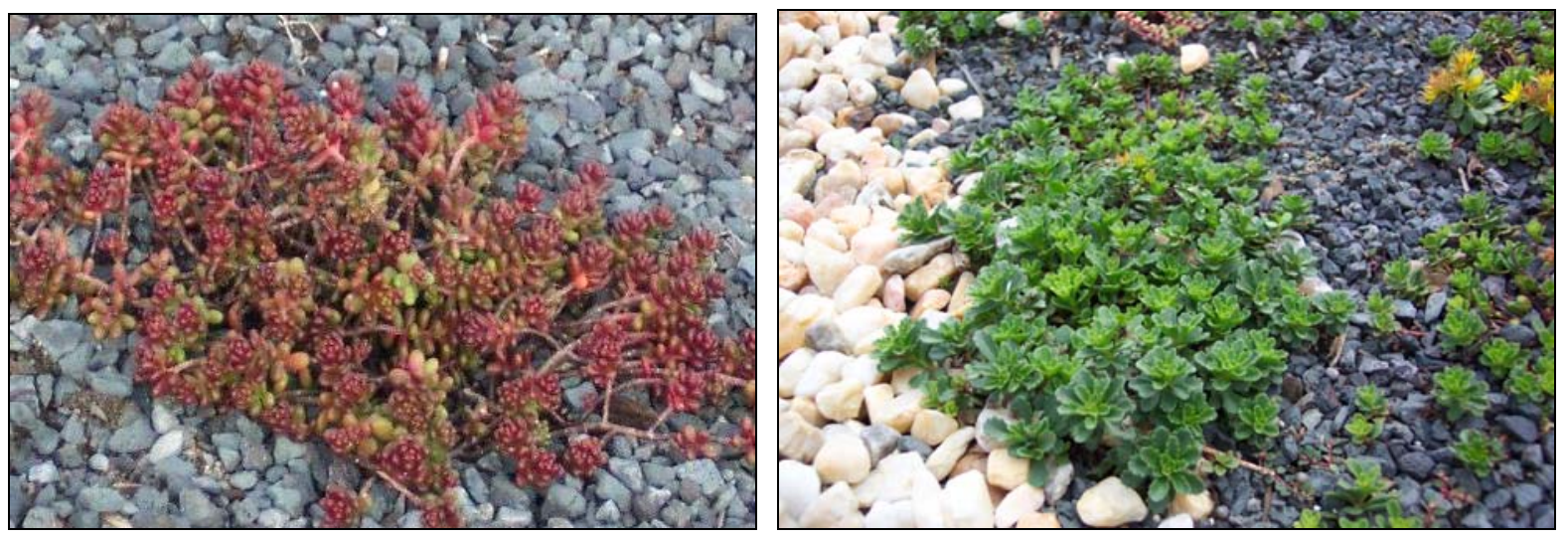

Figure 6-3. Sedum album murale (left) and Sedum floriferum (right). 

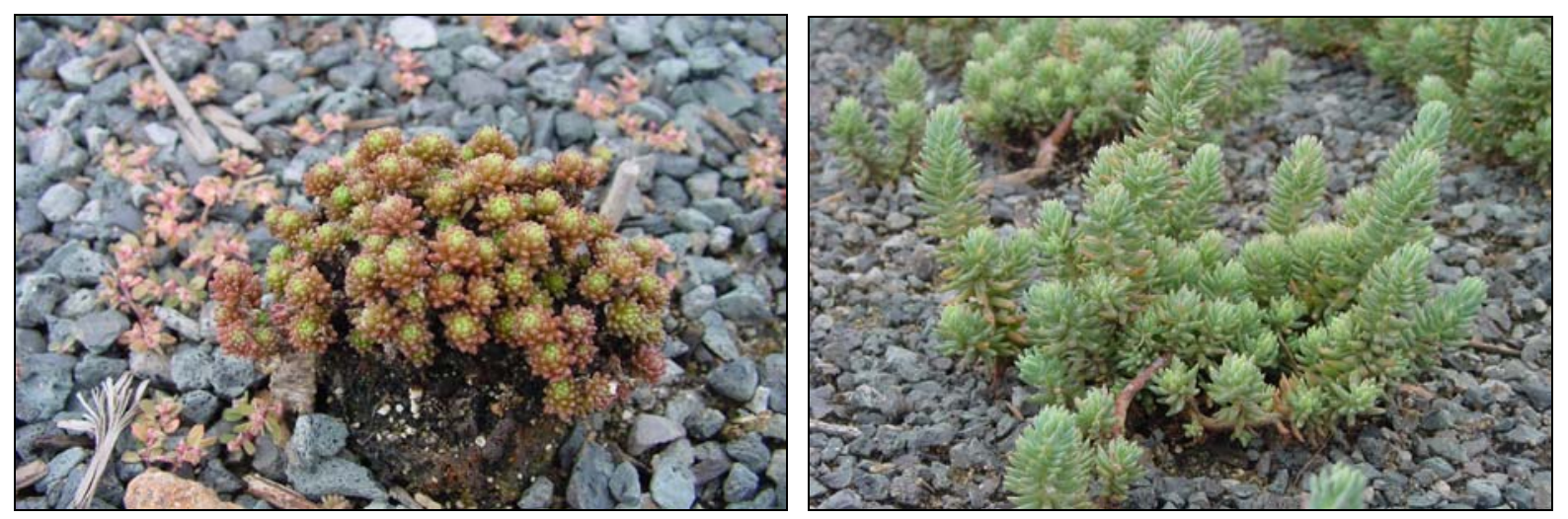

Figure 6-4. Sedum grisebachii (left) and Sedum reflexum (right)
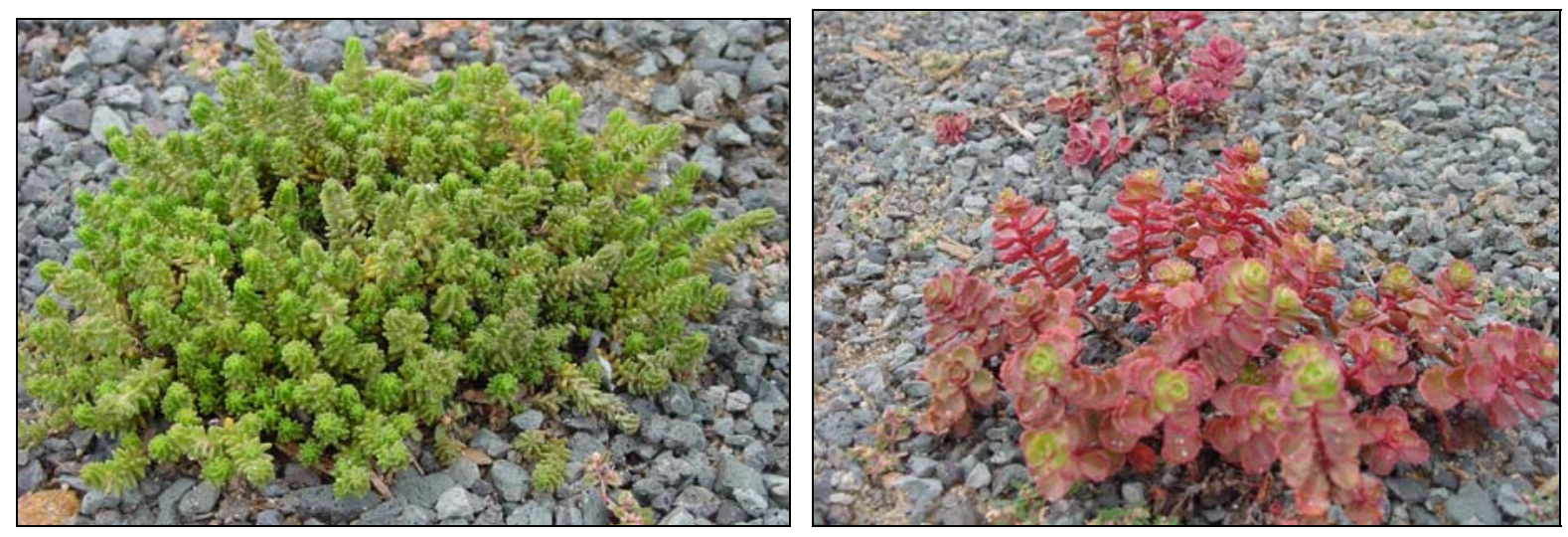

Figure 6-5. Sedum sexangulare (left) and Sedum spurium fuldaglut (right).

\subsubsection{Plant Species Survival and Plant Selection Recommendations}

The object of this study was to determine which vegetation species survive in the eastern and central North Carolina climate. Therefore, a comparison was not made to determine which species grow faster than others. The twelve different plant species were recommended and selected by Ed Snodgrass, President and CEO of Emory Knoll Farms; the plant species were purchased from Emory Knoll Farms. The majority of the plants did survive the North 
Carolina climate; however, several species did not survive or are not recommended for use in eastern or central North Carolina.

The following plants are not recommended for use in extensive greenroof implementation in central and eastern North Carolina. These plant species are not recommended because they either did not survive or because they did not establish well enough on the greenroof to support further growth.

- Delosperma cooperi

- Sedum acre
- Sedum album chloroticum

- Sedum grisebachii

The following plants are recommended for use in extensive greenroof implementation in central and eastern North Carolina. These plants are recommended because they established quickly in the greenroof soil media and had much higher growth rates than the four plant species that are not recommended for use in North Carolina.

- Delosperma nubigenum

- Sedum album

- Sedum album murale

- Sedum floriferum
- Sedum reflexum

- Sedum sexangulare

- Sedum spurium fuldaglut

\subsection{Plant Growth Study}

The purpose of this study was to determine if there was a significant difference between greenroof plant growth in $50 \mathrm{~mm}(2$ in.) and $100 \mathrm{~mm}$ (4 in.) soil media depths. The goal of any greenroof is to establish plant coverage over the soil media as soon as possible. The sooner vegetation is established on a greenroof, the less soil media will be lost through wind 
erosion and the sooner evapotranspiration rates can increase through the vegetation's uptake of moisture through the soil media. In North Carolina, there are currently no design standards for greenroof construction; this study was developed to advise developers on what soil media depth would provide a higher growth rate within the first year. It is hypothesized that the percent coverage of vegetation in the $102 \mathrm{~mm}$ (4 in.) deep soil media will be significantly higher than the percent coverage of vegetation in the $51 \mathrm{~mm}(2 \mathrm{in}$.) soil media.

\subsubsection{FIELD SiTE}

Plant coverage was measured at the WCC Greenroof in Goldsboro, NC. At this greenroof, the different plant species were planted in separate sections and each plant species could be easily measured. At the Neuseway Nature Center Greenroof in Kinston, NC, the different plant species were all mixed together; therefore, this was not an ideal location to measure growth rates of different plant species.

\subsubsection{Soil Depth Variation and Plant Species}

The soil media depth at the WCC Greenroof was divided into two different depths. One block section of the greenroof had a soil media depth of $51 \mathrm{~mm}(2 \mathrm{in}$.) and another section of the greenroof had a $102 \mathrm{~mm}$ (4 in.) soil media depth. The same plant species were planted in each block section. Each block section was subdivided into four different sections and the

same three species were planted in each block section. The three plant species planted in each block section were Delosperma nubigenum, Sedum album, and Sedum reflexum. Figure 
6-6 and Figure 6-7 display each block section of the roof. The average plant spacing is 305 $\mathrm{mm}(12$ in.).

\subsubsection{Data Measurement and Data Collection}

The percent coverage of each plant species was measured after one full year of growth. The greenroof was constructed and planted in May 2002; therefore, the growth measurement was recorded in May 2003. The growth measurement was the percent coverage of the plant in the planar view, or the spread of each plant across the soil media of the roof. Growth was measured in percent coverage because (1) the goal of greenroof establishment is to establish quick vegetation cover to reduce soil erosion through wind loss, therefore, vertical growth of the vegetation was not an important factor and (2) the majority of extensive greenroof vegetation grows close to the ground, only $51 \mathrm{~mm}$ ( 2 in.) to $152 \mathrm{~mm}$ (6 in.) high.

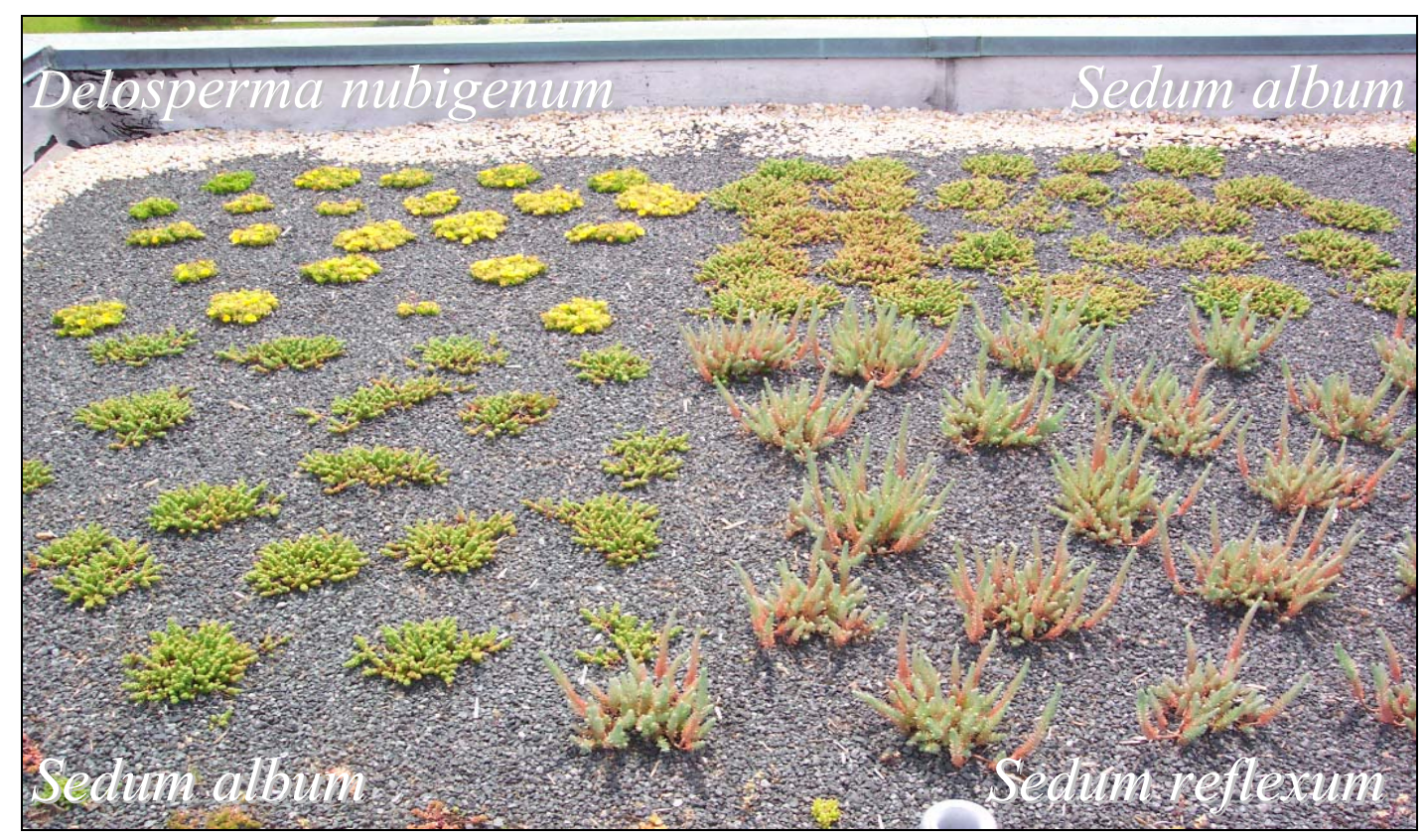

Figure 6-6. Display of $50 \mathrm{~mm}$ (2 in.) Soil Media Depth Block Section. 


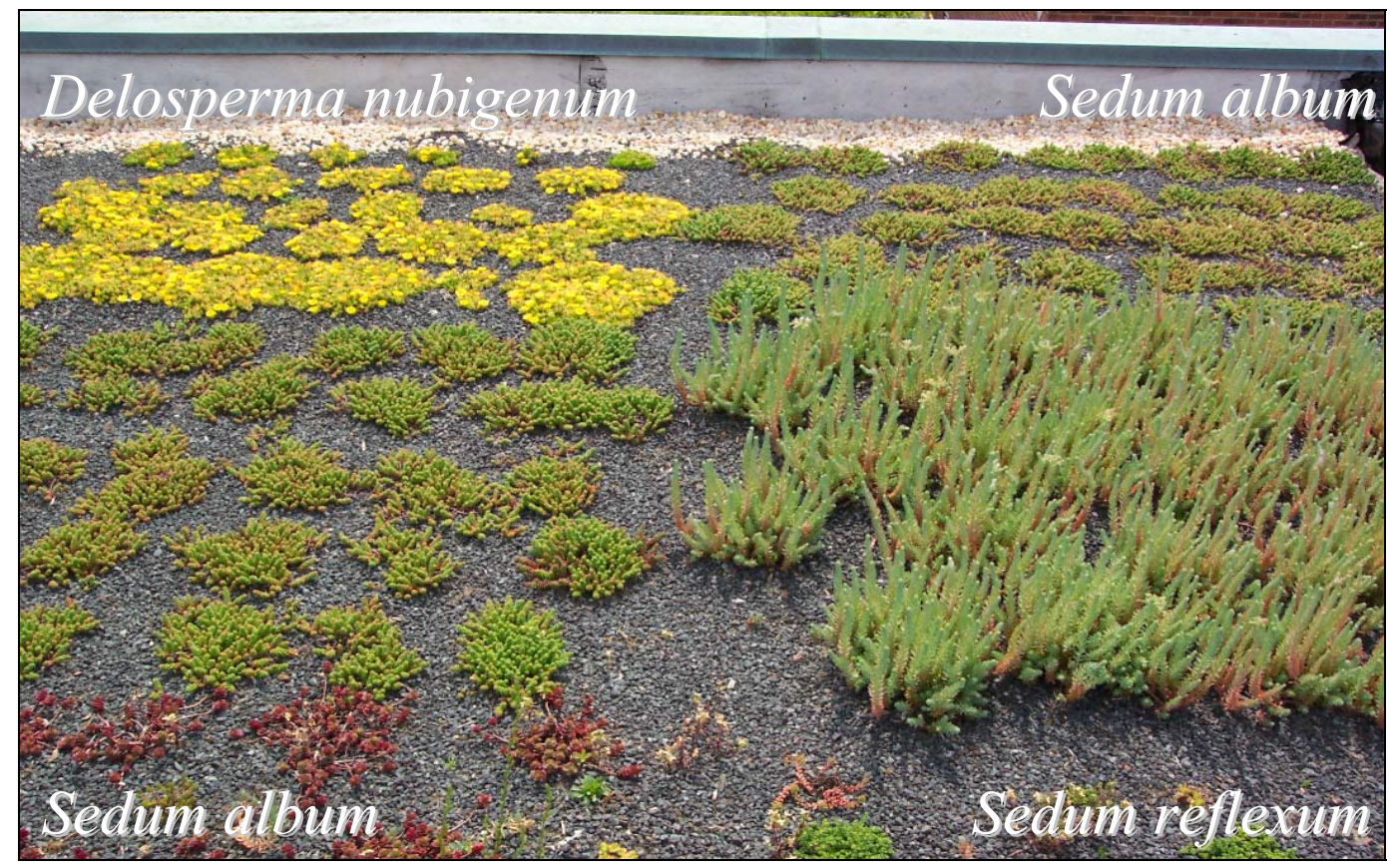

Figure 6-7. Display of 100 mm (4 in.) Soil Media Depth Block Section.

The percent coverage was measured for each plant species in each block section on the same afternoon. A circular hoop approximately $406 \mathrm{~mm}$ (16 in.) in diameter was randomly tossed onto each plant species section and a percent coverage estimate of the plant species within the hoop was made by three different observers. The observers did not express opinions of the percent coverage; therefore, all observers' measurements were independent. After the first measurement was recorded by each observer, the circular hoop was randomly tossed again and a second percent coverage estimate was made by each observer. The second random toss of the circular hoop accounted for variations of percent coverage within the same block section. This process was repeated for the Sedum album in the $51 \mathrm{~mm}$ (2 in.) soil media, the Delosperma nubigenum in the $51 \mathrm{~mm}(2 \mathrm{in}$.) soil media, the Sedum reflexum in the $51 \mathrm{~mm}$ (2 in.) soil media, the Sedum album in the $102 \mathrm{~mm}$ (4 in.) soil 
media, the Delosperma nubigenum in the $102 \mathrm{~mm}$ (4 in.) soil media, and the Sedum reflexum in the $102 \mathrm{~mm}(4 \mathrm{in}$.$) . After all observations were recorded, the results were tabulated and$ analyzed for statistically significant effects.

\subsubsection{Plant Growth Results}

As hypothesized, the percent coverage of the vegetation was significantly higher in the 102 mm (4 in.) soil media depth than in the $51 \mathrm{~mm}(2$ in.) soil media depth $(\alpha<0.05)$. In addition, there was no statistically significant difference between the percent coverage of Delosperma nubigenum and Sedum album $(\alpha<0.05)$. The percent coverage of Sedum reflexum was significantly higher than Delosperma nubigenum and Sedum album $(\alpha<0.05)$. Figure 6-8 displays the average percent coverage for each vegetation species after the first year of growth.

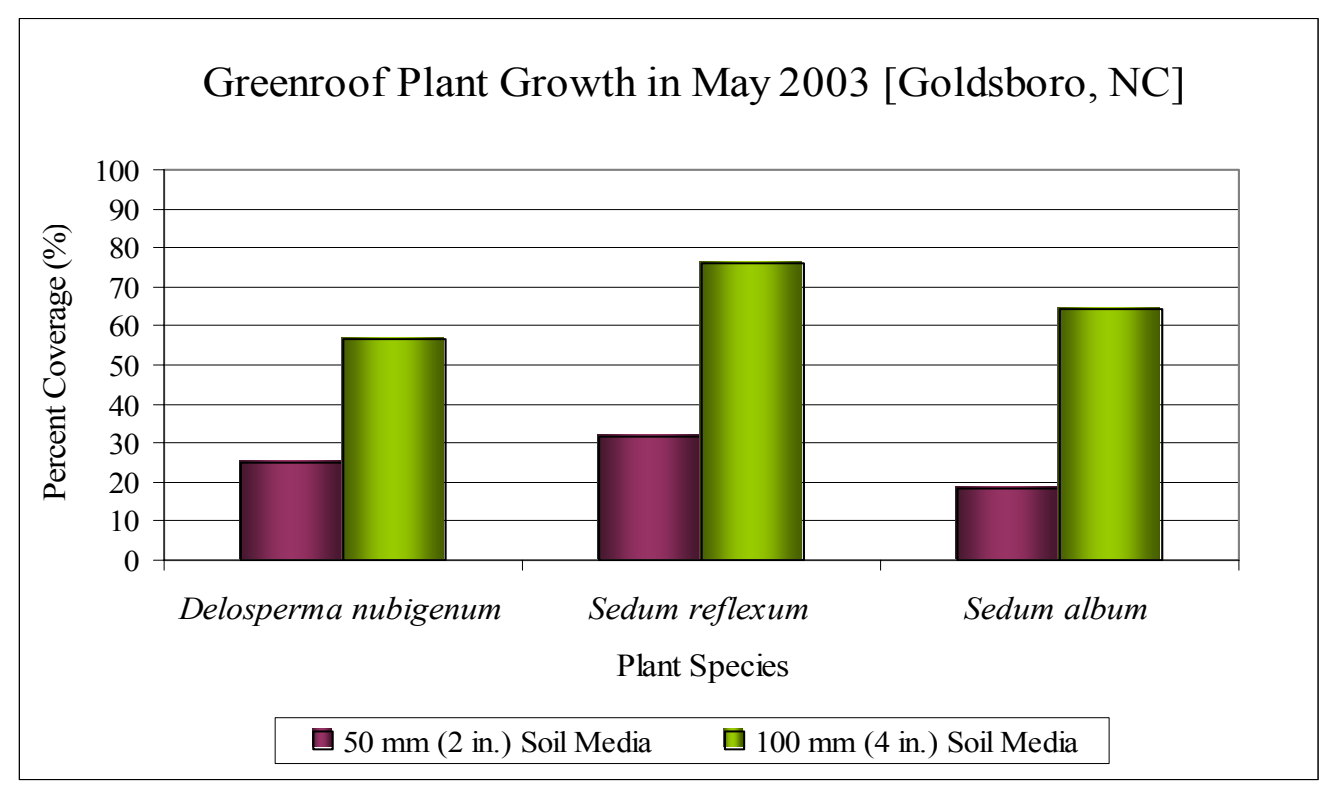

Figure 6-8. Display of Average Percent Coverage for Each Plant Species in Each Soil Media Depth. 


\subsection{Plant Survival ANd Growth Study Discussion}

As a result of this study, developers can be provided with a list of extensive greenroof plant species that have thrived in two greenroof locations in eastern and central North Carolina. As more greenroofs are constructed and more vegetation species are planted, more plant species can be added to the list. The following plants are recommended for use in extensive greenroof construction in eastern and central North Carolina:

(1) Delosperma nubigenum

(2) Sedum album

(3) Sedum album murale

(4) Sedum floriferum

(5) Sedum reflexum

(6) Sedum sexangulare

(7) Sedum spurium fuldaglut.

On average, these plant species have shown between 60 and 75 percent coverage of the soil media after one full year of growth.

This study also showed that the percent coverage of the vegetation is significantly increased when soil media depths of $102 \mathrm{~mm}$ (4 in.) are used instead of $51 \mathrm{~mm}(2 \mathrm{in}$.). Therefore, if establishing quick vegetation cover is important to the developer, the $102 \mathrm{~mm}$ (4 in.) soil depth would provide much higher vegetation coverage at a faster rate. 


\subsection{CONCLUSIONS}

\subsection{Hydrologic CONCLUSIONS}

Two goals of this research were to determine the percent precipitation retained on each greenroof and to determine the percent peak flow reduction of each greenroof. It was hypothesized that each greenroof would retain a significant portion of the precipitation $(\alpha<$ 0.05 ) and that the peak flow of the greenroof would be significantly less than the peak rainfall rate at each site $(\alpha<0.05)$.

The WCC Greenroof in Goldsboro, NC and the Nature Center Greenroof in Kinston, $\mathrm{NC}$ both retained a significant portion of the precipitation that fell on each greenroof $(\alpha<$ 0.05 ). The WCC Greenroof retained approximately $62 \%$ of the total precipitation and the Nature Center Greenroof retained approximately $63 \%$ of the total precipitation over the duration of the monitoring periods. This data unmistakably shows that greenroofs have the capability to dramatically reduce the amount of stormwater runoff from building rooftops. On average, each greenroof retained the first $12.7 \mathrm{~mm}(0.5 \mathrm{in}$.) of rainfall for precipitation events larger than $12.7 \mathrm{~mm}$ ( $0.5 \mathrm{in.}$.). On average, each greenroof retained nearly $100 \%$ of the precipitation of rain events smaller than $12.7 \mathrm{~mm}(0.5 \mathrm{in}$.). The precipitation that is retained on the greenroof is temporarily stored within the media and then either taken up by vegetation through transpiration or it is lost to the atmosphere due to evaporation.

The peak flows observed at the WCC Greenroof and the Nature Center Greenroof were significantly less than the peak rainfall rates observed at each site $(\alpha<0.05)$. The average peak flow reduction observed at the WCC Greenroof over the 9-month observation 
period was $78 \%$; the average peak flow reduction of the Nature Center Greenroof during its 4-month observation period was $87 \%$. This was valuable information because not only does the volume of stormwater affect the water quality of urban streams and rivers, but the flow rate is also an important factor. While large quantities of stormwater often cause soil erosion of stream banks, thereby increasing the sediment loads in the streams, high velocities of stormwater flow in the storm sewers channeling the runoff to the streams and rivers also cause stream bank erosion. During intense storm events, high peak flows of stormwater runoff in urban areas can increase flow rates when the runoff enters into the stormwater sewer system. A result, the increased peak flows scour stream beds when the runoff exits the storm drainage system and enters the nearby bodies of water. This concept is particularly important in urban watersheds prone to flash flooding during intense rain events because there is so little pervious land area in the watershed to allow the precipitation to infiltrate into the ground.

To aid in the future design of greenroofs and analysis of urban stormwater management, Rational coefficients were developed for each observed rain event at the WCC Greenroof in Goldsboro, NC. These results showed that average greenroof Rational coefficients were far less than typical coefficients observed on a conventional rooftop. Typical Rational coefficient values of a conventional rooftop range between 0.75 and 0.95 . The greenroof Rational coefficients ranged from 0.25 for storms between $25 \mathrm{~mm}(1 \mathrm{in}$.) and $39 \mathrm{~mm}$ (1.5 in.) to 0.55 for storms greater than $39 \mathrm{~mm}$ (1.5 in.). These Rational coefficients will prove useful in future modeling and design of greenroofs in urban watersheds. 


\subsection{Water Quality CONCLusions}

One goal of this research was to discover if greenroofs could be used as nutrient reduction BMPs. The pollutant source of these rooftops was atmospheric deposition of $\mathrm{N}$ and $\mathrm{P}$ through precipitation. It was therefore initially hypothesized that the greenroofs would have runoff concentrations and mass loadings of nitrogen $(\mathrm{N})$ and phosphorus $(\mathrm{P})$ significantly less than concentrations and mass loadings found in the rainfall and the control roof runoff ( $\alpha<$ 0.05). The field data did not support these hypotheses.

The concentration of $\mathrm{N}$ in the greenroof runoff was significantly higher than in the rainfall $(\alpha<0.05)$ and there was no significant difference between the concentration of $\mathrm{N}$ in the greenroof runoff and the control roof at each site. In general, however, the concentrations of total nitrogen $(\mathrm{TN})$ in the greenroof runoff were higher than the concentrations present in the rainfall and the control roof runoff. Due to the dependency not only on the concentrations present in each source, but also the volume of runoff from each rooftop and the volume of rainfall, there was no significant difference between the mass loadings of $\mathrm{N}$ in the greenroof, in the control roof, and the precipitation.

While no consistent trends were observed in the field concentrations of $\mathrm{N}$ and in the field mass loadings of $\mathrm{N}$, there were trends observed in the concentrations and mass loadings of $\mathrm{P}$ in the greenroof runoff. The concentrations of $\mathrm{P}$ were significantly higher in the greenroof runoff than in the rainfall and in the control roof runoff at each site $(\alpha<0.05)$.

There were typically higher mass loadings of $\mathrm{P}$ in the greenroof runoff than in the rainfall and the control roof runoff. The mass loading of $\mathrm{P}$ in the greenroof runoff was significantly 
higher than the mass loading of $\mathrm{P}$ in the rainfall $(\alpha<0.05)$; however, there was no statistical difference between the mass loading of $\mathrm{P}$ in the greenroof runoff and the control roof runoff.

The results of the field study indicated that $\mathrm{N}$ and $\mathrm{P}$ may have been leaching from the soil media into the greenroof runoff from the sites. The composition of the soil media used at both greenroofs was 55\% expanded slate, $30 \%$ sand, and $15 \%$ approved composted cow manure (Friedrich, 2003). A soil media column study was performed at the Department of Soil Science at NCSU to further investigate the leaching effects of soil media with varying amounts of compost in the soil media. Because the compost serves as an additional source of nutrients, it was hypothesized that the results of this study would show that the concentrations of $\mathrm{N}$ and $\mathrm{P}$ would be significantly less in the drainage from soil media with $5 \%$ compost than in the drainage from soil media with $15 \%$ and $33 \%$ compost in the composition $(\alpha<0.05)$. It was also hypothesized that the concentrations of $\mathrm{N}$ and $\mathrm{P}$ in the outflow of the soil columns would significantly decrease over time $(\alpha<0.05)$. Three greenroof soil media were researched in this study: Carolina Stalite Soil Mix contained 15\% compost, ERTH HydRocks Soil Mix contained 5\% compost, and ERTH Light Soil Mix contained 33\% compost. The three greenroof soil media were also compared to Play Sand, which served as a control for the experiment.

The results of the soil media column study revealed very high concentrations of TN in the outflow of the Carolina Stalite Soil Mix and the ERTH Light Soil Mix in the first three weeks of the study. In the first three weeks of the study, there were significant differences between the TN concentrations in each of the three greenroof soil media $(\alpha<0.05)$. However, after week 5, there were no significant differences between the soil media. The 
results indicated that while there may be high concentrations of TN present in the outflow after the first several simulated rainfall events, the concentrations of TN did decrease to a minimum. While the concentrations of TN in the ERTH HydRocks Soil Mix were significantly less than the concentrations present in the other two greenroof soil media at the beginning of the study $(\alpha<0.05)$, the concentrations were still more than ten times higher than the concentration present in the synthetic rainwater serving as the inflow for the experiment. This shows that while the concentrations in the ERTH HydRocks were significantly less than the two soil media with more organic matter present in the soil mix, the mix with the smallest proportion of organic compost still leached nutrients out of the media.

The most prominent form of $\mathrm{N}$ present in the outflow concentrations was $\mathrm{NO}_{3}-\mathrm{NO}_{2}$ as $\mathrm{N}$, indicating that inorganic $\mathrm{N}$ was the largest source of $\mathrm{N}$ in this experiment. This was not the same trend observed in the field study. Results of the field study indicated that the dominant form of $\mathrm{N}$ present in the outflow concentrations was TKN, indicating that organic $\mathrm{N}$ may have been the largest source of N. However, the laboratory study did indicate that $\mathrm{TKN}$, in addition to all other forms of $\mathrm{N}$, concentrations will decrease with time.

Similar trends were not observed in the $\mathrm{P}$ concentrations from the outflow of the soil media columns. Significant differences between the concentrations of $\mathrm{P}$ observed in the outflow of each soil media column were not observed. In some cases, the concentration of TP and OP increased in the soil media outflow over a several week period. This can best be explained to be a result of saturation of soil microsites. When soils are saturated, the phosphorus anions, known as orthophosphate (OP) can become reduced and thereby released 
into the soil solution and can then drain out of the soil. This is believed to have occurred during this study because evapotranspiration was minimized in the experiment; therefore, the soil media could remain partially saturated for a period of time between the applications of the synthetic rainwater. With saturation of soil microsites, more OP was released into the soil solution, thereby increasing the concentration of OP in the outflow. This trend can be easily observed in the data from the Carolina Stalite Soil Mix because this mix retained the largest percentage of synthetic rainwater and the OP concentrations very closely followed the TP concentrations present in the outflow.

These results indicate that more $\mathrm{P}$ may leach from greenroof soil media when portions of the media remain saturated for a period of time. While the likelihood of this occurring in North Carolina is minimal, this information may be more applicable to other climates. For example, in climates with frequent intense rainfalls where evapotranspiration would be negligible, more P may leach from the media if it remains saturated and the P can become released into the soil solution.

The results of the NCDA test on each of the different soil media also indicated that the soil test phosphorus (STP) levels initially present within the three greenroof soil media were much higher than necessary to provide enough nutrition for plant growth. Phosphorus leaching could also be reduced if the initial levels of $\mathrm{P}$ present in the soil media were reduced.

In conclusion, the laboratory study revealed that the $\mathrm{N}$ concentrations will reduce to a minimum over time. The laboratory study also revealed that less $\mathrm{N}$ will leach from the soil media with less organic compost present in the soil media composition. However, no 
vegetation was included in this study; therefore, it is not known how well the vegetation will survive in growth media with only $5 \%$ organic compost present in the soil. This soil media column study also demonstrated that greenroof soil media with less compost present in the composition will leach less $\mathrm{P}$ than soil media with higher compost present in the composition. The study also showed that less $\mathrm{P}$ will leach from the soil media if higher percentages of silts and clay soil are present in the soil media composition.

\subsection{Plant Survival and Plant Growth Conclusions}

As there are currently no design guidelines in North Carolina for greenroof plant selection, a goal of this study was to provide a list of extensive greenroof plant species recommended for growth in North Carolina. At this time, seven extensive greenroof plant species are recommended for growth in North Carolina and are listed below:

\section{Delosperma nubigenum}

2. Sedum album

3. Sedum album murale

4. Sedum floriferum

5. Sedum reflexum

6. Sedum sexangulare

7. Sedum spurium fuldaglut.

The goal of this study was to determine if there was an optimal depth of soil for desirable vegetation growth in North Carolina. It was hypothesized that vegetation growth in $102 \mathrm{~mm}$ (4 in.) deep soil media would be significantly higher than vegetation growth in 51 $\mathrm{mm}(2$ in.) deep soil media after the first year of growth $(\alpha<0.05)$. 
It was shown that the vegetation growth in the $102 \mathrm{~mm}$ (4 in.) deep soil media was significantly higher than that in the $51 \mathrm{~mm}$ ( 2 in.) deep soil media $(\alpha<0.05)$. The three plant species included in this portion of the study were Delosperma nubigenum, Sedum album, and Sedum reflexum. It was also shown that there was no significant difference between the growth of Delosperma nubigenum and Sedum album $(\alpha<0.05)$, and the growth of Sedum reflexum was significantly higher than either of the other two plant species $(\alpha<0.05)$.

This data shows that the vegetation will establish at a faster rate in the $102 \mathrm{~mm}$ (4 in.) deep soil media during the first year. While, in time, it may be observed that the vegetation growth in the $51 \mathrm{~mm}(2 \mathrm{in}$.) deep soil media reaches approximately the same amount as the $102 \mathrm{~mm}$ (4 in.) deep soil media, the growth within the first year is the most important for establishing the greenroof. It is desirable to firmly establish the vegetation on a greenroof as soon as possible for several reasons. In environments where the greenroof would be exposed to high wind velocities, especially between building corridors in intense urban environments, higher percentages of vegetation cover of the soil will protect the greenroof soil media from wind erosion. As evapotranspiration rates will increase with more vegetation established on the greenroof, the faster vegetation is established, the faster increased retention rates may be observed.

However, as the $102 \mathrm{~mm}$ (4 in.) media depth was shown to help establish plant cover faster than the $51 \mathrm{~mm}$ ( $2 \mathrm{in}$.) deep soil media, this could be remedied if the vegetation was planted closer together in the shallow soil. This would allow for a larger percentage of the greenroof surface area to be covered by vegetation. However, this must be considered into the design and budget of a greenroof. The cost of deeper soil media and more individual 
plants must be balanced for each greenroof design to see which design is the most costeffective to quickly establish plant cover on the greenroof. 


\subsection{RECOMMENDATIONS FOR FURTHER RESEARCH}

This research has provided valuable information for the greenroof industry, and this research has supplied valuable information specific to North Carolina. While this study did provide much needed precipitation retention data and peak flow reduction data, data was only for approximately nine months. It would be more beneficial to have long term data to reflect the behavior of greenroof retention over time. It would also be beneficial to have an estimate of the annual precipitation retention.

Many developers and engineers would like to be able to model the behavior of greenroofs in hydrologic modeling programs. Further research could be performed on the retention analysis of greenroofs to produce appropriate information to include in these models. For example, the behavior of greenroofs in large storm events, such as the 2-year storm or 10 -year storm. The 2-year storm is a storm so large, it only occurs roughly every 2 years; the 10-year storm is a storm so large, it only occurs roughly every 10 years. Further analysis of the peak flow reduction of greenroofs could be used in calculating more accurate Rational coefficients for greenroofs to aid in future design and modeling of greenroofs in urban watersheds.

While it is now known that concentrations of $\mathrm{N}$ will decrease over time and concentrations of $\mathrm{N}$ and $\mathrm{P}$ are lower in soil media with lower percentages of compost in the soil mix, it is not known how well the vegetation will grow in soil media with fewer nutrients initially present in the soil media.

Further research could be performed by constructing pilot scale greenroofs and testing different plant species in different soil media. For example, one pilot scale greenroof 
could have Sedum reflexum planted in ERTH HydRocks Soil Mix, one pilot scale greenroof could have the same species planted in ERTH Light Soil Mix, one pilot scale greenroof could have Sedum album planted in ERTH HydRocks Soil Mix, one pilot scale greenroof could have the same species planted in ERTH Light Soil Mix, and so on. This study would reveal if plant growth is affected by lower amounts of compost present in the soil media. This study would also show the effect of each individual plant species on the nutrients, possibly answering the question: Would one plant uptake more nutrients than another?

A further study involving pilot scale greenroofs could also determine if the drainage layer has an effect on water retention or peak flow reduction. This study could be performed by setting up multiple pilot scale greenroofs with different drainage layers, some with negligible storage capacity and other drainage layers offering an amount of storage within the layer.

Another study could also look at the effect of roof pitch on water retention and peak flow reduction. Identical pilot scale greenroofs could be constructed with varying roof pitches to see if the pitch of the roof would affect the amount of precipitation retained and the reduction of peak flow.

In addition, it would be beneficial to measure the moisture content of the soil media to adequately determine the full capacity of the media before and after rain events.

Little information on the performance of greenroofs is available in the United States. More studies, such as previously mentioned, need to be performed to demonstrate the effectiveness of greenroofs, not only in North Carolina, but across the United States. 


\subsection{REFERENCES}

American Hydrotech, Inc. 1997. The Garden Roof ${ }^{\mathrm{TM}}$ Planning Guide. Chicago, Illinois: American Hydrotech, Inc.

American Sigma. 2004. Product Specifications: Sigma 900Max Portable Wastewater Samplers. Loveland, Colorado: American Sigma.

Available Online at http://www.americansigma.com/products/900maxportable.cfm

Bass, B. and B. Baskaran. 2003. Evaluating Rooftop and Vertical Gardens as an Adaptation Strategy for Urban Areas. Institute for Research and Construction, NRCC-46737, Project no. A020, CCAF Report B1046. Ottawa, Canada: National Research Council.

Bass, K.L. 2000. Evaluation of a Small In-Stream Constructed Wetland in North Carolina's Coastal Plain. M.S. thesis, Biological and Agricultural Engineering Dept., Raleigh, North Carolina: North Carolina State University.

Booth, D.B. and J. Leavitt. 1999. Field Evaluation of Permeable Pavement Systems for Improved Stormwater Management. Journal of the American Planning Association, 65 (3): 314-325.

Borden, R. C., J.L. Dorn, J.B. Stillman, and S.K. Liehr. 1998. Effect of In-Lake Water Quality on Pollutant Removal in Two Ponds. Journal of Environmental Engineering, 124 (8): 737-743.

Brattebo, B.O. and D.B. Booth. 2003. Long-Term Stormwater Quantity and Quality Performance of Permeable Pavement Systems. Center for Water and Watershed Studies, Seattle, Washington: Department of Civil and Environmental Engineering, University of Washington.

Brenneisen, S. 2003. The Benefits of Biodiversity from Green Roofs Key Design Consequences. In Proc. Greening Rooftops for Sustainable Communities: Chicago 2003: May 29-30, 2003; Chicago, Illinois.

Burkholder, J.M. 1998. Implications of Harmful Microalgae and Heterotrophic Dinoflagellates in Management of Sustainable Marine Fisheries. Ecological Applications, 8 (1, Supplement: Ecosystem Management for Sustainable Marine Fisheries), S37-S62.

Burkholder, J.M. and H.B. Glasgow. 1997. Pfiesteria piscicida and Other Pfiesteria-Like Dinoflagellates: Behavior, Impacts, and Environmental Controls. Limnology and Oceanography, 42 (5, Part 2): 1052-1075. 
Cheney, C. and C. Rosenzweig. 2003. Green Roofs and Environmental Restoration Towards an Ecological Infrastructure for New York City. In Proc. Greening Rooftops for Sustainable Communities: Chicago 2003: May 29-30, 2003; Chicago, Illinois.

Clesceri, L.S, A.E. Greenberg, A.D. Eaton, M.H. Franson, American Public Health Association, American Water Works Association, and Water Environment Federation. 1998. Sample Storage and Preservation. In Standard Methods for the Examination of Water and Wastewater. ed. L.S. Clesceri, A.E. Greenberg. A.D. Eaton, and M.H. Franson. $20^{\text {th }}$ Edition. ch. 1060 C, 1-34-1-35. Washington, DC: American Public Health Association, American Water Works Association, and Water Environment Federation.

Davis, A.P., M. Shokouhian, H. Sharma, and C. Minami. 2001. Laboratory Study of Biological Retention for Urban Stormwater Management. Water Environment Research, 73(1): 5-14.

DeNardo, J. C., A.R. Jarrett, H.B. Manbeck, D.J. Beattie, and R.D. Berghage. 2003. Green Roof Mitigation of Stormwater and Energy Usage. ASAE Meeting Paper No. 032305. St. Joseph, Michigan: ASAE.

Emilsson, T. 2003. The Influence of Substrate, Establishment Method and Species Mix on Plant Cover. In Proc. Greening Rooftops for Sustainable Communities: Chicago 2003: May 29-30, 2003; Chicago, Illinois.

Environmental Services, City of Portland, and Clean River Works. 2002. Stormwater Management Manual-2002. Revision \#2. Portland, Oregon: City of Portland.

Friedrich, C. 2003. Personal Communication. Carolina Stalite Company: Salisbury, North Carolina, 12 November 2003.

Global Water Instrumentation, Inc. 2004. 8" Rain Gauge (RG600) Product Description. Gold River, California: Global Water Instrumentation, Inc.

Available at: http://www.globalw.com/rain_gauge.html

Grant, G., L. Engleback, B. Nicholson, D. Gedge, M. Frith, and P. Harvey. 2003. Greenroofs: their existing status and potential for conserving biodiversity in urban areas. English Nature Reports, Number 498. Peterborough, England: English Nature/MAB.

Hardy, D.H., M.R. Tucker, and C.E. Stokes. 2003a. Crop Fertilization Based on North Carolina Soil Tests. Circular No. 1. Raleigh, North Carolina: North Carolina Department of Agriculture and Consumer Services, Agronomic Division.

Available at: http://www.ncagr.com/agronomi/obook.htm 
Hardy, D.H., M.R. Tucker, and C.E. Stokes. 2003b. Understanding the Soil Test Results. North Carolina Department of Agriculture and Consumer Services, Agronomic Division. Available at: http://www.ncagr.com/agronomi/ustr.htm

Herman, R. 2003. Green Roofs in Germany: Yesterday, Today and Tomorrow. In Proc. Greening Rooftops for Sustainable Communities: Chicago 2003: May 29-30, 2003; Chicago, Illinois.

Hunt, W.F. 2003. Pollutant Removal Evaluation and Hydraulic Characterization for Bioretention Stormwater Treatment Devices. Ph.D. diss., Agricultural and Biological Engineering Dept., University Park, Pennsylvania: Pennsylvania State University.

Hunt, W.F. 1999. Urban Waterways: Urban Stormwater Structural Best Management Practices (BMPs). (AG-588) Raleigh, North Carolina: North Carolina Cooperative Extension Service.

Hunt, W.F. 1999. Unpublished Data Collected from 1989 to 1999 in Raleigh-Durham, NC.

Hunt, W.F. and N.W. White. 2001. Urban Waterways: Designing Rain Gardens (BioRetention Areas). (AG-588-3) Raleigh, North Carolina: North Carolina Cooperative Extension Service.

Hutchinson, D., P. Abrams, R. Retzlaff, and T. Liptan. 2003. Stormwater Monitoring Two Ecoroofs in Portland, Oregon, USA. In Proc. Greening Rooftops for Sustainable Communities: Chicago 2003: May 29-30, 2003; Chicago, Illinois.

Johnston, W.H. and D.A. Sherwood. 1996. Water Resources of Monroe County, New York, Water Years 1984-1988, With Emphasis on Water Quality in the Irondequoit Creek Basin. Part 2: Atmospheric Deposition, Ground Water, Stream Flow, Trends in Water Quality, and Chemical Loads to Irondequoit Bay. Water-Resources Investigations Report 96-4054; Ithaca, New York: U.S. Geological Survey.

Kim, H.; E.A. Seagren, and A.P. Davis. 2003. Engineered Bioretention for Removal of Nitrate from Stormwater Runoff. Water Environment Research, 75 (4): 355-367.

King, S. 2003. Personal Communication. ERTH Products, LLC: Peachtree City, Georgia. 9 December 2003.

King, W. 2004. Personal Communication. ERTH Products, LLC: Peachtree City, Georgia. 6 April 2004.

Laberge, K. 2003. Urban Oasis: Chicago's City Hall Green Roof. In Proc. Greening Rooftops for Sustainable Communities: Chicago 2003: May 29-30, 2003; Chicago, Illinois. 
Liesecke, H-J. 1999. Extensive Begrünung bei $5^{\circ}$ Dachneigung. Stadt Und Grün, 48 (5): 337-346. (In German)

Liesecke, H-J. 1998. Das Retentionsvermögen von Dachbegrünungen. Stadt Und Grün, 47 (1): 46-53. (In German)

Lindhqvist, V. 2003. Swedish Green Roof Initiative: The Green Roof Society, The International Green Roof Institute and Augustenborg's Botanical Roof Garden. In Proc. Greening Rooftops for Sustainable Communities: Chicago 2003: May 29-30, 2003; Chicago, Illinois.

Line, D.E., N.W. White, D.L. Osmond, G.D. Jennings, and C.B. Mojonnier. 2002. Pollutant Export from Various Land Uses in the Upper Neuse River Basin. Water Environment Research, 74 (1): 100-108.

Lipton, T. 2003. Planning, Zoning and Financial Incentives for Ecoroofs in Portland, Oregon. In Proc. Greening Rooftops for Sustainable Communities: Chicago 2003: May 2930, 2003; Chicago, Illinois.

Liu, K. and B. Baskaran. 2003. Thermal Performance of Green Roofs Through Field Evaluation. In Proc. Greening Rooftops for Sustainable Communities: Chicago 2003: May 29-30, 2003; Chicago, Illinois.

Malcom, H.R. 2003. Urban Stormwater Management. CE 785, Section 001 Course pack. Raleigh, North Carolina: North Carolina State University.

Mallin, M.A., J.M. Burkholder, L.B. Cahoon, and M.H. Posey. 2000. Marine Pollution Bulletin, 41 (1-6): 56-75.

Masch, F.D., United States Federal Highway Administration, and Stottler Stagg \& Associates Architects, Engineers, Planners, Inc. 1984. Hydrology. Hydraulic Engineering Circular No. 19, FHWA-IP-84-15. McLean, Virginia: U.S. Department of Transportation, Federal Highway Administration; Springfield, Virginia: National Technical Information Service.

MDE. 2000. 2000 Maryland Stormwater Design Manual, Volumes I \& II. Baltimore, Maryland: Maryland Department of the Environment.

NCDENR. 1998. 15A NCAC 2B .0235. Neuse River Basin-Nutrient Sensitive Waters Management Strategy: Basinwide Stormwater Requirements. Raleigh, North Carolina: Environmental Management Commission.

Available at: http://h2o.enr.state.nc.us/nps/Neuse_NSW_Rules.htm 
NCDENR. 2001. 15A NCAC 02B .0258. Tar-Pamlico River Basin-Nutrient Sensitive Waters Management Strategy: Basinwide Stormwater Requirements. Raleigh, North Carolina: Environmental Management Commission.

Available at: http://h2o.enr.state.nc.us/nps/tarpam.htm

Nelson, E.J. and D.B. Booth. 2002. Sediment sources in an urbanizing, mixed land-use watershed. Journal of Hydrology, 264 (1-4): 51-68.

Osmundson, T. 1999. Roof Gardens: History, Design, and Construction. New York, New York: W.W. Norton \& Company Ltd.

Rao, P.V. 1998. Statistical Research Methods in the Life Sciences. New York, New York: Brooks/Cole Publishing Company.

Robarge, W.P. and W.W. Cure. 1999. Quantification of Atmospheric Nitrogen Deposition in the vicinity of a Large Scale Swine Production Facility Located in the Neuse River Basin-Final Report to the North Carolina Division of Air Quality, December 31, 1998. Status Report on Emissions and Deposition of Atmospheric Nitrogen: Compounds from Animal Production in North Carolina. Raleigh, North Carolina: NCDENR, Division of Air Quality.

Rowe, D.B., C.L. Rugh, N. VanWoert, M.A. Monterusso, and D.K. Russell. 2003. Green Roof Slope, Substrate Depth, and Vegetation Influence Runoff. In Proc. Greening Rooftops for Sustainable Communities: Chicago 2003: May 29-30, 2003; Chicago, Illinois.

Schade, C. 2000. Wasserrückhaltung und Abflußbeiwerte bei dünnschichtigen Extensivbegrünungen. Stadt Und Grün, 49 (2): 95-100. (In German)

Slone, D.K. and D.E. Evans. 2003. Integrating Green Roofs and Low Impact Design into Municipal Storm Water Regulations. In Proc. Greening Rooftops for Sustainable Communities: Chicago 2003: May 29-30, 2003; Chicago, Illinois.

Skaggs, R.W. 2003. Personal Communication. North Carolina State University: Raleigh, North Carolina. 12 May 2003.

Taube, B. 2003. City of Atlanta Greenroof Demonstration Project. In Proc. Greening Rooftops for Sustainable Communities: Chicago 2003: May 29-30, 2003; Chicago, Illinois.

Trimble, S.W. 1997. Contribution of Stream Channel Erosion to Sediment Yield from an Urbanizing Watershed. Science, 278 (5342): 1442-1444.

U.S. EPA. 2002a. National Water Quality Inventory: 2000 Report. EPA-841-R-02-001. Washington, D.C.: U.S. Environmental Protection Agency. 
U.S. EPA. 2002b. Urban Stormwater BMP Performance Monitoring: A Guidance Manual for Meeting the National Stormwater BMP Database Requirements. EPA-821-b-01-001. Pg 128. Washington, D.C.: U.S. Environmental Protection Agency.

U.S. EPA. 2000. Storm Water Phase II Final Rule: An Overview. EPA-833-F-00-001. Washington, D.C.: U.S. Environmental Protection Agency.

Available at: http://www.epa.gov/npdes/pubs/fact1-0.pdf

U.S. EPA. 1996. Overview of the Storm Water Program. EPA-833-R-96-008. Washington, D.C.: U.S. Environmental Protection Agency.

Available at: http://www.epa.gov/npdes/pubs/owm0195.pdf

U.S. EPA. 1994. National Water Quality Inventory: 1992 Report to Congress. EPA-841-R94-001. Washington, D.C.: U.S. Environmental Protection Agency.

U.S. EPA. 1993. Methods for the Determination of Inorganic Substances in Environmental Samples. EPA/600/R-93-100. Washington, D.C.: U.S. Environmental Protection Agency.

U.S. EPA. 1983. Methods for Chemical Analysis of Water and Wastes. EPA/600/4-79020. Washington, D.C.: U.S. Environmental Protection Agency.

Vepraskas, M.J. and S.P. Faulkner. 2001. Redox Chemistry of Hydric Soils. In Wetland Soils: Genesis, Hydrology, Landscapes, and Classification. ed. J.L. Richardson and M.J. Vepraskas, ch. 4, 85-105. Washington, DC: CRC Press LLC.

Viessman, W., G.L Lewis, and J.W. Knapp. 1989. Introduction to Hydrology. $3^{\text {rd }}$ Edition. New York, New York: Haper \& Row Publishers, Inc.

Wossink, A. and W.F. Hunt. 2003. The Economics of Structural Stormwater BMPs in North Carolina. Water Resources Research Institute of The University of North Carolina, Report No. 344; Raleigh, North Carolina.

Wu, J.S., C.J. Allan, W.L. Saunders, and J.B. Evett. 1998. Characterization and Pollutant Loading Estimation for Highway Runoff. Journal of Environmental Engineering, 124 (7): 584-592.

Wu, J.S., R.E. Holman, J.R. and Dorney. 1996. Systematic Evaluation of Pollutant Removal by Urban Wet Detention Ponds. Journal of Environmental Engineering, 122 (11): 983-988.

ZinCo GmbH. 2002. ZinCo International: Roof Landscapes in their most attractive form. Unterensingen, Germany: ZinCo GmbH. Available at: http://www.zinco.de

ZinCo GmbH. 2000. "Planning Guide-The Green Roof." $6^{\text {th }}$ Edition. Unterensingen, Germany: ZinCo GmbH. 


\section{A.0 APPENDIX A - GOLDSBORO HYDROLOGIC DATA}

\section{A.1 Total Summary}

Table A-1. Summary Table of all Rainfall Events Recorded at WCC Greenroof in Goldsboro, NC

\begin{tabular}{|c|c|c|c|c|c|c|}
\hline Date & Rainfall (in.) & Runoff (in) & Retained (in.) & Rain Peak $(\mathrm{mm} / \mathrm{hr})$ & $\mathrm{R} / \mathrm{O}$ Peak $(\mathrm{mm} / \mathrm{hr})$ & $\operatorname{Diff}(\mathrm{mm} / \mathrm{hr})$ \\
\hline 7-Apr-2003 & 0.89 & 0.22 & 0.67 & 36.6 & 3.65 & 32.95 \\
\hline 8-Apr-2003 & 1.02 & 0.57 & 0.45 & 21.3 & 4.34 & 16.9 \\
\hline 9-Apr-2003 & 1.63 & 1.11 & 0.52 & 42.7 & 32.5 & 10.2 \\
\hline 21-Apr-2003 & 0.57 & 0.045 & 0.53 & 48.8 & 0.21 & 48.59 \\
\hline 6-May-2003 & 0.77 & 0.13 & 0.64 & 42.7 & 1.76 & 40.94 \\
\hline 15-May-2003 & 0.31 & 0 & 0.31 & 21.4 & 0 & 21.4 \\
\hline 18-May-2003 & 0.77 & 0.11 & 0.66 & 15.3 & 1.76 & 13.54 \\
\hline 22-May-2003 & 1.36 & 1.11 & 0.25 & 9.16 & 5.09 & 4.07 \\
\hline 26-May-2003 & 0.68 & 0.52 & 0.16 & 15.8 & 5.93 & 9.87 \\
\hline 31-May-2003 & 1.00 & 0.66 & 0.34 & 33.5 & 7.33 & 26.17 \\
\hline 7-Jun-2003 & 0.41 & 0.22 & 0.19 & 9.16 & 0.27 & 8.89 \\
\hline 15-Jun-2003 & 0.71 & 0.03 & 0.68 & 54.9 & 0.78 & 54.12 \\
\hline 28-Jun-2003 & 1.06 & 0.15 & 0.91 & 82.3 & 9.58 & 72.72 \\
\hline 2-Jul-2003 & 0.98 & 0.36 & 0.62 & 21.4 & 6.00 & 15.4 \\
\hline 2-Jul-2003 & 0.44 & 0.13 & 0.31 & 30.5 & 4.40 & 26.1 \\
\hline 10-Jul-2003 & 0.61 & 0.02 & 0.59 & 51.8 & 0.36 & 51.44 \\
\hline 11-Jul-2003 & 0.78 & 0.17 & 0.61 & 48.8 & 2.54 & 46.26 \\
\hline 13-Jul-2003 & 1.7 & 0.69 & 1.01 & 45.7 & 15.7 & 30 \\
\hline \begin{tabular}{|l|}
$14-J u l-2003$ \\
\end{tabular} & 0.31 & 0.17 & 0.14 & 18.3 & 4.76 & 13.54 \\
\hline \begin{tabular}{|l|}
$18-J u l-2003$ \\
\end{tabular} & 1.21 & 0.75 & 0.46 & 94.5 & 35.2 & 59.3 \\
\hline 23-Jul-2003 & 3.05 & 1.88 & 1.17 & 122 & 105 & 17 \\
\hline 24-Jul-2003 & 0.35 & 0.09 & 0.26 & 36.6 & 4.04 & 32.56 \\
\hline 29-Jul-2003 & 1.03 & 0.63 & 0.40 & 85.3 & 27.2 & 58.1 \\
\hline 5-Aug-2003 & 0.18 & 0.009 & 0.17 & 9.16 & 0.05 & 9.11 \\
\hline 7-Aug-2003 & 0.53 & 0.14 & 0.39 & 79.2 & 2.54 & 76.66 \\
\hline 10-Aug-2003 & 0.64 & 0.26 & 0.38 & 54.9 & 15.1 & 39.8 \\
\hline 12-Aug-2003 & 0.47 & 0.17 & 0.30 & 61.0 & 6.06 & 54.94 \\
\hline 16-Aug-2003 & 0.81 & 0.27 & 0.54 & 33.5 & 9.10 & 24.4 \\
\hline 2-Sep-2003 & 0.45 & 0.0014 & 0.45 & 61.0 & 0.08 & 60.92 \\
\hline 4-Sep-2003 & 1.32 & 0.46 & 0.86 & 116 & 18.4 & 97.6 \\
\hline 18-Sep-2003 & 1.29 & 0.26 & 1.03 & 12.2 & 2.04 & 10.16 \\
\hline 23-Sep-2003 & 0.24 & 0.012 & 0.23 & 6.10 & 0.16 & 5.94 \\
\hline 8-Oct-2003 & 0.54 & 0.05 & 0.49 & 3.05 & 0.45 & 2.6 \\
\hline 14-Oct-2003 & 0.54 & 0.07 & 0.47 & 9.16 & 0.66 & 8.5 \\
\hline 28-Oct-2003 & 2.29 & 0.71 & 1.58 & 24.4 & 5.18 & 19.22 \\
\hline 19-Nov-2003 & 1.2 & 0.14 & 1.06 & 27.5 & 1.24 & 26.26 \\
\hline 4-Dec-2003 & 0.45 & 0.01 & 0.44 & 3.05 & 0.13 & 2.92 \\
\hline 10-Dec-2003 & 1.52 & 0.71 & 0.81 & 15.3 & 7.99 & 7.31 \\
\hline 14-Dec-2003 & 1.38 & 0.56 & 0.82 & 21.4 & 7.50 & 13.9 \\
\hline
\end{tabular}




\section{A.2 Monthly Summaries}

\section{A.2.1 APRIL 2003}

Table A-2. Summary Table of Rainfall Events in April 2003 at WCC Greenroof in Goldsboro, NC

\begin{tabular}{|l|c|c|c|c|c|c|c|c|c|c|}
\hline \multirow{2}{*}{ Date } & \multicolumn{2}{|c|}{ Inflow } & \multicolumn{2}{c|}{ Greenroof } & \multicolumn{2}{c|}{ Precipitation Retained } & \multicolumn{3}{c|}{ Peak Flow Reduction } \\
\cline { 2 - 13 } & $\begin{array}{c}\text { Rainfall } \\
\text { (in.) }\end{array}$ & $\begin{array}{c}\text { Rainfall } \\
\text { (mm) }\end{array}$ & $\begin{array}{c}\text { Runoff } \\
\text { (in.) }\end{array}$ & $\begin{array}{c}\text { Runoff } \\
\text { (mm) }\end{array}$ & $\begin{array}{c}\text { Amount } \\
\text { (in.) }\end{array}$ & $\begin{array}{c}\text { Amount } \\
\text { (mm) }\end{array}$ & $\begin{array}{c}\text { Percent } \\
(\%)\end{array}$ & $\begin{array}{c}\text { Rain Peak } \\
(\mathrm{mm} / \mathrm{hr})\end{array}$ & $\begin{array}{c}\text { R/O Peak } \\
\text { (mm/hr) }\end{array}$ & $\begin{array}{c}\text { Percent } \\
(\%)\end{array}$ \\
\hline \hline 7-Apr-2003 & 0.89 & 22.6 & 0.22 & 5.6 & 0.67 & 17.0 & $75 \%$ & 36.6 & 3.65 & $90 \%$ \\
\hline 8-Apr-2003 & 1.02 & 25.9 & 0.57 & 14.5 & 0.45 & 11.4 & $44 \%$ & 21.3 & 4.34 & $80 \%$ \\
\hline 9-Apr-2003 & 1.63 & 41.4 & 1.11 & 28.2 & 0.52 & 13.2 & $32 \%$ & 42.7 & 32.5 & $24 \%$ \\
\hline 21-Apr-2003 & 0.57 & 14.5 & 0.045 & 1.1 & 0.53 & 13.3 & $92 \%$ & 48.8 & 0.21 & $99 \%$ \\
\hline Average & 1.03 & 26.1 & 0.49 & 12.4 & 0.54 & 13.7 & $61 \%$ & 37.3 & 10.2 & $73 \%$ \\
TOTAL & 4.11 & 104.4 & 1.945 & 49.4 & 2.165 & 55.0 & $53 \%$ & & &
\end{tabular}

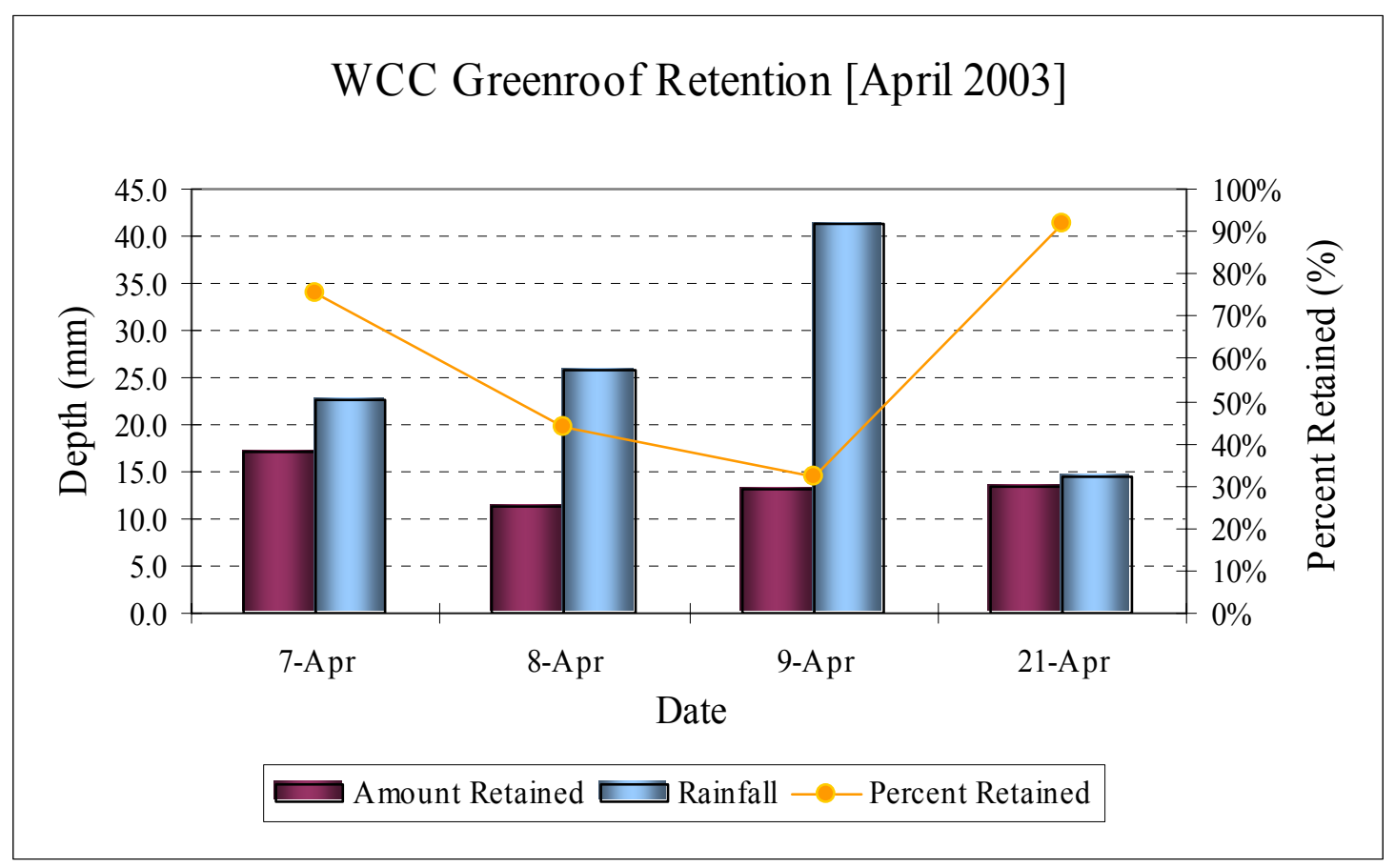

Figure A-1. Display of Percent Retention in April 2003 at WCC Greenroof in Goldsboro, NC. 


\section{A.2.2 MAY 2003}

Table A-3. Summary Table of Rainfall Events in May 2003 at WCC Greenroof in Goldsboro, NC

\begin{tabular}{|c|c|c|c|c|c|c|c|c|c|c|}
\hline \multirow[b]{2}{*}{ Date } & \multicolumn{2}{|c|}{ Inflow } & \multicolumn{2}{|c|}{ Greenroof } & \multicolumn{3}{|c|}{ Precipitation Retained } & \multicolumn{3}{|c|}{ Peak Flow Reduction } \\
\hline & $\begin{array}{c}\text { Rainfall } \\
\text { (in.) }\end{array}$ & $\begin{array}{c}\text { Rainfall } \\
(\mathrm{mm})\end{array}$ & $\begin{array}{c}\text { Runoff } \\
\text { (in.) }\end{array}$ & \begin{tabular}{|c|} 
Runoff \\
$(\mathrm{mm})$
\end{tabular} & $\begin{array}{c}\text { Amount } \\
\text { (in.) }\end{array}$ & $\begin{array}{c}\text { Amount } \\
(\mathrm{mm})\end{array}$ & $\begin{array}{c}\text { Percent } \\
(\%)\end{array}$ & \begin{tabular}{|c|} 
Rain Peak \\
$(\mathrm{mm} / \mathrm{hr})$
\end{tabular} & \begin{tabular}{|c|} 
R/O Peak \\
$(\mathrm{mm} / \mathrm{hr})$
\end{tabular} & \begin{tabular}{|c|} 
Percent \\
$(\%)$ \\
\end{tabular} \\
\hline 6-May-2003 & 0.77 & 19.6 & 0.13 & 3.3 & 0.64 & 16.3 & $83 \%$ & "42.7 & 1.76 & $96 \%$ \\
\hline 15-Мay-2003 & 0.31 & 7.9 & 0 & 0.0 & 0.31 & 7.9 & $100 \%$ & 21.4 & 0 & $100 \%$ \\
\hline 18-May-2003 & 0.77 & 19.6 & 0.11 & 2.8 & 0.66 & 16.8 & $86 \%$ & 15.3 & 1.76 & $88 \%$ \\
\hline 22-May-2003 & 1.36 & 34.5 & 1.11 & 28.2 & 0.25 & 6.4 & $18 \%$ & 9.16 & 5.09 & $44 \%$ \\
\hline 26-Мay-2003 & 0.68 & 17.3 & 0.52 & 13.2 & 0.16 & 4.1 & $24 \%$ & 15.8 & 5.93 & $63 \%$ \\
\hline 31-May-2003 & 1.00 & 25.4 & 0.66 & 16.8 & 0.34 & 8.6 & $34 \%$ & 33.5 & 7.33 & $78 \%$ \\
\hline Average & 0.82 & 20.7 & 0.42 & 10.7 & 0.39 & 10.0 & $57 \%$ & 22.9 & 3.65 & $78 \%$ \\
\hline TOTAL & 4.89 & 124.2 & 2.53 & 64.3 & 2.36 & 59.9 & $48 \%$ & & & \\
\hline
\end{tabular}

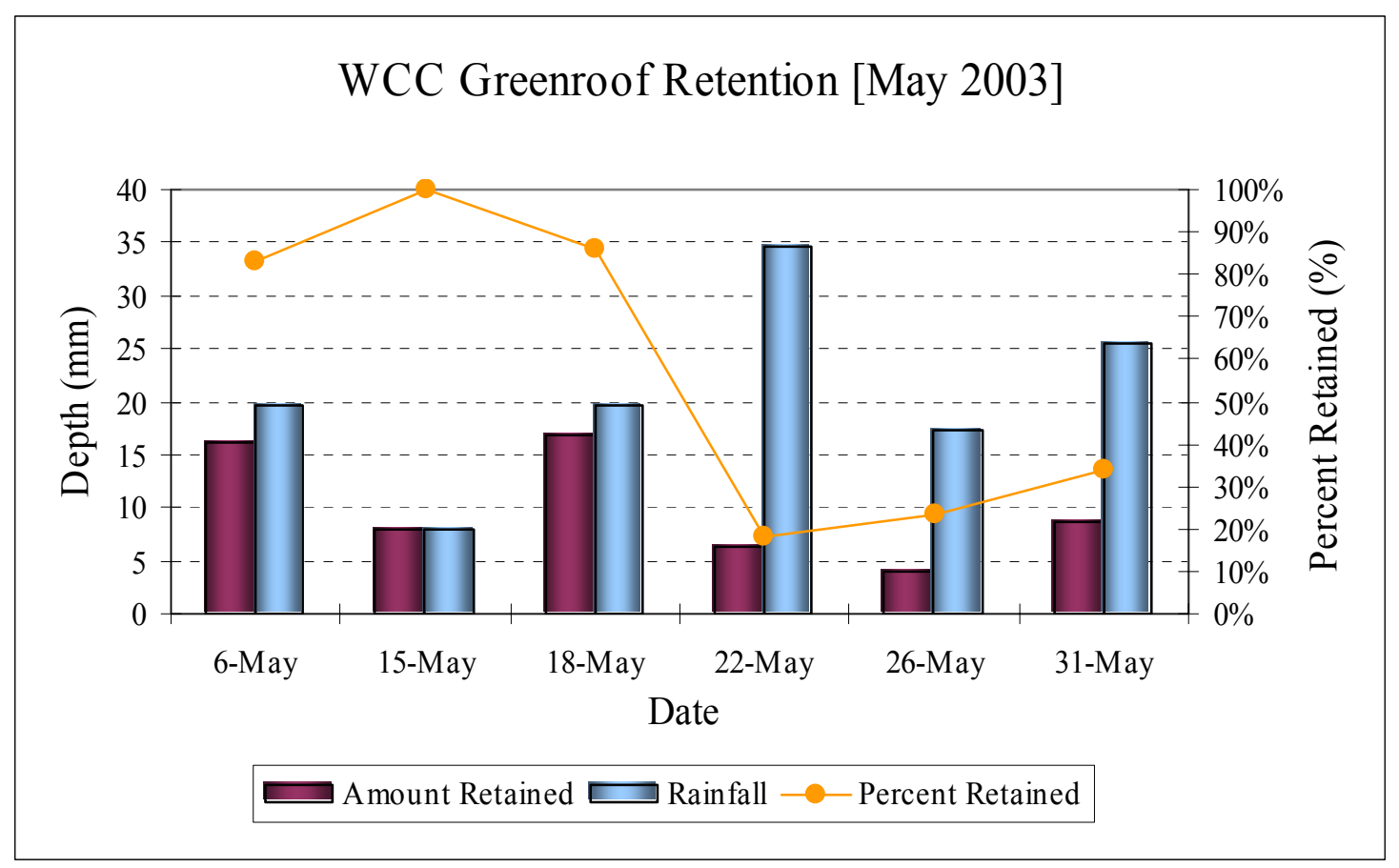

Figure A-2. Display of Percent Retention in May 2003 at WCC Greenroof in Goldsboro, NC. 


\section{A.2.3 JUNE 2003}

Table A-4. Summary Table of Rainfall Data for June 2003 at WCC Greenroof in Goldsboro, NC

\begin{tabular}{|l|c|c|c|c|c|c|c|c|c|c|}
\hline \multirow{2}{*}{ Date } & \multicolumn{2}{|c|}{ Inflow } & \multicolumn{2}{c|}{ Greenroof } & \multicolumn{2}{c|}{ Precipitation Retained } & \multicolumn{3}{c|}{ Peak Flow Reduction } \\
\cline { 2 - 12 } & $\begin{array}{c}\text { Rainfall } \\
\text { (in.) }\end{array}$ & $\begin{array}{c}\text { Rainfall } \\
\text { (mm) }\end{array}$ & $\begin{array}{c}\text { Runoff } \\
\text { (in.) }\end{array}$ & $\begin{array}{c}\text { Runoff } \\
\text { (mm) }\end{array}$ & $\begin{array}{c}\text { Amount } \\
\text { (in.) }\end{array}$ & $\begin{array}{c}\text { Amount } \\
\text { (mm) }\end{array}$ & $\begin{array}{c}\text { Percent } \\
(\%)\end{array}$ & $\begin{array}{c}\text { Rain Peak } \\
(\mathrm{mm} / \mathrm{hr})\end{array}$ & $\begin{array}{c}\text { R/O Peak } \\
(\mathrm{mm} / \mathrm{hr})\end{array}$ & $\begin{array}{c}\text { Percent } \\
(\%)\end{array}$ \\
\hline \hline 7-Jun-2003 & 0.41 & 10.4 & 0.22 & 5.6 & 0.19 & 4.8 & $46 \%$ & 9.16 & 0.27 & $97 \%$ \\
\hline 15-Jun-2003 & 0.71 & 18.0 & 0.03 & 0.8 & 0.68 & 17.3 & $96 \%$ & 54.9 & 0.78 & $99 \%$ \\
\hline 28-Jun-2003 & 1.06 & 26.9 & 0.15 & 3.8 & 0.91 & 23.1 & $86 \%$ & 82.3 & 9.58 & $88 \%$ \\
\hline Average & 0.73 & 18.5 & 0.13 & 3.4 & 0.59 & 15.1 & $76 \%$ & 48.8 & 3.54 & $95 \%$ \\
TOTAL & 2.18 & 55.4 & 0.4 & 10.2 & 1.78 & 45.2 & $82 \%$ & & &
\end{tabular}

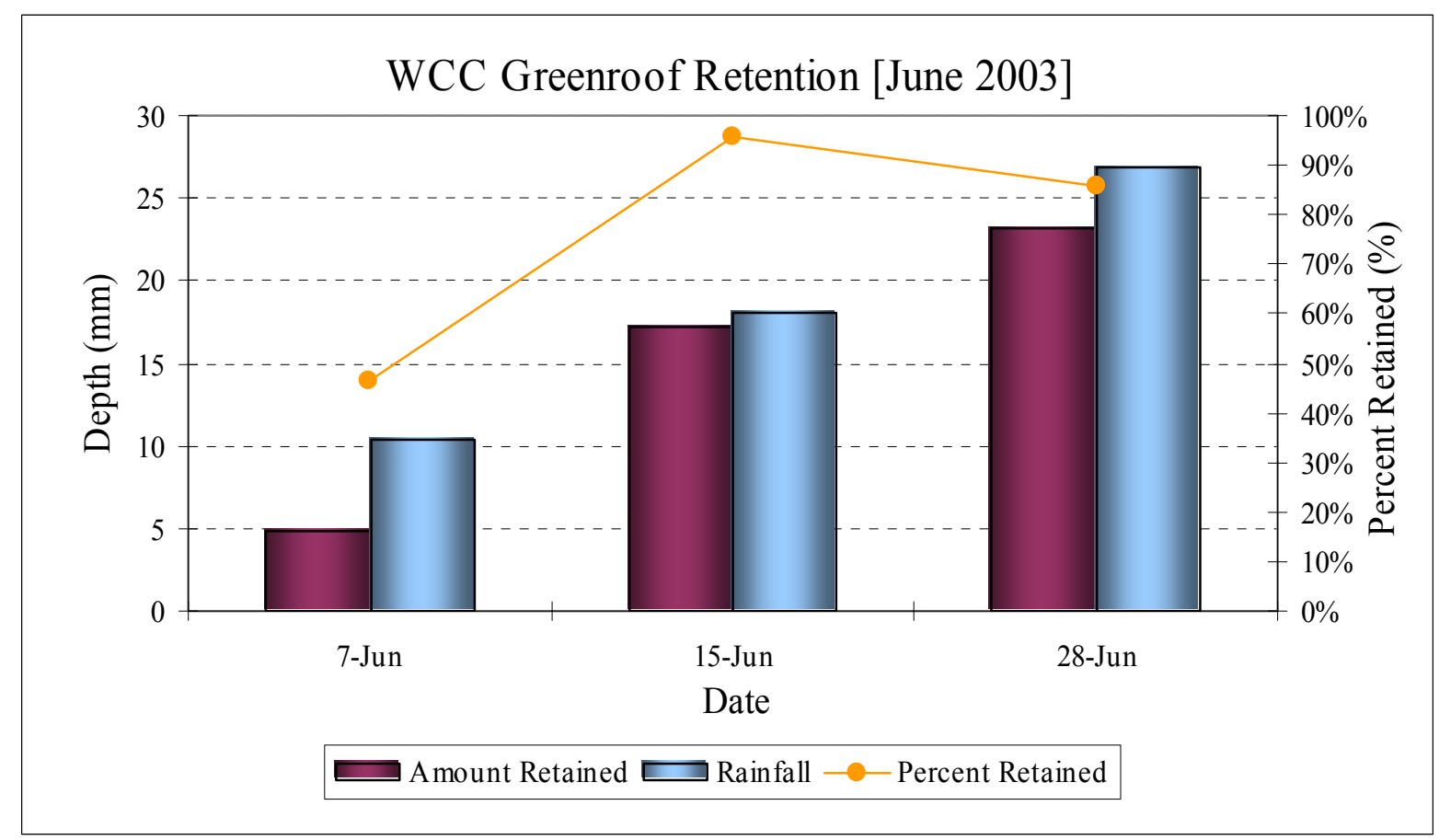

Figure A-3. Display of Percent Retention for June 2003 at WCC Greenroof in Goldsboro, NC. 


\section{A.2.4 JULY 2003}

Table A-5. Summary Table of Rainfall Data in July 2003 at WCC Greenroof in Goldsboro, NC

\begin{tabular}{|l|c|c|c|c|c|c|c|c|c|c|}
\hline \multirow{2}{*}{ Date } & \multicolumn{2}{|c|}{ Inflow } & \multicolumn{2}{c|}{ Greenroof } & \multicolumn{2}{c|}{ Precipitation Retained } & \multicolumn{2}{c|}{ Peak Flow Reduction } \\
\cline { 2 - 12 } & $\begin{array}{c}\text { Rainfall } \\
\text { (in.) }\end{array}$ & $\begin{array}{c}\text { Rainfall } \\
\text { (mm) }\end{array}$ & $\begin{array}{c}\text { Runoff } \\
\text { (in.) }\end{array}$ & $\begin{array}{c}\text { Runoff } \\
\text { (mm) }\end{array}$ & $\begin{array}{c}\text { Amount } \\
\text { (in.) }\end{array}$ & $\begin{array}{c}\text { Amount } \\
(\mathrm{mm})\end{array}$ & $\begin{array}{c}\text { Percent } \\
(\%)\end{array}$ & $\begin{array}{c}\text { Rain Peak } \\
(\mathrm{mm} / \mathrm{hr})\end{array}$ & $\begin{array}{c}\text { R/O Peak } \\
(\mathrm{mm} / \mathrm{hr})\end{array}$ & $\begin{array}{c}\text { Percent } \\
(\%)\end{array}$ \\
\hline \hline 2-Jul-2003 & 0.98 & 24.9 & 0.36 & 9.1 & 0.62 & 15.7 & $63 \%$ & 21.4 & 6.00 & $72 \%$ \\
\hline 2-Jul-2003 & 0.44 & 11.2 & 0.13 & 3.3 & 0.31 & 7.9 & $70 \%$ & 30.5 & 4.40 & $86 \%$ \\
\hline 10-Jul-2003 & 0.61 & 15.5 & 0.02 & 0.5 & 0.59 & 15.0 & $97 \%$ & 51.8 & 0.36 & $99 \%$ \\
\hline 11-Jul-2003 & 0.78 & 19.8 & 0.17 & 4.3 & 0.61 & 15.5 & $78 \%$ & 48.8 & 2.54 & $95 \%$ \\
\hline 13-Jul-2003 & 1.7 & 43.2 & 0.69 & 17.5 & 1.01 & 25.7 & $59 \%$ & 45.7 & 15.7 & $66 \%$ \\
\hline 14-Jul-2003 & 0.31 & 7.9 & 0.17 & 4.3 & 0.14 & 3.6 & $45 \%$ & 18.3 & 4.76 & $74 \%$ \\
\hline 18-Jul-2003 & 1.21 & 30.7 & 0.75 & 19.1 & 0.46 & 11.7 & $38 \%$ & 94.5 & 35.2 & $63 \%$ \\
\hline 23-Jul-2003 & 3.05 & 77.5 & 1.88 & 47.8 & 1.17 & 29.7 & $38 \%$ & 122 & 105 & $14 \%$ \\
\hline 24-Jul-2003 & 0.35 & 8.9 & 0.09 & 2.3 & 0.26 & 6.6 & $74 \%$ & 36.6 & 4.04 & $89 \%$ \\
\hline 29-Jul-2003 & 1.03 & 26.2 & 0.63 & 16.0 & 0.40 & 10.2 & $39 \%$ & 85.3 & 27.2 & $68 \%$ \\
\hline Average & 1.05 & 26.6 & 0.49 & 12.4 & 0.56 & 14.1 & $60 \%$ & 55.5 & 20.6 & $72 \%$ \\
TOTAL & 10.46 & 265.7 & 4.89 & 124.2 & 5.57 & 141.5 & $53 \%$ & & & \\
\hline
\end{tabular}

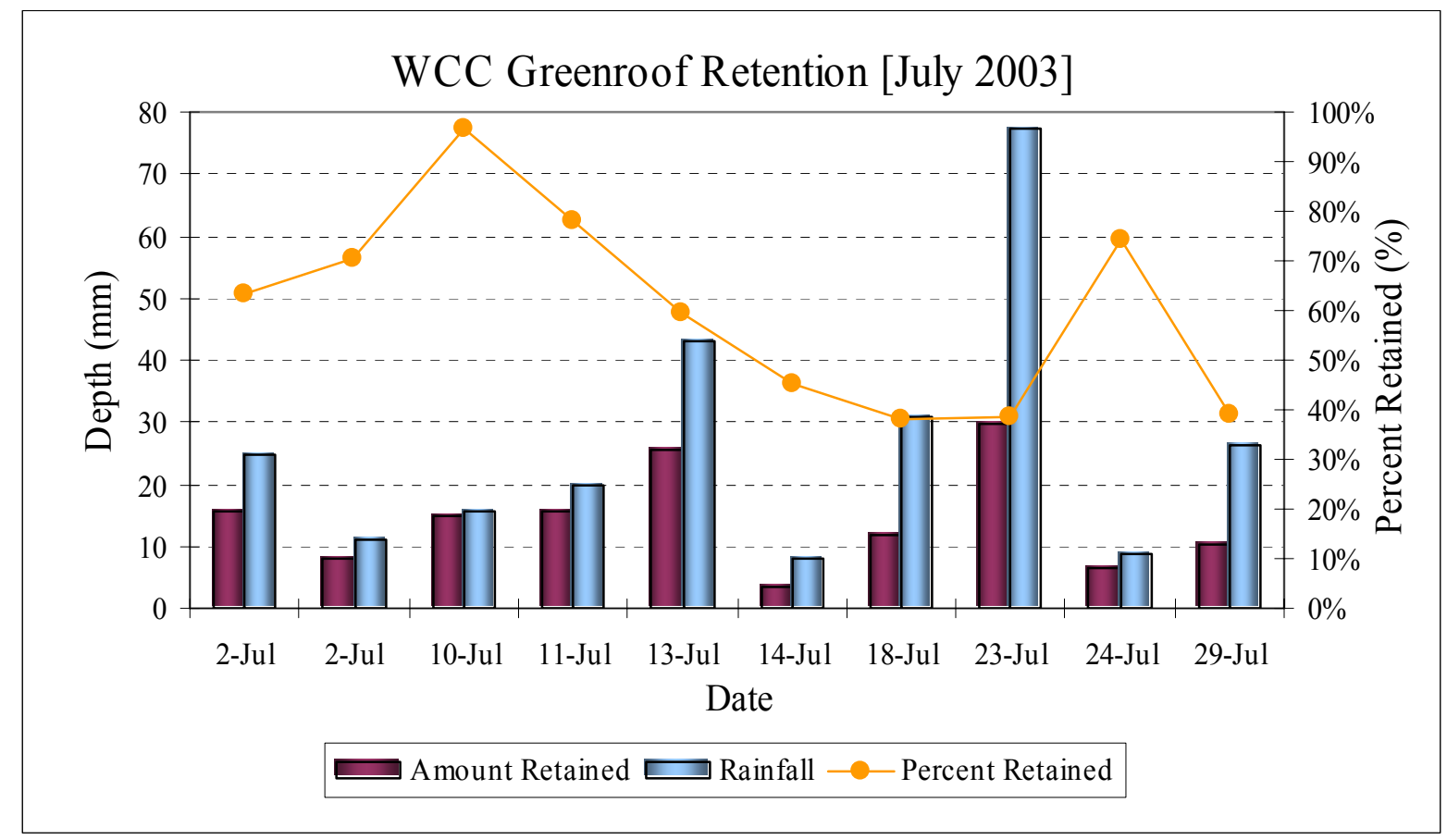

Figure A-4. Display of Percent Retention in July 2003 at WCC Greenroof in Goldsboro, NC. 


\section{A.2.5 August 2003}

Table A-6. Summary Table of Rainfall Data in August 2003 at WCC Greenroof in Goldsboro, NC

\begin{tabular}{|l|c|c|c|c|c|c|c|c|c|c|}
\hline \multirow{2}{*}{ Date } & \multicolumn{2}{|c|}{ Inflow } & \multicolumn{2}{c|}{ Greenroof } & \multicolumn{2}{c|}{ Precipitation Retained } & \multicolumn{2}{c|}{ Peak Flow Reduction } \\
\cline { 2 - 12 } & $\begin{array}{c}\text { Rainfall } \\
\text { (in.) }\end{array}$ & $\begin{array}{c}\text { Rainfall } \\
\text { (mm) }\end{array}$ & $\begin{array}{c}\text { Runoff } \\
\text { (in.) }\end{array}$ & $\begin{array}{c}\text { Runoff } \\
\text { (mm) }\end{array}$ & $\begin{array}{c}\text { Amount } \\
\text { (in.) }\end{array}$ & $\begin{array}{c}\text { Amount } \\
\text { (mm) }\end{array}$ & $\begin{array}{c}\text { Percent } \\
(\%)\end{array}$ & $\begin{array}{c}\text { Rain Peak } \\
(\mathrm{mm} / \mathrm{hr})\end{array}$ & $\begin{array}{c}\text { R/O Peak } \\
(\mathrm{mm} / \mathrm{hr})\end{array}$ & $\begin{array}{c}\text { Percent } \\
(\%)\end{array}$ \\
\hline \hline 5-Aug-2003 & 0.18 & 4.6 & 0.009 & 0.2 & 0.17 & 4.3 & $95 \%$ & 9.16 & 0.05 & $99 \%$ \\
\hline 7-Aug-2003 & 0.53 & 13.5 & 0.14 & 3.6 & 0.39 & 9.9 & $74 \%$ & 79.2 & 2.54 & $97 \%$ \\
\hline 10-Aug-2003 & 0.64 & 16.3 & 0.26 & 6.6 & 0.38 & 9.7 & $59 \%$ & 54.9 & 15.1 & $72 \%$ \\
\hline 12-Aug-2003 & 0.47 & 11.9 & 0.17 & 4.3 & 0.30 & 7.6 & $64 \%$ & 61.0 & 6.06 & $90 \%$ \\
\hline 16-Aug-2003 & 0.81 & 20.6 & 0.27 & 6.9 & 0.54 & 13.7 & $67 \%$ & 33.5 & 9.10 & $73 \%$ \\
\hline Average & 0.53 & 13.4 & 0.17 & 4.3 & 0.36 & 9.0 & $72 \%$ & 47.6 & 6.57 & $86 \%$ \\
TOTAL & 2.63 & 66.8 & 0.849 & 21.6 & 1.781 & 45.2 & $68 \%$ & & & \\
\end{tabular}

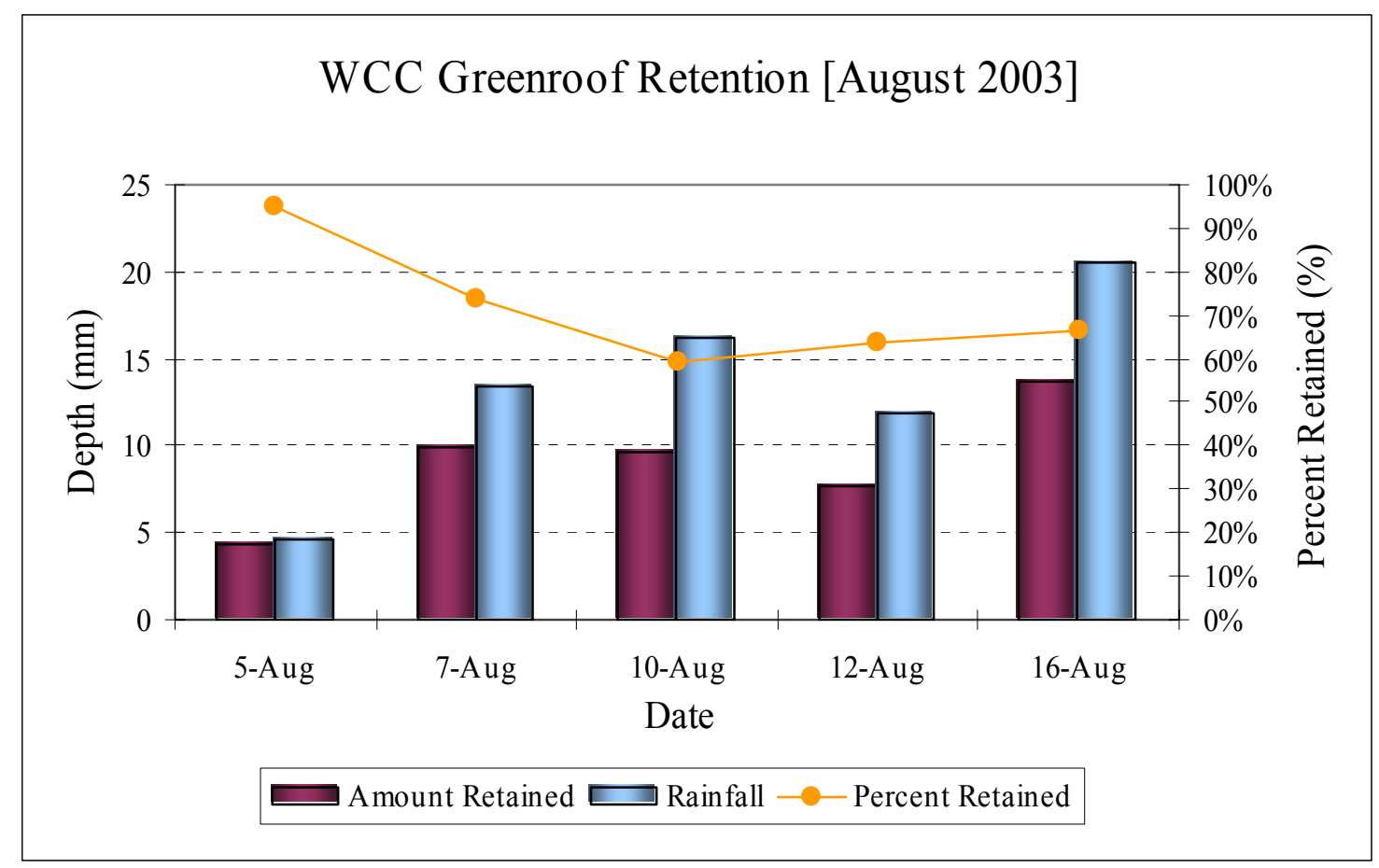

Figure A-5. Display of Percent Retention in August 2003 at WCC Greenroof in Goldsboro, NC. 


\section{A.2.6 SEPTEMBER 2003}

Table A-7. Summary Table of Rainfall Data in September 2003 at WCC Greenroof in Goldsboro, NC

\begin{tabular}{|c|c|c|c|c|c|c|c|c|c|c|}
\hline \multirow[b]{2}{*}{ Date } & \multicolumn{2}{|c|}{ Inflow } & \multicolumn{2}{|c|}{ Greenroof } & \multicolumn{3}{|c|}{ Precipitation Retained } & \multicolumn{3}{|c|}{ Peak Flow Reduction } \\
\hline & $\begin{array}{c}\text { Rainfall } \\
\text { (in.) } \\
\end{array}$ & $\begin{array}{c}\text { Rainfall } \\
(\mathrm{mm})\end{array}$ & \begin{tabular}{|c|} 
Runoff \\
(in.)
\end{tabular} & $\begin{array}{c}\text { Runoff } \\
(\mathrm{mm})\end{array}$ & $\begin{array}{c}\text { Amount } \\
\text { (in.) } \\
\end{array}$ & $\begin{array}{c}\text { Amount } \\
(\mathrm{mm}) \\
\end{array}$ & $\begin{array}{c}\text { Percent } \\
(\%)\end{array}$ & $\begin{array}{c}\text { Rain Peak } \\
(\mathrm{mm} / \mathrm{hr})\end{array}$ & $\begin{array}{c}\text { R/O Peak } \\
(\mathrm{mm} / \mathrm{hr}) \\
\end{array}$ & $\begin{array}{c}\text { Percent } \\
(\%)\end{array}$ \\
\hline 2-Sep-2003 & 0.45 & 11.4 & 0.0014 & 0.0 & 0.45 & 11.4 & $100 \%$ & 61.0 & 0.08 & $100 \%$ \\
\hline 4-Sep-2003 & 1.32 & 33.5 & 0.46 & 11.7 & 0.86 & 21.8 & $65 \%$ & 116 & 18.4 & $84 \%$ \\
\hline 18-Sep-2003 & 1.29 & 32.8 & 0.26 & 6.6 & 1.03 & 26.2 & $80 \%$ & 12.2 & 2.04 & $83 \%$ \\
\hline 23-Sep-2003 & 0.24 & 6.1 & 0.012 & 0.3 & 0.23 & 5.8 & $95 \%$ & 6.10 & 0.16 & $97 \%$ \\
\hline Average & 0.83 & 21.0 & 0.18 & 4.7 & 0.64 & 16.3 & $85 \%$ & 48.8 & 5.17 & $91 \%$ \\
\hline TOTAL & 3.3 & 83.8 & 0.733 & 18.6 & 2.56 & 65.2 & $78 \%$ & & & \\
\hline
\end{tabular}

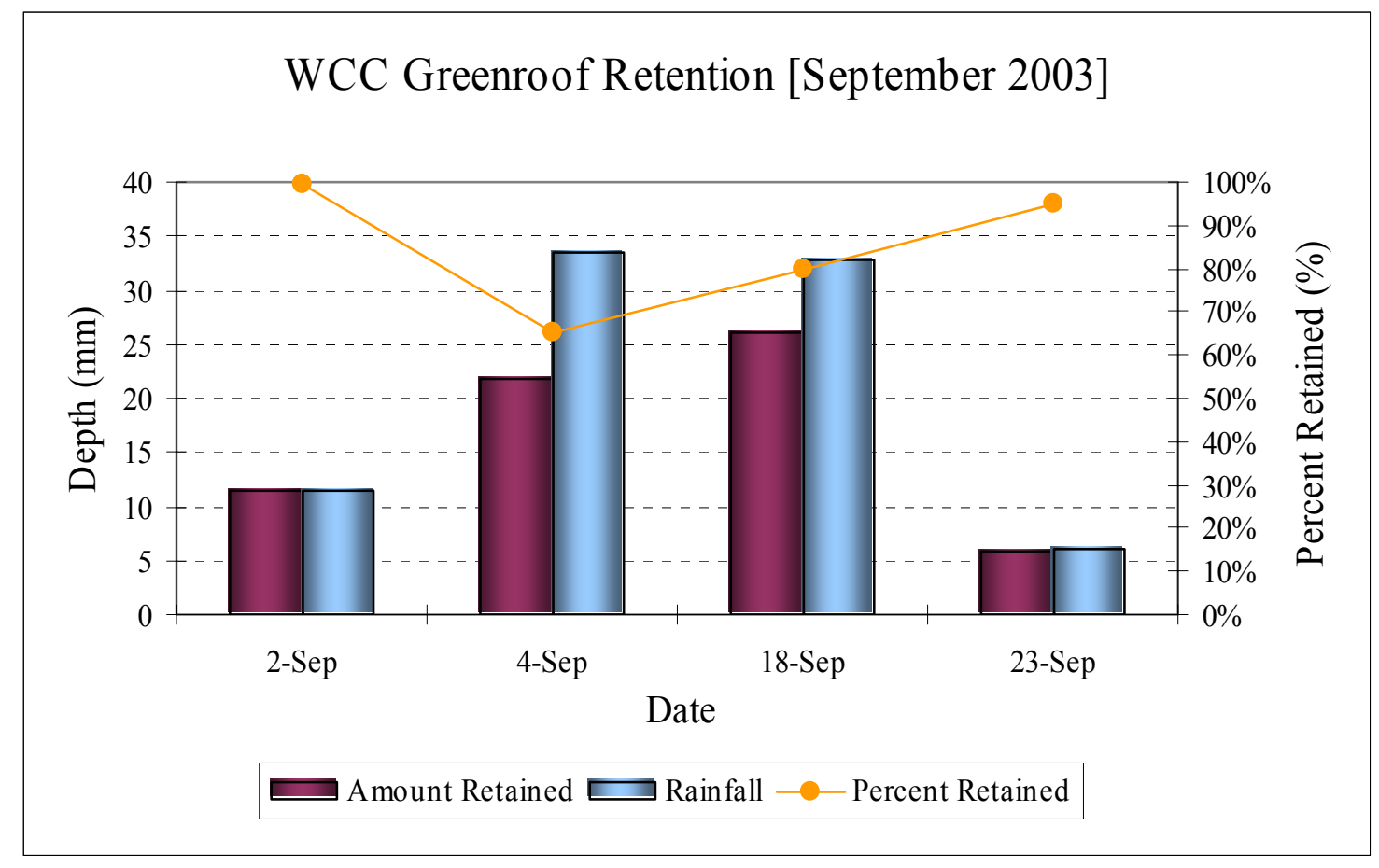

Figure A-6. Display of Percent Retention in September 2003 at WCC Greenroof in Goldsboro, NC. 


\section{A.2.7 OCTOBER 2003}

Table A-8. Summary Table of Rainfall Data in October 2003 at WCC Greenroof in Goldsboro, NC

\begin{tabular}{|l|c|c|c|c|c|c|c|c|c|c|}
\hline \multirow{2}{*}{ Date } & \multicolumn{2}{|c|}{ Inflow } & \multicolumn{2}{c|}{ Greenroof } & \multicolumn{2}{c|}{ Precipitation Retained } & \multicolumn{2}{c|}{ Peak Flow Reduction } \\
\cline { 2 - 12 } & $\begin{array}{c}\text { Rainfall } \\
\text { (in.) }\end{array}$ & $\begin{array}{c}\text { Rainfall } \\
\text { (mm) }\end{array}$ & $\begin{array}{c}\text { Runoff } \\
\text { (in.) }\end{array}$ & $\begin{array}{c}\text { Runoff } \\
\text { (mm) }\end{array}$ & $\begin{array}{c}\text { Amount } \\
\text { (in.) }\end{array}$ & $\begin{array}{c}\text { Amount } \\
\text { (mm) }\end{array}$ & $\begin{array}{c}\text { Percent } \\
(\%)\end{array}$ & $\begin{array}{c}\text { Rain Peak } \\
\text { (mm/hr) }\end{array}$ & $\begin{array}{c}\text { R/O Peak } \\
\text { (mm/hr) }\end{array}$ & $\begin{array}{c}\text { Percent } \\
(\%)\end{array}$ \\
\hline \hline 8 -Oct-2003 & 0.54 & 13.7 & 0.05 & 1.3 & 0.49 & 12.4 & $91 \%$ & 3.05 & 0.45 & $85 \%$ \\
\hline 14-Oct-2003 & 0.54 & 13.7 & 0.07 & 1.8 & 0.47 & 11.9 & $87 \%$ & 9.16 & 0.66 & $93 \%$ \\
\hline 28-Oct-2003 & 2.29 & 58.2 & 0.71 & 18.0 & 1.58 & 40.1 & $69 \%$ & 24.4 & 5.18 & $79 \%$ \\
\hline Average & 1.12 & 28.5 & 0.28 & 7.0 & 0.85 & 21.5 & $82 \%$ & 12.2 & 2.10 & $86 \%$ \\
TOTAL & 3.37 & 85.6 & 0.83 & 21.1 & 2.54 & 64.5 & $75 \%$ & & &
\end{tabular}

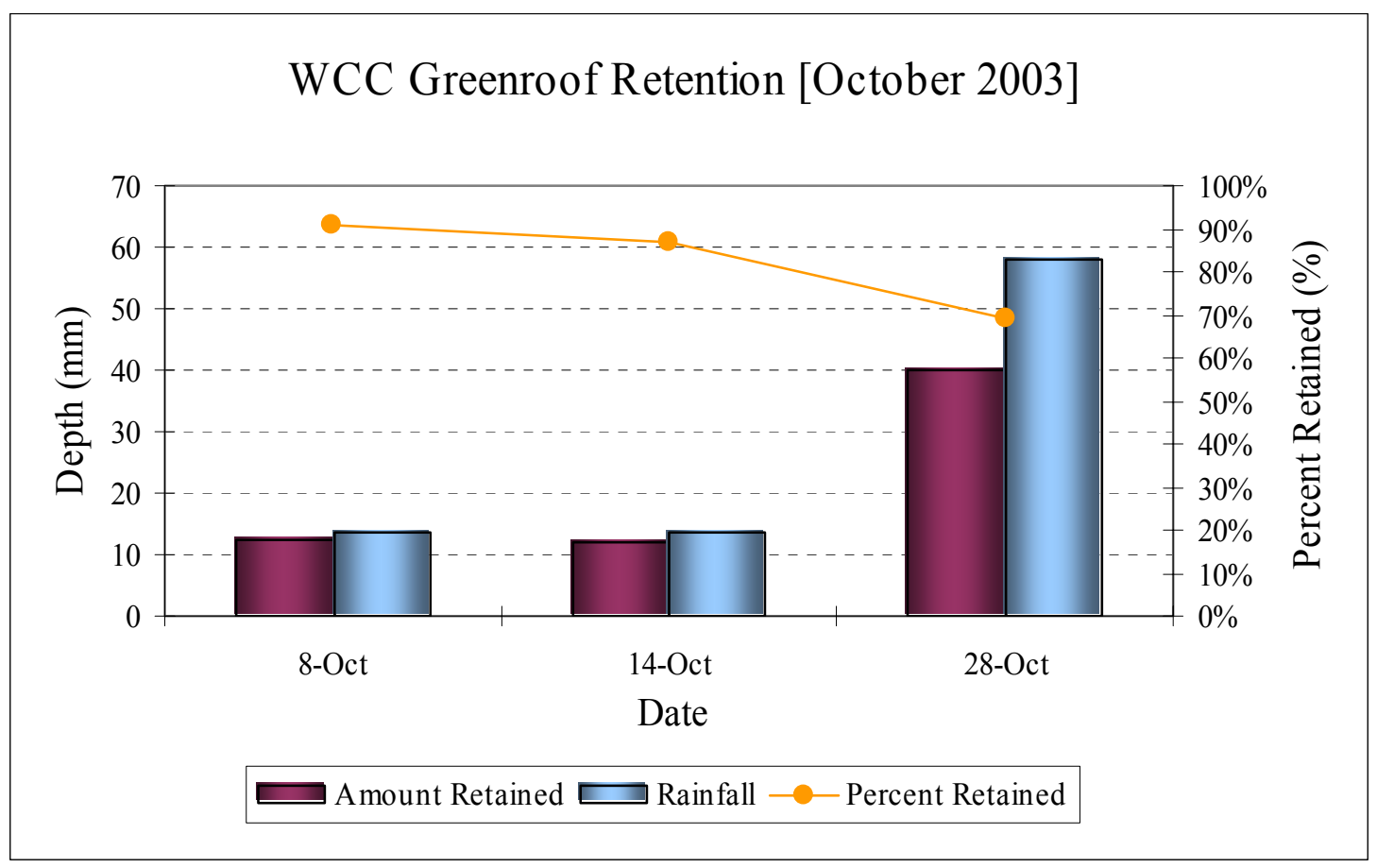

Figure A-7. Display of Percent Retention in October 2003 at WCC Greenroof in Goldsboro, NC. 


\section{A.2.8 NOVEMBER 2003}

Table A-9. Summary Table of Rainfall Data in November 2003 at WCC Greenroof in Goldsboro, NC

\begin{tabular}{|l|c|c|c|c|c|c|c|c|c|c|}
\hline \multirow{3}{*}{ Date } & \multicolumn{2}{|c|}{ Inflow } & \multicolumn{2}{c|}{ Greenroof } & \multicolumn{2}{c|}{ Precipitation Retained } & \multicolumn{3}{c|}{ Peak Flow Reduction } \\
\cline { 2 - 11 } & $\begin{array}{c}\text { Rainfall } \\
\text { (in.) }\end{array}$ & $\begin{array}{c}\text { Rainfall } \\
\text { (mm) }\end{array}$ & $\begin{array}{c}\text { Runoff } \\
\text { (in.) }\end{array}$ & $\begin{array}{c}\text { Runoff } \\
\text { (mm) }\end{array}$ & $\begin{array}{c}\text { Amount } \\
\text { (in.) }\end{array}$ & $\begin{array}{c}\text { Amount } \\
\text { (mm) }\end{array}$ & $\begin{array}{c}\text { Percent } \\
(\%)\end{array}$ & $\begin{array}{c}\text { Rain Peak } \\
(\mathrm{mm} / \mathrm{hr})\end{array}$ & $\begin{array}{c}\text { R/O Peak } \\
(\mathrm{mm} / \mathrm{hr})\end{array}$ & $\begin{array}{c}\text { Percent } \\
(\%)\end{array}$ \\
\hline \hline 19-Nov-2003 & 1.2 & 30.48 & 0.14 & 3.56 & 1.06 & 26.92 & $88 \%$ & 27.5 & 1.24 & $95 \%$ \\
\hline Average & 1.20 & 30.48 & 0.14 & 3.56 & 1.06 & 26.92 & $88 \%$ & 27.5 & 1.24 & $95 \%$ \\
TOTAL & 1.2 & 30.5 & 0.14 & 3.6 & 1.06 & 26.9 & $88 \%$ & & & \\
\hline
\end{tabular}

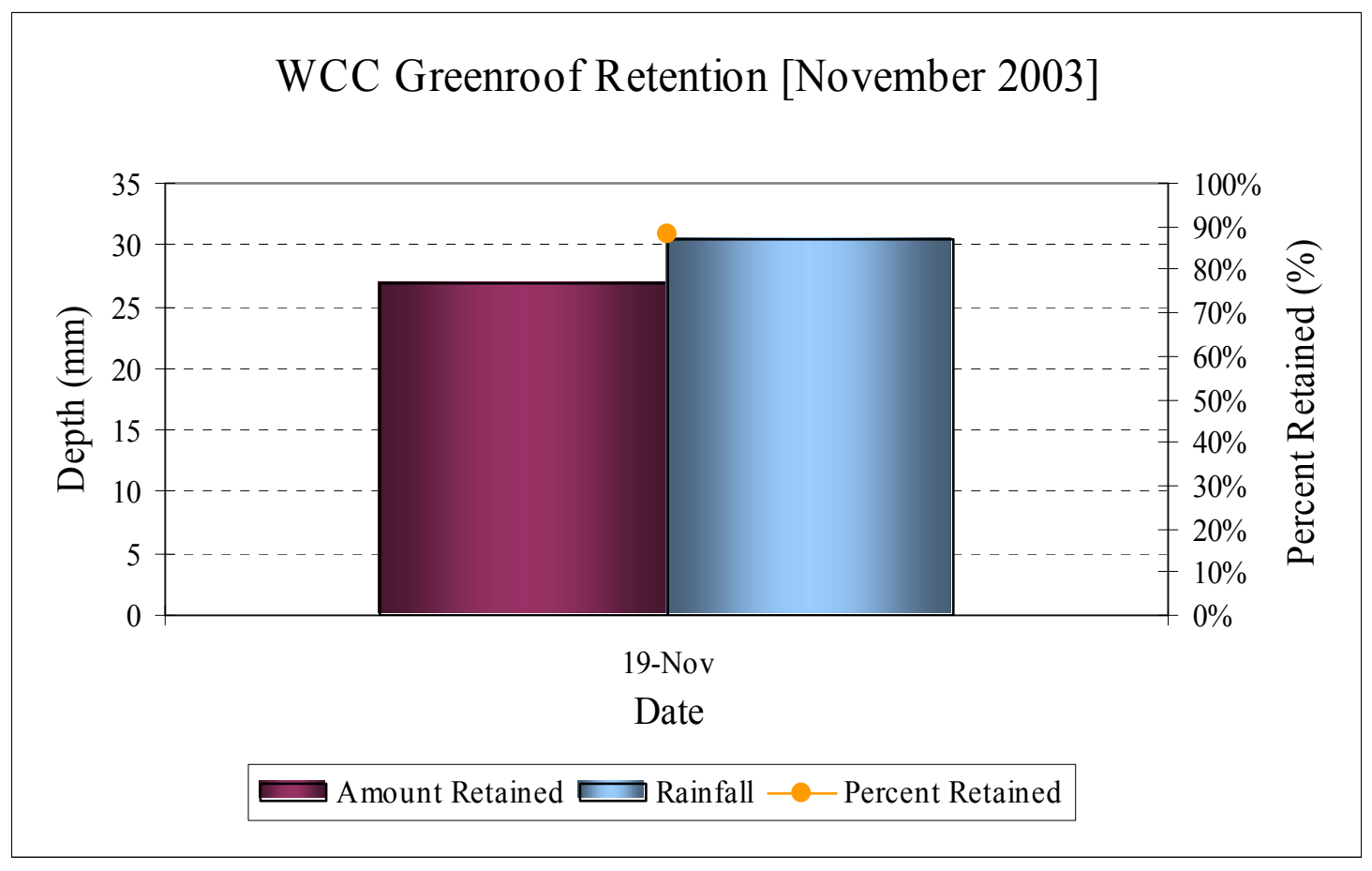

Figure A-8. Display of Percent Retention in November 2003 at WCC Greenroof in Goldsboro, NC. 


\section{A.2.9 DECEMBER 2003}

Table A-10. Summary Table of Rainfall Data in December 2003 at WCC Greenroof in Goldsboro, NC

\begin{tabular}{|l|c|c|c|c|c|c|c|c|c|c|}
\hline \multirow{2}{*}{ Date } & \multicolumn{2}{|c|}{ Inflow } & \multicolumn{2}{c|}{ Greenroof } & \multicolumn{2}{c|}{ Precipitation Retained } & \multicolumn{2}{|c|}{ Peak Flow Reduction } \\
\cline { 2 - 12 } & $\begin{array}{c}\text { Rainfall } \\
\text { (in.) }\end{array}$ & $\begin{array}{c}\text { Rainfall } \\
(\mathrm{mm})\end{array}$ & $\begin{array}{c}\text { Runoff } \\
\text { (in.) }\end{array}$ & $\begin{array}{c}\text { Runoff } \\
(\mathrm{mm})\end{array}$ & $\begin{array}{c}\text { Amount } \\
\text { (in.) }\end{array}$ & $\begin{array}{c}\text { Amount } \\
(\mathrm{mm})\end{array}$ & $\begin{array}{c}\text { Percent } \\
(\%)\end{array}$ & $\begin{array}{c}\text { Rain Peak } \\
(\mathrm{mm} / \mathrm{hr})\end{array}$ & $\begin{array}{c}\text { R/O Peak } \\
(\mathrm{mm} / \mathrm{hr})\end{array}$ & $\begin{array}{c}\text { Percent } \\
(\%)\end{array}$ \\
\hline \hline 4-Dec-2003 & 0.45 & 11.4 & 0.01 & 0.3 & 0.44 & 11.2 & $98 \%$ & 3.05 & 0.13 & $96 \%$ \\
\hline 10-Dec-2003 & 1.52 & 38.6 & 0.71 & 18.0 & 0.81 & 20.6 & $53 \%$ & 15.3 & 7.99 & $48 \%$ \\
\hline 14-Dec-2003 & 1.38 & 35.1 & 0.56 & 14.2 & 0.82 & 20.8 & $59 \%$ & 21.4 & 7.50 & $65 \%$ \\
\hline Average & 1.12 & 28.4 & 0.43 & 10.8 & 0.69 & 17.5 & $70 \%$ & 13.2 & 5.20 & $69 \%$ \\
TOTAL & 3.35 & 85.1 & 1.28 & 32.5 & 2.07 & 52.6 & $62 \%$ & & &
\end{tabular}

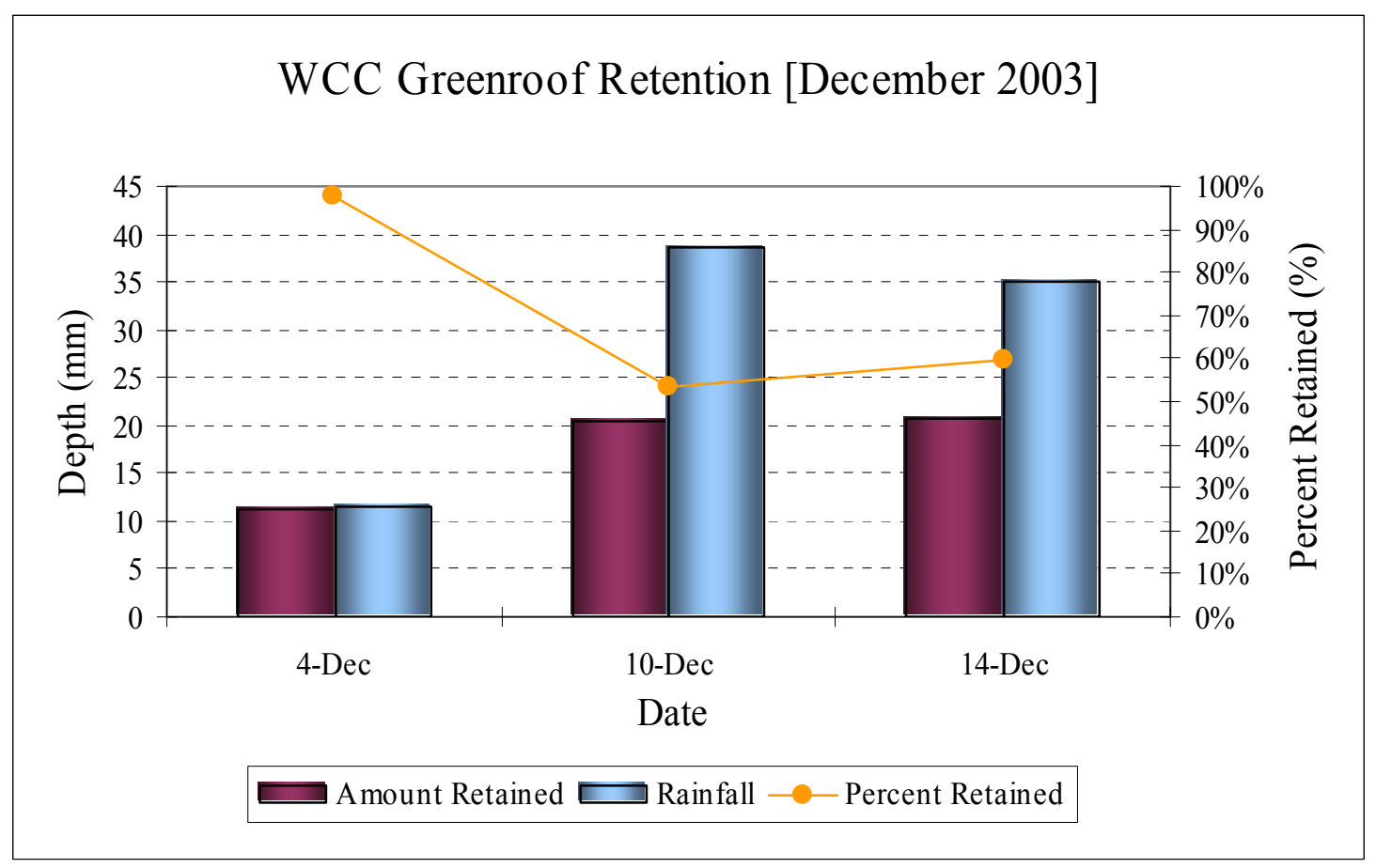

Figure A-9. Display of Percent Retention in December 2003 at WCC Greenroof in Goldsboro, NC. 


\section{B.0 APPENDIX B - GOLDSBORO HYDROLOGIC DATA: STATISTICAL ANALYSIS}

All input data for the statistical analysis of the hydrologic performance of the WCC Greenroof in Goldsboro, NC is presented in Appendix A.

\section{B.1 Water RETENTION}

The distribution of the amount retained (in.) was determined not to be normally distributed through the proc univariate analysis shown below ( $\mathrm{p}$-values $<0.05$ ).

\begin{tabular}{|c|c|c|c|c|}
\hline Test & \multicolumn{2}{|c|}{ - -Statistic- - - } & \multicolumn{2}{|c|}{$\ldots$} \\
\hline Shapiro-Wilk & W & 0.922681 & $\mathrm{Pr}<\mathrm{W}$ & 0.0105 \\
\hline Kolmogorov-Smirnov & $\mathrm{D}$ & 0.123043 & $\mathrm{Pr}>\mathrm{D}$ & 0.1399 \\
\hline Cramer-von Mises & $\mathrm{W}-\mathrm{Sq}$ & 0.125858 & $\mathrm{Pr}>\mathrm{W}-\mathrm{Sq}$ & 0.0483 \\
\hline Anderson-Darling & $\mathrm{A}-\mathrm{Sq}$ & 0.777369 & $\mathrm{Pr}>\mathrm{A}-\mathrm{Sq}$ & 0.0414 \\
\hline
\end{tabular}

A t-test assumes the distribution of the amount retained is normally distributed; therefore, a ttest for this data is invalid. A Sign test was performed and the analysis is shown below. There was a significant statistical difference between the amount of rainfall (in.) and the amount of runoff (in.) from the greenroof $(\alpha<0.05)$. Therefore, the greenroof retained a significant portion of the rainfall.

\begin{tabular}{|c|c|c|c|c|}
\hline Test & \multicolumn{2}{|c|}{-Statistic- } & \multicolumn{2}{|c|}{-... p Value..... } \\
\hline Student's $t$ & $\mathrm{t}$ & 11.10249 & $\operatorname{Pr}>|t|$ & $<.0001$ \\
\hline Sign & M & 19.5 & $\operatorname{Pr}>=|M|$ & $<.0001$ \\
\hline Signed Rank & $\mathrm{S}$ & 390 & $\operatorname{Pr}>=|S|$ & $<.0001$ \\
\hline
\end{tabular}




\section{B.2 PEAK Flow ReduCtion}

The difference between the peak rainfall rate $(\mathrm{mm} / \mathrm{hr})$ and the greenroof runoff $(\mathrm{mm} / \mathrm{hr})$ was determined to not be normally distributed through the proc univariate analysis shown below (p-values $<0.05)$.

\begin{tabular}{|c|c|c|c|c|}
\hline Test & \multicolumn{2}{|c|}{ - -Statistic- - - } & \multicolumn{2}{|c|}{$\ldots$} \\
\hline Shapiro-Wilk & W & 0.900319 & $\mathrm{Pr}<\mathrm{W}$ & 0.0023 \\
\hline Kolmogorov-Smirnov & D & 0.15341 & $\mathrm{Pr}>\mathrm{D}$ & 0.0208 \\
\hline Cramer-von Mises & W-Sq & 0.218188 & $\mathrm{Pr}>\mathrm{W}-\mathrm{Sq}$ & $<0.0050$ \\
\hline Anderson-Darling & $\mathrm{A}-\mathrm{Sq}$ & 1.281516 & $\mathrm{Pr}>\mathrm{A}-\mathrm{Sq}$ & $<0.0050$ \\
\hline
\end{tabular}

A t-test assumes the distribution for the difference between the peak flows is normally distributed; therefore, a t-test for this data is invalid. A Sign test was performed and the analysis is shown below. There was a statistically significant difference between the peak rainfall rate $(\mathrm{mm} / \mathrm{hr})$ and the peak flow of the greenroof runoff $(\mathrm{mm} / \mathrm{hr})(\alpha<0.05)$. Therefore, the peak flow of runoff from the greenroof was significantly less than the peak rainfall rate onto the roof.

\begin{tabular}{|c|c|c|c|c|}
\hline Test & \multicolumn{2}{|c|}{-Statistic- } & \multicolumn{2}{|c|}{$\ldots$} \\
\hline Student's $t$ & $\mathrm{t}$ & 7.951369 & $\operatorname{Pr}>|t|$ & $<.0001$ \\
\hline Sign & M & 19.5 & $\operatorname{Pr}>=|\mathrm{M}|$ & $<.0001$ \\
\hline Signed Rank & $\mathrm{s}$ & 390 & $\operatorname{Pr}>=|S|$ & $<.0001$ \\
\hline
\end{tabular}




\section{C.0 APPENDIX C - KINSTON HYDROLOGIC DATA}

\section{C.1 Total Summary}

Table C-1. Summary Table of Rainfall Events Recorded at Neuseway Nature Center Greenroof in Kinston, NC

\begin{tabular}{|l|c|c|c|c|c|c|}
\hline Date & Rainfall (in.) & Runoff (in.) & Retained (in.) & Rain Peak (mm/hr) & R/O Peak (mm/hr) & Diff (mm/hr) \\
\hline \hline 11-Jul-2003 & 0.71 & 0.06 & 0.65 & 82.3 & 1.77 & 80.53 \\
\hline 4-Aug-2003 & 0.79 & 0.26 & 0.53 & 94.5 & 12.4 & 82.1 \\
\hline 6-Aug-2003 & 0.15 & 0.004 & 0.15 & 12.2 & 0.10 & 12.1 \\
\hline 10-Aug-2003 & 0.22 & 0.03 & 0.19 & 21.3 & 0.69 & 20.61 \\
\hline 16-Aug-2003 & 0.64 & 0.05 & 0.59 & 54.9 & 0.69 & 54.21 \\
\hline 17-Aug-2003 & 2.53 & 1.00 & 1.53 & 60.9 & 12.4 & 48.5 \\
\hline 22-Aug-2003 & 0.3 & 0.00 & 0.30 & 30.5 & 0.15 & 30.35 \\
\hline 19-Nov-2003 & 0.97 & 0.2 & 0.77 & 21.3 & 2.04 & 19.26 \\
\hline 4-Dec-2003 & 0.86 & 0.19 & 0.67 & 12.2 & 1.49 & 10.71 \\
\hline 10-Dec-2003 & 1.53 & 1.18 & 0.35 & 48.7 & 19.6 & 29.1 \\
\hline 14-Dec-2003 & 1.61 & 0.8 & 0.81 & 21.3 & 9.95 & 11.35 \\
\hline
\end{tabular}




\section{C.2 Monthly Summaries}

\section{C.2.1 JULY 2003}

Table C-2. Summary Table of Rainfall Events in July 2003 at Nature Center Greenroof in Kinston, NC

\begin{tabular}{|c|c|c|c|c|c|c|c|c|c|c|}
\hline \multirow[b]{2}{*}{ Date } & \multicolumn{2}{|c|}{ Inflow } & \multicolumn{2}{|c|}{ Greenroof } & \multicolumn{3}{|c|}{ Retained } & \multicolumn{3}{|c|}{ Peak Flow Reduction } \\
\hline & $\begin{array}{c}\text { Rainfall } \\
\text { (in.) }\end{array}$ & \begin{tabular}{|c} 
Rainfall \\
$(\mathrm{mm})$
\end{tabular} & $\begin{array}{l}\text { Runoff } \\
\text { (in.) }\end{array}$ & $\begin{array}{l}\text { Runoff } \\
\text { (mm) }\end{array}$ & $\begin{array}{l}\text { Amount } \\
\text { (in.) }\end{array}$ & $\begin{array}{c}\text { Amount } \\
(\mathrm{mm})\end{array}$ & $\begin{array}{c}\text { Percent } \\
(\%)\end{array}$ & $\begin{array}{c}\text { Rain Peak } \\
(\mathrm{mm} / \mathrm{hr})\end{array}$ & $\begin{array}{l}\text { R/O Peak } \\
(\mathrm{mm} / \mathrm{hr})\end{array}$ & $\begin{array}{c}\text { Percent } \\
(\%)\end{array}$ \\
\hline 11-Jul-2003 & 0.71 & 18.0 & 0.06 & 1.5 & 0.65 & 16.5 & $92 \%$ & 82.3 & 1.77 & $98 \%$ \\
\hline Average & 0.71 & 18.0 & 0.06 & 1.5 & 0.65 & 16.5 & $92 \%$ & 82.3 & 1.77 & $98 \%$ \\
\hline TOTAL & 0.71 & 18.0 & 0.06 & 1.5 & 0.65 & 16.5 & $92 \%$ & & & \\
\hline
\end{tabular}

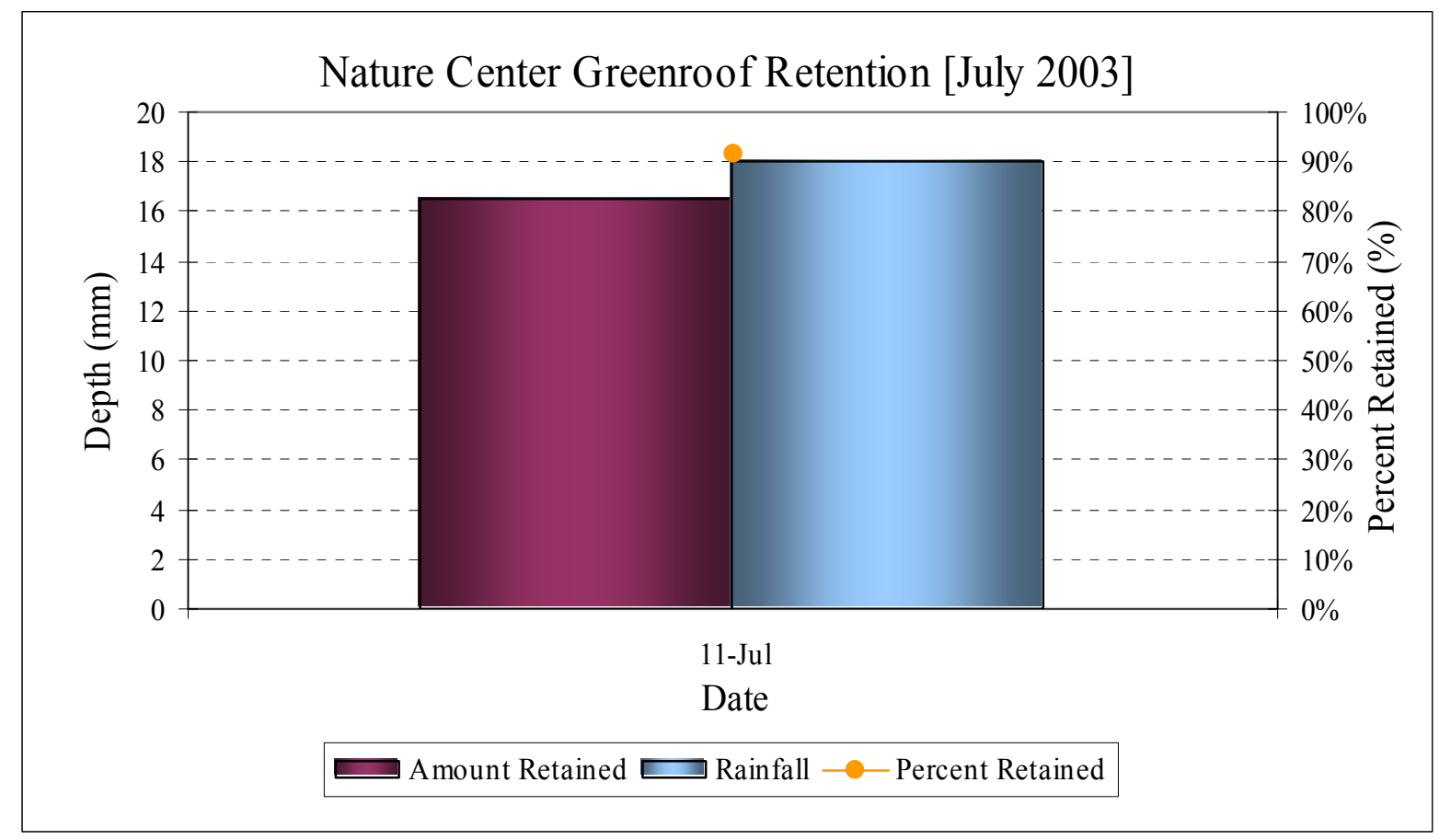

Figure C-1. Display of Percent Retention in July 2003 at Nature Center Greenroof in Kinston, NC 


\section{C.2.2 August 2003}

Table C-3. Summary Table of Rainfall Events in August 2003 at Nature Center Greenroof in Kinston, NC

\begin{tabular}{|l|c|c|c|c|c|c|c|c|c|c|}
\hline \multirow{2}{*}{ Date } & \multicolumn{2}{|c|}{ Inflow } & \multicolumn{2}{c|}{ Greenroof } & \multicolumn{3}{c|}{ Retained } & \multicolumn{3}{c|}{ Peak Flow Reduction } \\
\cline { 2 - 13 } & $\begin{array}{c}\text { Rainfall } \\
\text { (in.) }\end{array}$ & $\begin{array}{c}\text { Rainfall } \\
(\mathrm{mm})\end{array}$ & $\begin{array}{c}\text { Runoff } \\
\text { (in.) }\end{array}$ & $\begin{array}{c}\text { Runoff } \\
(\mathrm{mm})\end{array}$ & $\begin{array}{c}\text { Amount } \\
\text { (in.) }\end{array}$ & $\begin{array}{c}\text { Amount } \\
(\mathrm{mm})\end{array}$ & $\begin{array}{c}\text { Percent } \\
(\%)\end{array}$ & $\begin{array}{c}\text { Rain Peak } \\
(\mathrm{mm} / \mathrm{hr})\end{array}$ & $\begin{array}{c}\text { R/O Peak } \\
(\mathrm{mm} / \mathrm{hr})\end{array}$ & $\begin{array}{c}\text { Percent } \\
(\%)\end{array}$ \\
\hline \hline 4-Aug-2003 & 0.79 & 20.1 & 0.26 & 6.6 & 0.53 & 13.5 & $67 \%$ & 94.5 & 12.4 & $87 \%$ \\
\hline 6-Aug-2003 & 0.15 & 3.8 & 0.004 & 0.1 & 0.15 & 3.7 & $97 \%$ & 12.2 & 0.10 & $99 \%$ \\
\hline 10-Aug-2003 & 0.22 & 5.6 & 0.03 & 0.8 & 0.19 & 4.8 & $86 \%$ & 21.3 & 0.69 & $97 \%$ \\
\hline 16-Aug-2003 & 0.64 & 16.3 & 0.05 & 1.3 & 0.59 & 15.0 & $92 \%$ & 54.9 & 0.69 & $99 \%$ \\
\hline 17-Aug-2003 & 2.53 & 64.3 & 1.00 & 25.4 & 1.53 & 38.9 & $60 \%$ & 60.9 & 12.4 & $80 \%$ \\
\hline 22-Aug-2003 & 0.3 & 7.6 & 0.00 & 0.0 & 0.30 & 7.6 & $100 \%$ & 30.5 & 0.15 & $100 \%$ \\
\hline Average & 0.77 & 19.6 & 0.22 & 5.7 & 0.55 & 13.9 & $84 \%$ & 45.7 & 4.4 & $93 \%$ \\
TOTAL & 4.63 & 117.6 & 1.34 & 34.1 & 3.29 & 83.5 & $71 \%$ & & &
\end{tabular}

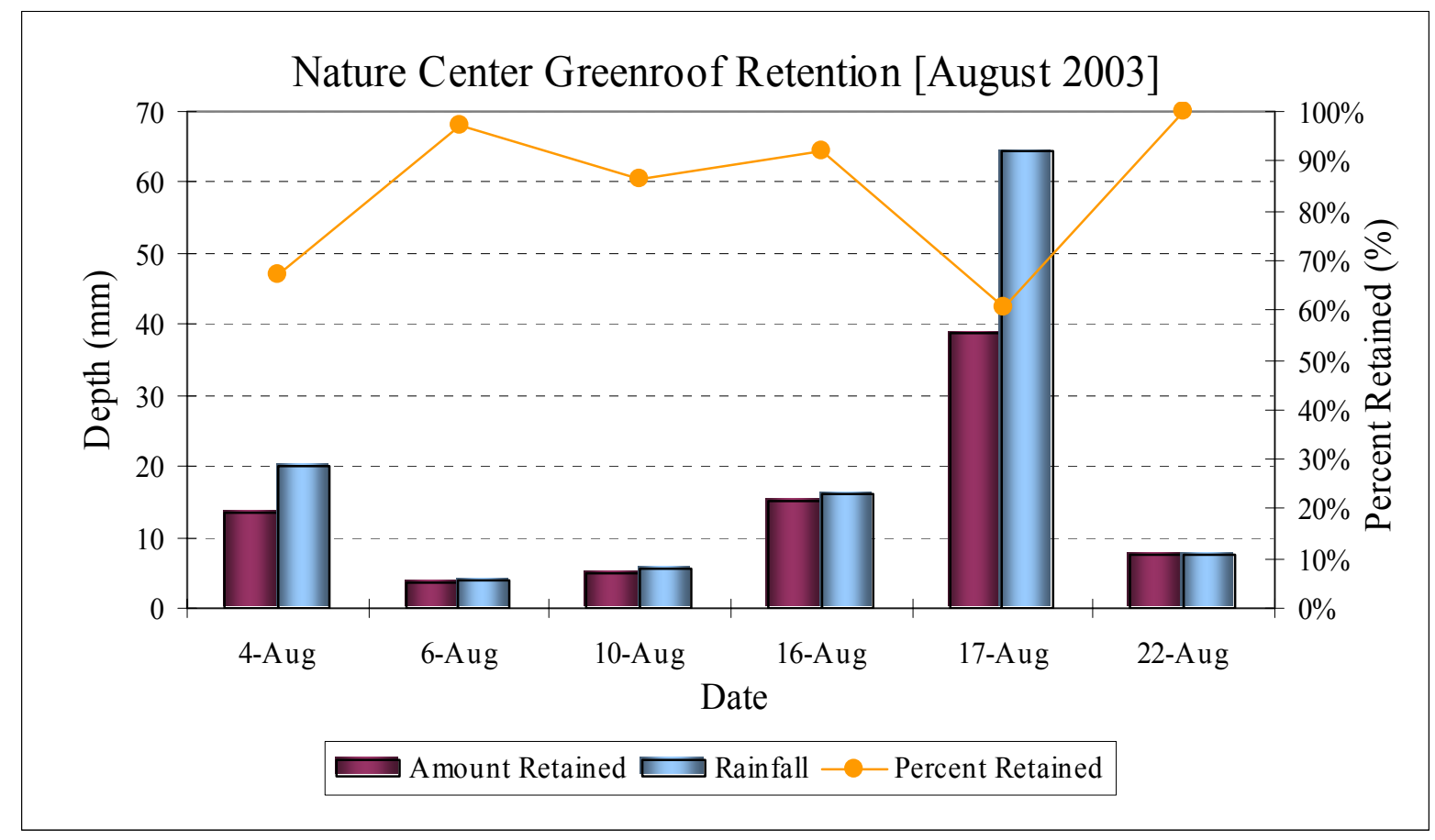

Figure C-2. Display of Percent Retention in August 2003 at Nature Center Greenroof in Kinston, NC 


\section{C.2.3 November 2003}

Table C-4. Summary Table of Rainfall Events in November 2003 at Nature Center Greenroof in Kinston, NC

\begin{tabular}{|c|c|c|c|c|c|c|c|c|c|c|}
\hline \multirow[b]{2}{*}{ Date } & \multicolumn{2}{|c|}{ Inflow } & \multicolumn{2}{|c|}{ Greenroof } & \multicolumn{3}{|c|}{ Retained } & \multicolumn{3}{|c|}{ Peak Flow Reduction } \\
\hline & \begin{tabular}{|c} 
Rainfall \\
(in.)
\end{tabular} & $\begin{array}{c}\text { Rainfall } \\
(\mathrm{mm})\end{array}$ & $\begin{array}{c}\text { Runoff } \\
\text { (in.) } \\
\end{array}$ & $\begin{array}{c}\text { Runoff } \\
(\mathrm{mm})\end{array}$ & $\begin{array}{c}\text { Amount } \\
\text { (in.) } \\
\end{array}$ & $\begin{array}{c}\text { Amount } \\
(\mathrm{mm})\end{array}$ & $\begin{array}{c}\text { Percent } \\
(\%) \\
\end{array}$ & $\begin{array}{c}\text { Rain Peak } \\
(\mathrm{mm} / \mathrm{hr})\end{array}$ & $\begin{array}{c}\mathrm{R} / \mathrm{O} \text { Peak } \\
(\mathrm{mm} / \mathrm{hr})\end{array}$ & \begin{tabular}{|c} 
Percent \\
$(\%)$
\end{tabular} \\
\hline 19-Nov-2003 & 0.97 & 24.6 & 0.2 & 5.1 & 0.77 & 19.6 & $79 \%$ & 21.3 & 2.04 & $90 \%$ \\
\hline Average & 0.97 & 24.6 & 0.20 & 5.1 & 0.77 & 19.6 & $79 \%$ & 21.3 & 2.04 & $90 \%$ \\
\hline TOTAL & 0.97 & 24.6 & 0.20 & 5.1 & 0.77 & 19.6 & $79 \%$ & & & \\
\hline
\end{tabular}

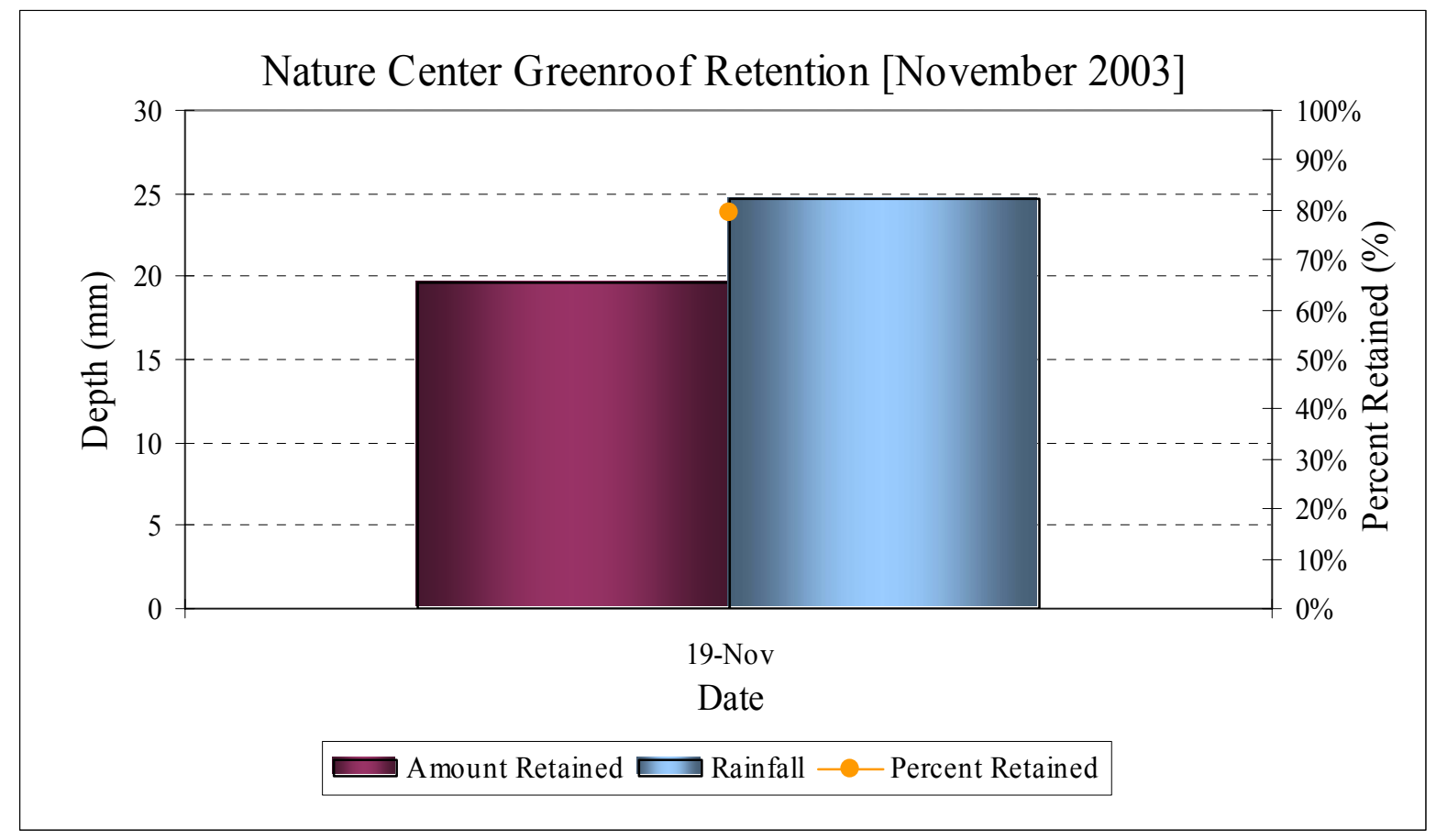

Figure C-3. Display of Percent Retention in November 2003 at Nature Center Greenroof in Kinston, NC 


\section{C.2.4 DeCEMBER 2003}

Table C-5. Summary Table of Rainfall Events at Nature Center Greenroof in December 2003

\begin{tabular}{|l|c|c|c|c|c|c|c|c|c|c|}
\hline \multirow{2}{*}{ Date } & \multicolumn{2}{|c|}{ Inflow } & \multicolumn{2}{c|}{ Greenroof } & \multicolumn{3}{c|}{ Retained } & \multicolumn{2}{c|}{ Peak Flow Reduction } \\
\cline { 2 - 12 } & $\begin{array}{c}\text { Rainfall } \\
\text { (in.) }\end{array}$ & $\begin{array}{c}\text { Rainfall } \\
\text { (mm) }\end{array}$ & $\begin{array}{c}\text { Runoff } \\
\text { (in.) }\end{array}$ & $\begin{array}{c}\text { Runoff } \\
\text { (mm) }\end{array}$ & $\begin{array}{c}\text { Amount } \\
\text { (in.) }\end{array}$ & $\begin{array}{c}\text { Amount } \\
(\mathrm{mm})\end{array}$ & $\begin{array}{c}\text { Percent } \\
(\%)\end{array}$ & $\begin{array}{c}\text { Rain Peak } \\
(\mathrm{mm} / \mathrm{hr})\end{array}$ & $\begin{array}{c}\text { R/O Peak } \\
(\mathrm{mm} / \mathrm{hr})\end{array}$ & $\begin{array}{c}\text { Percent } \\
(\%)\end{array}$ \\
\hline \hline 4-Dec-2003 & 0.86 & 21.84 & 0.19 & 4.83 & 0.67 & 17.02 & $78 \%$ & 12.2 & 1.49 & $88 \%$ \\
\hline 10-Dec-2003 & 1.53 & 38.86 & 1.18 & 29.97 & 0.35 & 8.89 & $23 \%$ & 48.7 & 19.6 & $60 \%$ \\
\hline 14-Dec-2003 & 1.61 & 40.89 & 0.8 & 20.32 & 0.81 & 20.57 & $50 \%$ & 21.3 & 9.95 & $53 \%$ \\
\hline Average & 1.33 & 33.87 & 0.72 & 18.37 & 0.61 & 15.49 & $50 \%$ & 27.4 & 10.33 & $67 \%$ \\
TOTAL & 4.0 & 101.6 & 2.17 & 55.1 & 1.83 & 46.5 & $46 \%$ & & &
\end{tabular}

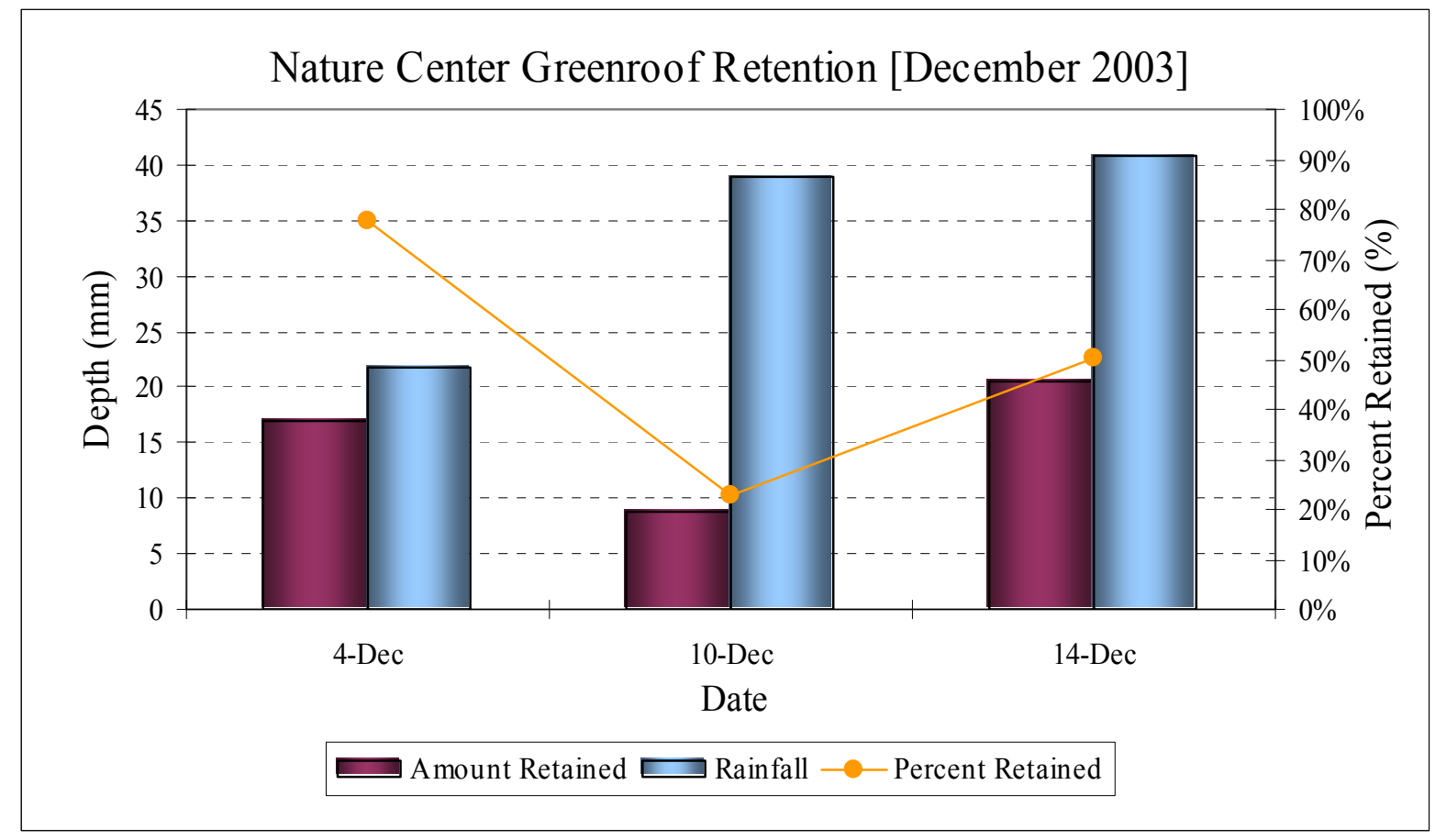

Figure C-4. Display of Percent Retention in December 2003 at Nature Center Greenroof in Kinston, NC 


\section{D.0 APPENDIX D - KINSTON HYDROLOGIC DATA: STATISTICAL ANALYSIS}

All input data for the statistical analysis of the hydrologic performance of the Neuseway Nature Center Greenroof in Kinston, NC is presented in Appendix C.

\section{D.1 WATER RETENTION}

The distribution of the amount retained (in.) was determined to be normally distributed through the proc univariate analysis shown below ( $p$-values $>0.05)$.

\begin{tabular}{|c|c|c|c|c|}
\hline Test & \multicolumn{2}{|c|}{ - -Statistic-- - } & \multicolumn{2}{|c|}{$\ldots$} \\
\hline Shapiro-Wilk & W & 0.880403 & $\mathrm{Pr}<\mathrm{W}$ & 0.1053 \\
\hline Kolmogorov-Smirnov & $\mathrm{D}$ & 0.196366 & $\mathrm{Pr}>\mathrm{D}$ & $>0.1500$ \\
\hline Cramer-von Mises & W-Sq & 0.062984 & $\mathrm{Pr}>\mathrm{W}-\mathrm{Sq}$ & $>0.2500$ \\
\hline Anderson-Darling & $\mathrm{A}-\mathrm{Sq}$ & 0.47636 & $\mathrm{Pr}>\mathrm{A}-\mathrm{Sq}$ & 0.1976 \\
\hline
\end{tabular}

A t-test was performed and the analysis is shown below. There was a statistically significant difference between the amount of rainfall and the amount of runoff from the greenroof $(\alpha<$ 0.05). Therefore, the greenroof is retaining a significant portion of the rainfall.

\begin{tabular}{|c|c|c|c|c|c|c|c|c|}
\hline \multirow[b]{3}{*}{ Difference } & \multicolumn{6}{|c|}{ Statistics } & & \\
\hline & \multicolumn{2}{|c|}{ Lower CL } & \multicolumn{2}{|r|}{ Upper CL } & Lower CL & \multicolumn{3}{|c|}{ Upper CL } \\
\hline & $\mathrm{N}$ & Mean & Mean & Mean & Std Dev & Std Dev & Std Dev & Std Err \\
\hline Rainfall - Runoff & 11 & 0.336 & 0.5942 & 0.8523 & 0.2685 & 0.3843 & 0.6744 & 0.1159 \\
\hline \multicolumn{9}{|c|}{$\mathrm{T}$-Tests } \\
\hline \multicolumn{4}{|c|}{ Difference } & DF & Value & \multicolumn{3}{|l|}{$\operatorname{Pr}>|\mathrm{t}|$} \\
\hline & Rainf & - Run & & 10 & 5.13 & 0.0004 & & \\
\hline
\end{tabular}




\section{D.2 Peak Flow Reduction}

The difference between the peak rainfall rate $(\mathrm{mm} / \mathrm{hr})$ and the greenroof runoff $(\mathrm{mm} / \mathrm{hr})$ was determined to not be normally distributed through the proc univariate analysis shown below (p-values $<0.05)$.

\begin{tabular}{|c|c|c|c|c|}
\hline Test & - -Sta & tistic- - & $\ldots-p$ Va] & e - - . - \\
\hline Shapiro-Wilk & W & 0.852554 & $\mathrm{Pr}<\mathrm{W}$ & 0.0461 \\
\hline Kolmogorov-Smirnov & $\mathrm{D}$ & 0.224761 & $\mathrm{Pr}>\mathrm{D}$ & 0.1207 \\
\hline Cramer-von Mises & $\mathrm{W}-\mathrm{Sq}$ & 0.098455 & $\mathrm{Pr}>\mathrm{W}-\mathrm{Sq}$ & 0.1041 \\
\hline Anderson-Darling & $\mathrm{A}-\mathrm{Sq}$ & 0.631962 & $\mathrm{Pr}>\mathrm{A}-\mathrm{Sq}$ & 0.0769 \\
\hline
\end{tabular}

A t-test assumes the distribution for the difference between the peak flows is normally distributed; therefore, a t-test for this data is invalid. A Sign test was performed and the analysis is shown below. There was a statistically significant difference between the peak rainfall rate $(\mathrm{mm} / \mathrm{hr})$ and the peak flow of the greenroof runoff $(\mathrm{mm} / \mathrm{hr})(\alpha<0.05)$. Therefore, the runoff peak flow from the greenroof was significantly less than the peak rainfall rate onto the roof.

\begin{tabular}{|c|c|c|c|c|}
\hline Test & \multicolumn{2}{|c|}{-Statistic- } & \multicolumn{2}{|c|}{$\ldots$. } \\
\hline Student's $t$ & $t$ & 4.546839 & $\operatorname{Pr}>|t|$ & 0.0011 \\
\hline Sign & M & 5.5 & $\operatorname{Pr}>=|\mathrm{M}|$ & 0.0010 \\
\hline Signed Rank & $\mathrm{S}$ & 33 & $\operatorname{Pr}>=|S|$ & 0.0010 \\
\hline
\end{tabular}


North CARolina StATE UniVERSity

178

\section{E.0 APPENDIX E - GOLDSBORO WATER QUALITY DATA}

\section{E.1 TKN, $\mathrm{NO}_{3}-\mathrm{NO}_{2}$, AND TN}

Table E-1. Summary Table of TKN as $\mathrm{N}, \mathrm{NO}_{3}-\mathrm{NO}_{2}$ as $\mathrm{N}$, and $\mathrm{TN}$ Concentration and Mass Loading at WCC Greenroof in Goldsboro, NC

\begin{tabular}{|c|c|c|c|c|c|c|c|c|c|}
\hline \multirow[b]{2}{*}{ DATE } & \multirow[b]{2}{*}{ Source } & \multicolumn{2}{|c|}{$\begin{array}{c}\text { INFLOW/ } \\
\text { OUTFLOW }\end{array}$} & \multicolumn{2}{|c|}{ TKN as $\mathrm{N}$} & \multicolumn{2}{|c|}{$\mathrm{NO}_{3}-\mathrm{NO}_{2}$ as $\mathrm{N}$} & \multicolumn{2}{|c|}{$\mathrm{TN}$} \\
\hline & & in. & $\mathrm{L}$ & $\mathrm{mg} / \mathrm{L}$ & $\mathrm{g}$ & $\mathrm{mg} / \mathrm{L}$ & $\mathrm{g}$ & $\mathrm{mg} / \mathrm{L}$ & $\mathrm{g}$ \\
\hline \multirow{3}{*}{6 May } & RAINFALL (in) & 0.77 & 95.11 & $\mathrm{n} / \mathrm{a}$ & $\mathrm{n} / \mathrm{a}$ & $\mathrm{n} / \mathrm{a}$ & $\mathrm{n} / \mathrm{a}$ & $\mathrm{n} / \mathrm{a}$ & $\mathrm{n} / \mathrm{a}$ \\
\hline & GREENROOF (out) & 0.13 & 16.06 & 3.44 & 0.055 & 1.93 & 0.031 & 5.37 & 0.086 \\
\hline & CONTROL (out) & 0.52 & 64.23 & 6.91 & 0.444 & 0.29 & 0.019 & 7.2 & 0.462 \\
\hline \multirow{3}{*}{19 May } & RAINFALL (in) & 0.77 & 95.11 & 0.25 & 0.024 & 0.11 & 0.010 & 0.36 & 0.034 \\
\hline & GREENROOF (out) & 0.11 & 13.59 & 4.03 & 0.055 & 1.36 & 0.018 & 5.39 & 0.073 \\
\hline & CONTROL (out) & 0.52 & 64.23 & $\mathrm{n} / \mathrm{a}$ & $\mathrm{n} / \mathrm{a}$ & $\mathrm{n} / \mathrm{a}$ & $\mathrm{n} / \mathrm{a}$ & $\mathrm{n} / \mathrm{a}$ & $\mathrm{n} / \mathrm{a}$ \\
\hline \multirow{3}{*}{22 May } & RAINFALL (in) & 1.36 & 167.98 & 0.53 & 0.089 & 0.11 & 0.018 & 0.64 & 0.108 \\
\hline & GREENROOF (out) & 1.11 & 137.10 & 2.2 & 0.302 & 0.5 & 0.069 & 2.7 & 0.370 \\
\hline & CONTROL (out) & 1.11 & 137.10 & $\mathrm{n} / \mathrm{a}$ & $\mathrm{n} / \mathrm{a}$ & $\mathrm{n} / \mathrm{a}$ & $\mathrm{n} / \mathrm{a}$ & $\mathrm{n} / \mathrm{a}$ & $\mathrm{n} / \mathrm{a}$ \\
\hline \multirow{3}{*}{2 July } & RAINFALL (in) & 0.98 & 121.04 & 0.25 & 0.030 & 0.09 & 0.011 & 0.34 & 0.041 \\
\hline & GREENROOF (out) & 0.36 & 44.46 & 2.21 & 0.098 & 1.63 & 0.072 & 3.84 & 0.171 \\
\hline & CONTROL (out) & 0.73 & 90.17 & $\mathrm{n} / \mathrm{a}$ & $\mathrm{n} / \mathrm{a}$ & $\mathrm{n} / \mathrm{a}$ & $\mathrm{n} / \mathrm{a}$ & $\mathrm{n} / \mathrm{a}$ & $\mathrm{n} / \mathrm{a}$ \\
\hline \multirow{3}{*}{23 July } & RAINFALL (in) & 3.05 & 376.72 & 0.67 & 0.252 & 0.12 & 0.045 & 0.79 & 0.298 \\
\hline & GREENROOF (out) & 1.88 & 232.21 & 0.93 & 0.216 & 0.27 & 0.063 & 1.2 & 0.279 \\
\hline & CONTROL (out) & 2.80 & 345.84 & 1.19 & 0.412 & 0.91 & 0.315 & 2.1 & 0.726 \\
\hline \multirow{3}{*}{$4 \mathrm{Sept}$} & RAINFALL (in) & 1.32 & 163.04 & 0.77 & 0.126 & 0.18 & 0.029 & 0.95 & 0.155 \\
\hline & GREENROOF (out) & 0.46 & 56.82 & 2.41 & 0.137 & 4.44 & 0.252 & 6.85 & 0.389 \\
\hline & CONTROL (out) & 1.07 & 132.16 & 1.06 & 0.140 & 0.23 & 0.030 & 1.29 & 0.170 \\
\hline \multirow{3}{*}{$18 \mathrm{Sept}$} & RAINFALL (in) & 1.29 & 159.33 & 1.84 & 0.293 & 0.57 & 0.091 & 2.41 & 0.384 \\
\hline & GREENROOF (out) & 0.26 & 32.11 & 3.37 & 0.108 & 0.97 & 0.031 & 4.34 & 0.139 \\
\hline & CONTROL (out) & 1.04 & 128.45 & 0.48 & 0.062 & 0.23 & 0.030 & 0.71 & 0.091 \\
\hline \multirow{3}{*}{8 Oct } & RAINFALL (in) & 0.54 & 66.70 & 0.61 & 0.041 & 0.22 & 0.015 & 0.83 & 0.055 \\
\hline & GREENROOF (out) & 0.05 & 6.18 & 3.35 & 0.021 & 1.43 & 0.009 & 4.78 & 0.030 \\
\hline & CONTROL (out) & 0.29 & 35.82 & $\mathrm{n} / \mathrm{a}$ & $\mathrm{n} / \mathrm{a}$ & $\mathrm{n} / \mathrm{a}$ & $\mathrm{n} / \mathrm{a}$ & $\mathrm{n} / \mathrm{a}$ & $\mathrm{n} / \mathrm{a}$ \\
\hline \multirow{3}{*}{$10 \mathrm{Dec}$} & RAINFALL (in) & 1.52 & 187.74 & 0.25 & 0.009 & 0.06 & 0.002 & 0.06 & 0.002 \\
\hline & GREENROOF (out) & 0.71 & 87.69 & 0.63 & 0.055 & 0.11 & 0.010 & 0.74 & 0.065 \\
\hline & CONTROL (out) & 1.27 & 156.86 & 0.45 & 0.071 & 0.25 & 0.039 & 0.7 & 0.110 \\
\hline
\end{tabular}




\section{E.2 $\mathrm{NH}_{3}, \mathrm{TP}$, AND OP}

Table E-2. Summary Table of $\mathrm{NH}_{3}$, TP, and OP Concentration and Mass Loading at WCC Greenroof in Goldsboro, NC

\begin{tabular}{|c|c|c|c|c|c|c|c|c|c|}
\hline \multirow[b]{2}{*}{ DATE } & \multirow[b]{2}{*}{ Source } & \multicolumn{2}{|c|}{$\begin{array}{c}\text { INFLOW/ } \\
\text { OUTFLOW }\end{array}$} & \multicolumn{2}{|c|}{$\mathrm{NH}_{3}$ as $\mathrm{N}$} & \multicolumn{2}{|c|}{ TP } & \multicolumn{2}{|c|}{$\mathrm{OP}$} \\
\hline & & in. & $\mathrm{L}$ & $\mathrm{mg} / \mathrm{L}$ & $\mathrm{g}$ & $\mathrm{mg} / \mathrm{L}$ & $\mathrm{g}$ & $\mathrm{mg} / \mathrm{L}$ & $\mathrm{g}$ \\
\hline \multirow{3}{*}{6 May } & RAINFALL (in) & 0.77 & 95.11 & $\mathrm{n} / \mathrm{a}$ & $\mathrm{n} / \mathrm{a}$ & $\mathrm{n} / \mathrm{a}$ & $\mathrm{n} / \mathrm{a}$ & $\mathrm{n} / \mathrm{a}$ & $\mathrm{n} / \mathrm{a}$ \\
\hline & GREENROOF (out) & 0.13 & 16.06 & 0.64 & 0.010 & 1.01 & 0.016 & 0.82 & 0.013 \\
\hline & CONTROL (out) & 0.52 & 64.23 & 4.12 & 0.265 & 0.35 & 0.022 & 0.14 & 0.009 \\
\hline \multirow{3}{*}{19 May } & RAINFALL (in) & 0.77 & 95.11 & 0.17 & 0.016 & 0.05 & 0.005 & 0.02 & 0.002 \\
\hline & GREENROOF (out) & 0.11 & 13.59 & 0.6 & 0.008 & 1.41 & 0.019 & 1.22 & 0.017 \\
\hline & CONTROL (out) & 0.52 & 64.23 & $\mathrm{n} / \mathrm{a}$ & $\mathrm{n} / \mathrm{a}$ & $\mathrm{n} / \mathrm{a}$ & $\mathrm{n} / \mathrm{a}$ & $\mathrm{n} / \mathrm{a}$ & $\mathrm{n} / \mathrm{a}$ \\
\hline \multirow{3}{*}{22 May } & RAINFALL (in) & 1.36 & 167.98 & 0.22 & 0.037 & 0.05 & 0.008 & 0.01 & 0.002 \\
\hline & GREENROOF (out) & 1.11 & 137.10 & 0.17 & 0.023 & 1.17 & 0.160 & 0.24 & 0.033 \\
\hline & CONTROL (out) & 1.11 & 137.10 & $\mathrm{n} / \mathrm{a}$ & $\mathrm{n} / \mathrm{a}$ & $\mathrm{n} / \mathrm{a}$ & $\mathrm{n} / \mathrm{a}$ & $\mathrm{n} / \mathrm{a}$ & $\mathrm{n} / \mathrm{a}$ \\
\hline \multirow{3}{*}{2 July } & RAINFALL (in) & 0.98 & 121.04 & 0.22 & 0.027 & 0.05 & 0.006 & 0.02 & 0.002 \\
\hline & GREENROOF (out) & 0.36 & 44.46 & 0.08 & 0.004 & 1.12 & 0.050 & 1.18 & 0.052 \\
\hline & CONTROL (out) & 0.73 & 90.17 & $\mathrm{n} / \mathrm{a}$ & $\mathrm{n} / \mathrm{a}$ & $\mathrm{n} / \mathrm{a}$ & $\mathrm{n} / \mathrm{a}$ & $\mathrm{n} / \mathrm{a}$ & $\mathrm{n} / \mathrm{a}$ \\
\hline \multirow{3}{*}{23 July } & RAINFALL (in) & 3.05 & 376.72 & $\mathrm{n} / \mathrm{a}$ & $\mathrm{n} / \mathrm{a}$ & 0.05 & 0.019 & $\mathrm{n} / \mathrm{a}$ & $\mathrm{n} / \mathrm{a}$ \\
\hline & GREENROOF (out) & 1.88 & 232.21 & $\mathrm{n} / \mathrm{a}$ & $\mathrm{n} / \mathrm{a}$ & 0.61 & 0.142 & $\mathrm{n} / \mathrm{a}$ & $\mathrm{n} / \mathrm{a}$ \\
\hline & CONTROL (out) & 2.80 & 345.84 & $\mathrm{n} / \mathrm{a}$ & $\mathrm{n} / \mathrm{a}$ & 0.05 & 0.017 & $\mathrm{n} / \mathrm{a}$ & $\mathrm{n} / \mathrm{a}$ \\
\hline \multirow{3}{*}{$4 \mathrm{Sept}$} & RAINFALL (in) & 1.32 & 163.04 & 0.54 & 0.088 & 0.05 & 0.008 & 0.02 & 0.003 \\
\hline & GREENROOF (out) & 0.46 & 56.82 & 0.02 & 0.001 & 0.96 & 0.055 & 1.1 & 0.062 \\
\hline & CONTROL (out) & 1.07 & 132.16 & 0.71 & 0.094 & 0.05 & 0.007 & 0.02 & 0.003 \\
\hline \multirow{3}{*}{18 Sept } & RAINFALL (in) & 1.29 & 159.33 & 0.02 & 0.003 & 0.05 & 0.008 & 0.02 & 0.003 \\
\hline & GREENROOF (out) & 0.26 & 32.11 & 0.02 & 0.001 & 1.4 & 0.045 & 1.16 & 0.037 \\
\hline & CONTROL (out) & 1.04 & 128.45 & 0.17 & 0.022 & 0.05 & 0.006 & 0.02 & 0.003 \\
\hline \multirow{3}{*}{8 Oct } & RAINFALL (in) & 0.54 & 66.70 & 0.26 & 0.017 & 0.05 & 0.003 & 0.02 & 0.001 \\
\hline & GREENROOF (out) & 0.05 & 6.18 & 0.02 & 0.000 & 0.98 & 0.006 & 0.83 & 0.005 \\
\hline & CONTROL (out) & 0.29 & 35.82 & $\mathrm{n} / \mathrm{a}$ & $\mathrm{n} / \mathrm{a}$ & $\mathrm{n} / \mathrm{a}$ & $\mathrm{n} / \mathrm{a}$ & $\mathrm{n} / \mathrm{a}$ & $\mathrm{n} / \mathrm{a}$ \\
\hline \multirow{3}{*}{$10 \mathrm{Dec}$} & RAINFALL (in) & 1.52 & 187.74 & 0.07 & 0.003 & 0.05 & 0.002 & 0.02 & 0.001 \\
\hline & GREENROOF (out) & 0.71 & 87.69 & 0.02 & 0.002 & 0.64 & 0.056 & 0.72 & 0.063 \\
\hline & CONTROL (out) & 1.27 & 156.86 & 0.07 & 0.011 & 0.05 & 0.008 & 0.02 & 0.003 \\
\hline
\end{tabular}




\section{E.3 Graphs OF CONCENTRATIONS AND MASS LoAdingS FOR EACH NUTRIENT}

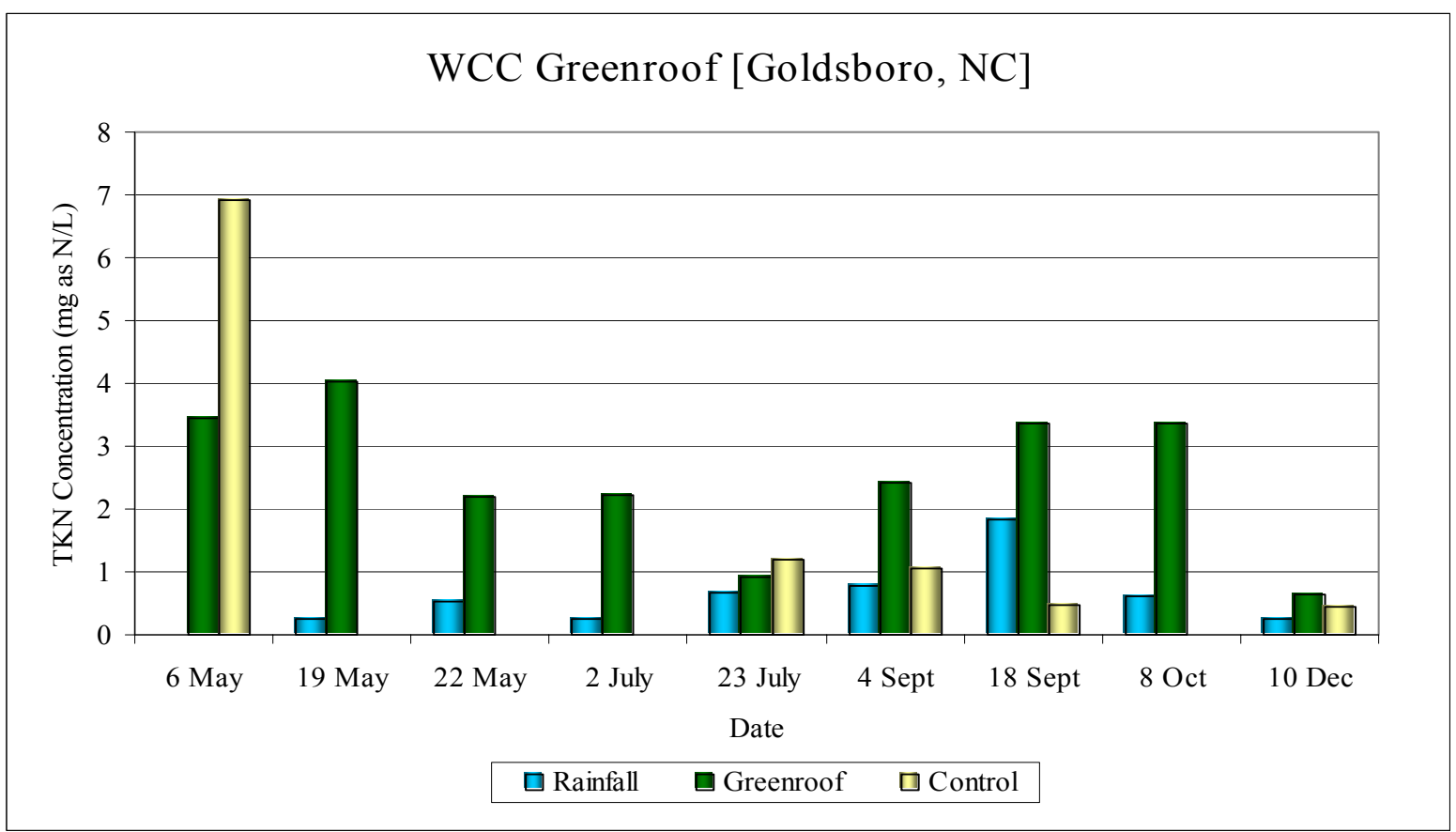

Figure E-1. Display of TKN Concentrations at WCC Greenroof in Goldsboro, NC. (Note: Rainfall data is unavailable for 6 May; Control data is unavailable for 19 May, 22 May, 2 July, and 8 October)

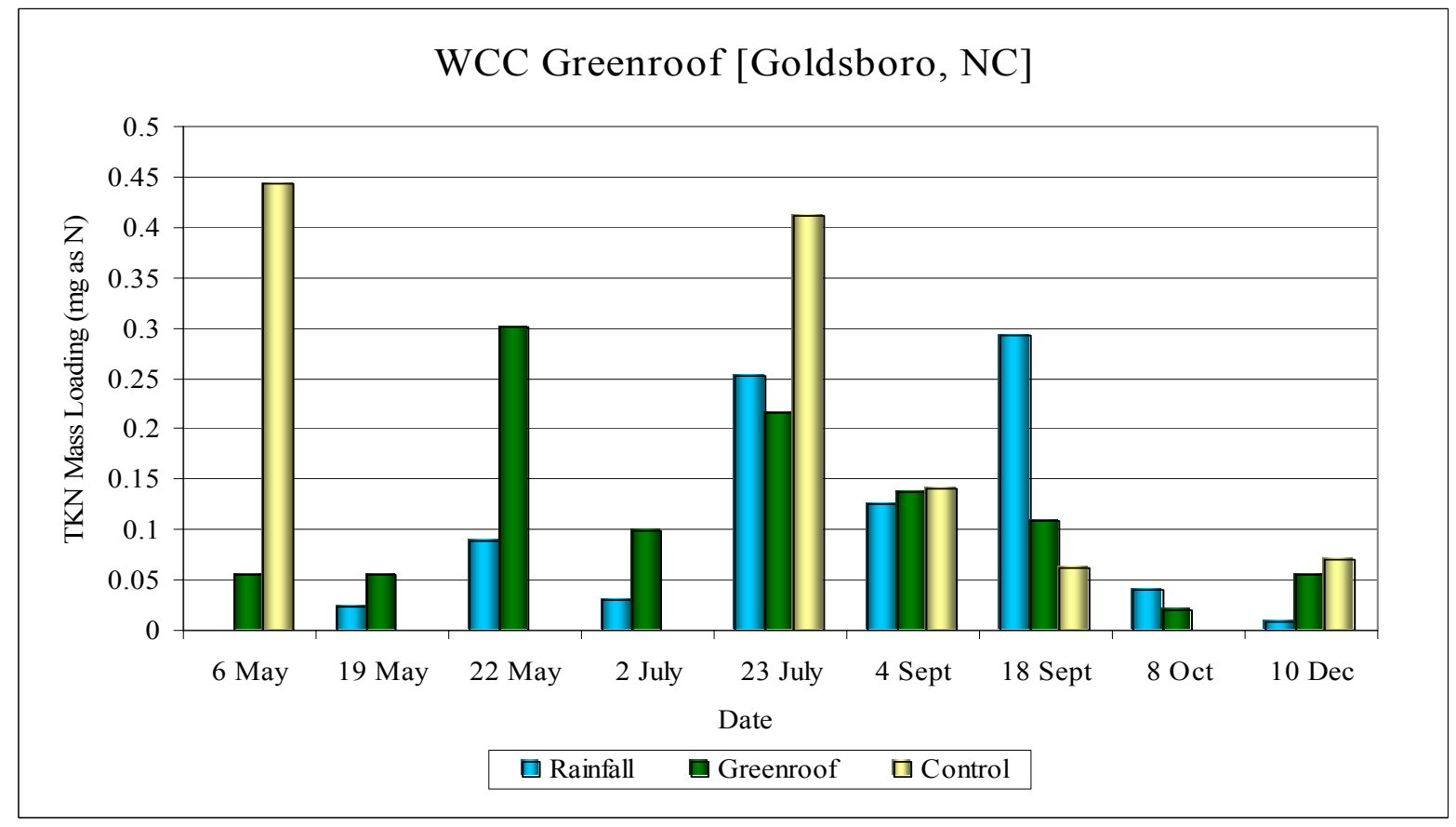

Figure E-2. Display of TKN Mass Loadings at WCC Greenroof in Goldsboro, NC. (Note: Rainfall data is unavailable for 6 May; Control data is unavailable for 19 May, 22 May, 2 July, and 8 October) 


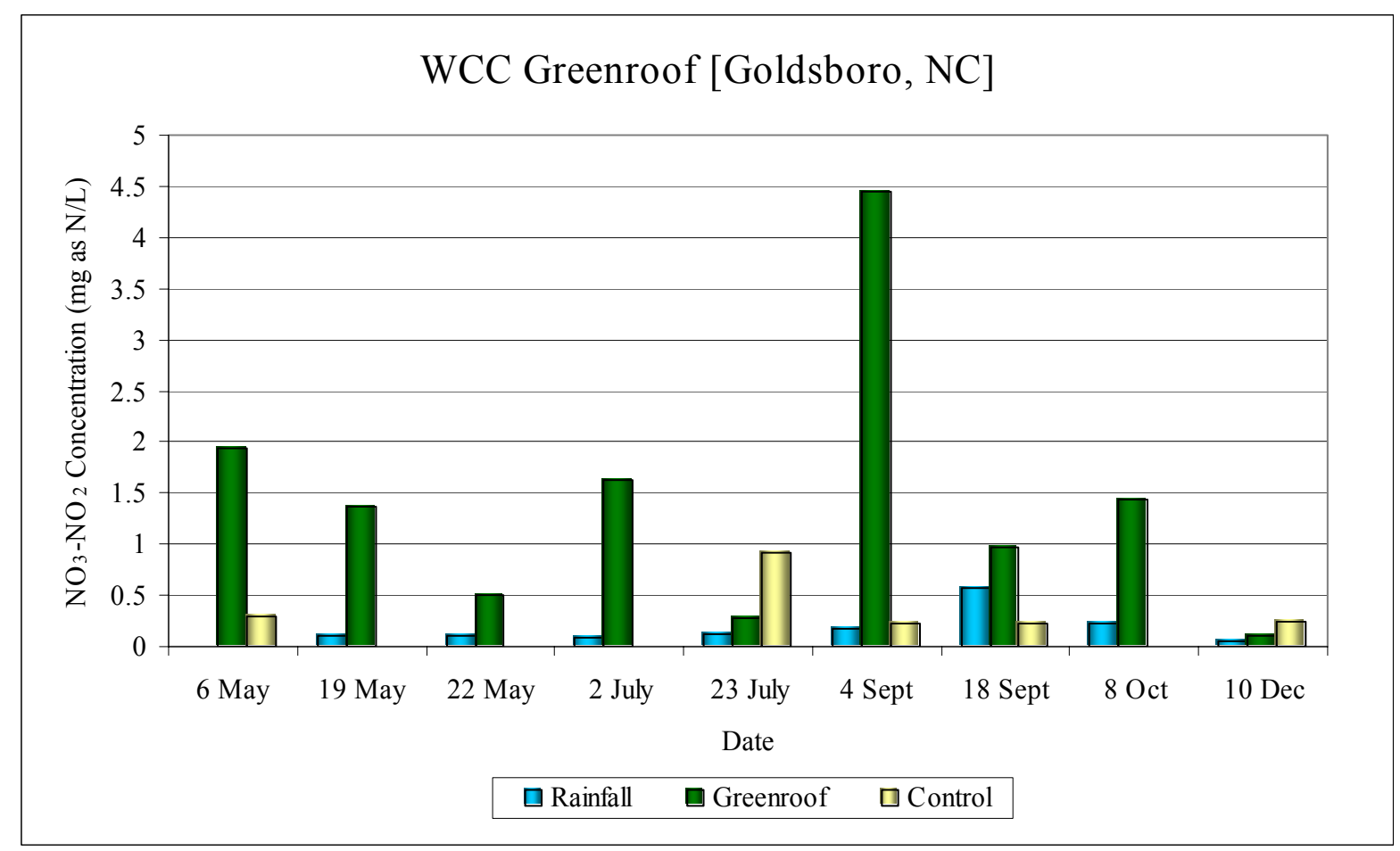

Figure E-3. Display of $\mathrm{NO}_{3}-\mathrm{NO}_{2}$ Concentrations at WCC Greenroof in Goldsboro, NC. (Note: Rainfall data is unavailable for 6 May; Control data is unavailable for 19 May, 22 May, 2 July, and 8 October)

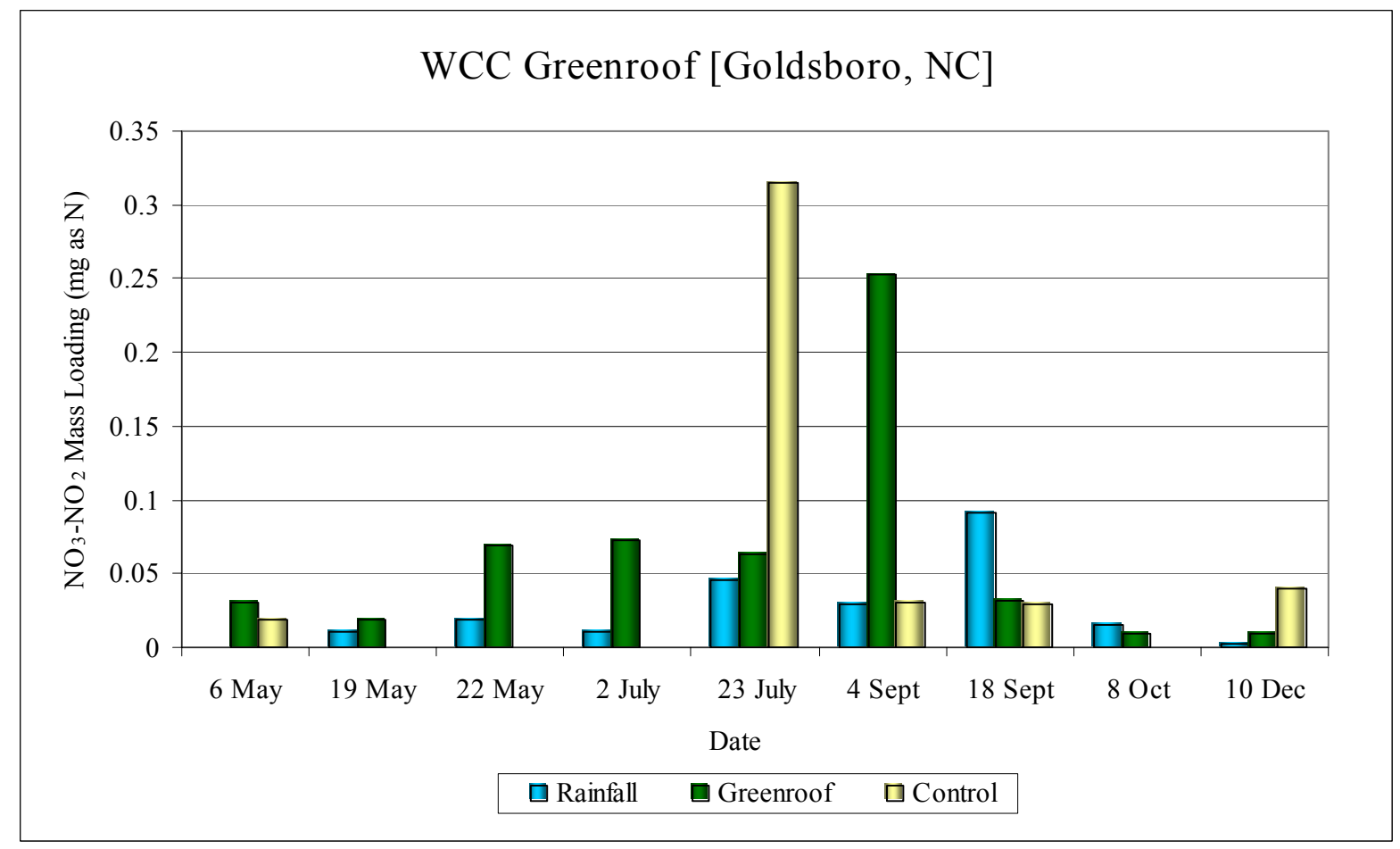

Figure E-4. Display of $\mathrm{NO}_{3}-\mathrm{NO}_{2}$ Mass Loadings at WCC Greenroof in Goldsboro, NC. (Note: Rainfall data is unavailable for 6 May; Control data is unavailable for 19 May, 22 May, 2 July, and 8 October) 


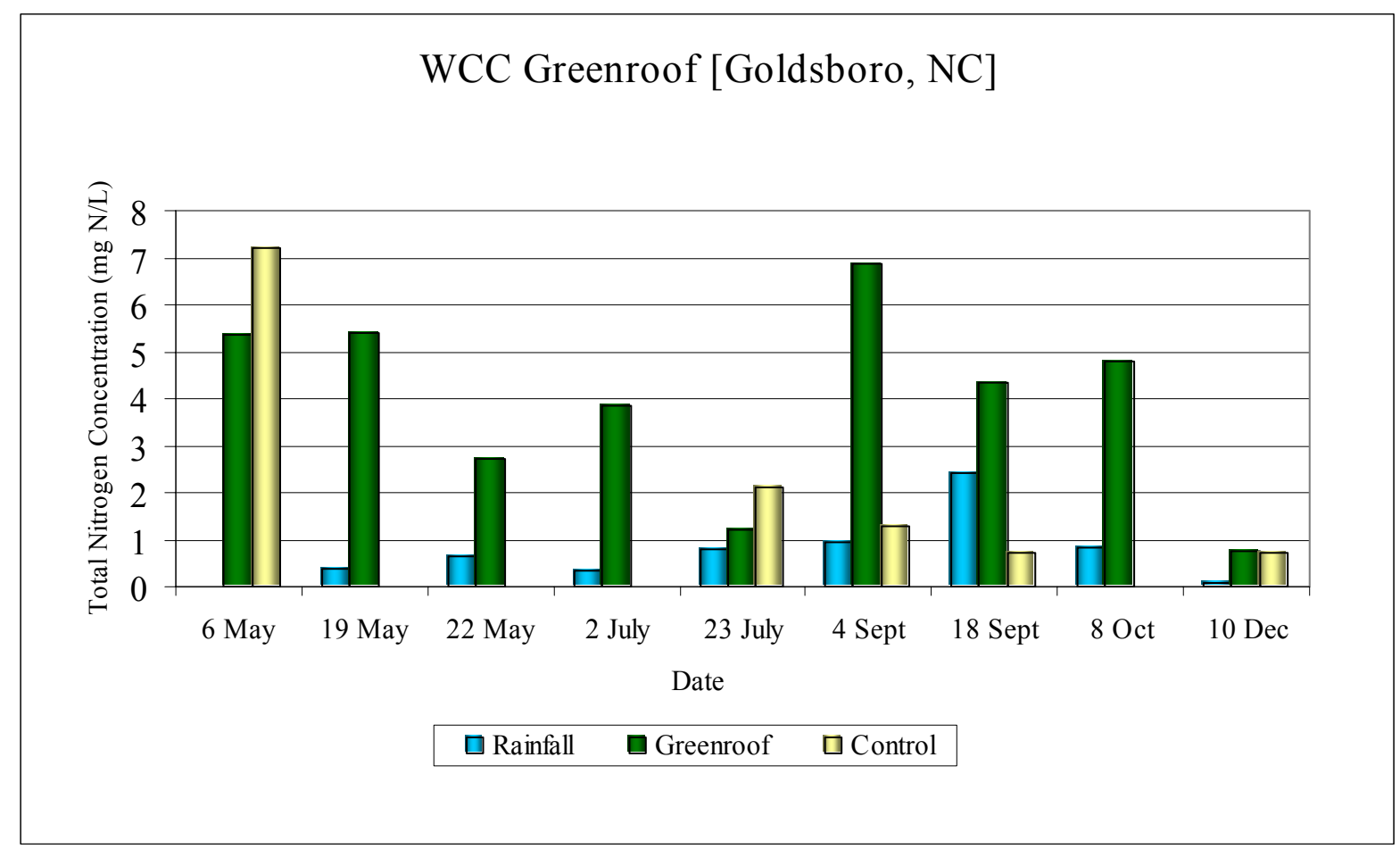

Figure E-5. Display of TN Concentrations at WCC Greenroof in Goldsboro, NC. (Note: Rainfall data is unavailable for 6 May; Control data is unavailable for 19 May, 22 May, 2 July, and 8 October)

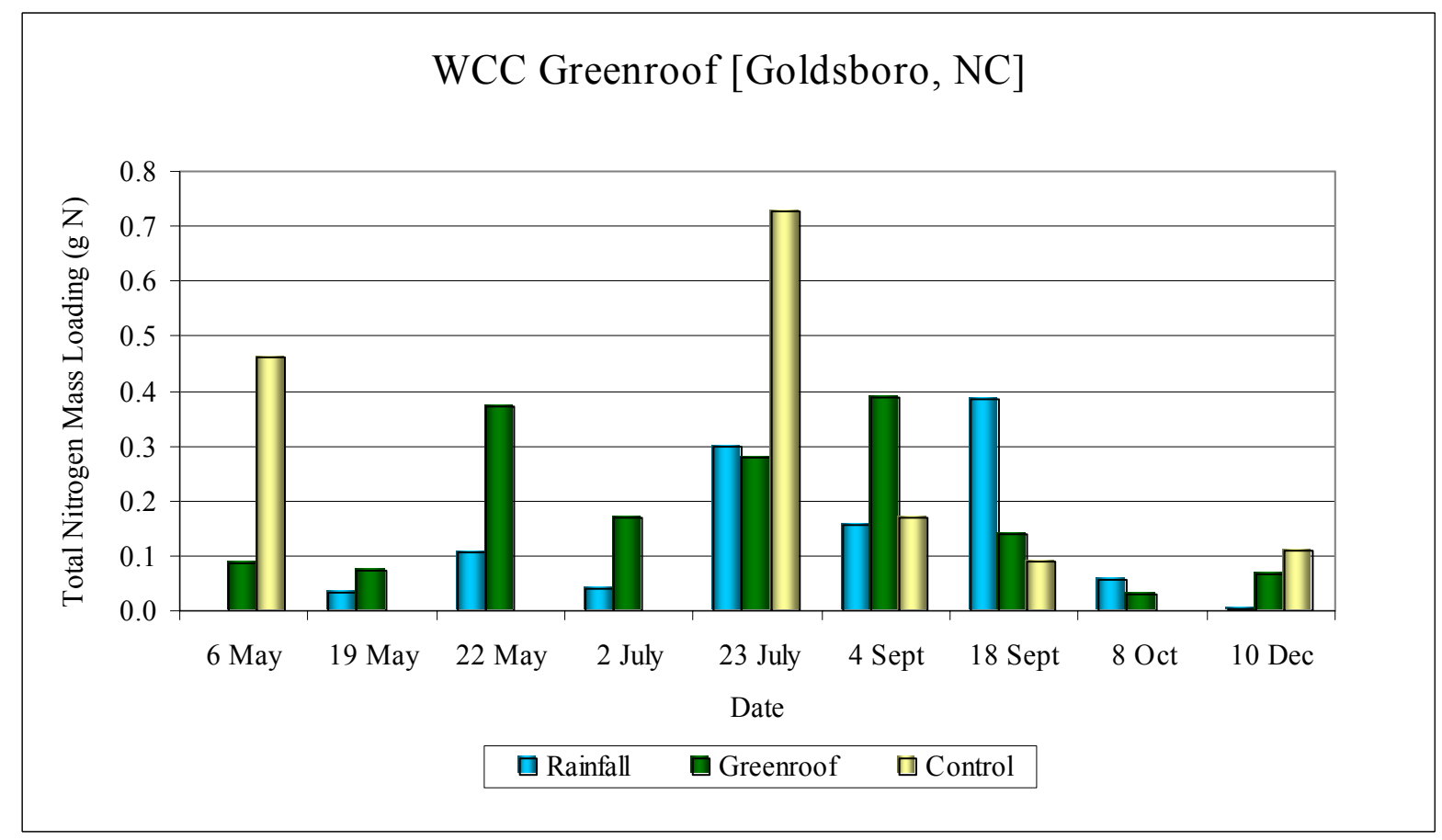

Figure E-6. Display of TN Mass Loadings at WCC Greenroof in Goldsboro, NC. (Note: Rainfall data is unavailable for 6 May; Control data is unavailable for 19 May, 22 May, 2 July, and 8 October) 


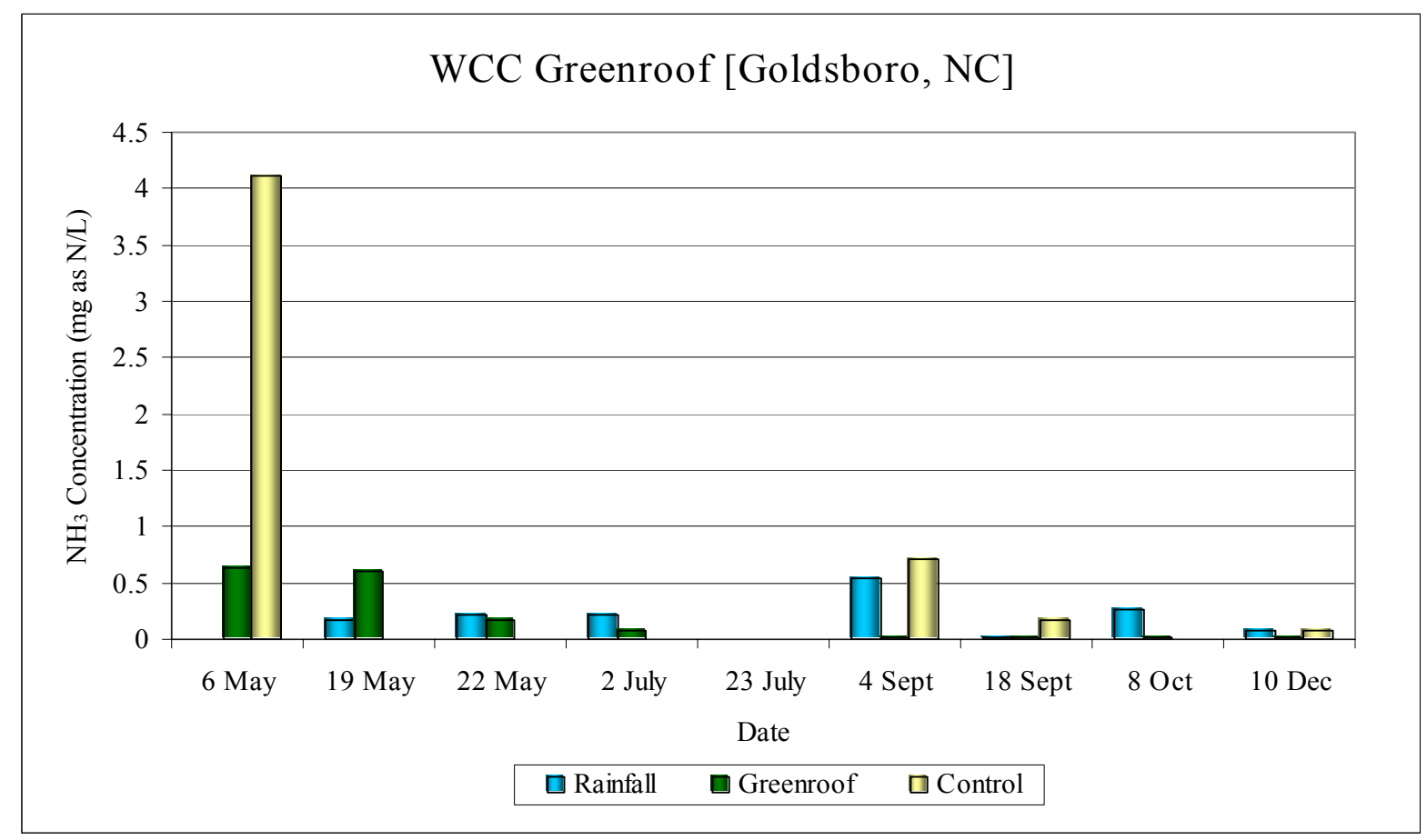

Figure E-7. Display of $\mathrm{NH}_{3}$ Concentrations at WCC Greenroof in Goldsboro, NC. (Note: Rainfall data is unavailable for 6 May and 23 July; Greenroof data is unavailable for 23 July; Control data is unavailable for 19 May, 22 May, 2 July, 23 July, and 8 October)

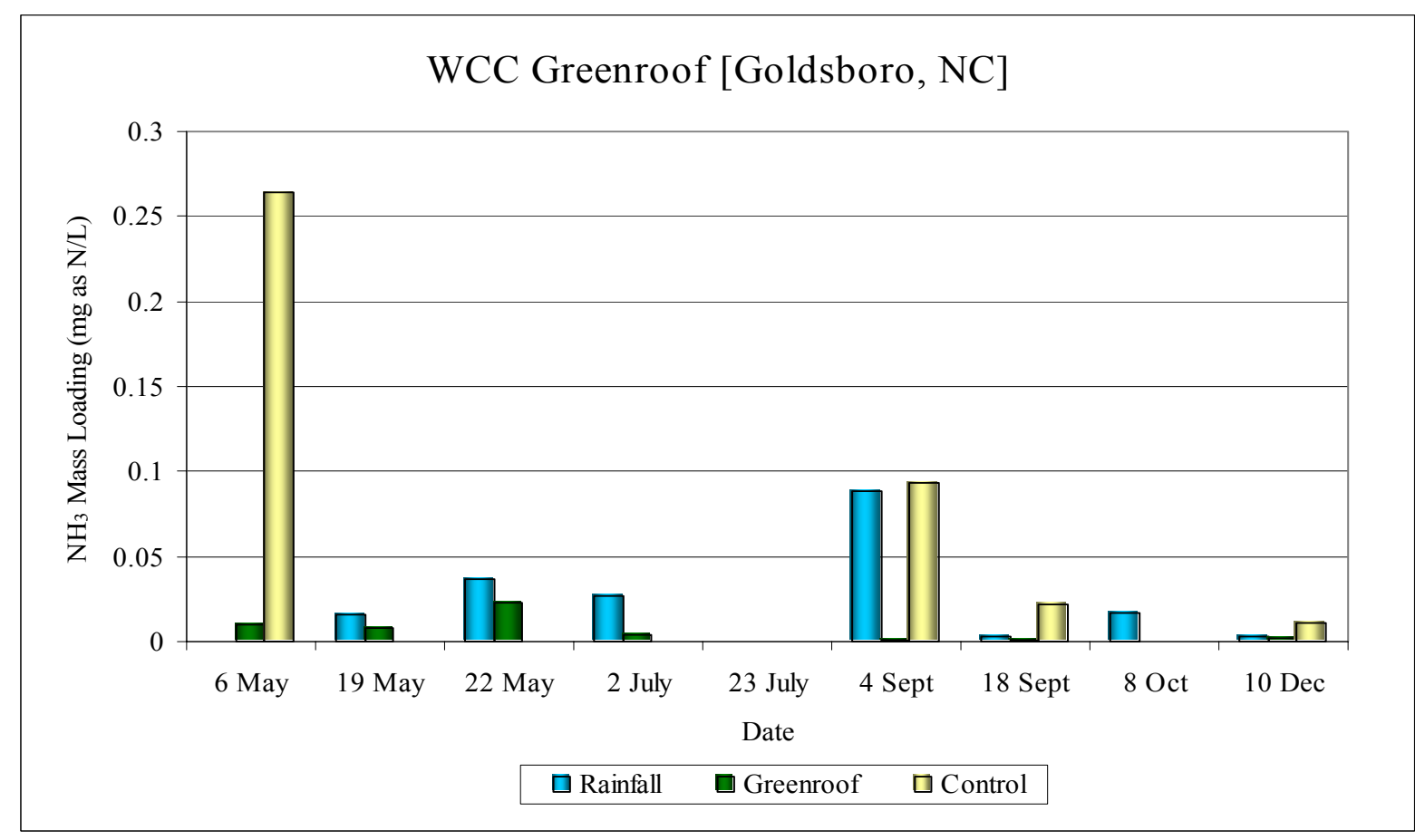

Figure E-8. Display of $\mathrm{NH}_{3}$ Mass Loadings at WCC Greenroof in Goldsboro, NC. (Note: Rainfall data is unavailable for 6 May and 23 July; Greenroof data is unavailable for 23 July; Control data is unavailable for 19 May, 22 May, 2 July, 23 July, and 8 October) 


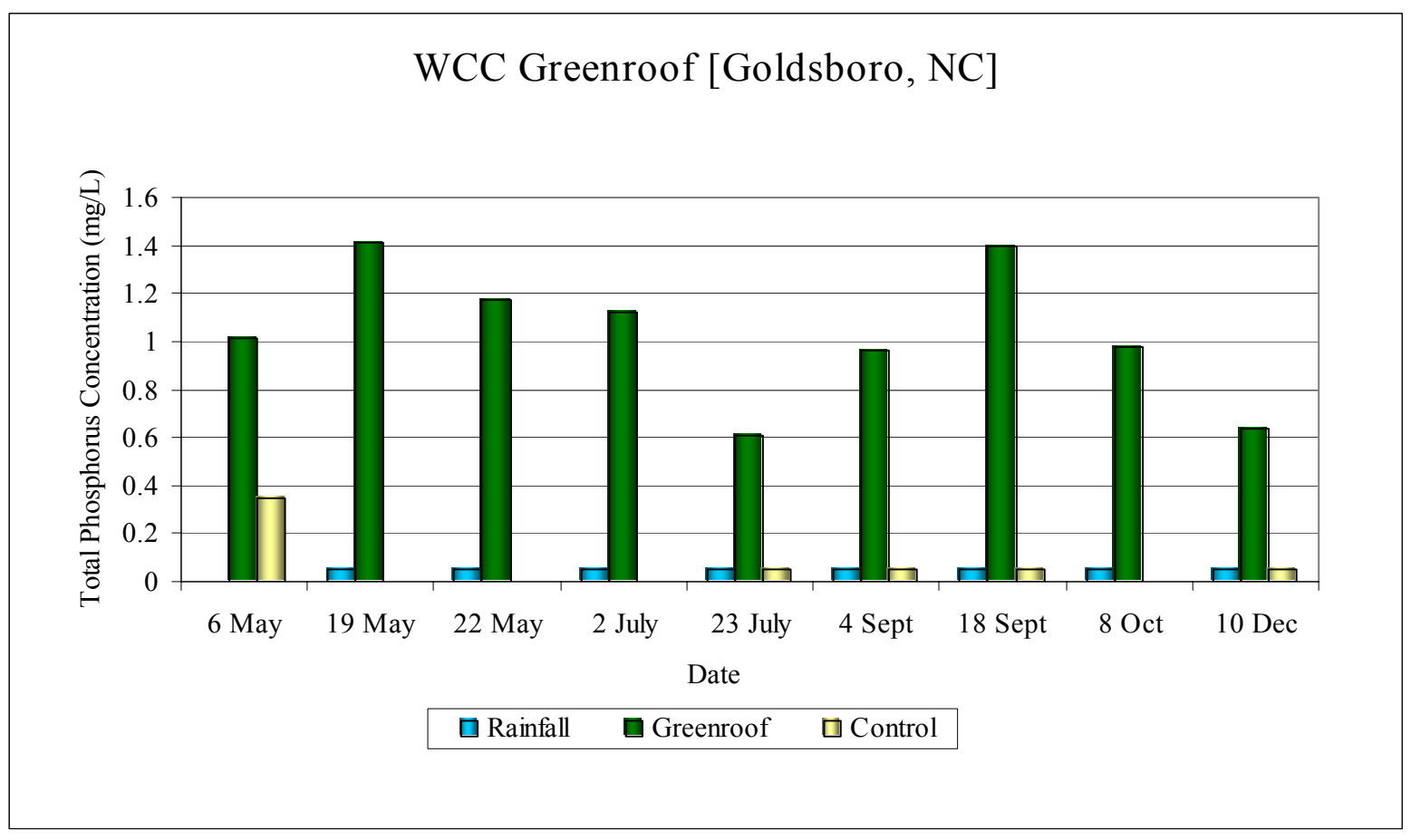

Figure E-9. Display of TP Concentrations at WCC Greenroof in Goldsboro, NC. (Note: Rainfall data is unavailable for 6 May; Control data is unavailable for 19 May, 22 May, 2 July, and 8 October)

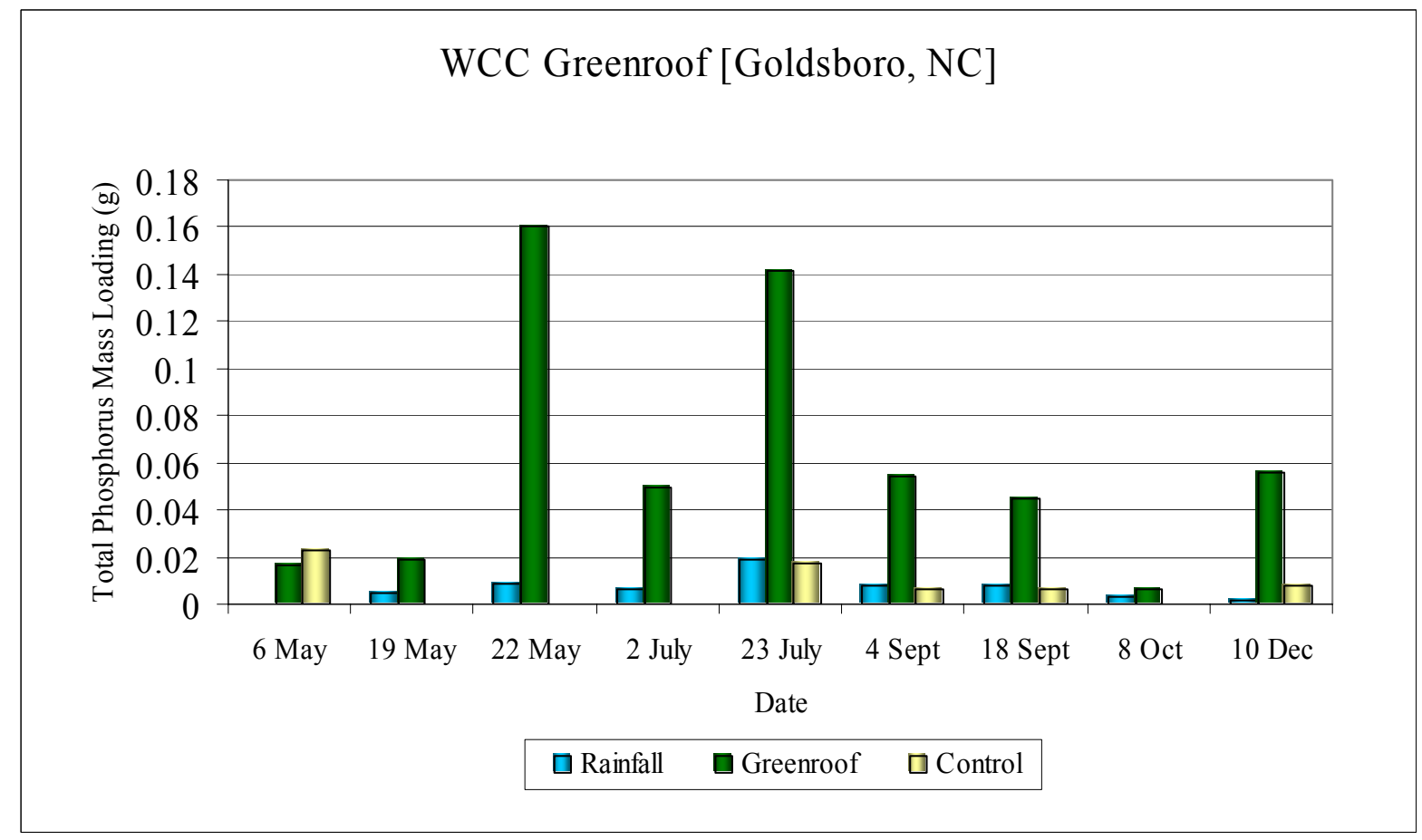

Figure E-10. Display of TP Mass Loadings at WCC Greenroof in Goldsboro, NC. (Note: Rainfall data is unavailable for 6 May; Control data is unavailable for 19 May, 22 May, 2 July, and 8 October) 


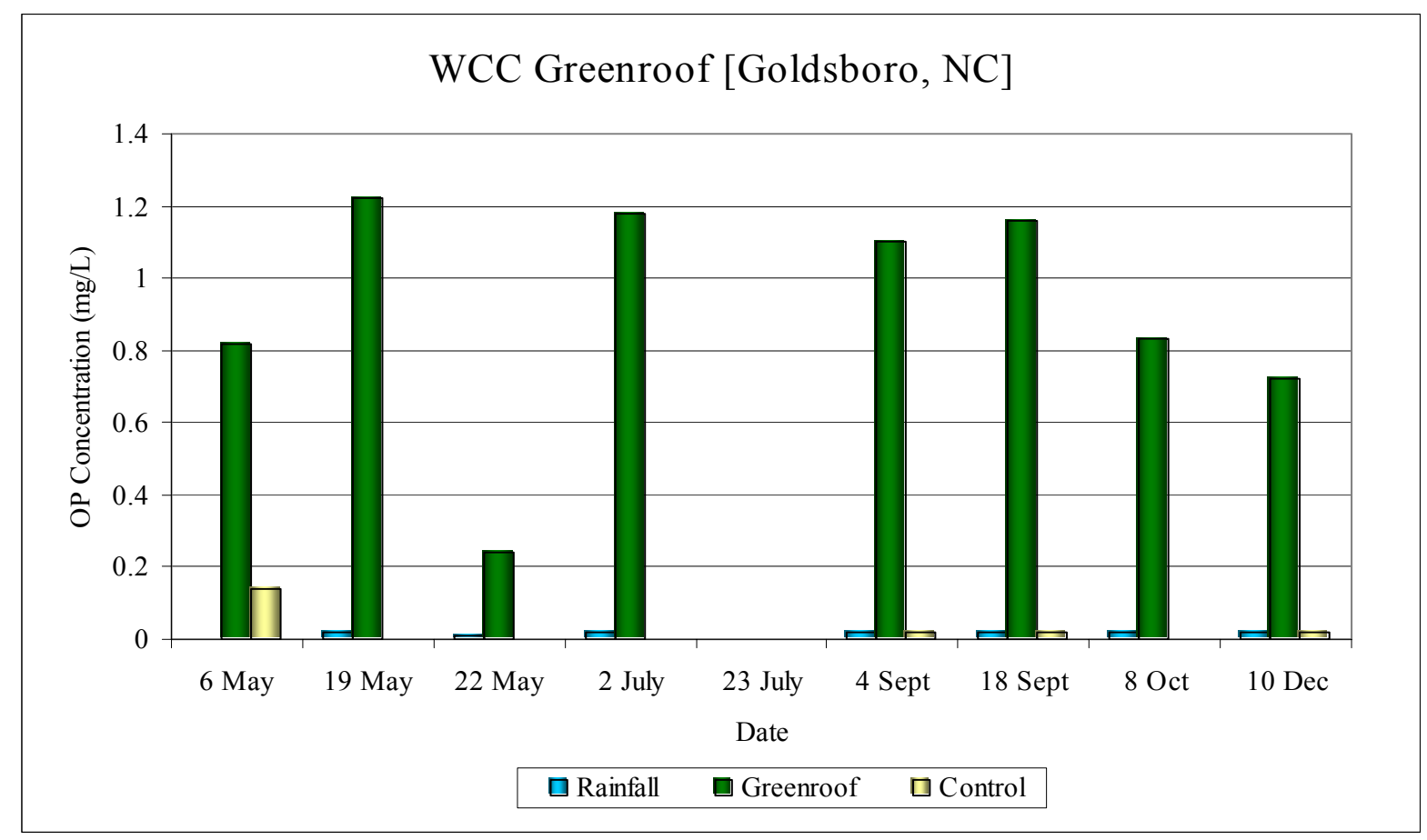

Figure E-11. Display of OP Concentrations at WCC Greenroof in Goldsboro, NC. (Note: Rainfall data is unavailable for 6 May and 23 July; Greenroof data is unavailable for 23 July; Control data is unavailable for 19 May, 22 May, 2 July, 23 July, and 8 October)

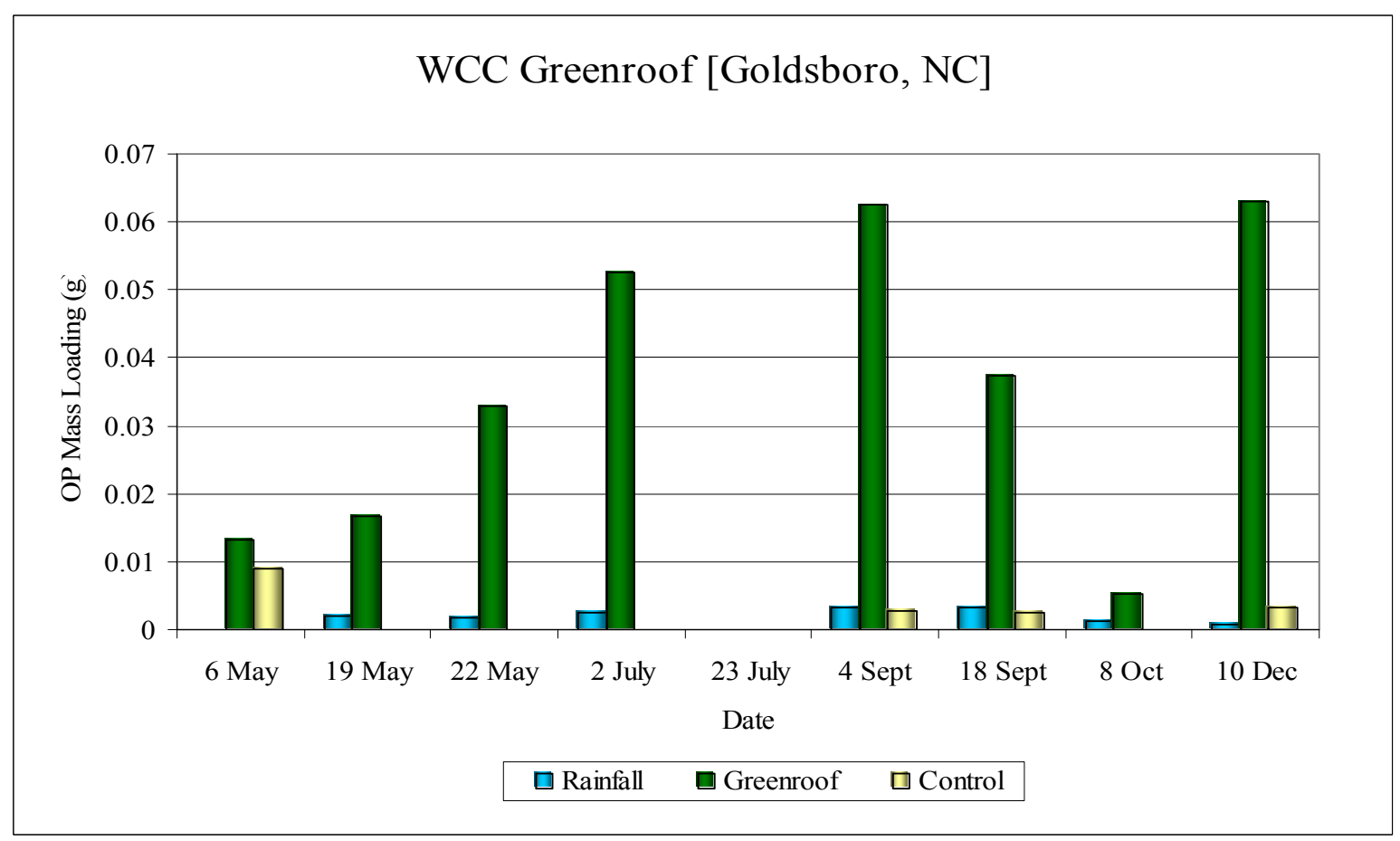

Figure E-12. Display of OP Mass Loadings at WCC Greenroof in Goldsboro, NC. (Note: Rainfall data is unavailable for 6 May and 23 July; Greenroof data is unavailable for 23 July; Control data is unavailable for 19 May, 22 May, 2 July, 23 July, and 8 October) 


\section{F.0 APPENDIX F - GOLDSBORO WATER QUALITY DATA: STATISTICAL ANALYSIS}

\section{F.1 Concentration of Total KJELDAHL Nitrogen (TKN AS N)}

\section{F.1.1 COMPARISON OF RAINFALl AND GREENROOF CONCENTRATIONS (MG AS N/L)}

SAS Data Input

\begin{tabular}{|l|c|c|c|}
\hline Date & TKN_conc_R & TKN_conc_G & Diff TKN \\
\hline \hline 19-May-03 & 0.25 & 4.03 & 3.78 \\
\hline 22-May-03 & 0.53 & 2.2 & 1.67 \\
\hline 2-Jul-03 & 0.25 & 2.21 & 1.96 \\
\hline 24-Jul-03 & 0.67 & 0.93 & 0.26 \\
\hline 4-Sep-03 & 0.77 & 2.41 & 1.64 \\
\hline 18-Sep-03 & 1.84 & 3.37 & 1.53 \\
\hline 8-Oct-03 & 0.61 & 3.35 & 2.74 \\
\hline 10-Dec-03 & 0.25 & 0.63 & 0.38 \\
\hline
\end{tabular}

Note: $\mathrm{R}=$ Rainfall Concentration; $\mathrm{G}=$ Greenroof Concentration; Diff = Difference

\section{$>$ SAS Analysis}

The difference between the mean concentrations was determined to be normally distributed through the proc univariate analysis shown below ( $p$-value $>0.05)$.

\begin{tabular}{|c|c|c|c|c|}
\hline \multicolumn{5}{|c|}{ Tests for Normality } \\
\hline Test & - -sta & tistic-- - & $\ldots-p$ Va] & de.... \\
\hline Shapiro-Wilk & W & 0.936948 & $\mathrm{Pr}<\mathrm{W}$ & 0.5813 \\
\hline Kolmogorov-Smirnov & $\mathrm{D}$ & 0.17605 & $\mathrm{Pr}>\mathrm{D}$ & $>0.1500$ \\
\hline Cramer-von Mises & W-Sq & 0.051435 & $\mathrm{Pr}>\mathrm{W}-\mathrm{Sq}$ & $>0.2500$ \\
\hline Anderson-Darling & $\mathrm{A}-\mathrm{Sq}$ & 0.304054 & $\mathrm{Pr}>\mathrm{A}-\mathrm{Sq}$ & $>0.2500$ \\
\hline
\end{tabular}

A t-test was performed and the results are shown below. There were significantly higher concentrations of TKN ( $\mathrm{mg}$ as $\mathrm{N} / \mathrm{L})$ found in greenroof runoff than in the rainfall $(\alpha<0.05)$. 


\begin{tabular}{|c|c|c|c|c|c|c|c|c|}
\hline \multirow{2}{*}{ Difference } & \multicolumn{6}{|c|}{ Statistics } & \multirow{2}{*}{\multicolumn{2}{|c|}{ Upper CL }} \\
\hline & \multicolumn{3}{|c|}{ Lower CL } & Upper CL & $\begin{array}{l}\text { Lower CL } \\
\text { Std Dev }\end{array}$ & Lower CL & & \\
\hline TKN_conc_G & 8 & 0.7809 & 1.745 & 2.7091 & 0.7625 & 1.1532 & 2.347 & 0.4077 \\
\hline & & & & Tests & & & & \\
\hline & Differe & & & DF & t Value & $\operatorname{Pr}>|t|$ & & \\
\hline & TKN_con & $G-T K N$ & onc_R & 7 & 4.28 & 0.0037 & & \\
\hline
\end{tabular}

\section{F.1.2 COMParison of GreENROOF AND CONTROL Roof CONCENTRATIONS (MG AS N/L)}

\section{SAS Data Input}

\begin{tabular}{|l|c|c|c|}
\hline Date & TKN_conc_G & TKN_conc_C & Diff TKN \\
\hline 6-May-03 & 3.44 & 6.91 & 3.47 \\
\hline 24-Jul-03 & 0.93 & 1.19 & 0.26 \\
\hline 4-Sep-03 & 2.41 & 1.06 & -1.35 \\
\hline 18-Sep-03 & 3.37 & 0.48 & -2.89 \\
\hline 10-Dec-03 & 0.63 & 0.45 & -0.18 \\
\hline
\end{tabular}

Note: $\mathrm{G}=$ Greenroof Concentration; $\mathrm{C}=$ Control Roof Concentration; Diff = Difference

\section{$>$ SAS Analysis}

The difference between the mean concentrations was determined to be normally distributed through the proc univariate analysis shown below ( $\mathrm{p}$-value $>0.05$ ).

\begin{tabular}{|c|c|c|c|c|}
\hline Test & \multicolumn{2}{|c|}{ - -Statistic- - } & \multicolumn{2}{|c|}{.... p Value..... } \\
\hline Shapiro-Wilk & W & 0.958793 & $\mathrm{Pr}<\mathrm{W}$ & 0.7996 \\
\hline Kolmogorov-Smirnov & $\mathrm{D}$ & 0.232952 & $\mathrm{Pr}>\mathrm{D}$ & $>0.1500$ \\
\hline Cramer-von Mises & W-Sq & 0.036243 & $\mathrm{Pr}>\mathrm{W}-\mathrm{Sq}$ & $>0.2500$ \\
\hline Anderson-Darling & $\mathrm{A}-\mathrm{Sq}$ & 0.229697 & $\mathrm{Pr}>\mathrm{A}-\mathrm{Sq}$ & $>0.2500$ \\
\hline
\end{tabular}


A t-test was performed and the results are shown below. There was no statistically significant difference between the control roof concentration of TKN (mg as N/L) and the greenroof concentration of TKN (mg as N/L).

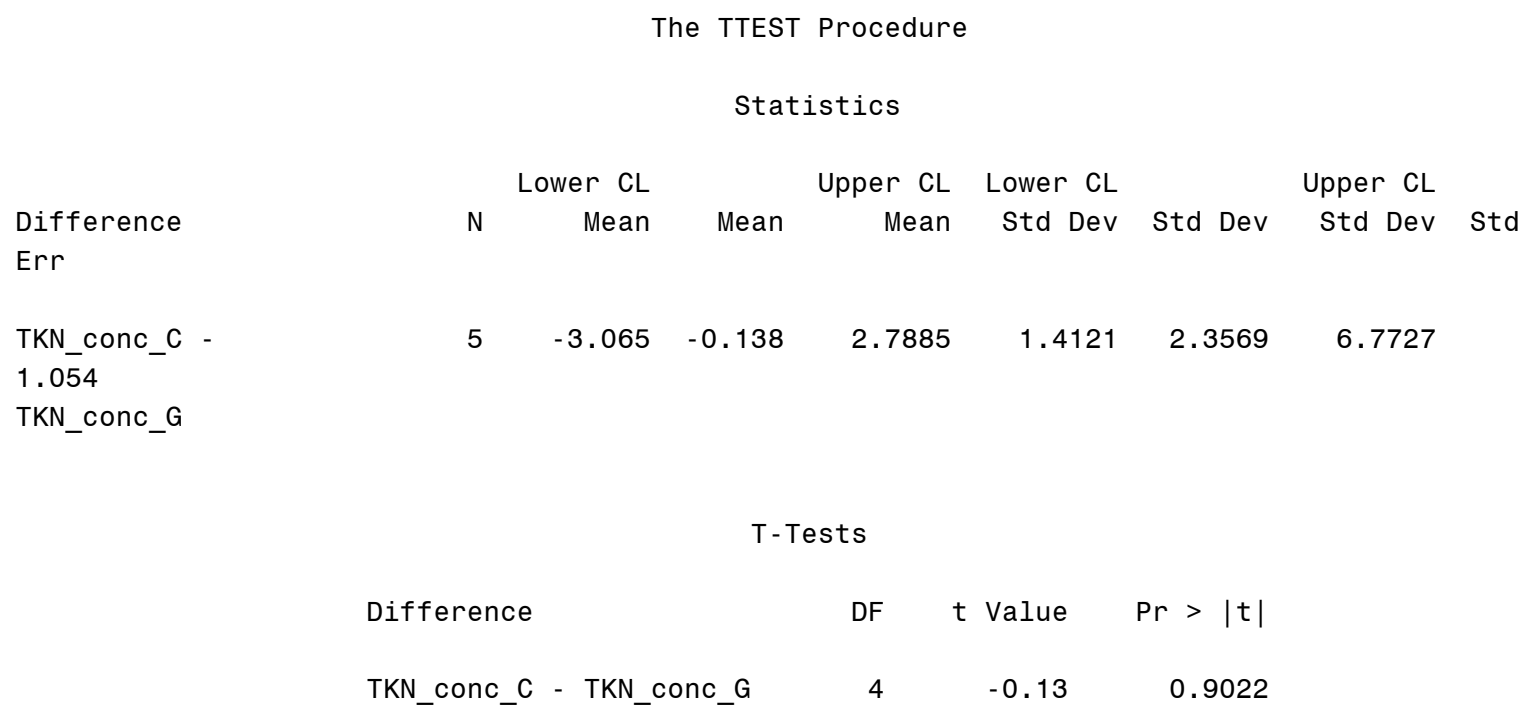




\section{F.2 Mass LoAding OF Total KJELdahl Nitrogen (TKN AS N)}

\section{F.2.1 COMPARISON OF RAINFALl AND GREENROOF MASS LoAdingS (G AS N)}

\section{SAS Data Input}

\begin{tabular}{|l|c|c|c|}
\hline Date & TKN_mass_R & TKN_mass_G & Diff TKN \\
\hline \hline 19-May-03 & 0.024 & 0.055 & 0.031 \\
\hline 22-May-03 & 0.089 & 0.302 & 0.213 \\
\hline 2-Jul-03 & 0.030 & 0.098 & 0.068 \\
\hline 24-Jul-03 & 0.252 & 0.216 & -0.036 \\
\hline 4-Sep-03 & 0.126 & 0.137 & 0.011 \\
\hline 18-Sep-03 & 0.293 & 0.108 & -0.185 \\
\hline 8-Oct-03 & 0.041 & 0.021 & -0.020 \\
\hline 10-Dec-03 & 0.009 & 0.055 & 0.046 \\
\hline
\end{tabular}

Note: $\mathrm{R}=$ Rainfall Mass Loading; $\mathrm{G}=$ Greenroof Mass Loading; Diff = Difference

\section{SAS Analysis}

The difference between the means was determined to be normally distributed through the proc univariate analysis shown below ( $\mathrm{p}$-value $>0.05)$.

\begin{tabular}{|c|c|c|c|c|}
\hline \multicolumn{5}{|c|}{ Tests for Normality } \\
\hline Test & \multicolumn{2}{|c|}{ - -Statistic-- - } & \multicolumn{2}{|c|}{... - p Value..... } \\
\hline Shapiro-Wilk & W & 0.9421 & $\mathrm{Pr}<\mathrm{W}$ & 0.6319 \\
\hline Kolmogorov-Smirnov & $\mathrm{D}$ & 0.195513 & $\mathrm{Pr}>\mathrm{D}$ & $>0.1500$ \\
\hline Cramer-von Mises & W-Sq & 0.059506 & $\mathrm{Pr}>\mathrm{W}-\mathrm{Sq}$ & $>0.2500$ \\
\hline Anderson-Darling & $\mathrm{A}-\mathrm{Sq}$ & 0.353269 & $\mathrm{Pr}>\mathrm{A}-\mathrm{Sq}$ & $>0.2500$ \\
\hline
\end{tabular}

A t-test was performed on the data. There was no statistically significant difference between the mass loading ( $\mathrm{g}$ TKN as $\mathrm{N}$ ) in the greenroof runoff and the rainfall. 


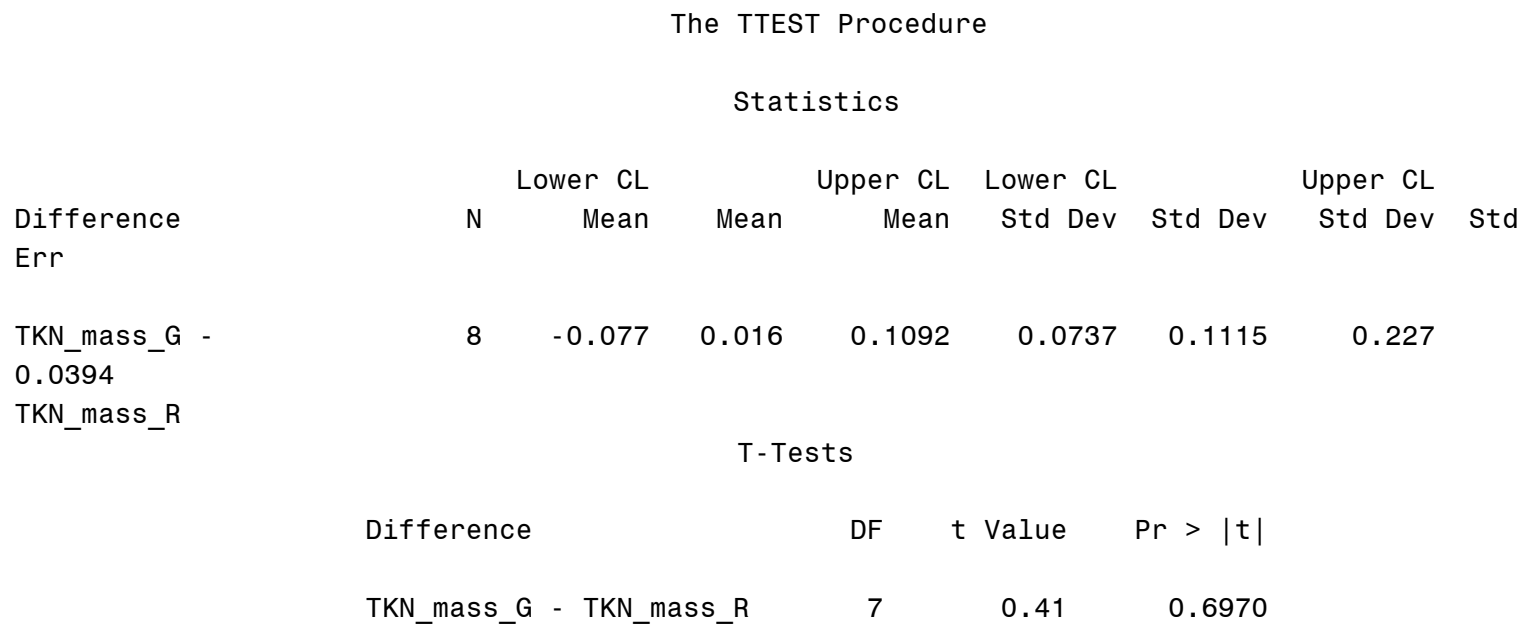

\section{F.2.2 COMPARISON OF GREENROOF AND CONTROL ROOF MASS LOADINGS (G AS N)}

\section{SAS Data Input}

\begin{tabular}{|l|c|c|c|}
\hline Date & TKN_mass_G & TKN_mass_C & Diff TKN \\
\hline 6-May-03 & 0.055 & 0.444 & 0.389 \\
\hline 24-Jul-03 & 0.216 & 0.412 & 0.196 \\
\hline 4-Sep-03 & 0.137 & 0.140 & 0.003 \\
\hline 18-Sep-03 & 0.108 & 0.062 & -0.047 \\
\hline 10-Dec-03 & 0.055 & 0.071 & 0.015 \\
\hline
\end{tabular}

Note: $\mathrm{G}=$ Greenroof Mass Loading; $\mathrm{C}=$ Control Roof Mass Loading; Diff = Difference

\section{SAS Analysis}

The difference between the mean values was determined to be normally distributed through the proc univariate analysis shown below ( $\mathrm{p}$-value $>0.05$ ). 


\begin{tabular}{|c|c|c|c|c|}
\hline Test & - -Sta & tistic-- - & $\ldots-p$ Va] & e. - . - \\
\hline Shapiro-Wilk & W & 0.867964 & $\mathrm{Pr}<\mathrm{W}$ & 0.2583 \\
\hline Kolmogorov-Smirnov & $\mathrm{D}$ & 0.302948 & $\mathrm{Pr}>\mathrm{D}$ & 0.1335 \\
\hline Cramer-von Mises & $\mathrm{W}-\mathrm{Sq}$ & 0.068504 & $\mathrm{Pr}>\mathrm{W}-\mathrm{Sq}$ & 0.2420 \\
\hline Anderson-Darling & $\mathrm{A}-\mathrm{Sq}$ & 0.398099 & $\mathrm{Pr}>\mathrm{A}-\mathrm{Sq}$ & 0.2240 \\
\hline
\end{tabular}

A t-test was performed on the data. There was no statistically significant difference between the mass loading of TKN ( $\mathrm{g} \mathrm{TKN}$ as $\mathrm{N}$ ) in the greenroof runoff and the control roof runoff.

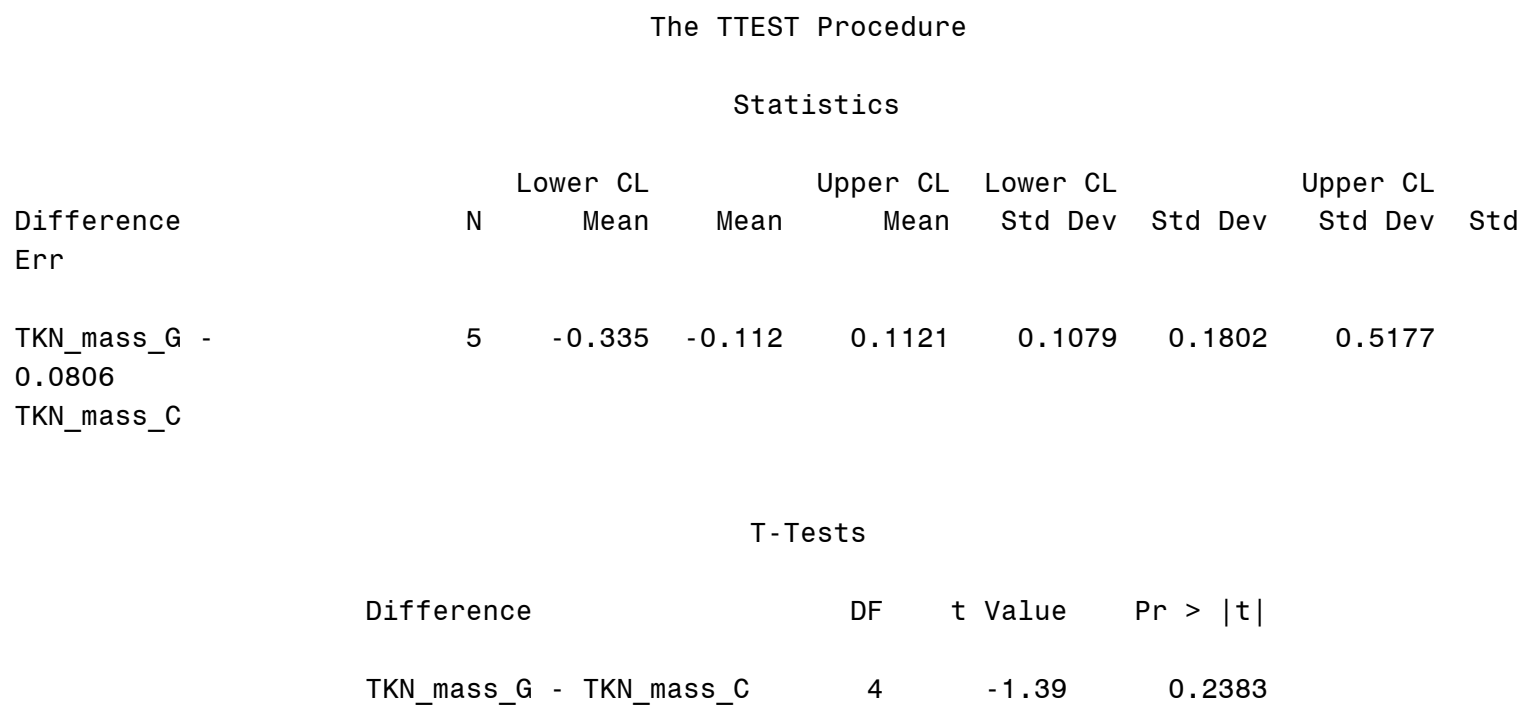




\section{F.3 CONCENTRATION OF NitRATE-Nitrite $\left(\mathrm{NO}_{3}-\mathrm{NO}_{2}\right.$ AS N)}

\section{F.3.1 COMPARison OF RAINFALl AND GREENROOF CONCENTRATIONS (MG AS N/L)}

\section{SAS Data Input}

\begin{tabular}{|l|c|c|c|}
\hline Date & NO3_conc_R & NO3_conc_G & Diff NO3 \\
\hline \hline 19-May-03 & 0.11 & 1.36 & 1.25 \\
\hline 22-May-03 & 0.11 & 0.5 & 0.39 \\
\hline 2-Jul-03 & 0.09 & 1.63 & 1.54 \\
\hline 24-Jul-03 & 0.12 & 0.27 & 0.15 \\
\hline 4-Sep-03 & 0.18 & 4.44 & 4.26 \\
\hline 18-Sep-03 & 0.57 & 0.97 & 0.4 \\
\hline 8-Oct-03 & 0.22 & 1.43 & 1.21 \\
\hline 10-Dec-03 & 0.06 & 0.11 & 0.05 \\
\hline
\end{tabular}

Note: $\mathrm{R}$ = Rainfall Concentration; $\mathrm{G}=$ Greenroof Concentration; Diff= Difference

\section{SAS Analysis}

The distribution of the mean difference between the concentration of $\mathrm{NO}_{3}-\mathrm{NO}_{2}(\mathrm{mg}$ as $\mathrm{N} / \mathrm{L})$ in the rainfall and the greenroof runoff was determined to not be a normal distribution through the proc univariate analysis shown below ( $\mathrm{p}$-values $<0.05$ ).

\begin{tabular}{|c|c|c|c|c|}
\hline \multicolumn{5}{|c|}{ Tests for Normality } \\
\hline Shapiro-Wilk & W & 0.768411 & $\mathrm{Pr}<\mathrm{W}$ & 0.0130 \\
\hline Kolmogorov-Smirnov & $\mathrm{D}$ & 0.264898 & $\mathrm{Pr}>\mathrm{D}$ & 0.0953 \\
\hline Cramer-von Mises & W-Sq & 0.127679 & $\mathrm{Pr}>\mathrm{W}-\mathrm{Sq}$ & 0.0390 \\
\hline Anderson-Darling & $\mathrm{A}-\mathrm{Sq}$ & 0.786825 & $\mathrm{Pr}>\mathrm{A}-\mathrm{Sq}$ & 0.0236 \\
\hline
\end{tabular}

The $\mathrm{t}$-test assumes the difference between the means is normally distributed; therefore, the $\mathrm{t}-$ test is invalid for this data set. A Sign test was performed and is shown below. The 

the rainfall $(\alpha<0.05)$.

\begin{tabular}{lrrlr}
\multicolumn{7}{c}{ Tests for Location: Mu0 $=0$} \\
Test & -Statistic- & $-\ldots-$ - & \\
& & & \\
Student's $t$ & $\mathrm{t}$ & 2.382666 & $\mathrm{Pr}>|\mathrm{t}|$ & 0.0487 \\
Sign & $\mathrm{M}$ & 4 & $\mathrm{Pr}>=|\mathrm{M}|$ & 0.0078 \\
Signed Rank & $\mathrm{S}$ & 18 & $\mathrm{Pr}>=|\mathrm{S}|$ & 0.0078
\end{tabular}

\section{F.3.2 COMPARISON OF GREENROOF AND CONTROL RoOF CONCENTRATIONS (MG AS N/L)}

SAS Data Input

\begin{tabular}{|l|c|c|c|}
\hline Date & NO3_conc_G & NO3_conc_C & Diff NO3 \\
\hline \hline 6-May-03 & 1.93 & 0.29 & -1.64 \\
\hline 24-Jul-03 & 0.27 & 0.91 & 0.64 \\
\hline 4-Sep-03 & 4.44 & 0.23 & -4.21 \\
\hline 18-Sep-03 & 0.97 & 0.23 & -0.74 \\
\hline 10-Dec-03 & 0.11 & 0.25 & 0.14 \\
\hline
\end{tabular}

Note: $\mathrm{G}=$ Greenroof Concentration; $\mathrm{C}=$ Control Roof Concentration; Diff= Difference

\section{SAS Analysis}

The distribution of the differences between the greenroof and the control roof was determined to be normally distributed through the proc univariate analysis shown below (pvalue $>0.05)$.

\begin{tabular}{|c|c|c|c|c|}
\hline Test & \multicolumn{2}{|c|}{ - -Statistic-- - } & \multicolumn{2}{|c|}{.... p Value..... } \\
\hline Shapiro-Wilk & W & 0.911609 & $\mathrm{Pr}<\mathrm{W}$ & 0.4773 \\
\hline Kolmogorov-Smirnov & $\mathrm{D}$ & 0.201348 & $\mathrm{Pr}>\mathrm{D}$ & $>0.1500$ \\
\hline Cramer-von Mises & W-Sq & 0.044576 & $\mathrm{Pr}>\mathrm{W}-\mathrm{Sq}$ & $>0.2500$ \\
\hline Anderson-Darling & $\mathrm{A}-\mathrm{Sq}$ & 0.292777 & $\mathrm{Pr}>\mathrm{A}-\mathrm{Sq}$ & $>0.2500$ \\
\hline
\end{tabular}


Therefore, a t-test was performed on the data. There was no statistically significant difference between the concentrations of $\mathrm{NO}_{3}-\mathrm{NO}_{2}(\mathrm{mg}$ as $\mathrm{N} / \mathrm{L})$ in the greenroof runoff and the control roof runoff.

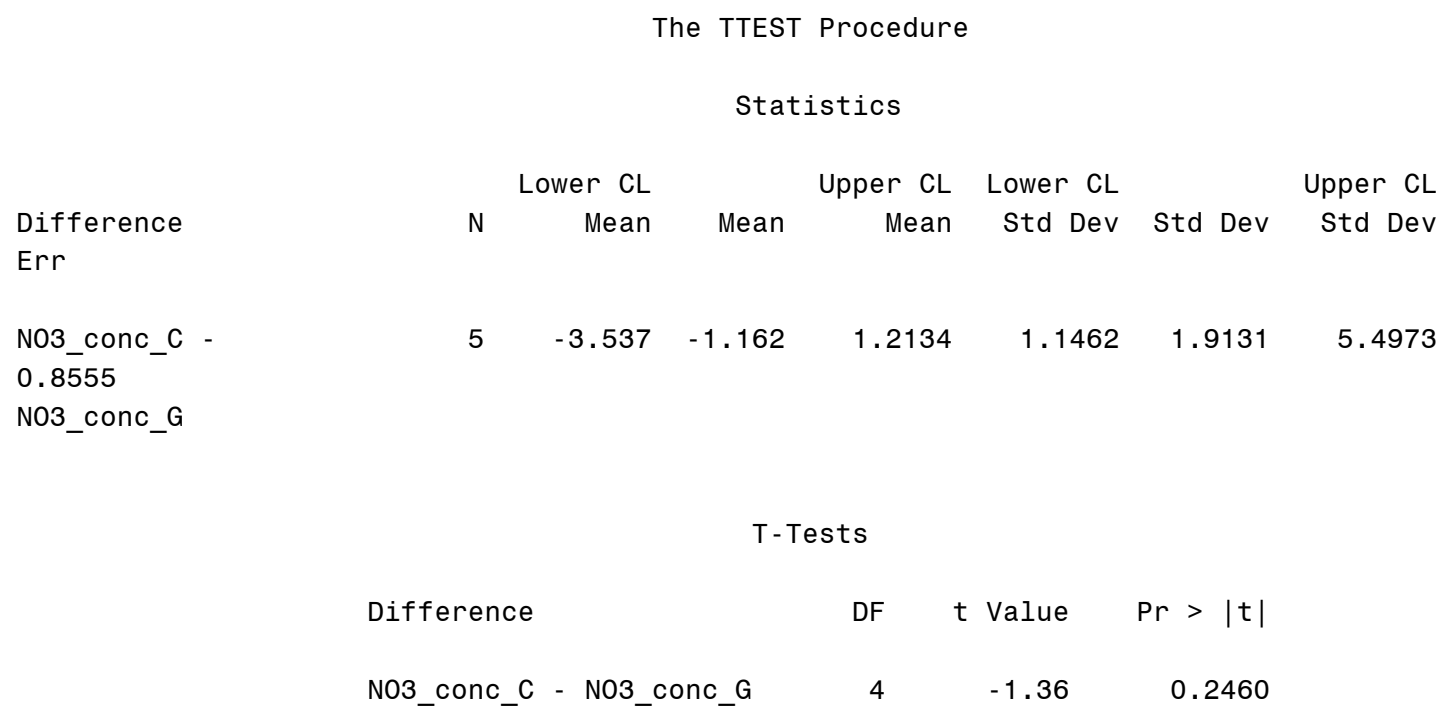




\section{F.4 Mass LoAding OF Nitrate-Nitrite $\left(\mathrm{NO}_{3}-\mathrm{NO}_{2}\right.$ AS N)}

\section{F.4.1 COMPARISON OF RAINFALl AND GREENROOF MASS LOADINGS (G AS N)}

\section{SAS Data Input}

\begin{tabular}{|l|c|c|c|}
\hline Date & NO3_mass_R & NO3_mass_G & Diff NO3 \\
\hline \hline 19-May-03 & 0.010 & 0.018 & 0.008 \\
\hline 22-May-03 & 0.018 & 0.069 & 0.050 \\
\hline 2-Jul-03 & 0.011 & 0.072 & 0.062 \\
\hline 24-Jul-03 & 0.045 & 0.063 & 0.017 \\
\hline 4-Sep-03 & 0.029 & 0.252 & 0.223 \\
\hline 18-Sep-03 & 0.091 & 0.031 & -0.060 \\
\hline 8-Oct-03 & 0.015 & 0.009 & -0.006 \\
\hline 10-Dec-03 & 0.002 & 0.010 & 0.007 \\
\hline
\end{tabular}

Note: $\mathrm{R}=$ Rainfall Mass Loading; $\mathrm{G}=$ Greenroof Mass Loading; Diff = Difference

\section{$>$ SAS Analysis}

The distribution of the difference between the rainfall mass loading $(\mathrm{g})$ of $\mathrm{NO}_{3}-\mathrm{NO}_{2}$ and the greenroof mass loading (g) of $\mathrm{NO}_{3}-\mathrm{NO}_{2}$ was determined to not be normally distributed through the proc univariate analysis shown below ( $p$-value $<0.05)$.

\begin{tabular}{|c|c|c|c|c|}
\hline \multicolumn{5}{|c|}{ Tests for Normality } \\
\hline Test & \multicolumn{2}{|c|}{ - -Statistic-- - } & \multicolumn{2}{|c|}{... - p Value ..... } \\
\hline Shapiro-Wilk & W & 0.826308 & $\mathrm{Pr}<\mathrm{W}$ & 0.0543 \\
\hline Kolmogorov-Smirnov & $\mathrm{D}$ & 0.260153 & $\mathrm{Pr}>\mathrm{D}$ & 0.1086 \\
\hline Cramer-von Mises & W-Sq & 0.118074 & $\mathrm{Pr}>\mathrm{W}-\mathrm{Sq}$ & 0.0512 \\
\hline Anderson-Darling & $\mathrm{A}-\mathrm{Sq}$ & 0.683867 & $\mathrm{Pr}>\mathrm{A}-\mathrm{Sq}$ & 0.0459 \\
\hline
\end{tabular}

The t-test assumes the distribution of the mean differences is normally distributed; therefore, the t-test is invalid for this data. A Sign test was used to analyze the data and is shown 
below. There was no significant difference between the rainfall mass loading $(\mathrm{g})$ of $\mathrm{NO}_{3}$ $\mathrm{NO}_{2}$ and the greenroof runoff mass loading $(\mathrm{g})$ of $\mathrm{NO}_{3}-\mathrm{NO}_{2}$.

\begin{tabular}{|c|c|c|c|c|}
\hline Test & Tests for Location: MuO $=0$ & $\begin{array}{l}=\text { or Locat } \\
\text { =atistic- }\end{array}$ & $\begin{array}{l}: M u 0=0 \\
----p ~ v a\end{array}$ & e- - - - \\
\hline Student's t & $\mathrm{t}$ & 1.274745 & $\operatorname{Pr}>|t|$ & 0.2431 \\
\hline Sign & M & 2 & $\operatorname{Pr}>=|M|$ & 0.2891 \\
\hline Signed Rank & $\mathrm{s}$ & 11 & $\operatorname{Pr}>=|S|$ & 0.1484 \\
\hline
\end{tabular}

\section{F.4.2 COMPARISON OF GREENROOF AND CONTROL ROOF MASS LOADINGS (G AS N)}

\section{SAS Data Input}

\begin{tabular}{|l|c|c|c|}
\hline Date & NO3_mass_G & NO3_mass_C & Diff NO3 \\
\hline 6-May-03 & 0.031 & 0.019 & -0.012 \\
\hline 24-Jul-03 & 0.063 & 0.315 & 0.252 \\
\hline 4-Sep-03 & 0.252 & 0.030 & -0.222 \\
\hline 18-Sep-03 & 0.031 & 0.030 & -0.002 \\
\hline 10-Dec-03 & 0.010 & 0.039 & 0.030 \\
\hline
\end{tabular}

Note: $\mathrm{G}=$ Greenroof Mass Loading; $\mathrm{C}=$ Control Roof Mass Loading; Diff = Difference

\section{$>$ SAS Analysis}

The difference between the mass loading of $\mathrm{NO}_{3}-\mathrm{NO}_{2}(\mathrm{~g})$ between the greenroof and the control roof was determined to be normally distributed through the proc univariate analysis shown below ( $\mathrm{p}$-values $>0.05)$.

\begin{tabular}{|c|c|c|c|c|}
\hline Test & \multicolumn{2}{|c|}{ - -Statistic- - - } & \multicolumn{2}{|c|}{$\ldots$} \\
\hline Shapiro-Wilk & W & 0.932342 & $\mathrm{Pr}<\mathrm{W}$ & 0.6124 \\
\hline Kolmogorov-Smirnov & $\mathrm{D}$ & 0.250845 & $\mathrm{Pr}>\mathrm{D}$ & $>0.1500$ \\
\hline Cramer-von Mises & W-Sq & 0.063466 & $\mathrm{Pr}>\mathrm{W}-\mathrm{Sq}$ & $>0.2500$ \\
\hline Anderson-Darling & $\mathrm{A}-\mathrm{Sq}$ & 0.333775 & $\mathrm{Pr}>\mathrm{A}-\mathrm{Sq}$ & $>0.2500$ \\
\hline
\end{tabular}


A t-test was performed on the data and is shown below. There was no statistically significant difference between the mass loading of $\mathrm{NO}_{3}-\mathrm{NO}_{2}(\mathrm{~g})$ in the greenroof runoff and the control roof runoff.

Difference

Err

N03_mass_G -

0.0753

N03_mass_C
The TTEST Procedure

Statistics

$\begin{array}{rrrrrr} & \text { Lower } \mathrm{CL} & \text { Upper CL } & \text { Lower CL } & \text { Upper CL } \\ \mathrm{N} & \text { Mean } & \text { Mean } & \text { Mean } & \text { Std Dev Std Dev } & \text { Std Dev Std }\end{array}$

$5 \quad-0.218-0.009$

0.1998

0.1009

0.1683

0.4837

\begin{tabular}{|c|c|c|c|}
\hline \multicolumn{4}{|c|}{$\mathrm{T}$-Tests } \\
\hline Difference & DF & t Value & $\operatorname{Pr}>|t|$ \\
\hline NO3_mass_G - NO3_mass_C & 4 & -0.12 & 0.9086 \\
\hline
\end{tabular}




\section{F.5 CONCENTRATion OF TOTAL Nitrogen (TN)}

\section{F.5.1 COMPARISON OF RAINFALL AND GREENROOF CONCENTRATIONS (MG/L)}

\section{SAS Data Input}

\begin{tabular}{|l|c|c|c|}
\hline Date & TN_conc_R & TN_conc_G & Diff TN \\
\hline \hline 19-May-03 & 0.36 & 5.39 & 5.03 \\
\hline 22-May-03 & 0.64 & 2.7 & 2.06 \\
\hline 2-Jul-03 & 0.34 & 3.84 & 3.5 \\
\hline 24-Jul-03 & 0.79 & 1.2 & 0.41 \\
\hline 4-Sep-03 & 0.95 & 6.85 & 5.9 \\
\hline 18-Sep-03 & 2.41 & 4.34 & 1.93 \\
\hline 8-Oct-03 & 0.83 & 4.78 & 3.95 \\
\hline 10-Dec-03 & 0.06 & 0.74 & 0.68 \\
\hline
\end{tabular}

Note: $\mathrm{R}=$ Rainfall Concentration; $\mathrm{G}=$ Greenroof Concentration; Diff = Difference

\section{SAS Analysis}

The difference between the concentration of TN (mg as N/L) in the rainfall and the greenroof runoff was determined to be normally distributed through the proc univariate analysis shown below ( $\mathrm{p}$-values $>0.05)$.

\begin{tabular}{|c|c|c|c|c|}
\hline \multicolumn{5}{|c|}{ Tests for Normality } \\
\hline Shapiro-Wilk & W & 0.948832 & $\mathrm{Pr}<\mathrm{W}$ & 0.6995 \\
\hline Kolmogorov-Smirnov & $\mathrm{D}$ & 0.169338 & $\mathrm{Pr}>\mathrm{D}$ & $>0.1500$ \\
\hline Cramer-von Mises & W-Sq & 0.031158 & $\mathrm{Pr}>\mathrm{W}-\mathrm{Sq}$ & $>0.2500$ \\
\hline Anderson-Darling & $\mathrm{A}-\mathrm{Sq}$ & 0.211647 & $\mathrm{Pr}>\mathrm{A}-\mathrm{Sq}$ & $>0.2500$ \\
\hline
\end{tabular}

A t-test was performed and is shown below. The concentration of TN (mg as N/L) is significantly higher in the greenroof runoff than the rainfall $(\alpha<0.05)$. 


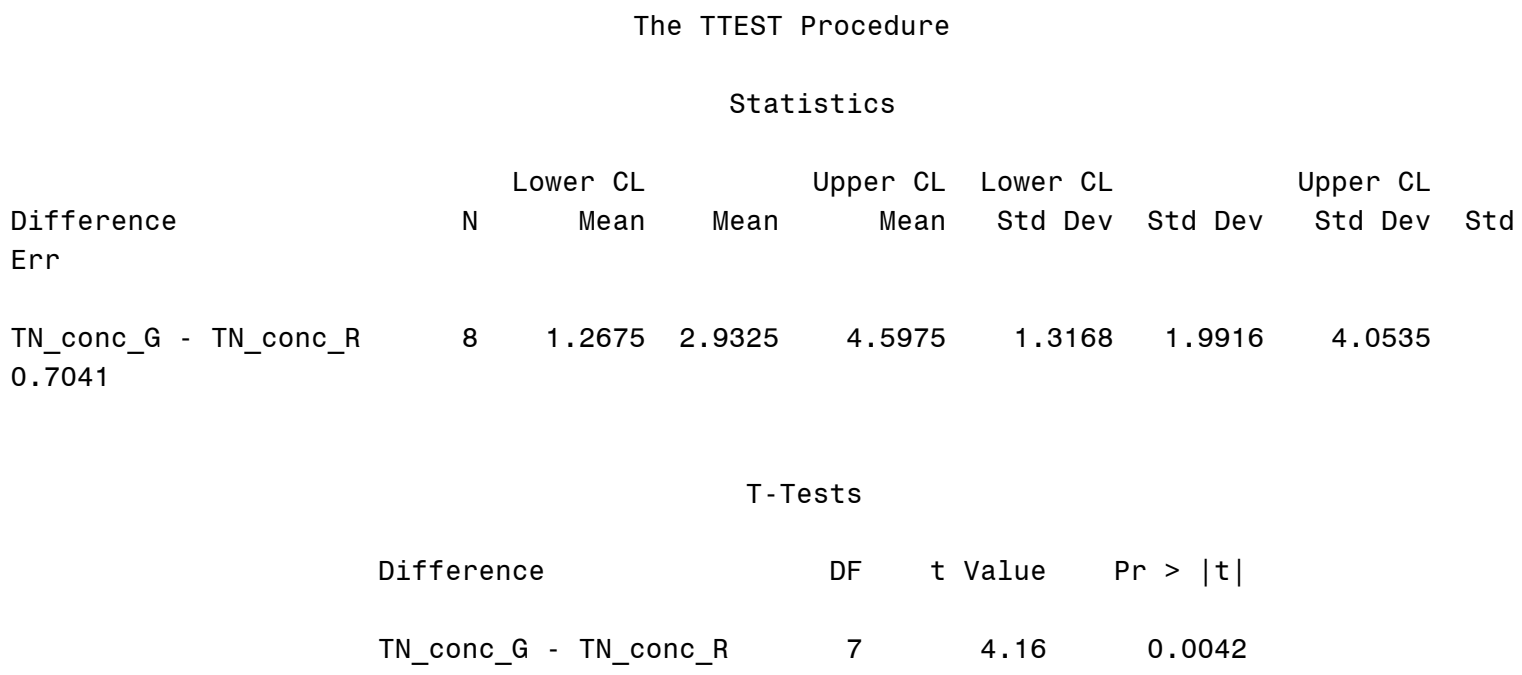

\section{F.5.2 COMParison OF GREENROOF AND CONTROL ROOF CONCENTRATIONS (MG/L)}

\section{SAS Data Input}

\begin{tabular}{|l|c|c|c|}
\hline Date & TN_conc_G & TN_conc_C & Diff TN \\
\hline \hline 6-May-03 & 5.37 & 7.2 & 1.83 \\
\hline 24-Jul-03 & 1.2 & 2.1 & 0.9 \\
\hline 4-Sep-03 & 6.85 & 1.29 & -5.56 \\
\hline 18-Sep-03 & 4.34 & 0.71 & -3.63 \\
\hline 10-Dec-03 & 0.74 & 0.7 & -0.04 \\
\hline
\end{tabular}

Note: $\mathrm{G}=$ Greenroof Concentration; $\mathrm{C}=$ Control Roof Concentration; Diff = Difference

\section{SAS Analysis}

The distribution of the differences between the greenroof and the control roof were determined to be normally distributed through the proc univariate analysis shown below (pvalue $>0.05)$ 


\begin{tabular}{|c|c|c|c|c|}
\hline Test & - -Sta & tistic-- - & $\ldots-p$ Va] & de - . - - \\
\hline Shapiro-Wilk & W & 0.906022 & $\mathrm{Pr}<\mathrm{W}$ & 0.4441 \\
\hline Kolmogorov-Smirnov & $\mathrm{D}$ & 0.255216 & $\mathrm{Pr}>\mathrm{D}$ & $>0.1500$ \\
\hline Cramer-von Mises & $\mathrm{W}-\mathrm{Sq}$ & 0.052725 & $\mathrm{Pr}>\mathrm{W}-\mathrm{Sq}$ & $>0.2500$ \\
\hline Anderson-Darling & $\mathrm{A}-\mathrm{Sq}$ & 0.306605 & $\mathrm{Pr}>\mathrm{A}-\mathrm{Sq}$ & $>0.2500$ \\
\hline
\end{tabular}

A t-test was performed on the data and is shown below. There was no statistically significant difference between the concentrations of $\mathrm{TN}(\mathrm{mg}$ as $\mathrm{N} / \mathrm{L})$ in the greenroof and in the control roof.

Difference

Err

TN_conc_C - TN_conc_G 1.4107
The TTEST Procedure

Statistics

$\begin{array}{rrrr}\text { Lower CL } & \text { Upper CL } & \text { Lower CL } & \text { Upper CL } \\ \text { Mean } & \text { Mean } & \text { Mean } & \text { Std Dev Std Dev Std Dev Std }\end{array}$

$5 \quad-5.217-1.3$

2.6167

1.8899

3.1544

9.0643

$\begin{array}{lcrr} & \text { T-Tests } & & \\ \text { Difference } & \text { DF } & t \text { Value } & \mathrm{Pr}>|\mathrm{t}| \\ \text { TN_conc_C - TN_conc_G } & 4 & -0.92 & 0.4089\end{array}$




\section{F.6 Mass LoAding OF Total Nitrogen (TN)}

\section{F.6.1 COMPARISON OF RAINFALl AND GREENROOF MASS LOADINGS (G)}

\section{SAS Data Input}

\begin{tabular}{|l|c|c|c|}
\hline Date & TN_mass_R & TN_mass_G & Diff TN \\
\hline \hline 19-May-03 & 0.034 & 0.073 & 0.039 \\
\hline 22-May-03 & 0.108 & 0.370 & 0.263 \\
\hline 2-Jul-03 & 0.041 & 0.171 & 0.130 \\
\hline 24-Jul-03 & 0.298 & 0.279 & -0.019 \\
\hline 4-Sep-03 & 0.155 & 0.389 & 0.234 \\
\hline 18-Sep-03 & 0.384 & 0.139 & -0.245 \\
\hline 8-Oct-03 & 0.055 & 0.030 & -0.026 \\
\hline 10-Dec-03 & 0.002 & 0.065 & -0.063 \\
\hline
\end{tabular}

Note: $\mathrm{R}$ = Rainfall Mass Loading; $\mathrm{G}=$ Greenroof Mass Loading; Diff = Difference

\section{SAS Analysis}

The distribution of the difference between the rainfall mass loading ( $g$ ) of $\mathrm{TN}$ and the greenroof runoff mass loading $(\mathrm{g})$ of $\mathrm{TN}$ was determined to be normally distributed through the proc univariate analysis shown below ( $\mathrm{p}$-values $>0.05)$.

\begin{tabular}{|c|c|c|c|c|}
\hline \multicolumn{5}{|c|}{ Tests for Normality } \\
\hline Shapiro-Wilk & W & 0.948983 & $\mathrm{Pr}<\mathrm{W}$ & 0.7010 \\
\hline Kolmogorov-Smirnov & $\mathrm{D}$ & 0.183607 & $\mathrm{Pr}>\mathrm{D}$ & $>0.1500$ \\
\hline Cramer-von Mises & W-Sq & 0.032772 & $\mathrm{Pr}>\mathrm{W}-\mathrm{Sq}$ & $>0.2500$ \\
\hline Anderson-Darling & $\mathrm{A}-\mathrm{Sq}$ & 0.240062 & $\mathrm{Pr}>\mathrm{A}-\mathrm{Sq}$ & $>0.2500$ \\
\hline
\end{tabular}

A t-test was performed on the data and is shown below. There was no significant difference between the mass loading ( $\mathrm{g}$ ) of $\mathrm{TN}$ in the rainfall and in the greenroof runoff. 


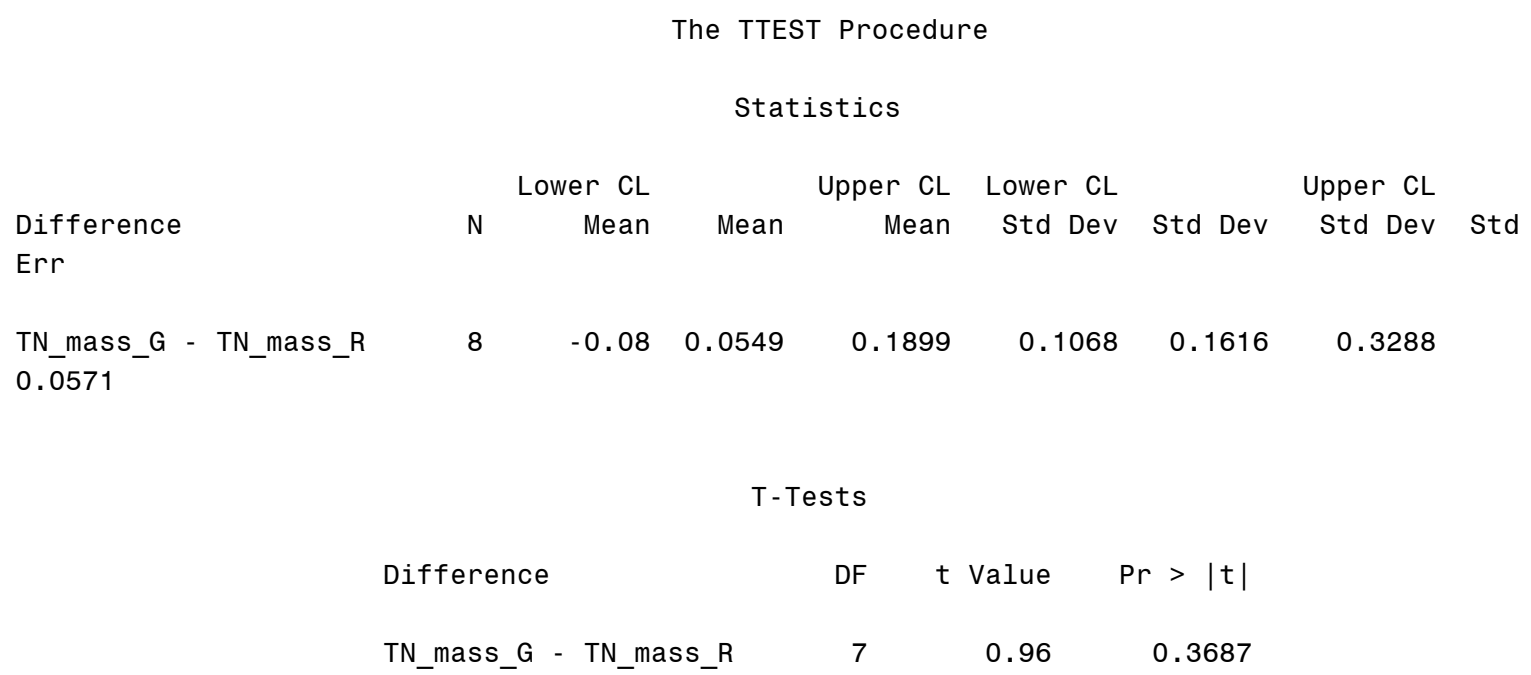

\section{F.6.2 COMParison OF GREENROOF AND CONTROL ROOF MASS LoAdings (G)}

\section{SAS Data Input}

\begin{tabular}{|l|c|c|c|}
\hline Date & TN_mass_G & TN_mass_C & Diff TN \\
\hline \hline 6-May-03 & 0.086 & 0.462 & 0.376 \\
\hline 24-Jul-03 & 0.279 & 0.726 & 0.448 \\
\hline 4-Sep-03 & 0.389 & 0.170 & -0.219 \\
\hline 18-Sep-03 & 0.139 & 0.091 & -0.048 \\
\hline 10-Dec-03 & 0.065 & 0.110 & -0.045 \\
\hline
\end{tabular}

Note: $\mathrm{G}=$ Greenroof Mass Loading; $\mathrm{C}=$ Control Roof Mass Loading; Diff = Difference

\section{$>$ SAS Analysis}

The difference between the mass loading of $\mathrm{TN}(\mathrm{g})$ between the greenroof runoff and the control roof runoff was determined to be normally distributed through the proc univariate analysis shown below ( $\mathrm{p}$-values $>0.05$ ). 


\begin{tabular}{|c|c|c|c|c|}
\hline Test & \multicolumn{2}{|c|}{ - -Statistic-- - } & \multicolumn{2}{|c|}{.... p Value..... } \\
\hline Shapiro-Wilk & W & 0.924961 & $\mathrm{Pr}<\mathrm{W}$ & 0.5624 \\
\hline Kolmogorov-Smirnov & $\mathrm{D}$ & 0.216213 & $\mathrm{Pr}>\mathrm{D}$ & $>0.1500$ \\
\hline Cramer-von Mises & $\mathrm{W}-\mathrm{Sq}$ & 0.042542 & $\mathrm{Pr}>\mathrm{W}-\mathrm{Sq}$ & $>0.2500$ \\
\hline Anderson-Darling & $\mathrm{A}-\mathrm{Sq}$ & 0.264919 & $\mathrm{Pr}>\mathrm{A}-\mathrm{Sq}$ & $>0.2500$ \\
\hline
\end{tabular}

A t-test was performed on the data and is shown below. There was no statistically significant difference between the mass loading of $\mathrm{TN}(\mathrm{g})$ in the greenroof runoff and the control roof runoff.

\begin{tabular}{|c|c|c|c|c|c|c|c|}
\hline & & ower CL & & Upper CL & Lower CL & \multicolumn{2}{|r|}{ Upper CL } \\
\hline $\begin{array}{l}\text { Difference } \\
\text { Err }\end{array}$ & $\mathrm{N}$ & Mean & Mean & Mean & Std Dev & Std Dev & Std Dev \\
\hline $\begin{array}{l}\text { TN_mass_G - TN_mass_C } \\
0.1267\end{array}$ & 5 & -0.472 & -0.12 & 0.2317 & 0.1698 & 0.2834 & 0.8143 \\
\hline
\end{tabular}

$\begin{array}{lcrr} & \text { T-Tests } & & \\ \text { Difference } & \text { DF } & t \text { Value } & \mathrm{Pr}>|\mathrm{t}| \\ \text { TN_mass_G - TN_mass_C } & 4 & -0.95 & 0.3966\end{array}$




\section{F.7 CONCENTRAtion OF Ammonia ( NH $_{3}$ AS N)}

\section{F.7.1 COMPARISON OF RAINFALl AND GREENROOF CONCENTRATIONS (MG AS N/L)}

\section{SAS Data Input}

\begin{tabular}{|l|c|c|c|}
\hline Date & NH3_conc_R & NH3_conc_G & Diff NH3 \\
\hline \hline 19-May-03 & 0.17 & 0.6 & 0.43 \\
\hline 22-May-03 & 0.22 & 0.17 & -0.05 \\
\hline 2-Jul-03 & 0.22 & 0.08 & -0.14 \\
\hline 4-Sep-03 & 0.54 & 0.02 & -0.52 \\
\hline 18-Sep-03 & 0.02 & 0.02 & 0 \\
\hline 8-Oct-03 & 0.26 & 0.02 & -0.24 \\
\hline 10-Dec-03 & 0.07 & 0.02 & -0.05 \\
\hline
\end{tabular}

Note: $\mathrm{R}=$ Rainfall Concentration; $\mathrm{G}=$ Greenroof Concentration; Diff = Difference

\section{$>$ SAS Analysis}

The difference between the concentration of $\mathrm{NH}_{3}(\mathrm{mg}$ as $\mathrm{N} / \mathrm{L})$ in the rainfall and the greenroof runoff was determined to be normally distributed through the proc univariate analysis shown below ( $\mathrm{p}$-values $>0.05)$.

\begin{tabular}{|c|c|c|c|c|}
\hline Test & - - Sta & tistic-- - & $\cdots p$ Va & ue - - - - \\
\hline Shapiro-Wilk & W & 0.934338 & $\mathrm{Pr}<\mathrm{W}$ & 0.5884 \\
\hline Kolmogorov-Smirnov & $\mathrm{D}$ & 0.245108 & $\mathrm{Pr}>\mathrm{D}$ & $>0.1500$ \\
\hline Cramer-von Mises & $\mathrm{W}-\mathrm{Sq}$ & 0.064575 & $\mathrm{Pr}>\mathrm{W}-\mathrm{Sq}$ & $>0.2500$ \\
\hline Anderson-Darling & $\mathrm{A}-\mathrm{Sq}$ & 0.360133 & $\mathrm{Pr}>\mathrm{A}-\mathrm{Sq}$ & $>0.2500$ \\
\hline
\end{tabular}

A t-test was performed on the data and is shown below. There was no significant difference between the concentration of $\mathrm{NH}_{3}(\mathrm{mg}$ as $\mathrm{N} / \mathrm{L})$ in the rainfall and in the greenroof runoff. 


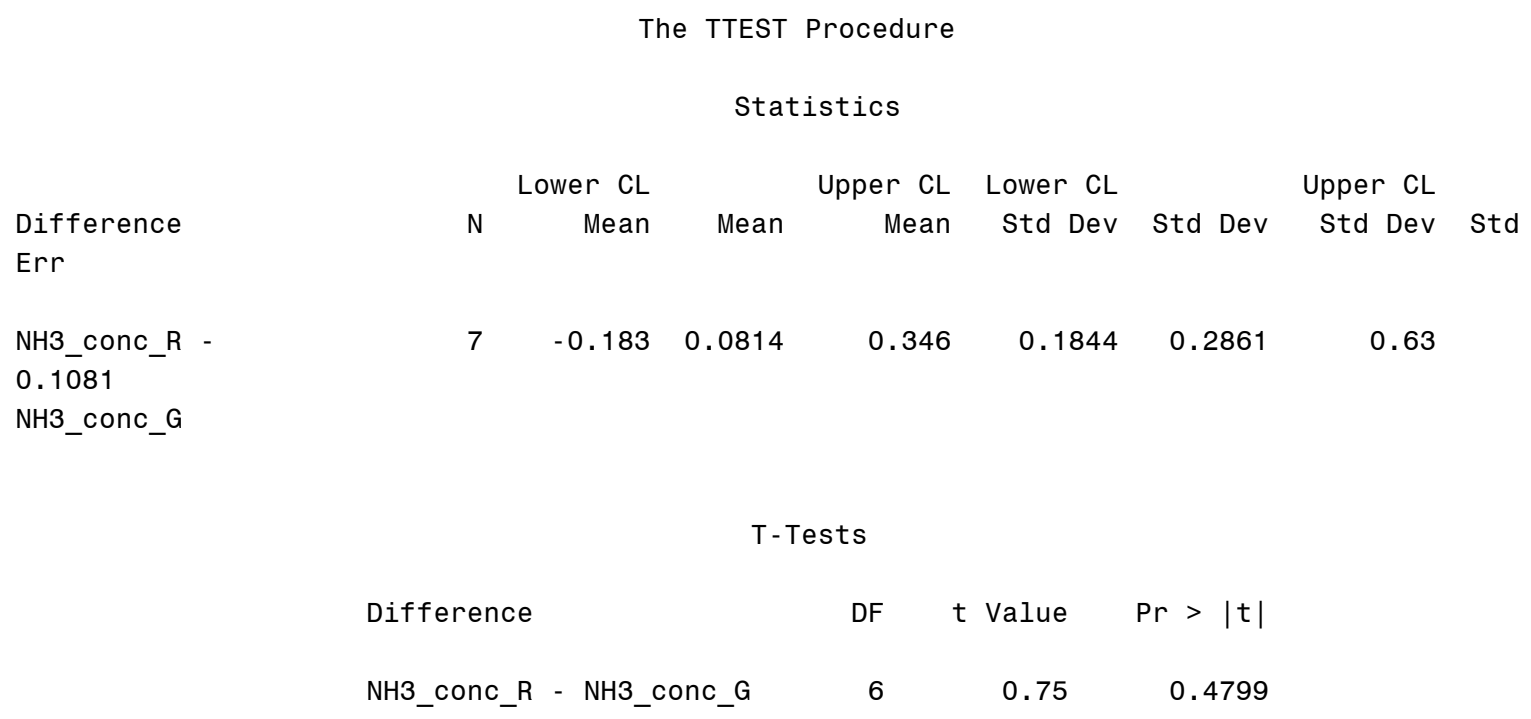

\section{F.7.2 COMPARISON OF GREENROOF AND CONTROL RoOF CONCENTRATIONS (MG AS N/L)}

\section{SAS Data Input}

\begin{tabular}{|l|c|c|c|}
\hline Date & NH3_conc_G & NH3_conc_C & Diff NH3 \\
\hline \hline 6-May-03 & 0.64 & 4.12 & 3.48 \\
\hline 4-Sep-03 & 0.02 & 0.71 & 0.69 \\
\hline 18-Sep-03 & 0.02 & 0.17 & 0.15 \\
\hline 10-Dec-03 & 0.02 & 0.07 & 0.05 \\
\hline
\end{tabular}

Note: $\mathrm{G}=$ Greenroof Concentration; $\mathrm{C}=$ Control Roof Concentration; Diff = Difference

\section{$>$ SAS Analysis}

The distribution of the difference between the $\mathrm{NH}_{3}$ concentration ( $\mathrm{mg}$ as $\mathrm{N} / \mathrm{L}$ ) between the greenroof and the control roof was determined to not be normally distributed through the proc univariate analysis shown below ( $\mathrm{p}$-value $>0.05)$ 


\begin{tabular}{|c|c|c|c|c|}
\hline Test & - -Sta & tistic-- - & $\ldots-p$ Va] & e. - . - \\
\hline Shapiro-Wilk & W & 0.764103 & $\mathrm{Pr}<\mathrm{W}$ & 0.0519 \\
\hline Kolmogorov-Smirnov & $\mathrm{D}$ & 0.34833 & $\mathrm{Pr}>\mathrm{D}$ & 0.0854 \\
\hline Cramer-von Mises & $\mathrm{W}-\mathrm{Sq}$ & 0.100878 & $\mathrm{Pr}>\mathrm{W}-\mathrm{Sq}$ & 0.0784 \\
\hline Anderson-Darling & $\mathrm{A}-\mathrm{Sq}$ & 0.545882 & $\mathrm{Pr}>\mathrm{A}-\mathrm{Sq}$ & 0.0612 \\
\hline
\end{tabular}

Therefore, a t-test would be invalid because the t-test assumes the data is normally distributed. A Sign test was performed and is shown below. There was no significant difference between the $\mathrm{NH}_{3}$ concentration (mg as N/L) between the greenroof and the control roof.

\begin{tabular}{|c|c|c|c|c|}
\hline Test & \multicolumn{2}{|c|}{-Statistic- } & \multicolumn{2}{|c|}{.... p Value..... } \\
\hline Student's $t$ & $\mathrm{t}$ & 1.351853 & $\operatorname{Pr}>|t|$ & 0.2693 \\
\hline Sign & M & 2 & $\operatorname{Pr}>=|M|$ & 0.1250 \\
\hline Signed Rank & $S$ & 5 & $\operatorname{Pr}>=|S|$ & 0.1250 \\
\hline
\end{tabular}




\section{F.8 Mass LoAding OF Ammonia ( $\mathrm{NH}_{3}$ AS N)}

\section{F.8.1 COMPARISON OF RAINFALl AND GREENROOF MASS LOADINGS (G AS N/L)}

\section{SAS Data Input}

\begin{tabular}{|l|c|c|c|}
\hline Date & NH3_mass_R & NH3_mass_G & Diff NH3 \\
\hline \hline 19-May-03 & 0.016 & 0.008 & -0.008 \\
\hline 22-May-03 & 0.037 & 0.023 & -0.014 \\
\hline 2-Jul-03 & 0.027 & 0.004 & -0.023 \\
\hline 4-Sep-03 & 0.088 & 0.001 & -0.087 \\
\hline 18-Sep-03 & 0.003 & 0.001 & -0.003 \\
\hline 8-Oct-03 & 0.017 & 0.000 & -0.017 \\
\hline 10-Dec-03 & 0.003 & 0.002 & -0.001 \\
\hline
\end{tabular}

Note: $\mathrm{R}=$ Rainfall Mass Loading; $\mathrm{G}=$ Greenroof Mass Loading; Diff = Difference

\section{SAS Analysis}

The distribution of the difference between the mass loading $(\mathrm{g})$ of $\mathrm{NH}_{3}$ in the rainfall and the greenroof runoff was determined to be not normally distributed through the proc univariate analysis shown below ( $\mathrm{p}$-values $<0.05)$.

\begin{tabular}{|c|c|c|c|c|}
\hline Test & \multicolumn{2}{|c|}{ - -Statistic-. - } & \multicolumn{2}{|c|}{.... p Value..... } \\
\hline Shapiro-Wilk & W & 0.698487 & $\mathrm{Pr}<\mathrm{W}$ & 0.0036 \\
\hline Kolmogorov-Smirnov & $\mathrm{D}$ & 0.341825 & $\mathrm{Pr}>\mathrm{D}$ & 0.0145 \\
\hline Cramer-von Mises & $\mathrm{W}-\mathrm{Sq}$ & 0.174957 & $\mathrm{Pr}>\mathrm{W}-\mathrm{Sq}$ & 0.0079 \\
\hline Anderson-Darling & $\mathrm{A}-\mathrm{Sq}$ & 0.972355 & $\mathrm{Pr}>\mathrm{A}-\mathrm{Sq}$ & 0.0065 \\
\hline
\end{tabular}

The t-test assumes the distribution between the differences is normal; therefore, $\mathrm{t}$-test is invalid for this data set. A Sign test was performed and is shown below. The mass loading (g) of $\mathrm{NH}_{3}$ in the rainfall was significantly higher than in the greenroof runoff $(\alpha<0.05)$. 


\begin{tabular}{|c|c|c|c|c|}
\hline Test & \multicolumn{2}{|c|}{-Statistic- } & \multicolumn{2}{|c|}{.... p Value..... } \\
\hline Student's $t$ & $\mathrm{t}$ & -1.94336 & $\operatorname{Pr}>|t|$ & 0.1000 \\
\hline Sign & M & -3.5 & $\operatorname{Pr}>=|M|$ & 0.0156 \\
\hline Signed Rank & $\mathrm{S}$ & -14 & $\operatorname{Pr}>=|S|$ & 0.0156 \\
\hline
\end{tabular}

\section{F.8.2 COMPARISON OF GREENROOF AND CONTROL RoOF MASS LOAdings (G AS N/L)}

\section{SAS Data Input}

\begin{tabular}{|l|c|c|c|}
\hline Date & NH3_mass_G & NH3_mass_C & Diff NH3 \\
\hline \hline 6-May-03 & 0.010 & 0.265 & 0.254 \\
\hline 4-Sep-03 & 0.001 & 0.094 & 0.093 \\
\hline 18-Sep-03 & 0.001 & 0.022 & 0.021 \\
\hline 10-Dec-03 & 0.002 & 0.011 & 0.09 \\
\hline
\end{tabular}

Note: $\mathrm{G}=$ Greenroof Mass Loading; $\mathrm{C}=$ Control Roof Mass Loading; Diff = Difference

\section{$>$ SAS Analysis}

The difference between the mass loading of $\mathrm{NH}_{3}(\mathrm{~g})$ in the greenroof runoff and the control roof runoff was determined to be normally distributed through the proc univariate analysis shown below ( $\mathrm{p}$-values $>0.05)$.

\begin{tabular}{|c|c|c|c|c|}
\hline Test & \multicolumn{2}{|c|}{--Statistic-- - } & \multicolumn{2}{|c|}{$\ldots$} \\
\hline Shapiro-Wilk & W & 0.852535 & $\mathrm{Pr}<\mathrm{W}$ & 0.2345 \\
\hline Kolmogorov-Smirnov & D & 0.254422 & $\mathrm{Pr}>\mathrm{D}$ & $>0.1500$ \\
\hline Cramer-von Mises & W-Sq & 0.063421 & $\mathrm{Pr}>\mathrm{W}-\mathrm{Sq}$ & $>0.2500$ \\
\hline Anderson-Darling & $A-S q$ & 0.378174 & $\mathrm{Pr}>\mathrm{A}-\mathrm{Sq}$ & 0.2145 \\
\hline
\end{tabular}


A t-test was performed on the data and is shown below. There was no statistically significant difference between the mass loading of $\mathrm{NH}_{3}(\mathrm{~g})$ in the greenroof runoff and the control roof runoff.

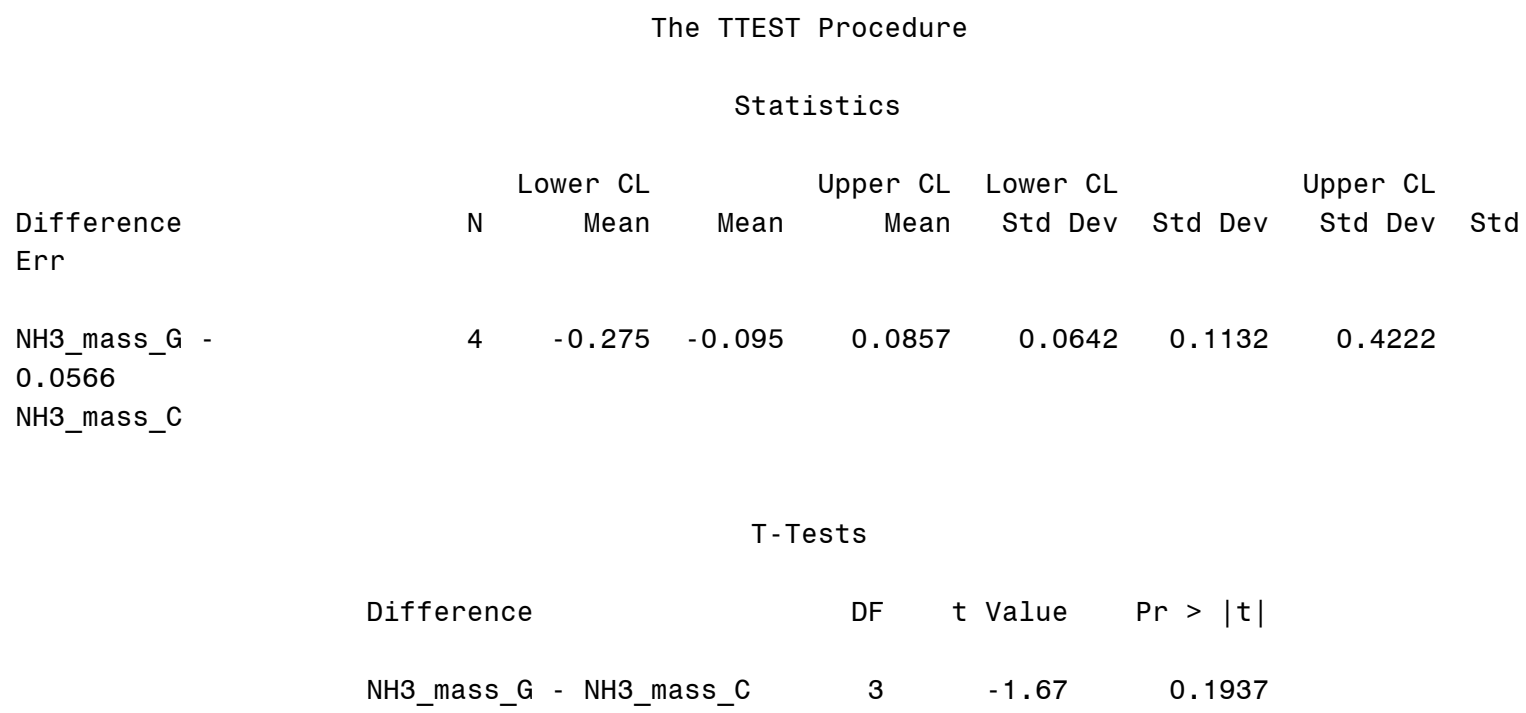




\section{F.9 Concentration of Total Phosphorus (TP)}

\section{F.9.1 COMPARISON OF RAINFALl AND GREENROOF CONCENTRATIONS (MG/L)}

\section{SAS Data Input}

\begin{tabular}{|l|c|c|c|}
\hline Date & TP_conc_R & TP_conc_G & Diff TP \\
\hline \hline 19-May-03 & 0.05 & 1.41 & 1.36 \\
\hline 22-May-03 & 0.05 & 1.17 & 1.12 \\
\hline 2-Jul-03 & 0.05 & 1.12 & 1.07 \\
\hline 24-Jul-03 & 0.05 & 0.61 & 0.56 \\
\hline 4-Sep-03 & 0.05 & 0.96 & 0.91 \\
\hline 18-Sep-03 & 0.05 & 1.40 & 1.35 \\
\hline 8-Oct-03 & 0.05 & 0.98 & 0.93 \\
\hline 10-Dec-03 & 0.05 & 0.64 & 0.59 \\
\hline
\end{tabular}

Note: $\mathrm{R}=$ Rainfall Concentration; $\mathrm{G}=$ Greenroof Concentration; Diff = Difference

\section{SAS Analysis}

The difference between the concentration of TP $(\mathrm{mg} / \mathrm{L})$ in the rainfall and the greenroof was determined to be normally distributed through the proc univariate analysis shown below (pvalues $>0.05)$.

\begin{tabular}{|c|c|c|c|c|}
\hline Test & \multicolumn{2}{|c|}{ - -Statistic-- - } & \multicolumn{2}{|c|}{-... p Value.... } \\
\hline Shapiro-Wilk & W & 0.917711 & $\mathrm{Pr}<\mathrm{W}$ & 0.4116 \\
\hline Kolmogorov-Smirnov & D & 0.15419 & $\mathrm{Pr}>\mathrm{D}$ & $>0.1500$ \\
\hline Cramer-von Mises & $\mathrm{W}-\mathrm{Sq}$ & 0.036858 & $\mathrm{Pr}>\mathrm{W}-\mathrm{Sq}$ & $>0.2500$ \\
\hline Anderson-Darling & $\mathrm{A}-\mathrm{Sq}$ & 0.287665 & $\mathrm{Pr}>\mathrm{A}-\mathrm{Sq}$ & $>0.2500$ \\
\hline
\end{tabular}

A t-test was performed on the data and is shown below. The concentration of TP $(\mathrm{mg} / \mathrm{L})$ in the greenroof was significantly higher than the concentration of TP $(\mathrm{mg} / \mathrm{L})$ in the rainfall $(\alpha$ $<0.05)$ 


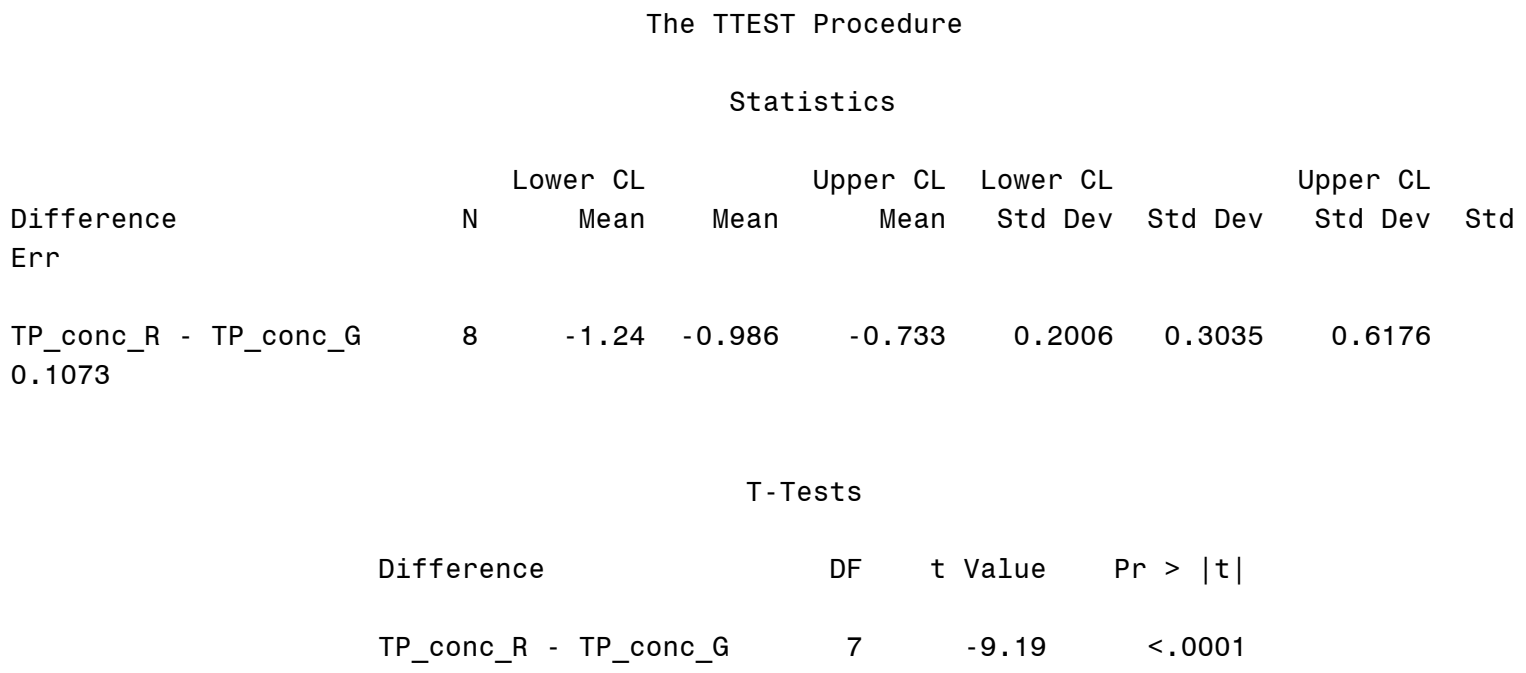

\section{F.9.2 COMPARISON OF GreENROOF AND CONTROL RoOF CONCENTRATIONS (MG/L)}

\section{SAS Data Input}

\begin{tabular}{|l|c|c|c|}
\hline Date & TP_conc_G & TP_conc_C & Diff TP \\
\hline \hline 6-May-03 & 1.01 & 0.35 & -0.66 \\
\hline 24-Jul-03 & 0.61 & 0.05 & -0.56 \\
\hline 4-Sep-03 & 0.96 & 0.05 & -0.91 \\
\hline 18-Sep-03 & 1.4 & 0.05 & -1.35 \\
\hline 10-Dec-03 & 0.64 & 0.05 & -0.59 \\
\hline
\end{tabular}

Note: $\mathrm{G}=$ Greenroof Concentration; $\mathrm{C}=$ Control Roof Concentration; Diff = Difference

\section{SAS Analysis}

The difference between the mean values of the TP concentration $(\mathrm{mg} / \mathrm{L})$ in the greenroof and the control roof runoff were determined to be normally distributed through the proc univariate analysis shown below ( $\mathrm{p}$-value $>0.05$ ). 


\begin{tabular}{|c|c|c|c|c|}
\hline Test & \multicolumn{2}{|c|}{ - -Statistic-- - } & \multicolumn{2}{|c|}{.... p Value..... } \\
\hline Shapiro-Wilk & W & 0.834097 & $\mathrm{Pr}<\mathrm{W}$ & 0.1493 \\
\hline Kolmogorov-Smirnov & $\mathrm{D}$ & 0.279761 & $\mathrm{Pr}>\mathrm{D}$ & $>0.1500$ \\
\hline Cramer-von Mises & $\mathrm{W}-\mathrm{Sq}$ & 0.075779 & $\mathrm{Pr}>\mathrm{W}-\mathrm{Sq}$ & 0.1950 \\
\hline Anderson-Darling & $\mathrm{A}-\mathrm{Sq}$ & 0.451913 & $\mathrm{Pr}>\mathrm{A}-\mathrm{Sq}$ & 0.1507 \\
\hline
\end{tabular}

A t-test was performed on the data. The concentration $(\mathrm{mg} / \mathrm{L})$ of TP present in the greenroof runoff was significantly higher than the concentration $(\mathrm{mg} / \mathrm{L})$ of TP in the control roof runoff $(\alpha<0.05)$.

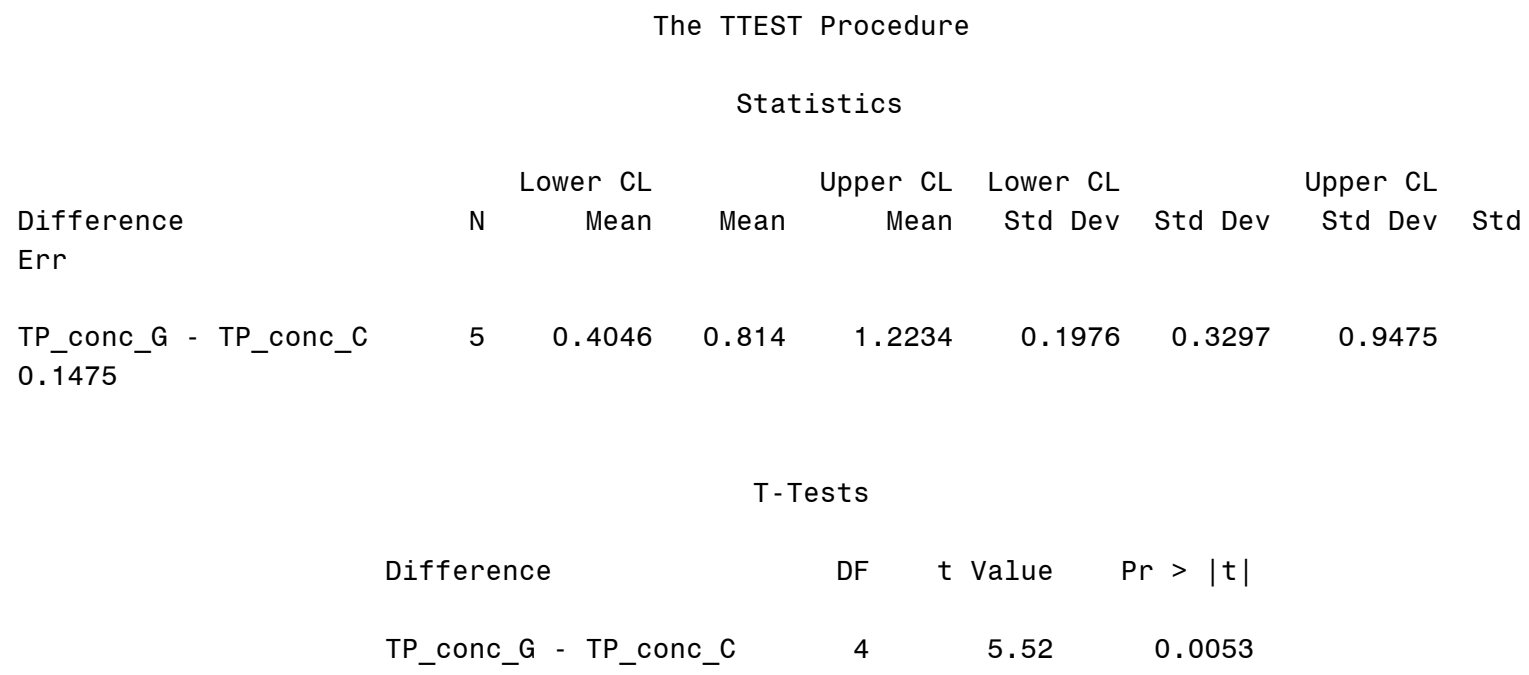




\section{F.10 Mass Loading of Total Phosphorus (TP)}

\section{F.10.1 COMPARISON OF RAINFALl AND GREENROOF MASS LOADINGS (G AS N/L)}

\section{SAS Data Input}

\begin{tabular}{|l|c|c|c|}
\hline Date & TP_mass_R & TP_mass_G & Diff TP \\
\hline 19-May-03 & 0.005 & 0.019 & 0.014 \\
\hline 22-May-03 & 0.008 & 0.160 & 0.152 \\
\hline 2-Jul-03 & 0.006 & 0.050 & 0.044 \\
\hline 24-Jul-03 & 0.019 & 0.142 & 0.123 \\
\hline 4-Sep-03 & 0.008 & 0.055 & 0.046 \\
\hline 18-Sep-03 & 0.008 & 0.045 & 0.037 \\
\hline 8-Oct-03 & 0.003 & 0.006 & 0.003 \\
\hline 10-Dec-03 & 0.002 & 0.056 & 0.054 \\
\hline
\end{tabular}

Note: $\mathrm{R}=$ Rainfall Mass Loading; $\mathrm{G}=$ Greenroof Mass Loading; Diff = Difference

\section{$>$ SAS Analysis}

The distribution of the differences between the TP mass loading ( $\mathrm{g}$ ) of the rainfall and the greenroof were determined not to be normally distributed through the proc univariate analysis shown below ( $\mathrm{p}$-values $<0.05)$.

\begin{tabular}{|c|c|c|c|c|}
\hline \multicolumn{5}{|c|}{ Tests for Normality } \\
\hline Test & - -Sta & istic-- - & $\ldots-\ldots \mathrm{Va}$ & e-..- - \\
\hline Shapiro-Wilk & W & 0.867283 & $\mathrm{Pr}<\mathrm{W}$ & 0.1418 \\
\hline Kolmogorov-Smirnov & $\mathrm{D}$ & 0.289379 & $\mathrm{Pr}>\mathrm{D}$ & 0.0469 \\
\hline Cramer-von Mises & W-Sq & 0.104295 & $\mathrm{Pr}>\mathrm{W}-\mathrm{Sq}$ & 0.0845 \\
\hline Anderson-Darling & $\mathrm{A}-\mathrm{Sq}$ & 0.551206 & $\mathrm{Pr}>\mathrm{A}-\mathrm{Sq}$ & 0.1062 \\
\hline
\end{tabular}

The t-test assumes the distribution is normal; therefore, the t-test is invalid for this data set. A Sign test was performed and is shown below. The mass loading of TP ( $g$ ) was significantly higher in the greenroof runoff than the rainfall $(\alpha<0.05)$. 


\begin{tabular}{|c|c|c|c|c|}
\hline Test & & atistic- & $-\ldots-p$ Va & - - - - - - \\
\hline Student's $t$ & $\mathrm{t}$ & 3.226144 & $\operatorname{Pr}>|t|$ & 0.0145 \\
\hline Sign & M & 4 & $\operatorname{Pr}>=|M|$ & 0.0078 \\
\hline Signed Rank & S & 18 & $\operatorname{Pr}>=|S|$ & 0.0078 \\
\hline
\end{tabular}

\section{F.10.2 COMParison OF GREENROOF AND CONTROL RoOf MASS LOAdingS (G AS N/L)}

\section{SAS Data Input}

\begin{tabular}{|l|c|c|c|}
\hline Date & TP_mass_G & TP_mass_C & Diff TP \\
\hline \hline 6-May-03 & 0.016 & 0.022 & 0.006 \\
\hline 24-Jul-03 & 0.142 & 0.017 & -0.124 \\
\hline 4-Sep-03 & 0.055 & 0.007 & -0.048 \\
\hline 18-Sep-03 & 0.045 & 0.006 & -0.039 \\
\hline 10-Dec-03 & 0.056 & 0.008 & -0.048 \\
\hline
\end{tabular}

Note: $\mathrm{G}=$ Greenroof Mass Loading; $\mathrm{C}=$ Control Roof Mass Loading; Diff = Difference

\section{SAS Analysis}

The difference between the mass loading of TP $(\mathrm{g})$ in the greenroof runoff and the control roof runoff was determined to be normally distributed through the proc univariate analysis shown below ( $\mathrm{p}$-values $>0.05)$.

\begin{tabular}{|c|c|c|c|c|}
\hline Test & \multicolumn{2}{|c|}{ - -Statistic-- - } & \multicolumn{2}{|c|}{-... p Value..... } \\
\hline Shapiro-Wilk & W & 0.897747 & $\mathrm{Pr}<\mathrm{W}$ & 0.3976 \\
\hline Kolmogorov-Smirnov & $\mathrm{D}$ & 0.32218 & $\mathrm{Pr}>\mathrm{D}$ & 0.0864 \\
\hline Cramer-von Mises & W-Sq & 0.078844 & $\mathrm{Pr}>\mathrm{W}-\mathrm{Sq}$ & 0.1751 \\
\hline Anderson-Darling & $\mathrm{A}-\mathrm{Sq}$ & 0.407308 & $\mathrm{Pr}>\mathrm{A}-\mathrm{Sq}$ & 0.2115 \\
\hline
\end{tabular}


A t-test was performed on the data and the analysis is shown below. There was no statistically significant difference between the mass loading of TP $(\mathrm{g})$ in the greenroof runoff and the control roof runoff.

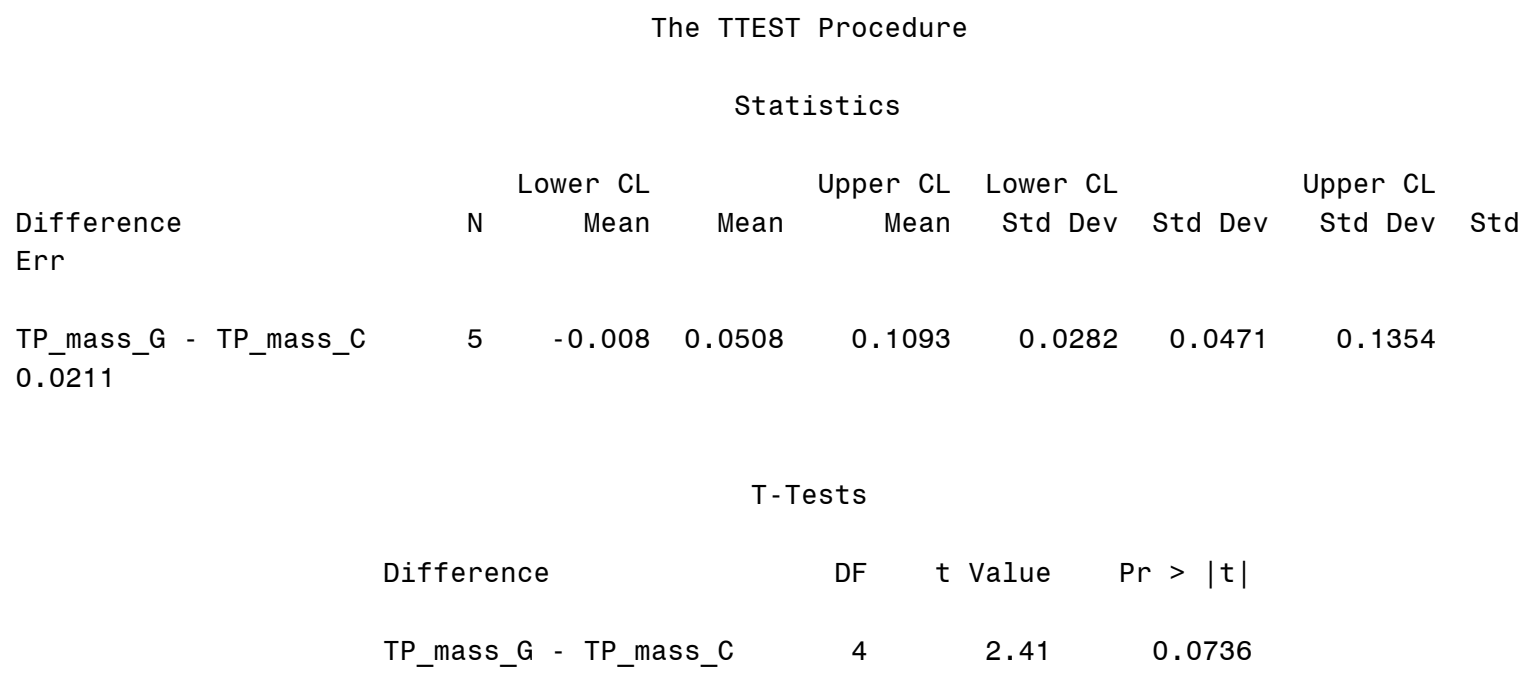




\section{F.11 CONCENTRATION OF ORTHO-PhOSPHORUS (OP)}

\section{F.11.1 COMPARISON OF RAINFALl AND GREENROOF CONCENTRATIONS (MG/L)}

SAS Data Input

\begin{tabular}{|l|c|c|c|}
\hline Date & OP_conc_R & OP_conc_G & Diff OP \\
\hline \hline 19-May-03 & 0.02 & 1.22 & 1.2 \\
\hline 22-May-03 & 0.01 & 0.24 & 0.23 \\
\hline 2-Jul-03 & 0.02 & 1.18 & 1.16 \\
\hline 4-Sep-03 & 0.02 & 1.1 & 1.08 \\
\hline 18-Sep-03 & 0.02 & 1.16 & 1.14 \\
\hline 8-Oct-03 & 0.02 & 0.83 & 0.81 \\
\hline 10-Dec-03 & 0.02 & 0.72 & 0.7 \\
\hline
\end{tabular}

Note: $\mathrm{R}=$ Rainfall Concentration; $\mathrm{G}=$ Greenroof Concentration; Diff = Difference

\section{$>$ SAS Analysis}

The difference between the concentration of OP $(\mathrm{mg} / \mathrm{L})$ in the rainfall and greenroof runoff was determined to be normally distributed through the proc univariate analysis shown below $(p$-values $>0.05)$.

\begin{tabular}{|c|c|c|c|c|}
\hline \multicolumn{5}{|c|}{ Tests for Normality } \\
\hline Test & \multicolumn{2}{|c|}{ - -Statistic-- - } & \multicolumn{2}{|c|}{... p Value..... } \\
\hline Shapiro-Wilk & W & 0.839028 & $\mathrm{Pr}<\mathrm{W}$ & 0.0973 \\
\hline Kolmogorov-Smirnov & $\mathrm{D}$ & 0.2639 & $\mathrm{Pr}>\mathrm{D}$ & 0.1439 \\
\hline Cramer-von Mises & W-Sq & 0.085102 & $\mathrm{Pr}>\mathrm{W}-\mathrm{Sq}$ & 0.1493 \\
\hline Anderson-Darling & $\mathrm{A}-\mathrm{Sq}$ & 0.527461 & $\mathrm{Pr}>\mathrm{A}-\mathrm{Sq}$ & 0.1163 \\
\hline
\end{tabular}

A t-test was performed on the data and is shown below. The concentration of OP $(\mathrm{mg} / \mathrm{L})$ was significantly higher in the greenroof runoff than in the rainfall $(\alpha<0.05)$. 


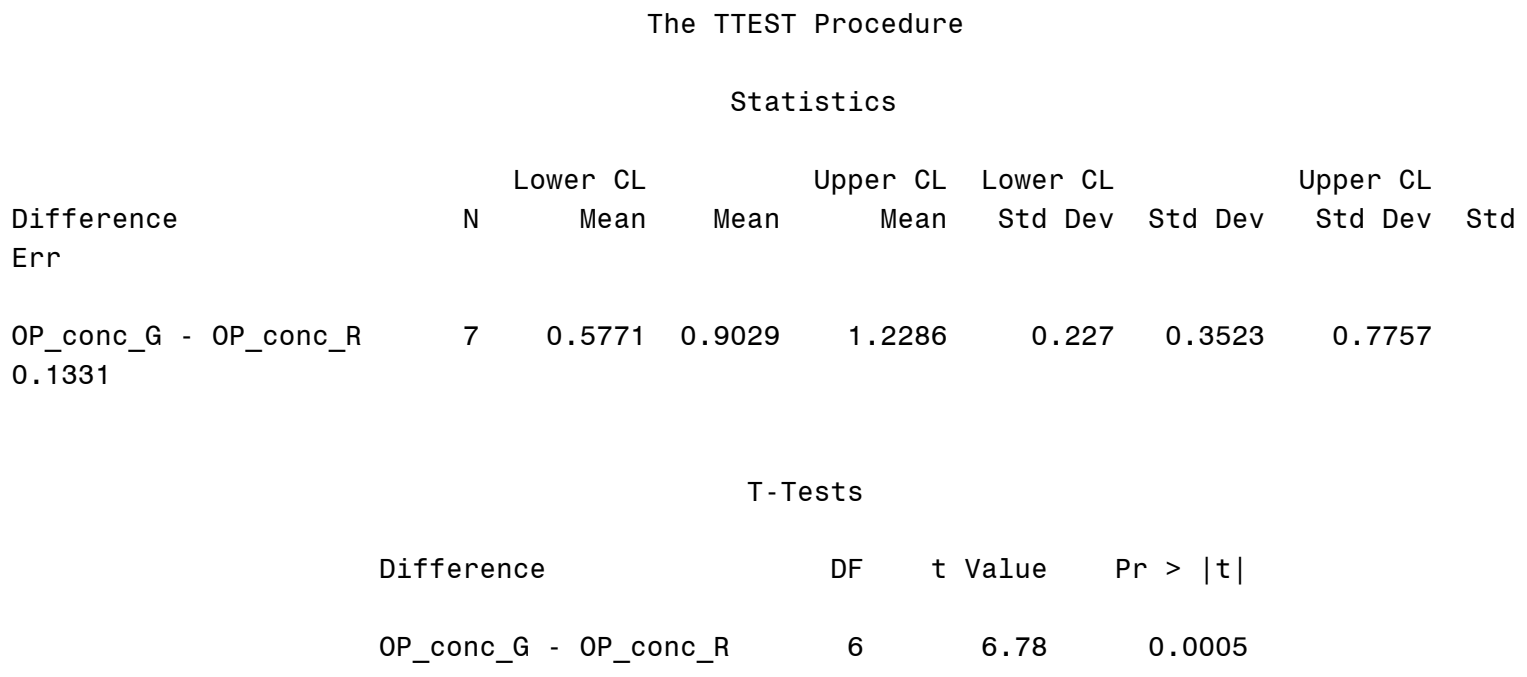

F.11.2 COMParison of GREenroof AND CONTROL Roof ConCENTRATIONS (MG AS N/L)

SAS Data Input

\begin{tabular}{|l|c|c|c|}
\hline Date & OP_conc_G & OP_conc_C & Diff OP \\
\hline 6-May-03 & 1.01 & 0.35 & -0.66 \\
\hline 4-Sep-03 & 1.1 & 0.02 & -1.08 \\
\hline 18-Sep-03 & 1.16 & 0.02 & -1.14 \\
\hline 10-Dec-03 & 0.72 & 0.02 & -0.7 \\
\hline
\end{tabular}

Note: $\mathrm{G}=$ Greenroof Concentration; $\mathrm{C}=$ Control Roof Concentration; Diff = Difference

\section{SAS Analysis}

The distribution of the difference between the concentration $(\mathrm{mg} / \mathrm{L})$ of OP in the greenroof runoff and the control roof runoff was determined to be normally distributed (p-values > $0.05)$ through the proc univariate analysis shown below. 


\begin{tabular}{|c|c|c|c|c|}
\hline Test & \multicolumn{2}{|c|}{ - -Statistic-- - } & \multicolumn{2}{|c|}{.... p Value..... } \\
\hline Shapiro-Wilk & W & 0.824125 & $\mathrm{Pr}<\mathrm{W}$ & 0.1530 \\
\hline Kolmogorov-Smirnov & $\mathrm{D}$ & 0.282305 & $\mathrm{Pr}>\mathrm{D}$ & $>0.1500$ \\
\hline Cramer-von Mises & $\mathrm{W}-\mathrm{Sq}$ & 0.070553 & $\mathrm{Pr}>\mathrm{W}-\mathrm{Sq}$ & 0.2184 \\
\hline Anderson-Darling & $\mathrm{A}-\mathrm{Sq}$ & 0.416545 & $\mathrm{Pr}>\mathrm{A}-\mathrm{Sq}$ & 0.1585 \\
\hline
\end{tabular}

A t-test was performed on the data and is shown below. The concentration of OP $(\mathrm{mg} / \mathrm{L})$ in the greenroof runoff was significantly higher than the concentration of $\mathrm{OP}(\mathrm{mg} / \mathrm{L})$ in the control roof runoff $(\alpha<0.05)$.

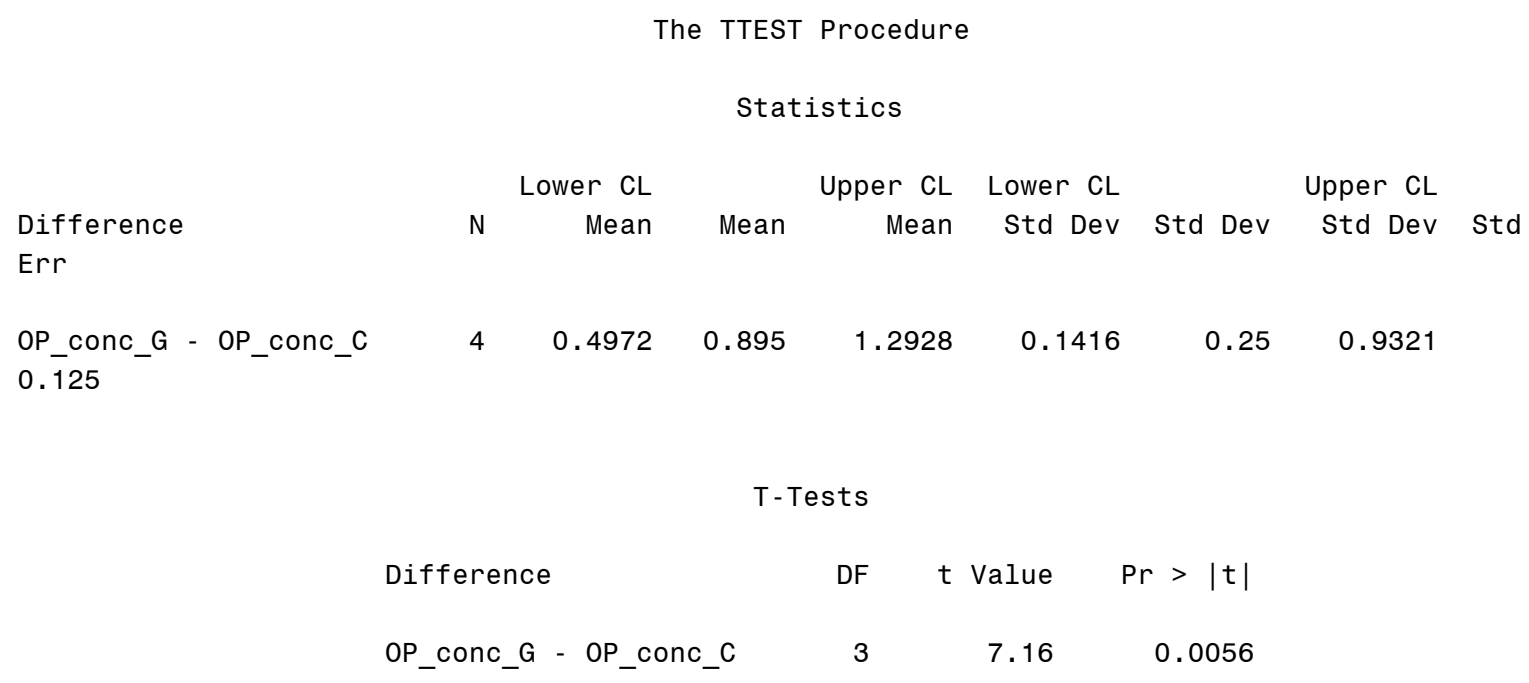




\section{F.12 Mass LoAding OF ORThO-Phosphorus (OP)}

\section{F.12.1 COMPARISON OF RAINFALl AND GREENROOF MASS LOADINGS (G)}

\section{SAS Data Input}

\begin{tabular}{|l|c|c|c|}
\hline Date & OP_mass_R & OP_mass_G & Diff OP \\
\hline \hline 19-May-03 & 0.002 & 0.017 & 0.015 \\
\hline 22-May-03 & 0.002 & 0.033 & 0.031 \\
\hline 2-Jul-03 & 0.002 & 0.052 & 0.050 \\
\hline 4-Sep-03 & 0.003 & 0.062 & 0.059 \\
\hline 18-Sep-03 & 0.003 & 0.037 & 0.034 \\
\hline 8-Oct-03 & 0.001 & 0.005 & 0.004 \\
\hline 10-Dec-03 & 0.001 & 0.063 & 0.062 \\
\hline
\end{tabular}

Note: $\mathrm{R}$ = Rainfall Mass Loading; $\mathrm{G}=$ Greenroof Mass Loading; Diff = Difference

\section{$>$ SAS Analysis}

The difference between the mass loading of $\mathrm{OP}(\mathrm{g})$ in the rainfall and the greenroof runoff were determined to be normally distributed through the proc univariate analysis shown below $(p$-values $>0.05)$.

\begin{tabular}{|c|c|c|c|c|}
\hline \multicolumn{5}{|c|}{ Tests for Normality } \\
\hline Test & \multicolumn{2}{|c|}{ - -Statistic-- - } & \multicolumn{2}{|c|}{... p Value..... } \\
\hline Shapiro-Wilk & W & 0.940001 & $\mathrm{Pr}<\mathrm{W}$ & 0.6387 \\
\hline Kolmogorov-Smirnov & $\mathrm{D}$ & 0.160277 & $\mathrm{Pr}>\mathrm{D}$ & $>0.1500$ \\
\hline Cramer-von Mises & W-Sq & 0.032703 & $\mathrm{Pr}>\mathrm{W}-\mathrm{Sq}$ & $>0.2500$ \\
\hline Anderson-Darling & $\mathrm{A}-\mathrm{Sq}$ & 0.226877 & $\mathrm{Pr}>\mathrm{A}-\mathrm{Sq}$ & $>0.2500$ \\
\hline
\end{tabular}

A t-test was performed on the data and is shown below. There was a significantly higher amount of OP $(\mathrm{g})$ present in the greenroof runoff than in the rainfall $(\alpha<0.05)$. 


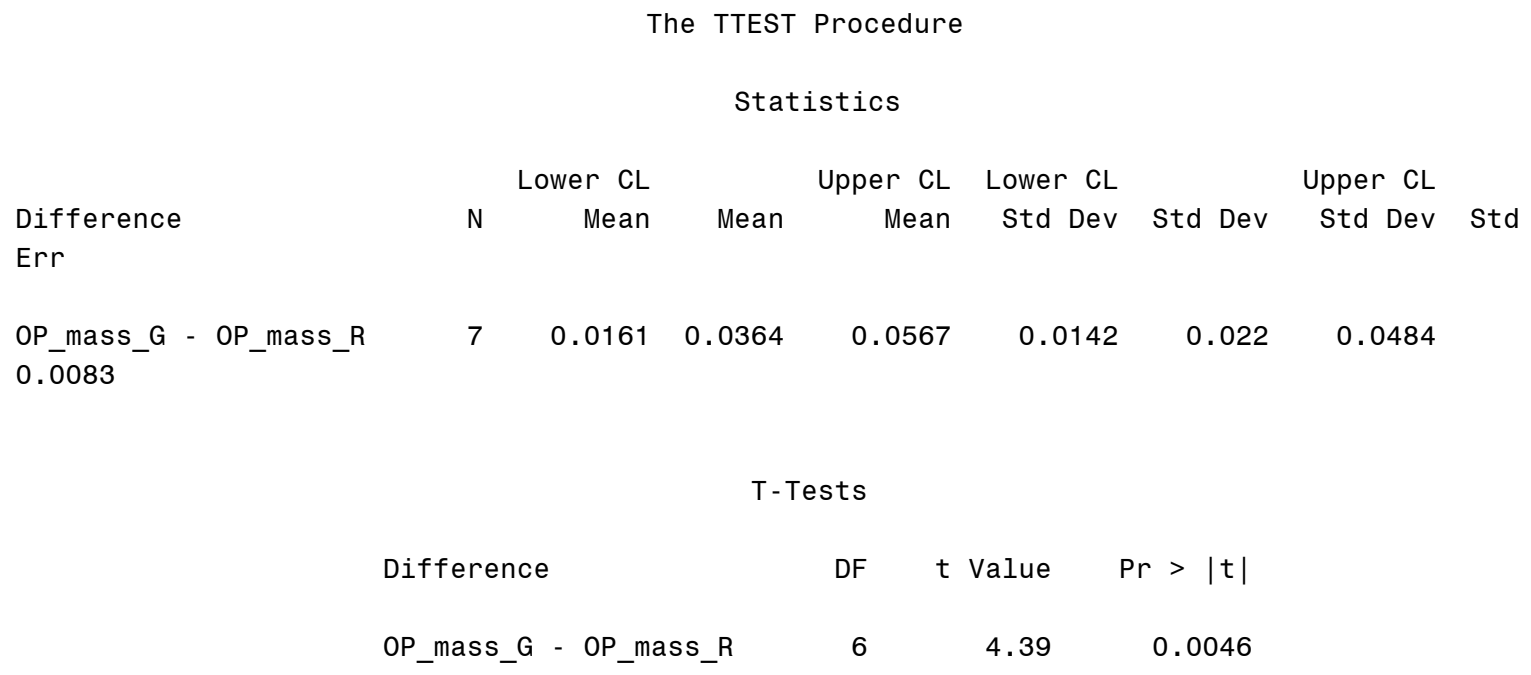

\section{F.12.2 Comparison of Greenroof AND Control Roof Mass LoAdings (G)}

\section{SAS Data Input}

\begin{tabular}{|l|c|c|c|}
\hline Date & OP_mass_G & OP_mass_C & Diff OP \\
\hline \hline 6-May-03 & 0.013 & 0.009 & -0.004 \\
\hline 4-Sep-03 & 0.062 & 0.003 & -0.060 \\
\hline 18-Sep-03 & 0.037 & 0.003 & -0.035 \\
\hline 10-Dec-03 & 0.063 & 0.003 & -0.060 \\
\hline
\end{tabular}

Note: $\mathrm{G}=$ Greenroof Mass Loading; $\mathrm{C}=$ Control Roof Mass Loading; Diff = Difference

\section{$>$ SAS Analysis}

The difference between the mass loading of OP $(\mathrm{g})$ in the greenroof runoff and the control roof runoff was determined to be normally distributed through the proc univariate analysis shown below ( $\mathrm{p}$-values $>0.05$ ). 


\begin{tabular}{|c|c|c|c|c|}
\hline Test & - -Sta & tistic-- - & $\ldots-p$ Va] & ue - . - . \\
\hline Shapiro-Wilk & W & 0.857533 & $\mathrm{Pr}<\mathrm{W}$ & 0.2515 \\
\hline Kolmogorov-Smirnov & $\mathrm{D}$ & 0.276858 & $\mathrm{Pr}>\mathrm{D}$ & $>0.1500$ \\
\hline Cramer-von Mises & $\mathrm{W}-\mathrm{Sq}$ & 0.057722 & $\mathrm{Pr}>\mathrm{W}-\mathrm{Sq}$ & $>0.2500$ \\
\hline Anderson-Darling & $\mathrm{A}-\mathrm{Sq}$ & 0.360236 & $\mathrm{Pr}>\mathrm{A}-\mathrm{Sq}$ & 0.2407 \\
\hline
\end{tabular}

A t-test was performed on the data and is shown below. There was no statistically significant difference between the mass loading of OP $(\mathrm{g})$ in the greenroof runoff and the control roof runoff.

Difference

Err

OP_mass_G - OP_mass_C 0.0132
The TTEST Procedure

Statistics

$\begin{array}{rrrr}\text { Lower CL } & \text { Upper CL Lower CL } & \text { Upper CL } \\ \text { Mean } & \text { Mean } & \text { Mean Std Dev Std Dev } & \text { Std Dev Std }\end{array}$

$4 \quad-0.003 \quad 0.0393$

0.0813

0.015

0.0264

0.0984

$\begin{array}{lcrr}\text { Difference } & \text { DF } & \text { t Value } & \mathrm{Pr}>|\mathrm{t}| \\ \text { OP_mass_G - OP_mass_C } & 3 & 2.97 & 0.0589\end{array}$




\section{G.0 APPENDIX G - KINSTON WATER QUALITY DATA}

The mass loadings of each nutrient species were determined by multiplying the concentration of each nutrient with the volume of flow from the rainfall, greenroof runoff, or control roof runoff. The volume of rainfall (L) was determined by multiplying the depth of rainfall (in.) by the surface area of the greenroof $\left(290 \mathrm{ft}^{2}\right)$ with a SI conversion factor. The volume of greenroof runoff (L) was determined by multiplying the depth of runoff (in.) by the surface area of the greenroof $\left(290 \mathrm{ft}^{2}\right)$ with a SI conversion factor. The volume of the control roof runoff (L) was determined by multiplying the depth of runoff (in.) by the surface area of the rooftop $\left(290 \mathrm{ft}^{2}\right)$ with a SI conversion factor. The surface area of the control roof is actually $1820 \mathrm{ft}^{2}$, but this was normalized in the calculations so the amount of runoff would be relative to the greenroof. As with the WCC Greenroof in Goldsboro, the amount of runoff from the control roof was determined by subtracting an initial abstraction from the total rainfall for each rain event. In Goldsboro, the initial abstraction was determined to be 6.4 $\mathrm{mm}(0.25 \mathrm{in}$.$) ; this was not the initial abstraction assumed for the control roof in Kinston.$ The control roof in Kinston is a sloped roof (less than $10^{\circ}$ slope); therefore, the initial abstraction would be less than $6.4 \mathrm{~mm}(0.25 \mathrm{in}$.). The initial abstraction of rainfall from the control roof in Kinston was assumed to be equivalent to typical interception amounts of 0.51 mm (0.02 in.). In a design manual published by the U.S. Department of Transportation, typical interception depths are recorded as $0.51 \mathrm{~mm}(0.02 \mathrm{in}$.) (Masch et al., 1984).

Because little mass loading data was available for the Nature Center Greenroof in Kinston, this data was neither graphed nor analyzed for statistical significance. The data is, however, presented in Table G-1 and Table G-2. 


\section{G.1 TKN, $\mathrm{NO}_{3}-\mathrm{NO}_{2}$, AND TN}

Table G-1. Summary Table of $\mathrm{TKN}, \mathrm{NO}_{3}-\mathrm{NO}_{2}$, and $\mathrm{TN}$ Concentrations and Mass Loadings at Nature Center Greenroof in Kinston, NC

\begin{tabular}{|c|c|c|c|c|c|c|c|c|c|}
\hline \multirow[b]{2}{*}{ DATE } & \multirow[b]{2}{*}{ Source } & \multicolumn{2}{|c|}{$\begin{array}{c}\text { INFLOW/ } \\
\text { OUTFLOW }\end{array}$} & \multicolumn{2}{|c|}{ TKN as $\mathrm{N}$} & \multicolumn{2}{|c|}{$\mathrm{NO}_{3}-\mathrm{NO}_{2}$ as $\mathrm{N}$} & \multicolumn{2}{|c|}{$\mathrm{TN}$} \\
\hline & & in. & $\mathrm{L}$ & $\mathrm{mg} / \mathrm{L}$ & g & $\mathrm{mg} / \mathrm{L}$ & $\mathrm{g}$ & $\mathrm{mg} / \mathrm{L}$ & $\mathrm{g}$ \\
\hline \multirow{3}{*}{19 May } & RAINFALL (in) & 1.86 & 88.83 & 0.25 & 0.022 & 0.1 & 0.009 & 0.35 & 0.031 \\
\hline & GREENROOF (out) & $\mathrm{n} / \mathrm{a}$ & $\mathrm{n} / \mathrm{a}$ & 2.21 & $\mathrm{n} / \mathrm{a}$ & 0.16 & $\mathrm{n} / \mathrm{a}$ & 2.37 & $\mathrm{n} / \mathrm{a}$ \\
\hline & CONTROL (out) & 1.84 & 87.88 & $\mathrm{n} / \mathrm{a}$ & $\mathrm{n} / \mathrm{a}$ & $\mathrm{n} / \mathrm{a}$ & $\mathrm{n} / \mathrm{a}$ & $\mathrm{n} / \mathrm{a}$ & $\mathrm{n} / \mathrm{a}$ \\
\hline \multirow{3}{*}{23 May } & RAINFALL (in) & 2.38 & 113.67 & 0.31 & 0.035 & 0.09 & 0.010 & 0.4 & 0.045 \\
\hline & GREENROOF (out) & $\mathrm{n} / \mathrm{a}$ & $\mathrm{n} / \mathrm{a}$ & 2 & $\mathrm{n} / \mathrm{a}$ & 0.06 & $\mathrm{n} / \mathrm{a}$ & 2.06 & $\mathrm{n} / \mathrm{a}$ \\
\hline & CONTROL (out) & 2.36 & 112.71 & $\mathrm{n} / \mathrm{a}$ & $\mathrm{n} / \mathrm{a}$ & $\mathrm{n} / \mathrm{a}$ & $\mathrm{n} / \mathrm{a}$ & $\mathrm{n} / \mathrm{a}$ & $\mathrm{n} / \mathrm{a}$ \\
\hline \multirow{3}{*}{2 July } & RAINFALL (in) & 2.85 & 136.11 & 0.25 & 0.034 & 0.09 & 0.012 & 0.34 & 0.046 \\
\hline & GREENROOF (out) & $\mathrm{n} / \mathrm{a}$ & $\mathrm{n} / \mathrm{a}$ & 2.91 & $\mathrm{n} / \mathrm{a}$ & 2.32 & $\mathrm{n} / \mathrm{a}$ & 5.23 & $\mathrm{n} / \mathrm{a}$ \\
\hline & CONTROL (out) & 2.83 & 135.16 & 0.35 & 0.047 & 0.13 & 0.018 & 0.48 & 0.065 \\
\hline \multirow{3}{*}{23 July } & RAINFALL (in) & $\mathrm{n} / \mathrm{a}$ & $\mathrm{n} / \mathrm{a}$ & 0.53 & $\mathrm{n} / \mathrm{a}$ & 0.24 & $\mathrm{n} / \mathrm{a}$ & 0.77 & $\mathrm{n} / \mathrm{a}$ \\
\hline & GREENROOF (out) & $\mathrm{n} / \mathrm{a}$ & $\mathrm{n} / \mathrm{a}$ & 2.71 & $\mathrm{n} / \mathrm{a}$ & 0.47 & $\mathrm{n} / \mathrm{a}$ & 3.18 & $\mathrm{n} / \mathrm{a}$ \\
\hline & CONTROL (out) & $\mathrm{n} / \mathrm{a}$ & $\mathrm{n} / \mathrm{a}$ & 0.76 & $\mathrm{n} / \mathrm{a}$ & 0.3 & $\mathrm{n} / \mathrm{a}$ & 1.06 & $\mathrm{n} / \mathrm{a}$ \\
\hline \multirow{3}{*}{8 Oct } & RAINFALL (in) & $\mathrm{n} / \mathrm{a}$ & $\mathrm{n} / \mathrm{a}$ & 0.52 & $\mathrm{n} / \mathrm{a}$ & 0.12 & $\mathrm{n} / \mathrm{a}$ & 0.64 & $\mathrm{n} / \mathrm{a}$ \\
\hline & GREENROOF (out) & 0.24 & 11.46 & 2.51 & 0.029 & 0.67 & 0.008 & 3.18 & 0.036 \\
\hline & CONTROL (out) & $\mathrm{n} / \mathrm{a}$ & $\mathrm{n} / \mathrm{a}$ & 0.47 & $\mathrm{n} / \mathrm{a}$ & 0.1 & $\mathrm{n} / \mathrm{a}$ & 0.57 & $\mathrm{n} / \mathrm{a}$ \\
\hline \multirow{3}{*}{$10 \mathrm{Dec}$} & RAINFALL (in) & 1.53 & 73.07 & 0.25 & 0.018 & 0.11 & 0.008 & 0.11 & 0.008 \\
\hline & GREENROOF (out) & 1.18 & 56.36 & 1.23 & 0.069 & 0.15 & 0.008 & 1.38 & 0.078 \\
\hline & CONTROL (out) & 1.51 & 72.12 & 0.25 & 0.018 & 0.05 & 0.004 & 0.05 & 0.004 \\
\hline
\end{tabular}




\section{G.2 $\mathrm{NH}_{3}, \mathrm{TP}$, AND OP}

Table G-2. Summary Table of $\mathrm{NH}_{3}$, TP, and OP Concentrations and Mass Loadings at Nature Center Greenroof in Kinston, NC

\begin{tabular}{|c|c|c|c|c|c|c|c|c|c|}
\hline \multirow[b]{2}{*}{ DATE } & \multirow[b]{2}{*}{ Source } & \multicolumn{2}{|c|}{$\begin{array}{c}\text { INFLOW/ } \\
\text { OUTFLOW }\end{array}$} & \multicolumn{2}{|c|}{$\mathrm{NH}_{3}$ as $\mathrm{N}$} & \multicolumn{2}{|c|}{$\mathrm{TP}$} & \multicolumn{2}{|c|}{ OP } \\
\hline & & in. & $\mathrm{L}$ & $\mathrm{mg} / \mathrm{L}$ & $\mathrm{g}$ & $\mathrm{mg} / \mathrm{L}$ & $\mathrm{g}$ & $\mathrm{mg} / \mathrm{L}$ & $\mathrm{g}$ \\
\hline \multirow{3}{*}{19 May } & RAINFALL (in) & 1.86 & 88.83 & 0.1 & 0.009 & 0.05 & 0.004 & 0.15 & 0.013 \\
\hline & GREENROOF (out) & $\mathrm{n} / \mathrm{a}$ & $\mathrm{n} / \mathrm{a}$ & 0.02 & $\mathrm{n} / \mathrm{a}$ & 1.33 & $\mathrm{n} / \mathrm{a}$ & 1.24 & $\mathrm{n} / \mathrm{a}$ \\
\hline & CONTROL (out) & 1.84 & 87.88 & $\mathrm{n} / \mathrm{a}$ & $\mathrm{n} / \mathrm{a}$ & $\mathrm{n} / \mathrm{a}$ & $\mathrm{n} / \mathrm{a}$ & $\mathrm{n} / \mathrm{a}$ & $\mathrm{n} / \mathrm{a}$ \\
\hline \multirow{3}{*}{23 May } & RAINFALL (in) & 2.38 & 113.67 & 0.12 & 0.014 & 0.05 & 0.006 & 0.01 & 0.001 \\
\hline & GREENROOF (out) & $\mathrm{n} / \mathrm{a}$ & $\mathrm{n} / \mathrm{a}$ & 0.02 & $\mathrm{n} / \mathrm{a}$ & 1.2 & $\mathrm{n} / \mathrm{a}$ & 0.24 & $\mathrm{n} / \mathrm{a}$ \\
\hline & CONTROL (out) & 2.36 & 112.71 & $\mathrm{n} / \mathrm{a}$ & $\mathrm{n} / \mathrm{a}$ & $\mathrm{n} / \mathrm{a}$ & $\mathrm{n} / \mathrm{a}$ & $\mathrm{n} / \mathrm{a}$ & $\mathrm{n} / \mathrm{a}$ \\
\hline \multirow{3}{*}{2 July } & RAINFALL (in) & 2.85 & 136.11 & 0.13 & 0.018 & 0.05 & 0.007 & 0.02 & 0.003 \\
\hline & GREENROOF (out) & $\mathrm{n} / \mathrm{a}$ & $\mathrm{n} / \mathrm{a}$ & 0.13 & $\mathrm{n} / \mathrm{a}$ & 1.55 & $\mathrm{n} / \mathrm{a}$ & 1.54 & $\mathrm{n} / \mathrm{a}$ \\
\hline & CONTROL (out) & 2.83 & 135.16 & 0.22 & 0.030 & 0.08 & 0.011 & 0.02 & 0.003 \\
\hline \multirow{3}{*}{23 July } & RAINFALL (in) & $\mathrm{n} / \mathrm{a}$ & $\mathrm{n} / \mathrm{a}$ & $\mathrm{n} / \mathrm{a}$ & $\mathrm{n} / \mathrm{a}$ & 0.05 & $\mathrm{n} / \mathrm{a}$ & $\mathrm{n} / \mathrm{a}$ & $\mathrm{n} / \mathrm{a}$ \\
\hline & GREENROOF (out) & $\mathrm{n} / \mathrm{a}$ & $\mathrm{n} / \mathrm{a}$ & $\mathrm{n} / \mathrm{a}$ & $\mathrm{n} / \mathrm{a}$ & 1.28 & $\mathrm{n} / \mathrm{a}$ & $\mathrm{n} / \mathrm{a}$ & $\mathrm{n} / \mathrm{a}$ \\
\hline & CONTROL (out) & $\mathrm{n} / \mathrm{a}$ & $\mathrm{n} / \mathrm{a}$ & $\mathrm{n} / \mathrm{a}$ & $\mathrm{n} / \mathrm{a}$ & 0.05 & $\mathrm{n} / \mathrm{a}$ & $\mathrm{n} / \mathrm{a}$ & $\mathrm{n} / \mathrm{a}$ \\
\hline \multirow{3}{*}{8 Oct } & RAINFALL (in) & $\mathrm{n} / \mathrm{a}$ & $\mathrm{n} / \mathrm{a}$ & 0.15 & $\mathrm{n} / \mathrm{a}$ & 0.1 & $\mathrm{n} / \mathrm{a}$ & 0.04 & $\mathrm{n} / \mathrm{a}$ \\
\hline & GREENROOF (out) & 0.24 & 11.46 & 0.08 & 0.001 & 1.24 & 0.014 & 1.18 & 0.014 \\
\hline & CONTROL (out) & $\mathrm{n} / \mathrm{a}$ & $\mathrm{n} / \mathrm{a}$ & 0.18 & $\mathrm{n} / \mathrm{a}$ & 0.1 & $\mathrm{n} / \mathrm{a}$ & 0.04 & $\mathrm{n} / \mathrm{a}$ \\
\hline \multirow{3}{*}{$10 \mathrm{Dec}$} & RAINFALL (in) & 1.53 & 73.07 & 0.13 & 0.009 & 0.05 & 0.004 & 0.02 & 0.001 \\
\hline & GREENROOF (out) & 1.18 & 56.36 & 0.02 & 0.001 & 1.06 & 0.060 & 1.03 & 0.058 \\
\hline & CONTROL (out) & 1.51 & 72.12 & 0.07 & 0.005 & 0.09 & 0.006 & 0.02 & 0.001 \\
\hline
\end{tabular}




\section{G.3 Graphs of CONCENTrations For EACH Nutrient}

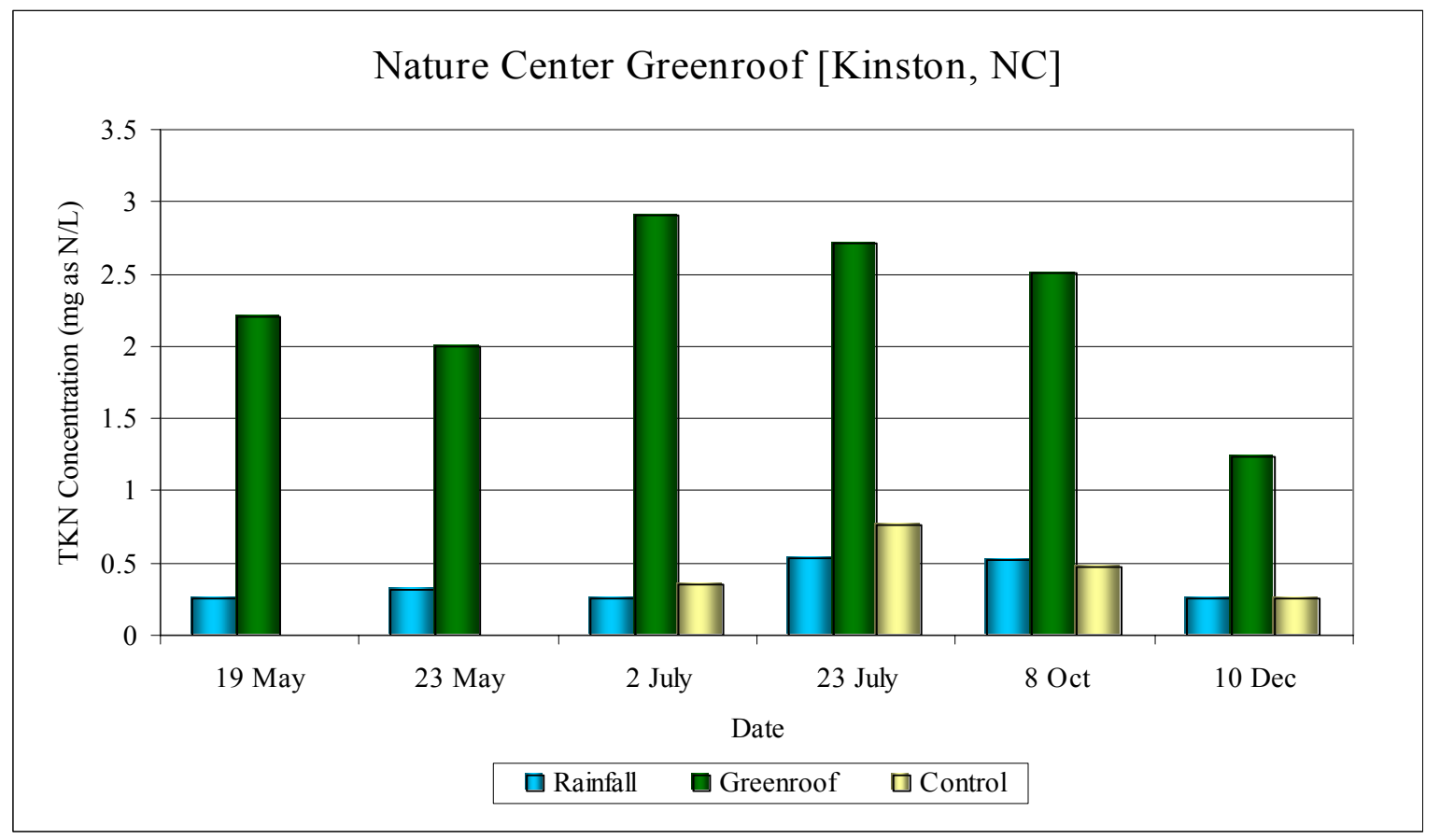

Figure G-1. Display of TKN Concentrations at Nature Center Greenroof in Kinston, NC. (Note: Control data is unavailable for 19 May and 23 May)

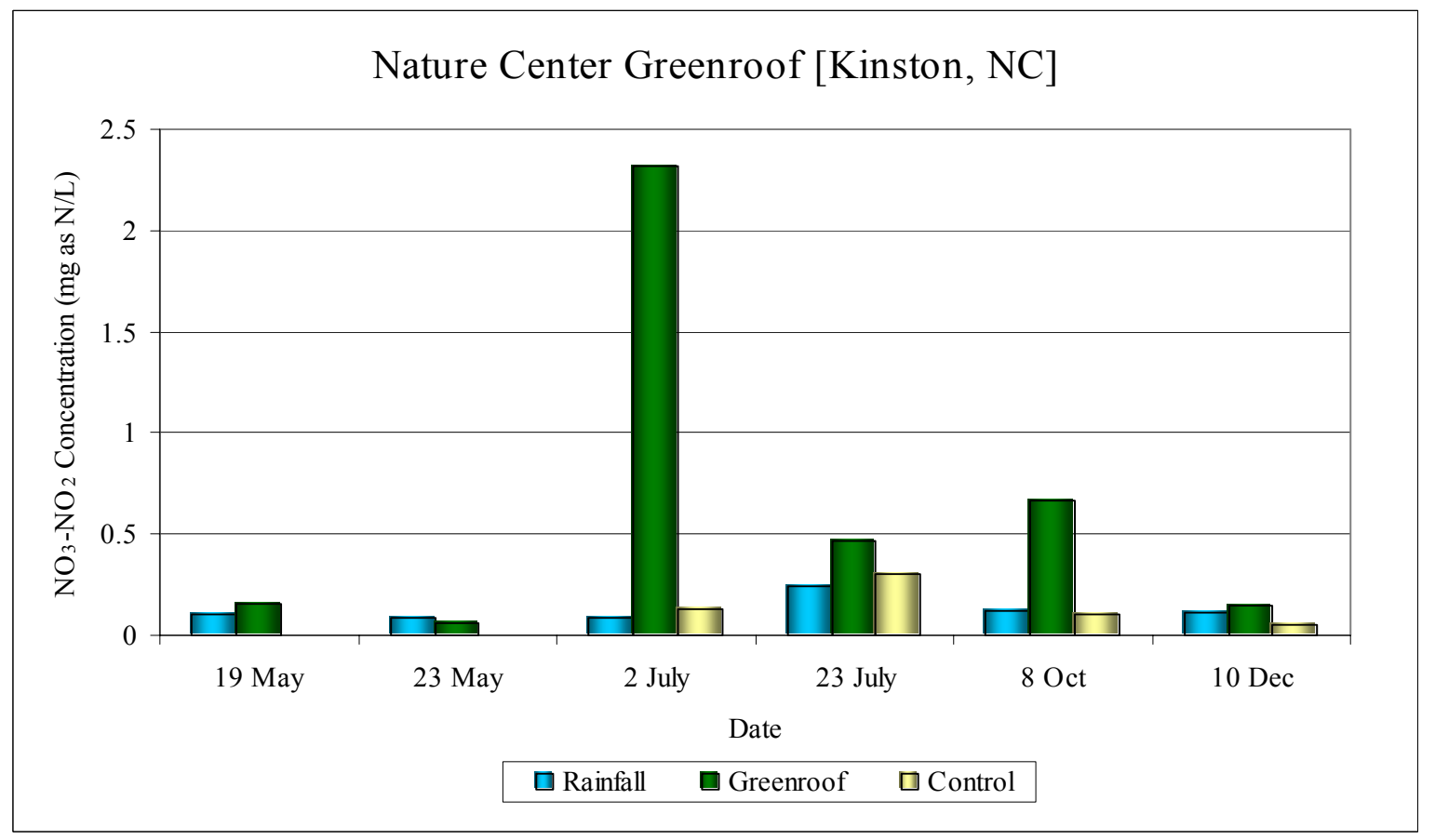

Figure G-2. Display of $\mathrm{NO}_{3}-\mathrm{NO}_{2}$ Concentrations at Nature Center Greenroof in Kinston, NC. (Note: Control data is unavailable for 19 May and 23 May) 


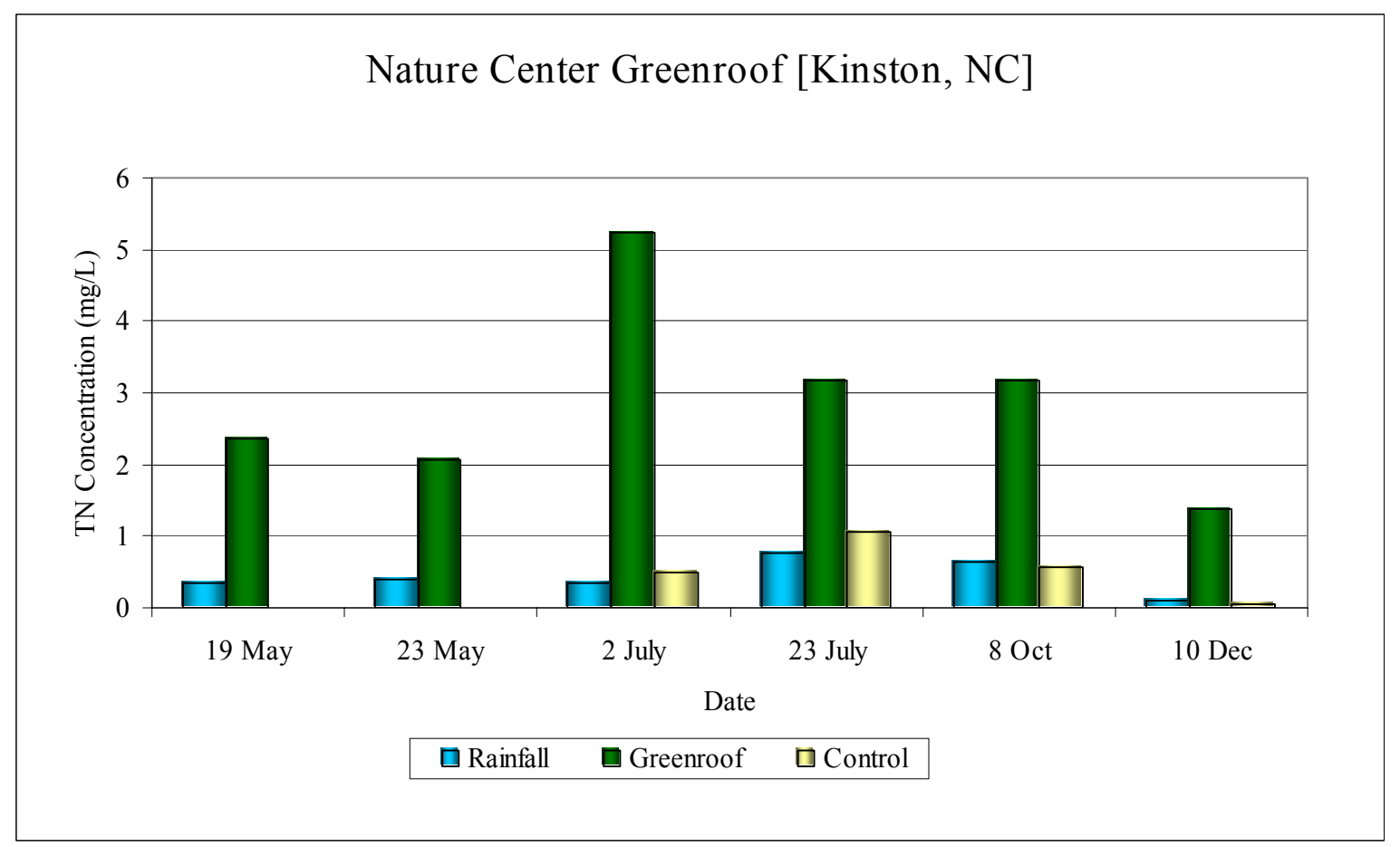

Figure G-3. Display of TN Concentrations at Nature Center Greenroof in Kinston, NC. (Note: Control data is unavailable for 19 May and 23 May)

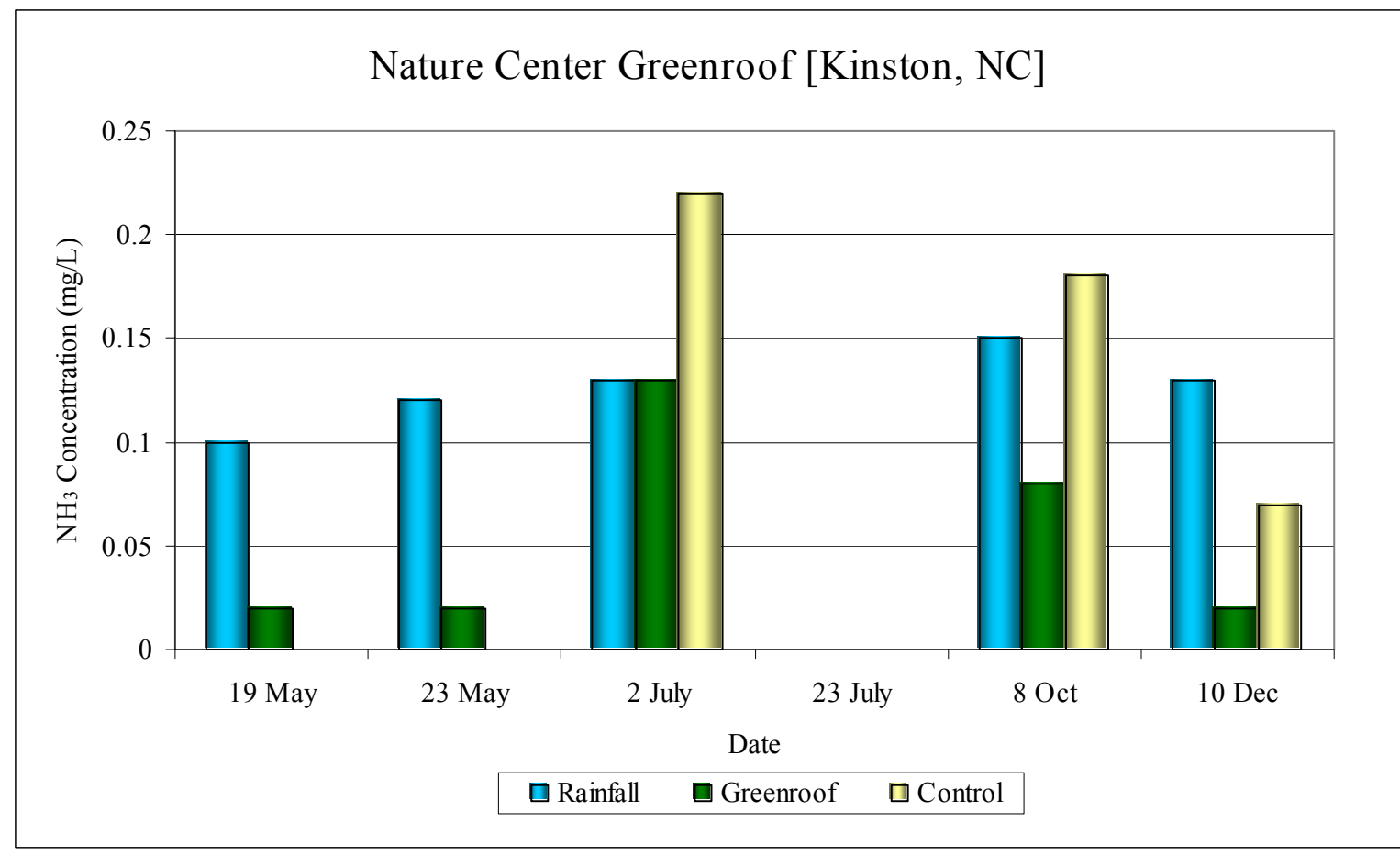

Figure G-4. Display of $\mathrm{NH}_{3}$ Concentrations at Nature Center Greenroof in Kinston, NC. (Note: Control data is unavailable for 19 May and 23 May; Rainfall data is unavailable for 23 July; Greenroof data is unavailable for 23 July) 


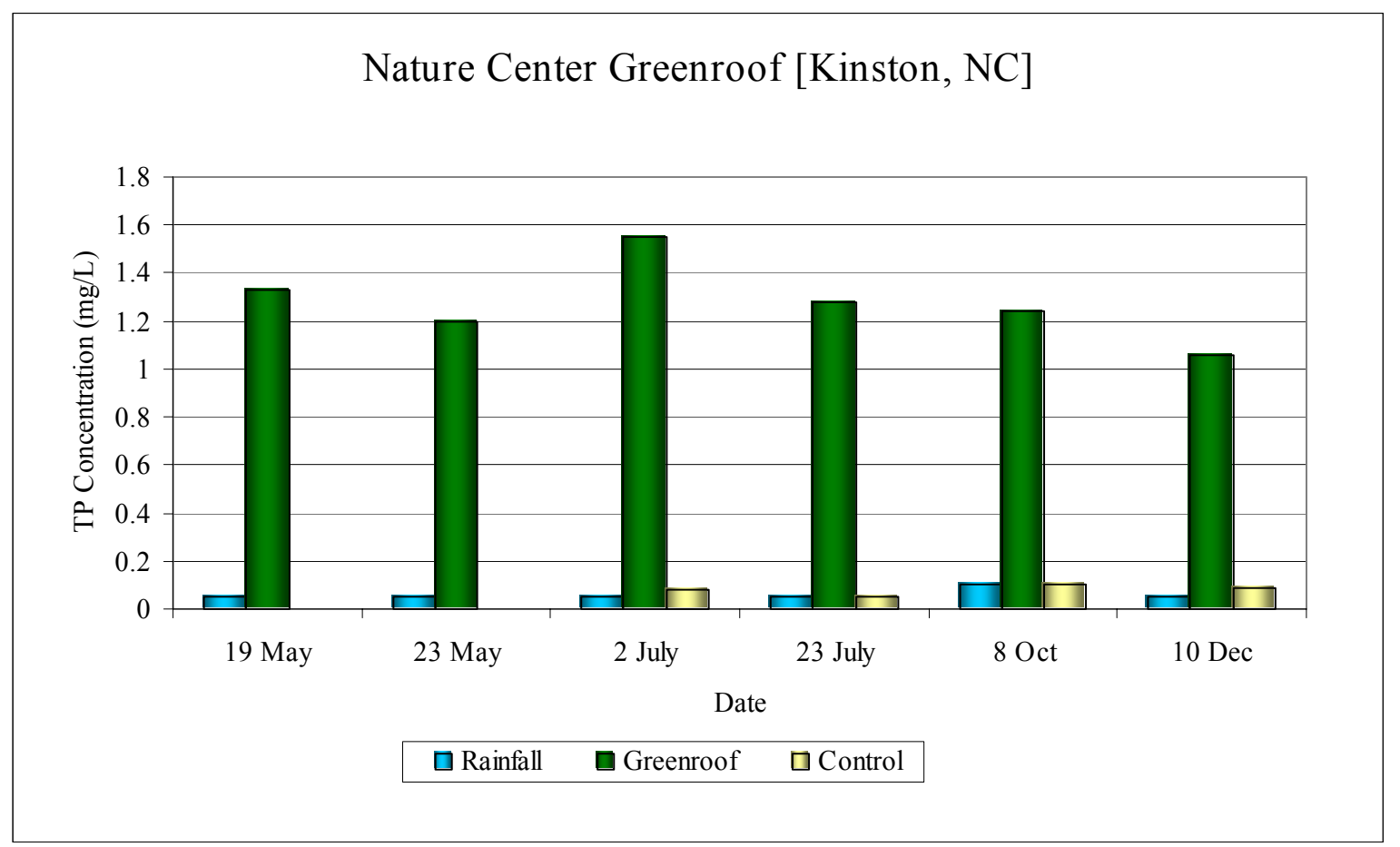

Figure G-5. Display of TP Concentrations at Nature Center Greenroof in Kinston, NC. (Note: Control data is unavailable for 19 May and 23 May)

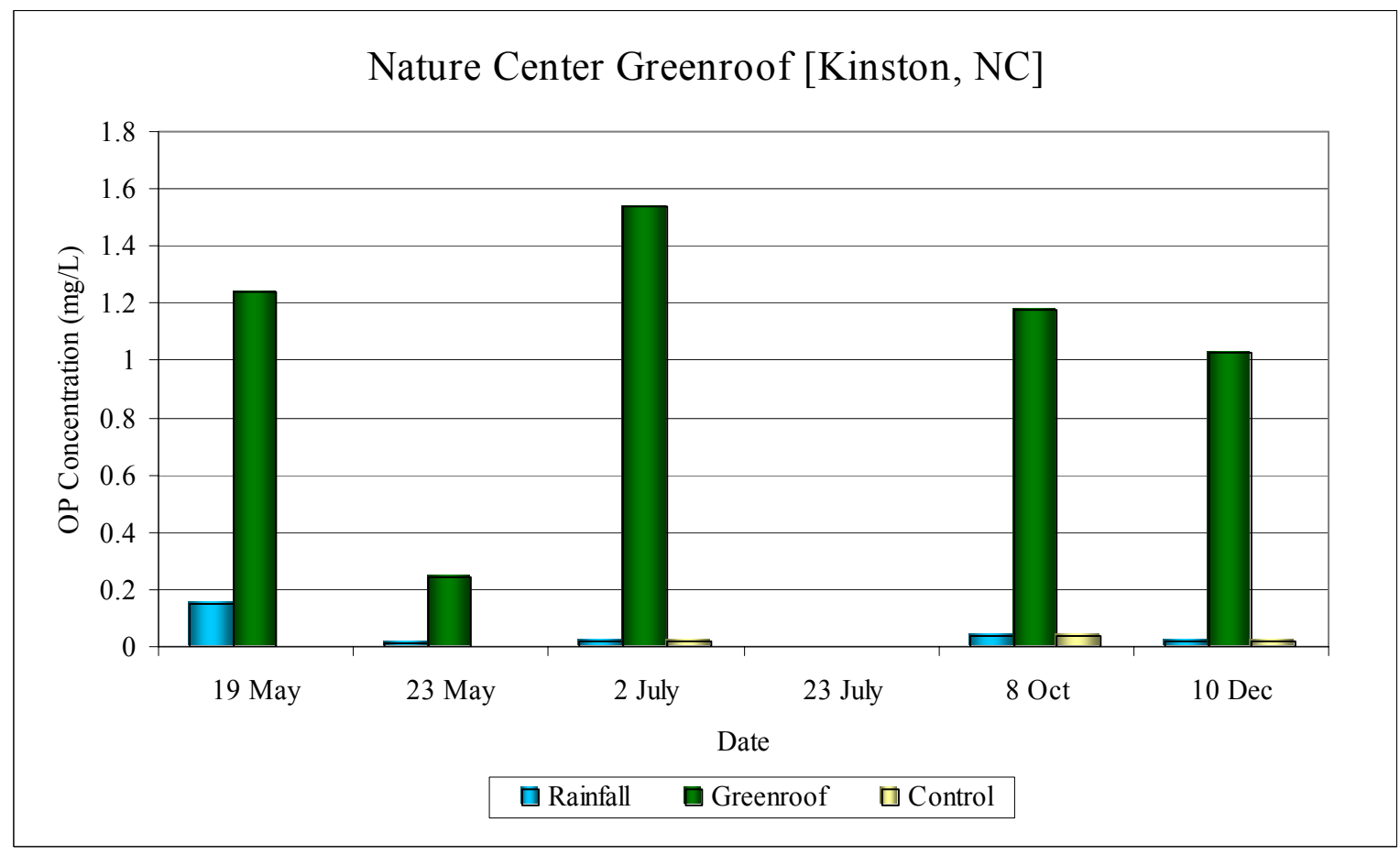

Figure G-6. Display of OP Concentrations at Nature Center Greenroof in Kinston, NC. (Note: Control data is unavailable for 19 May, 23 May, and 23 July; Rainfall data is unavailable for 23 July; Greenroof data is unavailable for 23 July) 


\section{H.0 APPENDIX H - KINSTON WATER QUALITY DATA: STATISTICAL ANALYSIS}

\section{H.1 Concentration OF Total KJELDAhl Nitrogen (TKN AS N)}

\section{H.1.1 COMPARISON OF RAINFALl AND GREENROOF CONCENTRATIONS (MG AS N/L)}

SAS Data Input

\begin{tabular}{|l|c|c|c|}
\hline Date & TKN_conc_R & TKN_conc_G & Diff TKN \\
\hline \hline 19-May-03 & 0.25 & 2.21 & 1.96 \\
\hline 23-May-03 & 0.31 & 2 & 1.69 \\
\hline 2-Jul-03 & 0.25 & 2.91 & 2.66 \\
\hline 23-Jul-03 & 0.53 & 2.71 & 2.18 \\
\hline 8-Oct-03 & 0.52 & 2.51 & 1.99 \\
\hline 10-Dec-03 & 0.25 & 1.23 & 0.98 \\
\hline
\end{tabular}

Note: $\mathrm{R}=$ Rainfall Concentration; $\mathrm{G}=$ Greenroof Concentration; Diff = Difference

\section{SAS Analysis}

The difference between the mean concentrations was determined to be normally distributed through the proc univariate analysis shown below ( $p$-value $>0.05)$.

\begin{tabular}{|c|c|c|c|c|}
\hline Test & \multicolumn{2}{|c|}{ - -Statistic- - } & \multicolumn{2}{|c|}{... - p Value.... } \\
\hline Shapiro-Wilk & W & 0.956181 & $\mathrm{Pr}<\mathrm{W}$ & 0.7899 \\
\hline Kolmogorov-Smirnov & $\mathrm{D}$ & 0.202357 & $\mathrm{Pr}>\mathrm{D}$ & $>0.1500$ \\
\hline Cramer-von Mises & W-Sq & 0.043537 & $\mathrm{Pr}>\mathrm{W}-\mathrm{Sq}$ & $>0.2500$ \\
\hline Anderson-Darling & $\mathrm{A}-\mathrm{Sq}$ & 0.260052 & $\mathrm{Pr}>\mathrm{A}-\mathrm{Sq}$ & $>0.2500$ \\
\hline
\end{tabular}

A t-test was performed and the results are shown below. There were significantly higher ( $\alpha$ $<0.05$ ) concentrations of TKN ( $\mathrm{mg}$ as $\mathrm{N} / \mathrm{L}$ ) found in greenroof runoff than in the rainfall. 


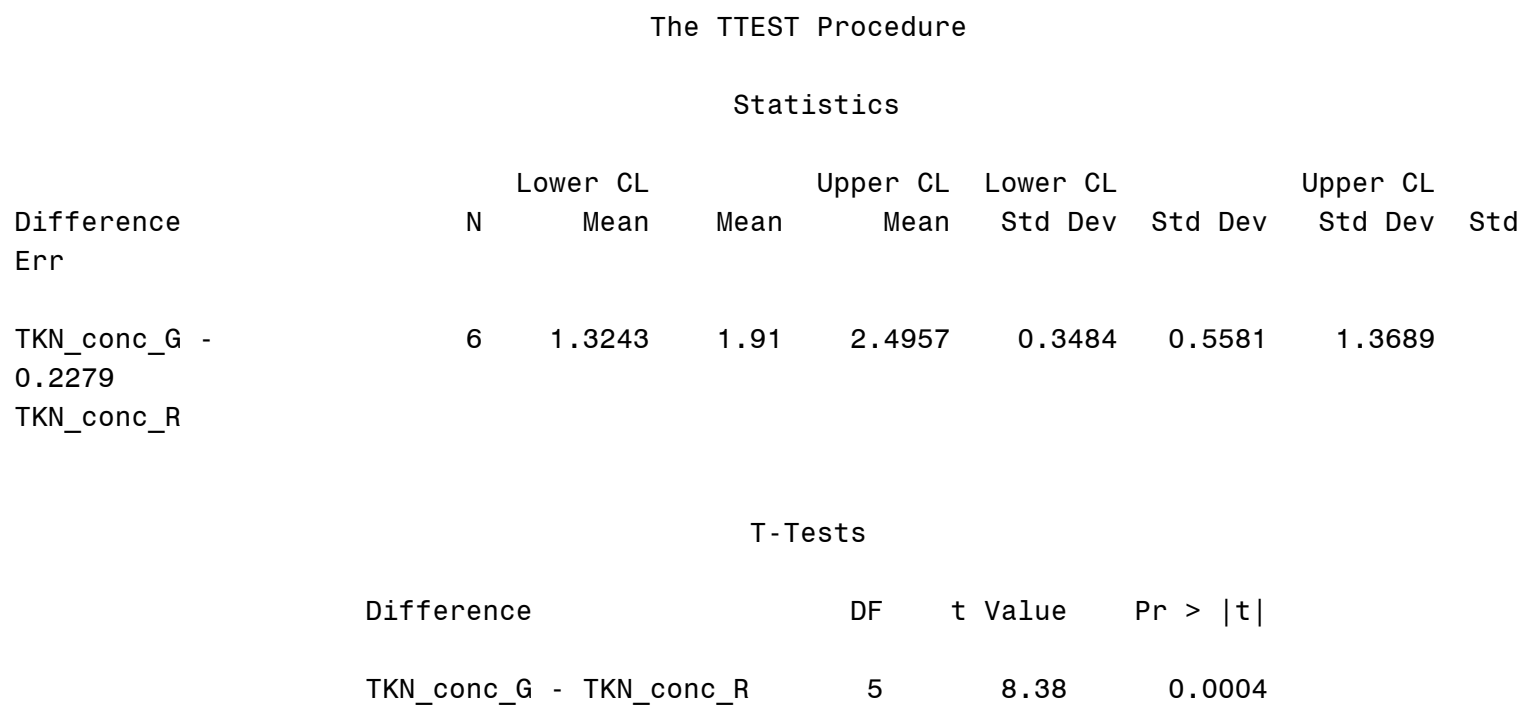

\section{H.1.2 COMParison of GreEnRoOf AND CONTROL RoOf CONCENTRATIONS (MG AS N/L)}

\section{SAS Data Input}

\begin{tabular}{|l|c|c|c|}
\hline Date & TKN_conc_G & TKN_conc_C & Diff TKN \\
\hline \hline 2-Jul-03 & 2.91 & 0.35 & 2.56 \\
\hline 23-Jul-03 & 2.71 & 0.76 & 1.95 \\
\hline 8-Oct-03 & 2.51 & 0.47 & 2.04 \\
\hline 10-Dec-03 & 1.23 & 0.25 & 0.98 \\
\hline
\end{tabular}

Note: $\mathrm{G}=$ Greenroof Concentration; $\mathrm{C}=$ Control Roof Concentration; Diff = Difference

\section{SAS Analysis}

The difference between the mean concentrations was determined to be normally distributed through the proc univariate analysis shown below ( $\mathrm{p}$-value $>0.05)$.

\begin{tabular}{|c|c|c|c|c|}
\hline \multicolumn{5}{|c|}{ Tests for Normality } \\
\hline Shapiro-Wilk & W & 0.930148 & $\mathrm{Pr}<\mathrm{W}$ & 0.5953 \\
\hline Kolmogorov-Smirnov & $\mathrm{D}$ & 0.290791 & $\mathrm{Pr}>\mathrm{D}$ & $>0.1500$ \\
\hline Cramer-von Mises & $\mathrm{W}-\mathrm{Sq}$ & 0.051547 & $\mathrm{Pr}>\mathrm{W}-\mathrm{Sq}$ & $>0.2500$ \\
\hline Anderson-Darling & $\mathrm{A}-\mathrm{Sq}$ & 0.291667 & $\mathrm{Pr}>\mathrm{A}-\mathrm{Sq}$ & $>0.2500$ \\
\hline
\end{tabular}


A t-test was performed and the results are shown below. The concentration of TKN in the greenroof runoff was significantly higher than the concentration of TKN in the control roof runoff $(\alpha<0.05)$.

Difference

Err

TKN_conc_G 0.3295

TKN_conc_C

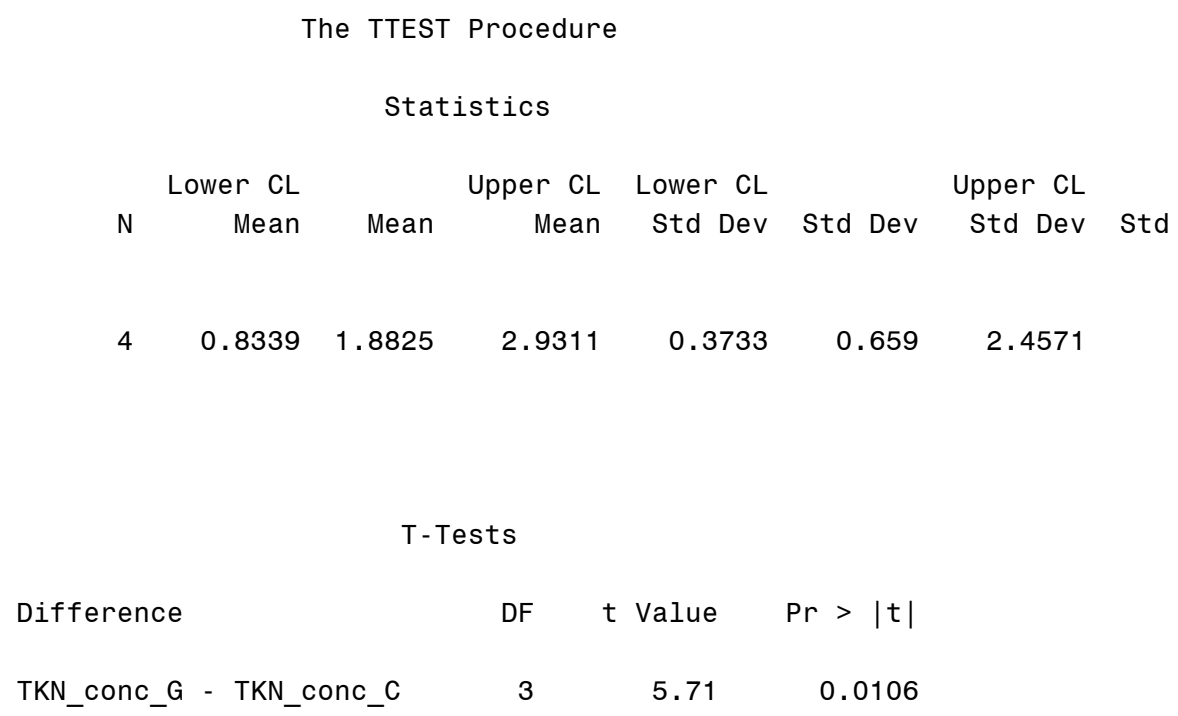




\section{H.2 CONCENTRATION OF NitRATE-Nitrite $\left(\mathrm{NO}_{3}-\mathrm{NO}_{2}\right.$ AS N)}

\section{H.2.1 COMPARISON OF RAINFALl AND GREENROOF CONCENTRATIONS (MG AS N/L)}

\section{SAS Data Input}

\begin{tabular}{|l|c|c|c|}
\hline Date & NO3_conc_R & NO3_conc_G & Diff NO3 \\
\hline \hline 19-May-03 & 0.1 & 0.16 & 0.06 \\
\hline 23-May-03 & 0.09 & 0.06 & -0.03 \\
\hline 2-Jul-03 & 0.09 & 2.32 & 2.23 \\
\hline 23-Jul-03 & 0.24 & 0.47 & 0.23 \\
\hline 8-Oct-03 & 0.12 & 0.67 & 0.55 \\
\hline 10-Dec-03 & 0.11 & 0.15 & 0.04 \\
\hline
\end{tabular}

Note: $\mathrm{R}$ = Rainfall Concentration; $\mathrm{G}=$ Greenroof Concentration; Diff= Difference

\section{$>$ SAS Analysis}

The distribution of the mean difference between the concentration of $\mathrm{NO}_{3}-\mathrm{NO}_{2}(\mathrm{mg}$ as $\mathrm{N} / \mathrm{L})$ between the rainfall and the greenroof runoff was determined to not be normally distributed through the proc univariate analysis shown below ( $\mathrm{p}$-values $<0.05$ ).

\begin{tabular}{|c|c|c|c|c|}
\hline Test & - -Sta & tistic-.- & $\ldots-p$ Va] & e. - . - \\
\hline Shapiro-Wilk & W & 0.691712 & $\mathrm{Pr}<\mathrm{W}$ & 0.0050 \\
\hline Kolmogorov-Smirnov & $\mathrm{D}$ & 0.316455 & $\mathrm{Pr}>\mathrm{D}$ & 0.0587 \\
\hline Cramer-von Mises & W-Sq & 0.164943 & $\mathrm{Pr}>\mathrm{W}-\mathrm{Sq}$ & 0.0099 \\
\hline Anderson-Darling & $\mathrm{A}-\mathrm{Sq}$ & 0.901591 & $\mathrm{Pr}>\mathrm{A}-\mathrm{Sq}$ & 0.0086 \\
\hline
\end{tabular}

A t-test assumes the data is normally distributed; therefore, a t-test was invalid for this data. A sign test was performed and is shown below. There was no statistically significant 
difference between the concentration of $\mathrm{NO}_{3}-\mathrm{NO}_{2}$ in the rainfall and the concentration of $\mathrm{NO}_{3}-\mathrm{NO}_{2}$ in the greenroof runoff.

\begin{tabular}{|c|c|c|c|c|}
\hline \multirow{2}{*}{$\begin{array}{l}\text { Test } \\
\text { Student's t }\end{array}$} & \multicolumn{2}{|c|}{-Statistic- } & \multicolumn{2}{|c|}{$\ldots$ - } \\
\hline & $\mathrm{t}$ & 1.451281 & $\operatorname{Pr}>|t|$ & 0.206 \\
\hline Sign & M & 2 & $\operatorname{Pr}>=|M|$ & 0.2188 \\
\hline Signed Rank & $\mathrm{s}$ & 9.5 & $\operatorname{Pr}>=|S|$ & 0.0625 \\
\hline
\end{tabular}

\section{H.2.2 COMPARISON OF GREENROOF AND CONTROL RoOF CONCENTRATIONS (MG AS N/L)}

\section{SAS Data Input}

\begin{tabular}{|l|c|c|c|}
\hline Date & NO3_conc_G & NO3_conc_C & Diff NO3 \\
\hline 2-Jul-03 & 2.32 & 0.13 & 2.19 \\
\hline 23-Jul-03 & 0.47 & 0.3 & 0.17 \\
\hline 8-Oct-03 & 0.67 & 0.1 & 0.57 \\
\hline 10-Dec-03 & 0.15 & 0.05 & 0.1 \\
\hline
\end{tabular}

Note: $\mathrm{G}=$ Greenroof Concentration; $\mathrm{C}=$ Control Roof Concentration; Diff= Difference

\section{SAS Analysis}

The distribution of the differences between the greenroof and the control roof was determined to be normally distributed through the proc univariate analysis shown below (pvalue $>0.05$ )

\begin{tabular}{|c|c|c|c|c|}
\hline Test & \multicolumn{2}{|c|}{ - -Statistic-- - } & \multicolumn{2}{|c|}{.... p Value..... } \\
\hline Shapiro-Wilk & W & 0.788487 & $\mathrm{Pr}<\mathrm{W}$ & 0.0831 \\
\hline Kolmogorov-Smirnov & $\mathrm{D}$ & 0.326081 & $\mathrm{Pr}>\mathrm{D}$ & 0.1358 \\
\hline Cramer-von Mises & W-Sq & 0.090134 & $\mathrm{Pr}>\mathrm{W}-\mathrm{Sq}$ & 0.1100 \\
\hline Anderson-Darling & $\mathrm{A}-\mathrm{Sq}$ & 0.498101 & $\mathrm{Pr}>\mathrm{A}-\mathrm{Sq}$ & 0.0874 \\
\hline
\end{tabular}


Therefore, a t-test was performed on the data. There was no statistically significant difference between the concentrations of $\mathrm{NO}_{3}-\mathrm{NO}_{2}(\mathrm{mg}$ as $\mathrm{N} / \mathrm{L})$ in the greenroof and the control roof.

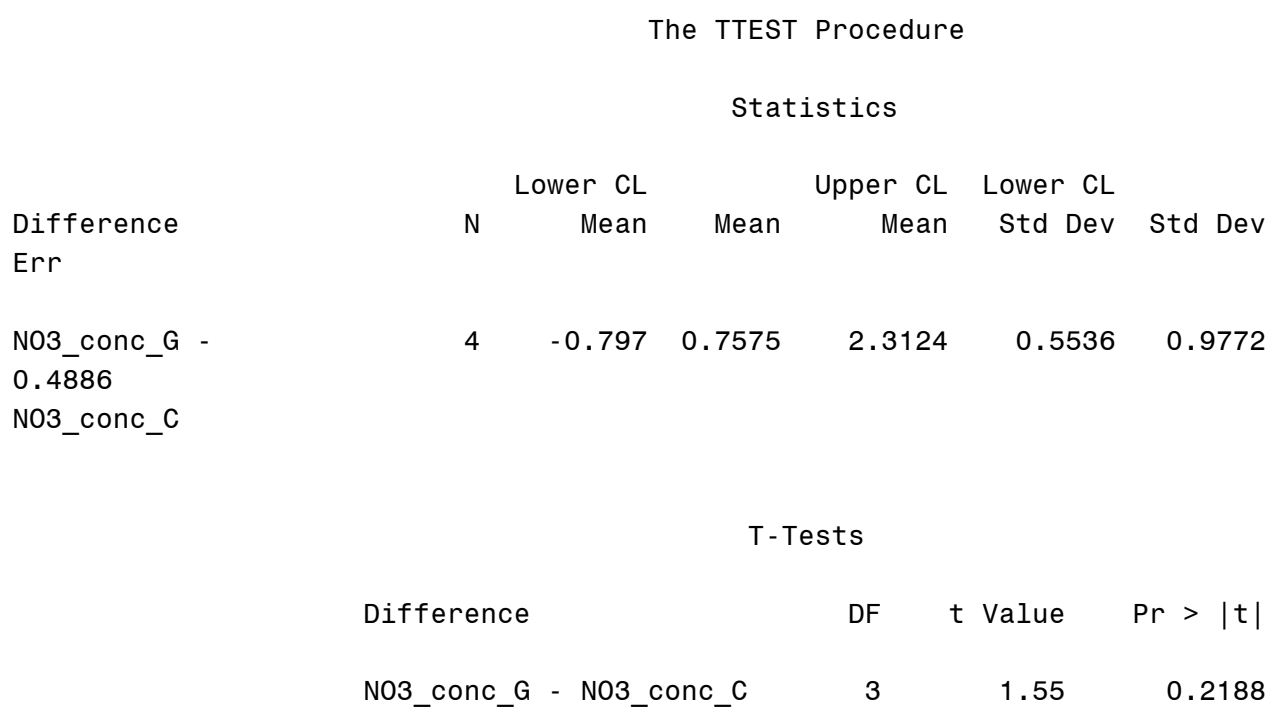




\section{H.3 CONCENTRATion OF Total Nitrogen (TN)}

\section{H.3.1 COMPARISON OF RAINFALl AND GREENROOF CONCENTRATIONS (MG/L)}

\section{SAS Data Input}

\begin{tabular}{|l|c|c|c|}
\hline Date & TN_conc_R & TN_conc_G & Diff TN \\
\hline \hline 19-May-03 & 0.35 & 2.37 & 2.02 \\
\hline 23-May-03 & 0.4 & 2.06 & 1.66 \\
\hline 2-Jul-03 & 0.34 & 5.23 & 4.89 \\
\hline 23-Jul-03 & 0.77 & 3.18 & 2.41 \\
\hline 8-Oct-03 & 0.64 & 3.18 & 2.54 \\
\hline 10-Dec-03 & 0.11 & 1.38 & 1.27 \\
\hline
\end{tabular}

Note: $\mathrm{R}=$ Rainfall Concentration; $\mathrm{G}=$ Greenroof Concentration; Diff = Difference

\section{$>$ SAS Analysis}

The difference between the concentration of $\mathrm{TN}(\mathrm{mg} / \mathrm{L})$ in the rainfall and the greenroof runoff was determined to be normally distributed through the proc univariate analysis shown below ( $\mathrm{p}$-values $>0.05)$.

\begin{tabular}{|c|c|c|c|c|}
\hline Test & \multicolumn{2}{|c|}{ - -Statistic- - } & \multicolumn{2}{|c|}{... p Value..... } \\
\hline Shapiro-Wilk & W & 0.833835 & $\mathrm{Pr}<\mathrm{W}$ & 0.1158 \\
\hline Kolmogorov-Smirnov & D & 0.30993 & $\mathrm{Pr}>\mathrm{D}$ & 0.0706 \\
\hline Cramer-von Mises & W-Sq & 0.089674 & $\mathrm{Pr}>\mathrm{W}-\mathrm{Sq}$ & 0.1264 \\
\hline Anderson-Darling & $\mathrm{A}-\mathrm{Sq}$ & 0.524091 & $\mathrm{Pr}>\mathrm{A}-\mathrm{Sq}$ & 0.1062 \\
\hline
\end{tabular}

A t-test was performed and is shown below. The concentration of TN (mg as N/L) was significantly higher in the greenroof runoff than the rainfall $(\alpha<0.05)$. 


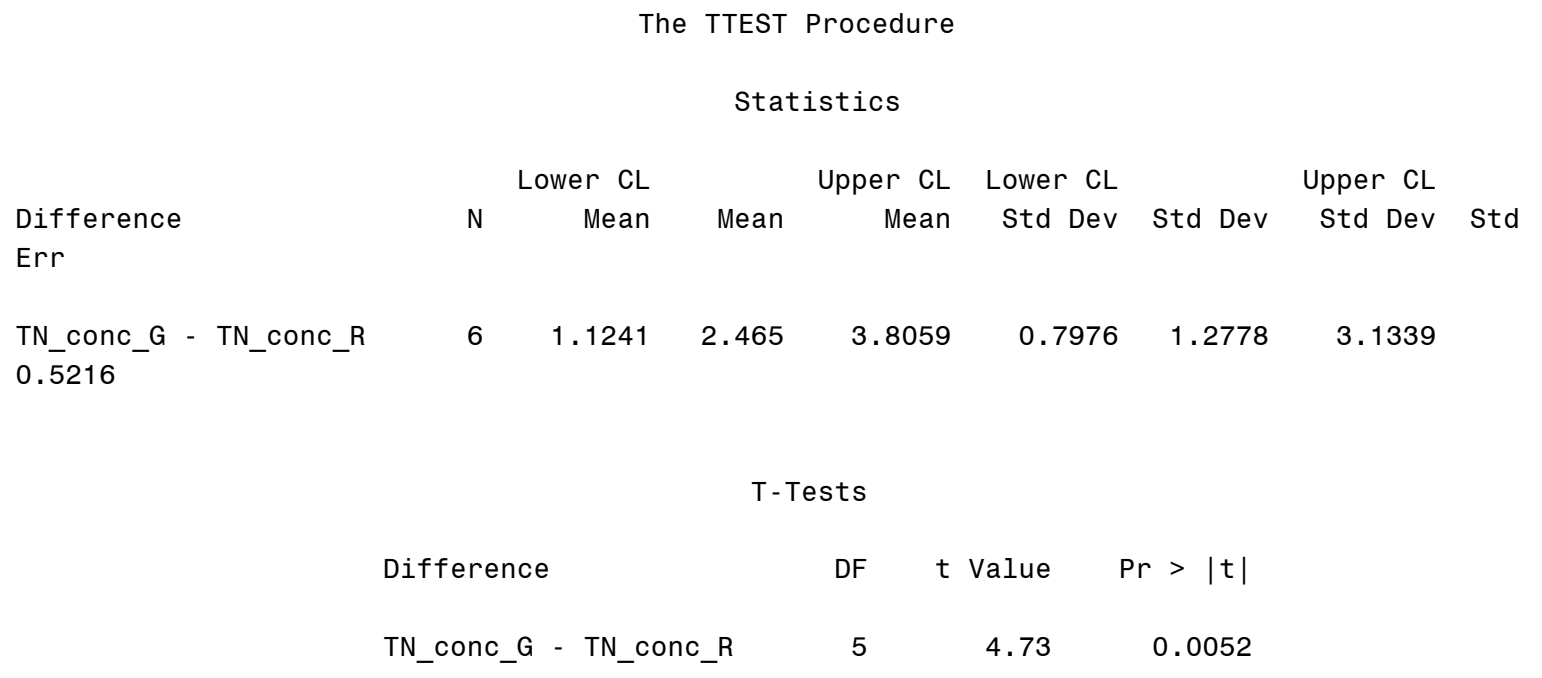

\section{H.3.2 COMPARISON OF GREenRoOF AND CONTROL RoOF CONCENTRATIONS (MG/L)}

\section{$>$ SAS Data Input}

\begin{tabular}{|l|c|c|c|}
\hline Date & TN_conc_G & TN_conc_C & Diff TN \\
\hline \hline 2-Jul-03 & 5.23 & 0.48 & 4.75 \\
\hline 23-Jul-03 & 3.18 & 1.06 & 2.12 \\
\hline 8-Oct-03 & 3.18 & 0.57 & 2.61 \\
\hline 10-Dec-03 & 1.38 & 0.05 & 1.33 \\
\hline
\end{tabular}

Note: $\mathrm{G}=$ Greenroof Concentration; $\mathrm{C}=$ Control Roof Concentration; Diff $=$ Difference

\section{SAS Analysis}

The distribution of the differences between the greenroof and the control roof were determined to be normally distributed through the proc univariate analysis shown below (pvalue $>0.05)$. 


\begin{tabular}{|c|c|c|c|c|}
\hline Test & - -St & tistic-- - & $\ldots-p$ Va] & ue - . - . \\
\hline Shapiro-Wilk & W & 0.920686 & $\mathrm{Pr}<\mathrm{W}$ & 0.5408 \\
\hline Kolmogorov-Smirnov & $\mathrm{D}$ & 0.275201 & $\mathrm{Pr}>\mathrm{D}$ & $>0.1500$ \\
\hline Cramer-von Mises & W-Sq & 0.048638 & $\mathrm{Pr}>\mathrm{W}-\mathrm{Sq}$ & $>0.2500$ \\
\hline Anderson-Darling & $\mathrm{A}-\mathrm{Sq}$ & 0.28914 & $\mathrm{Pr}>\mathrm{A}-\mathrm{Sq}$ & $>0.2500$ \\
\hline
\end{tabular}

A t-test was performed on the data and is shown below. The concentration of TN in the greenroof runoff was significantly higher than the concentration of $\mathrm{TN}$ in the control roof $\operatorname{runoff}(\alpha<0.05)$.

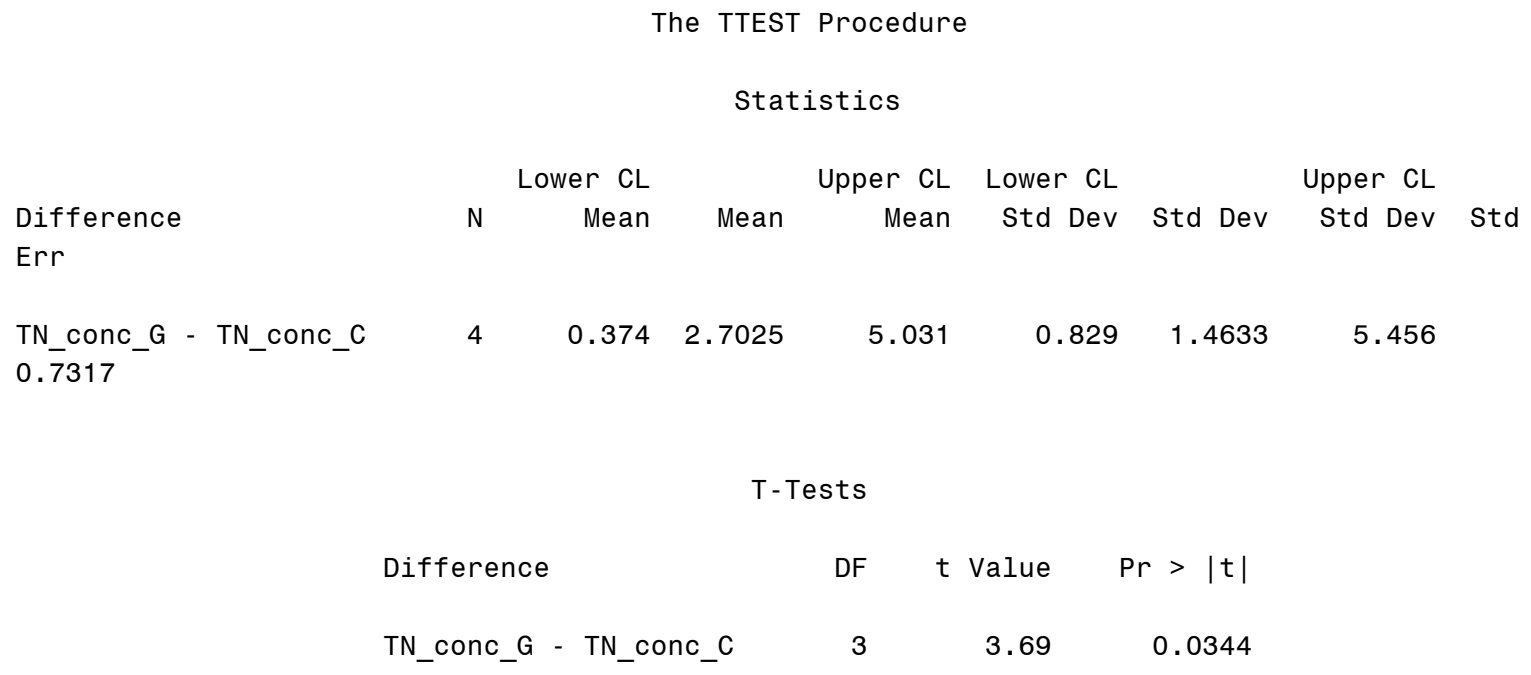




\section{H.4 Concentration OF Ammonia ( $\left.\mathrm{NH}_{3} \mathrm{AS} \mathrm{N}\right)$}

\section{H.4.1 COMPARISON OF RAINFALl AND GREENROOF CONCENTRATIONS (MG AS N/L)}

\section{SAS Data Input}

\begin{tabular}{|l|r|r|r|}
\hline Date & NH3_conc_R & NH3_conc_G & \multicolumn{1}{|c|}{ Diff NH3 } \\
\hline \hline 19-May-03 & 0.1 & 0.02 & -0.08 \\
\hline 23-May-03 & 0.12 & 0.02 & -0.1 \\
\hline 2-Jul-03 & 0.13 & 0.13 & 0 \\
\hline 8-Oct-03 & 0.15 & 0.08 & -0.07 \\
\hline 10-Dec-03 & 0.13 & 0.02 & -0.11 \\
\hline
\end{tabular}

Note: $\mathrm{R}=$ Rainfall Concentration; $\mathrm{G}=$ Greenroof Concentration; Diff = Difference

\section{SAS Analysis}

The difference between the concentration of $\mathrm{NH}_{3}(\mathrm{mg}$ as $\mathrm{N} / \mathrm{L})$ in the rainfall and the greenroof runoff was determined to be normally distributed through the proc univariate analysis shown below ( $\mathrm{p}$-values $>0.05)$.

\begin{tabular}{|c|c|c|c|c|}
\hline Test & \multicolumn{2}{|c|}{ - -Statistic- - } & \multicolumn{2}{|c|}{$\ldots$} \\
\hline Shapiro-Wilk & W & 0.863142 & $\mathrm{Pr}<\mathrm{W}$ & 0.2398 \\
\hline Kolmogorov-Smirnov & D & 0.281556 & $\mathrm{Pr}>\mathrm{D}$ & $>0.1500$ \\
\hline Cramer-von Mises & $\mathrm{W}-\mathrm{Sq}$ & 0.067491 & $\mathrm{Pr}>\mathrm{W}-\mathrm{Sq}$ & 0.2486 \\
\hline Anderson-Darling & $\mathrm{A}-\mathrm{Sq}$ & 0.403689 & $\mathrm{Pr}>\mathrm{A}-\mathrm{Sq}$ & 0.2164 \\
\hline
\end{tabular}

A t-test was performed on the data and is shown below. The concentration of $\mathrm{NH}_{3}$ was significantly higher in the rainfall than the greenroof runoff $(\alpha<0.05)$. 


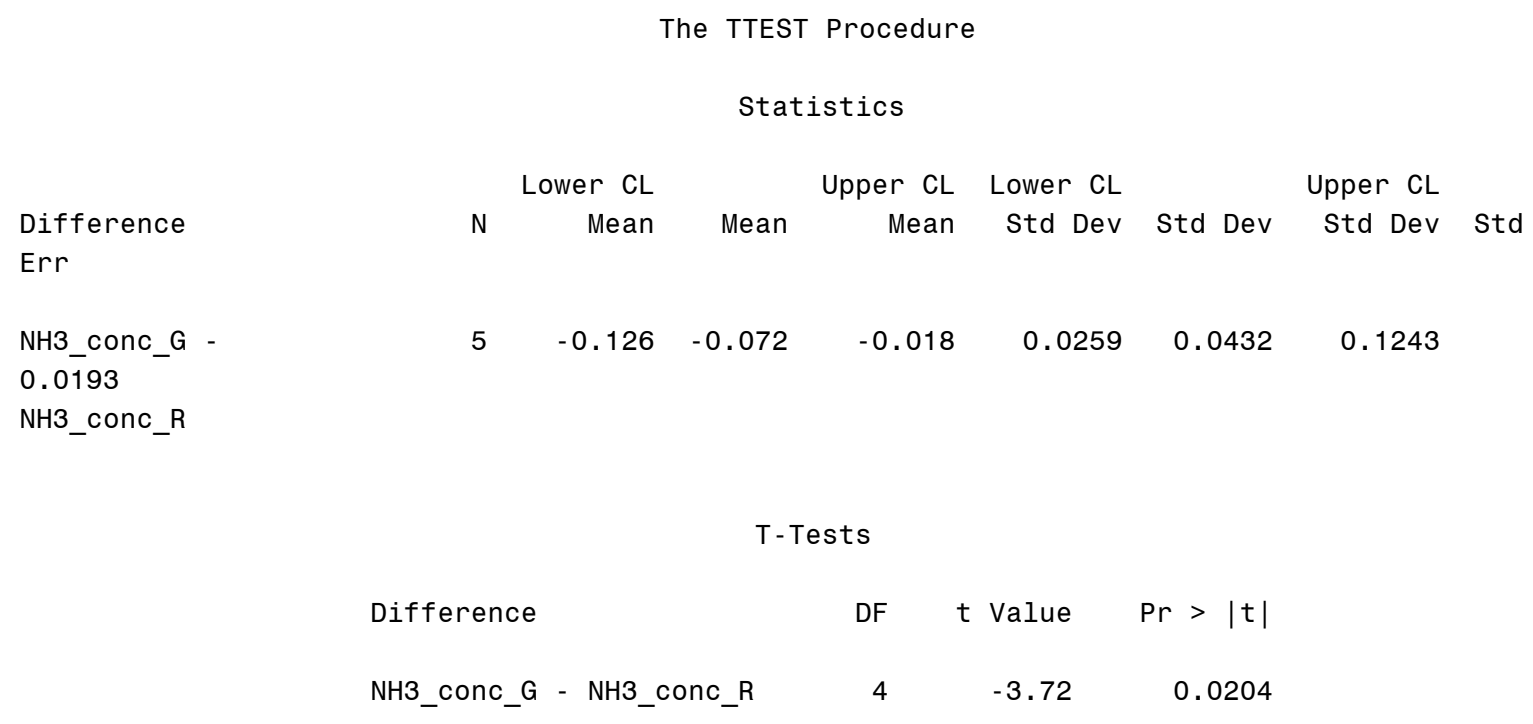

\section{H.4.2 COMParison OF GREENROOF AND CONTROL RoOF CONCENTRATIONS (MG AS N/L)}

\section{SAS Data Input}

\begin{tabular}{|l|r|r|r|}
\hline Date & NH3_conc_G & NH3_conc_C & \multicolumn{1}{|c|}{ Diff NH3 } \\
\hline \hline 2-Jul-03 & 0.13 & 0.22 & -0.09 \\
\hline 8-Oct-03 & 0.08 & 0.18 & -0.1 \\
\hline 10-Dec-03 & 0.02 & 0.07 & -0.05 \\
\hline
\end{tabular}

Note: $\mathrm{R}=$ Rainfall Concentration; $\mathrm{G}=$ Greenroof Concentration; Diff = Difference

\section{$>$ SAS Analysis}

The distribution of the difference between the $\mathrm{NH}_{3}$ concentration ( $\mathrm{mg}$ as $\mathrm{N} / \mathrm{L}$ ) between the greenroof and the control roof was determined to be normally distributed through the proc univariate analysis shown below ( $\mathrm{p}$-value $>0.05)$. 


\begin{tabular}{|c|c|c|c|c|}
\hline Test & \multicolumn{2}{|c|}{--Statistic-. - } & \multicolumn{2}{|c|}{.... p Value .... } \\
\hline Shapiro-Wilk & w & 0.892857 & $\mathrm{Pr}<\mathrm{W}$ & 0.36 \\
\hline Kolmogorov-Smirnov & D & 0.313938 & $\mathrm{Pr}>\mathrm{D}$ & $>0.15$ \\
\hline Cramer-von Mises & W-Sq & 0.054314 & $\mathrm{Pr}>\mathrm{W}-\mathrm{Sq}$ & $>0.2500$ \\
\hline Anderson-Darling & $A-S q$ & 0.312211 & $\mathrm{Pr}>\mathrm{A}-\mathrm{Sq}$ & $>0.2500$ \\
\hline
\end{tabular}

A t-test was performed on the data and is shown below. The concentration of $\mathrm{NH}_{3}$ (mg as $\mathrm{N} / \mathrm{L}$ ) was significantly higher in the control roof runoff than in the greenroof runoff ( $\alpha<$ $0.05)$.

Difference

Err

NH3_conc_G -

0.0153

NH3_conc_C
The TTEST Procedure

Statistics

Lower $\mathrm{CL} \quad$ Upper $\mathrm{CL}$ Lower $\mathrm{CL} \quad$ Upper $\mathrm{CL}$

N Mean Mean Mean Std Dev Std Dev Std Dev Std

3

$-0.146-0.08$

$-0.014$

0.0138

0.0265

0.1663

T-Tests

Difference




\section{H.5 Concentration of Total Phosphorus}

\section{H.5.1 COMPARISON OF RAINFALl AND GREENROOF CONCENTRATIONS (MG/L)}

\section{SAS Data Input}

\begin{tabular}{|l|c|c|c|}
\hline Date & TP_conc_R & TP_conc_G & Diff TP \\
\hline \hline 19-May-03 & 0.05 & 1.33 & 1.28 \\
\hline 23-May-03 & 0.05 & 1.2 & 1.15 \\
\hline 2-Jul-03 & 0.05 & 1.55 & 1.5 \\
\hline 23-Jul-03 & 0.05 & 1.28 & 1.23 \\
\hline 8-Oct-03 & 0.1 & 1.24 & 1.14 \\
\hline 10-Dec-03 & 0.05 & 1.06 & 1.01 \\
\hline
\end{tabular}

Note: $\mathrm{R}=$ Rainfall Concentration; $\mathrm{G}=$ Greenroof Concentration; Diff = Difference

\section{$>$ SAS Analysis}

The difference between the concentration of $\mathrm{TP}(\mathrm{mg} / \mathrm{L})$ in the rainfall and the greenroof was determined to be normally distributed through the proc univariate analysis shown below (pvalues $>0.05)$.

\begin{tabular}{|c|c|c|c|c|}
\hline Test & - -Sta & tistic-- - & $\ldots-p$ Va] & ue - . - . \\
\hline Shapiro-Wilk & W & 0.950089 & $\mathrm{Pr}<\mathrm{W}$ & 0.7410 \\
\hline Kolmogorov-Smirnov & $\mathrm{D}$ & 0.188322 & $\mathrm{Pr}>\mathrm{D}$ & $>0.1500$ \\
\hline Cramer-von Mises & $\mathrm{W}-\mathrm{Sq}$ & 0.040434 & $\mathrm{Pr}>\mathrm{W}-\mathrm{Sq}$ & $>0.2500$ \\
\hline Anderson-Darling & $\mathrm{A}-\mathrm{Sq}$ & 0.257704 & $\mathrm{Pr}>\mathrm{A}-\mathrm{Sq}$ & $>0.2500$ \\
\hline
\end{tabular}

A t-test was performed on the data and is shown below. The concentration of TP $(\mathrm{mg} / \mathrm{L})$ in the greenroof was significantly higher than the concentration of TP $(\mathrm{mg} / \mathrm{L})$ in the rainfall $(\alpha$ $<0.05)$ 


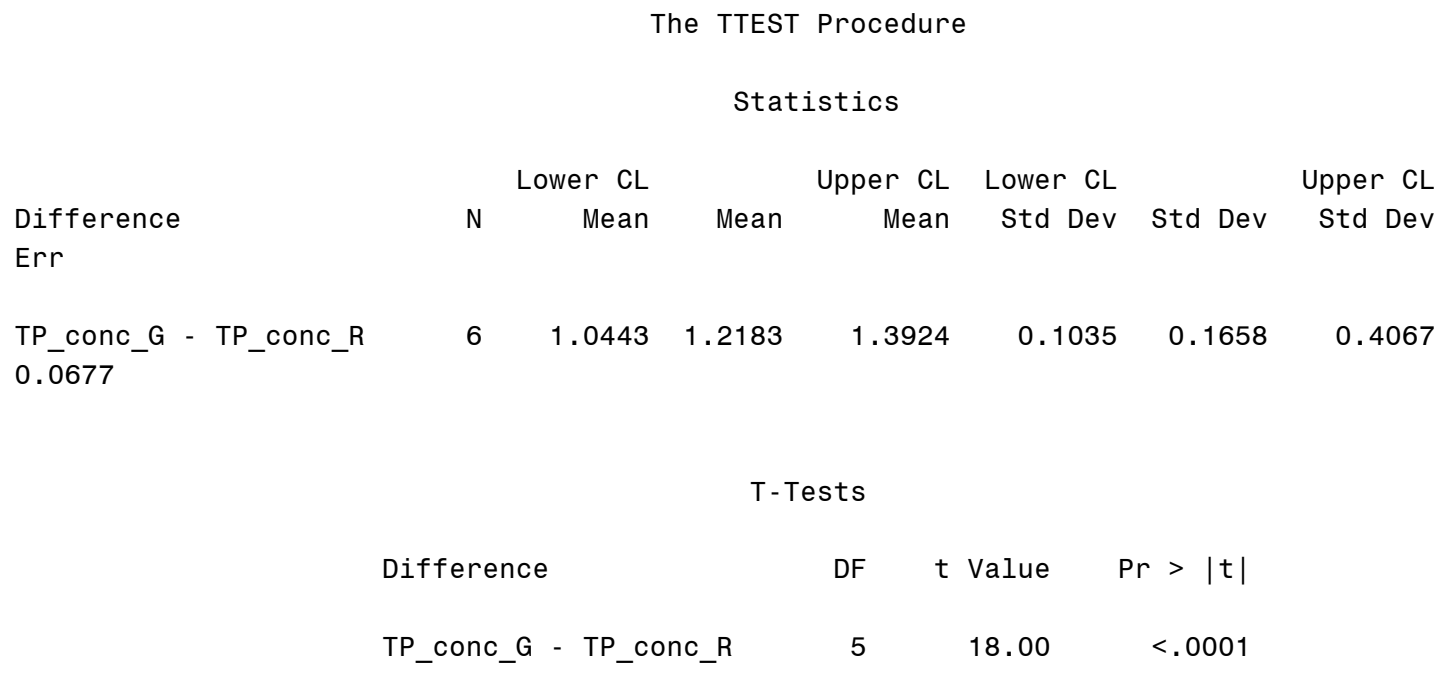

\section{H.5.2 COMPARISON OF GREENROOF AND CONTROL ROOF CONCENTRATIONS (MG/L)}

SAS Data Input

\begin{tabular}{|l|r|r|r|}
\hline Date & \multicolumn{1}{|c|}{ TP_conc_G } & \multicolumn{1}{|c|}{ TP_conc_C } & \multicolumn{1}{c|}{ Diff TP } \\
\hline 2-Jul-03 & 1.55 & 0.08 & 1.47 \\
\hline 23-Jul-03 & 1.28 & 0.05 & 1.23 \\
\hline 8-Oct-03 & 1.24 & 0.1 & 1.14 \\
\hline 10-Dec-03 & 1.06 & 0.09 & 0.97 \\
\hline
\end{tabular}

Note: $\mathrm{G}=$ Greenroof Concentration; $\mathrm{C}=$ Control Roof Concentration; Diff = Difference

\section{$>$ SAS Analysis}

The difference between the mean values of the TP concentration $(\mathrm{mg} / \mathrm{L})$ in the greenroof and the control roof runoff were determined to be normally distributed through the proc univariate analysis shown below ( $\mathrm{p}$-value $>0.05$ ). 


\begin{tabular}{|c|c|c|c|c|}
\hline Test & \multicolumn{2}{|c|}{ - -Statistic-- - } & \multicolumn{2}{|c|}{... - p Value..... } \\
\hline Shapiro-Wilk & W & 0.98711 & $\mathrm{Pr}<\mathrm{W}$ & 0.9422 \\
\hline Kolmogorov-Smirnov & D & 0.197506 & $\mathrm{Pr}>\mathrm{D}$ & $>0.1500$ \\
\hline Cramer-von Mises & $\mathrm{W}-\mathrm{Sq}$ & 0.026838 & $\mathrm{Pr}>\mathrm{W}-\mathrm{Sq}$ & $>0.2500$ \\
\hline Anderson-Darling & $\mathrm{A}-\mathrm{Sq}$ & 0.182275 & $\mathrm{Pr}>\mathrm{A}-\mathrm{Sq}$ & $>0.2500$ \\
\hline
\end{tabular}

A t-test was performed on the data. The concentration $(\mathrm{mg} / \mathrm{L})$ of TP present in the greenroof runoff was significantly higher than the concentration $(\mathrm{mg} / \mathrm{L})$ of TP in the control roof runoff $(\alpha<0.05)$.

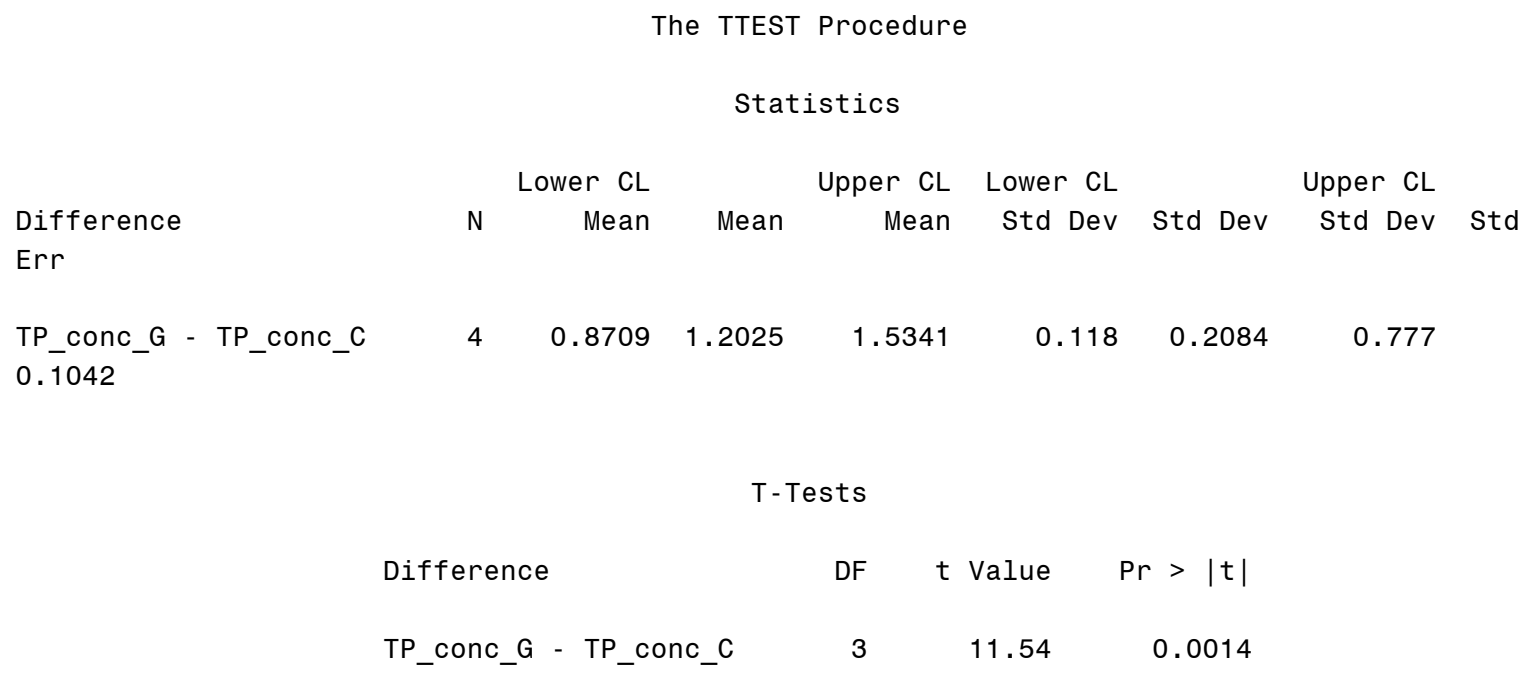




\section{H.6 CONCENTRATION OF ORTHO-PHOSPHORUS}

\section{H.6.1 COMPARISON OF RAINFALl AND GREENROOF CONCENTRATIONS (MG/L)}

\section{SAS Data Input}

\begin{tabular}{|l|r|r|r|}
\hline Date & OP_conc_R & OP_conc_G & Diff OP \\
\hline \hline 19-May-03 & 0.15 & 1.24 & 1.09 \\
\hline 23-May-03 & 0.01 & 0.24 & 1.52 \\
\hline 2-Jul-03 & 0.02 & 1.54 & 1.14 \\
\hline 8-Oct-03 & 0.04 & 1.18 & 1.01 \\
\hline 10-Dec-03 & 0.02 & 1.03 & . \\
\hline
\end{tabular}

Note: $\mathrm{R}=$ Rainfall Concentration; $\mathrm{G}=$ Greenroof Concentration; Diff = Difference

\section{SAS Analysis}

The difference between the concentration of $\mathrm{OP}(\mathrm{mg} / \mathrm{L})$ in the rainfall and greenroof runoff was determined to be normally distributed through the proc univariate analysis shown below $(p$-values $>0.05)$.

\begin{tabular}{|c|c|c|c|c|}
\hline Test & \multicolumn{2}{|c|}{ - -Statistic-- - } & \multicolumn{2}{|c|}{$\ldots-\ldots$ Value $\ldots$} \\
\hline Shapiro-Wilk & W & 0.837145 & $\mathrm{Pr}<\mathrm{W}$ & 0.1872 \\
\hline Kolmogorov-Smirnov & D & 0.337386 & $\mathrm{Pr}>\mathrm{D}$ & 0.1048 \\
\hline Cramer-von Mises & W-Sq & 0.078579 & $\mathrm{Pr}>\mathrm{W}-\mathrm{Sq}$ & 0.1653 \\
\hline Anderson-Darling & $\mathrm{A}-\mathrm{Sq}$ & 0.431838 & $\mathrm{Pr}>\mathrm{A}-\mathrm{Sq}$ & 0.1410 \\
\hline
\end{tabular}

A t-test was performed on the data and is shown below. The concentration of OP $(\mathrm{mg} / \mathrm{L})$ was significantly higher in the greenroof runoff than in the rainfall $(\alpha<0.05)$. 


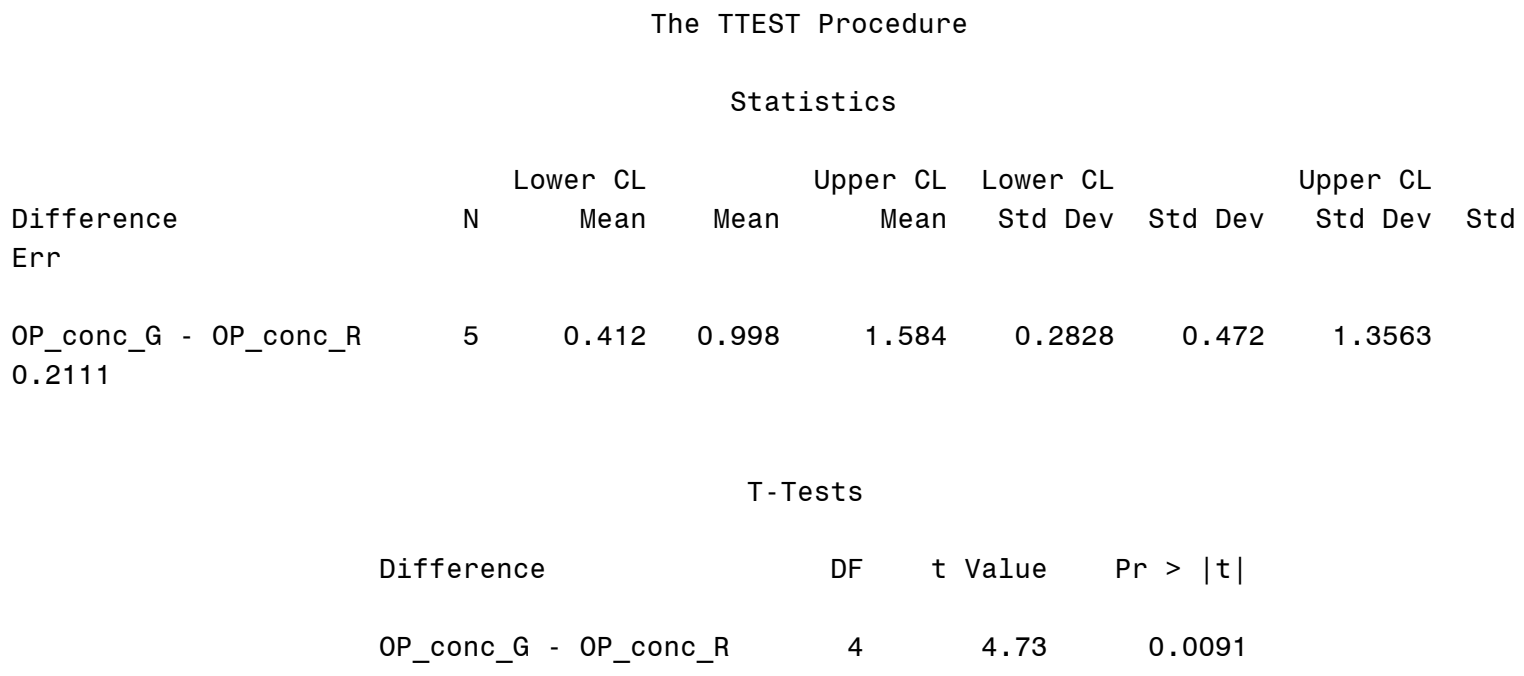

\section{H.6.2 COMParison OF GreENROOF AND CONTROL ROOF CONCENTRATIONS (MG AS N/L)}

\section{SAS Data Input}

\begin{tabular}{|l|r|r|r|}
\hline Date & OP_conc_G & \multicolumn{1}{|c|}{ OP_conc_C } & \multicolumn{1}{|c|}{ Diff OP } \\
\hline 2-Jul-03 & 1.54 & 0.02 & 1.52 \\
\hline 8-Oct-03 & 1.18 & 0.04 & 1.14 \\
\hline 10-Dec-03 & 1.03 & 0.02 & 1.01 \\
\hline
\end{tabular}

Note: $\mathrm{G}=$ Greenroof Concentration; $\mathrm{C}=$ Control Roof Concentration; Diff = Difference

\section{SAS Analysis}

The distribution of the difference between the concentration $(\mathrm{mg} / \mathrm{L})$ of $\mathrm{OP}$ in the greenroof runoff and the control roof runoff was determined to be normally distributed ( $p$-values $>$ 0.05) through the proc univariate analysis shown below. 


\begin{tabular}{|c|c|c|c|c|}
\hline Test & - -St & tistic-- - & $\ldots-p$ Va] & ue - . - . \\
\hline Shapiro-Wilk & W & 0.925842 & $\mathrm{Pr}<\mathrm{W}$ & 0.4733 \\
\hline Kolmogorov-Smirnov & $\mathrm{D}$ & 0.290076 & $\mathrm{Pr}>\mathrm{D}$ & $>0.1500$ \\
\hline Cramer-von Mises & W-Sq & 0.04616 & $\mathrm{Pr}>\mathrm{W}-\mathrm{Sq}$ & $>0.2500$ \\
\hline Anderson-Darling & $\mathrm{A}-\mathrm{Sq}$ & 0.273694 & $\mathrm{Pr}>\mathrm{A}-\mathrm{Sq}$ & $>0.2500$ \\
\hline
\end{tabular}

A t-test was performed on the data and is shown below. The concentration of OP $(\mathrm{mg} / \mathrm{L})$ in the greenroof runoff was significantly higher than the concentration of $\mathrm{OP}(\mathrm{mg} / \mathrm{L})$ in the control roof runoff $(\alpha<0.05)$.

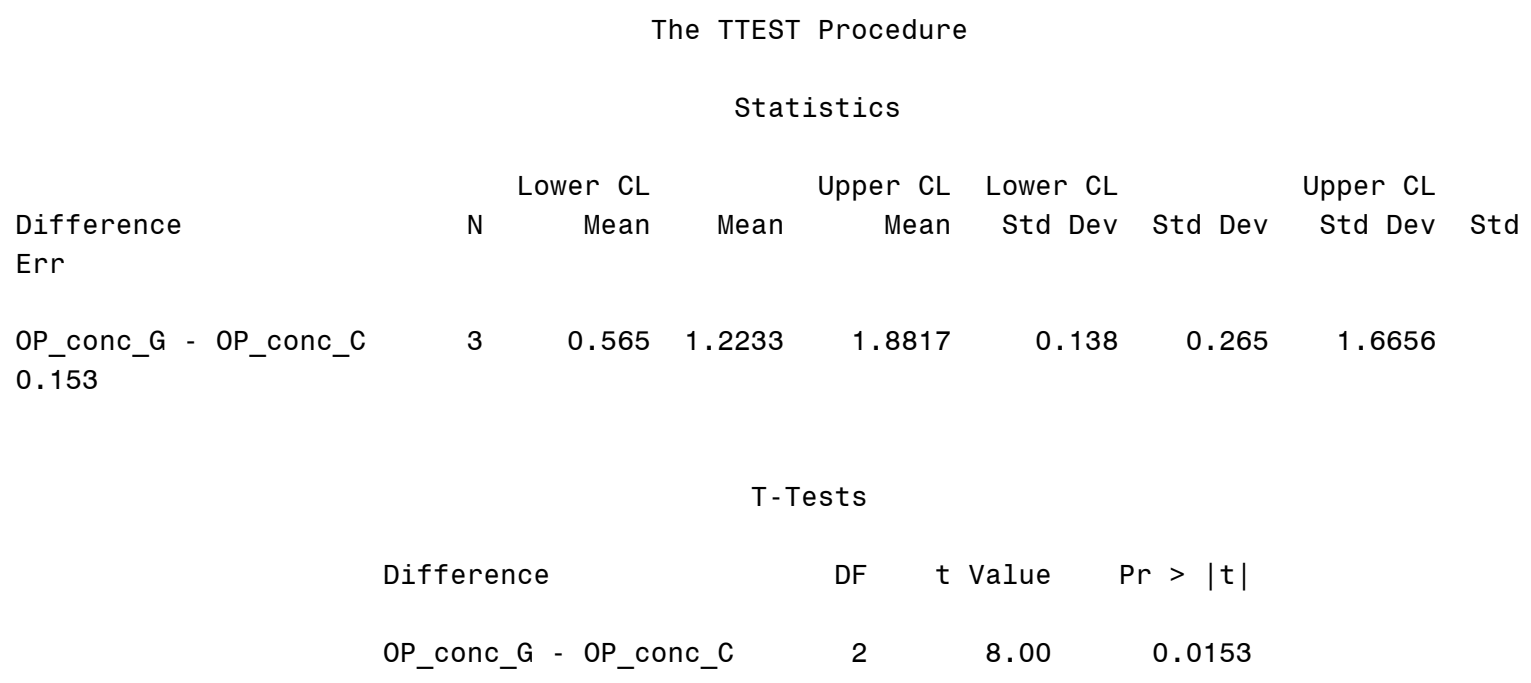




\section{I.0 APPENDIX I - SYNTHETIC RAINFALL CALCULATIONS}

\section{I.1 Total Volume of Synthetic Rainfall NeEded for EntiRe EXPERIMENT}

$$
\begin{aligned}
& \frac{\text { Volume }}{\text { Sample }}=(1.5 \mathrm{in} .)(\pi)(3 \mathrm{in} .)^{2}=42.4 \mathrm{in}^{3}\left(\frac{1 \mathrm{~L}}{61.02 \mathrm{in}^{3}}\right)=0.695 \mathrm{~L}=700 \mathrm{~mL} \\
& \text { Total Volume }=\left(\frac{700 \mathrm{~mL}}{\text { Sample }}\right)(16 \text { Samples })=11200 \mathrm{~mL}(10 \text { weeks })=112000 \mathrm{~mL}=112 \mathrm{~L} \\
& \text { Weekly Volume }=\frac{112 \mathrm{~L}}{10 \text { weeks }}=\frac{11.2 \mathrm{~L}}{\text { week }} \Rightarrow 12 \mathrm{~L} \text { each week }
\end{aligned}
$$

\section{I.2 $\mathrm{NH}_{3}$ Calculation}

Desired Concentration $=0.38 \mathrm{mg} / \mathrm{L}$ as N

$$
\begin{aligned}
& \left(\frac{0.38 m g \mathrm{NH}_{3} \text { as } \mathrm{N}}{\mathrm{L}}\right)(3 \mathrm{~L} \mathrm{sol'n})=0.00114 \mathrm{~g} \mathrm{NH}_{3} \text { as } \mathrm{N} \\
& \left(0.00114 \mathrm{~g} \mathrm{NH}_{3} \text { as } \mathrm{N}\right)\left(\frac{52.484 \mathrm{~g} \mathrm{NH} \mathrm{Cl}_{3}}{14.007 \mathrm{~g} \mathrm{~N}}\right)=\underline{\underline{0.0043 \mathrm{~g} \mathrm{NH} \mathrm{Cl}_{3}}} \begin{array}{l}
\Leftarrow \text { Amount of } \\
\mathrm{NH}_{3} \mathrm{Cl} \text { needed }
\end{array}
\end{aligned}
$$

\section{I.3 $\mathrm{NO}_{3}-\mathrm{NO}_{2}$ CALCUlation}

Desired Concentration $=0.12 \mathrm{mg} / \mathrm{L}$ as $\mathrm{N}$

$$
\begin{aligned}
& \left(\frac{0.12 m g \mathrm{NO}_{3}-\mathrm{NO}_{2} \text { as } \mathrm{N}}{\mathrm{L}}\right)(3 \mathrm{~L} \mathrm{sol'n})=3.6 e-4 m g \mathrm{NO}_{3}-\mathrm{NO}_{2} \text { as } \mathrm{N} \\
& \left(3.6 e-4 \mathrm{~g} \mathrm{NO}_{3}-\mathrm{NO}_{2} \text { as } \mathrm{N}\right)\left(\frac{101.10 \mathrm{gNNO}}{14.007 \mathrm{gN}}\right)=\underline{\underline{0.0026 g \mathrm{KNO}_{3}}} \Leftarrow \text { Amount of } \\
& \mathrm{KNO}_{3} \text { needed }
\end{aligned}
$$




\section{I.4 OP CALCULATION}

Desired Concentration $=0.04 \mathrm{mg} / \mathrm{L}$

$$
\begin{aligned}
& \left(\frac{0.04 m g}{L}\right)(3 L \text { sol'n })=1.2 e-4 g P \\
& (1.2 e-4 g P)\left(\frac{120.09 g \mathrm{KH}_{2} \mathrm{PO}_{4}}{30.974 g \mathrm{P}}\right)=\underline{\underline{0.0005 g \mathrm{KH}_{2} \mathrm{PO}_{4}}} \Leftarrow \text { Amount of } \mathrm{KH}_{2} \mathrm{PO}_{4} \\
& \text { needed }
\end{aligned}
$$

\section{I.5 Total Nitrogen Calculation}

Actual Field Nitrogen Calculation:

$T N=T K N+\left(\mathrm{NO}_{3}-\mathrm{NO}_{2}\right)=0.38+0.12=0.50 \mathrm{mg} / \mathrm{L}$

Modified Experimental Total Nitrogen Calculation:

$T N=\left(\mathrm{NO}_{3}-\mathrm{NO}_{2}\right)+\mathrm{NH}_{3}=0.12+0.38=0.50 \mathrm{mg} / \mathrm{L}$ 


\section{J.0 APPENDIX J-SOIL MEDIA STUDY DATA}

\section{J.1 SoIl Media Study Results}

Table J-1. Table of Results from Soil Media Column Study

\begin{tabular}{|c|c|c|c|c|c|c|}
\hline Sample ID & $\begin{array}{c}\mathrm{NO}_{3} \\
(\mathrm{mg} \mathrm{N} / \mathrm{L}) \\
\end{array}$ & $\begin{array}{c}\mathrm{NH}_{3} \\
(\mathrm{mg} \mathrm{N} / \mathrm{L})\end{array}$ & $\begin{array}{c}\text { TKN } \\
(\mathrm{mg} \mathrm{N} / \mathrm{L})\end{array}$ & $\begin{array}{c}\mathrm{TN} \\
(\mathrm{mg} \mathrm{N} / \mathrm{L})\end{array}$ & $\begin{array}{c}\mathrm{OP} \\
(\mathrm{mg} \mathrm{P} / \mathrm{L})\end{array}$ & $\begin{array}{c}\mathrm{TP} \\
(\mathrm{mg} \mathrm{P} / \mathrm{L})\end{array}$ \\
\hline Week 1 & & & Date: & $01 / 12 / 2004$ & & \\
\hline CLAY-1 & 2.9 & 0.31 & 4.1 & 7.0 & 0.1 & 0.34 \\
\hline CLAY-2 & 4 & 0.39 & 5.4 & 9.4 & 0.06 & 0.32 \\
\hline CLAY-3 & 3.9 & 0.35 & 4.6 & 8.5 & 0.21 & 0.45 \\
\hline CLAY-4 & 3.9 & 0.32 & 6.1 & 10.0 & 0.12 & 0.54 \\
\hline AVERAGE & 3.68 & 0.34 & 5.05 & 8.73 & 0.12 & 0.41 \\
\hline LIGHT-1 & 109 & 30 & 47 & 156.0 & 0.25 & 0.7 \\
\hline LIGHT-2 & 71 & 26 & 39 & 110.0 & 0.22 & 0.62 \\
\hline LIGHT-3 & 28 & 16 & 25 & 53.0 & 0.14 & 0.49 \\
\hline LIGHT-4 & 34 & 23 & 36 & 70.0 & 0.26 & 0.71 \\
\hline AVERAGE & 60.50 & 23.75 & 36.75 & 97.25 & 0.22 & 0.63 \\
\hline SAND-1 & $\mathrm{n} / \mathrm{a}$ & $\mathrm{n} / \mathrm{a}$ & $\mathrm{n} / \mathrm{a}$ & $\mathrm{n} / \mathrm{a}$ & $\mathrm{n} / \mathrm{a}$ & $\mathrm{n} / \mathrm{a}$ \\
\hline SAND-2 & $\mathrm{n} / \mathrm{a}$ & $\mathrm{n} / \mathrm{a}$ & $\mathrm{n} / \mathrm{a}$ & $\mathrm{n} / \mathrm{a}$ & $\mathrm{n} / \mathrm{a}$ & $\mathrm{n} / \mathrm{a}$ \\
\hline SAND-3 & $\mathrm{n} / \mathrm{a}$ & $\mathrm{n} / \mathrm{a}$ & $\mathrm{n} / \mathrm{a}$ & $\mathrm{n} / \mathrm{a}$ & $\mathrm{n} / \mathrm{a}$ & $\mathrm{n} / \mathrm{a}$ \\
\hline SAND-4 & $\mathrm{n} / \mathrm{a}$ & $\mathrm{n} / \mathrm{a}$ & $\mathrm{n} / \mathrm{a}$ & $\mathrm{n} / \mathrm{a}$ & $\mathrm{n} / \mathrm{a}$ & $\mathrm{n} / \mathrm{a}$ \\
\hline AVERAGE & $\mathrm{n} / \mathrm{a}$ & $\mathrm{n} / \mathrm{a}$ & $\mathrm{n} / \mathrm{a}$ & $\mathrm{n} / \mathrm{a}$ & $\mathrm{n} / \mathrm{a}$ & $\mathrm{n} / \mathrm{a}$ \\
\hline STALITE-1 & 17 & 23 & 69 & 86.0 & 0.9 & 2.8 \\
\hline STALITE-2 & 18 & 24 & 73 & 91.0 & 1 & 3.1 \\
\hline STALITE-3 & 17 & 24 & 71 & 88.0 & 1.3 & 3.2 \\
\hline STALITE-4 & 14 & 19 & 56 & 70.0 & 0.92 & 2.6 \\
\hline AVERAGE & 16.50 & 22.50 & 67.25 & 83.75 & 1.03 & 2.93 \\
\hline INFLOW & 0.12 & 0.39 & 0.59 & 0.7 & 0.06 & 0.06 \\
\hline Week 2 & & & Date: & $01 / 20 / 2004$ & & \\
\hline CLAY-1 & 4.4 & 0.1 & 3.9 & 8.3 & 0.14 & 0.22 \\
\hline CLAY-2 & 3.6 & 0.1 & 4.2 & 7.8 & 0.16 & 0.24 \\
\hline CLAY-3 & 5.1 & 0.1 & 3.5 & 8.6 & 0.24 & 0.38 \\
\hline CLAY-4 & 4.2 & 0.1 & 3.5 & 7.7 & 0.21 & 0.4 \\
\hline AVERAGE & 4.33 & 0.10 & 3.78 & 8.10 & 0.19 & 0.31 \\
\hline LIGHT-1 & 440 & 0.99 & 36 & 476.0 & 0.42 & 0.9 \\
\hline
\end{tabular}




\begin{tabular}{|c|c|c|c|c|c|c|}
\hline Sample ID & $\begin{array}{c}\mathrm{NO}_{3} \\
(\mathrm{mg} \mathrm{N} / \mathrm{L})\end{array}$ & $\begin{array}{c}\mathrm{NH}_{3} \\
(\mathrm{mg} \mathrm{N} / \mathrm{L})\end{array}$ & $\begin{array}{c}\mathrm{TKN} \\
(\mathrm{mg} \mathrm{N} / \mathrm{L})\end{array}$ & $\begin{array}{c}\mathrm{TN} \\
(\mathrm{mg} \mathrm{N} / \mathrm{L})\end{array}$ & $\begin{array}{c}\text { OP } \\
(\mathrm{mg} \mathrm{P} / \mathrm{L})\end{array}$ & $\begin{array}{c}\mathrm{TP} \\
(\mathrm{mg} \mathrm{P} / \mathrm{L})\end{array}$ \\
\hline LIGHT-2 & 314 & 0.94 & 32 & 346.0 & 0.38 & 0.76 \\
\hline LIGHT-3 & 349 & 1.1 & 35 & 384.0 & 0.39 & 0.77 \\
\hline LIGHT-4 & 358 & 0.93 & 32 & 390.0 & 0.43 & 0.99 \\
\hline AVERAGE & 365.25 & 0.99 & 33.75 & 399.00 & 0.41 & 0.86 \\
\hline SAND-1 & 0.48 & 0.19 & 1.9 & 2.4 & 0.01 & 0.07 \\
\hline SAND-2 & 0.2 & 0.1 & 1.2 & 1.4 & 0.01 & 0.08 \\
\hline SAND-3 & 0.26 & 0.1 & 1.4 & 1.7 & 0.01 & 0.01 \\
\hline SAND-4 & 0.1 & 0.1 & 1.6 & 1.7 & 0.01 & 0.01 \\
\hline AVERAGE & 0.26 & 0.12 & 1.53 & 1.79 & 0.01 & 0.04 \\
\hline STALITE-1 & 65 & 1.6 & 36 & 101.0 & 0.64 & 1.2 \\
\hline STALITE-2 & 60 & 4.1 & 40 & 100.0 & 2.1 & 2.6 \\
\hline STALITE-3 & 75 & 1.5 & 35 & 110.0 & 0.63 & 1.2 \\
\hline STALITE-4 & 65 & 2.9 & 42 & 107.0 & 0.87 & 1.7 \\
\hline AVERAGE & 66.25 & 2.53 & 38.25 & 104.50 & 1.06 & 1.68 \\
\hline INFLOW & 0.16 & 0.39 & 0.8 & 1.0 & 0.07 & 0.05 \\
\hline Week 3 & & & Date: & $01 / 27 / 2004$ & & \\
\hline CLAY-1 & 3.1 & 0.15 & 2.5 & 5.6 & 0.31 & 0.51 \\
\hline CLAY-2 & 3.6 & 0.13 & 3.2 & 6.8 & 0.3 & 0.53 \\
\hline CLAY-3 & 3.9 & 0.1 & 3 & 6.9 & 0.32 & 0.53 \\
\hline CLAY-4 & 3.7 & 0.11 & 3 & 6.7 & 0.31 & 0.53 \\
\hline AVERAGE & 3.58 & 0.12 & 2.93 & 6.50 & 0.31 & 0.53 \\
\hline LIGHT-1 & 266 & 0.5 & 31 & 297.0 & 0.44 & 1 \\
\hline LIGHT-2 & 165 & 0.32 & 18 & 183.0 & 0.47 & 0.93 \\
\hline LIGHT-3 & 174 & 0.37 & 20 & 194.0 & 0.43 & 0.95 \\
\hline LIGHT-4 & 193 & 0.35 & 21 & 214.0 & 0.5 & 1 \\
\hline AVERAGE & 199.50 & 0.39 & 22.50 & 222.00 & 0.46 & 0.97 \\
\hline SAND-1 & 0.19 & 0.21 & 0.73 & 0.9 & 0.01 & 0.01 \\
\hline SAND-2 & 0.13 & 0.14 & 0.51 & 0.6 & 0.01 & 0.01 \\
\hline SAND-3 & 0.16 & 0.12 & 0.56 & 0.7 & 0.01 & 0.04 \\
\hline SAND-4 & 0.1 & 0.1 & 0.39 & 0.5 & 0.01 & 0.05 \\
\hline AVERAGE & 0.15 & 0.14 & 0.55 & 0.69 & 0.01 & 0.03 \\
\hline STALITE-1 & 11 & 0.3 & 13 & 24.0 & 0.94 & 1.1 \\
\hline STALITE-2 & 12 & 0.68 & 14 & 26.0 & 1.4 & 1.5 \\
\hline STALITE-3 & 14 & 0.22 & 14 & 28.0 & 0.89 & 1 \\
\hline STALITE-4 & 13 & 0.63 & 16 & 29.0 & 1.3 & 1.4 \\
\hline AVERAGE & 12.50 & 0.46 & 14.25 & 26.75 & 1.13 & 1.25 \\
\hline
\end{tabular}




\begin{tabular}{|c|c|c|c|c|c|c|}
\hline Sample ID & $\begin{array}{c}\mathrm{NO}_{3} \\
(\mathrm{mg} \mathrm{N} / \mathrm{L})\end{array}$ & $\begin{array}{c}\mathrm{NH}_{3} \\
(\mathrm{mg} \mathrm{N} / \mathrm{L})\end{array}$ & $\begin{array}{c}\mathrm{TKN} \\
(\mathrm{mg} \mathrm{N} / \mathrm{L})\end{array}$ & $\begin{array}{c}\mathrm{TN} \\
(\mathrm{mg} \mathrm{N} / \mathrm{L})\end{array}$ & $\begin{array}{c}\mathrm{OP} \\
(\mathrm{mg} \mathrm{P} / \mathrm{L})\end{array}$ & $\begin{array}{c}\mathrm{TP} \\
(\mathrm{mg} \mathrm{P} / \mathrm{L})\end{array}$ \\
\hline INFLOW & 0.14 & 0.39 & 0.58 & 0.7 & 0.03 & 0.02 \\
\hline Week 4 & & & Date: & $02 / 03 / 2004$ & & \\
\hline CLAY-1 & 2 & 0.2 & 2.3 & 4.3 & 0.34 & 0.38 \\
\hline CLAY-2 & 1.3 & 0.1 & 2.5 & 3.8 & 0.26 & 0.44 \\
\hline CLAY-3 & 1.4 & 0.51 & 2.7 & 4.1 & 1.2 & 1.3 \\
\hline CLAY-4 & 1.3 & 0.1 & 2.4 & 3.7 & 0.28 & 0.29 \\
\hline AVERAGE & 1.50 & 0.23 & 2.48 & 3.98 & 0.52 & 0.60 \\
\hline LIGHT-1 & 118 & 0.22 & 17 & 135.0 & 0.59 & 0.83 \\
\hline LIGHT-2 & 77 & 0.16 & 13 & 90.0 & 0.57 & 0.79 \\
\hline LIGHT-3 & 55 & 0.56 & 13 & 68.0 & 0.62 & 0.76 \\
\hline LIGHT-4 & 79 & 0.17 & 15 & 94.0 & 0.59 & 0.81 \\
\hline AVERAGE & 82.25 & 0.28 & 14.50 & 96.75 & 0.59 & 0.80 \\
\hline SAND-1 & 0.37 & 0.32 & 0.9 & 1.3 & 0.1 & 0.09 \\
\hline SAND-2 & 0.13 & 0.24 & 0.66 & 0.8 & 0.01 & 0.04 \\
\hline SAND-3 & 0.11 & 0.4 & 0.59 & 0.7 & 0.04 & 0.06 \\
\hline SAND-4 & 0.1 & 0.15 & 0.54 & 0.6 & 0.02 & 0.04 \\
\hline AVERAGE & 0.18 & 0.28 & 0.67 & 0.85 & 0.04 & 0.06 \\
\hline STALITE-1 & 1.1 & 0.17 & 10 & 11.1 & 1.3 & 1.4 \\
\hline STALITE-2 & 1.3 & 0.39 & 10 & 11.3 & 2.2 & 2.3 \\
\hline STALITE-3 & 1.3 & 0.18 & 10 & 11.3 & 1.2 & 1.4 \\
\hline STALITE-4 & 1.5 & 0.36 & 9.7 & 11.2 & 1.8 & 2 \\
\hline AVERAGE & 1.30 & 0.28 & 9.93 & 11.23 & 1.63 & 1.78 \\
\hline INFLOW & 0.11 & 0.38 & 0.63 & 0.7 & 0.05 & 0.02 \\
\hline Week 5 & & & Date: & $02 / 10 / 2004$ & & \\
\hline CLAY-1 & 0.44 & 0.21 & 2.2 & 2.6 & 0.28 & 0.35 \\
\hline CLAY-2 & 0.23 & 0.13 & 4.8 & 5.0 & 0.31 & 0.36 \\
\hline CLAY-3 & 0.24 & 0.14 & 2.1 & 2.3 & 0.32 & 0.34 \\
\hline CLAY-4 & 0.3 & 0.16 & 2 & 2.3 & 0.31 & 0.34 \\
\hline AVERAGE & 0.30 & 0.16 & 2.78 & 3.08 & 0.31 & 0.35 \\
\hline LIGHT-1 & 27 & 0.64 & 17 & 44.0 & 1.3 & 1.7 \\
\hline LIGHT-2 & 14 & 0.37 & 11 & 25.0 & 1.2 & 1.4 \\
\hline LIGHT-3 & 6.8 & 0.37 & 11 & 17.8 & 1.2 & 1.4 \\
\hline LIGHT-4 & 16 & 0.48 & 13 & 29.0 & 1.4 & 1.6 \\
\hline AVERAGE & 15.95 & 0.47 & 13.00 & 28.95 & 1.28 & 1.53 \\
\hline SAND-1 & 0.12 & 0.29 & 0.38 & 0.5 & 0.01 & 0.03 \\
\hline SAND-2 & 0.11 & 0.24 & 0.34 & 0.5 & 0.03 & 0.04 \\
\hline
\end{tabular}




\begin{tabular}{|c|c|c|c|c|c|c|}
\hline Sample ID & $\begin{array}{c}\mathrm{NO}_{3} \\
(\mathrm{mg} \mathrm{N} / \mathrm{L})\end{array}$ & $\begin{array}{c}\mathrm{NH}_{3} \\
(\mathrm{mg} \mathrm{N} / \mathrm{L})\end{array}$ & $\begin{array}{c}\mathrm{TKN} \\
(\mathrm{mg} \mathrm{N} / \mathrm{L})\end{array}$ & $\begin{array}{c}\mathrm{TN} \\
(\mathrm{mg} \mathrm{N} / \mathrm{L})\end{array}$ & $\begin{array}{c}\mathrm{OP} \\
(\mathrm{mg} \mathrm{P} / \mathrm{L})\end{array}$ & $\begin{array}{c}\mathrm{TP} \\
(\mathrm{mg} \mathrm{P} / \mathrm{L})\end{array}$ \\
\hline SAND-3 & 0.12 & 0.29 & 0.35 & 0.5 & 0.02 & 0.05 \\
\hline SAND-4 & 0.11 & 0.24 & 0.31 & 0.4 & 0.01 & 0.07 \\
\hline AVERAGE & 0.12 & 0.27 & 0.35 & 0.46 & 0.02 & 0.05 \\
\hline STALITE-1 & 0.24 & 0.35 & 6.7 & 6.9 & 1.8 & 2 \\
\hline STALITE-2 & 0.25 & 0.34 & 7.1 & 7.4 & 2.5 & 2.7 \\
\hline STALITE-3 & 0.32 & 0.35 & 6.5 & 6.8 & 1.8 & 2.1 \\
\hline STALITE-4 & 0.27 & 0.38 & 6.8 & 7.1 & 2.6 & 2.7 \\
\hline AVERAGE & 0.27 & 0.36 & 6.78 & 7.05 & 2.18 & 2.38 \\
\hline INFLOW & 0.1 & 0.31 & 0.37 & 0.5 & 0.03 & 0.04 \\
\hline Week 6 & & & Date: & $02 / 17 / 2004$ & & \\
\hline CLAY-1 & 0.23 & 0.15 & 1.6 & 1.8 & 0.31 & 0.37 \\
\hline CLAY-2 & 0.14 & 0.12 & 2.3 & 2.4 & 0.41 & 0.48 \\
\hline CLAY-3 & 0.14 & 0.1 & 2 & 2.1 & 0.39 & 0.44 \\
\hline CLAY-4 & 0.12 & 0.1 & 2.1 & 2.2 & 0.42 & 0.46 \\
\hline AVERAGE & 0.16 & 0.12 & 2.00 & 2.16 & 0.38 & 0.44 \\
\hline LIGHT-1 & 1.2 & 0.39 & 13 & 14.2 & 2.2 & 2.5 \\
\hline LIGHT-2 & 1.4 & 0.31 & 10 & 11.4 & 1.7 & 1.9 \\
\hline LIGHT-3 & 0.53 & 0.43 & 14 & 14.5 & 1.7 & 2 \\
\hline LIGHT-4 & 0.91 & 0.3 & 12 & 12.9 & 2.4 & 2.7 \\
\hline AVERAGE & 1.01 & 0.36 & 12.25 & 13.26 & 2.00 & 2.28 \\
\hline SAND-1 & 0.13 & 0.34 & 0.51 & 0.6 & 0.01 & 0.04 \\
\hline SAND-2 & 0.16 & 0.28 & 0.39 & 0.6 & 0.01 & 0.01 \\
\hline SAND-3 & 0.15 & 0.3 & 0.36 & 0.5 & 0.01 & 0.04 \\
\hline SAND-4 & 0.13 & 0.28 & 0.41 & 0.5 & 0.01 & 0.01 \\
\hline AVERAGE & 0.14 & 0.30 & 0.42 & 0.56 & 0.01 & 0.03 \\
\hline STALITE-1 & 0.16 & 0.23 & 5.9 & 6.1 & 2.3 & 2.5 \\
\hline STALITE-2 & 0.17 & 0.19 & 6.4 & 6.6 & 3 & 3.1 \\
\hline STALITE-3 & 0.13 & 0.2 & 5.5 & 5.6 & 2.4 & 2.5 \\
\hline STALITE-4 & 0.17 & 0.21 & 6.4 & 6.6 & 3.3 & 3.5 \\
\hline AVERAGE & 0.16 & 0.21 & 6.05 & 6.21 & 2.75 & 2.90 \\
\hline INFLOW & 0.12 & 0.42 & 0.51 & 0.6 & 0.06 & 0.11 \\
\hline Week 7 & & & Date: & $02 / 24 / 2004$ & & \\
\hline CLAY-1 & 0.23 & 0.21 & 1.7 & 1.9 & 0.46 & 0.58 \\
\hline CLAY-2 & 0.15 & 0.17 & 2 & 2.2 & 0.48 & 0.57 \\
\hline CLAY-3 & 0.12 & 0.19 & 2.1 & 2.2 & 0.47 & 0.49 \\
\hline CLAY-4 & 0.17 & 0.17 & 1.6 & 1.8 & 0.47 & 0.59 \\
\hline
\end{tabular}




\begin{tabular}{|c|c|c|c|c|c|c|}
\hline Sample ID & $\begin{array}{c}\mathrm{NO}_{3} \\
(\mathrm{mg} \mathrm{N} / \mathrm{L})\end{array}$ & $\begin{array}{c}\mathrm{NH}_{3} \\
(\mathrm{mg} \mathrm{N} / \mathrm{L})\end{array}$ & $\begin{array}{c}\text { TKN } \\
(\mathrm{mg} \mathrm{N} / \mathrm{L})\end{array}$ & $\begin{array}{c}\mathrm{TN} \\
(\mathrm{mg} \mathrm{N} / \mathrm{L})\end{array}$ & $\begin{array}{c}\mathrm{OP} \\
(\mathrm{mg} \mathrm{P} / \mathrm{L})\end{array}$ & $\begin{array}{c}\mathrm{TP} \\
(\mathrm{mg} \mathrm{P} / \mathrm{L})\end{array}$ \\
\hline AVERAGE & 0.17 & 0.19 & 1.85 & 2.02 & 0.47 & 0.56 \\
\hline LIGHT-1 & 0.16 & 0.4 & 12 & 12.2 & 2.2 & 2.4 \\
\hline LIGHT-2 & 0.11 & 0.26 & 8.6 & 8.7 & 1.6 & 1.7 \\
\hline LIGHT-3 & 0.15 & 0.27 & 9.5 & 9.7 & 1.2 & 1.4 \\
\hline LIGHT-4 & 0.15 & 0.29 & 11 & 11.2 & 2.2 & 2.5 \\
\hline AVERAGE & 0.14 & 0.31 & 10.28 & 10.42 & 1.80 & 2.00 \\
\hline SAND-1 & 0.14 & 0.44 & 0.48 & 0.6 & 0.01 & 0.03 \\
\hline SAND-2 & 0.15 & 0.4 & 0.48 & 0.6 & 0.01 & 0.01 \\
\hline SAND-3 & 0.14 & 0.39 & 0.39 & 0.5 & 0.01 & 0.01 \\
\hline SAND-4 & 0.14 & 0.37 & 0.42 & 0.6 & 0.01 & 0.01 \\
\hline AVERAGE & 0.14 & 0.40 & 0.44 & 0.59 & 0.01 & 0.02 \\
\hline STALITE-1 & 0.17 & 0.17 & 4.6 & 4.8 & 2.4 & 2.5 \\
\hline STALITE-2 & 0.17 & 0.17 & 5.2 & 5.4 & 2.9 & 3 \\
\hline STALITE-3 & 0.11 & 0.18 & 4.6 & 4.7 & 2.4 & 2.5 \\
\hline STALITE-4 & 0.14 & 0.15 & 5 & 5.1 & 3.4 & 3.5 \\
\hline AVERAGE & 0.15 & 0.17 & 4.85 & 5.00 & 2.78 & 2.88 \\
\hline INFLOW & 0.12 & 0.43 & 0.44 & 0.6 & 0.04 & 0.07 \\
\hline Week 8 & & & Date: & $03 / 03 / 2004$ & & \\
\hline CLAY-1 & 0.15 & 0.1 & 1.6 & 1.8 & 0.45 & 0.53 \\
\hline CLAY-2 & 0.1 & 0.1 & 1.8 & 1.9 & 0.45 & 0.52 \\
\hline CLAY-3 & 0.1 & 0.1 & 1.3 & 1.4 & 0.36 & 0.4 \\
\hline CLAY-4 & 0.1 & 0.1 & 1.7 & 1.8 & 0.41 & 0.49 \\
\hline AVERAGE & 0.11 & 0.10 & 1.60 & 1.71 & 0.42 & 0.49 \\
\hline LIGHT-1 & 0.1 & 0.23 & 12 & 12.1 & 1.6 & 1.9 \\
\hline LIGHT-2 & 0.1 & 0.14 & 6.7 & 6.8 & 1.4 & 1.4 \\
\hline LIGHT-3 & 0.1 & 0.21 & 8.9 & 9.0 & 1.1 & 1.3 \\
\hline LIGHT-4 & 0.1 & 0.22 & 12 & 12.1 & 2.3 & 2.9 \\
\hline AVERAGE & 0.10 & 0.20 & 9.90 & 10.00 & 1.60 & 1.88 \\
\hline SAND-1 & 0.1 & 0.32 & 0.34 & 0.4 & 0.01 & 0.07 \\
\hline SAND-2 & 0.1 & 0.3 & 0.46 & 0.6 & 0.01 & 0.01 \\
\hline SAND-3 & 0.11 & 0.3 & 0.41 & 0.5 & 0.01 & 0.01 \\
\hline SAND-4 & 0.15 & 0.33 & 0.42 & 0.6 & 0.01 & 0.03 \\
\hline AVERAGE & 0.12 & 0.31 & 0.41 & 0.52 & 0.01 & 0.03 \\
\hline STALITE-1 & 0.13 & 0.11 & 4.5 & 4.6 & 2.3 & 2.5 \\
\hline STALITE-2 & 0.1 & 0.12 & 5.2 & 5.3 & 3 & 3.1 \\
\hline STALITE-3 & 0.1 & 0.11 & 4.6 & 4.7 & 2.5 & 2.7 \\
\hline
\end{tabular}




\begin{tabular}{|c|c|c|c|c|c|c|}
\hline Sample ID & $\begin{array}{c}\mathrm{NO}_{3} \\
(\mathrm{mg} \mathrm{N} / \mathrm{L})\end{array}$ & $\begin{array}{c}\mathrm{NH}_{3} \\
(\mathrm{mg} \mathrm{N} / \mathrm{L})\end{array}$ & $\begin{array}{c}\text { TKN } \\
(\mathrm{mg} \mathrm{N} / \mathrm{L})\end{array}$ & $\begin{array}{c}\mathrm{TN} \\
(\mathrm{mg} \mathrm{N} / \mathrm{L})\end{array}$ & $\begin{array}{c}\mathrm{OP} \\
(\mathrm{mg} \mathrm{P} / \mathrm{L})\end{array}$ & $\begin{array}{c}\mathrm{TP} \\
(\mathrm{mg} \mathrm{P} / \mathrm{L})\end{array}$ \\
\hline STALITE-4 & 0.1 & 0.1 & 5.1 & 5.2 & 3.3 & 3.5 \\
\hline AVERAGE & 0.11 & 0.11 & 4.85 & 4.96 & 2.78 & 2.95 \\
\hline INFLOW & 0.12 & 0.39 & 0.45 & 0.6 & 0.01 & 0.05 \\
\hline Week 9 & & & Date: & $03 / 09 / 2004$ & & \\
\hline CLAY-1 & 0.16 & 0.12 & 1.4 & 1.6 & 0.29 & 0.32 \\
\hline CLAY-2 & 0.11 & 0.1 & 1.5 & 1.6 & 0.33 & 0.38 \\
\hline CLAY-3 & 0.12 & 0.1 & 1.8 & 1.9 & 0.46 & 0.51 \\
\hline CLAY-4 & 0.16 & 0.11 & 1.4 & 1.6 & 0.3 & 0.35 \\
\hline AVERAGE & 0.14 & 0.11 & 1.53 & 1.66 & 0.35 & 0.39 \\
\hline LIGHT-1 & 0.2 & 0.22 & 8.1 & 8.3 & 0.77 & 1 \\
\hline LIGHT-2 & 0.15 & 0.17 & 7.5 & 7.7 & 1.3 & 1.6 \\
\hline LIGHT-3 & 0.13 & 0.2 & 7.5 & 7.6 & 0.75 & 0.96 \\
\hline LIGHT-4 & 0.16 & 0.17 & 8.3 & 8.5 & 1.6 & 1.9 \\
\hline AVERAGE & 0.16 & 0.19 & 7.85 & 8.01 & 1.11 & 1.37 \\
\hline SAND-1 & 0.1 & 0.1 & 0.32 & 0.4 & 0.01 & 0.05 \\
\hline SAND-2 & 0.1 & 0.1 & 0.28 & 0.4 & 0.01 & 0.06 \\
\hline SAND-3 & 0.1 & 0.1 & 0.29 & 0.4 & 0.01 & 0.06 \\
\hline SAND-4 & 0.1 & 0.1 & 0.27 & 0.4 & 0.01 & 0.07 \\
\hline AVERAGE & 0.10 & 0.10 & 0.29 & 0.39 & 0.01 & 0.06 \\
\hline STALITE-1 & 0.15 & 0.12 & 4.9 & 5.1 & 2.7 & 2.8 \\
\hline STALITE-2 & 0.18 & 0.13 & 4.6 & 4.8 & 2 & 2.1 \\
\hline STALITE-3 & 0.1 & 0.14 & 4.8 & 4.9 & 2 & 2.2 \\
\hline STALITE-4 & 0.11 & 0.1 & 5.1 & 5.2 & 2.9 & 3.1 \\
\hline AVERAGE & 0.14 & 0.12 & 4.85 & 4.99 & 2.40 & 2.55 \\
\hline INFLOW & 0.13 & 0.4 & 0.63 & 0.8 & 0.03 & 0.03 \\
\hline Week 10 & & & Date: & $03 / 16 / 2004$ & & \\
\hline CLAY-1 & 0.1 & 0.1 & 1.9 & 2.0 & 0.31 & 0.3 \\
\hline CLAY-2 & 0.1 & 0.1 & 2.1 & 2.2 & 0.33 & 0.34 \\
\hline CLAY-3 & 0.1 & 0.1 & 2.3 & 2.4 & 0.44 & 0.5 \\
\hline CLAY-4 & 0.1 & 0.1 & 1.8 & 1.9 & 0.31 & 0.3 \\
\hline AVERAGE & 0.10 & 0.10 & 2.03 & 2.13 & 0.35 & 0.36 \\
\hline LIGHT-1 & 0.1 & 0.19 & 7.7 & 7.8 & 0.44 & 0.63 \\
\hline LIGHT-2 & 0.16 & 0.15 & 7.6 & 7.8 & 0.91 & 1.3 \\
\hline LIGHT-3 & 0.1 & 0.18 & 6.7 & 6.8 & 0.58 & 0.78 \\
\hline LIGHT-4 & 0.1 & 0.13 & 6.5 & 6.6 & 0.93 & 1.3 \\
\hline AVERAGE & 0.12 & 0.16 & 7.13 & 7.24 & 0.72 & 1.00 \\
\hline
\end{tabular}




\begin{tabular}{|l|c|c|c|c|c|c|}
\hline Sample ID & $\begin{array}{c}\mathrm{NO}_{3} \\
(\mathrm{mg} \mathrm{N} / \mathrm{L})\end{array}$ & $\begin{array}{c}\mathrm{NH}_{3} \\
(\mathrm{mg} \mathrm{N} / \mathrm{L})\end{array}$ & $\begin{array}{c}\mathrm{TKN} \\
(\mathrm{mg} \mathrm{N} / \mathrm{L})\end{array}$ & $\begin{array}{c}\mathrm{TN} \\
(\mathrm{mg} \mathrm{N} / \mathrm{L})\end{array}$ & $\begin{array}{c}\mathrm{OP} \\
(\mathrm{mg} \mathrm{P} / \mathrm{L})\end{array}$ & $\begin{array}{c}\mathrm{TP} \\
(\mathrm{mg} \mathrm{P} / \mathrm{L})\end{array}$ \\
\hline SAND-1 & 0.1 & 0.1 & 0.38 & 0.5 & 0.03 & 0.06 \\
\hline SAND-2 & 0.1 & 0.1 & 0.33 & 0.4 & 0.04 & 0.05 \\
\hline SAND-3 & 0.1 & 0.1 & 0.23 & 0.3 & 0.03 & 0.06 \\
\hline SAND-4 & 0.1 & 0.1 & 0.23 & 0.3 & 0.03 & 0.06 \\
\hline AVERAGE & 0.10 & 0.10 & 0.29 & 0.39 & 0.03 & 0.06 \\
\hline STALITE-1 & 0.1 & 0.1 & 4.5 & 4.6 & 1.5 & 2.1 \\
\hline STALITE-2 & 0.1 & 0.1 & 4.9 & 5.0 & 2 & 2.9 \\
\hline STALITE-3 & 0.1 & 0.13 & 4.7 & 4.8 & 1.5 & 2.1 \\
\hline STALITE-4 & 0.1 & 0.1 & 5 & 5.1 & 2.1 & 3.2 \\
\hline AVERAGE & 0.10 & 0.11 & 4.78 & 4.88 & 1.78 & 2.58 \\
\hline INFLOW & 0.1 & 0.1 & 0.59 & 0.7 & 0.03 & 0.03 \\
\hline
\end{tabular}

Note: No outflow from the sand columns was observed in week 1; all synthetic rainwater was retained for week 1 .

Key:

Clay $=$ ERTH HydRocks Soil Mix

Light $=$ ERTH Light Soil Mix

Sand $=$ Play Sand

Stalite $=$ Carolina Stalite Soil Mix

$\mathrm{NO}_{3}=$ Nitrate-Nitrite $\left(\mathrm{NO}_{3}-\mathrm{NO}_{2}\right)$ 


\section{J.2 Graphics of AVErage Concentrations for EACH SOIL Nutrient}

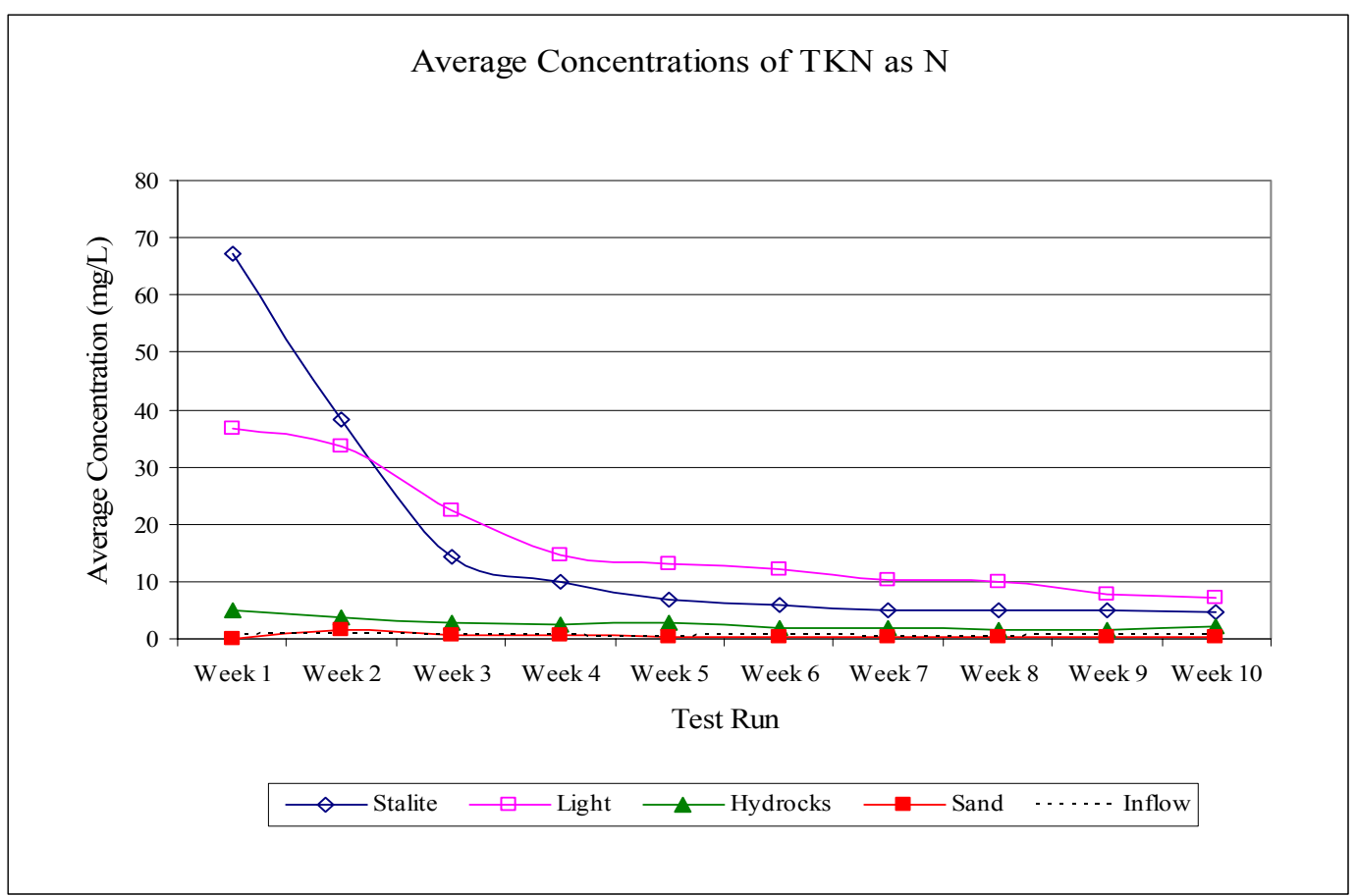

Figure J-1. Display of Average TKN Concentrations in All Four Soil Media.

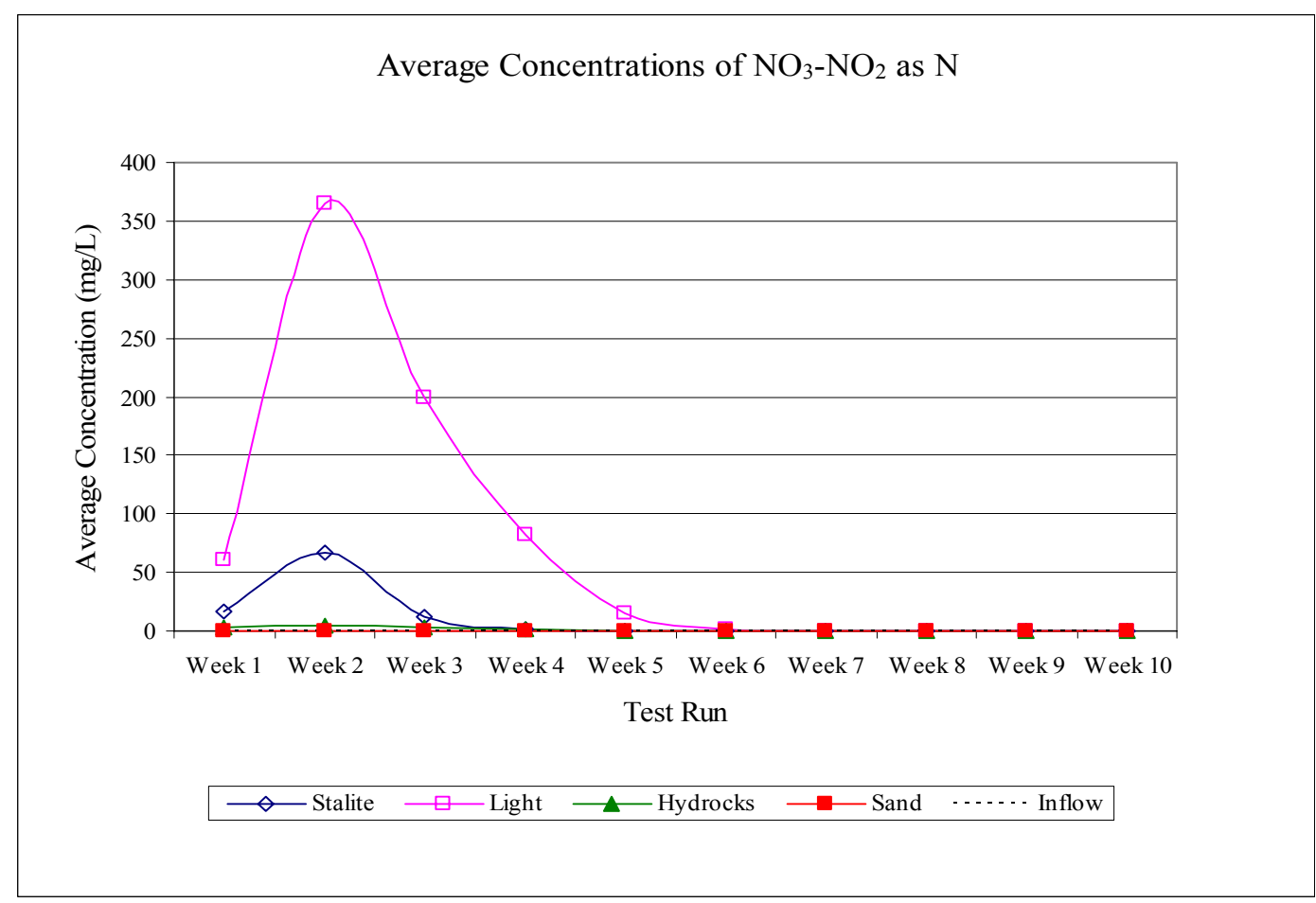

Figure J-2. Display of Average $\mathrm{NO}_{3}-\mathrm{NO}_{2}$ Concentrations in All Four Soil Media. 


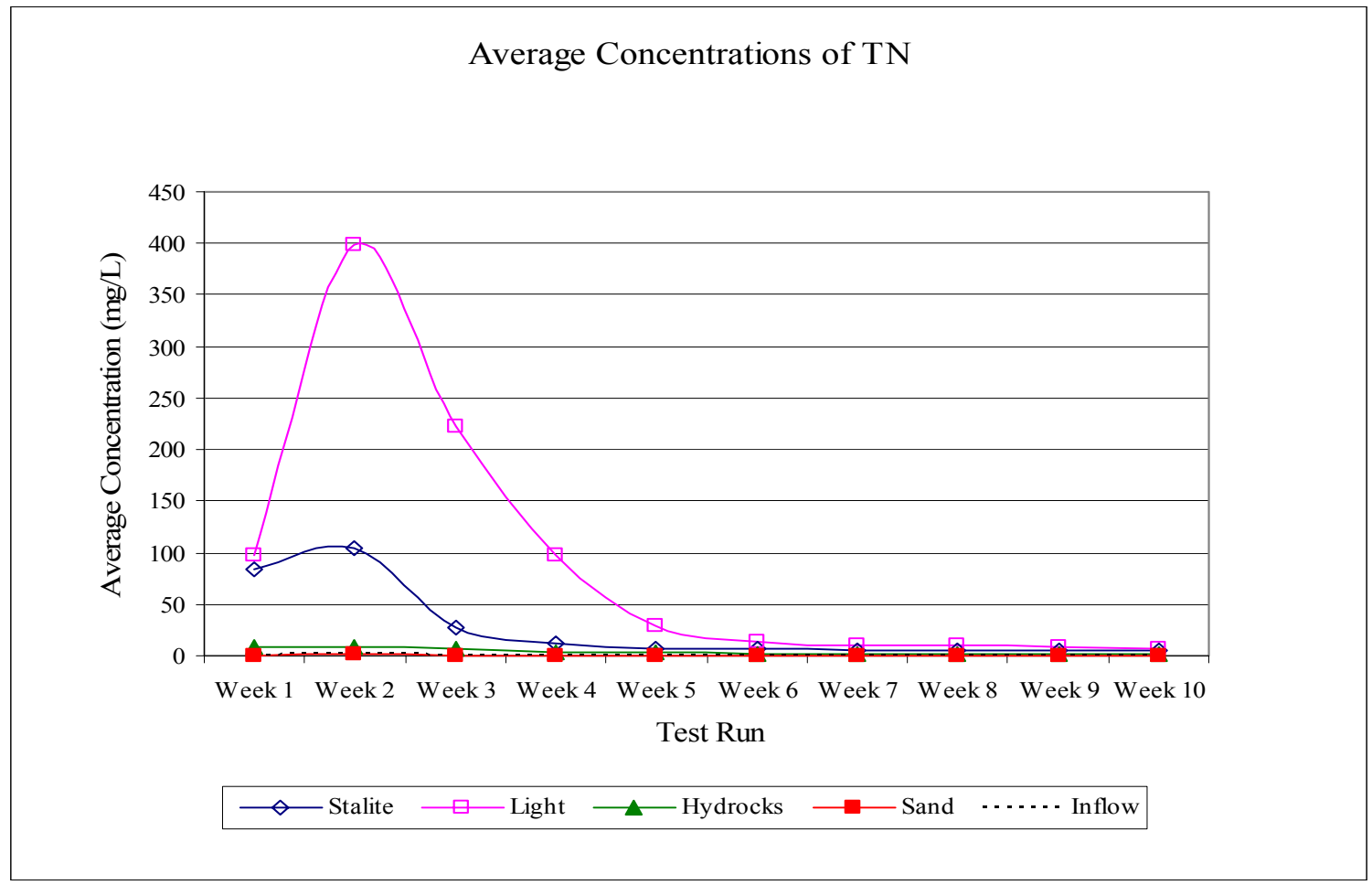

Figure J-3. Display of Average TN Concentrations in All Four Soil Media.

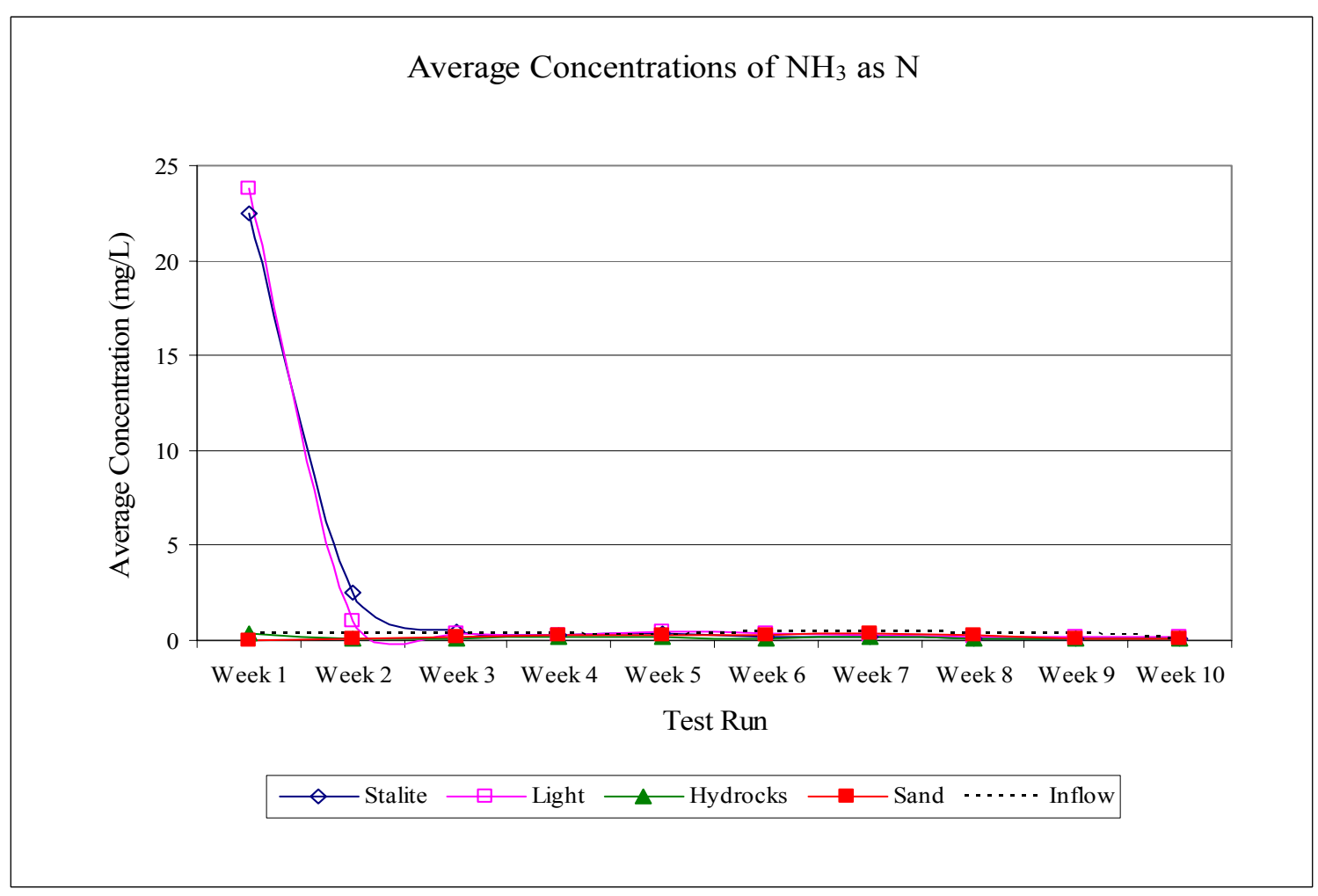

Figure J-4. Display of Average $\mathrm{NH}_{3}$ Concentrations in All Four Soil Media. 


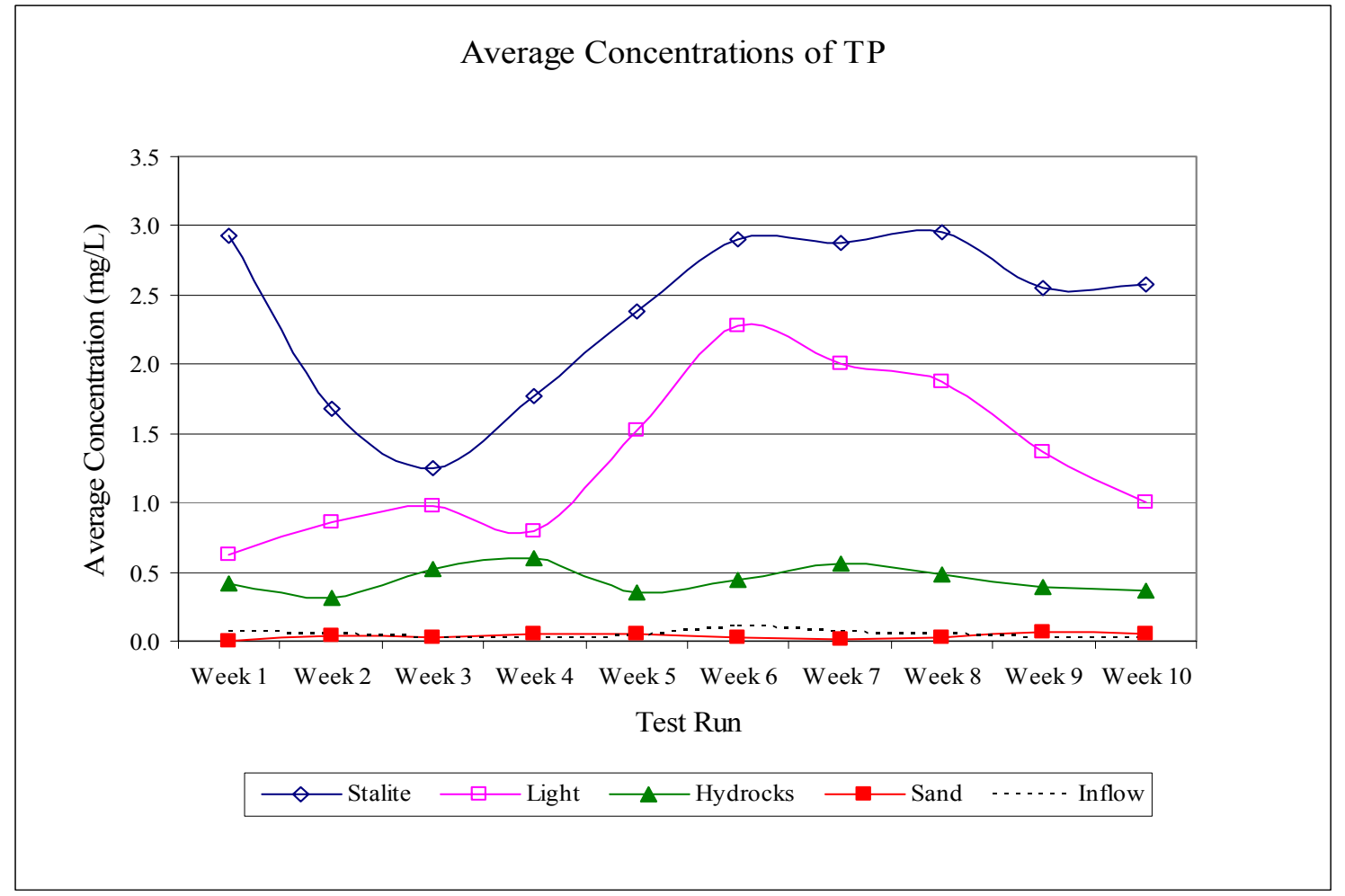

Figure J-5. Display of Average TP Concentrations in All Four Soil Media.

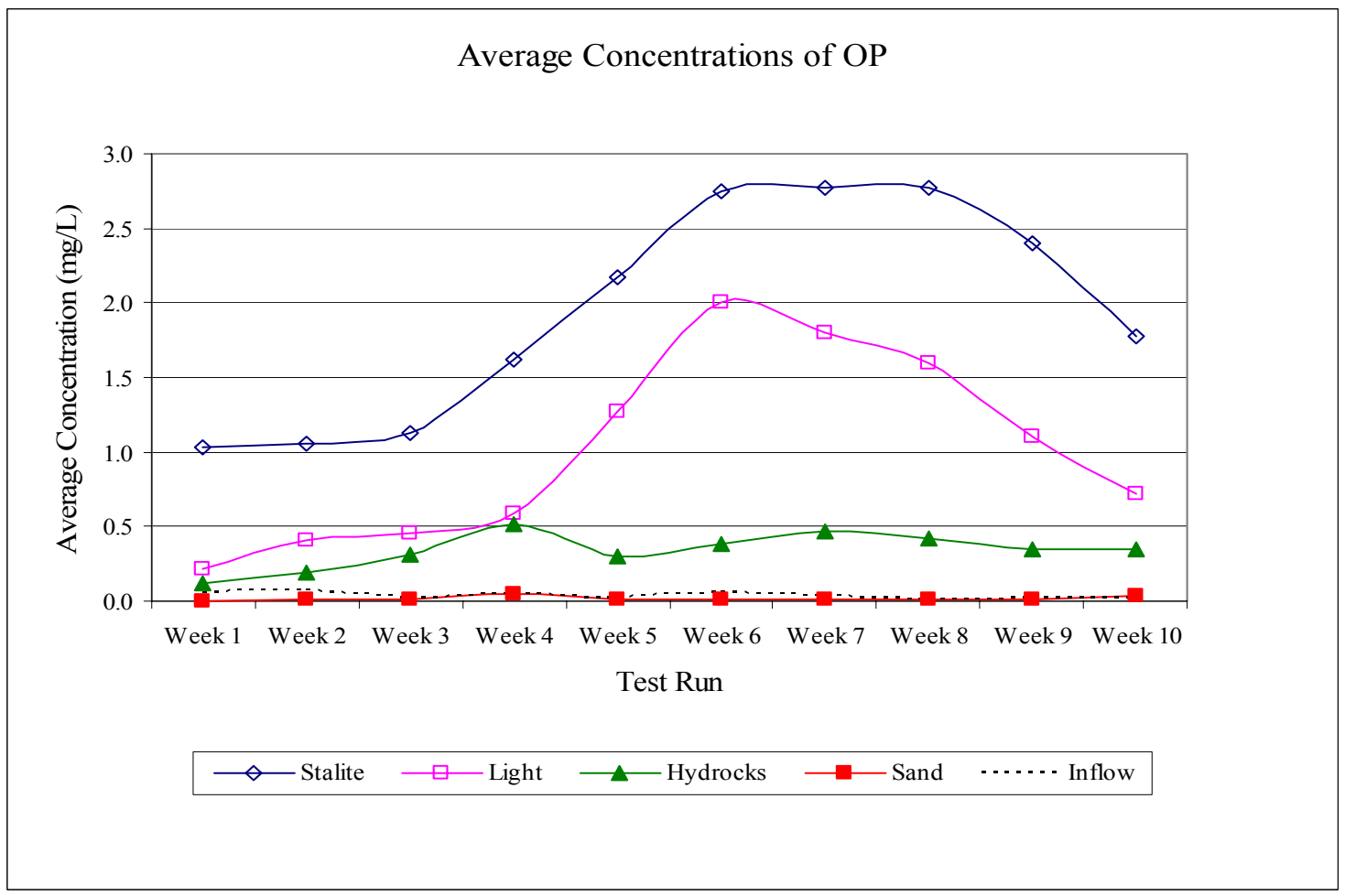

Figure J-6. Display of Average OP Concentrations in All Four Soil Media. 


\section{J.3 Graphics of Average Concentrations for Each SoIl Media}

\section{J.3.1 ERTH HydRocks SOIL MIX}

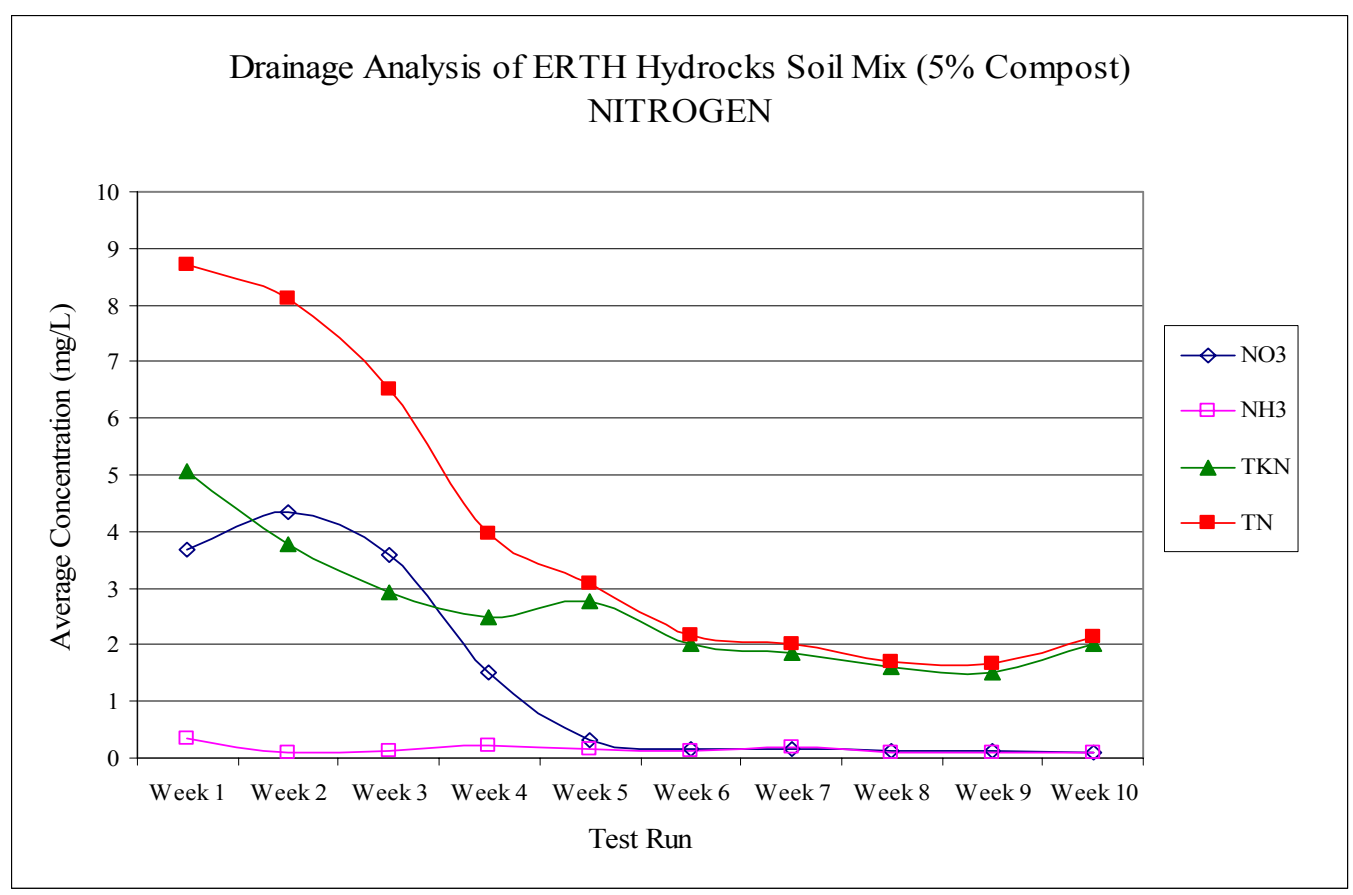

Figure J-7. Display of Nitrogen Concentrations in ERTH HydRocks Soil Mix (5\% Compost).

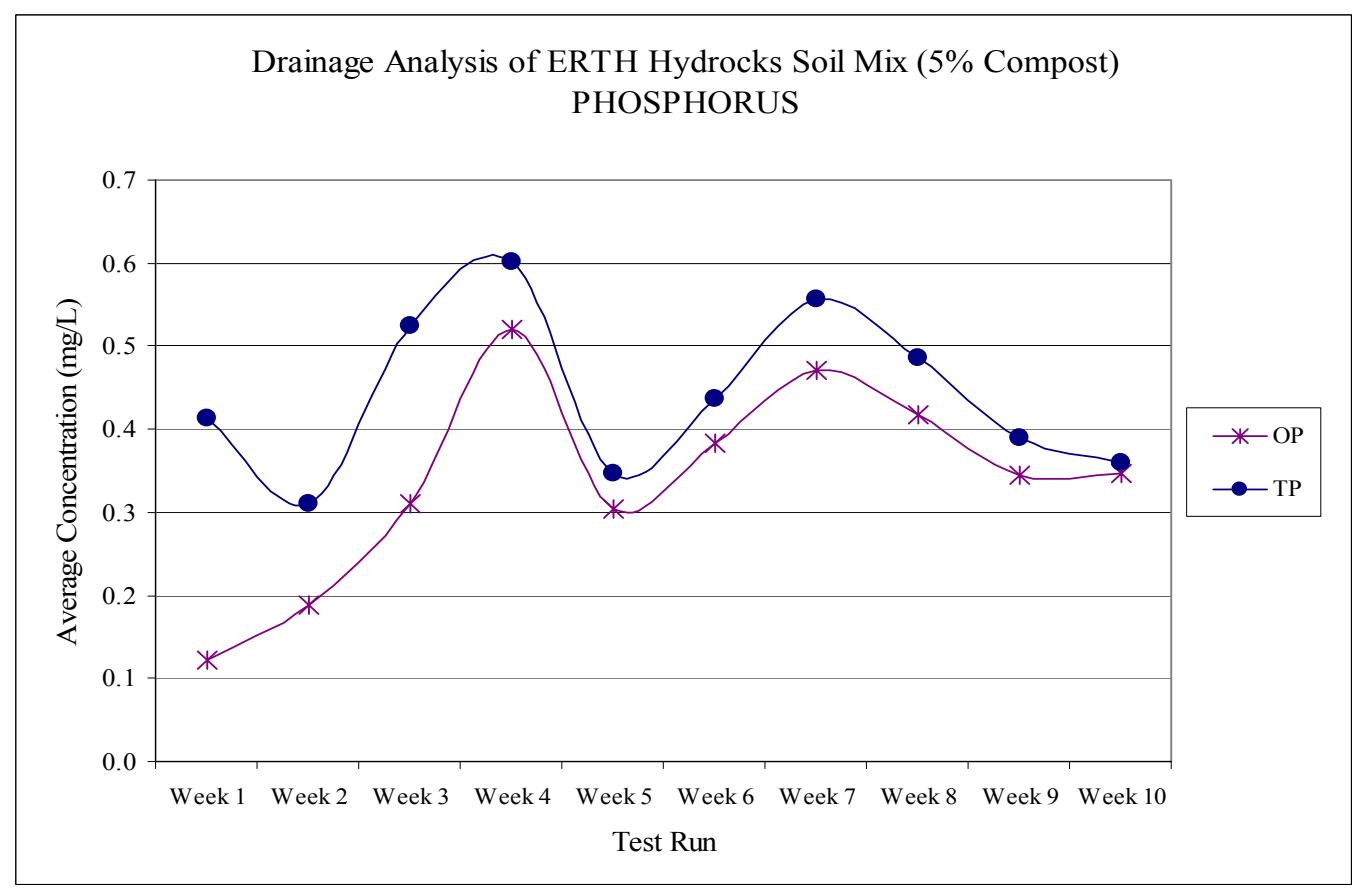

Figure J-8. Display of Phosphorus Concentrations in ERTH HydRocks Soil Mix (5\% Compost). 


\section{J.3.2 CARolina Stalite SoIl MiX}

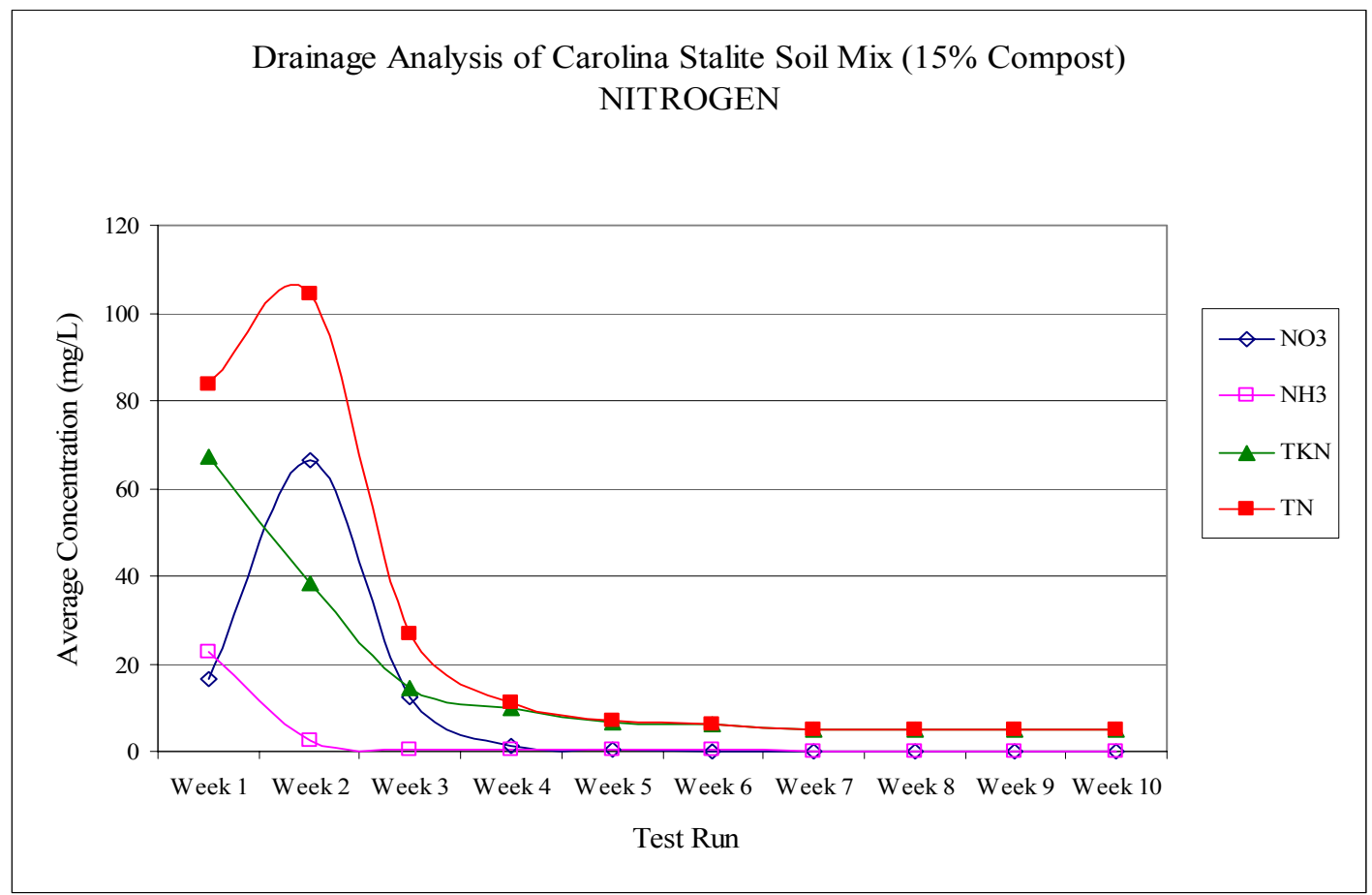

Figure J-9. Display of Nitrogen Concentrations in Carolina Stalite Soil Mix (15\% Compost).

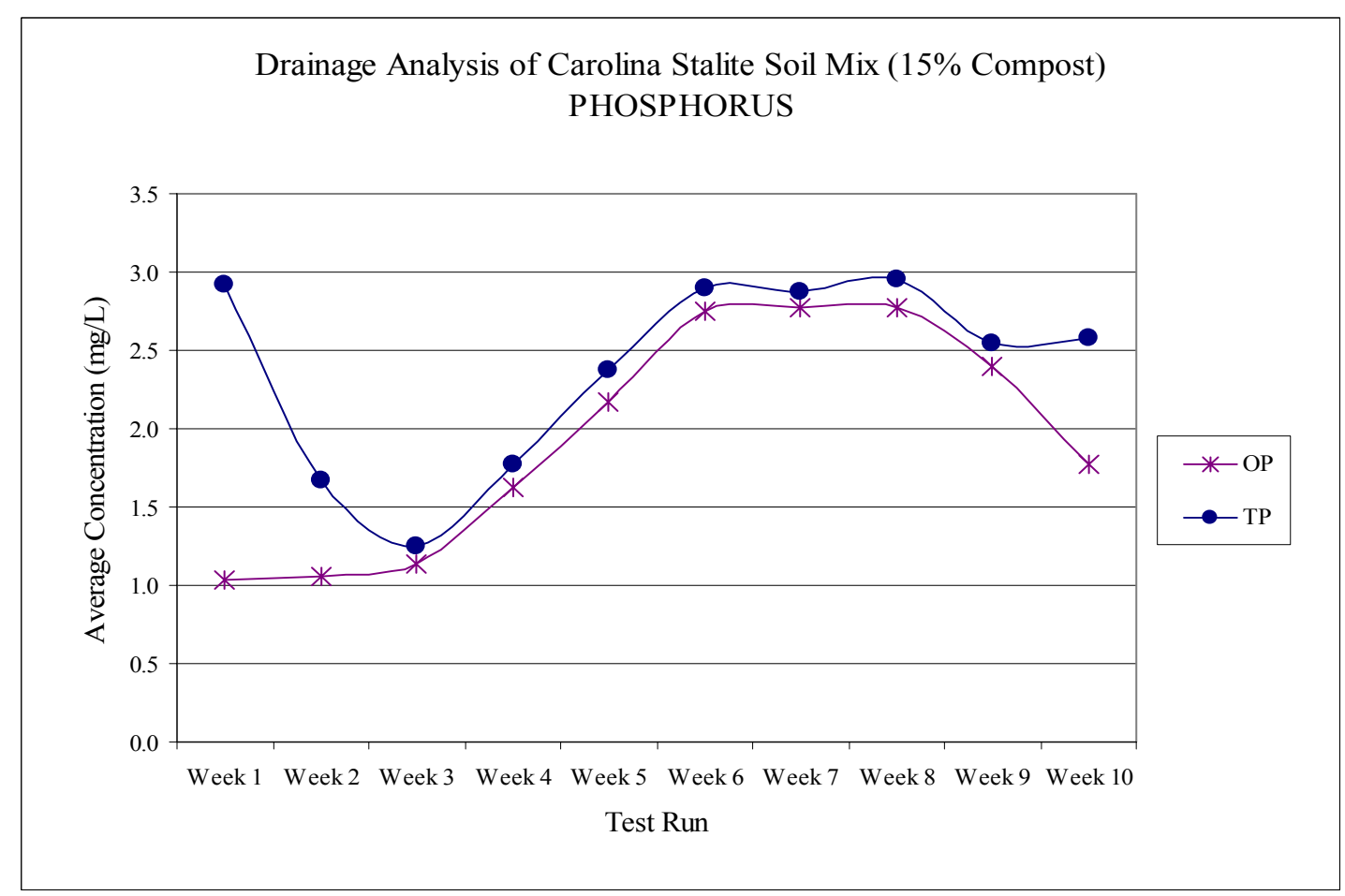

Figure J-10. Display of Phosphorus Concentrations in Carolina Stalite Soil Mix (15\% Compost). 


\section{J.3.3 ERTH LIGHT SOIL MIX}

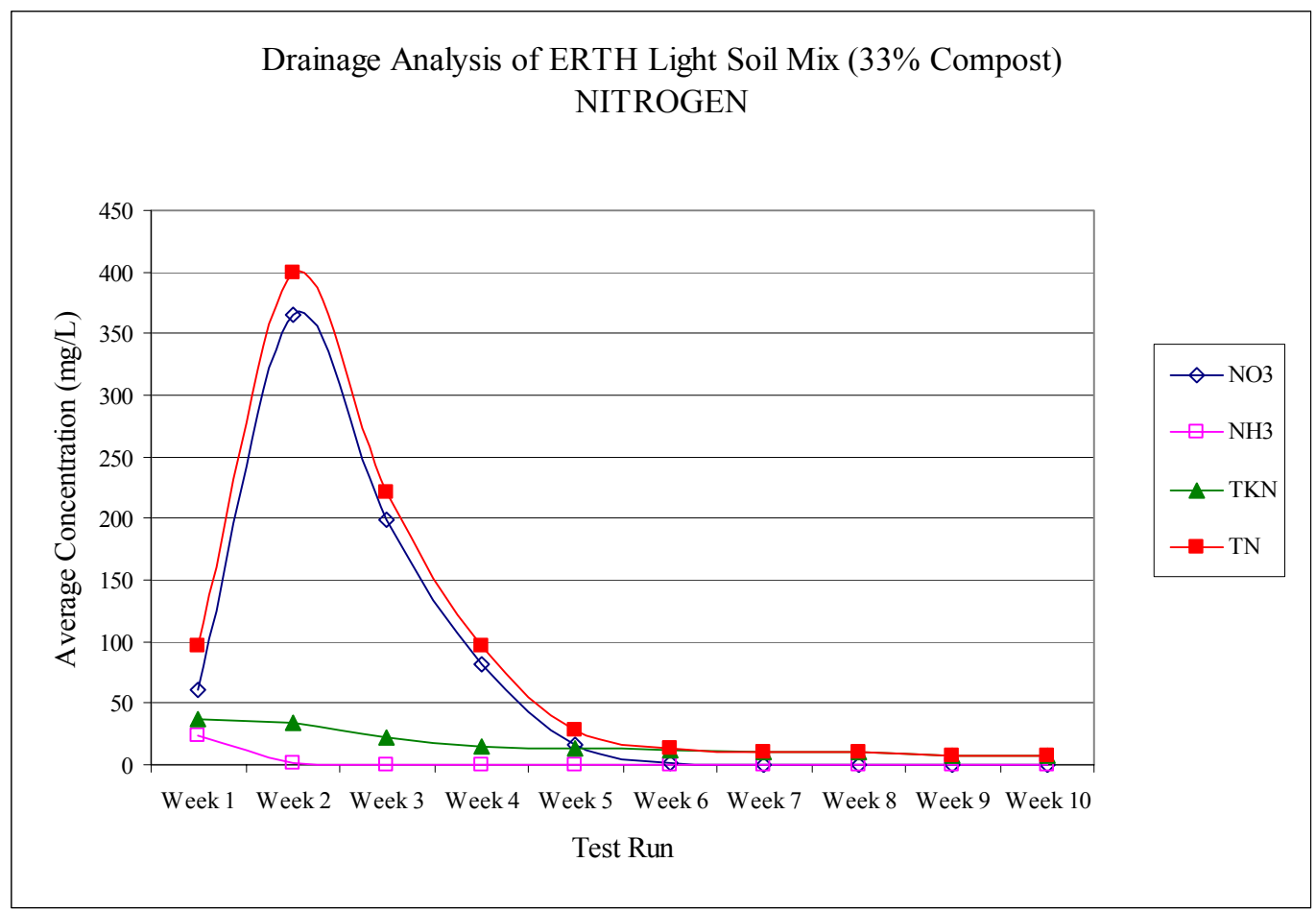

Figure J-11. Display of Nitrogen Concentrations in ERTH Light Soil Mix (33\% Compost).

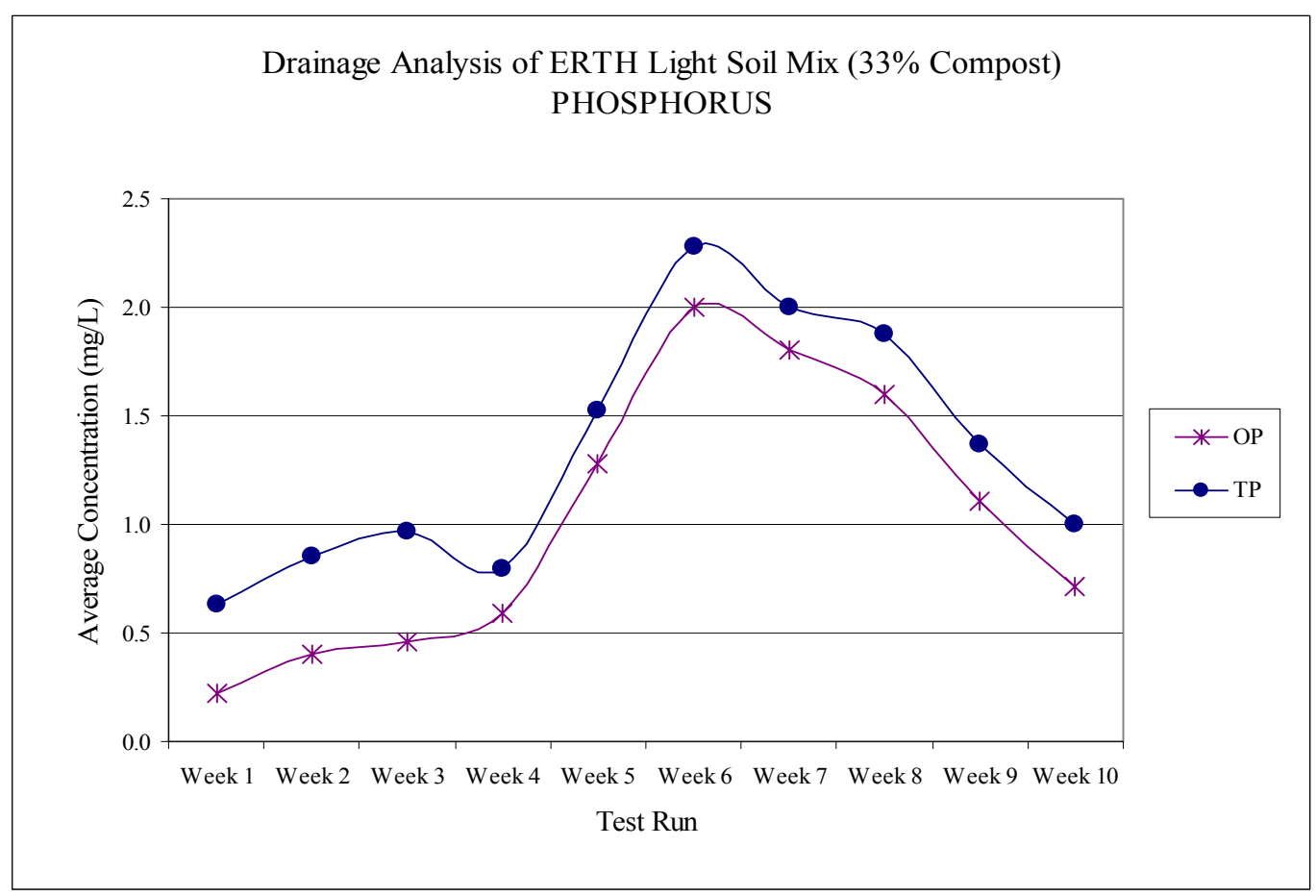

Figure J-12. Display of Phosphorus Concentrations in ERTH Light Soil Mix (33\% Compost). 


\section{J.3.4 PLAY SAND}

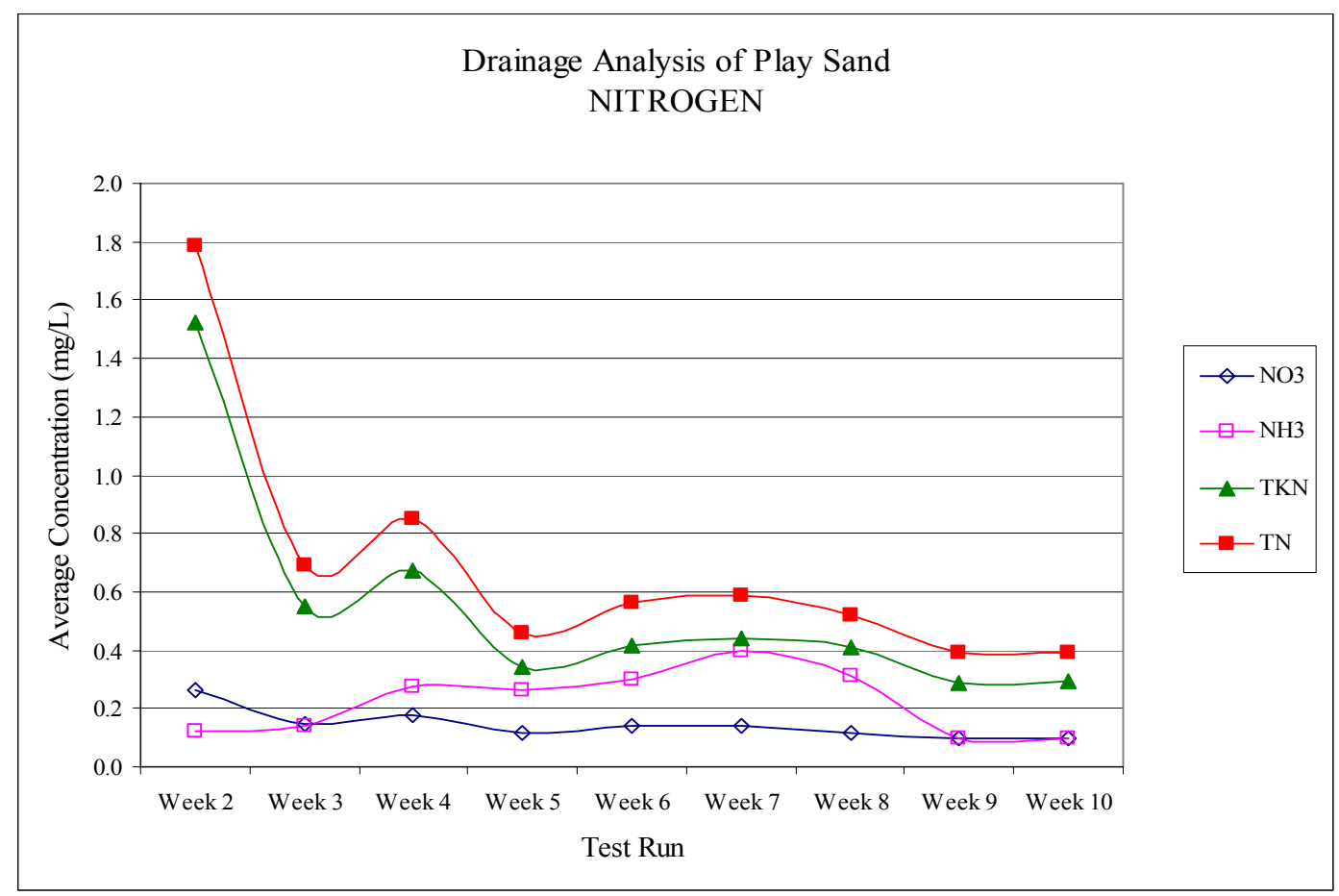

Figure J-13. Display of Nitrogen Concentrations in Play Sand.

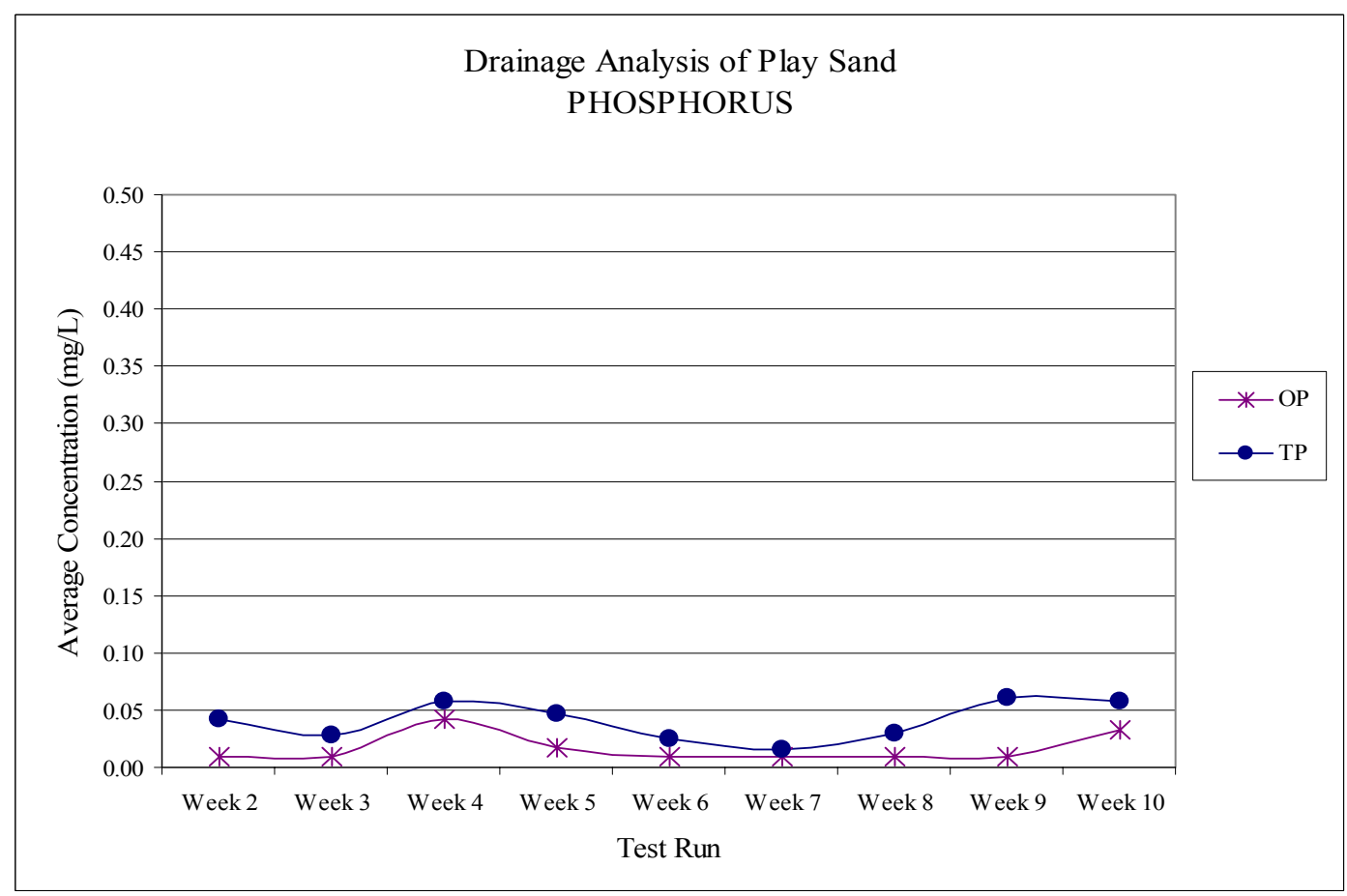

Figure J-14. Display of Phosphorus Concentrations in Play Sand. 


\section{K.0 APPENDIX K - SOIL MEDIA STUDY DATA: STATISTICAL ANALYSIS}

All input data for the statistical analysis of the soil media column study is presented in Appendix J.

\section{K.1 CONCENTRATIONS OF Total KJELDAHL Nitrogen (TKN AS N)}

The proc glm output below compares the outflow concentration of TKN as $\mathrm{N}$ from each soil media over the course of the 10 weeks of the column study. The parameter estimate table compares each week of data to the final week of the data; for example, it compares the outflow of week 1 to week 10, week 2 to week 10, etc. This table shows that significant differences were observed between the individual soil media in the first three weeks and the outflow of the soil media in the final week $(\alpha<0.05)$; however, no significant differences were observed between the soil media in the final weeks.

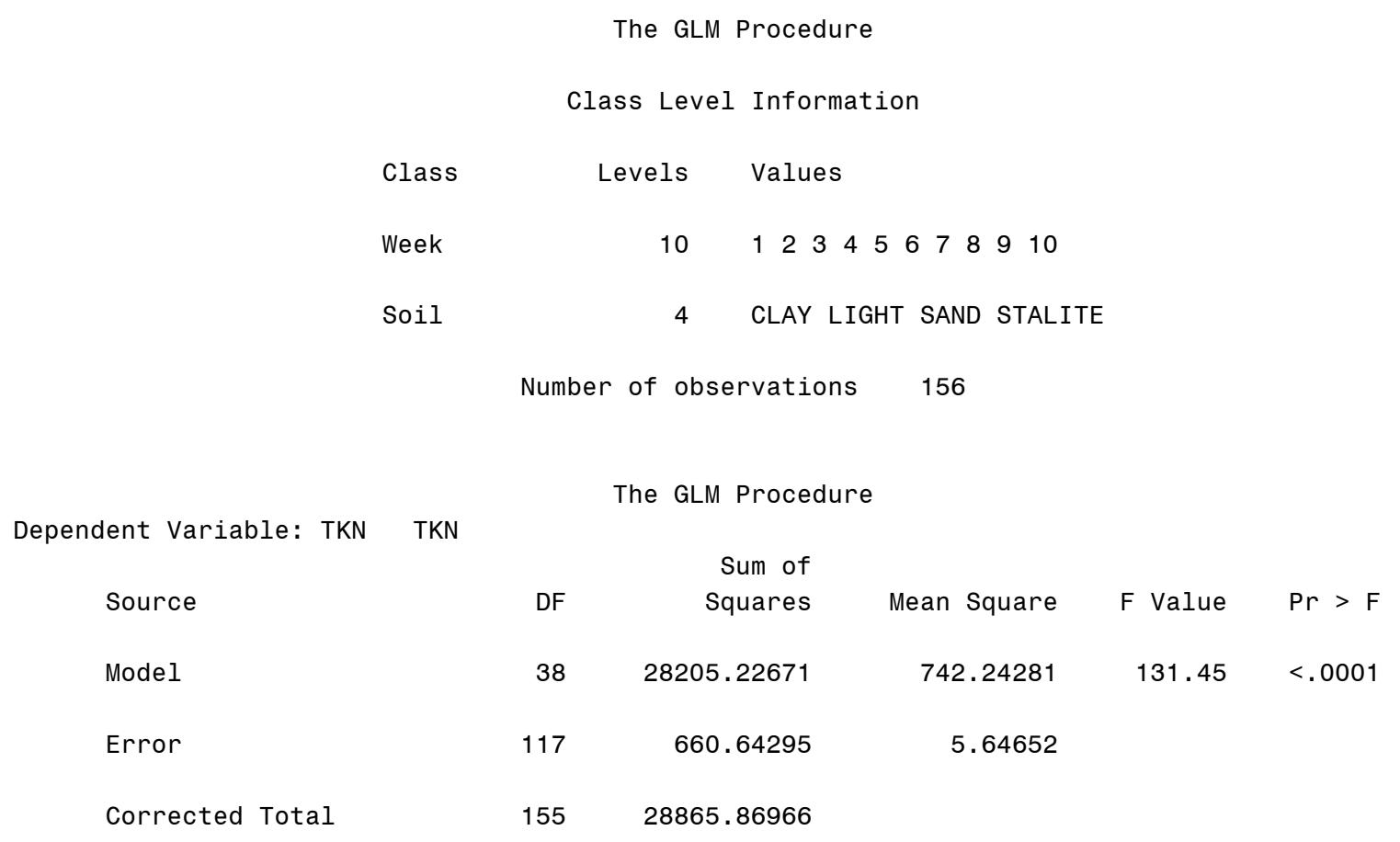




$\begin{array}{llll}\text { R-Square } & \text { Coeff Var } & \text { Root MSE } & \text { TKN Mean } \\ 0.977113 & 25.69515 & 2.376241 & 9.247821\end{array}$

Source
Soil
Inflow_TKN
Week
Week*Soil

Source

Soil

Inflow_TKN

Week

Week*Soil

$\begin{array}{ll}\text { Parameter } & \\ \text { Intercept } & \\ \text { Soil } & \text { CLAY } \\ \text { Soil } & \text { LIGHT } \\ \text { Soil } & \text { SAND } \\ \text { Soil } & \text { STALITE } \\ \text { Inflow_TKN } & \\ \text { Week } & 1 \\ \text { Week } & 2 \\ \text { Week } & 3 \\ \text { Week } & 4 \\ \text { Week } & 5 \\ \text { Week } & 6 \\ \text { Week } & 7 \\ \text { Week } & 8 \\ \text { Week } & 9 \\ \text { Week } & 10 \\ \text { Week*Soil } & 1 \text { CLAY } \\ \text { Week*Soil } & 1 \text { LIGHT } \\ \text { Week*Soil } & 1 \text { STALITE } \\ \text { Week*Soil } & 2 \text { CLAY } \\ \text { Week*Soil } & 2 \text { LIGHT } \\ \text { Week*Soil } & 2 \text { SAND } \\ \text { Week*Soil } & 2 \text { STALITE } \\ \text { Week*Soil } & 3 \text { CLAY } \\ \text { Week*Soil } & 3 \text { LIGHT } \\ \text { Week*Soil } & 3 \text { SAND } \\ \text { Week*Soil } & 3 \text { STALITE } \\ \text { Week*Soil } & 4 \text { CLAY } \\ \text { Week*Soil } & 4 \text { LIGHT } \\ \text { Week*Soil } & 4 \text { SAND } \\ \text { Week*Soil } & 4 \text { STALITE } \\ & \end{array}$

$\begin{array}{rrrrr}\text { DF } & \text { Type I SS } & \text { Mean Square } & \text { F Value } & \text { Pr }>\text { F } \\ & & & & \\ 3 & 8690.881553 & 2896.960518 & 513.05 & <.0001 \\ 1 & 2164.860116 & 2164.860116 & 383.40 & <.0001 \\ 8 & 9102.901235 & 1137.862654 & 201.52 & <.0001 \\ 26 & 8246.583804 & 317.176300 & 56.17 & <.0001 \\ & & & \\ \text { DF } & \text { Type III SS } & \text { Mean Square } & \text { F Value } & \text { Pr }>\text { F } \\ & & & & \\ 3 & 7140.449908 & 2380.149969 & 421.53 & <.0001 \\ 0 & 0.000000 & & & . \\ 8 & 9102.901235 & 1137.862654 & 201.52 & <.0001 \\ 26 & 8246.583804 & 317.176300 & 56.17 & <.0001\end{array}$

Error

$t$ Value $\operatorname{Pr}>|t|$

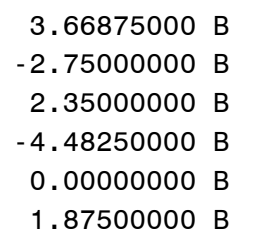

25.63767400

0.14

0.8865

1.68025607

1.68025607

1.68025607

$-1.64$

0.1044

$1.40 \quad 0.1646$

$-2.67$

0.0087

42.00640182

1.68025607

8.11278372

1.92497516

1.68025607

10.18601111

4.44553971

7.28783833

6.87674435

0.04

0.9645

$33.08125000 \mathrm{~B}$

37.18

$<.0001$

$4.08<.0001$

$4.93<.0001$

$5.07500000 \mathrm{~B}$

$2.41250000 \mathrm{~B}$

3.02

0.0031

$1.42500000 \mathrm{~B}$

$0.35625000 \mathrm{~B}$

$0.33750000 \mathrm{~B}$

$0.00000000 \mathrm{~B}$

$0.00000000 \mathrm{~B}$

$-59.45000000 \mathrm{~B}$

$-32.85000000 B$

$0.00000000 \mathrm{~B}$

$-31.72500000 \mathrm{~B}$

$-6.85000000 \mathrm{~B}$

$-32.24250000 \mathrm{~B}$

$0.00000000 \mathrm{~B}$

$-8.57500000 \mathrm{~B}$

$5.90000000 \mathrm{~B}$

$-9.22000000 B$

$0.00000000 \mathrm{~B}$

$-4.70000000 \mathrm{~B}$

$2.22500000 \mathrm{~B}$

$-4.77000000 \mathrm{~B}$

0.24

0.8132

0.32

0.7491

$0.05 \quad 0.9611$

$0.05 \quad 0.9609$

2. 37624093

2.37624093

$-25.02$

.

.

2.37624093

$-13.82$

$<.0001$

$-13.35$

$<.0001$

2. 37624093

$-2.88$

$<.0001$

$-13.57$

0.0047

2. 37624093

$-3.61$

$<.0001$

2. 37624093

2.48

0.0005

2. 37624093

$-3.88$

0.0144

2. 37624093

$-1.98$

0.0002

2. 37624093

0.94

0.0503

2. 37624093

0.3510

$0.00000000 \mathrm{~B}$ 


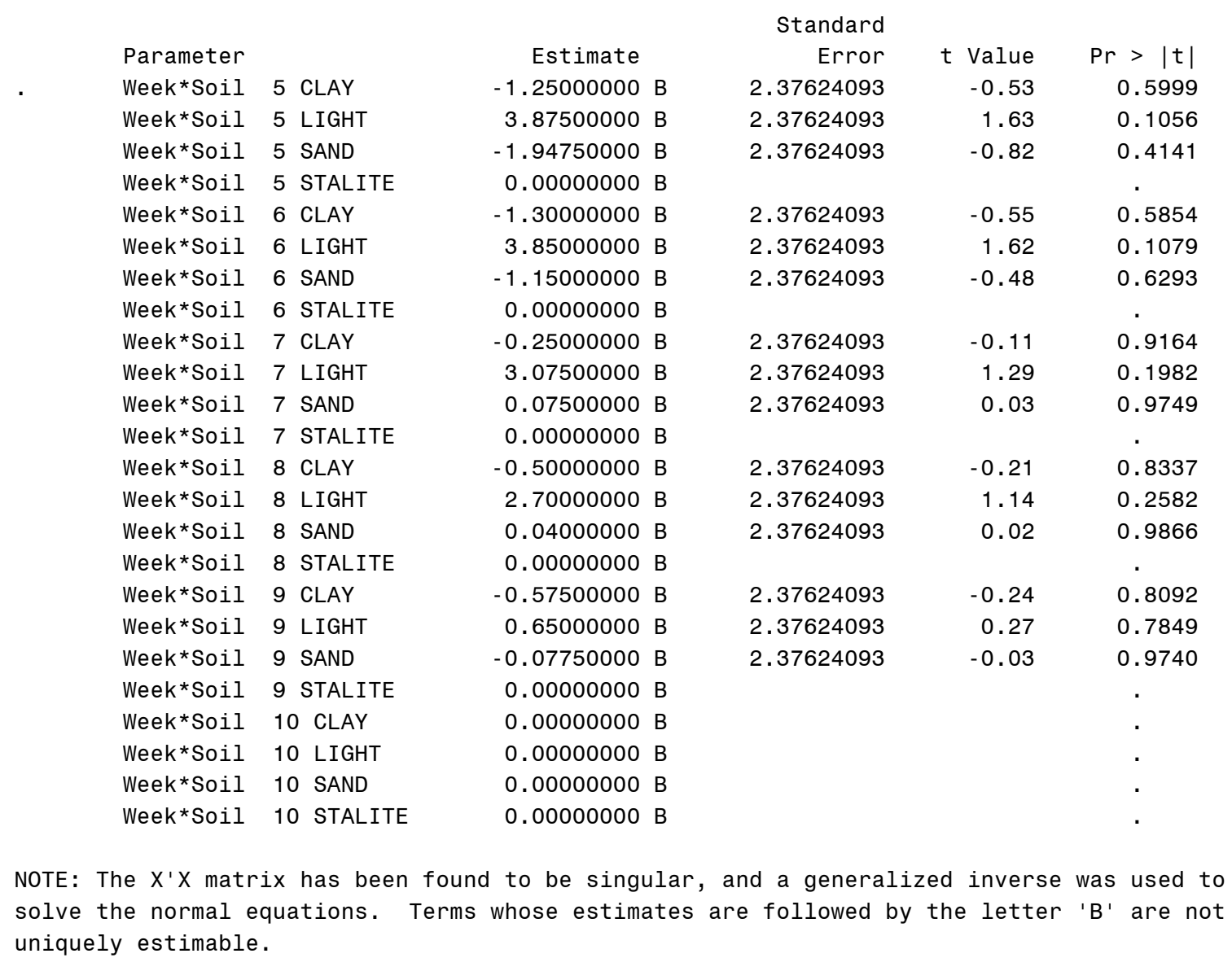

\section{K.2 CONCENTRATIONS OF NitRATE-NitRite $\left(\mathrm{NO}_{3}-\mathrm{NO}_{2}\right.$ AS N)}

The proc glm output below compares the outflow concentration of $\mathrm{NO}_{3}-\mathrm{NO}_{2}$ as $\mathrm{N}$ from each soil media over the course of the 10 weeks of the column study. The parameter estimate table compares each week of data to the final week of data; for example, it compares week 1 with week 10 , week 2 with week 10 , etc. The parameter estimate table illustrates that significant differences were observed between the outflows of the soil media in the first two weeks, however, no significant differences were observed in the final weeks of the study ( $\alpha<$ $0.05)$. 


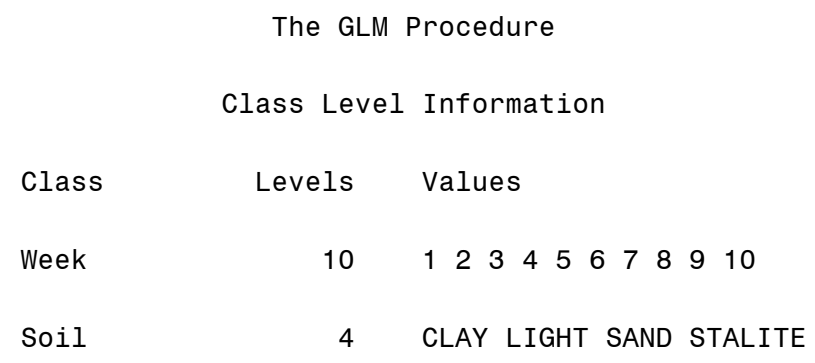

Number of observations 156

The GLM Procedure

Dependent Variable: N03 N03

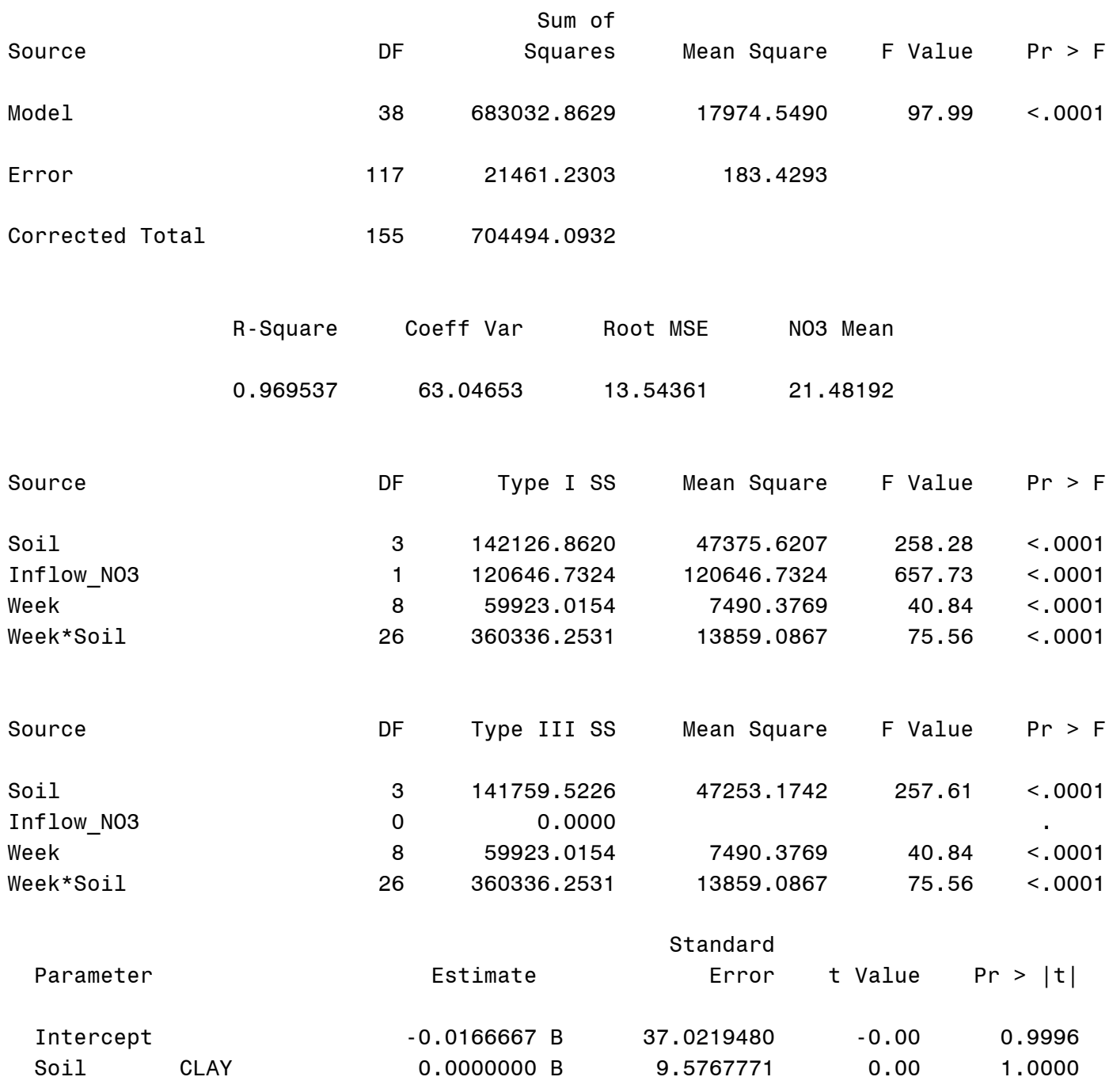




\begin{tabular}{|c|c|c|}
\hline Parameter & & Estimate \\
\hline Soil & LIGHT & $0.0150000 \mathrm{~B}$ \\
\hline Soil & SAND & $0.0000000 \mathrm{~B}$ \\
\hline Soil & STALITE & $0.0000000 \mathrm{~B}$ \\
\hline Inflow_NO3 & & $1.1666667 \mathrm{~B}$ \\
\hline Week & 1 & $16.3766667 \mathrm{~B}$ \\
\hline Week & 2 & $66.0800000 \mathrm{~B}$ \\
\hline Week & 3 & $12.3533333 \mathrm{~B}$ \\
\hline Week & 4 & $1.1883333 \mathrm{~B}$ \\
\hline Week & 5 & $0.1700000 \mathrm{~B}$ \\
\hline Week & 6 & $0.0341667 \mathrm{~B}$ \\
\hline Week & 7 & $0.0241667 \mathrm{~B}$ \\
\hline Week & 8 & $-0.0158333 B$ \\
\hline Week & 9 & $0.0000000 \mathrm{~B}$ \\
\hline Week & 10 & $0.0000000 \mathrm{~B}$ \\
\hline Week*Soil & 1 CLAY & -12.8250000 \\
\hline Week*Soil & 1 LIGHT & $43.9850000 \mathrm{~B}$ \\
\hline Week*Soil & 1 STALITE & $0.0000000 \mathrm{~B}$ \\
\hline Week*Soil & 2 CLAY & $-61.9250000 \mathrm{~B}$ \\
\hline Week*Soil & 2 LIGHT & $298.9850000 \mathrm{~B}$ \\
\hline Week*Soil & 2 SAND & $-65.9900000 \mathrm{~B}$ \\
\hline Week*Soil & 2 STALITE & $0.0000000 \mathrm{~B}$ \\
\hline Week*Soil & 3 CLAY & $-8.9250000 \mathrm{~B}$ \\
\hline Week*Soil & $3 \mathrm{LIGHT}$ & $186.9850000 \mathrm{~B}$ \\
\hline Week*Soil & 3 SAND & -12.3550000 \\
\hline Week*Soil & 3 STALITE & $0.0000000 \mathrm{~B}$ \\
\hline Week*Soil & 4 CLAY & $0.2000000 \mathrm{~B}$ \\
\hline Week*Soil & 4 LIGHT & $80.9350000 \mathrm{~B}$ \\
\hline Week*Soil & 4 SAND & $-1.1225000 \mathrm{~B}$ \\
\hline Week*Soil & 4 STALITE & $0.0000000 \mathrm{~B}$ \\
\hline Week*Soil & 5 CLAY & $0.0325000 \mathrm{~B}$ \\
\hline Week*Soil & 5 LIGHT & $15.6650000 \mathrm{~B}$ \\
\hline Week*Soil & 5 SAND & $-0.1550000 \mathrm{~B}$ \\
\hline Week*Soil & 5 STALITE & $0.0000000 \mathrm{~B}$ \\
\hline Week*Soil & 6 CLAY & $-0.0000000 \mathrm{~B}$ \\
\hline Week*Soil & 6 LIGHT & $0.8375000 \mathrm{~B}$ \\
\hline Week*Soil & 6 SAND & $-0.0150000 \mathrm{~B}$ \\
\hline Week*Soil & 6 STALITE & $0.0000000 \mathrm{~B}$ \\
\hline Week*Soil & 7 CLAY & $0.0200000 \mathrm{~B}$ \\
\hline Week*Soil & 7 LIGHT & $-0.0200000 \mathrm{~B}$ \\
\hline Week*Soil & 7 SAND & $-0.0050000 \mathrm{~B}$ \\
\hline Week*Soil & 7 STALITE & $0.0000000 \mathrm{~B}$ \\
\hline Week*Soil & 8 CLAY & $0.0050000 \mathrm{~B}$ \\
\hline Week*Soil & 8 LIGHT & $-0.0225000 \mathrm{~B}$ \\
\hline Week*Soil & 8 SAND & $0.0075000 \mathrm{~B}$ \\
\hline Week*Soil & 8 STALITE & $0.0000000 \mathrm{~B}$ \\
\hline Week*Soil & 9 CLAY & $0.0025000 \mathrm{~B}$ \\
\hline Week*Soil & 9 LIGHT & $0.0100000 \mathrm{~B}$ \\
\hline Week*Soil & 9 SAND & $-0.0350000 \mathrm{~B}$ \\
\hline Week*Soil & 9 STALITE & $0.0000000 \mathrm{~B}$ \\
\hline Week*Soil & $10 \mathrm{CLAY}$ & $0.0000000 \mathrm{~B}$ \\
\hline Week*Soil & 10 LIGHT & $0.0000000 \mathrm{~B}$ \\
\hline
\end{tabular}

\begin{tabular}{|c|c|c|}
\hline \multicolumn{3}{|l|}{ Standard } \\
\hline 9.5767771 & 0.00 & 0.9988 \\
\hline 9.5767771 & 0.00 & 1.0000 \\
\hline 319.2259029 & 0.00 & 9971 \\
\hline $\begin{array}{r}319.2259029 \\
8.4459235\end{array}$ & 0.00 & 0.0549 \\
\hline 8.4459235 & 1.94 & 0.0549 \\
\hline 16.5874645 & 3.98 & 0.0001 \\
\hline 11.5098536 & 1.07 & 0.2854 \\
\hline 8.4459235 & 0.14 & 0.8883 \\
\hline 9.5767771 & 0.02 & 0.9859 \\
\hline 8.4459235 & 0.00 & 0.9968 \\
\hline 8.4459235 & 0.00 & 0.9977 \\
\hline 8.4459235 & -0.00 & 0.9985 \\
\hline & & . \\
\hline 13.5436080 & -0.95 & 0.3456 \\
\hline 13.5436080 & 3.25 & 0.0015 \\
\hline 13.5436080 & -4.57 & $<.0001$ \\
\hline 13.5436080 & 22.08 & $<.0001$ \\
\hline 13.5436080 & -4.87 & $<.0001$ \\
\hline 13.5436080 & -0.66 & 0.5112 \\
\hline 13.5436080 & 13.81 & $<.0001$ \\
\hline 13.5436080 & -0.91 & 0.3635 \\
\hline 13.5436080 & 0.01 & 0.9882 \\
\hline 13.5436080 & 5.98 & $<.0001$ \\
\hline 13.5436080 & -0.08 & 0.9341 \\
\hline 13.5436080 & 0.0 & 0.9981 \\
\hline 13.5436080 & 1.16 & 0.2498 \\
\hline 13.5436080 & -0.01 & 0.9909 \\
\hline 13.5436080 & -0.00 & 1.0000 \\
\hline 13.5436080 & 0.06 & 0.9508 \\
\hline 13.5436080 & -0.00 & 0.9991 \\
\hline & & - \\
\hline 13.5436080 & 0.00 & 0.9988 \\
\hline 13.5436080 & -0.00 & 0.9988 \\
\hline 13.5436080 & -0.00 & 0.9997 \\
\hline 13.5436080 & 0.00 & 0.9997 \\
\hline 13.5436080 & -0.00 & 0.9987 \\
\hline 13.5436080 & 0.00 & 0.9996 \\
\hline 13.5436080 & 0.00 & 0.9999 \\
\hline 13.5436080 & 0.00 & 0.9994 \\
\hline 13.5436080 & -0.00 & 0.9979 \\
\hline & & . \\
\hline & & - \\
\hline & & 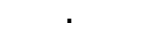 \\
\hline
\end{tabular}




\begin{tabular}{|c|c|c|c|c|c|}
\hline \multirow{2}{*}{\multicolumn{2}{|c|}{ Parameter }} & \multicolumn{4}{|c|}{ Standard } \\
\hline & & Estimate & Error & $t$ Value & $\operatorname{Pr}>|t|$ \\
\hline Week*Soil & 10 SAND & $0.0000000 \mathrm{~B}$ & & & . \\
\hline Week*Soil & 10 STALITE & $0.0000000 \mathrm{~B}$ & & & . \\
\hline
\end{tabular}

NOTE: The $X ' X$ matrix has been found to be singular, and a generalized inverse was used to solve the normal equations. Terms whose estimates are followed by the letter 'B' are not uniquely estimable.

\section{K.3 CONCENTRATiOnS OF TOTAL Nitrogen (TN)}

The proc glm output below compares the outflow concentration of $\mathrm{TN}$ from each soil media over the course of the 10 weeks of the column study. The parameter estimate table compares each week of data to the final week of data; for example, it compares week 1 with week 10 , week 2 with week 10, etc. This table illustrates how significant differences between the soil media were observed in almost each individual soil media in the first three weeks and no significant differences were observed between the outflows of the soil media in the final six weeks $(\alpha<0.05)$.

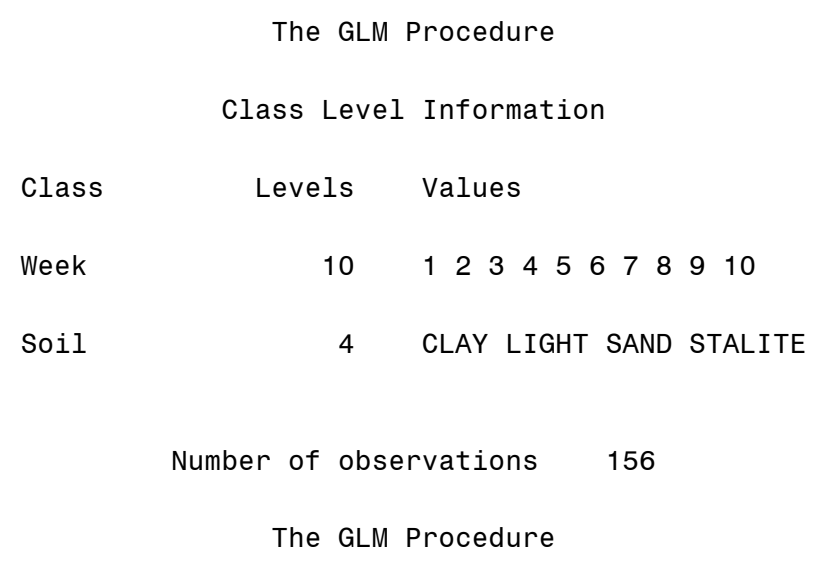




$\begin{array}{lrrrrr}\text { Source } & \text { DF } & \begin{array}{r}\text { Sum of } \\ \text { Squares }\end{array} & \text { Mean Square } & \mathrm{F} \text { Value } & \mathrm{Pr}>\mathrm{F} \\ \text { Model } & 38 & 48473.73872 & 1275.62470 & 119.92 & <.0001 \\ \text { Error } & 117 & 1244.59555 & 10.63757 & & \\ \text { Corrected Total } & 155 & 49718.33427 & \end{array}$

\begin{tabular}{|c|c|c|c|c|c|c|c|}
\hline \multirow[b]{3}{*}{ Source } & R-Square & \multicolumn{2}{|c|}{ Coeff Var } & \multicolumn{3}{|c|}{ TN Mean } & \multirow[b]{3}{*}{$\mathrm{Pr}>\mathrm{F}$} \\
\hline & 0.974967 & & 42216 & & 10.7 & 90 & \\
\hline & & DF & Type I & SS & Mean Square & F Value & \\
\hline Soil & & 3 & 11827.640 & 43 & 3942.54681 & 370.62 & $<.0001$ \\
\hline Inflow_TN & & 1 & 2081.690 & 36 & 2081.69036 & 195.69 & $<.0001$ \\
\hline Week & & 8 & 20931.382 & 254 & 2616.42282 & 245.96 & $<.0001$ \\
\hline Week*Soil & & 26 & 13633.025 & 540 & 524.34713 & 49.29 & $<.0001$ \\
\hline Source & & DF & Type III & SS & Mean Square & F Value & $\mathrm{Pr}>\mathrm{F}$ \\
\hline Soil & & 3 & 9235.569 & 990 & 3078.52330 & 289.40 & $<.0001$ \\
\hline Inflow_TN & & 0 & 0.000 & 00 & & & . \\
\hline Week & & 8 & 20931.382 & 254 & 2616.42282 & 245.96 & $<.0001$ \\
\hline Week*Soil & & 26 & 13633.025 & 540 & 524.34713 & 49.29 & $<.0001$ \\
\hline
\end{tabular}

\begin{tabular}{|c|c|}
\hline Parameter & \\
\hline Intercept & \\
\hline Soil & CLAY \\
\hline Soil & LIGHT \\
\hline Soil & SAND \\
\hline Soil & STALITE \\
\hline Inflow_TN & \\
\hline Week & 1 \\
\hline Week & 2 \\
\hline Week & 3 \\
\hline Week & 4 \\
\hline Week & 5 \\
\hline Week & 6 \\
\hline Week & 7 \\
\hline Week & 8 \\
\hline Week & 9 \\
\hline Week & 10 \\
\hline Week*Soil & $1 \mathrm{CLAY}$ \\
\hline Week*Soil & 1 LIGHT \\
\hline Week*Soil & 1 STALITE \\
\hline $\begin{array}{l}\text { Week*Soil } \\
\text { Week*Soil }\end{array}$ & 2 CLAY \\
\hline
\end{tabular}

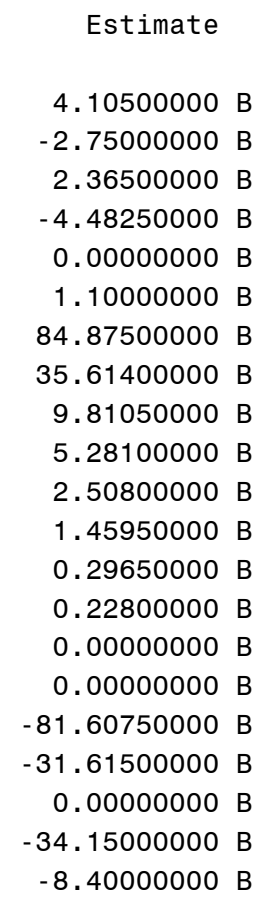

$\begin{array}{rrc}\begin{array}{r}\text { Standard } \\ \text { Error }\end{array} & \mathrm{t} \text { Value } & \mathrm{Pr}>|\mathrm{t}| \\ & & \\ 17.33526229 & 0.24 & 0.8132 \\ 2.30624899 & -1.19 & 0.2355 \\ 2.30624899 & 1.03 & 0.3073 \\ 2.30624899 & -1.94 & 0.0543 \\ & & . \\ 23.06248990 & 0.05 & 0.9620 \\ 2.30624899 & 36.80 & <.0001 \\ 5.23879065 & 6.80 & <.0001 \\ 2.11371211 & 4.64 & <.0001 \\ 2.01054126 & 2.63 & 0.0098 \\ 6.75931639 & 0.37 & 0.7113 \\ 3.41293684 & 0.43 & 0.6697 \\ 4.81558927 & 0.06 & 0.9510 \\ 4.60672875 & 0.05 & 0.9606 \\ & & . \\ 3.26152860 & -25.02 & <.0001 \\ 3.26152860 & -9.69 & <.0001 \\ & & . \\ 3.26152860 & -10.47 & <.0001 \\ 3.26152860 & -2.58 & 0.0113\end{array}$




\begin{tabular}{|c|c|}
\hline Parameter & Estimate \\
\hline Week*Soil 2 SAND & -34.64500000 \\
\hline Week*Soil 2 STALITE & 0.00000000 \\
\hline Week*Soil 3 CLAY & -8.91000000 \\
\hline Week*Soil 3 LIGHT & 5.81250000 \\
\hline Week*Soil 3 SAND & -9.53500000 \\
\hline Week*Soil 3 STALITE & 0.00000000 \\
\hline Week*Soil 4 CLAY & -4.74750000 \\
\hline Week*Soil 4 LIGHT & 2.21250000 \\
\hline Week*Soil 4 SAND & -4.76750000 \\
\hline Week*Soil 4 STALITE & 0.00000000 \\
\hline Week*Soil 5 CLAY & -1.44500000 \\
\hline Week*Soil 5 LIGHT & 3.97000000 \\
\hline Week*Soil 5 SAND & -2.03750000 \\
\hline Week*Soil 5 STALITE & 0.00000000 \\
\hline Week*Soil 6 CLAY & -1.39000000 \\
\hline Week*Soil 6 LIGHT & 3.98500000 \\
\hline Week*Soil 6 SAND & -1.05750000 \\
\hline Week*Soil 6 STALITE & 0.00000000 \\
\hline Week*Soil 7 CLAY & -0.23250000 \\
\hline Week*Soil 7 LIGHT & 3.19750000 \\
\hline Week*Soil 7 SAND & 0.30750000 \\
\hline Week*Soil 7 STALITE & 0.00000000 \\
\hline Week*Soil 8 CLAY & -0.51000000 \\
\hline Week*Soil 8 LIGHT & 2.77500000 \\
\hline Week*Soil 8 SAND & 0.24250000 \\
\hline Week*Soil 8 STALITE & 0.00000000 \\
\hline Week*Soil 9 CLAY & -0.57250000 \\
\hline Week*Soil 9 LIGHT & 0.66000000 \\
\hline Week*Soil 9 SAND & -0.11250000 \\
\hline Week*Soil 9 STALITE & 0.00000000 \\
\hline Week*Soil 10 CLAY & 0.00000000 \\
\hline Week*Soil 10 LIGHT & 0.00000000 \\
\hline Week*Soil 10 SAND & 0.00000000 \\
\hline Week*Soil 10 STALITE & 0.00000000 \\
\hline
\end{tabular}

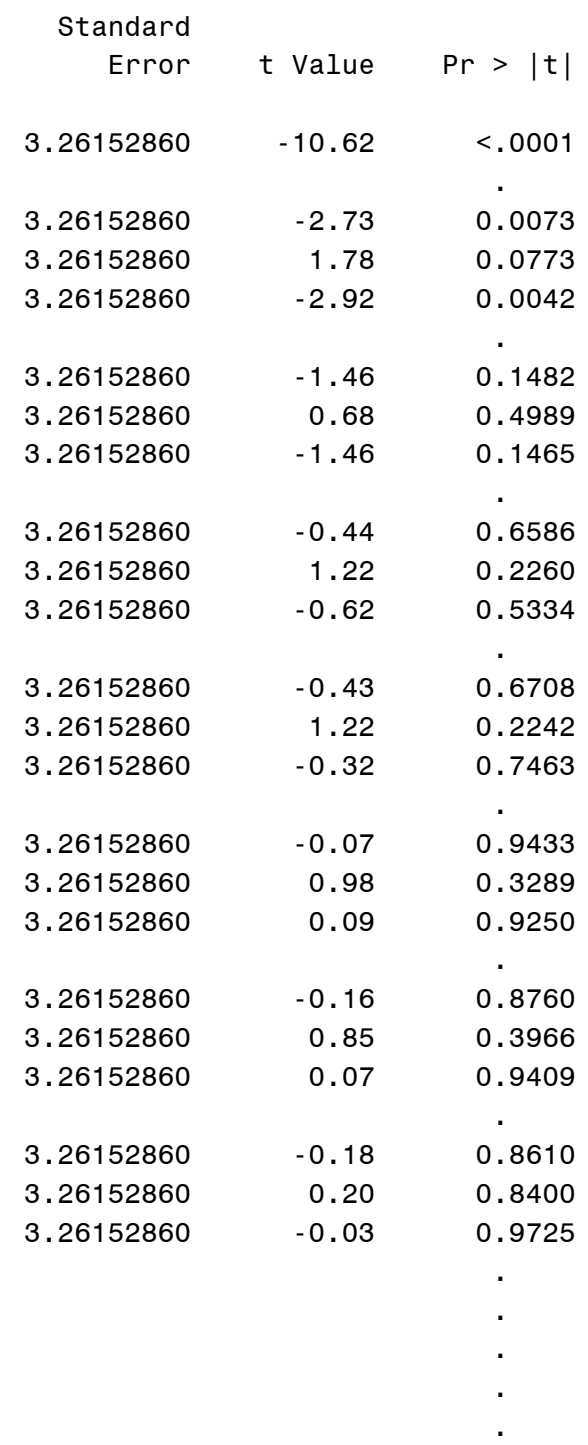

NOTE: The $X ' X$ matrix has been found to be singular, and a generalized inverse was used to solve the normal equations. Terms whose estimates are followed by the letter 'B' are not uniquely estimable.

\section{K.4 COnCENTRations OF AMmonia ( $\mathrm{NH}_{3}$ AS N)}

The proc glm output below compares the outflow concentration of $\mathrm{NH}_{3}$ as $\mathrm{N}$ of each of the four soil media over the course of the 10 week study. The parameter estimate table compares each week of data with the final week of data; for example, it compares week 1 with week 
10, week 2 with week 10 , etc. The parameter estimate table demonstrates that there were almost no significant differences observed between each soil media at the beginning of the study and the end of the study.

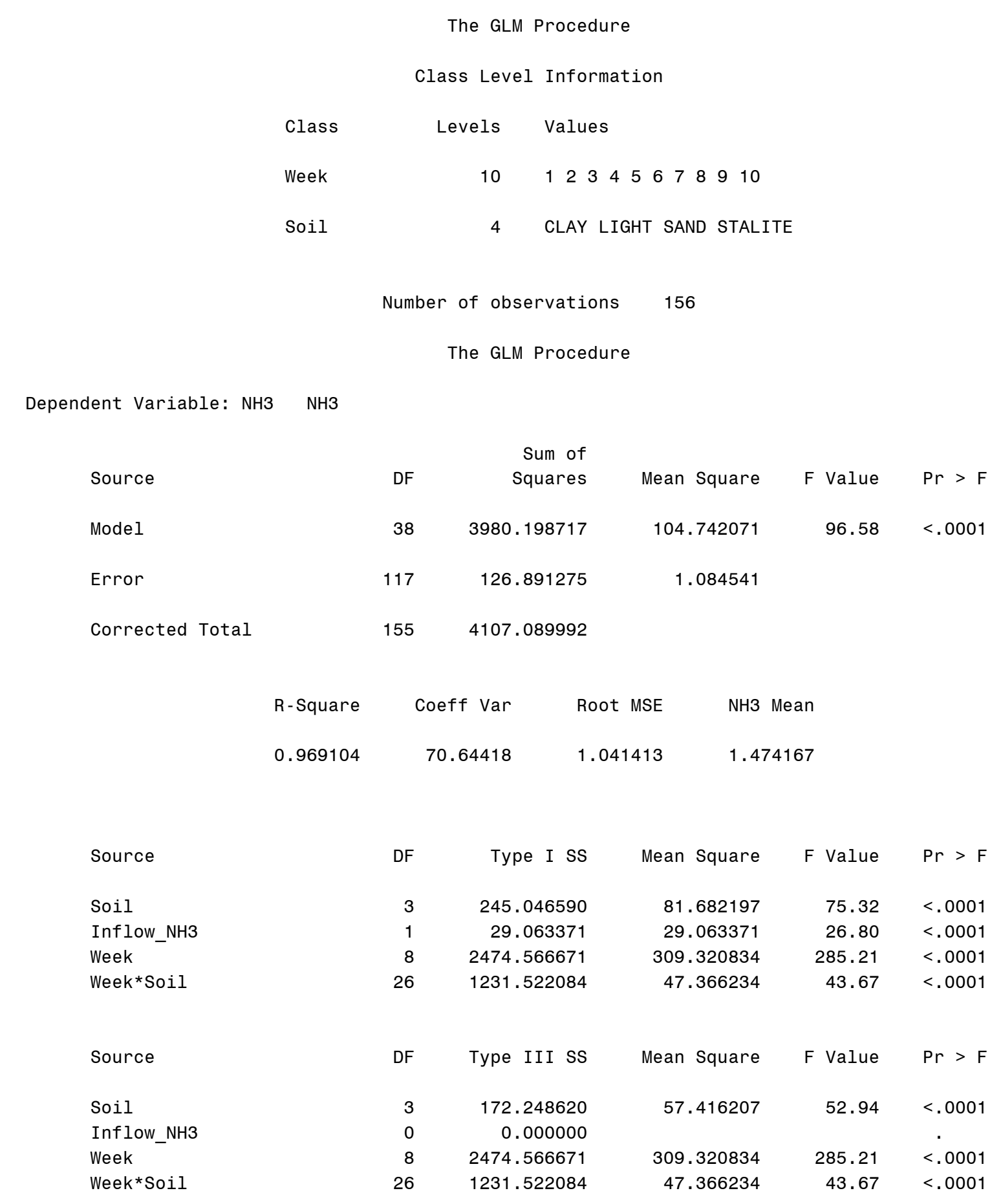




\begin{tabular}{|c|c|c|c|c|c|c|}
\hline \multirow{2}{*}{ Parameter } & & \multicolumn{5}{|c|}{ Standard } \\
\hline & & Estimate & & Error & t Value & $\operatorname{Pr}>|t|$ \\
\hline Intercept & & 0.10250000 & B & 0.71564256 & 0.14 & 0.8864 \\
\hline Soil & CLAY & -0.00750000 & B & 0.73639012 & -0.01 & 0.9919 \\
\hline Soil & LIGHT & 0.05500000 & B & 0.73639012 & 0.07 & 0.9406 \\
\hline Soil & SAND & -0.00750000 & B & 0.73639012 & -0.01 & 0.9919 \\
\hline Soil & STALITE & 0.00000000 & B & & & . \\
\hline Inflow_NH3 & & 0.05000000 & B & 2.45463373 & 0.02 & 0.9838 \\
\hline Week & 1 & 22.37800000 & B & 0.72442891 & 30.89 & $<.0001$ \\
\hline Week & 2 & 2.40300000 & B & 0.72442891 & 3.32 & 0.0012 \\
\hline Week & 3 & 0.33550000 & B & 0.72442891 & 0.46 & 0.6441 \\
\hline Week & 4 & 0.15350000 & B & 0.71311229 & 0.22 & 0.8299 \\
\hline Week & 5 & 0.23700000 & B & 0.65451785 & 0.36 & 0.7179 \\
\hline Week & 6 & 0.08400000 & B & 0.76212326 & 0.11 & 0.9124 \\
\hline Week & 7 & 0.04350000 & B & 0.77583513 & 0.06 & 0.9554 \\
\hline Week & 8 & -0.01200000 & B & 0.72442891 & -0.02 & 0.9868 \\
\hline Week & 9 & 0.00000000 & B & & & . \\
\hline Week & 10 & 0.00000000 & B & & & . \\
\hline Week*Soil & 1 CLAY & -22.15000000 & B & 1.04141289 & -21.27 & $<.0001$ \\
\hline Week*Soil & 1 LIGHT & 1.19500000 & B & 1.04141289 & 1.15 & 0.2535 \\
\hline Week*Soil & 1 STALITE & 0.00000000 & B & & & . \\
\hline Week*Soil & 2 CLAY & -2.41750000 & B & 1.04141289 & -2.32 & 0.0220 \\
\hline Week*Soil & 2 LIGHT & -1.59000000 & B & 1.04141289 & -1.53 & 0.1295 \\
\hline Week*Soil & 2 SAND & -2.39500000 & B & 1.04141289 & -2.30 & 0.0232 \\
\hline Week*Soil & 2 STALITE & 0.00000000 & B & & & . \\
\hline Week*Soil & 3 CLAY & -0.32750000 & B & 1.04141289 & -0.31 & 0.7537 \\
\hline Week*Soil & 3 LIGHT & -0.12750000 & B & 1.04141289 & -0.12 & 0.9028 \\
\hline Week*Soil & 3 SAND & -0.30750000 & B & 1.04141289 & -0.30 & 0.7683 \\
\hline Week*Soil & 3 STALITE & 0.00000000 & B & & & . \\
\hline Week*Soil & 4 CLAY & -0.04000000 & B & 1.04141289 & -0.04 & 0.9694 \\
\hline Week*Soil & 4 LIGHT & -0.05250000 & B & 1.04141289 & -0.05 & 0.9599 \\
\hline Week*Soil & 4 SAND & 0.01000000 & B & 1.04141289 & 0.01 & 0.9924 \\
\hline Week*Soil & 4 STALITE & 0.00000000 & B & & & . \\
\hline Week*Soil & 5 CLAY & -0.18750000 & B & 1.04141289 & -0.18 & 0.8574 \\
\hline Week*Soil & 5 LIGHT & 0.05500000 & B & 1.04141289 & 0.05 & 0.9580 \\
\hline Week*Soil & 5 SAND & -0.08250000 & B & 1.04141289 & -0.08 & 0.9370 \\
\hline Week*Soil & 5 STALITE & 0.00000000 & B & & & . \\
\hline Week*Soil & 6 CLAY & -0.08250000 & B & 1.04141289 & -0.08 & 0.9370 \\
\hline Week*Soil & 6 LIGHT & 0.09500000 & B & 1.04141289 & 0.09 & 0.9275 \\
\hline Week*Soil & 6 SAND & 0.10000000 & B & 1.04141289 & 0.10 & 0.9237 \\
\hline Week*Soil & 6 STALITE & 0.00000000 & B & & & . \\
\hline Week*Soil & 7 CLAY & 0.02500000 & B & 1.04141289 & 0.02 & 0.9809 \\
\hline Week*Soil & 7 LIGHT & 0.08250000 & B & 1.04141289 & 0.08 & 0.9370 \\
\hline Week*Soil & 7 SAND & 0.24000000 & B & 1.04141289 & 0.23 & 0.8181 \\
\hline Week*Soil & 7 STALITE & 0.00000000 & B & & & . \\
\hline Week*Soil & 8 CLAY & -0.00250000 & B & 1.04141289 & -0.00 & 0.9981 \\
\hline Week*Soil & 8 LIGHT & 0.03500000 & B & 1.04141289 & 0.03 & 0.9732 \\
\hline Week*Soil & 8 SAND & 0.21000000 & B & 1.04141289 & 0.20 & 0.8405 \\
\hline Week*Soil & 8 STALITE & 0.00000000 & B & & & . \\
\hline Week*Soil & 9 CLAY & -0.00750000 & B & 1.04141289 & -0.01 & 0.9943 \\
\hline Week*Soil & 9 LIGHT & 0.01250000 & B & 1.04141289 & 0.01 & 0.9904 \\
\hline Week*Soil & 9 SAND & -0.01500000 & B & 1.04141289 & -0.01 & 0.9885 \\
\hline Week*Soil & 9 STALITE & 0.00000000 & B & & & . \\
\hline
\end{tabular}




\begin{tabular}{|c|c|c|c|c|c|}
\hline \multirow[b]{2}{*}{ Parameter } & & \multicolumn{4}{|c|}{ Standard } \\
\hline & & Estimate & Error & $t$ Value & $\mathrm{Pr}>$ \\
\hline Week*Soil & $10 \mathrm{CLAY}$ & $0.00000000 \mathrm{~B}$ & & & . \\
\hline Week*Soil & 10 LIGHT & $0.00000000 \mathrm{~B}$ & & & . \\
\hline Week*Soil & 10 SAND & $0.00000000 \mathrm{~B}$ & & & . \\
\hline Week*Soil & 10 STALITE & $0.00000000 \mathrm{~B}$ & & & . \\
\hline
\end{tabular}

NOTE: The $X ' X$ matrix has been found to be singular, and a generalized inverse was used to solve the normal equations. Terms whose estimates are followed by the letter 'B' are not uniquely estimable.

\section{K.5 Concentrations of Total Phosphorus (TP)}

The proc glm output below compares the concentration outflow of TP between each of the four soil media over the course of the 10 week study. The parameter estimate table compares each week of data with the final week of data; for example, it compares week 1 with week 10, week 2 with week 10, etc. The parameter estimate table shows that there were significant differences observed in the first several weeks of study, however, no significant differences were observed between the soil media in the final weeks of the study $(\alpha<0.05)$.

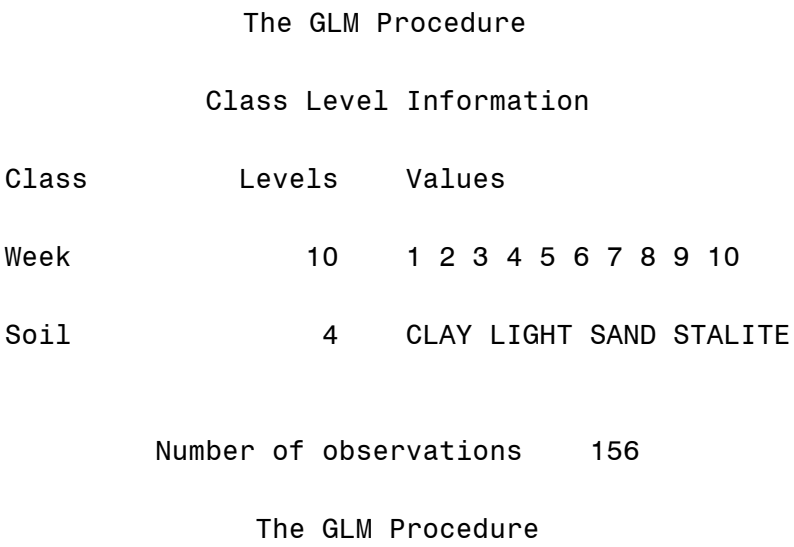

Dependent Variable: TP TP 


$\begin{array}{lrrrrr}\begin{array}{lrr}\text { Source } \\ \text { Model }\end{array} & \text { DF } & \begin{array}{r}\text { Sum of } \\ \text { Squares }\end{array} & \text { Mean Square } & \mathrm{F} \text { Value } & \text { Pr }>\text { F } \\ \text { Error } & 38 & 151.1474897 & 3.9775655 & 41.41 & <.0001 \\ \text { Corrected Total } & 117 & 11.2374000 & 0.0960462 & \\ & 155 & 162.3848897 & \end{array}$

$\begin{array}{llll}\text { R-Square } & \text { Coeff Var } & \text { Root MSE } & \text { TP Mean } \\ 0.930798 & 28.82225 & 0.309913 & 1.075256\end{array}$

Source

Soil

Inflow_TP

Week

Week*Soil

Source

Soil

Inflow_TP

Week

Week*Soil

$\begin{array}{rrrrr}\text { DF } & \text { Type I SS } & \text { Mean Square } & \text { F Value } & \text { Pr }>\text { F } \\ & & & & \\ 3 & 125.7678050 & 41.9226017 & 436.48 & <.0001 \\ 1 & 4.8712890 & 4.8712890 & 50.72 & <.0001 \\ 8 & 4.8890908 & 0.6111363 & 6.36 & <.0001 \\ 26 & 15.6193050 & 0.6007425 & 6.25 & <.0001\end{array}$

DF

Type III SS

Mean Square

F Value $\mathrm{Pr}>\mathrm{F}$

$\begin{array}{rr}3 & 125.0264637 \\ 0 & 0.0000000 \\ 8 & 4.8890908 \\ 26 & 15.6193050\end{array}$

41.6754879

$433.91<.0001$

0.6111363

0.6007425

$6.36<.0001$

$6.25<.0001$

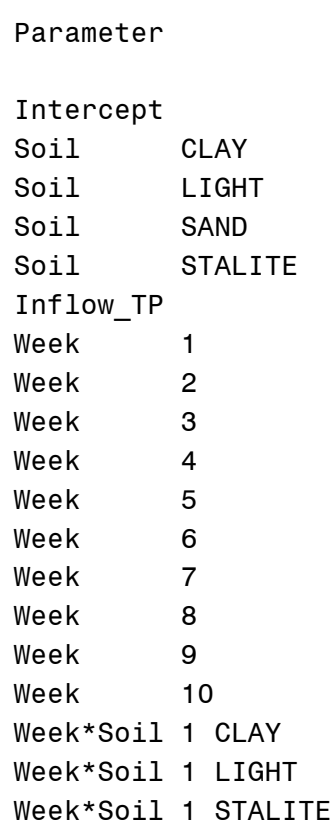

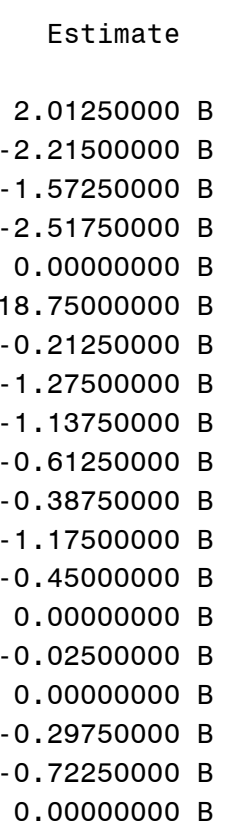

$\begin{array}{rrc}\begin{array}{r}\text { Standard } \\ \text { Error }\end{array} & \mathrm{t} \text { Value } & \mathrm{Pr}>|\mathrm{t}| \\ 0.45177215 & 4.45 & <.0001 \\ 0.21914168 & -10.11 & <.0001 \\ 0.21914168 & -7.18 & <.0001 \\ 0.21914168 & -11.49 & <.0001 \\ & & . \\ 10.95708412 & 1.71 & 0.0897 \\ 0.28989720 & -0.73 & 0.4650 \\ 0.21914168 & -5.82 & <.0001 \\ 0.28989720 & -3.92 & 0.0001 \\ 0.28989720 & -2.11 & 0.0367 \\ 0.18978226 & -2.04 & 0.0434 \\ 0.79012657 & -1.49 & 0.1397 \\ 0.37956453 & -1.19 & 0.2382 \\ 0.21914168 & -0.11 & 0.9094 \\ 0.30991314 & -0.96 & 0.3391 \\ 0.30991314 & -2.33 & 0.0214 \\ & & .\end{array}$


APPENDIX K — SOIL MEDIA STUDY DATA: STATISTICAL ANALYSIS

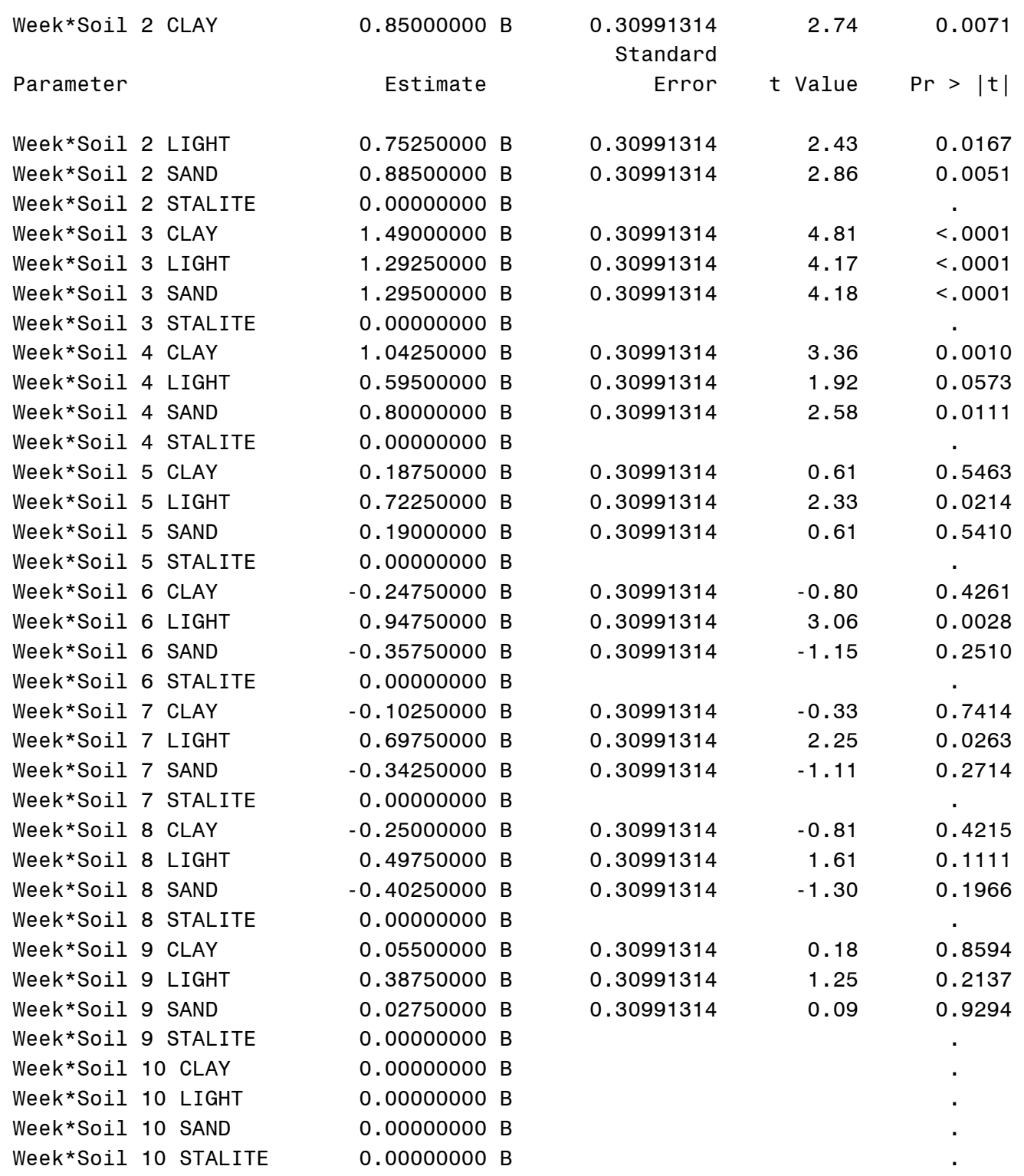

NOTE: The $X ' X$ matrix has been found to be singular, and a generalized inverse was used to solve the normal equations. Terms whose estimates are followed by the letter 'B' are not uniquely estimable.

\section{K.6 CONCENTRATIONS OF ORThO-PhOSPHORUS (OP)}

The proc glm output below compares the concentration outflow of $\mathrm{OP}$ as $\mathrm{P}$ between each soil media over the course of the 10 week study. The parameter estimate table compares 
each week of data with the final week of data; for example, it compares week 1 with week 10, week 2 with week 10, etc. The parameter estimate table illustrates how few significant differences between the soil media were observed over the 10 week period.

The GLM Procedure
Class Level Information
Class
Levels
Week
Soil

Number of observations 156

The GLM Procedure

Dependent Variable: P04 P04

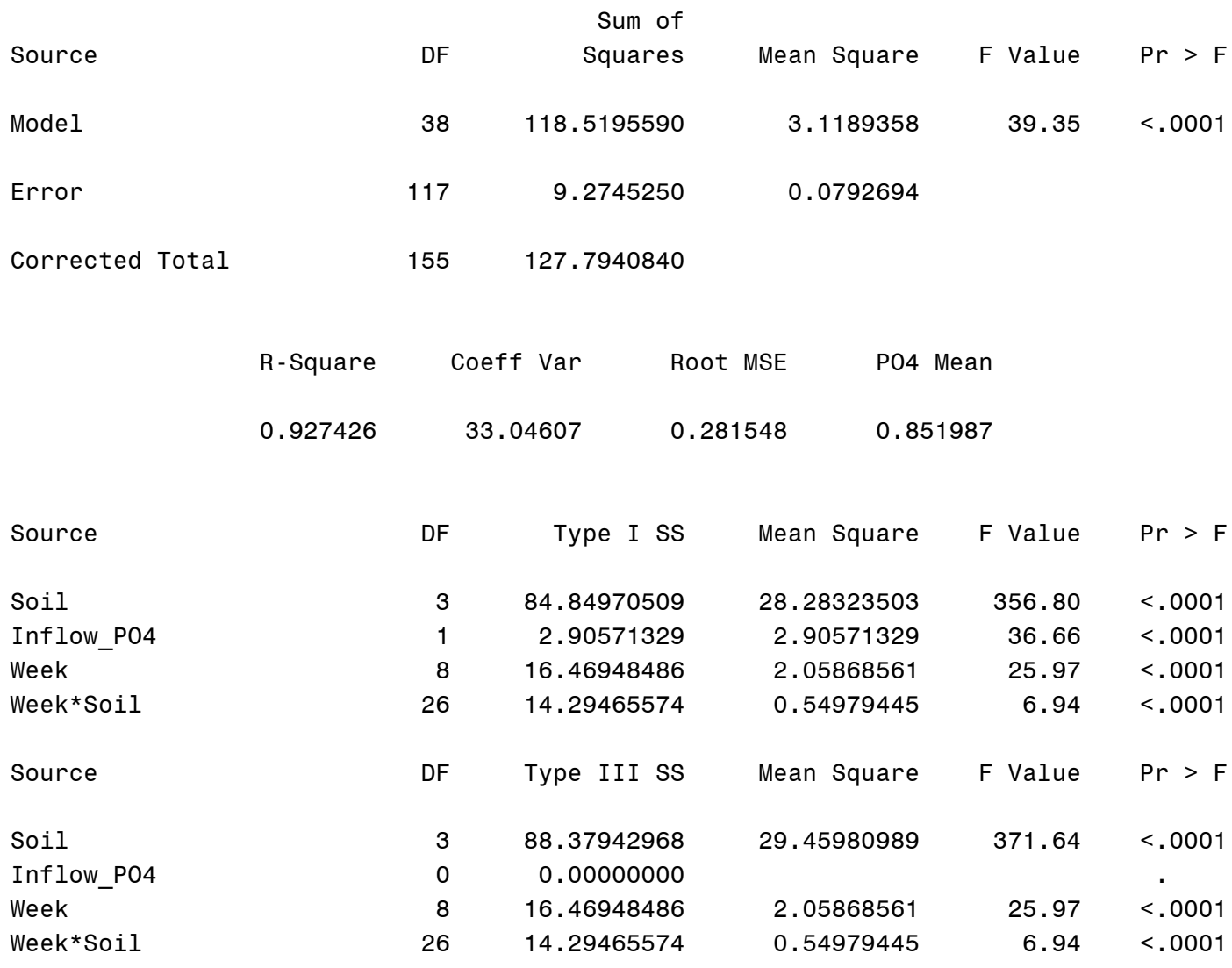




\begin{tabular}{|c|c|c|}
\hline Parameter & & Estimate \\
\hline Intercept & & $3.27500000 \mathrm{~B}$ \\
\hline Soil & CLAY & $-1.42750000 \mathrm{~B}$ \\
\hline Soil & LIGHT & $-1.06000000 \mathrm{~B}$ \\
\hline Soil & SAND & $-1.74250000 \mathrm{~B}$ \\
\hline Soil & STALITE & $0.00000000 \mathrm{~B}$ \\
\hline Inflow_P04 & & -50.00000000 \\
\hline Week & 1 & $0.75500000 \mathrm{~B}$ \\
\hline Week & 2 & $1.28500000 \mathrm{~B}$ \\
\hline Week & 3 & $-0.64250000 \mathrm{~B}$ \\
\hline Week & 4 & $0.85000000 \mathrm{~B}$ \\
\hline Week & 5 & $0.40000000 \mathrm{~B}$ \\
\hline Week & 6 & $2.47500000 \mathrm{~B}$ \\
\hline Week & 7 & $1.50000000 \mathrm{~B}$ \\
\hline Week & 8 & $0.00000000 \mathrm{~B}$ \\
\hline Week & 9 & $0.62500000 \mathrm{~B}$ \\
\hline Week & 10 & $0.00000000 \mathrm{~B}$ \\
\hline Week*Soil & 1 CLAY & $0.52000000 \mathrm{~B}$ \\
\hline Week*Soil & 1 LIGHT & $0.24750000 \mathrm{~B}$ \\
\hline Week*Soil & 1 STALITE & $0.00000000 \mathrm{~B}$ \\
\hline Week*Soil & 2 CLAY & $0.55500000 \mathrm{~B}$ \\
\hline Week*Soil & 2 LIGHT & $0.40500000 \mathrm{~B}$ \\
\hline Week*Soil & 2 SAND & $0.69250000 \mathrm{~B}$ \\
\hline Week*Soil & 2 STALITE & $0.00000000 \mathrm{~B}$ \\
\hline Week*Soil & 3 CLAY & $0.60500000 \mathrm{~B}$ \\
\hline Week*Soil & 3 LIGHT & $0.38750000 \mathrm{~B}$ \\
\hline Week*Soil & 3 SAND & $0.62000000 \mathrm{~B}$ \\
\hline Week*Soil & 3 STALITE & $0.00000000 \mathrm{~B}$ \\
\hline Week*Soil & 4 CLAY & $0.32250000 \mathrm{~B}$ \\
\hline Week*Soil & 4 LIGHT & $0.02750000 \mathrm{~B}$ \\
\hline Week*Soil & 4 SAND & $0.16000000 \mathrm{~B}$ \\
\hline Week*Soil & 4 STALITE & $0.00000000 \mathrm{~B}$ \\
\hline Week*Soil & 5 CLAY & $-0.44250000 \mathrm{~B}$ \\
\hline Week*Soil & 5 LIGHT & 0.16000000 \\
\hline Week*Soil & 5 SAND & -0.41500000 \\
\hline Week*Soil & 5 STALITE & 0.00000000 \\
\hline Week*Soil & 6 CLAY & -0.94000000 \\
\hline Week*Soil & 6 LIGHT & 0.31000000 \\
\hline Week*Soil & 6 SAND & -0.99750000 \\
\hline Week*Soil & 6 STALITE & 0.00000000 \\
\hline Week*Soil & 7 CLAY & -0.87750000 \\
\hline Week*Soil & 7 LIGHT & 0.08500000 \\
\hline Week*Soil & 7 SAND & -1.02250000 \\
\hline Week*Soil & 7 STALITE & 0.00000000 \\
\hline Week*Soil & 8 CLAY & -0.93000000 \\
\hline Week*Soil & 8 LIGHT & -0.11500000 \\
\hline Week*Soil & 8 SAND & -1.02250000 \\
\hline Week*Soil & 8 STALITE & 0.00000000 \\
\hline Week*Soil & 9 CLAY & -0.62750000 \\
\hline Week*Soil & 9 LIGHT & -0.23500000 \\
\hline Week*Soil & 9 SAND & -0.64750000 \\
\hline Week*Soil & 9 STALITE & 0.00000000 \\
\hline
\end{tabular}

\begin{tabular}{|c|c|c|}
\hline $\begin{array}{r}\text { Standard } \\
\text { Error }\end{array}$ & t Value & $\mathrm{Pr}>|\mathrm{t}|$ \\
\hline 0.22258347 & 14.71 & $<.0001$ \\
\hline 0.19908471 & -7.17 & $<.0001$ \\
\hline 0.19908471 & -5.32 & $<.0001$ \\
\hline 0.19908471 & -8.75 & $<.0001$ \\
\hline 9.95423556 & -5.02 & $<.0001$ \\
\hline 0.43389507 & 1.74 & 0.0845 \\
\hline 0.52672864 & 2.44 & 0.0162 \\
\hline 0.19908471 & -3.23 & 0.0016 \\
\hline 0.34482483 & 2.47 & 0.0152 \\
\hline 0.19908471 & 2.01 & 0.0468 \\
\hline 0.43389507 & 5.70 & $<.0001$ \\
\hline 0.26336432 & 5.70 & $<.0001$ \\
\hline 0.19908471 & 3.14 & 0.0021 \\
\hline & & $\cdot 9673$ \\
\hline $\begin{array}{l}0.28154830 \\
0.28154830\end{array}$ & $\begin{array}{l}1.85 \\
0.88\end{array}$ & $\begin{array}{l}0.0673 \\
0.3812\end{array}$ \\
\hline & & . \\
\hline 0.28154830 & 1.97 & 0.0511 \\
\hline 0.28154830 & 1.44 & 0.1530 \\
\hline 0.28154830 & 2.46 & 0.0154 \\
\hline 0.28154830 & 2.15 & 0.0337 \\
\hline 0.28154830 & 1.38 & 0.1714 \\
\hline 0.28154830 & 2.20 & 0.0296 \\
\hline 0.28154830 & 1.15 & 0.2544 \\
\hline 0.28154830 & 0.10 & 0.9224 \\
\hline 0.28154830 & 0.57 & 0.5709 \\
\hline & & $\cdot 1187$ \\
\hline 0.28154830 & -1.57 & 0.1187 \\
\hline 0.28154830 & 0.57 & 0.5709 \\
\hline 0.28154830 & -1.47 & 0.1432 \\
\hline 0.28154830 & -334 & $\cdot 9011$ \\
\hline 0.28154830 & 1.10 & 0.2731 \\
\hline 0.28154830 & -3.54 & 0.0006 \\
\hline 0.28154830 & -3.12 & 0.0023 \\
\hline 0.28154830 & 0.30 & 0.7633 \\
\hline 0.28154830 & -3.63 & 0.0004 \\
\hline 0.28154830 & -3.30 & 0.0013 \\
\hline 0.28154830 & -0.41 & 0.6837 \\
\hline 0.28154830 & -3.63 & 0.0004 \\
\hline & & $\cdot$ \\
\hline 0.28154830 & -2.23 & 0.0277 \\
\hline 0.28154830 & -0.83 & 0.4056 \\
\hline 0.28154830 & -2.30 & 0.0232 \\
\hline
\end{tabular}


APPENDIX K — SOIL MEDIA STUDY DATA: STATISTICAL ANALYSIS

\begin{tabular}{|c|c|c|c|c|c|}
\hline \multirow[b]{2}{*}{ Parameter } & & \multicolumn{4}{|c|}{ Standard } \\
\hline & & Estimate & Error & t Value & $\mathrm{Pr}>|\mathrm{t}|$ \\
\hline Week*Soil & $10 \mathrm{CLAY}$ & $0.00000000 \mathrm{~B}$ & & & . \\
\hline Week*Soil & 10 LIGHT & $0.00000000 \mathrm{~B}$ & & & . \\
\hline Week*Soil & 10 SAND & $0.00000000 \mathrm{~B}$ & & & . \\
\hline Week*Soil & 10 STALITE & $0.00000000 \mathrm{~B}$ & & & . \\
\hline
\end{tabular}

NOTE: The $X ' X$ matrix has been found to be singular, and a generalized inverse was used to solve the normal equations. Terms whose estimates are followed by the letter ' $B$ ' are not uniquely estimable. 


\section{L.0 APPENDIX L - PLANT GROWTH DATA}

Table L-1. Summary Table of Plant Growth Data after 1 Year of Growth

\begin{tabular}{|c|c|c|c|c|c|}
\hline \multicolumn{7}{|c|}{ MAY 2003 } \\
\hline \hline Depth (in.) & Person (Observer) & Plant & Cover 1 (\%) & Cover 2 (\%) & Cover Avg (\%) \\
\hline 2 & Amy & Delosperma & 20 & 40 & 30 \\
\hline 2 & Dave & Delosperma & 15 & 25 & 20 \\
\hline 2 & Jon & Delosperma & 20 & 30 & 25 \\
\hline 2 & Amy & Reflexum & 30 & 25 & 28 \\
\hline 2 & Dave & Reflexum & 30 & 25 & 28 \\
\hline 2 & Jon & Reflexum & 40 & 40 & 40 \\
\hline 2 & Amy & Album & 25 & 15 & 20 \\
\hline 2 & Dave & Album & 20 & 10 & 15 \\
\hline 2 & Jon & Album & 25 & 75 & 20 \\
\hline 4 & Amy & Delosperma & 70 & 70 & 70 \\
\hline 4 & Dave & Delosperma & 45 & 55 & 50 \\
\hline 4 & Jon & Delosperma & 50 & 50 & 50 \\
\hline 4 & Amy & Reflexum & 75 & 90 & 83 \\
\hline 4 & Dave & Reflexum & 75 & 85 & 80 \\
\hline 4 & Jon & Reflexum & 50 & 60 & 65 \\
\hline 4 & Amy & Album & 60 & 75 & 68 \\
\hline 4 & Dave & Album & 55 & 55 & 65 \\
\hline
\end{tabular}

Note: $\quad$ Person $=$ Person making observations; Plant $=$ Plant species; Cover $1=$ First percent coverage measurement; Cover 2 = Second percent coverage measurement; Cover Avg = Average of two percent coverage measurements. 


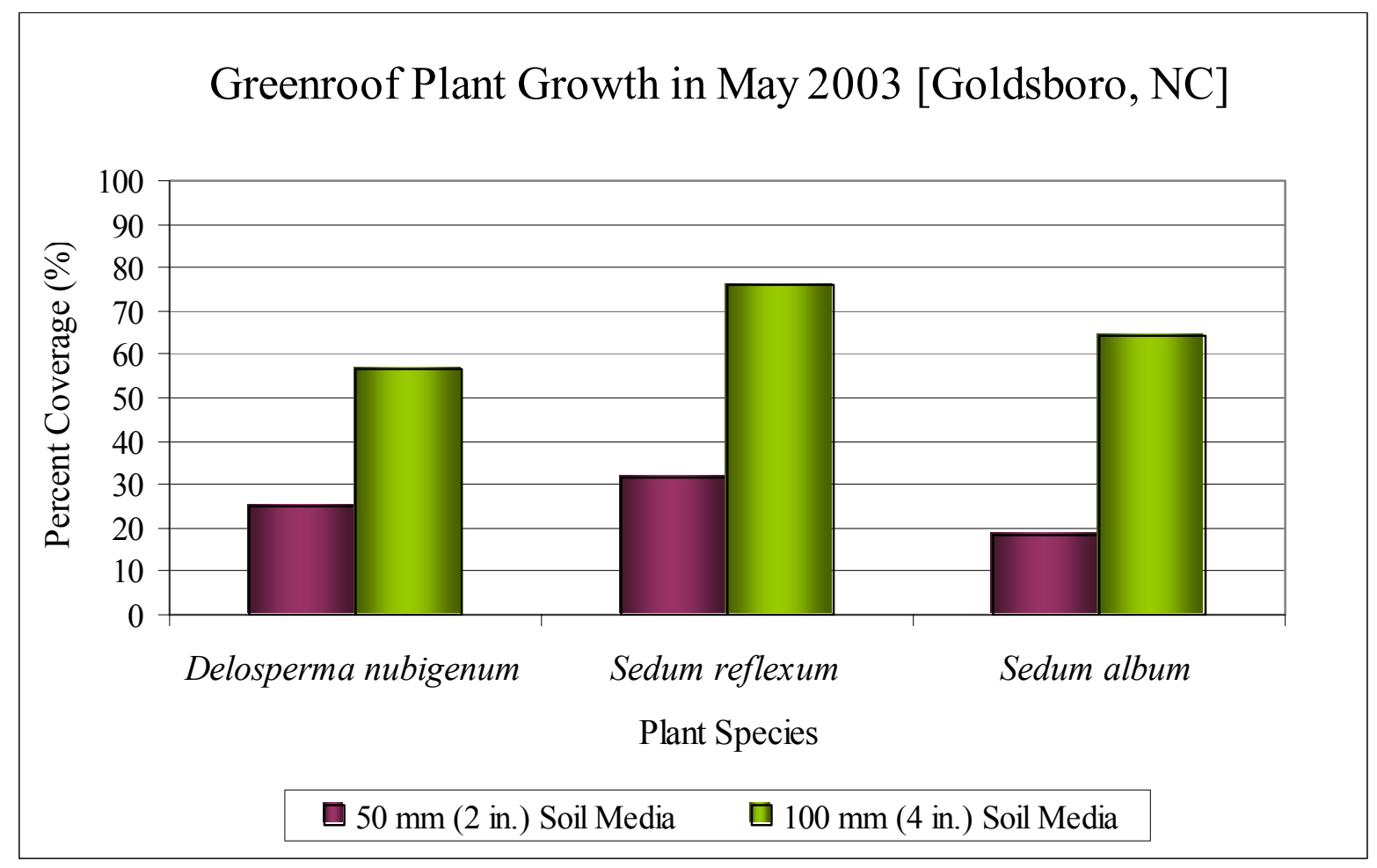

Figure L-1. Display of Average Plant Growth Data for each Plant Species in $50 \mathrm{~mm}$ (2 in.) and $100 \mathrm{~mm}$ (4 in.) Soil Media Depths. 


\section{M.0 APPENDIX M - PLANT GROWTH DATA: STATISTICAL ANALYSIS}

All input data for the statistical analysis of the plant growth data is presented in Appendix L. Through the Analysis of Variance results and the Difference of Least Square Means results, it can be seen that the depth and species have a significant effect on the percent coverage. Percent coverage of the vegetation was significantly higher in the $100 \mathrm{~mm}$ (4 in.) soil media than the $50 \mathrm{~mm}(2 \mathrm{in}$.$) (p-value <0.0001)$. The percent coverage was significantly different $(\alpha<0.05)$ between each plant species $(p-v a l u e=0.0139)$. The percent coverage of Sedum relfexum was significantly higher $(\alpha<0.05)$ than the Sedum album (p-value $=0.0264)$ and the Delosperma nubigenum ( $\mathrm{p}$-value $=0.0223$ ); there was no statistically significant difference between the percent coverage of Sedum album and Delosperma nubigenum (pvalue $=0.9940)$. There was no significant difference between each person's observations ( $\mathrm{p}$ value $=0.2232$ ). The entire output of the proc mixed procedure is displayed below.

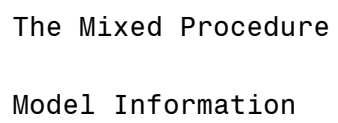

WORK. ONE

cover

Variance Components

Type 3

Factor

Model-Based

Containment

Class Level Information

$\begin{array}{lll}\text { Class } & \text { Levels } & \text { Values } \\ \text { Person } & 3 & \text { Amy Dave Jon } \\ \text { species } & 3 & \text { Album Delosperma Reflexum } \\ \text { rep } & 2 & 12 \\ \text { Depth } & 2 & 24\end{array}$




\begin{tabular}{lr}
\multicolumn{2}{c}{ Dimensions } \\
Covariance Parameters & 3 \\
Columns in X & 12 \\
Columns in Z & 21 \\
Subjects & 1 \\
Max Obs Per Subject & 36 \\
Observations Used & 36 \\
Observations Not Used & 0 \\
Total Observations & 36
\end{tabular}

Type 3 Analysis of Variance

\begin{tabular}{|c|c|c|c|}
\hline Source & DF & $\begin{array}{l}\text { Sum of } \\
\text { Squares }\end{array}$ & Mean Square \\
\hline Depth & 1 & 14803 & 14803 \\
\hline species & 2 & 1293.055556 & 646.527778 \\
\hline species*Depth & 2 & 359.722222 & 179.861111 \\
\hline Person & 2 & 334.722222 & 167.361111 \\
\hline Person*species*Depth & 10 & 956.944444 & 95.694444 \\
\hline Residual & 18 & 1500.000000 & 83.333333 \\
\hline
\end{tabular}

Type 3 Analysis of Variance

\begin{tabular}{|c|c|}
\hline Source & Expected Mean Square \\
\hline Depth & $\begin{array}{l}\operatorname{Var}(\text { Residual })+2 \operatorname{Var}(\text { Person*species*Depth }) \\
+Q(\text { Depth, species*Depth })\end{array}$ \\
\hline species & $\begin{array}{l}\operatorname{Var}(\text { Residual })+2 \operatorname{Var}(\text { Person*species*Depth }) \\
+Q(\text { species, species*Depth })\end{array}$ \\
\hline species*Depth & $\begin{array}{l}\operatorname{Var}(\text { Residual })+2 \operatorname{Var}(\text { Person*species*Depth }) \\
+Q(\text { species*Depth })\end{array}$ \\
\hline Person & $\begin{array}{l}\operatorname{Var}(\text { Residual })+2 \operatorname{Var}(\text { Person*species*Depth }) \\
+12 \operatorname{Var}(\text { Person })\end{array}$ \\
\hline Person*species & $\operatorname{Var}($ Residual $)+2 \operatorname{Var}($ Person*species*Depth $)$ \\
\hline Residual & Var(Residual) \\
\hline
\end{tabular}

Type 3 Analysis of Variance

$\begin{array}{llrrr}\text { Source } & \text { Error Term } & \text { DF } & \text { F Value } & \text { Pr }>\text { F } \\ \text { Depth } & & & & \\ \text { species } & \text { MS(Person*species*Depth) } & 10 & 154.69 & <.0001 \\ \text { species*Depth } & \text { MS(Person*species*Depth) } & 10 & 6.76 & 0.0139 \\ \text { Person } & \text { MS(Person*species*Depth) } & 10 & 1.88 & 0.2028 \\ \text { Person*species*Depth } & \text { MS(Residual) } & 10 & 1.75 & 0.2232 \\ \text { Residual } & \text { MS(Person*species*Depth) } & 18 & 1.15 & 0.3826\end{array}$




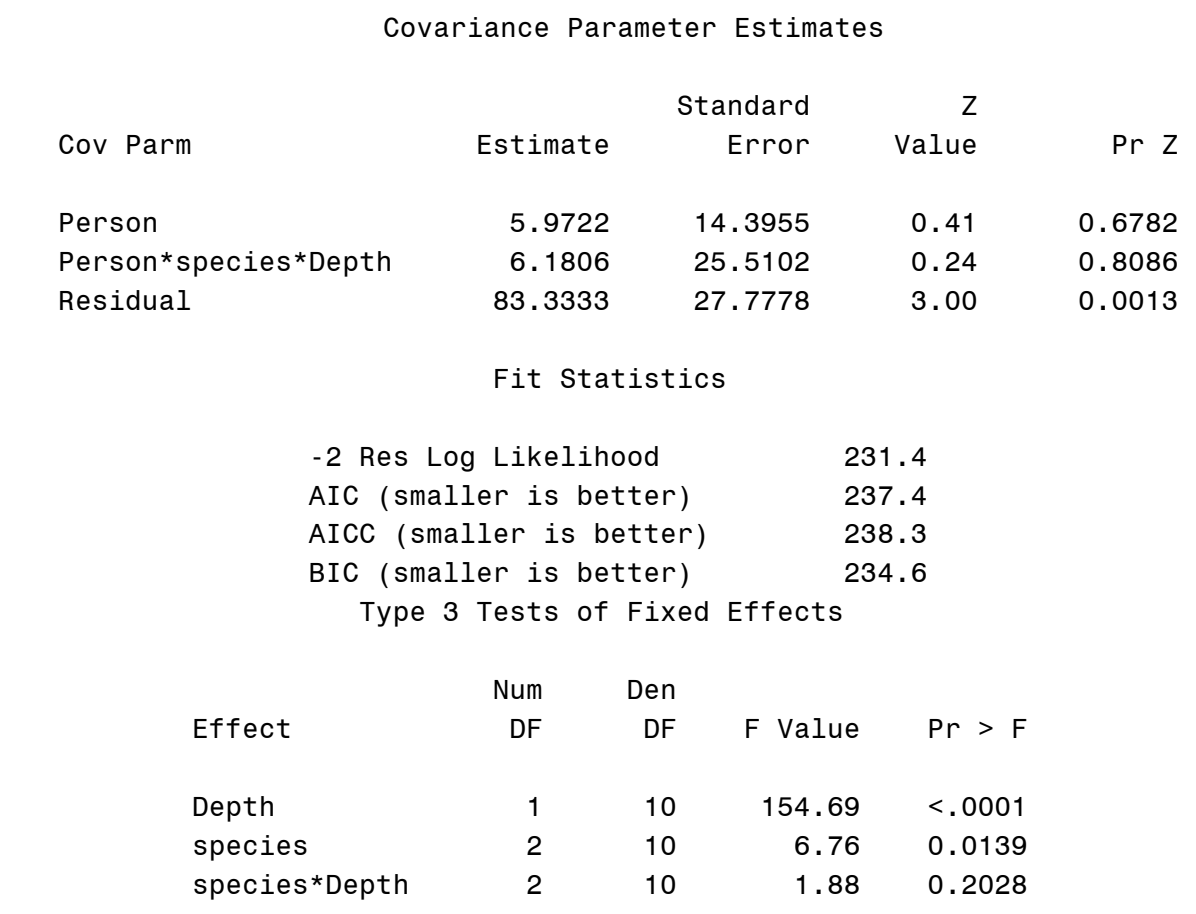

The Mixed Procedure

Least Squares Means

$\begin{array}{llrrrrr}\text { Effect } & \text { species } & \text { Estimate } & \begin{array}{c}\text { Standard } \\ \text { Error }\end{array} & \text { DF } & \text { t Value } & \operatorname{Pr}>|t| \\ \text { species } & \text { Album } & 41.2500 & 3.1568 & 10 & 13.07 & <.0001 \\ \text { species } & \text { Delosperma } & 40.8333 & 3.1568 & 10 & 12.94 & <.0001 \\ \text { species } & \text { Reflexum } & 53.7500 & 3.1568 & 10 & 17.03 & <.0001\end{array}$

Differences of Least Squares Means

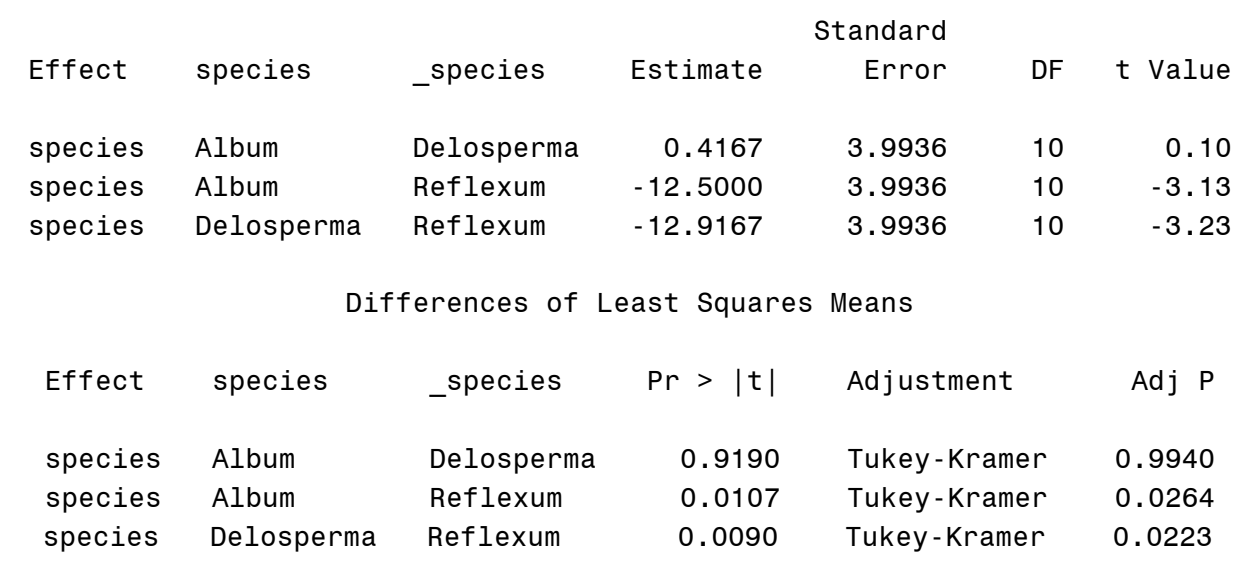

